UNIVERSIDADE DE SÃO PAULO

FACULDADE DE FILOSOFIA, LETRAS E CIÊNCIAS HUMANAS

DEPARTAMENTO DE LETRAS CLÁSSICAS E VERNÁCULAS

PROGRAMA DE PÓS-GRADUAÇÃO EM LITERATURA PORTUGUESA

\title{
CRÔNICA DE D. DUARDOS (PRIMEIRA PARTE) CÓD. BNL 12904 \\ Edição e estudo
}

Raúl Cesar Gouveia Fernandes

VOLUME I

São Paulo

2006 
UNIVERSIDADE DE SÃO PAULO

FACULDADE DE FILOSOFIA, LETRAS E CIÊNCIAS HUMANAS

DEPARTAMENTO DE LETRAS CLÁSSICAS E VERNÁCULAS

PROGRAMA DE PÓS-GRADUAÇÃO EM LITERATURA PORTUGUESA

\section{CRÔNICA DE D. DUARDOS (PRIMEIRA PARTE) \\ CÓD. BNL 12904}

Edição e estudo

Raúl Cesar Gouveia Fernandes

Tese apresentada ao Programa de PósGraduação em Literatura Portuguesa, do Departamento de Letras Clássicas e Vernáculas da Faculdade de Filosofia, Letras e Ciências Humanas da Universidade de São Paulo, para obtenção do título de Doutor em Letras.

Orientadora:

Profa. Dra. Lênia Márcia Mongelli

VOLUME I

São Paulo 
À memória de meu pai,

com saudades de quando ele contava histórias dos heróis de sua terra: Martim Moniz, Geraldo Sem Pavor e Vasco da Gama. "Aqui ao leme sou mais do que eu". 


\section{AGRADECIMENTOS}

Devo o início de meu interesse pelos livros de cavalarias renascentistas a sugestões recebidas do Prof. Massaud Moisés, por ocasião de um curso sobre a novela portuguesa realizado há mais de dez anos. A ele minha mais sincera admiração, pela generosidade com que compartilha seu saber.

À Profa. Lênia Márcia Mongelli também devo muito, por sua orientação minuciosa e exigente ao longo de todos esses anos de trabalho e convívio. Sinto-me grato por sua sempre renovada confiança em mim.

São muitos os que de alguma forma colaboraram com este trabalho. Alguns ofereceram sugestões ou socorreram-me de diversas formas (Aurelio Vargas Díaz-Toledo, Yara Frateschi Vieira, Jerusa Pires Ferreira e Marcelo Módolo, por exemplo). Outros simplesmente estiveram presentes: e felizmente foram tantos estes amigos, que não posso nomeá-los aqui. Muito obrigado a todos.

Desejo agradecer de modo especial a minha mãe, por seu zelo constante, e a minha irmã, pelo incentivo discreto e certo.

Mas este trabalho não teria sido possível sem o apoio, a dedicação e a paciência da Teresa. A ela, que me suportou durante o longo período de minhas lides quixotescas com montanhas de papel, minha gratidão e meu amor. 
RESUMO

O objetivo central deste trabalho é editar a primeira parte das continuações manuscritas do Palmeirim de Inglaterra, de Francisco de Morais. O livro, que chamamos Crônica de D. Duardos, Primeira Parte, foi provavelmente redigido por D. Gonçalo Coutinho nos anos 1580. Após estudo introdutório, apresentamos a transcrição do texto de acordo com o cód. BNL 12904.

\begin{abstract}
The main purpose of this work is to prepare an edition of the first part of the Palmeirim de Inglaterra's manuscript sequences. The book, wich we have called Crônica de D. Duardos, First Part, was probably written by D. Gonçalo Coutinho in the decade of 1580. After the introductory analysis, we present the transcription of the text, according to the cod. BNL 12904 (Lisbon National Library).
\end{abstract}




\section{SUMÁRIO}

\section{VOLUME I}

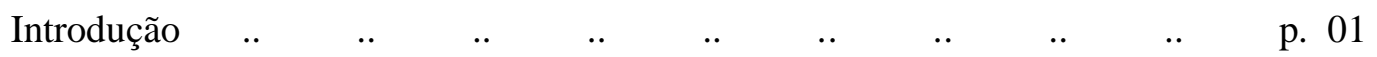

I. A CRÔNICA DE D. DUARDOS (PRIMEIRA PARTE) .. $\quad$.. $\quad$.. $\quad 10$

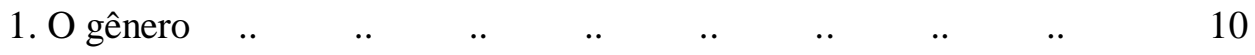

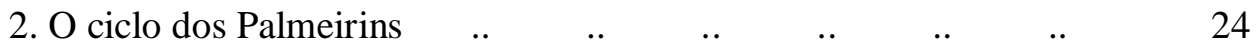

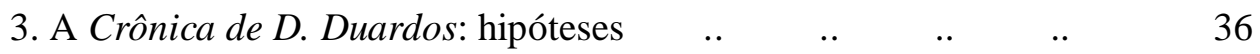

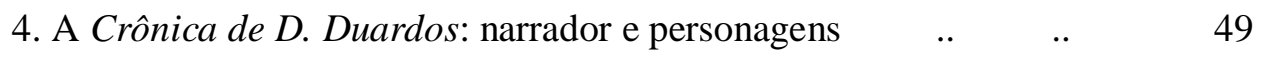

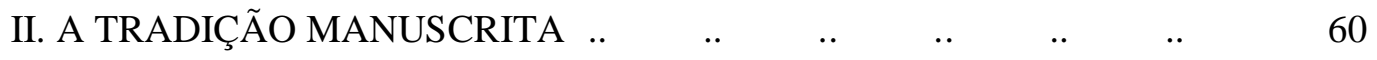

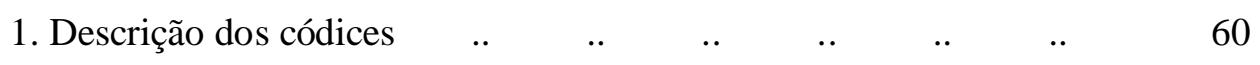

$\begin{array}{llllllll}\text { 1.1. Códice A .. } & . . & . . & . . & . . & . . & . . & 62\end{array}$

$\begin{array}{lllllllll}\text { 1.2. Códice B .. } & . . & . . & . . & . . & . . & . . & 65\end{array}$

$\begin{array}{lllllllll}\text { 1.3. Códice C .. } & . . & . . & . . & . . & . . & . . & 67\end{array}$

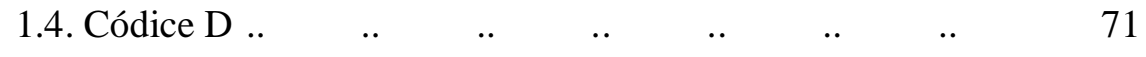

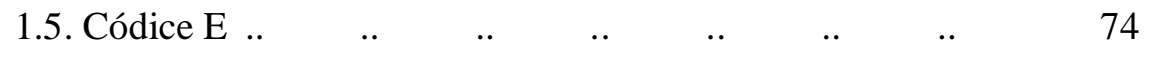

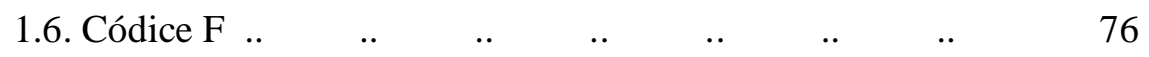

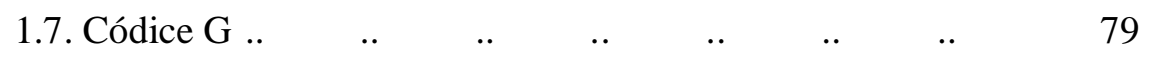

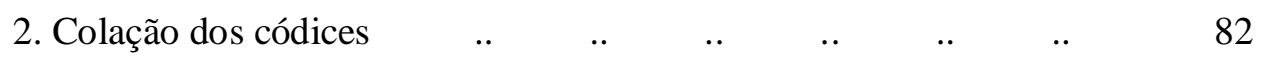

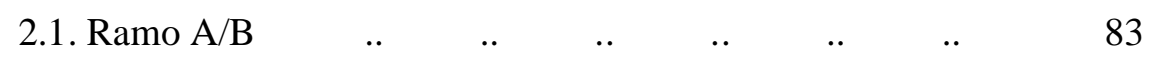

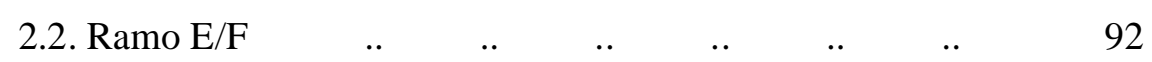

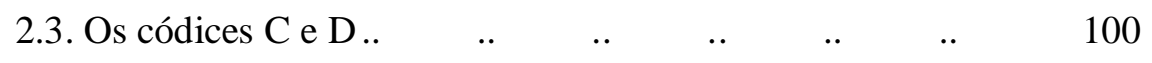

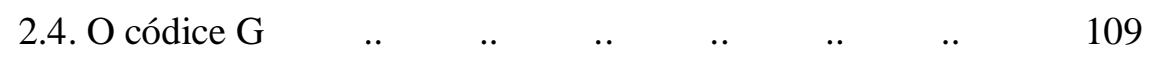

3. A tradição manuscrita: conclusões $\quad$.. $\quad$.

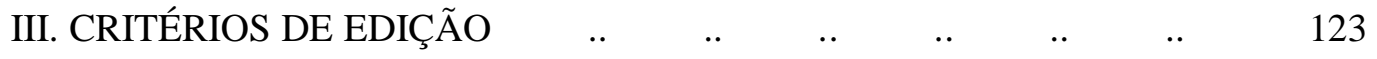

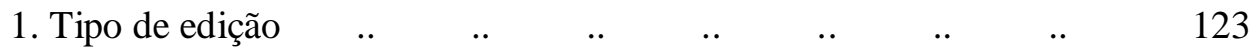

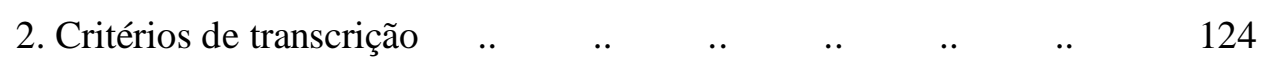

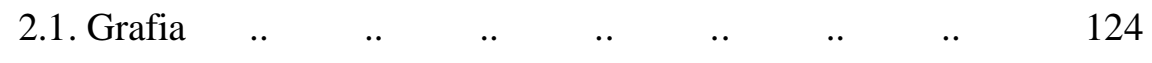

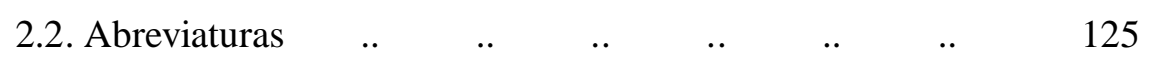

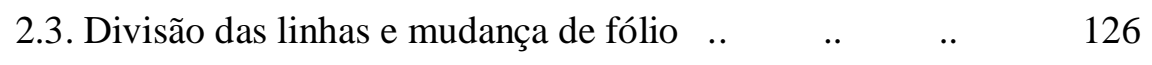

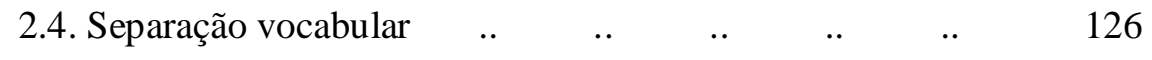




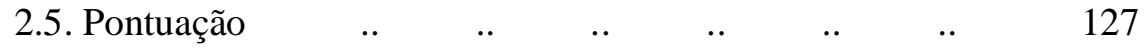

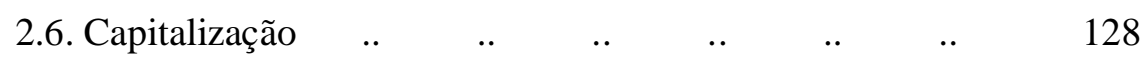

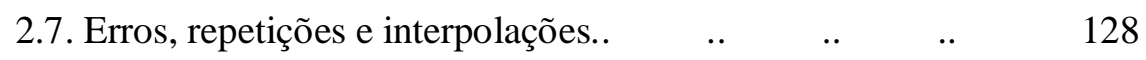

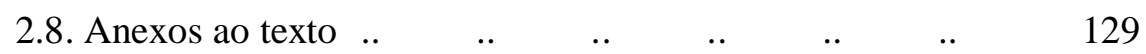

2.9. Alfabeto da Crônica de D. Duardos (Cód. BNL 12904).. 129

2.10. Exemplos dos sinais de pontuação $\quad$.. $\quad$. $\quad$. $\quad$. $\quad$. 131

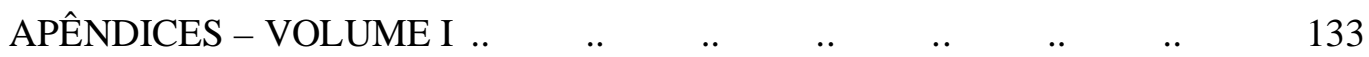

1. Quadro genealógico dos principais personagens do ciclo dos Palmeirins 134

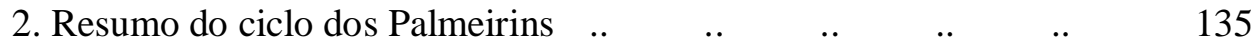

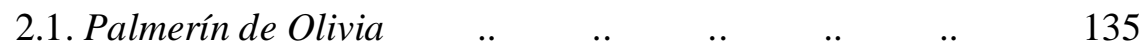

$\begin{array}{llllllll}\text { 2.2. Primaleón } & \text {.. } & \text {.. } & \text {.. } & \text {.. } & \text {.. } & \text {.. } & 139\end{array}$

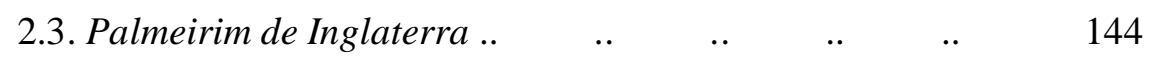

3. Reproduções de fólios dos códices da Crônica de D. Duardos $\quad$.. $\quad 148$

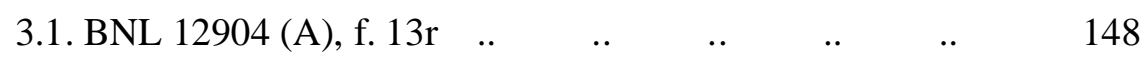

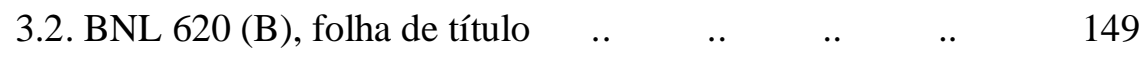

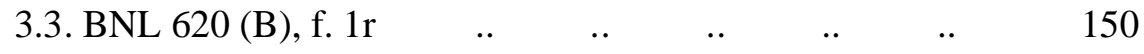

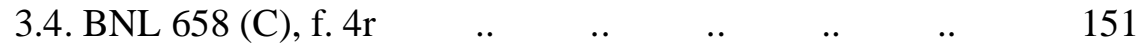

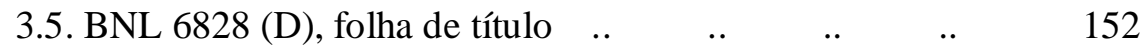

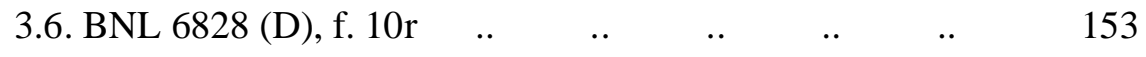

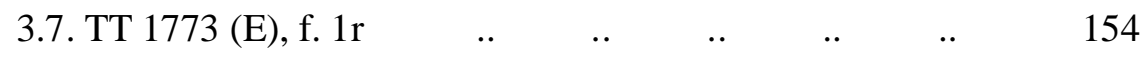

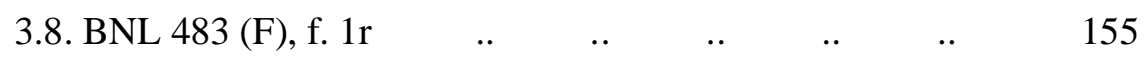

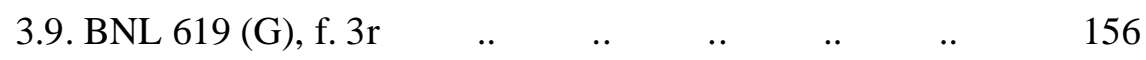

VOLUME II

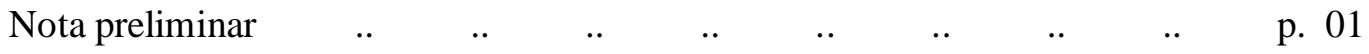

$\begin{array}{lllllllllll}\text { Folha de rosto (cód. BNL 12904) } & \text {.. } & \text {.. } & \text {. } & \text {. } & \text {.. } & \text {.. } & \text {. } & & 02\end{array}$

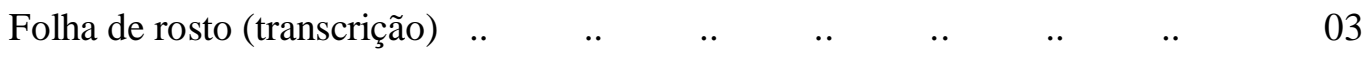

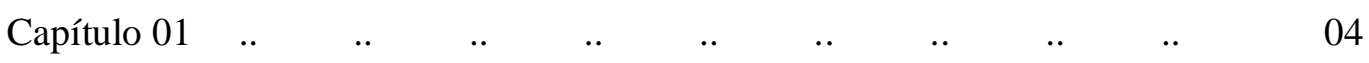

$\begin{array}{llllllllllllll}\text { Capítulo } 02 & . . & . . & . . & . . & . . & . . & . . & . . & . & & 08\end{array}$

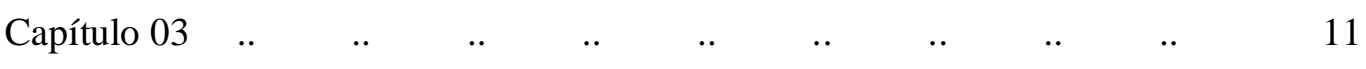

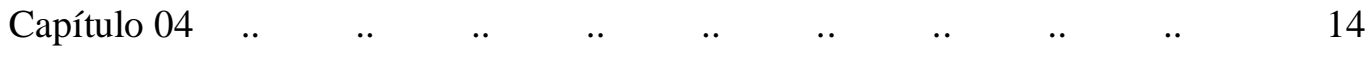


$\begin{array}{lllllllllllll}\text { Capítulo } 05 & . . & . . & . . & . . & . . & . . & . . & . . & . . & & 18\end{array}$

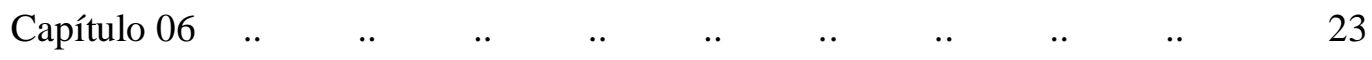

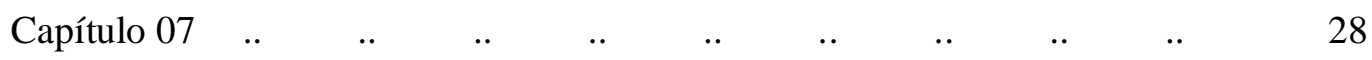

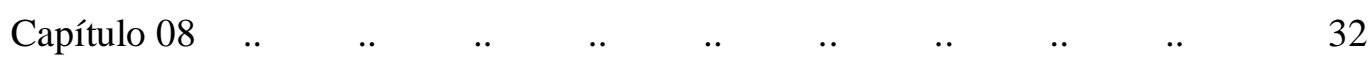

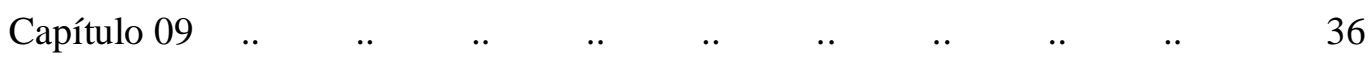

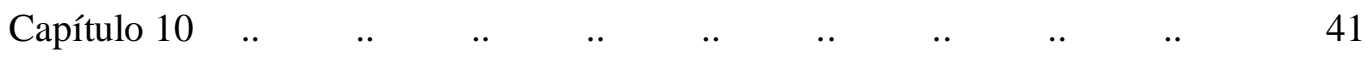

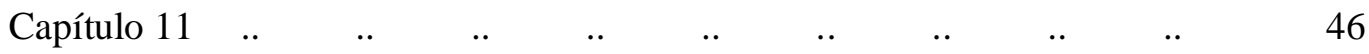

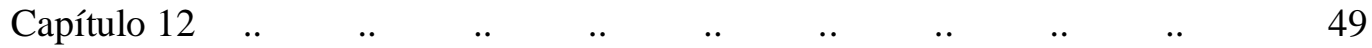

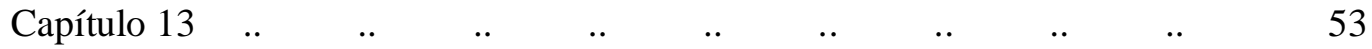

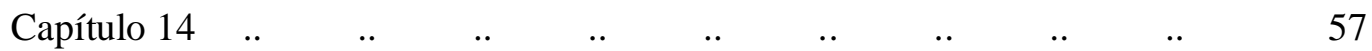

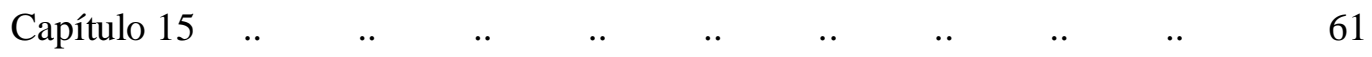

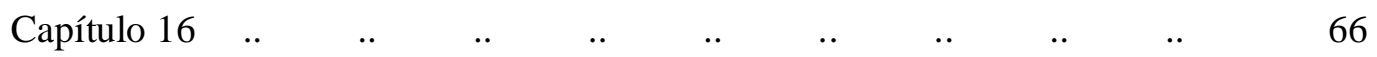

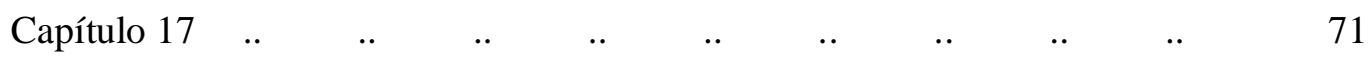

$\begin{array}{llllllllllllll}\text { Capítulo } 18 & . . & . . & . . & . . & . . & . . & . . & . . & . . & & 74\end{array}$

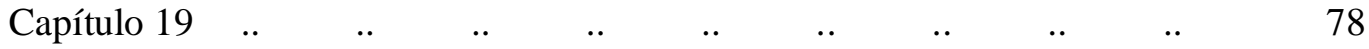

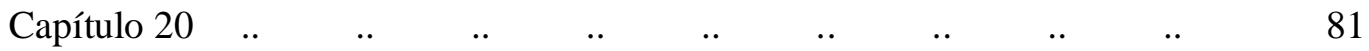

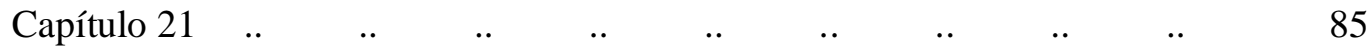

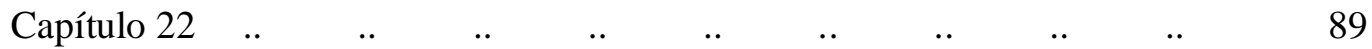

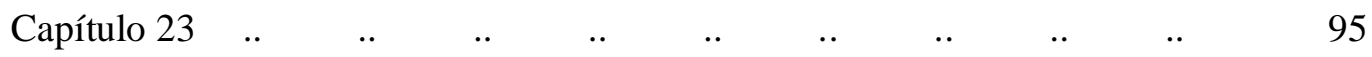

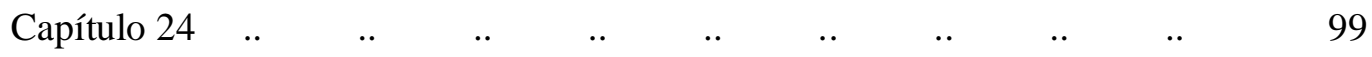

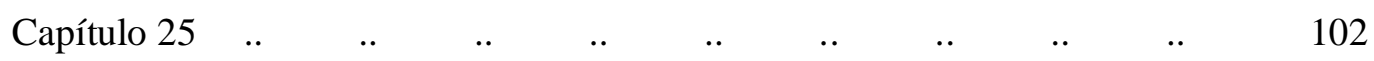

$\begin{array}{llllllllllllll}\text { Capítulo } 26 & . . & . . & . . & . & . & . & . & . . & . . & . . & . & & 106\end{array}$

$\begin{array}{lllllllllllll}\text { Capítulo } 27 & . . & . . & . . & . . & . . & . . & . . & . . & & . & & 110\end{array}$

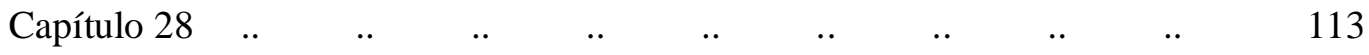

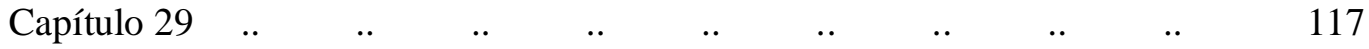

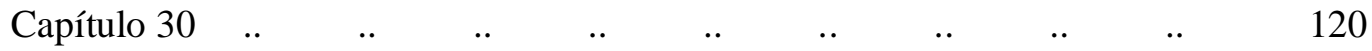

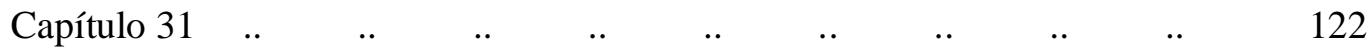

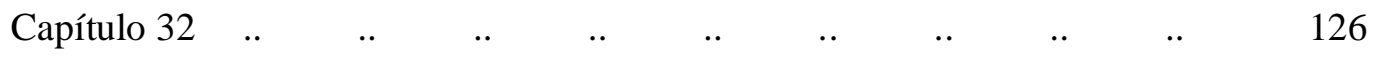

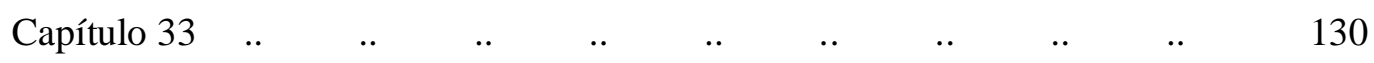

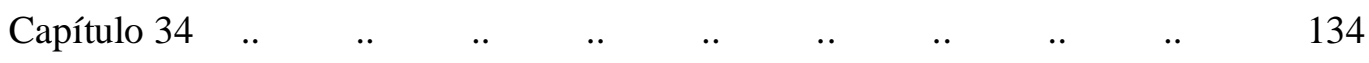

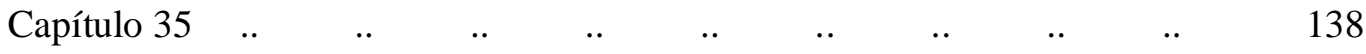

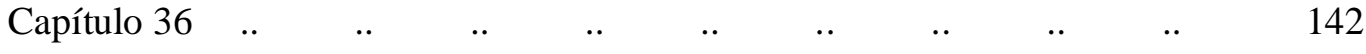




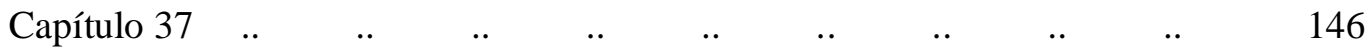

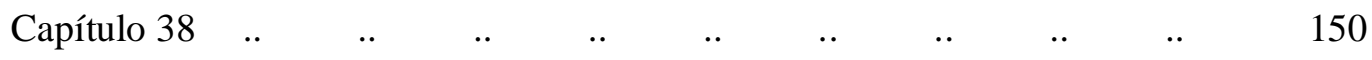

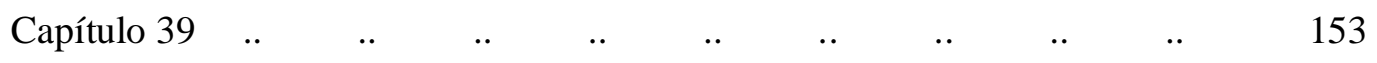

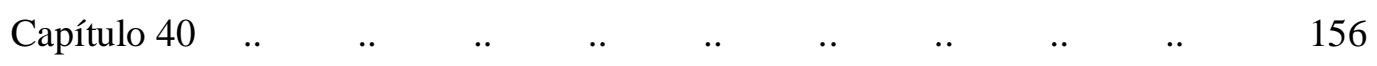

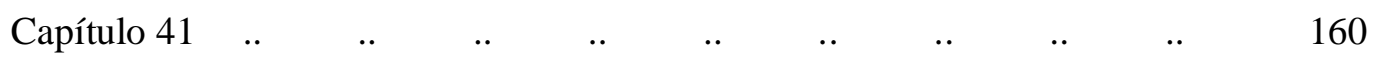

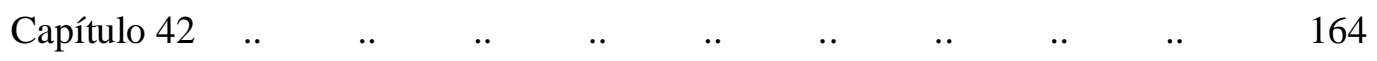

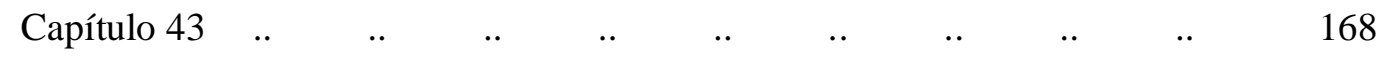

$\begin{array}{lllllllllllll}\text { Capítulo } 44 & . . & . . & . . & . . & . & . & . . & . & . & . . & . . & 172\end{array}$

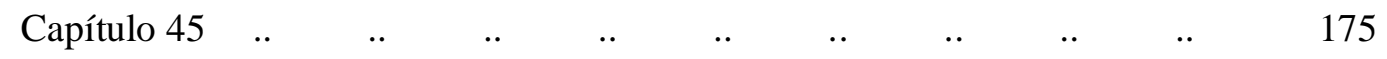

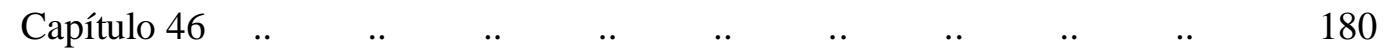

$\begin{array}{llllllllllllll}\text { Capítulo } 47 & . . & . . & . . & . & . & . & . & . & . & . & . . & . . & 184\end{array}$

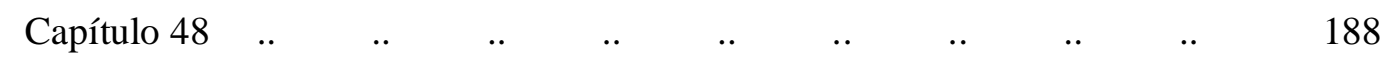

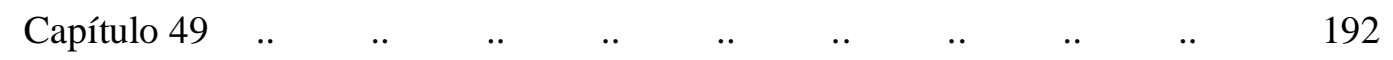

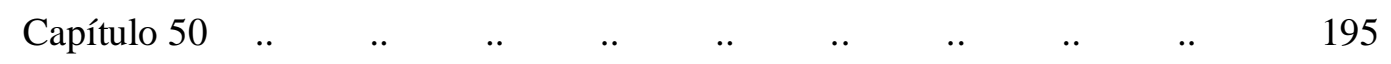

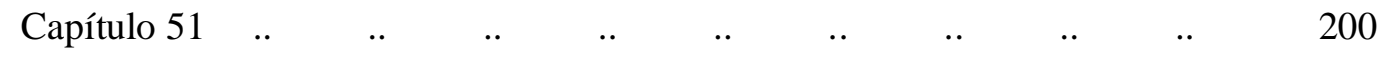

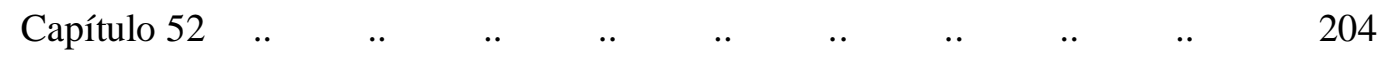

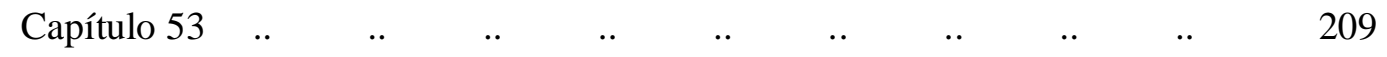

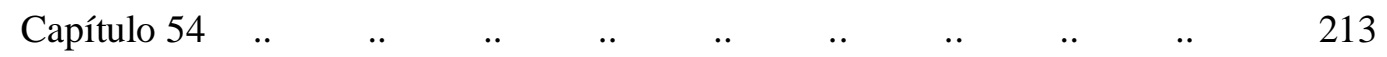

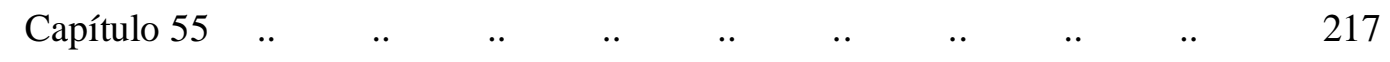

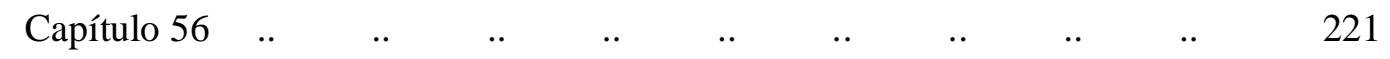

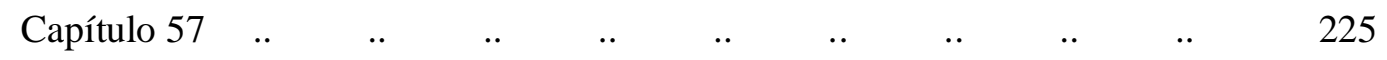

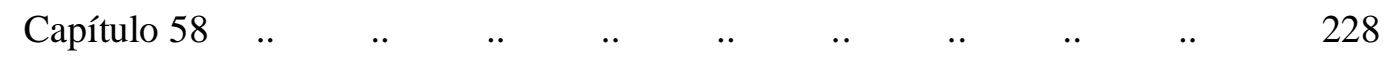

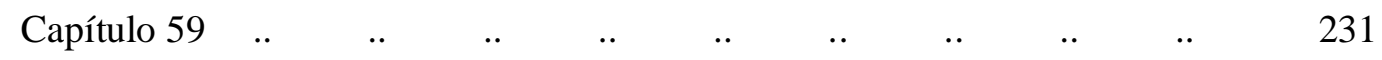

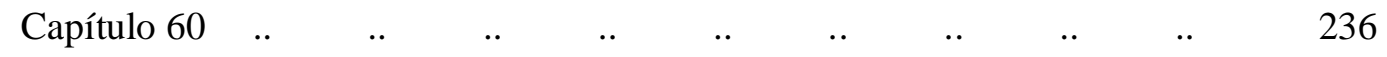

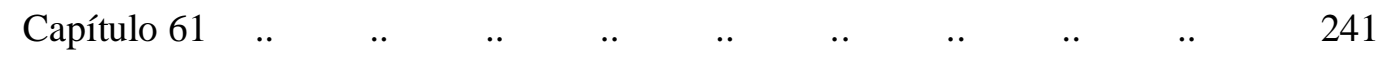

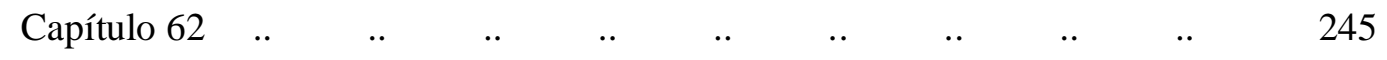

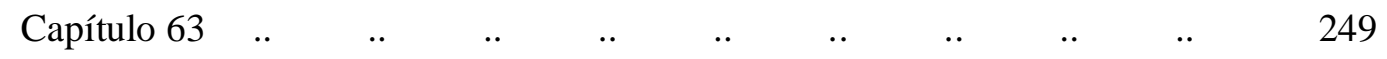

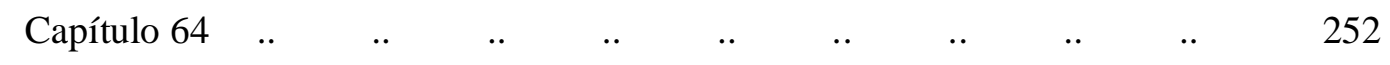

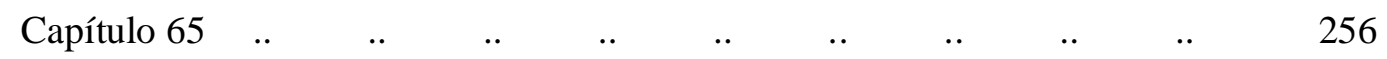

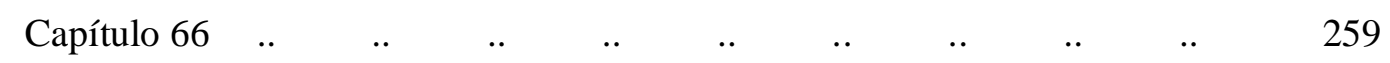

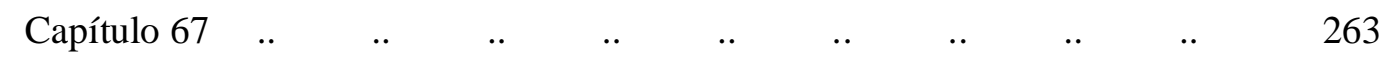

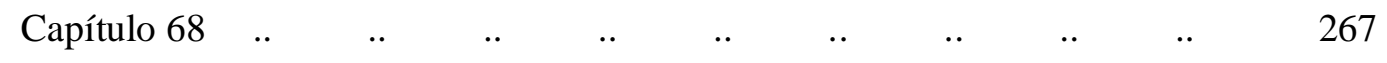




\begin{tabular}{|c|c|c|c|c|c|c|c|c|c|c|}
\hline Capítulo 69 & .. &.. & .. & .. & .. & .. & .. & .. & .. & 271 \\
\hline Capítulo 70 &.. & .. & .. &.. & .. & .. & .. & .. & .. & 275 \\
\hline Capítulo 71 &.. & .. & .. &.. & .. & .. & .. & .. & .. & 279 \\
\hline Capítulo 72 &.. &.. & .. &.. & .. & .. & .. & .. & .. & 283 \\
\hline Capítulo 73 &.. &.. & .. &.. & .. & .. & .. & .. & .. & 287 \\
\hline Capítulo 74 &.. &.. & .. &.. & .. & .. & .. & .. & .. & 290 \\
\hline Capítulo 75 &.. &.. & .. &.. & .. & .. & .. & .. & .. & 293 \\
\hline Capítulo 76 &.. &.. & .. &.. & .. & .. & . & .. & .. & 296 \\
\hline Capítulo 77 &.. &.. & .. &.. & .. & .. & . & .. & .. & 300 \\
\hline Capítulo 78 &.. &.. & .. &.. & .. & .. &.. & .. & .. & 305 \\
\hline Capítulo 79 &.. &.. & .. &.. & .. & .. & $\cdot \cdot$ & .. & .. & 308 \\
\hline Capítulo 80 &.. &.. & .. &.. & .. & .. & $\cdot \cdot$ & .. &.. & 312 \\
\hline Index .. &.. &.. & .. &.. & .. & .. & $\cdot \cdot$ & .. & .. & 316 \\
\hline \multicolumn{4}{|c|}{ APÊNDICES - VOLUME II. } & .. &.. & .. & $\cdot$ & .. & .. & 322 \\
\hline \multicolumn{2}{|c|}{ 1. Glossário } &.. & .. &.. & .. & .. & v & .. & .. & 323 \\
\hline \multicolumn{2}{|c|}{ 2. Índices } & .. & .. & .. & .. & .. & .. & .. & .. & 356 \\
\hline \multicolumn{5}{|c|}{ 2.1. Índice de personagens } &.. & .. & "* & .. & .. & 357 \\
\hline & \multicolumn{4}{|c|}{ 2.2. Índice geográfico.. } & .. & .. & • & .. & .. & 365 \\
\hline & \multicolumn{4}{|c|}{ 2.3. Índice de obras citadas } &.. & .. & $\cdot$ & .. & .. & 367 \\
\hline Bibliografia &.. &.. & .. &.. & .. & .. & .. & .. & .. & 368 \\
\hline
\end{tabular}




\section{INTRODUÇÃO}

"Cavalaria" é um termo pleno de ressonâncias: poucas palavras têm, como esta, tanto poder evocativo e tanta capacidade de despertar a imaginação. Transitando continuamente entre os pólos da realidade e da ficção, o cavaleiro errante ocupa ainda hoje posição de destaque na fantasia popular, que o retrata de diversas formas: como defensor de órfãos e viúvas, guiado por uma ética exigente que lhe impõe a lealdade e a justiça como valores máximos; como cruzado para libertar o túmulo de Cristo de mãos pagãs ou aventureiro inconseqüente no encalço da fama e do amor de nobres donzelas; como idealista incompreendido a combater moinhos de vento... Traços por vezes até contraditórios confluem a este personagem protéico que sobreviveu, adaptando-se ao longo de séculos, no imaginário coletivo.

A literatura cavaleiresca, criação tipicamente medieval, exerceu enorme fascínio sobre sucessivas gerações de leitores modernos. Com efeito, a ficção literária foi um dos ingredientes que contribuíram de modo decisivo para a idealização da cavalaria, possibilitando sua sobrevivência para além do contexto histórico que a engendrou, no século XII ${ }^{1}$. Assim, diversos ramos da cultura continuam a testemunhar a fecundidade do ideal cavaleiresco muito depois da Idade Média. Na literatura, além das óbvias referências a Cervantes e a escritores românticos (como Walter Scott, Dumas e Herculano), é preciso mencionar que romancistas contemporâneos voltaram a pôr em causa a figura do cavaleiro, como Ítalo Calvino e o português Almeida Faria. Guimarães Rosa e Ariano Suassuna atestam a vitalidade do imaginário cavaleiresco na cultura brasileira, assim como a poesia de cordel nordestina e as cavalhadas que ainda hoje se

\footnotetext{
${ }^{1}$ Embora guerreiros a cavalo sempre tenham existido, foi apenas a partir dos sécs. XI e XII que a cavalaria passou a ser associada aos elementos sociais e ético-religiosos que dão origem a uma peculiar "ideologia cavaleiresca" segundo a qual o cavaleiro é muito mais que um simples guerreiro montado. Surge, assim, a cavalaria como instituição, título nobiliário e "ordem", como se dizia na época: conceito que os franceses designam chevalerie, em oposição a cavalerie, contraste semelhante ao existente no inglês entre chivalry e cavalry. Cf. Cardini, F. O guerreiro e o cavaleiro, in: Le Goff, J (org.). O homem medieval. Lisboa: Presença, 1989, p. 57-78, e Flori, J. Cavalaria, in: Le Goff, J e Schmitt,J.-C. (orgs.) Dicionário temático do Ocidente Medieval. Bauru: Edusc / São Paulo: Imprensa Oficial, 2002, v. 1, p. 185-199. Sobre as relações entre a literatura cavaleiresca e o contexto histórico do séc. XII, veja-se Köhler, E. L'aventure chevaleresque: idéal et réalité dans le roman courtois. 2. ed. Paris: Gallimard, 1984.
} 
realizam em diversas regiões do país. No terreno da música, Wagner compôs em meados do séc. XIX duas óperas protagonizadas por cavaleiros medievais: Tristão e Parsifal. Também o cinema não ficou imune a sua influência: ainda hoje ressoam elementos cavaleirescos nas aventuras policiais e até mesmo nos grandes sucessos da ficção científica, em que novos heróis punem seus inimigos com golpes de espada laser. Nos tempos atuais, cada vez mais pragmáticos, em que o homem, carente de sentido e certeza, se vê como mero joguete de circunstâncias ou interesses, a figura do cavaleiro que a fantasia pinta como "representante da liberdade absoluta em direção ao ideal", de acordo com a bela expressão lembrada por Huizinga ${ }^{2}$ - pode parecer anacrônica ou até mesmo infantil, mas continua a seduzir.

Não é de estranhar, portanto, que o ideal da cavalaria permanecesse bastante vivo no imaginário do Renascimento. Não apenas textos medievais continuavam a ser lidos (lembre-se que a versão portuguesa da Demanda do Santo Graal foi preservada por um manuscrito datado de fins do século XV e que, no ano de 1535, a versão castelhana da obra ainda foi reeditada em Sevilha), como numerosos autores recorriam a antigas narrativas cavaleirescas, renovando-as: para confirmá-lo bastará citar a Morte de Artur, de Thomas Malory (1485), o Orlando Furioso, de Ariosto (1516), e as referências aos doze pares de França n’Os Lusíadas.

O elo menos conhecido desta longa tradição é o constituído pelos livros de cavalarias do Renascimento ibérico. Apesar de formarem uma vigorosa corrente literária durante todo o século XVI, com importantes repercussões também fora da Península, os livros de cavalarias espanhóis e portugueses foram por muito tempo praticamente ignorados. O exame das datas de edições constantes na Bibliografía de los libros de caballerías castellanos, organizada por Daniel Eisenberg e M. Carmen Marín Pina, mostra que é comum a situação de obras que, depois do séc. XVI, só voltaram a ser publicadas nas últimas décadas do séc. XX ou ainda continuam aguardando nova edição ${ }^{3}$. Ao ler o Quixote, o leitor moderno tem notícia desta volumosa produção que

\footnotetext{
${ }^{2}$ O declínio da Idade Média. 2. ed. Lisboa: Ulisséia, s/d, p. 79. A expressão é de W. James.

3 “Aunque se ha avanzado en la recuperación del género, resta mucho por hacer. Los libros de caballerías no se han librado todavía de la condena de Cervantes, y sólo unos pocos han podido publicarse", diziam ainda há poucos anos Eisenberg e Marín Pina, na referida Bibliografía (Zaragoza: Prensas Universitárias, 2000, p. 8). Quanto a Portugal, o mesmo se pode dizer: o único livro de cavalarias português que conta com edição recente é o Memorial das proezas da segunda Távola Redonda, de Jorge Ferreira de Vasconcelos (texto modernizado por Palma-Ferreira). Todos os demais continuam a aguardar edições críticas modernas e confiáveis.
} 
precede e justifica a obra-prima de Cervantes; mas, assim como o cura daquele obscuro vilarejo da Mancha que lançou quase toda a livraria de seu amigo às chamas, público e crítica relegaram boa parte dessas obras ao olvido quase completo por séculos.

Que os livros de cavalarias não ocupem posição central nas histórias da literatura renascentista, compreende-se; o que parece injustificado é o fato de pesar sobre todas essas obras, muitas das quais não foram sequer lidas por qualquer estudioso contemporâneo, uma verdadeira lápide de preconceito. Infelizmente, alguns bons conhecedores da literatura daquela época às vezes reforçam inadvertidamente essa animosidade. Menéndez y Pelayo, por exemplo, diz que os livros de cavalarias quinhentistas e seiscentistas, "exceptuados cuatro o cinco que merecen alto elogio", são pobres de idéias e de estilo, para concluir sua exposição da matéria com uma pergunta eloqüente: "como es posible que tan bárbaro y grosero modo de novelar coexistise en una civilización tan adelantada" como a do siglo de oro ${ }^{4}$ ? Embora referindo-se a uma das raras obras poupadas pelo erudito espanhol, o Palmeirim de Inglaterra, de Francisco de Morais, António José Saraiva e Óscar Lopes não se mostram convencidos de seu valor:

O seu interesse literário não nos parece extraordinário (...). Trata-se de um emaranhado de aventuras de Palmeirim e outros cavaleiros, tão compridas como as do Texas Jack ou dos velhos filmes em 24 partes e tão extraordinárias como as do Super-Homem na banda desenhada: combates e lutas com gigantes, feiticeiros, selvagens, dragões; prisões e libertações; passagens de pontes e outros passos defesos; traições castigadas; equívocos e reconhecimentos; duelos, torneios, sortes de magia. O herói vence todos estes obstáculos e é recompensado no final $^{5}$.

E assim se adensa a sombra de preconceito que recobre o conjunto dos livros de cavalarias quinhentistas. E, no entanto, mesmo sem despertar "interesse extraordinário", o Palmeirim de Inglaterra não carece de qualidades: o "estilo limpidíssimo", o interesse do argumento e o sábio equilíbrio do diverso material narrativo foram alguns dos aspectos destacados por estudiosos da obra ${ }^{6}$. Além disso, o Palmeirim foi reeditado

\footnotetext{
${ }^{4}$ Orígenes de la novela. Buenos Aires: Espasa-Calpe, 1946, v. 1, p. 466-447.

${ }^{5}$ História da Literatura Portuguesa. 16 ed., Porto: Porto Editora, 1989, p. 410.

${ }^{6}$ Cf. Finazzi-Agrò, Ettore. A novelística portuguesa do século XVI. Lisboa: Instituto de Cultura Portuguesa, 1978, p. 46; Thomas, Henry. Las novelas de caballerías españolas y portuguesas. Madrid: Consejo Superior de Investigaciones Científicas, 1952, p. 82; Ferreira, Jerusa Pires. O tapete preceptivo
} 
várias vezes até o séc. XIX, inclusive em diversas traduções estrangeiras, tendo ainda merecido referências elogiosas no Quixote.

Os livros de cavalarias permaneceram por longo período encerrados nos arquivos e alfarrábios também em consequiência de certos equívocos críticos, como a descrição de tais obras como mera "sobrevivência" da tradição medieval e, por isso mesmo, como pertencentes a um gênero secundário e decadente - moribundo à espera do golpe de misericórdia dado por Cervantes. Na realidade, contudo, as coisas se passaram de outra forma.

Certa visão simplista da História - hoje felizmente superada, embora permaneça arraigada no senso comum - esquece que muitos dos traços "novos" apresentados como distintivos do Renascimento (como a valorização da razão e dos autores clássicos, o desenvolvimento científico e as grandes navegações, para citar os mais comuns) lançam fundas raízes nos séculos anteriores. Da mesma forma, elementos tidos como tipicamente medievais marcaram presença nos séculos posteriores, demonstrando não haver fronteiras nítidas ou rupturas violentas entre a Idade Média e o Renascimento. No entanto, chavões cômodos usados para sublinhar a oposição entre os dois momentos transmitiram uma idéia demasiado florentina e artificial do século XVI, viciando a compreensão de todo o período. E, assim, porque não pareciam acomodar-se bem aos parâmetros utilizados para descrever a cultura quinhentista, os livros de cavalarias foram postos de lado, sob o pretexto de não serem representativos do que se cria ser o verdadeiro espírito da época ${ }^{7}$.

É preciso notar, contudo, que os leitores contemporâneos aos livros de cavalarias não os percebiam como antiquados ou ultrapassados ${ }^{8}$. Um escritor representativo da época como João de Barros não se furtou a compor a fantasiosa Crônica do Imperador Clarimundo, dedicando-a ao futuro monarca. Já o Palmeirim de Inglaterra, iniciador do

do Palmeirim de Inglaterra. Tese apresentada ao Instituto de Letras da Universidade Federal da Bahia para Concurso de Professor Assistente do Departamento de Letras Vernáculas. Salvador, 1973, p. 3.

${ }^{7}$ Embora possua inegáveis qualidades, a obra clássica de Jacob Burckhardt (A cultura do Renascimento da Itália) reforçava o esquematismo da oposição entre o mundo medieval e o renascentista. Sobre a falsidade desse postulado, ver Heers, Jacques. A Idade Média, uma impostura. Lisboa: Asa, 1994, e também Garin, Eugénio. Idade Média e Renascimento. Lisboa: Estampa, 1994.

8 "Ese público sí percibía el componente realista que incorporan estas obras, al lado de esa componente fantástica, porque alude a aspectos presentes en su realidad (...). Por otra parte, el conjunto de estas obras transmitían una ideología destinada a actuar sobre sus lectores, y en ese sentido no puede ser entendido como un género desligado de la realidad”. M. Luzdivina Cuesta Torre. La realidad histórica en la ficción de los libros de caballerías, in: Libros de caballerías (de “Amadís” al "Quijote”). Salamanca: SEMYR, 2002, p. 87-88. 
ciclo com o qual trabalharemos, surgiu durante o reinado de D. João III (1521-1557), período que, segundo Oliveira Marques, coincidiu com a grande época do Humanismo nacional ${ }^{9}$. Ignorar esses fatos, criando a impressão de suposta homogeneidade cultural em torno dos valores clássicos e humanistas no século XVI, é distorcer a realidade: com efeito, o "recorte" necessário a toda pesquisa histórica não pode mutilar o objeto de análise.

Em âmbito ibérico, os livros de cavalarias estão longe de formar um gênero crepuscular durante o Renascimento; ao contrário, o século XVI representa justamente seu zênite, que culmina com Cervantes. A quantidade de obras produzidas é testemunho inequívoco do fato de que elas correspondiam à sensibilidade dos leitores de Quinhentos e, em suma, atendiam a uma demanda do público de então. O descaso que essas obras têm merecido da crítica não apenas desfigura a imagem que se faz da cultura daquele tempo, como também distorce a visão que construímos acerca do sistema literário da época, impedindo por exemplo que se reconheçam possíveis influências que os livros de cavalarias possam ter exercido sobre outras obras ${ }^{10}$. Afinal, qualquer gênero é parte integrante de um sistema mais amplo, que interessa a todos compreender bem e não só aos poucos que se aventuram pelas sendas das narrativas cavaleirescas ${ }^{11}$.

Testemunhos literários pouco conhecidos de um período excepcional da história portuguesa, os livros de cavalarias, em grande parte ainda por editar e estudar, ocupam lugar próprio na história da literatura. Não será, é verdade, um posto de honra; nem por isso se justifica seu esquecimento. Essa vigorosa produção novelística representou um dado significativo no seu tempo, quando menos pelo aspecto quantitativo das obras e pelo caloroso acolhimento do público. Assim, não se pode ignorar seu papel na tentativa de reconstruir o painel do Quinhentismo português, que Joaquim Barradas de Carvalho considerava a "placa giratória" da história de Portugal ${ }^{12}$.

\footnotetext{
${ }^{9}$ História de Portugal. 12 ed., Lisboa: Palas, 1985, v. 1, p. 332-358.

10 Apenas em âmbito português, não se pode desprezar a influência dos livros de cavalarias sobre Gil Vicente, autor de D. Duardos (1522) e Amadis de Gaula (1523), bem como sobre Camões.

${ }^{11}$ Alan Deyermond já dizia, em célebre artigo de 1982, estar convencido "that one cannot adequately understand or appreciate the literature of Spain in the Middle Ages, or even a number of widely-read works, without taking account of the romances as an important Spanish manifestation of a major European genre" (The lost genre of medieval Spanish literature, in: Bustos Tovar, E (org.). Actas del cuarto congreso internacional de hispanistas. Salamanca: Universidade, 1982, v. 1, p. 809). É preciso observar que do "gênero desaparecido" ao qual Deyermond se refere fazem parte os livros de cavalarias. Por isso, sua observação pode ser considerada válida para a literatura do séc. XVI e também para o caso português.

${ }^{12}$ O Renascimento português: em busca de sua especificidade. Lisboa: IN / BM, 1980, p. 13.
} 
Apesar de tudo, o quadro felizmente vem se alterando na última década. Em Espanha, pesquisadores ligados ao Centro de Estudios Cervantinos (CEC) de Alcalá de Henares têm trazido a lume diversos livros esquecidos há séculos, em coleção dirigida por Carlos Alvar e José Manuel Lucía Megías. O Seminario de Estudios Medievales y Renacentistas (SEMYR) de Salamanca vem oferecendo também contribuição relevante para os estudiosos da área através da realização de congressos e da promoção de diversas publicações. No caso português, embora com menor intensidade, também se verifica crescente interesse pelos livros de cavalarias, fato testemunhado, por exemplo, pela apresentação da tese de doutoramento de Isabel Adelaide Penha Dinis de Lima e Almeida, trabalho pioneiro que deverá ser considerado referência obrigatória em qualquer futuro estudo sobre o tema (e não apenas no âmbito da Literatura Portuguesa), ou pelas pesquisas realizadas pelo investigador espanhol Aurelio Vargas Díaz-Toledo ${ }^{13}$.

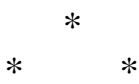

O presente trabalho lida com as continuações do Palmeirim de Inglaterra, o mais célebre livro de cavalarias português. A obra de Francisco de Morais, editada pela primeira vez em cerca de 1544, fez tal sucesso entre o público da época que, além de ter sido vertida para diversos outros idiomas (como francês, inglês e italiano, e mais o castelhano, que serviu de base para as demais traduções), estimulou vários autores a produzirem continuações da trama, processo então comum entre os livros de cavalarias. Duas delas foram publicadas em Lisboa: D. Duardos Segundo, de Diogo Fernandes (1587), e D. Clarisol de Bretanha, de Baltasar Gonçalves Lobato (1602). Mas há também outras continuações, que nunca foram impressas e permanecem inéditas ${ }^{14}$.

Nosso objetivo central foi o de resgatar a memória da primeira parte das continuações manuscritas do Palmeirim de Inglaterra (a que chamaremos Crônica de D. Duardos, Primeira Parte), divulgando um fragmento da Literatura Portuguesa que jaz no esquecimento há pelo menos três séculos e meio. Para tanto, realizamos a

${ }^{13}$ Cf. Isabel Adelaide de Lima e Almeida, Livros portugueses de cavalarias, do Renascimento ao Maneirismo. Dissertação de doutoramento em Literatura Portuguesa, apresentada à Faculdade de Letras da Universidade de Lisboa, 1988. Ver também Díaz-Toledo, Aurelio Vargas. Os livros de cavalarias renascentistas na história da Literatura Portuguesa, in: Península: Revista de Estudos Ibéricos, $\mathrm{n}^{\circ}$ 3, 2006, p. 233-248; e, do mesmo autor, Leomundo de Grecia: hallazgo de un nuevo libro de caballerías portugués, in: Voz y Letra, vol. 15 (2), 2004, p. 3-32.

${ }^{14}$ São ao todo 15 manuscritos, contendo 3 diferentes partes da continuação do Palmeirim. Ver, adiante, cap. 1 , item 3 . 
transcrição de uma das cópias do texto, o cód. 12904 da Biblioteca Nacional de Lisboa. Da mesma forma, desejamos oferecer nossa contribuição para a busca de respostas a questionamentos repetidos desde os anos 1930, quando Fidelino de Figueiredo divulgou a primeira notícia acerca dos manuscritos de que nos ocupamos: quem teria sido o autor desta Crônica? Quando teria sido escrita? Que relação mantém com as continuações impressas de Fernandes e Lobato? Qual a explicação para o fato de o assim chamado "ciclo dos Palmeirins" apresentar-se bifurcado, com duas seqüências paralelas (a impressa e a manuscrita) da obra de Morais? E acima de tudo: qual o valor das continuações manuscritas do Palmeirim, sobre as quais Fidelino de Figueiredo, mesmo sem tê-las lido, afirmou que "seus méritos literários são muito escassos, pois como imitações apenas repetem os defeitos do gênero" ${ }^{15}$ ?

A parte inicial desta tese é dividida em três capítulos. O primeiro serve de apresentação geral à Crônica de D. Duardos, Primeira Parte: para isso, buscamos contextualizá-la no conjunto dos livros de cavalarias ibéricos quinhentistas (item 1) e no interior do ciclo de que faz parte (item 2); em seguida, no $3^{\circ}$ item, apresentamos nossas hipóteses acerca da autoria e datação do texto, para enfim (item 4) proceder ao exame sumário da obra.

O segundo capítulo visa principalmente a justificar a escolha do manuscrito que serviu de base para nossa transcrição. Para tanto, empreendemos inicialmente a descrição detalhada dos sete testemunhos conhecidos da primeira parte da Crônica de D. Duardos e, em seguida, apresentamos as conclusões do cotejo entre as lições das diversas cópias, o que nos permitiu propor um estema abrangendo todos os códices deste grupo.

Por fim, no terceiro capítulo, são apresentados os critérios adotados na transcrição do texto.

A referida primeira parte possui ainda alguns apêndices, elaborados para auxiliar a leitura do texto transcrito. O primeiro consiste no quadro genealógico dos principais personagens do ciclo e o segundo, num breve resumo das obras que antecedem a Crônica de D. Duardos, ferramentas que podem se revelar úteis para o leitor pouco

${ }^{15}$ História da Literatura Clássica. 2 ed. Lisboa: Livraria Clássica, 1930, v. 3, p. 34. Que o crítico português não as leu, fica claro pelo fato de ele não ter notado que diversos manuscritos encontrados eram cópias do mesmo texto com títulos diferentes. 
familiarizado com o ciclo dos Palmeirins. No terceiro apêndice são reproduzidos alguns fólios dos manuscritos que contêm cópias do texto.

A segunda parte do trabalho, encadernada em volume separado, consiste basicamente na transcrição da Crônica de D. Duardos, Primeira Parte, de acordo com a lição do cód. BNL 12904, que também vem acompanhada de dois apêndices: glossário e índices.

Esperamos, com isso, oferecer nossa contribuição para reavivar o interesse pelos livros de cavalarias portugueses, de forma a que outros pesquisadores possam dedicar-se ao tema trabalhando com os demais textos que permanecem esquecidos, ou mesmo completando e corrigindo o que for preciso nesta nossa edição.

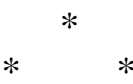

Cabem aqui algumas observações finais. Todo estudo sobre os livros de cavalarias ibéricos lida com o embaraço causado pela dificuldade de encontrar um termo adequado para indicar o gênero ${ }^{16}$. Embora não nos pareça injustificado chamá-los de novelas de cavalaria - pois é disto que se trata - optamos por adotar a expressão livros de cavalarias, que vem sendo empregada pelos estudiosos espanhóis da matéria e foi acolhida por Isabel Adelaide Penha Dinis de Lima e Almeida na recente tese de doutoramento, já referida. São tão poucos os que se dedicam a este assunto, que não seria razoável dividir o pequeno grupo criando obstáculos para a divulgação e conhecimento do gênero ${ }^{17}$.

\footnotetext{
${ }^{16}$ Veja-se, por exemplo, Deyermond, A., op. cit., p. 805-807, e Avalle-Arce, Juan Bautista. Amadís de Gaula: el primitivo y el de Montalvo. México: Fondo de Cultura Económica, 1990, p. 13-17.

${ }^{17}$ A recusa da expressão novela de cavalaria pelos estudiosos espanhóis parece melhor justificada, pois em castelhano o termo novela apresenta significado mais próximo dos termos correspondentes em francês e italiano, onde nouvelle e novella indicam textos de dimensões normalmente reduzidas, próximas a de um conto, como no caso das Novelas ejemplares, de Cervantes. Na tradição luso-brasileira, ao contrário, o conceito de novela é caracterizado pela pluralidade dramática, pela variedade espacial e por comportar grande quantidade de personagens, entre outros traços que implicam textos mais extensos e que são comuns nos livros de cavalarias. Dessa forma, não obstante o emprego da expressãolivros de cavalarias, poderá ser útil não esquecer que estas obras são representantes do que a crítica moderna chama de novela; aliás, elas estão entre os primeiros exemplos de novelas na literatura portuguesa e desempenharam papel de relevo na consolidação desta fôrma literária nas letras luso-brasileiras. Cf. Moisés, M. A criação literária. Prosa (I). 15 ed., São Paulo: Cultrix, 1994, especialmente o cap. III (p. 103-156) e a p. 31, onde é apresentado quadro geral das correspondências entre os termos romance, novela e conto nas principais línguas européias. É oportuno esclarecer ainda que: 1. emprega-se a expressão livro de cavalarias no singular; 2. de acordo com uso corrente nos estudos recentes sobre o tema, empregamos o conceito de gênero para designar o conjunto de livros de cavalarias quinhentistas (cf. Lucía Megías, José Manuel. Imprenta y libros de caballerías. Madrid: Olleros \& Ramos, 2000, p. 33-35).
} 
Quando mencionamos nomes de personagens dos livros estudados, optamos por utilizar a grafia portuguesa modernizada. Assim, por exemplo, preferimos "Palmeirim de Oliva" e "Primaleão" às formas castelhanas, que reservamos unicamente para os casos de referências aos títulos das obras por eles protagonizadas: Palmerín de Olivia e Primaleón. Também adaptamos certos nomes próprios às normas vigentes de acentuação, como os de Gridônia e Flérida. É claro que tais alterações não foram aplicadas nas citações de textos alheios e na transcrição do cód. BNL 12904. 


\section{CAPÍTULO 1}

\section{A CRÔNICA DE D. DUARDOS (PRIMEIRA PARTE)}

\section{O gênero.}

Embora não tenha sido propriamente o primeiro livro de cavalarias ibérico, o Amadís de Gaula é apontado pela crítica como o precursor do gênero na Península. A extraordinária obra de Garci Rodríguez de Montalvo (cujo exemplar mais antigo que se conhece é de 1508, ainda que os estudiosos postulem a existência de edições anteriores) tornou-se modelo de toda a numerosa prole dos livros de cavalarias no século XVI. A obra, reeditada 18 vezes entre 1508 e 1586, exerceu poderosa influência na literatura e nos costumes de seu tempo, a ponto de Menéndez y Pelayo ter afirmado que o Amadís converteu-se em

el doctrinal del cumplido caballero, la epopeya de la fidelidad amorosa, el código del honor que disciplinó a muchas generaciones; y aún entendido más superficialmente y en lo que tiene de frívolo, fué para todo el siglo XVI el manual del buen tono, el oráculo de la elegante conversación, el repertorio de las buenas maneras y de los discursos gallantes ${ }^{18}$.

O prestígio da obra não se restringe às fronteiras ibéricas: além das numerosas edições e traduções estrangeiras, cumpre lembrar que Castiglione menciona certos episódios do Amadís no Il Cortegiano e que sua importância como manual de cortesia foi tanta que se publicou em Paris um Trésor des Livre d'Amadis (1559) com ditos de educação e eloqüência, posteriormente traduzido para o inglês ${ }^{19}$.

O próprio Montalvo encarregou-se de escrever a primeira seqüência do Amadís, chamada Las Sergas de Espladián, que também recebeu caloroso acolhimento do

\footnotetext{
${ }^{18}$ Op. cit., v. 1, p. 358.

${ }^{19}$ Cf. Thomas, H. Las novelas de caballerías españolas y portuguesas. Madrid: Consejo Superior de Investigaciones Científicas, 1952, p. 139 e 183, e Avalle-Arce, J. B., op. cit., p. 58-63.
} 
público, ainda que sua difusão tenha sido menos exuberante que a de seu antecessor: entre os últimos anos do séc. XV, quando os estudiosos acreditam que o texto tenha sido impresso pela primeira vez, e o ano de 1588, contam-se cerca de 12 edições da obra, segundo as estimativas de Daniel Eisenberg e María Carmen Marín Pina ${ }^{20}$. Valendo-se do grande sucesso dos livros de Montalvo, vários outros escritores aventuraram-se a compor novas continuações da narrativa. A contribuição destes autores resultou num impressionante conjunto de textos conhecido por "ciclo dos Amadises", cujo último ramo foi publicado por Feliciano de Silva em 1551: trata-se da quarta parte do Florisel de Niquea, o décimo-primeiro livro amadisiano.

O exemplo de Montalvo serviu de estímulo também para o surgimento de numerosos outros livros de cavalarias que não apresentavam qualquer relação direta com o Amadís, aos quais devem ser somadas as reedições de obras mais antigas promovidas por diversas casas editoriais castelhanas, desejosas de lucrar com o filão recém descoberto. Dessa forma, a partir de 1508, a impressão de narrativas cavaleirescas ganha impulso e o elenco de títulos não pára de crescer de ano a ano: Oliveros de Castilla, em 1509; Florisando, além de novas edições de Oliveros de Castilla e do Espladián, em 1510; Reinaldos de Montalbán, Palmerín de Olivia, Tirante el Blanco e Tristán de Leonis, em 1511; e assim por diante. Examinando as datas das primeiras edições dos livros de cavalarias e a cronologia dos títulos lançados pelas prensas espanholas, nota-se que o auge da voga do gênero em Espanha ocorreu por volta do segundo quartel do séc. XVI; após os anos 1550, a quantidade de novos lançamentos e de reedições decresce sensivelmente, embora se mantenha em ritmo apreciável até o final daquela centúria ${ }^{21}$. Em Portugal, o panorama é ligeiramente distinto: além de ser quantitativamente mais modesta, a produção e edição de livros de cavalarias distribui-se de modo mais uniforme até os primeiros anos do século XVII ${ }^{22}$.

\footnotetext{
${ }^{20}$ Eisenberg e Marín Pina. Bibliografía, op. cit., p. 223-225.

${ }^{21}$ Cf. o "Libros de caballerías impresos: cronología de primeras ediciones", in: Eisenberg e Marín Pina, Bibliografía, op. cit., p. 458-459; veja-se também o "Índice cronológico de libros de caballerías castellanos" em Lucía Megías, José Manuel. Imprenta y libros de caballerías, op. cit., p. 609-618.

${ }^{22}$ Cf. Díaz-Toledo, Aurelio Vargas. Os livros de cavalarias em Castela e Portugal. Um caso particular: a Selva de Cavalarias Famozas, de António de Brito da Fonseca, item 1: "Sobre os livros de cavalarias impressos". Cópia do trabalho gentilmente cedida pelo autor. Sobre o caso português, veja-se ainda Isabel Adelaide Penha Dinis de Lima e Almeida. Livros portugueses de cavalarias, do Renascimento ao Maneirismo, op. cit., em especial as p. 21 e 74. Ao final da elaboração deste trabalho, tivemos notícia da recente publicação da versão castelhana do Palmerín de Inglaterra (Libro I), a cargo de Aurelio Vargas Díaz-Toledo (Alcalá de Henares: Centro de Estudios Cervantinos, 2006), onde em anexo constam
} 
A extraordinária difusão do gênero pode ser medida por uma observação de Francisco López Estrada: considerando que no século XVI houve 243 edições de livros de cavalarias e estimando que a tiragem de cada uma delas fosse de mil exemplares, chegaríamos à soma de 243.000 livros impressos "para una población que, incluido Portugal, no llegaba a los diez millones" ${ }^{23}$. Mas é preciso não esquecer que, numa época em que a grande maioria do público era analfabeta, a leitura individual não seria a única forma de contato com a literatura ${ }^{24}$. Certa passagem do Quixote retrata um hábito seguramente comum naquele tempo: o dono da venda em que alguns personagens estavam hospedados diz possuir "dos o tres" livros de cavalarias

que verdaderamente me han dado la vida, no sólo a mi, sino a otros muchos. Porque cuando es tiempo de la siega, se recogen aquí, las fiestas, muchos segadores, y siempre hay algunos que saben leer, el cual coge uno destos libros en las manos, y rodeámonos dél más de treinta, y estámosle escuchando con tanto gusto, que nos quita mil $\operatorname{canas}^{25}$.

Outro meio de difusão das aventuras cavaleirescas era a recitação. Juan Manuel Cacho Blecua refere a história de Román Ramírez, um mouro aficcionado por livros de cavalarias, o qual ganhava a vida recitando-os de memória para auditórios variados, tendo chegado inclusive a apresentar-se diante do próprio rei D. Filipe. Seu talento prodigioso custou-lhe caro, entretanto: intrigas pessoais levaram-no ao tribunal da Inquisição, acusado de ter parte com o demônio ${ }^{26}$. O caso de Román Ramírez é certamente excepcional, mas permite supor a existência de outros recitadores que viveriam de expedientes semelhantes, declamando trechos de livros de cavalarias alterados e adaptados ao sabor da platéia e de sua capacidade de memorização, recorrendo a fórmulas e motivos consagrados, aos quais talvez acrescentassem elementos de sua lavra.

informações sobre os livros de cavalarias impressos em Portugal, os livros manuscritos portugueses e uma árvore genealógica dos principais personagens do Palmeirim.

${ }^{23}$ Siglos de Oro: Renacimiento. Primer suplemento, in: Rico, F. (org). Historia y crítica de la Literatura Española. Barcelona: Crítica, 1991, p. 143.

${ }^{24}$ Sobre os índices de analfabetismo em Portugal no séc. XVI, cf. Curto, Diogo Ramada. Língua e memória, in: Magalhães, Joaquim Romero de (coord), História de Portugal (dir. J. Mattoso). Vol. III: No alvorecer da Modernidade (1480-1620). Lisboa: Estampa, 1997, p. 322.

${ }^{25}$ Cap. 32, parte I. Citamos a partir da edição de Martín de Riquer (Barcelona: Planeta, 2004, p. 339-340).

${ }^{26}$ Cacho Blecua, Juan Manuel. Introducción al estudio de los motivos en los libros e caballerías: la memoria de Román Ramírez, in: Libros de caballerías (de "Amadís" al "Quijote"). Salamanca: SEMYR, 2002, p. 27-53. 
Ainda que inicialmente o público a que se dirigiam tais obras fosse composto principalmente por cavaleiros e nobres, os livros de cavalarias foram aos poucos conquistando o favor de todos os extratos sociais ${ }^{27}$. Que entre seus leitores se encontravam mulheres, prova-o uma passagem do Memorial das proezas da segunda Távola Redonda, de Jorge Ferreira de Vasconcelos (cap. 13): em certa ocasião, o Cavaleiro das Armas Cristalinas encontra um grupo de donzelas que se entretinha com o livro da

história de Primaleão e Dom Duardos, que naqueles tempos foi muito tratado, porque (...) todos estimavam muito as Crónicas dos bons cavaleiros. E sendo este dos que mais nome tiveram, eram mui aceitos seus contos, maiormente das damas, por os terem por muito namorados. Donde sucedeu entre estas virem em prática sobre qual fora melhor namorado, Primaleão ou Dom Duardos ${ }^{28}$.

Menéndez y Pelayo reproduz uma anedota narrada por D. Francisco de Portugal que dá bem a medida do interesse com que a leitura dos livros de cavalarias era acompanhada pela família de um cavaleiro castelhano "mui principal". Ao entrar em casa certo dia, ele deparou com sua mulher e filha banhadas em lágrimas. Sobressaltado, pensando que alguém havia morrido, o cavaleiro lhes perguntou o que havia ocorrido e para sua surpresa a resposta foi que choravam a morte de Amadis, narrada em um dos volumes da série ${ }^{29}$.

Assim como D. Quixote, muitos acreditavam que tudo quanto os livros de cavalarias narravam era verdadeiro, especialmente o povo mais humilde. Francisco Rodrigues Lobo registra um episódio ilustrativo a este respeito:

Na milícia da Índia, tendo um Capitão nosso cercado uma cidade de imigos, certos soldados (...) traziam entre as armas um livro de cavalarias, com que passavam o tempo. Um deles, que sabia menos que os mais daquela leitura, tinha tudo o que ouvia ler por verdadeiro (e assim há alguns inocentes que cuidam que se não pode mentir em letra redonda); os outros, ajudando a sua simpreza, lhe diziam que assim era. Veio ocasião de um assalto em que o bom soldado, envejoso e animado do que ouvia ler, lhe pareceu ensejo de mostrar seu valor e fazer uma cavalaria de que ficasse memória: e assim se

${ }^{27}$ Cf. Isabel de Lima e Almeida, op. cit., p. 50-74.

${ }^{28}$ Citamos a partir da edição de João Palma-Ferreira (Lisboa: Lello, 1998, p. 81). Note-se que a obra mencionada é o Primaleón, segundo livro do ciclo dos Palmeirins, de que nos ocuparemos mais adiante.

${ }^{29}$ Op. cit., v. 1, p. 366-367. 
meteu entre os contrários (...). E repreendendo-o os amigos daquela temeridade, respondeu: Ah! deixai-me, que não fiz a metade do que cada noite ledes de qualquer cavaleiro do nosso livro. E ele dali por adiante o foi muito valeroso ${ }^{30}$.

Os livros de cavalarias atravessaram o mar a bordo das caravelas espanholas e portuguesas. Não apenas nas que viajavam rumo ao Oriente, como ficou comprovado no trecho supracitado; também os marinheiros que vieram ao continente americano seguramente conheciam e portavam consigo alguns exemplares. Dois exemplos eloqüentes deste fato ficaram eternizados na toponímia das terras recém-descobertas: os navegantes espanhóis batizaram as regiões da Califórnia e da Patagônia motivados pela associação da paisagem local a trechos que haviam lido no Espladián e no Primaleón, respectivamente. $\mathrm{O}$ decreto da coroa espanhola que proibiu a exportação destes livros para o Novo Mundo (1531) terá criado algumas dificuldades para transportá-los durante certo tempo, mas seguramente não representou um impedimento incontornável, pois sabe-se que novos exemplares de livros de cavalarias continuaram sendo trazidos para a América.

As fantásticas aventuras cavaleirescas granjearam adeptos de variadíssima procedência: desde o Imperador Carlos V, admirador confesso do Belianís de Grecia, até marinheiros analfabetos, foram muitos os que se deixavam seduzir por estas obras. É fato consabido que, durante a juventude, Santo Inácio de Loyola foi leitor aficcionado dos livros de cavalarias; também Santa Teresa os apreciava, embora mais tarde os tenha acusado de ser literatura vã, atribuindo ao motivo do deleite juvenil a pecha de tentação diabólica. Consta inclusive que antes de sua conversão ela e o irmão teriam escrito um livro do gênero, do qual infelizmente não restam notícias ${ }^{31}$.

Obras destinadas a público vasto e heterogêneo, os livros de cavalarias continham ingredientes capazes de agradar a gostos variados: aventuras e façanhas heróicas unidas a histórias de amores de todo tipo (puros e idealizados ou sensuais, como é o caso de Galaor no Amadís e de Floriano no Palmeirim); monstros, gigantes e encantamentos somados à paisagem exótica de terras distantes; a introdução de cenas bucólicas e poemas ou tiradas humorísticas; tudo isto entrecortado por digressões moralizantes ou pretensamente filosóficas sobre temas como a ética, o amor, os critérios

\footnotetext{
${ }^{30}$ Lobo, F. R. Corte na aldeia. Ed. de Afonso Lopes Vieira. Lisboa: Sá da Costa, 1945, p. 17-18.

${ }^{31}$ Cf. H. Thomas, op. cit., p. 115. Sobre o livro de cavalarias escrito por Santa Teresa e seu irmão, cf. a Bibliografía de Eisenberg e Marín Pina, p. 125-126.
} 
para avaliar o governo do príncipe, a fortuna e o destino humano, entre outros. Daí que o autor anônimo do Platir, terceiro volume da série dos Palmeirins, declare no prólogo que sua obra poderia servir "para doctrina y passatiempo de todos" 32 .

O livro de cavalarias apresentava, portanto, conteúdo variado que atraía a curiosidade do leitor, vertendo-o numa linguagem sugestiva a ponto de levar, como vimos, algumas leitoras às lágrimas. A multiplicidade dramática, a grande quantidade de personagens e a estrutura aberta (que sempre permitia prolongamentos com a introdução de novos personagens e novos conflitos a serem resolvidos), traços também característicos do gênero, explicam as volumosas dimensões dos livros de cavalarias. Uma obra assim devia ser objeto de leitura (solitária ou coletiva) que decorria ao longo de vários meses, num processo de lenta identificação com personagens e situações, que passavam a fazer parte da vida cotidiana do público.

Tem razão, portanto, Jerusa Pires Ferreira ao afirmar que "nos primeiros tempos da imprensa, a novela de cavalaria veio a transformar-se numa espécie de literatura de massas" ${ }^{, 3}$. E, como tal, o gênero foi objeto de severas críticas em seu tempo. O debate acerca da conveniência de permitir ou não a leitura destas narrativas parece ter sido acalorado: ao menos é o que permite supor a quantidade de testemunhos preservados, a maior parte dos quais proveniente dos detratores dos livros de cavalarias, críticos do estilo por vezes grosseiro, da falta de verossimilhança dos enredos e até da inutilidade dessas obras, que se prestavam mais a entreter que a formar e ilustrar. Alonso Ulloa, historiador do séc. XVI, é um dos que investem contra essas "histórias fingidas":

Torpe cosa es auiendo en nuestra España historias verdaderas y hazañas famosas $\mathrm{y}$ hechos señalados de varones esforçados $\mathrm{y}$ valerosos, assi antiguas como modernas, mas que en ninguna otra nacion del mundo dexar de celebrar y diuulgar estos de que tenemos tanta materia de escriuir tan a la mano... por componer patrañas y mentiras en numero infinito que no siruen de otra cosa sino de passar el tiempo ${ }^{34}$.

\footnotetext{
${ }^{32}$ Platir. Ed. M. Carmen Marín Pina. Alcalá de Henares: Centro de Estudios Cervantinos, 1997, p. 4.

${ }^{33}$ Os sermonários do diabo ou as novelas de cavalaria, in: Pinheiro, Amálio (org). Forma e ciência. São Paulo: Educ, 1995, p. 79.

${ }^{34}$ Citamos a partir de H. Thomas, op. cit. p. 122. O cap. V desta obra traz numerosíssimos exemplos de críticas aos livros de cavalarias elaboradas no séc. XVI, o que só faz reforçar a convicção de sua popularidade na época.
} 
Nos primeiros diálogos do Corte na aldeia (1619), Francisco Rodrigues Lobo apresenta uma espécie de sistematização dos argumentos pró e contra os livros de cavalarias, demonstrando que a discussão ainda era tida como pertinente depois de muito entrado o séc. XVII. É oportuno observar que por volta da mesma época, ou talvez um pouco mais tarde, os manuscritos da Crônica de D. Duardos estavam sendo copiados, conforme esclareceremos adiante (cf. item 3).

De qualquer modo, é preciso reconhecer que os argumentos usados por Alonso Ulloa, ao menos à primeira vista, não parecem desprovidos de sentido. É de fato intrigante constatar que neste período - justamente quando os reinos ibéricos lançavamse como precursores na aventura marítima e Castela aspirava à consecução de seu projeto imperial na Europa - os livros de cavalarias, herdeiros de uma tradição que lançava raízes na sociedade feudal do séc. XII, tenham alcançado o favor de tantos, inclusive de alguns monarcas. Diferentemente do Tirant lo Blanc - que remonta aos anos 1460, quando a cavalaria andante ainda era uma realidade histórica com significação própria na Península Ibérica ${ }^{35}$-, o Amadís de Gaula, escrito menos de meio século depois, reflete outro momento histórico, bastante distinto. No final do séc. XV, já estava em curso a perda de relevância militar da cavalaria, que cada vez mais parecia algo ultrapassado. E não deixa de ser surpreendente que seja a partir de então que a voga dos livros de cavalarias se afirme com força crescente.

Um episódio do Amadís retrata com clareza o descompasso aludido entre o ideal cavaleiresco e o contexto histórico na virada dos séculos XV e XVI. Quando as tropas do rei Lisuarte, compostas por mais de mil homens, estavam prontas para enfrentar Galvanes sin Tierra e os 215 cavaleiros que defendiam a ilha de Mongaça, seus aliados enviaram um mensageiro ao rei com a seguinte proposta: "Señor, embíaos dezir don Florestán y don Cuadragante, y los otros cavalleros que allí están para defender la tierra de Madasima, que hagades, si vos plaze, apartar los ballesteros y archeros de entre vos y ellos, y veréis una hermosa batalla" ${ }^{36}$. Lisuarte concorda e, mediante o acordo de evitar

\footnotetext{
35 Lembre-se que, embora tenha sido publicado pela primeira vez apenas em 1490, a obra foi provavelmente composta entre os anos 1460 e 1466. Martín de Riquer afirma que o Tirant é "fiel espejo de la sociedad y de la vida caballeresca de mediados del siglo XV" (Riquer, Martín de. Introducción, Martorell, J. Tirante el Blanco. Trad. castellana del siglo XVI. Barcelona: Planeta, 1990, p. XLIII).

${ }^{36}$ Cap. 67, livro III. Citamos de acordo com a edição de Cacho Blecua. Rodríguez de Montalvo, Garci. Amadís de Gaula. 2. ed. Madrid: Cátedra, 1991, v. 2, p. 1012.
} 
o uso de armas de longo alcance, os combatentes de ambas as partes se vêem desimpedidos para realizar as façanhas cavaleirescas que ambicionavam.

A artificial adequação do teatro de guerra às exigências da cavalaria, de modo a permitir que a batalha fosse decidida apenas entre nobres cavaleiros desejosos de provar seu valor, era algo cada vez mais distante da realidade criada pela introdução de novas técnicas militares surgidas no outono da Idade Média. Se desde o século XII os arcos e as balestras eram consideradas armas pouco nobres, pois permitiam o ataque a distância e evitavam o choque direto ${ }^{37}$, a difusão do uso da pólvora no século XV revolucionou completamente a estratégia militar - revolução que foi, inclusive, decisiva para a obsolescência da cavalaria ${ }^{38}$.

A guerra moderna, com efeito, caracteriza-se por mobilizar armadas incomparavelmente maiores que os pequenos exércitos arregimentados pelos senhores feudais. Além disso, os altos custos acarretados pelo recurso da artilharia e pela necessidade de contar com pessoal capacitado para lidar com os novos instrumentos bélicos contribuíam para transformar a guerra em assunto de competência exclusiva do Estado e prerrogativa dos monarcas, doravante os únicos capazes de sustentar armadas realmente eficazes. Em suma, a crescente profissionalização dos exércitos e transformação dos conflitos em eventos que envolviam grandes massas humanas conferiam importância cada vez maior à infantaria, em detrimento da tradicional cavalaria, pautada pelos valores de honra pessoal e nobreza ${ }^{39}$.

A progressiva perda de relevância militar da cavalaria, já sensível no tempo em que Montalvo refundia os antigos textos nos quais baseou sua narrativa, parece não ter afetado o prestígio dos valores cavaleirescos na época, e talvez a maior prova disso seja precisamente o extraordinário sucesso do Amadís de Gaula. Os numerosos leitores da obra terão notado, contudo, que as proezas de Amadís e seus companheiros não correspondiam mais à realidade do tempo em que viviam. Por outro lado, as exigências decorrentes da expansão marítima fizeram com que a cavalaria sofresse grandes transformações na Península Ibérica. Em ambiente português, a crescente dificuldade de

${ }^{37}$ Cf. Flori, J. La caballería. Madrid: Alianza, 2001, p. 86.

${ }^{38}$ Os canhões começaram a ser empregados ainda no século XIV, mas ganharam importância crescente ao longo do século $\mathrm{XV}$, quando inclusive começou a se difundir o uso de armas de fogo por combatentes a pé. Segundo Maurice Keen, no entanto, a introdução da artilharia não acarretou imediatamente o fim da intervenção da cavalaria nas operações militares da época (Chivalry. New Haven / Londres: Yale University Press, s/d, p. 241-242).

${ }^{39}$ Cf. Keen, op. cit., p. 239-243. 
garantir a segurança das praças africanas e asiáticas, associada à falta de recursos humanos e econômicos para mantê-las, exigiu um relaxamento nas condições até então vigentes para a admissão de novos membros na ordem da cavalaria. Dado que de início os únicos que se arriscavam a ir para além-mar eram membros da baixa aristocracia empobrecida e sem títulos, foi dentre suas famílias que se recrutaram os novos cavaleiros, nomeados para administrar e defender as possessões da Coroa ${ }^{40}$. Que as armas e as formas de combate desses novos cavaleiros em nada se pareciam com as de seus predecessores medievais não pode haver dúvida ${ }^{41}$. Além disso, o sustento dos que viviam no ultramar provinha do comércio, única ocupação que compensava os riscos de viagens tão difíceis ${ }^{42}$. Dessa forma, a ordem da cavalaria envilecia rapidamente, pela admissão de membros não nobres e pela associação a práticas comerciais, fato de todo incompatível com os velhos valores cavaleirescos. Alijada de sua eficácia militar - que, quando muito, sobrevive completamente alterada - e forçada a render-se à lógica interesseira do capital - que não leva em consideração as noções de honra, valor e nobreza, distintivas da ideologia cavaleiresca -, a cavalaria sobrevive principalmente como referencial ético e título honorífico.

Por isso, ao contrário do Tirant lo Blanc, os livros de cavalarias quinhentistas parecem afastar-se da realidade, refugiando-se atrás de um ideal antiquado recriado numa ambientação a-histórica, em que predomina a imprecisão cronológica e geográfica, visto que a ação ocorre num passado indeterminado e em regiões distantes ou exóticas. Até mesmo a Constantinopla do Palmerín de Olivia, iniciador do ciclo que nos ocupa, é uma cidade irreal: trata-se de uma Constantinopla cristã que não mais

\footnotetext{
40 “A expansão veio abrir novas vias de sobrevivência e de ascensão social (ou, pelo menos, de manutenção de status). Primeiro foram as praças do Norte de África. Era fácil ascender a cavaleiro e escudeiro. Enxamearam. (...) Depois, abre-se o campo bem mais vasto do Oriente. Não são os filhos e herdeiros das grandes famílias que se arriscam por estas paragens" (Magalhães, Joaquim Romero de (coord), História de Portugal (dir. J. Mattoso). Vol. III: No alvorecer da Modernidade (1480-1620). Lisboa: Estampa, 1997, p. 428).

${ }^{41}$ Durante o reinado de D. João III, ficou clara a necessidade de introduzir novas práticas militares nas praças de África e do Oriente, "impostas pela generalização das armas de tiro pesadas, e mesmo pelas armas de fogo ligeiras com que a moderna infantaria se equipa, ainda combinadas com armas brancas" (Magalhães, J. R. de, op. cit., p. 104).

42 "Enquanto no Brasil dominava o patriarca rural fidalgo (ou com fumos de fidalguia) - se bem que associado a mercadores, para escoamento do açúcar -, no Oriente modela-se e radica-se o cavaleiromercador, tão atento à guerra quanto ao preço da especiaria. Cavaleiros-mercadores que também se encontram instalados, e bem, em Lisboa - e de que o rei não é o menor. (...) $\mathrm{O}$ comércio não somava prestígio na sociedade aristocrática, que, contudo, não o dispensava, porque lhe dava riqueza. Um cavaleiro não desprezava o trato mercantil de que tirava lucros, exercitando-o por si ou por seus caixeiros" (Magalhães, J. R. de, op. cit., p. 430).
} 
existe e não pode rivalizar com o Ocidente, como antes de ser conquistada pelos turcos. Em outras palavras, ela não passa de mito ${ }^{43}$.

Assim como alguns de seus detratores contemporâneos, a crítica moderna muitas vezes acusou este aparente desligamento da realidade e, sem compreender seu significado, tachou os livros de cavalarias de mera literatura de evasão. Discorrendo sobre o Amadís de Gaula, Menéndez y Pelayo faz uma observação que à primeira vista poderia parecer válida também para todo o gênero nele inspirado. O crítico espanhol acredita que a obra de Montalvo carece "de toda base histórica", pois as empresas do protagonista

llevan el sello de lo quimérico, su actividad práctica se gasta las más veces inútilmente y deslumbra más que interesa. Sin que llegemos a decir, con el crítico alemán antes citado [F. Wolf], que 'la caballería en Amadís es una forma hueca, abortada, sin principio vivo ni fin transcedental', no dudamos en calificarla de forma de decadencia (...). Mientras la caballería era una realidad social, no hubo necesidad de idealizarla $^{44}$.

Ocorre, contudo, que a identificação de referências diretas ao contexto histórico ou a fatos e locais precisos não é o único meio de compreender a relação entre a literatura e a realidade. Ainda que seja legítimo descrever os livros de cavalarias como sendo resposta à necessidade de fantasia e sonho do público renascentista - o que, em si, não seria desqualificar o gênero, pois trata-se de um anseio permanente do homem -, estudos recentes têm demonstrado em que medida as fantasiosas aventuras cavaleirescas publicadas no séc. XVI são menos desvinculadas do contexto da época do que parecem.

O próprio autor de um dos livros de cavalarias dos quais trataremos, o Primaleón, sugere que D. Luís de Córdova, a quem dedicava a obra, poderia nela "reconocer los echos de sus mayores", o que segundo M. Carmen Marín Pina "demuestra un deseo expreso por parte del autor de conectar la ficción con la historia, como si en ella encontrara el relato su sentido" 45 . A idéia parece ter convencido a Francisco Delicado que, na introdução do Primaleón publicado em Veneza no ano de

${ }^{43}$ Cf. Picchio, L. Stegagno. Proto-história dos Palmeirins: a corte de Constantinopla do Cligès ao Palmeirín de Olivia, in: A lição do texto. Lisboa: Edições 70, 1979, p. 185.

${ }^{44}$ Menéndez Pelayo, op. cit., v. 1, p. 358.

${ }^{45}$ Marín Pina, M. Carmen La historia y los primeros libros de caballerías españoles, in: Paredes, Juan (ed). Actas del V Congreso de la AHLM. Granada: Universidad, 1995, v. III, p. 189; cf. ainda Primaleón. Ed. M. Carmen Marín Pina. Alcalá de Henares: Centro de Estudios Cervantinos, 1998, em particular o prólogo do autor (p. 2) e, na introdução, a p. XI. 
1534, declara ser possível identificar paralelos entre algumas das façanhas narradas no livro e certas passagens da história de Espanha. Além disso, o elogio que muitos dos livros de cavalarias, a começar pelo Amadís, fazem à figura do monarca (ou do Imperador, no caso do ciclo dos Palmeirins) certamente não desagradou à coroa espanhola. Por isso, conclui a estudiosa,

Transidos de la ideología propia de la clase dominante, los fabulosos livros de caballerías se convirtieron en un importante instrumento de propaganda política, de afirmación de la monarquía y de la clase aristocrática, además de en un excelente pasatiempo. Como la cultura caballeresca en general, estos libros representaron un eficaz instrumentum regni ideológico capaz de cohesionar la nobleza, otrora en constante pugna por el poder político, al servicio del poder real ${ }^{46}$.

O livro de cavalarias em que o serviço à coroa é mais explícito, constituindo o verdadeiro eixo da narrativa, é o Clarimundo, de João de Barros. Ao narrar a formação do herói destinado a ser origem fictícia da casa real portuguesa, o autor apresenta ao futuro rei D. João III um modelo de virtudes cavaleirescas no qual se inspirar a fim de conduzir Portugal a seu glorioso destino.

O valor didático da obra, como se pode depreender, está ligado ao aspecto épico, caracterizado principalmente pelo vínculo direto com fatos históricos, os quais se corporificam na profecia de Fanimor. Em vários momentos da narrativa (...) Barros traz à tona, como um lembrete, os altos fins traçados para Clarimundo, do que resulta um trânsito contínuo da ficção à realidade ${ }^{47}$.

Diante de episódios como a profecia de Fanimor, no livro III do Clarimundo, da narração do célebre torneio de Xabregas com que se encerra o Memorial das proezas da segunda Távola Redonda, de Jorge Ferreira de Vasconcelos, e das referências autobiográficas inseridas por Francisco de Morais no Palmeirim de Inglaterra, Ettore Finazzi-Agrò avança a hipótese de "tal mistura entre realidade e fantasia" ser "um elemento distintivo da narrativa portuguesa de inspiração cavaleiresca" ${ }^{48}$.

\footnotetext{
${ }^{46}$ Marín Pina, M Carmen, La historia y los primeros libros..., op. cit., p. 192.

${ }^{47}$ Mongelli, Lênia Márcia. Clarimundo e a épica de João de Barros. Tese de doutorado em Literatura Portuguesa, apresentada à Faculdade de Filosofia, Letras e Ciências Humanas da Universidade de São Paulo, 1982, p. 22.

${ }^{48}$ Op. cit., p. 39.
} 
No caso português, a voga dos livros de cavalarias em Quinhentos pode ser explicada ainda pelo que Fidelino de Figueiredo chamou de "deslocamento dos tempos heróicos" ocorrido em Portugal. Segundo o pesquisador português, enquanto em outros países europeus o período de formação das lendas heróicas remonta aos séculos de formação (como na França, com a matéria surgida em torno de Carlos Magno e seus companheiros, ou em Espanha, no período da Reconquista), no extremo ocidental da Península "a psicose heróica sobrevém no século XV-XVI, quando a nova dinastia confirmada com o sangue de Aljubarrota faz surgir uma forte consciência nacional"49. Assim, é possível afirmar que, de certa forma, a ficção cavaleiresca participa da "ambiência lendária" que Figueiredo assinala como característica do Renascimento português e preparadora do surgimento da grande epopéia nacional, nos versos de $O s$ Lusíadas.

Cumpre observar, contudo, que o "sentido" de um texto literário qualquer não se esgota com a identificação de suas possíveis conexões extra-literárias - e os livros de cavalarias quinhentistas são grande exemplo disso. Escritos num momento em que as navegações, o comércio e a observação científica pareciam apresentar a realidade (não só o globo, mas todo o universo) como algo compreensível e controlável - desprovida, portanto, do mistério prenhe de significado com que até então fôra imaginada - os livros de cavalarias representam uma poderosa trincheira de resistência contra o utilitarismo mercantilista e o esvaziamento do real operado pelo cientificismo incipiente. Partindo desse pressuposto (segundo o qual entre o Quixote e seus predecessores há mais continuidade que ruptura), compreende-se melhor o motivo de essas narrativas serem caracterizadas por repetidas imprecisões geográficas e "erros" históricos, que de outra forma seriam inexplicáveis no contexto renascentista. É que, em suma, os autores dos livros de cavalarias visavam também a estimular a imaginação do público leitor; por isso, o caráter tantas vezes irreal e fantasioso da ficção cavaleiresca desempenhava no séc. XVI a função, vital em todas as épocas, de resgatar o homem de sua tendência permanente a enclausular-se na estreiteza de horizontes da vida cotidiana. Ao contrário, diz Mircea Eliade,

os sonhos, os devaneios, as imagens de suas nostalgias, de seus desejos, de seus entusiasmos etc. [constituem] forças que projetam o

${ }^{49}$ A Épica Portuguesa no Século XVI. Lisboa, IN / CM, 1993. p. 65. 
ser humano historicamente condicionado em um mundo espiritual infinitamente mais rico que o mundo fechado do seu "momento histórico" ${ }^{\$ 0}$.

Fato incontestável é que o leitor do século XVI - e não apenas na Península Ibérica, é bom que se diga - encontrava nos livros de cavalarias qualidades que atendiam a seus anseios estéticos e correspondiam a sua visão de mundo. $\mathrm{O}$ gênero conquistou um público fiel e consolidou-se como bom negócio para os editores da época, que publicavam novos títulos ou lançavam reedições dos grandes sucessos a cada ano: durante o período compreendido entre 1507 a 1554, os únicos anos em que não se conhecem notícias de impressão de livros de cavalarias na Espanha são 1529, 1537 e 1538. O resultado disso é que, de acordo com Lucía Megías, o corpus dos livros de cavalarias castelhanos conta com 63 títulos impressos entre o séc. XVI e o princípio do seguinte, sem contar as obras perdidas. O mesmo estudioso aponta a existência de outros 17 textos que permanecem manuscritos ${ }^{51}$.

A produção portuguesa de livros de cavalarias é quantitativamente muito inferior à castelhana, somando apenas 5 títulos originais impressos. Na lista abaixo, cada obra é acompanhada de breve notícia sobre as edições realizadas em Portugal até os primeiros anos do séc. XVII:

1. Crônica do Imperador Clarimundo donde os reis de Portugal descendem, de João de Barros (Lisboa: Germão Galharde, 1522; Coimbra: João de Barreira, 1555; Lisboa: António Álvares, 1601);

2. Crônica do famoso e muito esforçado cavaleiro Palmeirim de Inglaterra, filho del Rei D. Duardos, no qual se contam suas proezas e de Floriano do Deserto seu irmão e algumas do príncipe Florendos, filho de Primaleão, de Francisco de Morais (além da provável primeira edição de 1544 e de outra também perdida, as edições conhecidas são: Évora: André Burgos, 1567; Lisboa: António Álvares, 1592; em Espanha, foi publicada uma tradução do texto em Toledo, no ano de 1547);

\footnotetext{
${ }^{50}$ Eliade, Mircea. Imagens e símbolos: ensaio sobre o simbolismo mágico-religioso. São Paulo: Martins Fontes, 1991, p. 9.

${ }^{51}$ Cf. Lucía Megías, op. cit., p. 65-67 e 72-73, onde o autor anota: “Como es lógico suponer, estos libros son sólo una pálido reflejo de aquellos que se debieron escribir en la época y que se han perdido irremediablemente".
} 
3. Os Triunfos de Sagramor, de Jorge Ferreira de Vasconcelos, de cuja primeira edição (Coimbra: João Álvares, 1554) não se conhece nenhum exemplar; a obra seria revisada e reeditada com o título de Memorial das proezas da segunda Távola Redonda (Coimbra: João de Barreira, 1567).

4. Terceira e quarta parte da Crônica de Palmeirim de Inglaterra, na qual se tratam as grandes cavalarias de seu filho o príncipe D. Duardos Segundo, de Diogo Fernandes (Lisboa: Marcos Borges, 1587; Lisboa: Jorge Rodrigues, 1604);

5. Quinta e sexta parte de Palmeirim de Inglaterra. Crônica do famoso príncipe D. Clarisol de Bretanha, de Baltasar Gonçalves Lobato (Lisboa: Jorge Rodrigues, 1602).

Para avaliar adequadamente a dimensão da voga dos livros de cavalarias em Portugal, é preciso considerar a existência de outras obras para além da limitada produção local impressa. Em primeiro lugar, convém mencionar as obras de autores portugueses editadas em Espanha, como as três continuações de Clarián de Landanís redigidas pelo português Jerônimo Lopes em castelhano. Além disso, é preciso lembrar que livros de cavalarias castelhanos também foram editados em Portugal, como é o caso do Palmerín de Olivia (Évora, 1581) e do Primaleón (Lisboa: Manuel João, 1566; Lisboa: Simão Lopes, 1598), entre diversos outros. E, sobretudo, não se pode esquecer a existência de vários livros de cavalarias portugueses que jamais foram impressos, muitos dos quais permanecem inéditos até os dias de hoje.

De acordo com os levantamentos mais recentes, há notícias de cinco obras manuscritas, algumas delas subdivididas em mais de uma parte e conservadas em vários testemunhos. São elas:

1. Crônica de D. Duardos. Continuação manuscrita do Palmeirim de Inglaterra. O texto é dividido em três partes, sendo a primeira o objeto de estudo do presente trabalho. Da Primeira Parte são conhecidas sete cópias; da Segunda há cinco manuscritos; a Terceira Parte encontra-se em três diferentes manuscritos.

2. História grega (ou Crônica de D. Belindo): livro composto por D. Leonor Coutinho e, a julgar pela quantidade de cópias remanescentes, deve ter sido 
muito difundido. Texto dividido em quatro partes, preservadas em 33 manuscritos.

3. Crônica do Imperador Maximiliano: livro anônimo e preservado por um único testemunho, foi publicado em 1983 pela Imprensa Nacional / Casa da Moeda.

4. Crônica do príncipe Agesilau e da rainha Sidónia: texto preservado por um único manuscrito e ainda inédito.

5. Leomundo de Grécia: obra de Tristão Gomes de Castro recentemente descoberta por Aurelio Vargas Díaz-Toledo. Texto preservado em manuscrito único ${ }^{52}$.

Devido ao tamanho do corpus e a seu peso na cultura lusitana da época, Massaud Moisés crê que o século XVI seja "indiscutivelmente a grande época da cavalaria portuguesa, pelo menos por causa da nacionalização do gênero e das novelas aparecidas, contendo expresso o nome do autor e qualquer dose de realidade física ou histórica de Portugal" ${ }^{\prime 3}$.

\section{O ciclo dos Palmeirins.}

Não foram poucos os autores que, desejando valer-se do sucesso obtido por obras alheias, puseram-se a narrar as aventuras dos filhos de heróis consagrados em outros livros. Por isso, como observa com certa ironia Rodrigues Lapa, "aqui temos como se ordenavam as novelas de cavalaria: nasciam umas das outras, como os filhos nascem das mães; e como os filhos se parecem com os pais, também as novelas, no geral, se pareciam umas com as outras" ${ }^{, 54}$. Dentre os ciclos assim formados, os dois mais importantes são o gerado a partir do Amadís de Gaula e o chamado "ciclo dos Palmeirins", inaugurado pela obra anônima Palmerín de Olivia, publicada em Salamanca no ano de 1511. Após brevíssimo intervalo de apenas 6 meses, publicou-se

\footnotetext{
${ }^{52}$ As informações sobre os livros de cavalarias em Portugal foram baseadas em Lima de Almeida, Isabel Adelaide, op. cit., p. 19-23 e Díaz-Toledo, Aurelio Vargas, Os livros de cavalarias em Castela e Portugal, op. cit., itens 1 e 2 . Note-se que, além dos livros referidos, há notícias sobre quatro outros títulos desaparecidos: as Aventuras do gigante Dominiscaldo, de Álvaro da Silvieira, a História do espantoso cavalleiro da lux, de Francisco Morais Sardinha, o Clarindo de Grécia, de Tristão Gomes de Castro, e um livro cujo título se desconhece, escrito por Fernão Lopes de Castanheda.

${ }^{53}$ A Novela de Cavalaria no Quinhentismo Português. O Memorial das Proezas da Segunda Távola Redonda, de Jorge Ferreira de Vasconcelos. São Paulo, Faculdade de Filosofia, Ciências e Letras da USP, Boletim 218, 1957, p. 47.

${ }^{54}$ Lapa, M. Rodrigues. Introdução, in: Morais, Francisco de. Palmeirim de Inglaterra. Seleção, prefácio e notas de M. R. Lapa. 2. ed., Lisboa: s/e, 1960, p. XII.
} 
já a primeira seqüência do livro, intitulada Libro segundo del Emperador Palmerín, en que se cuentan los grandes y hazañozos fechos de Primaleón y Polendus, sus fijos (Salamanca, 1512), obra que, a partir da edição de 1534, passou a ser conhecida simplesmente como Primaleón.

A autoria dos dois livros é uma questão ainda em aberto. Embora sejam muitos os elementos a apontar para a hipótese de um mesmo autor ter redigido o Palmerín e o Primaleón $^{55}$, nenhuma das duas obras fornece indicações seguras sobre sua identidade. Juan Augur de Trasmiera, que publicou versos anexos à primeira edição de ambas, as atribui a "mano de dueña prudente" de Ciudad Rodrigo. Não obstante a sedutora tese da autoria feminina dos livros ter sido bastante difundida (e ainda hoje não ser de todo descartável), os especialistas na matéria têm se inclinado a admitir como hipótese mais provável o nome de Francisco Vázquez, vizinho da mesma Ciudad Rodrigo, que figura como responsável pela revisão do texto no cólofon da primeira edição do Primaleón ${ }^{56}$.

Não é possível saber em que medida a atribuição dos livros a uma autora feminina contribuiu para sua difusão, pela novidade que representava; o dado concreto é que eles gozaram de grande prestígio. Prova disso é que o Palmerín conta com ao menos 13 edições até o fim do séc. XVI, sendo três delas no Exterior (duas em Veneza e uma em Évora), ao passo que o Primaleón foi impresso dez vezes, consideradas as duas edições lisbonenses e a veneziana. Além de estarem entre os livros de cavalarias castelhanos que mais se editaram no séc. XVI, sua influência ultrapassou as fronteiras ibéricas e dilatou-se no tempo. O Palmerín de Olivia não apenas foi traduzido para diversas línguas (italiano, francês, inglês, alemão e holandês, já no séc. XVII), como ainda serviu de inspiração para um drama de Pérez de Montalbán (1650) e um "romance" de Joseph Blas (1755). Como observou M. Carmen Marín Pina, narrativas orais sobre Palmeirim (ou Palmeiriz) de Oliva ainda foram recolhidas em Portugal no princípio do séc. $\mathrm{XX}^{57}$. Alguns episódios e temas do Primaleón (entre os quais o mais famoso é a conquista do amor de Flérida por D. Duardos disfarçado de jardineiro) tiveram larga sobrevivência literária, servindo de sugestão para o D. Duardos de Gil

${ }^{55}$ Cf. Ferrario de Orduña, L. "Palmerín de Olivia" y "Primaleón". Algunas observaciones sobre su autoría, in: Actas del VIII Congreso Internacional de la AHLM. Santander: Consejería de Cultura del Gobierno de Cantabria, 2000, p. 718-728.

${ }^{56}$ Cf. a introdução de M. Carmen Marín Pina a sua recente edição do Primaleón (Alcalá de Henares: Centro de Estudios Cervantinos, 1998), p. IX-XI.

${ }^{57}$ Cf. a introdução da autora à edição do Palmerín de Olivia (Alcalá de Henrares: Centro de Estudios Cervantinos, 2004), p. XXX-XXXIV. 
Vicente, o Le prince déguisé de Scudéry (1629) e até mesmo para uma comédia setecentista de autor cubano ${ }^{58}$.

Em que pese ao grande sucesso desses livros, alguns estudiosos modernos têm reprovado o estilo despretensioso de seu autor. Menéndez y Pelayo refere-se ao Palmerín de Olivia como "nulidade", classifica-o de imitação servil do Amadís e conclui, sentenciando: "el estilo es pobre, el sentimiento ninguno" anuir com a severidade do crítico espanhol, Luciana Stegagno Picchio também encontra "suficientes razões para condenar o Palmerín de Olivia no plano estético", reprovando a linguagem coloquial, a pobreza do léxico, a monotonia do estilo e (ao nosso ver, injustamente) a sintaxe confusa ${ }^{60}$. De fato, a simplicidade quase rústica do Palmerín e do Primaleón distanciam-nos grandemente do tom elegante e doutrinal impresso por Montalvo ao Amadís de Gaula; mas isso não quer dizer que eles não ofereçam outros atrativos. William Purser, por exemplo, considerou o Palmerín como "the most amusing of all the romances of chivalry I have read" ${ }^{\prime \prime}$.

A importância das duas obras no processo de consolidação do gênero é inegável. Escritos num momento em que a voga dos livros de cavalarias estava apenas no início, o autor do Palmerín soube realizar uma sábia combinação entre elementos inspirados no modelo amadisiano e certas inovações que marcaram de modo duradouro as trilhas que seriam percorridas pelas futuras obras congêneres. Além de deslocar pela primeira vez o centro de gravidade das aventuras para Constantinopla (cenário secundário em obras anteriores, como o Tirant lo Blanc e o Amadís), as duas primeiras partes do que estaria destinado a converter-se no ciclo dos Palmeirins introduziram motivos até então desconhecidos em livros de cavalarias - como o amor entre representantes de famílias inimigas (Primaleão e Gridônia) e o já referido meio inusitado encontrado por D.

\footnotetext{
${ }^{58}$ Cf. a introdução ao Primaleón, op. cit., p. XXI-XXII. A primeira parte da Crônica de D. Duardos que transcrevemos também menciona o tema dos amores entre Flérida e D. Duardos oculto sob o disfarce de Julião (cf. no segundo volume deste trabalho, o cap. 18, nota 13). O fato de Jorge Ferreira de Vasconcelos citar o Primaleón em seu Memorial das proezas da segunda Távola Redonda, conforme vimos, também atesta sua popularidade.

${ }^{59}$ Op. cit., v. 1, p. 422-423.

${ }^{60}$ Op. cit., p. 194.

${ }^{61}$ Palmerin of England. Some remarks on this romance and on the controversy concerning its authorship. Dublin: Browne and Nole, 1904, apêndice XII, p. 431. É preciso notar, porém, que o crítico não faz o mesmo juízo positivo acerca do Primaleón, que considera excessivamente longo.
} 
Duardos para conquistar Flérida - que ajudaram a demonstrar a viabilidade do gênero para além das continuações do Amadís ${ }^{62}$.

O autor do Primaleón provavelmente não contava com a possibilidade de nova continuação a prolongar o nascente ciclo. Esta deve ser a explicação para o fato de, nos capítulos finais da obra, ele apresentar sumariamente a trajetória de Platir, um dos filhos de Primaleão. Nesta seção final - excrescente a ponto de abalar a complexa estrutura da obra, até então bem equilibrada apesar das múltiplas tramas de que é composta - tudo é anômalo: além de ser protagonizada pelo quarto filho de Primaleão (e não pelo primogênito, como de hábito), o trecho prolonga sem qualquer necessidade uma narração que já se havia encaminhado naturalmente para a conclusão. Dessa forma, a história de Platir, condensação do que seria um novo livro da série, torna-se enfadonha para o leitor e praticamente inviabiliza o surgimento de novas seqüências - pois se, de um lado, a vida do novo herói já não poderia atrair a curiosidade dos leitores (que já saberiam "o fim da história” pelo rápido resumo do Primaleón), por outra parte, ao declarar que, dentre os quatro filhos de Primaleão, Platir foi o mais valente, o narrador desacreditava de antemão qualquer tentativa de seqüência protagonizada por um de seus irmãos.

Ainda assim, o ciclo dos Palmeirins não foi interrompido, muito ao contrário: do mesmo Primaleón brotaram duas continuações paralelas, bifurcando-se. A primeira delas teve vida fugaz e pequena descendência; a outra, representada pelo Palmeirim de Inglaterra, prosseguiu gerando novos frutos até o início do séc. XVII.

Em 1533 - mais de duas décadas depois do Primaleón, portanto - é publicada em Valladolid a terceira parte da série palmeriniana, intitulada Platir. O autor do livro, que M. Carmen Marín Pina crê ser Francisco Enciso Zárate, decide narrar a seu modo a biografia deste herói e, para isso, não hesita em alterar o final da obra anterior, desmentindo-a abertamente. Já no primeiro capítulo, após informar que o protagonista nascera no mesmo dia do falecimento de Palmeirim de Oliva, seu avô, o narrador observa: "aunque en Primaleón se tiene el contrario, ésta fue la verdad". Por isso, a editora da obra diz que a decisão do autor "es la de un lector insatisfecho no contento

\footnotetext{
${ }^{62}$ É preciso lembrar que, quando surgiu o Palmerín de Oliva, estavam editados apenas os três primeiros títulos do ciclo dos Amadises (Amadís, Espladián e Florisando), além de uma série de outros textos cavaleirescos que estudos recentes não consideram como representantes legítimos do gênero dos livros de cavalarias, tais como o Oliveros de Castilla ou o Henrique, fijo de doña Oliva, não acolhidos no rol da já citada Bibliografía de los libros de caballerías castellanos de Eisenberg e Marín Pina.
} 
con el desenlace de la obra que desea continuar, algo similar a lo que sucedió con el Amadís primitivo y después con ciertas continuaciones amadisianas" ${ }^{63}$. São numerosas as retificações impostas por Enciso Zárate a seu predecessor, a começar pela mudança de nomes de alguns personagens importantes: a esposa de Platir, por exemplo, que no Primaleón chamava-se Sidela, agora é rebatizada como Florinda.

Não obstante sua grande originalidade, e talvez mesmo em função dela, o Platir parece ter sido recebido com relativa frieza pelos leitores espanhóis. É possível que o protagonismo conferido a Florinda - a qual, vestida de cavaleiro para resgatar o amado de um encantamento, protagoniza algumas aventuras e chega mesmo a conquistar o amor de outra donzela, sem que ela percebesse tratar-se de mulher disfarçada - tenha desagradado ao público, ainda refratário a tentativas de renovação de um gênero que àquela altura estava no auge da popularidade. Mas se na Península Ibérica o Platir não voltou a ser editado depois de 1533, sua fortuna em Itália foi muito mais feliz. A tradução da obra foi lançada em 1548 e alguns anos depois foi editada uma continuação sua, protagonizada pelo filho de Platir, chamado Flortir, personagem já mencionado na obra castelhana de 1533, onde se prenunciam inclusive algumas aventuras futuras do jovem. Embora os editores do Flortir apresentem a obra como tradução de original castelhano, não restam dúvidas de que o autor do livro seja Mambrino Roseo da Fabriano - o que implica reconhecer a existência de contribuições italianas ao ciclo dos Palmeirins. Há notícias de diversas outras edições do conjunto Platir-Flortir realizadas na Itália até o início do séc. XVII ${ }^{64}$.

O sucesso dos dois livros no estrangeiro não impediu, contudo, que eles passassem a ocupar posição um tanto marginal no desenvolvimento da série palmeriniana. $\mathrm{O}$ famoso Palmeirim de Inglaterra - que estaria destinado a transplantar

${ }^{63}$ Platir. Ed. de M. Carmen Marín Pina, Alcalá de Henares: Centro de Estudios Cervantinos, 1997, p. 13 ( $1^{\circ}$ cap.) e p. X da introdução.

${ }^{64}$ As informações aqui resumidas estão baseadas nas fornecidas por Marín Pina (introdução ao Platir, op. cit., p. XVI) e Purser (op. cit., p. 433- 437). Entre os dois autores há, inclusive, uma discrepância quanto à data da publicação do Flortir: segundo Marín Pina ela teria ocorrido em 1560; mas, de acordo com Purser, a primeira edição é de 1554 (em 1560 teria sido publicada a Segunda parte do Platir; não dispomos de informações suficientes para afirmar se esta Segunda parte é o mesmo Flortir com outro nome). Além do Flortir, Mambrino Roseo da Fabriano escreveu várias outras obras ligadas ao ciclo dos Palmeirins, inclusive novas continuações do Primaleón e do Palmeirim de Inglaterra, como atesta $\mathrm{H}$. Thomas (op. cit., p. 142): não tivemos oportunidade de examinar nenhuma dessas obras, sobre as quais também não conhecemos estudos ou edições recentes. Convém mencionar aqui, brevemente, que durante muito tempo se considerou que o Polindo (ou Polendos) fosse obra integrante do ciclo dos Palmeirins, erro esclarecido por H. Thomas, op. cit., p. 76 e 142. Ainda assim, a informação é registrada por Jerusa Pires Ferreira, em seu $O$ tapete preceptivo do Palmeirim de Inglaterra, op. cit., p. 7, nota 3. 
o ciclo para Portugal, onde ele iria adquirir novo impulso - liga-se diretamente ao Primaleón, desconsiderando por completo as alterações sugeridas no Platir. É impossível determinar com segurança o que teria motivado tal fato: não se sabe se Francisco de Morais teria desaprovado os rumos impressos ao ciclo pelo Platir ou se ele simplesmente desconhecia a existência do livro de Enciso Zárate, o que não seria improvável em vista de sua restrita difusão ${ }^{65}$. Fato é que, no Palmeirim, o herói do livro de 1533 ficará relegado a segundo plano, juntamente com sua esposa (que readquire o nome original de Sidela); o protagonista das novas aventuras será seu primo, filho de D. Duardos e Flérida.

Assim como Platir, Palmeirim de Inglaterra é neto do iniciador da estirpe, Palmeirim de Oliva. A diferença entre eles é que Platir descende do velho Imperador de Constantinopla por linha masculina, ao passo que no caso de Palmeirim de Inglaterra a descendência ocorre por via feminina, como ficará claro ao leitor que consultar o quadro genealógico dos personagens do ciclo (cf. apêndice 1 deste volume). A insólita herança das virtudes cavaleirescas por via materna obriga a examinar mais detidamente a relação do Palmeirim com as demais partes da série.

Para justificar a opção de negar a Platir o papel de protagonista da nova obra não é preciso recorrer à hipótese de Morais ter tomado ciência do fato de que outro autor já se encarregara de compor um livro dedicado a este cavaleiro: conforme vimos anteriormente, a conclusão do Primaleón criava obstáculos suficientes para dissuadir qualquer escritor que desejasse fazê-lo. Neste caso, a opção natural talvez fosse eleger algum dentre os outros três irmãos de Platir não nomeados no final do Primaleón para dar prosseguimento à saga do clã, solução facilitada pelo fato de saber-se que Platir era o caçula da família (com efeito, no Palmeirim, o filho de Primaleão que mais se destaca é o primogênito Florendos, que protagoniza as famosas aventuras do castelo de Miraguarda). Mas Francisco de Morais evitou o caminho mais comum à tradição dos livros de cavalaria, em que o sucessor do herói costuma ser seu filho primogênito. E o fez sem razões aparentes, porque em todo caso gozaria de plena liberdade de criação: se Morais forjou Florendos, personagem não previsto na apressada conclusão do Primaleón, o que o impediria de forjar também outro Palmeirim, filho de Primaleão? A única explicação plausível é que a inovação foi resultado de escolha deliberada, fruto de

${ }^{65}$ Quanto ao Flortir, o problema sequer se coloca: se a primeira edição do Palmeirim é dos anos 1540, como crêem os estudiosos, ele é certamente anterior à seqüência italiana de Mambrino da Frabriano. 
uma predileção pela figura de D. Duardos. Como se sabe, o príncipe da Inglaterra compartilha com o herdeiro do reino de Constantinopla o protagonismo no Primaleón, onde os dois percorrem trajetórias paralelas e complementares. Ambos são cavaleiros invencíveis e namorados leais; o que os diferencia é que o traço dominante no caráter de Primaleão é a valentia, ao passo que em D. Duardos prevalece a característica do amante perfeito. Esta sutil diferença, possivelmente reforçada pela difusão do $D$. Duardos, de Gil Vicente (1522), deve ser a responsável pela subversão do andamento esperado no desenvolvimento de um ciclo de livros de cavalarias. Note-se, contudo, que a preeminência concedida a um herdeiro do trono inglês, como Palmeirim, não deslocou o centro para o qual convergem os personagens e aventuras da obra, que continua sendo a corte de Constantinopla, tanto no livro de Morais como nos de seus continuadores.

O Palmeirim de Inglaterra foi objeto de acalorada contenda entre portugueses e espanhóis que reivindicavam a paternidade da obra ${ }^{66}$. Hoje não restam dúvidas que seu autor seja o português Francisco de Morais, o qual deixou inclusive registro de elementos autobiográficos num curioso episódio da obra: trata-se do envolvimento de Floriano do Deserto, irmão de Palmeirim, com quatro fúteis damas francesas que levam os mesmos nomes de mulheres com quem o autor teria convivido durante sua permanência em França como secretário da embaixada enviada por D. João III entre os anos de 1541 e $1544^{67}$. A biografia de Francisco de Morais é muito lacunosa: ele teria nascido por volta de 1500; a serviço do conde de Linhares, D. António de Noronha, seguiu com seu filho para a França na referida embaixada e, depois de retornar a Portugal, casou-se com Bárbara Madeira. Seus serviços aos Noronha renderam-lhe uma pensão régia a partir de 1550, mesmo ano do famoso torneio cavaleiresco promovido

\footnotetext{
${ }^{66}$ Eximimo-nos aqui da tarefa de referir em detalhes a discussão, não apenas porque isso escaparia ao nosso objetivo, que se restringe a situar a posição da obra no interior do ciclo dos Palmeirins, como também porque se trata de questão definitivamente encerrada há mais de um século (mais precisamente desde 1904, quando Purser publica seu Palmerin of England: some remarks on this romance and on the controversy concerning its authorship). O leitor interessado poderá encontrar na bibliografia as referências dos principais lances do debate, ao qual contribuíram, entre outros, o filólogo brasileiro Odorico Mendes, os espanhóis D. Pascual Gayangos e Nicolás Díaz de Benjumea, além do inglês William E. Purser.

${ }^{67} \mathrm{O}$ episódio é narrado nos caps. 137-142 da segunda parte do Palmeirim. As damas francesas que inspiraram a passagem são referidas no texto "Desculpa de uns amores", de Francisco de Morais, que se encontra em apêndice da edição do Palmeirim de Inglaterra preparada por Geraldo Ulhoa Cintra (São Paulo: Anchietana, 1946, v. 3, p. 397-405). A crítica tem enxergado na referência às damas francesas um meio de Morais vingar-se da desilusão amorosa que lhe foi imposta por Torsi, uma dama de companhia da rainha Leonor da França (Cf. Díaz de Benjumea, Nicolas. Discurso sobre el "Palmerín de Inglaterra" y su verdadero autor, presentado a la Academia de Ciencias de Lisbona. Lisboa: Imprenta de la Real Academia de Ciencias, 1876, p. 67-73.
} 
em Xabregas, ao qual Morais assistiu. Por fim, sabe-se que Francisco de Morais foi assassinado em Évora no ano de 1572, por motivo desconhecido ${ }^{68}$.

Se em Espanha o Palmeirim foi impresso uma única vez (Toledo, 1547), em Portugal há notícias de ao menos quatro edições no séc. XVI, embora sejam conhecidos exemplares de apenas duas: a de 1567 (Évora: André de Burgos) e a de 1592 (Lisboa: António Álvares). É provável que a obra tenha sido impressa pela primeira vez em 1544 e, de acordo com Eugenio Asensio, a esta edição deve ter se seguido outra igualmente perdida, anterior à eborense de $1567^{69}$. Além do fato de ter conhecido quatro impressões, fato único no corpus dos livros de cavalarias portugueses, o prestígio da obra no Portugal de Quinhentos é atestado pelas referências a Francisco de Morais e Miraguarda em duas redondilhas de Camões e pela alusão a Palmeirim no Auto dos dois irmãos, de António Prestes, publicado em $1586^{70}$. No entanto, o dado que parece ter garantido a fama posterior do livro foi o juízo formulado pelo cura cervantino na sempre lembrada cena do expurgo da biblioteca de D. Quixote:

esa palma de Ingalaterra (sic) se guarde y se conserve como a cosa única y se haga para ello otra caja como la que halló Alejandro en los despojos de Dario, que la diputó para guardar en ella las obras del poeta Homero. Este libro, señor compadre, tiene autoridad por dos cosas: la una, porque él por sí es muy bueno, y la otra, porque es fama que le compuso un discreto rey de Portugal. Todas las aventuras del castillo de Miraguarda son bonísimas y de grande artificio; las razones, cortesanas y claras, que guardan y miran el decoro del que habla con mucha propiedad y entendimiento ${ }^{71}$.

A difusão do Palmeirim na Europa também foi considerável. Entre 1553 e 1554 surge a tradução italiana e provavelmente em 1558 é a vez de uma continuação da obra de Morais composta por Mambrino Roseo da Fabriano; na França, a tradução do Palmeirim foi editada em 1552-1553; em Inglaterra o livro foi publicado nas últimas

\footnotetext{
${ }^{68}$ Acerca da biografia de Morais, cf. o prólogo da edição do Palmeirim de 1786, reproduzida por Geraldo de Ulhoa Cintra (op. cit., v. 3, p. 419-433) e Purser, op. cit, p. 395-399.

${ }^{69}$ Cf. El Palmeirim de Inglaterra. Conjecturas y certezas, in: Garcia Orta. Revista da Junta de Investigações de Ultramar, núm. esp., 1972, p. 127-136. Diferentemente de outros autores, Asensio acredita que a suposta edição de 1544 deve ter sido realizada em Portugal e não na França, onde o autor teria redigido grande parte do livro.

${ }^{70}$ As redondilhas de Camões são: "Da lindeza vossa" e "Despois de sempre sofrer". Quanto a António Prestes, Purser observa que a referência a Palmeirim encontrada no Auto dos dois irmãos pode ser atribuída também ao Palmerín de Olivia (op. cit., p. 379).

${ }^{71}$ Cervante, Miguel de. Don Quijote de la Mancha. Ed. de Martín de Riquer, Barcelona: Planeta, 2004, p. 75-76 (cap. 6 da primeira parte).
} 
décadas do séc. XVI e em 1602 é lançada a tradução da seqüência italiana do Palmeirim de Inglaterra ${ }^{72}$. O interesse pelo livro nunca desapareceu de todo, fato confirmado pelas reedições portuguesas surgidas em 1786 e 1852 e pela brasileira de $1946^{73}$. Apesar disso, a maior parte da bibliografia crítica que lhe foi dedicada ficou circunscrita à polêmica em torno de sua autoria; uma vez dirimida a contenda em favor dos portugueses, poucos foram os que se dedicaram ao exame desta obra, considerada por muitos o exemplar mais bem acabado dentre os livros de cavalarias em língua portuguesa.

O Palmeirim de Inglaterra é também responsável pelo surgimento do único ciclo de livros de cavalarias em Portugal. Em 1587, cerca de 30 anos depois da primeira edição do livro de Morais portanto, é editada a Terceira e quarta parte da Crônica de Palmeirim de Inglaterra, na qual se tratam as grandes cavalarias de seu filho o príncipe D. Duardos Segundo, de Diogo Fernandes (Lisboa: Marcos Borges) ${ }^{74}$. A obra, que não teve qualquer repercussão conhecida no estrangeiro, ao menos em Portugal parece ter agradado, pois foi reeditada novamente em 1604 (Lisboa: Jorge Rodrigues). Em 1602, é a vez de Baltasar Gonçalves Lobato trazer a lume sua continuação do ciclo, retomando a trama do ponto deixado por Fernandes, com a Quinta e sexta parte de Palmeirim de Inglaterra. Crônica do famoso príncipe D. Clarisol de Bretanha (Lisboa: Jorge Rodrigues).

As informações de que dispomos acerca de Diogo Fernandes e Baltasar Gonçalves Lobato são quase nulas. De Fernandes, sabe-se com certeza apenas que era "vezinho de Lisboa", conforme notícia da portada da edição de 1604 do D. Duardos Segundo. Entre os numerosos homônimos presentes na documentação da época, Isabel Adelaide de Lima e Almeida descobriu que duas filhas de certo Diogo Fernandes foram afilhadas de batismo de Francisco de Morais; e ainda que seja este o autor do livro, continua-se a se saber pouquíssimo sobre ele. Quanto a Lobato, na edição do $D$.

\footnotetext{
${ }^{72}$ Cf. Thomas, op. cit., caps. VI e VII.

73 Apesar de termos compulsado os prefácios de algumas das edições anteriores (nomeadamente as de 1786 e 1852) durante breve período de pesquisa na Biblioteca Nacional de Lisboa, tivemos de nos socorrer da edição de Geraldo Ulhoa Cintra (São Paulo: Anchietana, 1946, 3 vols.), única disponível em São Paulo, como base para nosso trabalho com o texto. Chegaram-nos recentemente notícias dando conta de projeto de nova publicação brasileira do Palmeirim, baseada na edição de 1946, e do lançamento da versão castelhana do texto, a cargo de Aurelio Vargas Díaz-Toledo, pelo Centro de Estudios Cervantinos.

${ }^{74}$ Por motivo de clareza, é preciso notar que o Palmeirim já era dividido em duas partes; daí o fato de Diogo Fernandes continuá-lo a partir da terceira. Além disso, o leitor não deve confundir o D. Duardos Segundo, de Diogo Fernandes, com a Crônica de D. Duardos, obra manuscrita e anônima, que constitui o objeto de estudo deste trabalho.
} 
Clarisol registra-se que ele era "natural da cidade de Tauira"; a mesma investigadora portuguesa informa ter encontrado referência a um certo Baltasar que, de acordo com os arquivos paroquiais de Tavira, foi batizado em 1581. Dado, porém, que a mãe da criança tinha o apelido de Gonçalves mas o pai chamava-se Baltasar da Costa, não é possível afirmar com certeza se o registro é realmente de Baltasar Gonçalves Lobato. Há também notícias de outro homônimo que embarcou para a Índia em 1618, mas nada garante ser este o autor do Clarisol. Em vista de todas as dúvidas, Isabel Adelaide de Lima e Almeida conclui que a impossibilidade de identificar com segurança os dois autores sugere que ambos não teriam tido acesso ao restrito círculo cortesão, como os autores do livros de cavalarias portugueses anteriores (João de Barros, Francisco de Morais e Jorge Ferreira de Vasconcelos que, como se sabe, privavam com altos personagens da corte portuguesa e até mesmo com os príncipes). Ainda que Fernandes e Lobato tenham escrito durante a união ibérica, isso não altera os dados do problema:

mais justo se afigura crer que perdemos deles o rasto porque, sem nada que os distinguisse, terão vindo desse anónimo e crescente número de leitores que a partir da segunda metade de Quinhentos proliferou. $\mathrm{Ou}$, por outras palavras, o facto de ilustres desconhecidos como Diogo Fernandes e Baltasar Lobato terem empreendido a escrita de livros de cavalarias sugere uma progressiva democratização do género $^{75}$.

O D. Duardos Segundo e o D. Clarisol, como obras tardias, evidenciam já alterações no gênero. Talvez a mais saliente delas seja o pronunciado gosto pelo excepcional ou extraordinário que caracteriza esses livros. Ali, a magia e os encantamentos adquirem proporções notáveis, alterando a cada passo o rumo dos acontecimentos e imprimindo rapidez vertiginosa às aventuras, principalmente no $D$. Duardos Segundo. Os numerosos casos e acidentes são objeto de atenção permanente do sábio Daliarte, que ordena o caos dispondo dos cavaleiros como bem lhe parece: ora instruindo-os por carta lançada da boca de um golfinho, ora enviando-os para onde cumpre em fantásticas ilhas móveis. Os encantamentos excedem tudo o que se lê em obras anteriores, revelando-se em aparições gigantescas e multiformes em que predomina o bizarro ou o exótico. Abundam referências a animais de regiões longínquas, como o tigre e o elefante, e também os marcos geográficos são expandidos,

75 Isabel Adelaide de Lima e Almeida, op. cit., p. 66-67. As informações recolhidas sobre Fernandes e Lobato são apresentadas à p. 65 . 
abrangendo a África. A tudo isso somam-se figuras da mitologia clássica, numa fusão que só faz acentuar os contrastes, principalmente no D. Clarisol, onde "o estilo empolase em latinismos lexicais, num tom constantemente sentencioso", como observaram com razão Saraiva e Lopes ${ }^{76}$.

A superfetação e o recurso constante ao artificioso podem ser prenunciadores de um gosto maneirista, como propõe Isabel Adelaide de Lima e Almeida ${ }^{77}$, mas permitem inferir também o esgotamento do gênero literário. Embora a necessidade de superação dos antecedentes seja uma constante nos livros de cavalarias - o que explica a existência de episódios paralelos em diferentes obras, recurso em que a citação das proezas de personagens já consagrados permite a identificação do novo herói com seus modelos -, os processos de amplificação e hipérbole das aventuras narradas parecem ter atingido o limite. A necessidade permanente de exceder tudo o que já havia sido escrito e de causar estranhamento no leitor recorrendo ao bizarro e ao exótico, pressentida nas obras de Fernandes e Lobato, denuncia certa saturação do público que, demasiadamente acostumado com o extraordinário dos livros de cavalarias, talvez precisasse de doses cada vez mais altas da fórmula para despertar do entorpecimento. Neste sentido, é sintomático o fato de Gonçalves Lobato pôr seu Clarisol a combater com todos os famosos cavaleiros da Antigüidade e até mesmo com personagens mitológicos, vencendo-os todos: tentativa extrema de legitimar seu herói perante uma galeria de antepassados que já haviam realizado tantas proezas insuperáveis. Com efeito, quando o Clarisol foi lançado, a prosa de ficção encaminhava-se para novos modelos, como a novela pastoril, que suplantou a voga dos livros de cavalarias em Portugal no início do séc. $\mathrm{XVII}^{78}$.

De toda forma, o surgimento do D. Duardos Segundo e do D. Clarisol testemunham a vitalidade do ciclo dos Palmeirins no final do séc. XVI em Portugal, que pode ser verificada também pelas reedições que então se fizeram de obras anteriores da série, como a clandestina do Palmerín de Olivia (Évora: Cristóvão Burgos?, 1581), a lisboeta do Primaleón (Simão Lopes, 1598) e a já mencionada do Palmeirim de

\footnotetext{
${ }^{76}$ Op. cit., p. 411.

${ }_{77}$ Op. cit., p. $714-715$.

${ }^{78}$ Embora o gênero já fosse cultivado em Espanha desde meados do séc. XVI, a novela pastoril só se afirma nas letras portuguesas a partir da publicação de $A$ primavera, de Francisco Rodrigues Lobo, em 1601. Cf. a Introdução de Maria Lucília Gonçalves Pires a sua recente edição de A primavera. Lisboa: Vega, 2003, p. 7-11, onde a autora também destaca a importância do Menina e Moça, de Bernardim Ribeiro (1554) como precursora do gênero em Portugal.
} 
Inglaterra (Lisboa: António Ávares, 1592). Este tardio florescimento do ciclo demonstra a especificidade portuguesa no tocante ao desenvolvimento do gênero cavaleiresco, pois a esta altura os sintomas de perda de vigor criativo já eram evidentes em Espanha. O contraste é nítido: no período compreendido entre os anos 1580 e o início do séc. XVII, apenas quatro títulos novos foram acrescentados às dezenas de livros de cavalarias castelhanos já existentes; também a atividade editorial naquele país decresce sensivelmente, pois entre 1589 e 1623, de acordo com Lucía Megías, registram-se apenas 7 edições de livros de cavalarias, sendo duas delas realizadas em Lisboa, por Simão Lopes ${ }^{79}$.

Em Portugal, para além do período em que se publicaram livros de cavalarias (o último de que se tem notícia é justamente o D. Duardos Segundo, reeditado em 1604), a difusão do gênero cavaleiresco prolonga-se por todo o séc. XVII através da proliferação de obras manuscritas ${ }^{80}$. Dentre esses textos - cuja maioria permanece inédita, conforme tivemos oportunidade de ressaltar no item 1 - destacam-se os ligadas à série palmeriniana, que constituem nova bifurcação do ciclo, à semelhança do ocorrido com as seqüências do Primaleón. As três partes da Crônica de D. Duardos manuscrita, de que trataremos a seguir, vinculam-se diretamente ao Palmeirim de Inglaterra, de Francisco de Morais, formando um ramo paralelo ao das continuações impressas de Fernandes e Lobato.

Sintetizando o que foi exposto, apresentamos um quadro com o desenvolvimento do ciclo dos Palmeirins ${ }^{81}$.

\footnotetext{
${ }^{79}$ Para estas informações, cf. na Bibliografía de Eisenberg e Marín Pina a já referida cronologia das primeiras edições (p. 458-459) e de Lucía Megías o "Índice cronológico de libros de caballerías castellanos" em seu Imprenta y libros de caballerías, p. 609-618. Conforme vimos acima, os dados lembrados não significam que os livros de cavalarias tenham perdido repentinamente seus leitores. Há muitos indícios a apontar para o fato de que as obras anteriormente publicadas continuassem a ser lidas pelo público ibérico e europeu, a partir de traduções editadas em diversos outros países.

${ }^{80}$ Neste período, a preferência dos editores é pela novela pastoril. A primavera, de Rodrigues Lobo, foi editada em 1601, 1608, 1619, 1650 e 1670 (além das possíveis impressões em 1633 e 1635); sua continuação, intitulada $O$ pastor peregrino foi publicada em 1608, 1618, 1651 e 1670. A paciência constante, de Manuel Quintana de Vasconcelos, surge em 1622 e Os campos elísios, de João Nunes de Vasconcelos, em 1626. Durante todo este período, não há notícias de reedições de livros de cavalarias em Portugal.

${ }^{81} \mathrm{Na}$ elaboração do quadro, desconsideramos as contribuições italianas de Mambrino Roseo da Fabriano, que não tiveram repercussão na Península Ibérica, e também a História grega (ou Crônica de D. Belindo), de D. Leonor Coutinho, cuja vinculação com o ciclo dos Palmeirins não pudemos estabelecer com precisão: este livro pode tanto ser uma seqüência das continuações manuscritas por nós examinadas, como um prosseguimento do D. Clarisol. Além disso, é preciso observar que no quadro que se segue a disposição das obras em árvore não quer indicar a genealogia entre diferentes testemunhos, como de
} 


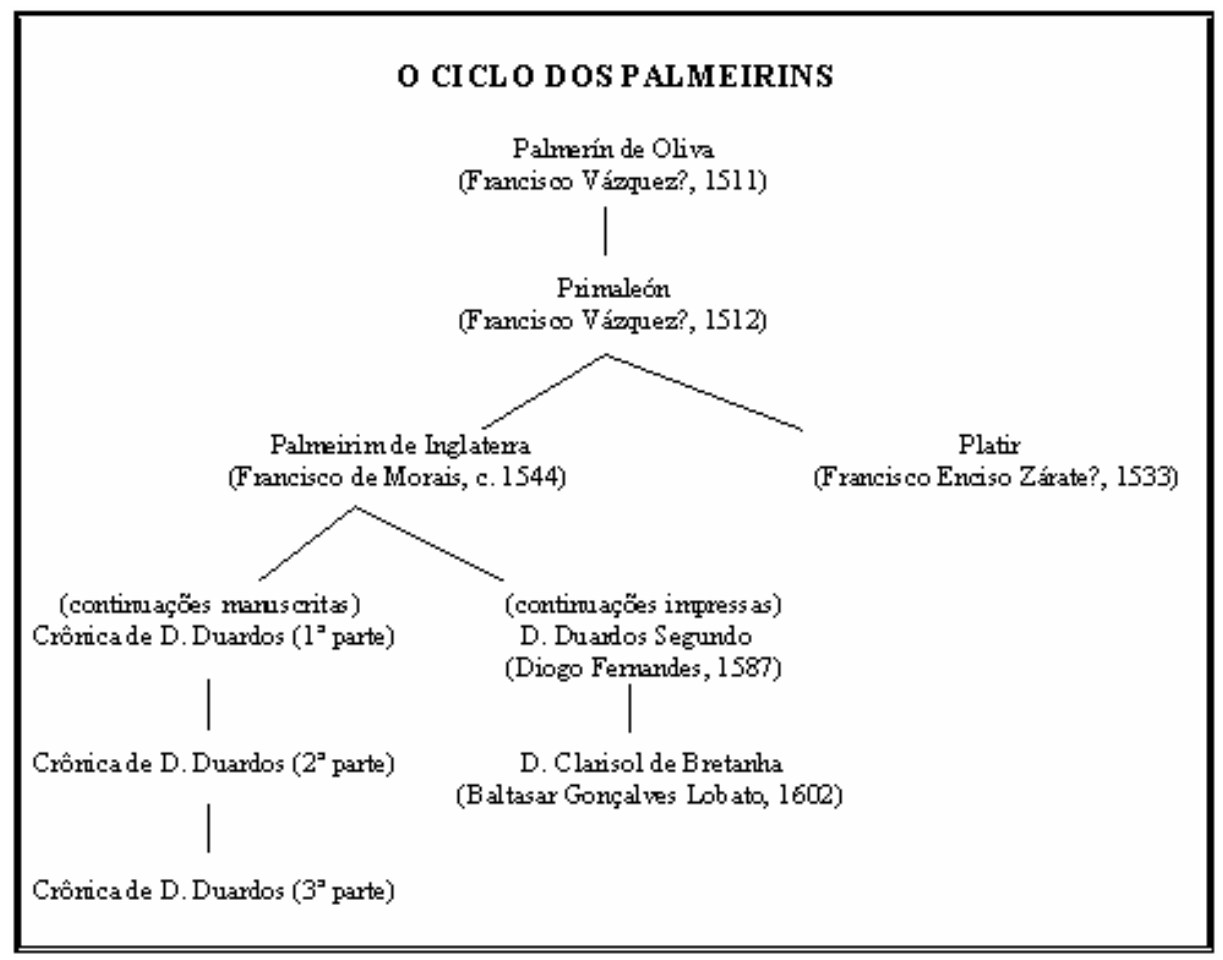

\section{A Crônica de D. Duardos: hipóteses}

Dentre os diversos livros de cavalarias portugueses do séc. XVI que permanecem inacessíveis ao grande público e virtualmente desconhecidos - seja porque não são reeditados há séculos, ou porque permanecem manuscritos - contam-se as continuações do Palmeirim de Inglaterra. Embora as obras de Diogo Fernandes e Baltasar Gonçalves Lobato não sejam propriamente inéditas, ambas estão a reclamar novas edições que as resgatem do esquecimento secular a que foram relegadas. Situação ainda pior, no entanto, é a das continuações manuscritas do Palmeirim, que permanecem virtualmente desconhecidas.

Fidelino de Figueiredo foi o primeiro a lembrar-se delas modernamente. Além de uma misteriosa História de Palmeirim de Inglaterra e de D. Duardos (texto desaparecido, que a Bibliotheca Lusitana, de Barbosa Machado, atribui a D. Gonçalo Coutinho) e da Crônica de D. Belindo, de D. Leonor Coutinho (do qual voltaremos a

hábito na crítica textual; nosso objetivo é simplesmente representar graficamente o encadeamento dos diversos livros que compõem o ciclo dos Palmeirins. 
falar adiante), Figueiredo dá notícia de oito manuscritos presentes na Biblioteca Nacional de Lisboa que se ligam ao ciclo dos Palmeirins, continuando a obra de Francisco de Morais. Ainda que não os tenha lido, o pesquisador português mostrou-se inclinado a crer que esses manuscritos fossem testemunhos de uma derivação autônoma do ciclo, diversa das continuações impressas já conhecidas do Palmeirim $^{82}$.

As informações de Fidelino de Figueiredo foram completadas por Massaud Moisés, num artigo de 1957. Nesta "achega bibliográfica", o autor dá notícia de diversos livros de cavalarias inéditos e manuscritos, ampliando consideravelmente o elenco apresentado por Figueiredo: sem contar com outros textos que não mantêm relação com o ciclo que ora nos ocupa, o estudioso brasileiro listou 14 cópias das continuações do Palmeirim de Inglaterra, provenientes de diversas bibliotecas portuguesas. Embora apresentem grandes variações com relação ao título e ao número de capítulos, Moisés encontrou elementos que lhe permitiram agrupar, de modo mais organizado que seu antecessor, os manuscritos em torno das três partes nas quais se estrutura a continuação da obra de Francisco de Morais, que ele chamou de: 1. Crônica de Primaleão (com 6 cópias); 2. Crônica de D. Duardos, I (5 cópias) e; 3. Crônica de D. Duardos, II (3 cópias), correspondentes ao que neste trabalho estamos apelidando de Crônica de D. Duardos Primeira, Segunda e Terceira Partes. Ao concluir suas observações, Moisés considerou duas hipóteses, não excludentes entre si: que os textos em questão fossem do mesmo autor do Palmeirim, Francisco de Morais, e que poderiam ser cópias de versões manuscritas anteriores à publicação da Terceira e Quarta Partes, de Diogo Fernandes, posteriormente refundidas por ele ${ }^{83}$.

Mais de 20 anos se passaram antes que nova busca por manuscritos inéditos contendo livros de cavalarias fosse realizada na Biblioteca Nacional de Lisboa, em 1982. Ainda que não tenha descoberto nenhum novo testemunho dos textos que nos interessam, João Palma-Ferreira traz mais informações sobre os manuscritos já conhecidos, transcrevendo seus capituleiros e indicando sumariamente as diferenças

${ }^{82}$ História da Literatura Clássica. Vol. III. Continuação da $2^{a}$ Época: 1580-1756 e $3^{a}$ Época: 1756-1825. $2^{a}$ ed., Lisboa, Livraria Clássica, 1930, p. 29-34. Algumas informações apresentadas por Figueiredo são inexatas. A Selva de Cavallarias Famozas não se vincula ao ciclo dos Palmeirins, como o autor dá a entender. Além disso, um manuscrito referido parece estar com a numeração errada: trata-se do $n^{\circ} 6483$ (B-6-55) que, de acordo com a descrição de Figueiredo, identifica-se com o n ${ }^{\circ} 483$ (B-6-35). Não descobrimos se houve mudança na numeração do manuscrito (o que é pouco provável) ou se a falha se deve a erro tipográfico (a $1^{\mathrm{a}}$ edição do livro, que também consultamos, traz a mesma informação).

83 "A novela de cavalaria portuguesa: achega bibliográfica", in: Revista de História, 29, 1959, p. 47-52. 
entre eles. Os títulos dos capítulos das três partes da Crônica de D. Duardos (que ele, seguindo a sugestão de Massaud Moisés, chama de Crônica de Primaleão e Crônicas de D. Duardos I e II) permitiram-lhe verificar que os personagens e alguns temas dessas novelas coincidem com os das continuações de Diogo Fernandes e Baltasar Gonçalves Lobato, o que, de certa forma, já havia sido intuído por Figueiredo e Moisés. Mas, ao contrário do que propusera este último, Palma-Ferreira supôs que os manuscritos representassem reelaborações posteriores aos livros impressos e não o contrário. Dessa forma, segundo o autor, as continuações manuscritas devem ter sido produzidas já no século XVII, o que desautorizaria sua atribuição a Francisco de Morais; Palma-Ferreira sugere mesmo que essas novelas sejam do já lembrado D. Gonçalo Coutinho ${ }^{84}$.

Há pouco o que acrescentar à breve história das conjeturas acerca desses textos. Além da descoberta recente de nova cópia da primeira parte da Crônica de $D$. $\operatorname{Duardos}^{85}$, resta observar que um dos mais antigos bibliógrafos portugueses, João Franco Barreto, registra informação que tem passado despercebida e permite formular outra hipótese sobre a autoria das obras manuscritas. Em sua Bibliotheca Luzitana, que antecede a homônima de Barbosa Machado em quase um século, o autor anota a propósito de Fernão Rodrigues Lobo Soropita:

Fernão Roiz Lobbo, advogado em Lx ${ }^{a}$ [Lisboa] a $q$ chamarão Soropitta muitto feio, mas de muitta abilidade e entendimento, muitto grande Poeta Latino e vulgar. Compos as obras seguintes. Terceira e $4^{a}$ parte da historia de Palmeirim de Inglaterra, em que tratta do segundo Dom Duardos que he D. Duardos de Bretanha. As quais andão impressas, dirigidas a Pero de Alcassova Carneiro, conde da Idanha, em nome de Diogo Fernandes, vizinho de Lxa daqual dizem alguns fora verdadeiramente Autor delas, mas que o Soropitta, lhas emendara ${ }^{86}$.

\footnotetext{
84 "Prefácio", in: Crónica do Imperador Maximiliano. Transcr. de Luís Carvalho Dias e rev. de Fernando F. Portugal. Lisboa, IN - CM / Biblioteca Nacional, 1983, em especial as p. 58-64. Também aqui, há erro de numeração em um manuscrito apresentado: o que, na p. 21, aparece com o número 569, na verdade é o 659.

${ }^{85}$ Trata-se do cód. 12904 da Biblioteca Nacional de Lisboa, que utilizamos como base para nossa transcrição. A descoberta foi feita por Aurelio Vargas Díaz-Toledo: cf. Os livros de cavalarias em Castela e Portugal, op. cit. Agradecemos ao autor a gentileza de enviar cópia do texto, ainda inédito.

${ }^{86}$ Barreto, João Franco. Bibliotheca Luzitana, cópia xerográfica do ms. da Casa de Cadaval presente na sala de reservados da Biblioteca Nacional de Lisboa, tomo III, p. 426. João Franco Barreto nasceu em Lisboa no ano de 1600 e morreu em data desconhecida, mas certamente posterior a 1674 . Foi literato do círculo de D. Francisco de Melo, a quem acompanhou como secretário em embaixada à França por ordem de D. João IV, em 1641. Sua Bibliotheca permaneceu inédita, mas foi consultada por Diogo Barbosa Machado, que não aproveitou esta informação sobre Fernão Rodrigues Lobo. Agradecemos a Aurelio Vargas Díaz-Toledo pela indicação desta referência.
} 
Em síntese, as informações sobre a Crônica de D. Duardos reunidas pelos pesquisadores citados são as seguintes: a seqüência do livro de Francisco de Morais é dividida em três partes, aparentemente redigidas pelo mesmo autor. Em que pese à evidente ligação entre as partes, cada uma delas devia ser considerada um livro com relativa autonomia, visto que foram copiadas em manuscritos diferentes. Quanto à autoria, as hipóteses avançadas mencionam os nomes de Francisco de Morais, Diogo Fernandes e D. Gonçalo Coutinho, aos quais devemos acrescentar o de Fernão Rodrigues Lobo, de acordo com a sugestão de João Franco Barreto. Entre as continuações manuscritas e as impressas (principalmente o D. Duardos Segundo, de Diogo Fernandes) há troca de temas e personagens, o que sugeriu aos poucos pesquisadores que examinaram a questão até agora a existência de algum tipo de parentesco entre as obras. São 15 as cópias conhecidas das diversas partes do texto, distribuídas da seguinte forma ${ }^{87}$ :

1. Crônica de D. Duardos, Primeira Parte (sete manuscritos):

- Biblioteca Nacional de Lisboa (BNL): cód. 483; cód. 619; cód. 620; cód. 658; cód. 6828; cód. 12904.

- Arquivo da Torre do Tombo (TT): Manuscritos da Livraria, cód. $1773\left(1^{\mathrm{a}}\right.$ parte).

2. Crônica de D. Duardos, Segunda Parte (cinco manuscritos):

- BNL: cód. 659; cód. 6829.

- TT: Manuscritos da Livraria, cód. 410; cód. 1201.

- Biblioteca do Paço Ducal de Vila Viçosa: seção de reservados.

3. Crônica de D. Duardos, Terceira Parte (três manuscritos):

- BNL: cód. 6830.

- TT: Manuscritos da Livraria, cód. 1202 e cód. 1773 ( $2^{\text {a }}$ parte).

${ }^{87}$ Reproduzimos aqui as conclusões da "achega bibliográfica" de Massaud Moisés, alterando apenas os nomes por ele dados às diversas partes da Crônica e acrescentando o dado relativo ao manuscrito recentemente descoberto. 
A leitura da Crônica de D. Duardos, somada a pesquisas que realizamos sobre o tema, permitem acrescentar dados novos à discussão e, ainda que sem sanar todas as dúvidas, descartar algumas das hipóteses formuladas anteriormente.

Em primeiro lugar, convém esclarecer o motivo de chamarmos ao livro em exame de Crônica de D. Duardos, contrariando uso estabelecido por Massaud Moisés. Conforme observamos anteriormente, as diferentes cópias do texto apresentam grande divergência com relação ao título. Restringindo-nos às sete cópias conhecidas da primeira parte da Crônica de D. Duardos, verifica-se que duas são intituladas Crônica de Primaleão, Imperador de Grécia (BNL códs. 620 e 12904); outras duas chamam-se Vida de Primaleão, Imperador de Grécia ou Vida de Primaleão, Imperador de Constantinopla (TT cód. 1773, 1ª parte, e BNL cód. 483, respectivamente); Crônica do Imperador Primaleão e outros príncipes é o nome atribuído pelo copista a outro manuscrito (BNL cód. 658). O título de apenas duas cópias faz menção a D. Duardos: Crônica do invicto D. Duardos de Bretanha (BNL cód. 6828) e Crônica de D. Duardos (BNL cód. 619). Na multiplicidade de títulos, que confundiu Fidelino de Figueiredo fazendo-o não notar que por trás deles havia cópias de um mesmo texto, nota-se clara predominância de referências a Primaleão. Embora tal fato possa explicar a opção de Massaud Moisés, que se decidiu pelo nome Crônica de Primaleão, a leitura do texto demonstra claramente que seu protagonista é o príncipe D. Duardos, filho de Palmeirim de Inglaterra. No cap. 58 da primeira parte, por exemplo, o narrador justifica ter negligenciado a relação de algumas aventuras de Trineo dizendo:

E se aqui não fazemos particular memoria de seus trabalhos, e dos fins gloriozos que nelles teve, he porque a Historia propria mente trata de D Duardos, e se Ouvessemos de particularizar as proezas de cada hũ dos cavalleiros que em seu tempo concorrião, fora necessaria nova formação no gosto dos homens para senão cançarẽ com volumes tão grandes ${ }^{88}$.

O motivo de a maioria dos manuscritos que preservaram o texto mencionarem o personagem Primaleão no título pode ter várias explicações: 1. as aventuras narradas são estreitamente vinculadas a Constantinopla, cuja coroa havia sido herdada por

${ }^{88}$ Cf. no segundo volume deste trabalho, o cap. 58, linhas 13-17. Doravante, todas as citações da Crônica de D. Duardos, Primeira Parte serão seguidas apenas da indicação do capítulo e linhas (por exemplo: 5813-17). As citações de passagens do texto seguem os critérios que serão expostos no cap. 3 do presente volume, eliminando-se apenas as marcas de mudança de linhas no códice. 
Primaleão depois da morte do velho Imperador Palmeirim de Oliva, narrada nos últimos capítulos da obra de Francisco de Morais; 2. além disso, ao atribuir o título ao livro que copiaram, os amanuenses podem ter sido influenciados pela importância conferida ao príncipe Primaleão (neto do Imperador), especialmente nos capítulos finais da primeira parte. Com efeito, dentre os muitos cavaleiros que povoam a obra, os príncipes D. Duardos e Primaleão parecem ser os mais importantes, reproduzindo de certa forma o co-protagonismo de seus avós homônimos no Primaleón, e 1512; 3. por fím, independentemente de o livro ter sido redigido antes ou depois da publicação do $D$. Duardos Segundo (aspecto que discutiremos adiante), as cópias hoje disponíveis da Crônica de D. Duardos são certamente posteriores à difusão da obra de Diogo Fernandes. Assim, é possível que os copistas, temerosos de ver o fruto de seu trabalho confundido com o livro já impresso, atribuíssem nomes distintos ao texto. De todo modo, as vicissitudes de um texto transmitido unicamente por via manuscrita favorecem a ocorrência deste tipo de oscilação, que se verifica também entre as cópias da Crônica de D. Belindo, de D. Leonor Coutinho.

Aludimos anteriormente às hipóteses acerca da interdependência entre as continuações manuscritas do Palmeirim de Inglaterra e as seqüências impressas por Fernandes e Lobato. Como vimos, a Crônica de D. Duardos ora foi considerada como uma espécie de rascunho preliminar, posteriormente revisto e publicado por Diogo Fernandes (tese sugerida por Massaud Moisés), ora foi tida como refundição posterior ao D. Duardos Segundo (opinião defendida por Palma-Ferreira). A leitura do texto manuscrito e a comparação com o livro publicado em 1587 são suficientes para demonstrar que nenhuma das hipóteses referidas é correta. Na realidade, conforme já havíamos sugerido ao final do item 2, entre a Crônica de D. Duardos e o D. Duardos Segundo não há relação de dependência: trata-se de dois textos autônomos, cujo único traço comum é a proposta de dar continuidade à mesma obra.

A coincidência quanto aos nomes de muitos personagens, verificada por PalmaFerreira, não significa que um dos livros seja a refundição de outro ${ }^{89}$. Nada mais natural

\footnotetext{
${ }^{89}$ Palma-Ferreira afirma que "quanto ao parentesco dos manuscritos com as $3^{\mathrm{a}} \mathrm{e} 4^{\mathrm{a}}$ partes do Palmeirim de Inglaterra, de Diogo Fernandes (1587), assinalamos o aproveitamento da intriga, retomando personagens como Albaizar, Florendos, Daliarte, Gridónia, Carmélia, D. Duardos, Leonarda, Primaleão, Dramusiando, Flérida, Polendos, Pavorante, Vasperaldo, Drúsia Velona, Targiana, Aliandro, Beliasem, Floramão e tantas outras e repetindo incidentes como o da Ilha e Floresta dos Ulmeiros, de Diogo Fernandes, que é paralelo aos da Ilha e Floresta dos Loureiros que aparecem em alguns manuscritos" (op.
} 
que haja personagens comuns às duas obras, visto que ambas não só pertencem ao mesmo ciclo, como também iniciam a narração partindo do mesmo ponto: o final do Palmeirim de Inglaterra. O leitor de Francisco de Morais sabe bem que, depois de relatar a terrível guerra contra o exército turco, o narrador informa que todos os reis e príncipes cristãos foram levados pelo sábio Daliarte à Ilha Perigosa. Ali, os mortos foram enterrados e os feridos receberam os cuidados necessários; naquela ilha, nascem os filhos dos principais personagens da obra, que protagonizarão as futuras aventuras. Morais informa cuidadosamente a identidade de cada um e qual sorte o destino lhes reservava: não pode surpreender portanto o fato de esses personagens figurarem nas continuações manuscritas e impressas do Palmeirim. Note-se, porém, que nenhum dos personagens novos da Crônica de D. Duardos (como D. Floris, a princesa Fidélia, o anão Pleonido, entre outros) consta do D. Duardos Segundo. Além disso, os mesmos personagens agem de modo completamente distinto nas duas obras: tome-se o caso de Albaizar como exemplo. Francisco de Morais já avisara os leitores que o filho de Targiana seria chamado Albaizar, como o pai. Nas duas obras, o jovem príncipe turco segue para Constantinopla acompanhado de seu amigo Beliazem (conforme indicação do Palmeirim), a fim de vingar a morte do pai. Ao chegar a Constantinopla, nos dois livros acontece o esperado: Albaizar começará a amar a filha de um de seus inimigos. Mas as semelhanças terminam aqui. Enquanto na Crônica de D. Duardos a eleita é Carmélia, filha de Floriano, no D. Duardos Segundo ele se apaixona pela princesa Gridônia, filha de Florendos.

Além disso, diferenças de estilo entre o texto manuscrito e o impresso impedem que se reconheçam ligações entre eles. O autor da Crônica de D. Duardos não recorre ao maravilhoso e bizarro com o mesmo exagero de Diogo Fernandes, preferindo aplicar seu talento na descrição e análise dos sentimentos e motivações íntimas dos personagens. São, em suma, dois autores com sensibilidades distintas.

Se é verdade que estamos diante de nova bifurcação do ciclo, essa constatação pode sugerir algumas conclusões a respeito da data de produção da Crônica de D. Duardos. Não parece plausível crer que seu autor se desse ao trabalho de redigir a

cit., p. 58). A observação merece alguns reparos: em primeiro lugar, Aliandro é personagem que não existe nas continuações manuscritas do Palmeirim; além disso, não sabemos a que episódio da Floresta dos Loureiros ele se refere. Em realidade, não há elementos que permitam identificar um "aproveitamento da intriga" que comprovasse a suposta interdependência entre as obras impressa e manuscrita. 
continuação do Palmeirim se soubesse da existência do D. Duardos Segundo, cuja impressão, para um admirador de livros de cavalarias como ele certamente devia ser, não passaria despercebida. Mais compreensível seria que ocorresse o contrário: isto é, que Diogo Fernandes tenha redigido seu livro sem saber que havia outro autor empenhado na mesma tarefa de dar prosseguimento ao ciclo dos Palmeirins. É claro que nosso raciocínio está baseado em conjecturas; em princípio, deveríamos admitir também a possibilidade de o autor da Crônica de D. Duardos ter posto mãos à obra exatamente por ter lido e desaprovado o livro de Fernandes. No entanto, visto que não encontramos em nenhum dos livros quaisquer referências ou desmentidos ao outro ramo da série (no estilo dos feitos pelo autor do Platir, conforme exemplificamos acima), tudo aponta para a conclusão de que os dois autores trabalharam mais ou menos no mesmo período, inscientes de haver outro escritor com o mesmo intento - o que situaria a redação da Crônica de D. Duardos para antes de 1587, ano em que surge a primeira edição do livro de Diogo Fernandes. A edição do D. Duardos Segundo pode inclusive ser a explicação para o fato de a Crônica de D. Duardos ter permanecido inconclusa: talvez seu autor tenha interrompido bruscamente a redação da obra quando soube que outro escritor se teria adiantado a ele no intento de apresentar ao público a seqüência do célebre Palmeirim de Inglaterra ${ }^{90}$.

Resta ainda a questão da autoria do texto. Cumpre descartar, de imediato, as fantasiosas referências que constam em alguns dos manuscritos, fenômeno de resto comum a muitos livros de cavalarias da época. Os códices BNL 12904 e 620 não apenas atribuem a Crônica de D. Duardos a certo "Author Hibernio" chamado Guilherme Frusto, como também oferecem detalhes sobre o suposto copista da obra: tratar-se-ia de Simisberto Pachorro, que teria realizado o trabalho enquanto esteve "encantado no Cume da Penha Riguroza, da Serra da Lua, pello odio do Sabio Bragamante". A curiosa mistura entre realidade e ficção certamente visava a aguçar a curiosidade dos potenciais leitores: afinal, o que esperar de um livro produzido em semelhantes circunstâncias? Os códices BNL 6828 e 619 alteram o nome do autor para Henrique Frusto, apresentando-o

${ }^{90}$ Com efeito, a terceira parte da Crônica de D. Duardos, tal como transmitida pelos manuscritos conhecidos, deixa diversas aventuras sem conclusão. Visto não haver quaisquer notícias acerca de uma hipotética quarta parte da Crônica, a explicação mais plausível para tal fato é que o autor tenha abandonado o trabalho de composição, por razão desconhecida. Em vista do que será exposto a seguir acerca da identidade do autor, não cremos que o motivo para a interrupção tenha sido sua morte; mais provável é que ele tenha desistido de levar a cabo tarefa tão trabalhosa ao tomar conhecimento da publicação do D. Duardos Segundo, de Diogo Fernandes. 
como "Chronista ingres". Além disso, as cópias acrescentam que a obra teria sido "tresladada" por "Gomes Ennes de Zurara, que fes a Chronica del Rey Dom Afonço Henrriques dePortugal" e, a fim de dar maior credibilidade à informação, notam que o texto havia sido achado recentemente (“de novo") entre seus papéis. É evidente que Henrique (ou Guilherme) Frusto e Simisberto Pachorro nunca existiram; quanto a Zurara, não é possível que este cronista do séc. XV tenha composto uma continuação do Palmeirim de Inglaterra ${ }^{91}$.

Dentre as quatro hipóteses restantes quanto à autoria da obra, formuladas pelos diversos investigadores citados, duas são facilmente descartáveis. Embora se saiba da existência de um manuscrito intitulado História de D. Duardos e atribuído a Diogo Fernandes na seção de reservados da Livraria do Paço Ducal de Vila Viçosa, em vista do que já foi exposto sobre este autor não pode haver dúvida que se trata de um erro ${ }^{92}$. Que o autor da Crônica de D. Duardos não seja Francisco de Morais, parece igualmente claro. A continuação manuscrita é estilisticamente inferior ao Palmeirim e apresenta diversas incongruências com relação a seu antecessor ${ }^{93}$; além disso, cremos que ela terá sido redigida nas proximidades do ano 1587 - depois, portanto, da morte de Francisco de Morais (1572).

As duas outras hipóteses referentes à autoria da Crônica de D. Duardos merecem ser examinadas com mais vagar. A primeira possibilidade é que o livro tenha sido escrito por Fernão Rodrigues Lobo. Uma vez que a Bibliotheca de João Franco Barreto, onde consta a informação, permaneceu inédita, esta hipótese não foi considerada pelos poucos pesquisadores que refletiram sobre o tema. Possivelmente

\footnotetext{
91 Ainda assim, o cód. BNL 6828 exibe ainda hoje antes do primeiro fólio uma carta de Inocêncio Francisco da Silva na qual, em resposta ao antigo proprietário do manuscrito, o Visconde de Fonte Arcada, o famoso bibliógrafo declara-se surpreso com a "descoberta" de um inédito de Zurara. O texto da carta deixa claro, entretanto, que àquela altura Inocêncio não tinha mais condições de saúde para examinar o caso com a devida atenção. A carta está transcrita adiante, no item 1.4 do cap. 2.

${ }^{92}$ Trata-se de cópia da Crônica de D. Duardos, Segunda Parte, conforme apresentado no elenco dos manuscritos referentes ao ciclo dos Palmeirins apresentado acima (p. 39). A notícia acerca deste códice foi dada por Joaquim de Carvalho. Cf. "Livros de D. Manuel II", in: Obra Completa. Vol. 4: História da Cultura (1948-1955). Lisboa: Calouste Gulbenkian, 1983, em especial a p. 446.

${ }^{93} \mathrm{O}$ fenômeno é comum nos ciclos de livros de cavalarias. Entre o Palmeirim e o Primaleón também são verificáveis uma série de discrepâncias, como as apontadas no prólogo da edição de 1786 do livro português. $\mathrm{O}$ autor do prólogo, atento leitor da série palmeriniana, identifica cuidadosamente todos os aspectos alterados por Morais: a sorte dos personagens Pompides e Blandindón; as referências aos filhos de Primaleão, em particular o Platir, e a morte de Palmeirim de Oliva. Entretanto, se o autor da Crônica de D. Duardos fosse o próprio Morais, não haveria como explicar os numerosos conflitos existentes entre o Palmeirim e sua continuação manuscrita. As discrepâncias entre os dois livros são indicadas em algumas das notas de rodapé ao texto transcrito no segundo volume.
} 
nascido em Lisboa ou Leiria por volta de meados do séc. XVI, oriundo de família de cristãos-novos e parente próximo de Francisco Rodrigues Lobo, autor de Corte na Aldeia, Fernão Rodrigues Lobo foi advogado de notoriedade em Lisboa. Sua alcunha, Soropita, devia acompanhá-lo desde os tempos de estudante em Coimbra, quando adquiriu fama de galhofeiro e pândego. Redigiu o prefácio da primeira edição das Rimas de Camões, com quem talvez tenha convivido, e foi autor de obras jurídicas e textos satíricos, além de poemas líricos e religiosos que só foram editados em 1868, por Camilo Castelo Branco ${ }^{94}$. Segundo Franco Barreto, quase seu contemporâneo, Soropita poderia ser o verdadeiro autor dos textos impressos com o nome de Diogo Fernandes, ou um revisor dessa obra, tese não desconsiderada por Isabel Adelaide de Lima e Almeida ${ }^{95}$.

Nos raros estudos que encontramos sobre a obra de Soropita, a hipótese de atribuição da autoria de um livro de cavalarias ao escritor não é recebida como digna de credibilidade. José Baptista Fernandes Querido nem sequer a menciona; já Maria Luísa do Couto Linhares de Deus a rejeita sumariamente, sem qualquer justificativa. Após citar as informações de João Franco Barreto, a pesquisadora declara simplesmente: "trata-se de uma hipótese a excluir" ${ }^{96}$. O exame da obra de Soropita, no entanto, parece confirmar esta opinião: é difícil imaginar que um escritor admirável como Fernão Rodrigues Lobo, dono de estilo ágil e irônico, seja o responsável pela Crônica de D. Duardos, texto tantas vezes marcado por uma certa hesitação sintática que o torna confuso e pesado ${ }^{97}$.

\footnotetext{
${ }^{94}$ Sobre a biografia de Soropita, cf. a introdução de Camilo Castelo Branco a sua edição das Poesias $e$ prosas inéditas, de Fernão Rodrigues Lobo. (Porto: Tipografia Lusitana, 1868, p. IX-XXXI) e as correções sugeridas por M. Luísa do Couto Linhares de Deus. Cartas éditas e inéditas de Fernão Rodrigues Lobo Soropita. Dissertação de mestrado apresentada à Faculdade de Letras da Universidade de Lisboa, 1987, p. 14-15. A autora declara não ter encontrado fundamento para a hipótese de que o Soropita tivesse convivido com Camões (p. 9) e também não se mostra convencida quanto a sua qualidade de cristão-novo, embora não apresente argumentos contrários à suposição (p. 10).

95 Op. cit., p. 309.

${ }^{96}$ Op. cit, p. 56. De toda forma, há indícios de que a autora não conheça bem os livros de cavalarias; além de transcrever com erro a citação de João Franco Barreto, para esclarecer a discussão sobre a possibilidade de Soropita ter escrito um livro de cavalarias a autora remete o leitor apenas à introdução de Rodrigues Lapa à edição de extratos do Palmeirim. Cf. também Querido, José Baptista Fernandes. Fernão Rodrigues Lobo Soropita. Éditos e inéditos. Prosa e verso. Fixação do texto, notas e comentários. Dissertação de mestrado apresentada à Faculdade de Letras da Universidade de Coimbra, s/d.

${ }^{97}$ Note-se que João Franco Barreto é explícito ao atribuir a Fernão Rodrigues Lobo não a autoria das continuações manuscritas do Palmeirim, que não menciona, mas sim a paternidade (ou ao menos a colaboração) das obras "que andam impressas", fornecendo inclusive detalhes precisos acerca da edição.
} 
Acreditamos que o autor do texto aqui transcrito seja D. Gonçalo Coutinho, a quem Barbosa Machado atribui uma História de Palmeirim de Inglaterra e de D. Duardos. Sempre de acordo com Bibliotheca Lusitana, cópia dessa obra hoje desaparecida teria sido vista por Francisco da Cruz na livraria de um certo João Saldanha, provavelmente na primeira metade do século XVIII. D. Gonçalo Coutinho (?1634) foi Comendador da Ordem de Cristo, Governador de Mazagão (no Marrocos) e do Algarve, além de Conselheiro de Estado de Filipe III. Poeta de pouca expressão, escreveu a biografia de Sá de Miranda e, segundo a tradição, mandou gravar no túmulo de Camões o famoso epitáfio: “Aqui jaz Luís de Camões, o príncipe dos poetas de seu tempo. Viveu pobre e miseravelmente e assim morreu". De acordo com João Franco Barreto, Coutinho "foy particular amo. do nosso Poeta Luis de Camoens, e o teve comsigo mtas. vezes em a sua quinta dos Vaqueiros á onde tambem lhe escreveo varias cartas o Poeta Diogo Bernardes"; partidário de D. António durante a crise dinástica nos anos 1580, "ficou menos aventejado do q seus merecim.tos pedião" e faleceu em Lisboa, "ja mto. velho no anno de 1634""

Em favor da hipótese de D. Gonçalo Coutinho conta o fato de Barbosa Machado anotar que seu livro perdido estava dividido em três tomos, os quais poderiam coincidir com as três partes das continuações manuscritas, e a existência de uma carta de D. Vasco Luiz da Gama, filho de D. Leonor Coutinho, datada de 12 de setembro de 1649, na qual ele diz que acabara de receber cópias de "dois livros de cavalarias de D. Gonçalo Coutinho", acrescentando que "já tinha o primeiro; e sendo muito bons, não chegam aos de minha mãe" 99 . Dessa forma, o conjunto de indícios parece apontar para D. Gonçalo Coutinho como sendo o autor da Crônica de D. Duardos e, se é verdade que

\footnotetext{
${ }^{98}$ Op. cit., v. III, p. 531-532. Barreto atribui-lhe ainda outras obras: "tradusio o livro de Jeronimo Franqui da sucessão de Portugal (...), escreveo hua sucessão historiada da casa dos Coutinhos de Marialva”, além de um Discurso da Jornada de D. Gonçalo Coutinho a Villa de Mazagam, e seu governo nella, publicado em Lisboa por Pedro Crasbeeck (1629). Na Biblioteca Nacional do Rio de Janeiro localizamos ainda uma Historia do svcesso que na ilha de S. Migvel ovve com a armada ingresa que sobre a ditta ilha foy, sendo Gouernador della Gonçalo Vaz Coutinho, publicada em Lisboa por Pedro Craesbeeck, em 1630, a qual não tivemos oportunidade de consultar.

${ }^{99}$ Barbosa Machado, Diogo. Biblioteca Lusitana. $2^{\mathrm{a}}$ ed., Lisboa, 1930, t. II, $1^{\mathrm{a}}$ parte, p. 360 . A carta de D. Vasco Luiz da Gama, lembrada por Figueiredo (op. cit., p. 30), foi publicada por Ramos Coelho, em "O primeiro Marquês de Niza", separata do Archivo Histórico Português, v. 1, 1903, p. 17-18. Vasco Luiz da Gama (1612-1676) foi o $5^{\circ}$ Conde da Vidigueira e o $1^{\circ}$ Marquês de Niza, título atribuído por D. João IV. Conforme já ficou dito, sua mãe, D. Leonor Coutinho (que, apesar do nome, não é parente de D. Gonçalo Coutinho), havia escrito um livro chamado D. Belindo, da qual se conhecem alguns manuscritos. $\mathrm{O}$ texto prende-se de alguma forma ao ciclo dos Palmeirins, pois entre seus personagens figura $\mathrm{D}$. Beliandro, filho do príncipe Primaleão.
} 
ele morreu "já muito velho" em 1634, deve-se imaginar que este livro de cavalarias tenha sido obra de sua juventude. De qualquer forma, é evidente que nossa conclusão está baseada mais sobre indícios e conjecturas do que sobre provas irrefutáveis ${ }^{100}$.

A difusão da Crônica de D. Duardos parece ter sido apreciável e duradoura. Os quinze manuscritos que contêm partes da obra, sendo sete apenas da primeira, provam que o texto deve ter tido muito mais leitores que os demais livros de cavalarias portugueses que não foram impressos, já que a maioria deles foi preservada por apenas um testemunho, como vimos acima (item 1). O favor do público - só ultrapassado pelo caso excepcional da Crônica de D. Belindo, da qual sobreviveram a espantosa cifra de 33 exemplares - estendeu-se para além de meados do séc. XVII, época em que seguramente algumas das cópias conhecidas ainda estavam sendo produzidas, de acordo com as estimativas de datação dos manuscritos (cf. cap. 2).

Um dos códices que preservaram a primeira parte da Crônica de D. Duardos foi datado pelo amanuense: trata-se do único exemplar presente na Torre do Tombo $\left(\mathrm{n}^{\circ}\right.$ 1773 dos Manuscritos da Livraria). Ali, ao final da $1^{\text {a }}$ parte do texto (pois o códice, como está encadernado hoje, traz em seguida a terceira parte da Crônica de D. Duardos, que primitivamente devia estar encadernada em separado), lê-se a seguinte nota: "Este livro he daSenhora D. Britis de Lima. / Foi acabado em doze dejulho de 1668".

Na História genealógica da casa real portuguesa, de D. António Caetano de Souza, encontram-se referências a várias personagens chamadas Britis de Lima. Uma delas (que foi casada com Jorge Furtado, Comendador de Loulé) era sobrinha de D. Leonor Coutinho, autora do D. Belindo. Como a tia, D. Britis de Lima, também parece ter tido pendores literários, de acordo com as informações registradas no mesmo passo da História genealógica: referindo-se a seu pai, Álvaro Pires da Távora (irmão de D. Leonor Coutinho), há a seguinte informação:

\footnotetext{
${ }^{100}$ Infelizmente, não tivemos oportunidade de ler textos cuja atribuição ao autor não seja questionada, com o objetivo de comparar o estilo e buscar alguma referência cruzada. Acreditamos que este deve ser o próximo passo para quem desejar aprofundar-se no tema.
} 
foy Senhor do Morgado de Caparica, teve duas Commendas na Ordem de Christo, e a das Entradas na Ordem de Santiago; escreveo hum livro com o título de Varoens illustres da Casa de Tavora, que sua filha mandou imprimir no anno de 1648; e faleceu a 7 de julho de 1640, havendo casado com D. Maria de Lima, filha de D. Lourenço de Lima, VII. Visconde de Villa-Nova da Cereeira, \&c. ${ }^{101}$

Não seria demasiado arriscado, em suma, afirmar que a data do referido manuscrito deve estar correta, tendo sido o texto copiado em 1668. O texto de base para a confecção da cópia pode ter sido o exemplar possuído pela tia de D. Britis de Lima, D. Leonor Coutinho, ao qual seu filho alude na carta transcrita.

Algumas das outras cópias conhecidas da primeira parte da Crônica de D. Duardos trazem informações sobre seus antigos proprietários, demonstrando como a obra teria circulado entre diversas famílias da nobreza portuguesa. O cód. BNL 658 pertenceu à família dos Viscondes de Fonte Arcada; uma carta de Inocêncio Francisco da Silva, apensa ao códice, permite inferir que o proprietário teria sido António Francisco Jacques de Magalhães, o $5^{\circ}$ e último Visconde de Fonte Arcada (1793-1880). Sobre ele, o Diccionario bibliographico portuguez, do mesmo Inocêncio, diz que colaborou em diversos periódicos políticos e literários de seu tempo, além de vários textos e discursos relativos à administração pública ${ }^{102}$. Já o cód. BNL 12904 pertenceu à família dos Condes do Bomfim e chegou à Biblioteca através de compra em leilão promovido pelo livreiro José M. Rodrigues em 1987. O catálogo do leilão informa que boa parte dos livros vendidos provinha da biblioteca de Arnaldo H. Oliveira, de quem não conseguimos informações ${ }^{103}$. Duas outras cópias foram doadas à Biblioteca Nacional por conhecidos estudiosos da literatura, como António Ribeiro dos Santos e António Lourenço Caminha (são os cód. 483 e 658, respectivamente), mas não encontramos qualquer indício sobre o meio pelo qual tais livros chegaram a suas mãos.

\footnotetext{
${ }^{101}$ Souza, D. António Caetano de. História genealógica da casa real portuguesa. Nova ed. revista por M. Lopes de Almeida e César Pegado. Coimbra: Atlântida: 1953, tomo XII, parte I, p. 51.

102 Diccionario bibliographico portuguez. Estudos aplicáveis a Portugal e ao Brasil. Lisboa: Imprensa Nacional / Casa da Moeda, 1973, vol. VIII, p. 172-173.

103 No mesmo catálogo (Rodrigues, José Manuel, Leilão $\mathrm{n}^{\circ}$ 20, 1987. Catálogo de uma curiosa biblioteca...., Lisboa: 1987, p. 74, núm. 624), há a informação de um exemplar da segunda e terceira partes da mesma obra, proveniente da antiga biblioteca do arquiteto José Maria Nepomuceno, que teria sido leiloado em 1897. Embora tenhamos localizado este catálogo na Biblioteca Nacional de Lisboa, infelizmente não tivemos oportunidade de compulsá-lo.
} 


\section{A Crônica de D. Duardos: narrador e personagens.}

A certo ponto do livro, buscando justificar a incrível coincidência que reunira vários dos principais personagens da obra em certa paragem remota, o narrador faz uma longa digressão metanarrativa que principia do seguinte modo:

Verdadeiramente que bem concideradas as couzas, que escrevemos, a variedade dos cazos, a grandeza dos dezastres, a novidade dos sucessos, que mais parecerà que fazemos rellação curioza de fabulas sonhadas, que Choronica grave de Historias verdadeiras. Eu pello menos não quero obrigar a maior credito aquem ler esta nesta lingoa, do que me ficou della quando a li na em que Henrrique Frusto a compos, porque não cei certo como partindo havia tanto tempo D. Duardos da Floresta das tres Fontes, e Albaizar algũ despois de Constantinopla, Vasperaldo da Ilha de Dramusiando, D. Floris de Napoles, se vierão a ajuntar por varios caminhos em occazião tão forçoza, em hũ mesmo dia, em hũa mesma paragẽ e em hũ Mesmo Navio (45,4-13).

Estão presentes no trecho algumas das características mais comuns aos livros de cavalarias quinhentistas, a começar pela atribuição da autoria do texto a um suposto escritor estrangeiro, neste caso chamado Henrique Frusto ${ }^{104}$. A maior parte dos livros de cavalarias foram apresentados como meras traduções de crônicas supostamente históricas: Montalvo, por exemplo, declara ter traduzido o Amadís de Gaula de texto encontrado numa ermida em Constantinopla e trazido à Espanha por certo mercador húngaro.

Por outro lado, no entanto, verifica-se nessa passagem uma dissociação incomum entre as duas instâncias narrativas, a do "tradutor" e a do suposto "autor" da crônica original. Ao admitir não saber como se teria produzido o acontecimento relatado por Henrique Frusto, o tradutor-narrador dá mostras de não se conformar com o papel

\footnotetext{
${ }^{104}$ Os códices BNL 12904 e 620 trazem no título referência a "Guilherme Frusto, Athor Hibernio", como vimos acima (cf. item 1.3). Trata-se de um erro, pois no interior do texto da Crônica de D. Duardos, todas as cópias (inclusive as duas mencionadas) referem-se apenas a Henrique Frusto. Este nome não é criação do autor desta Crônica, pois já havia sido mencionado ao final do Palmeirim de Inglaterra (cap. 172) como um dos cronistas que teriam relatado as aventuras posteriores à guerra com as tropas de Albaizar: "Joannes d’Esbrec, que compôs a crônica daqueles tempos, Jaimes Biut e Anrico Frusto, autênticos escritores, afirmam que...". O motivo da eleição deste último para suposto autor das continuações manuscritas não é claro, sobretudo se atentarmos para o fato de, poucas linhas à frente, o Palmeirim desautorizá-lo: “Jaimes Biut e Anrico Frusto confessam que (...): parece que nisto Joannes d'Esbrec seja o mais certo, porque em tudo se lhe dá mais autoridade. E na crônica do segundo Dom Duardos, que sai deste livro, e ainda não é trasladada...".
} 
de trasladar fielmente o original e, por meio de seus comentários, acrescenta um novo ponto de vista à narrativa. Assim, ele submete a seu juízo os fatos que teria encontrado no texto de Henrique Frusto, refletindo sobre a pretendida veracidade do livro que diz traduzir. Entre as opções extremas - a do texto ser um fiel retrato da realidade ("Choronica grave de Historias verdadeiras") ou de tudo não passar de invenção ("rellação curioza de fabulas sonhadas") - o tradutor escolhe a alternativa intermediária, fingindo especular acerca dos motivos que poderiam ter levado o "autor" original a afastar-se da realidade:

E se por ventura [as couzas que logo recitaremos] forão verdadeiras só em parte, que he o que mais verisimel me parece, persuadido estou, que o que tocca a o dezastre de Albaizar foi invenção sonhada por Hẽrrique Frusto, com raiva, e inveja de lhe ver merecer com ageneroza, enão accostumada magnanimidade, (...) porque vós crede que ha gente para quem he muito maior materia de inveja merecer hũ homẽ muito inda que possua pouco, que possuir tudo não merecendo nada $(45,29-35)$.

A cisão entre as duas vozes narrativas na Crônica de D. Duardos parece destoar da tipologia das intervenções do suposto tradutor nos livros de cavalarias, que, segundo Isabel Adelaide de Lima e Almeida, atendem a três objetivos principais: 1. servir de "realce da narração" e articulação entre episódios narrados; 2. chamar a atenção do leitor, lançando "pontes entre o mundo fabuloso e o real"; 3. corroborar a matriz, "comentando o intuito e a virtude da narrativa"; mas em nenhum dos casos, diz a pesquisadora, "se põe em causa o "original' ou o 'coronista"" ${ }^{105}$. Ora, é precisamente isto o que ocorre na Crônica de D. Duardos, onde o tradutor declara acreditar que sua fonte não seria inteiramente fidedigna. Ainda assim, diferentemente do que ocorre no $D$. Duardos Segundo, em cujo prólogo o autor confessa que sua obra não passa de "história fingida" ${ }^{06}$, o resultado do questionamento do suposto original na Crônica de D. Duardos só faz confirmar no leitor a crença de que o texto de Henrique Frusto tenha de fato existido, reforçando a pseudo-historicidade do livro.

\footnotetext{
${ }^{105}$ Isabel Adelaide de Lima e Almeida, op. cit., p. 671-676. Note-se que a autora afirma serem pouco freqüentes as intromissões do "tradutor" nas continuações impressas do Palmeirim de Inglaterra.

${ }^{106}$ Diogo Fernandes, prevenindo as críticas de quem o acusaria de estar compondo "cousas fabulosas", escreve no prólogo "folgaria que lhe lẽbrasse, que o intento de quẽ as faz não he acreditar fabulas que todos tẽ por essas”.
} 
Em outra passagem, este desenvolto tradutor toma a liberdade de preencher o que é apresentado como lacuna do original. Quando, no capítulo 35, Carmélia manifesta o desejo de partir de Constantinopla juntamente com seu pai, as demais princesas começam a especular sobre as possíveis causas de sua decisão. É o ensejo para que o tradutor manifeste novamente seu ponto de vista:

Varias oppiniões ouve entre as Princezas da resolução de Carmellia, e não faltou quem cuidasse que se queria ella ir a parte onde sem o embaraço de sua companhia pudesse occupparce nos pensamentos que lhe imaginava a dona deste discurso; mas eu que não achey escritto em Henrique Frusto a verdadeira cauza, fundandome nas rezistencias que ella fazia àquelles pensamentos, e nas calidades de sua pessoa conhecidas, eobservadas della, mais cuido que foi quererce apartar da Occazião que lhe faria algũa força em que a Natureza podia so ser a culpada ficando a vontade sem culpa $(35,26-33)$.

Esta alternância de vozes narrativas não é gratuita. O autor joga sabiamente com os diferentes pontos de vista para avançar hipóteses explicativas sobre certos acontecimentos narrados (no exemplo das páginas anteriores) e sobretudo para sondar as motivações interiores de personagens, como é o caso da passagem referente a Carmélia e de outro episódio, no qual a mesma princesa, incomodada com notícias recebidas sobre o Cavaleiro do Sol (que ela crê ser D. Duardos), pede a D. Floris que vá até o reino de Boêmia a fim de descobrir sua identidade. Após D. Floris aceitar a tarefa, diz o tradutor-narrador, "a Princeza lho agradeceu, e o despedio, não sei se ja arrependida do que lhe tinha pedido que mui de ordinario acontece a quem se precepita depressa não durar muito em hũa detreminação" (73, 39-41). As intromissões do tradutor - que se repetem em outros passos do livro, ainda que não de modo tão significativo como nos já lembrados ${ }^{107}$ - relacionam-se àquele que talvez seja o traço mais significativo da obra: a tentativa de retratar o universo psicológico dos personagens, aspecto a que os livros de cavalarias quinhentistas são normalmente alheios. A observação de Bohigas Balaguer sobre o Amadís de Gaula pode ser aplicada à grande maioria dos livros de cavalarias que se lhe seguiram:

Parecida a la ausencia de color local es la falta de caracterización o la simplicidad psicológica de los personajes del Amadís. La mayor parte

\footnotetext{
${ }^{107}$ Veja-se outras intromissões do tradutor nas seguintes passagens: 37,36; 62,26; 72,72 e 77,69. Alguns desses exemplos, no entanto, não escapam à tipologia proposta por Isabel Adelaide de Lima e Almeida.
} 
han sido pensados según modelos que les habían precedido. (...) El autor, seguiendo en esto a sus más importantes modelos, tampoco trabaja mucho la psicología de estos amantes [Amadis e Oriana] ${ }^{108}$.

A caracterização dos personagens nas obras do gênero dificilmente vai além da repetição de traços convencionais, alusivos a modelos abstratos e preexistentes. Em primeiro lugar, define-se o rasgo básico de seu caráter: o personagem será bom ou mau, marco que definirá à partida muitas de suas características. Os heróis serão invariavelmente leais, corajosos e corteses; seus inimigos são as mais das vezes ambiciosos, arrogantes e impiedosos ${ }^{109}$. Raras são as ocasiões em que esses contrastes nítidos e inapeláveis dão espaço a alternativas intermediárias. No Palmeirim de Inglaterra há apenas duas exceções: Dramusiando, o gigante que raptou D. Duardos para em seguida converter-se a sua amizade, e Targiana, cujo ódio a Floriano do Deserto não impede que ela alerte o Imperador de Constantinopla da traição urdida pelo Sultão da Babilônia, seu marido. Até mesmo a oposição entre os irmãos Amadis e Galaor (o primeiro representando o protótipo do amante leal e submisso e o segundo, o cavaleiro insensível ao verdadeiro amor, que se entrega a seguidas aventuras amorosas superficiais) foi convertida em modelo e reproduzida por João de Barros (Clarimundo e Dinarte) e Francisco de Morais (Palmeirim e Floriano).

A superficialidade no delineamento psicológico dos personagens, predominante nos livros de cavalarias, contrasta com o tratamento dado a alguns dos protagonistas da Crônica de D. Duardos. Embora a maioria dos heróis do livro (como os príncipes D. Duardos, Primaleão e Vasperaldo) não apresentem particularidades que os diferenciem entre si e da maioria dos cavaleiros de obras congêneres, outros personagens da obra possuem traços individualizadores mais definidos. Este talvez seja o maior mérito de D. Gonçalo Coutinho, a se confirmar a hipótese de a Crônica de D. Duardos ser obra sua: ter criado personagens com caracterização mais rica, sutil e consistente que na maioria dos demais livros de cavalarias da época.

\footnotetext{
108 Pedro Bohigas Balaguer. La novela caballeresca, sentimental y de aventuras, in: DÍAZ-PLAJA, Guillermo. Historia general de las Literaturas Hispánicas. Vol. II: Pre-Renacimiento y Renacimiento. Barcelona: Barna, 1951, p. 229.

${ }^{109}$ Mais parcimoniosas ainda costumam ser as informações acerca do aspecto físico dos personagens. Os heróis e suas amigas são sempre tidos por extremamente belos, mas trata-se de uma beleza abstrata que quase nunca é pormenorizada. No caso da Crônica de D. Duardos, por exemplo, o único registro concreto sobre as donzelas da corte é relativo à cor dos olhos e dos cabelos (curiosamente inferida a partir das sobrancelhas) de Carmélia e Valeriza: enquanto aquela teria os cabelos louros e olhos azuis, esta tem os olhos e cabelos pretos $(72,46-47)$.
} 
Dois dos perfis delineados com mais nitidez na obra são de cavaleiros oriundos da Península Ibérica, ambos de extração social inferior à dos demais protagonistas do livro, cuja maioria é formada por reis e príncipes poderosos. O primeiro é D. Floris de Lusitânia, o irmão menor de Miraguarda, dama que desempenha papel de destaque no Palmeirim de Inglaterra, que herda do Conde Arláo, seu pai, o castelo de Almourol, às margens do Tejo; o outro é Braceliano que se apresenta como vassalo de Beroldo, rei da Espanha (cf. 62, 42).

Desde sua primeira aparição na obra, D. Floris demonstra ser dono de temperamento voluntarioso e opiniões invulgares, impressionando Dramusiando por seu "humor Extraordinario" $(5,122)$. Embora fosse "bẽ nascido", como diz o narrador, D. Floris tinha uma "desconfiança natural" que não lhe permitia sentir-se à vontade em meio aos príncipes de Constantinopla.

Mas porque nas perfeições humanas não se achão nunca virtudes puras, não lhe faltàrão a D. Floris couzas, que o fizerão ser menos amado de algũns, do que se as não tivera acontecera, porque primeiramente sendo tão bẽ nascido, que incluhia em si dos melhores sangues de Hespanha, sendo tão esforçado, e tão entendido, como no discurso desta Historia veremos, la teve hũa desconfiança natural, que o fazia não converçar com os Princepes de seu tempo de boa vontade, particularmente com os da caza de Grecia, dos quais se aborrecia de maneira, que athe de seu proprio sobrinho Primaleão se apartava, e de Florendós ainda mais, dando por razão desta esquivança, que porque elles não cuidassem que folgava elle com aquelles parentescos $(6,52-$ $61)$.

Em outra ocasião, ele justifica sua altivez e independência alegando estar convencido que "seetros, e coroas farão mais ricos os homẽns, mas não fazem mais nobres os animos" (20, 34-35). Por isso, observa o narrador, D. Floris "era em extremo bem quisto dellas [das donzelas e princesas da corte], mais que dos cavaleiros" (23, 104-105).

Não obstante protagonizar um único episódio no livro (capítulos 58 a 62), Braceliano também sobressai aos demais personagens da Crônica de D. Duardos, inclusive porque expõe sua história, dúvidas e hesitações em primeira pessoa. Certa noite, enquanto procurava abrigo para descansar de suas deambulações por terras de Espanha, Trineo (filho de Vernau, Imperador da Alemanha) vê dois homens atravessar um rio a nado e, curioso, põe-se a segui-los. O narrador, assumindo habilmente o ponto 
de vista de Trineo, transcreve o saboroso diálogo entre os dois nadadores a partir do momento em que o príncipe pôde começar a acompanhá-lo, de modo que Trineo (e os leitores) não o compreendem bem. A cena, repleta de pormenores incomuns em livros de cavalarias (Braceliano e seu companheiro queixam-se do frio após sair da água e mudam de roupas, enquanto continuam a debater sobre seu caso), é descrita com a naturalidade de um observador presencial e arquitetada com grande destreza, aguçando a curiosidade do leitor. Mais tarde, depois de travar amizade com Trineo, Braceliano esclarece a situação, narrando seu envolvimento amoroso com Daraja, filha de seu vizinho. A história é apresentada com grande riqueza de detalhes: o início quase involuntário da paixão, a hesitação, os pretextos encontrados para justificar o erro e finalmente a dor de quem é ludibriado por moça tão jovem. Mesmo humilhado, Braceliano não encontrava forças para afastar-se dela: naquela mesma noite, atravessou o rio para vê-la e, como de hábito, Daraja faltara ao encontro. A complexidade do caso deixa o ouvinte perplexo:

Egraduadas as couzas assim como Trineo as Entendia, não sabia que julgasse das acções da quelle homẽ rezolvendoce emfim que nas Materias que com circunstancias mudão calidade, não podẽ ser bons juizes os que as vem defora, e devẽ so nestes cazos sello as partes (61, $52-55)$.

Certa casuística cortesã, que permite às damas e cavaleiros exibirem dotes retóricos e agudeza intelectual, é comum nos livros de cavalarias quinhentistas ${ }^{110}$. A singularidade da passagem em exame reside no fato de narrador e personagem não conseguirem formular uma conclusão acerca do problema proposto, deixando a questão em aberto. $\mathrm{O}$ caso se afigura mais incomum quando se tem em conta que a natureza do debate envolve uma grave questão moral, cuja solução é deixada a critério do leitor. Comentando um episódio semelhante do D. Duardos Segundo, de Diogo Fernandes,

\footnotetext{
${ }^{110}$ Com efeito, um dos traços definidores da cavalaria no séc. XVI é sua aproximação ao tipo mais representativo da época, o cortesão. O gosto pela eloqüência impõe ao cavaleiro renascentista a necessidade de dominar a arte da oratória, como notou Alberto del Río Nogueras: "Este planteamiento tiene también su consecuencia palpable en el campo de la caballería, que va tendiendo progresivamente hacia su entronque con el tipo humano del cortesano, dado a las letras y a la conversación. Y es que el caballero, por estas calendas, debe atender a algo más que a guerrear y debe completar sus habilidades con el desenvolvimiento en las artes del trato palaciego, entre las que destacan especialmente las de la charla amena" (Del caballero medieval al cortesano renacentista: un itinerario por los libros de caballerías, in: Nascimento, Airas e Ribeiro, Cristina A. (orgs.). Literatura medieval. Actas da Associação Hispânica de Literatura Medieval. Lisboa: Cosmos, 1993, v. 2, p. 73).
} 
Isabel Adelaide de Lima e Almeida observa que eles são excepcionais num gênero em que predominam "os contrastes nítidos, as esclarecedoras antíteses, o recorte franco entre bons e maus", ocorrendo apenas nas tardias continuações impressas do Palmeirim de Inglaterra. Segundo a estudiosa, tais episódios são "sinais de crise no paradigma que estas narrativas persistentemente cultivam", pois fazem periclitar "o vigor e a certeza que constitui o esteio maior do género" ${ }^{111}$.

D. Floris e Braceliano, no entanto, não são os únicos personagens que se destacam pela relativa nitidez de seu perfil: a algumas das princesas da Crônica de $D$. Duardos também são atribuídos traços mais precisos e alguma sutileza de sentimentos, incomuns à maioria das donzelas de outros livros de cavalarias. O fato acarreta conseqüências no modo como o livro retrata a convivência na corte, espaço ocupado quase unicamente por mulheres durante as aventuras dos cavaleiros, e no desenvolvimento dos relacionamentos amorosos.

O ambiente da corte costuma desempenhar nas narrativas cavaleirescas a função de espaço ideal ${ }^{112}$, que atrai para si os ânimos mais nobres e todos os acontecimentos relevantes. Sua harmonia é rompida apenas por aventuras que se lhe apresentam ou por ameaças externas. Se as aventuras (damas que vêm à procura de socorro ou aventureiros que desafiam os cavaleiros ali reunidos a fim de provar seu valor) apenas legitimam seu papel de modelo e garantia da ordem universal, a corte também estimula a cobiça de verdadeiros inimigos (invejosos sedentos de vingança, gigantes, mouros) que desejam destruí-la. Assim, verifica-se nos livros de cavalarias uma nítida oposição entre o idealizado mundo da corte, em permanente beatitude, e o mundo "exterior", em que freqüentemente reina a deslealdade e a violência. Ainda que tal contraste seja reproduzido na Crônica de D. Duardos, importa ressaltar que neste livro a corte de Constantinopla não é desprovida de tensões internas.

Diversamente do que ocorre em outras obras do gênero, e inclusive nas continuações impressas do Palmeirim de Inglaterra, a Crônica de D. Duardos apresenta a corte de Constantinopla como palco de permanentes conflitos e desencontros de

\footnotetext{
${ }^{111}$ Op. cit., p. 302-303. A passagem do D. Duardos Segundo a que a autora se refere está no cap. 48 da terceira parte da obra, entre os fólios 60r e 63r da edição de 1604 (note-se que a numeração dos fólios desta edição apresenta numerosos erros: apresentamos aqui a numeração corrigida).

${ }^{112}$ A propósito do roman courtois do séc. XII, Erich Köhler já afirmava que "la cour d'Arthur est le lieu de la Joie, d'un sentiment d'harmonie totale entre idéal et réalité” (op. cit., p. 90).
} 
opiniões, especialmente entre as princesas Carmélia, Valeriza, Flérida e Gridônia ${ }^{113}$. Além da constante disputa sobre qual seria mais bela (e da inveja que todas sentiam de Carmélia, cuja formosura era tida como inigualável) ${ }^{114}$, acrescentam-se as desavenças amorosas: ao ver como os sentimentos de D. Duardos eram desprezados por Carmélia, Flérida vinga-se no irmão dela, Vasperaldo, que a cortejava; mais tarde observa-se que Flérida "não deixava occazião de se atravessar com Carmellia" (cf. 22, 47-50 e 77, 23). Os conflitos mais agudos, no entanto, ocorrem entre Carmélia e Valeriza, que desaprova seu alheamento a pensamentos amorosos (cap. 18) antes de protagonizar com a amiga uma áspera discussão durante serão no paço (cap. 25). Mesmo depois de feitas as pazes, as duas voltam a se desentender (cf. caps. 72, 96 e seg. e 75, 59-66).

A atenção conferida aos acidentes da vida interior, especialmente no caso das princesas, faz com que o relacionamento do principal par amoroso (D. Duardos e Carmélia) sofra um desenvolvimento em certa medida incomum nos livros de cavalarias. É certo que o leitor, acostumado com as linhas gerais do gênero cavaleiresco, pressente que os dois jovens estão como que destinados um ao outro, pois a única recompensa digna do cavaleiro mais extremado só pode ser a donzela mais formosa de que se tem notícia. E, como de hábito, o caminho a percorrer até a união final dos amantes será repleto de percalços, situações em que os sentimentos do casal são ao mesmo tempo postos à prova e refinados. Ainda que muitas vezes os cavaleiros padeçam os cruéis rigores de suas altivas e aparentemente insensíveis senhoras (o exemplo mais notório desta situação é o episódio da Penha Pobre, no Amadís), não é incomum que as vicissitudes do relacionamento amoroso sejam compartilhadas pelo casal (como ocorre entre D. Duardos e Flérida, no Primaleón) ${ }^{115}$ enquanto os empecilhos que impedem a união dos amantes e a realização do matrimônio não sejam

${ }^{113}$ É oportuno notar que o mesmo sucede entre os personagens do reino de Boêmia (Fidélia, Enáclia e Pleonido), embora não creiamos necessário estender nossos comentários a esta outra corte, que desempenha papel secundário na obra.

${ }^{114}$ Quando as princesas se reúnem em Constantinopla pela primeira vez, o narrador comenta: “assi vivião todas com tamanhos ciumes de si mesmas nos primeiros dias, que não era necessario menos que seu juizos, e descrições, para encobrirem o que cada hũa sentia" (7, 28-30). Adiante, comenta-se que Carmélia tinha "hũa certa vaidade natural, que a não fazia ser mui amadas daquellas senhoras" (18, 3839).

${ }^{115}$ Não se deve confundir esses personagens com seus netos (o príncipe D. Duardos e a princesa Flérida), que estão entre os principais protagonistas da Crônica de D. Duardos. Ao consultar o quadro genealógico dos personagens do ciclo, em anexo a este volume do trabalho, o leitor terá uma visão mais clara da diferença entre estes personagens que têm os nomes repetidos. 
$\operatorname{superados}^{116}$. Esta situação típica levou Armado Durán a estabelecer uma oposição entre os livros de cavalarias e as novelas sentimentais com relação ao tratamento dado ao tema do amor:

El amor puede ser, indistintamente, erótico o sentimental, pero en la novela sentimental el análisis psicológico de la pasión amorosa determina que la mediación que se alza entre los amantes sea siempre el amor mismo (mediación interna), mientras que en la novela de caballerías, cuyos autores carecen de la preocupación por el análisis psicológico del sentimiento amoroso, es necesario introducir entre los amantes obstáculos ajenos al amor mismo (mediaciones externas) que regulen la progresión de sus relaciones ${ }^{117}$.

Na Crônica de D. Duardos, contudo, não há fatores externos a obstar o relacionamento amoroso de D. Duardos e Carmélia (assim como o de Vasperaldo e Flérida ou Trineo e Gridônia). Carmélia impõe o exílio a seu admirador porque é avessa a qualquer cogitação amorosa, que considera contrária a sua honra (cf. 18, 28-61). O excessivo rigor da princesa, causa das discussões com Valeriza, não a impedem de deixar-se impressionar pela bravura e cortesia de Albaizar, que a cortejava oculto sob a identidade de Cavaleiro da Morte (cf. 22, 1-15). O leitor acompanha, ao longo de toda a primeira parte da Crônica de D. Duardos, as sutis mudanças de atitude de Carmélia: a hesitante simpatia pelo misterioso Cavaleiro da Morte, a hostilidade declarada a D. Duardos (cap. 25) e, com o passar do tempo, o lento processo de reconhecimento do valor de seu pobre admirador. Quando se divulga a notícia que D. Duardos desfizera o encanto que prendia Carmélia numa ilha, ela pela primeira vez sente-se grata por seus serviços; no entanto, após ouvir os louvores à lealdade de Albaizar, que também lutara para libertá-la, a jovem decide não pensar mais no herói (cf. 49, 18-22); em outra ocasião, Carmélia sente a tentação de apiedar-se do sofrimento imposto a ele, mas logo afasta o pensamento para não "dar o seu braço a torcer", como diz o narrador $(53,93$ 98). Mais tarde, ao pensar que D. Duardos estaria servindo outra mulher, a princesa sente um incômodo: não era propriamente ciúme, mas talvez fosse o orgulho ferido. $\mathrm{O}$

\footnotetext{
${ }^{116}$ Nos livros de cavalarias, é muito comum que a união carnal dos amantes ocorra antes do matrimônio publicamente reconhecido, numa espécie de cerimônia privada (o casamento secreto, realizado mediante a simples promessa de fidelidade das partes). Situações como estas aparecem, por exemplo, noAmadís e no Primaleón e, nestes casos, as dificuldades amorosas envolvem não tanto a correspondência afetiva, mas sim a superação de certos obstáculos familiares ou de qualquer outra natureza, que impedem a realização do matrimônio público.

${ }^{117}$ Armando Durán. Estructura y técnicas de la novela sentimental y caballeresca. Madrid: Gredos, 1973, p. $176-177$.
} 
narrador anota um detalhe sutil, mas revelador: "Não bastou esta imaginação com tudo para que D Duardos the parecesse melhor, porem bastou toda via, para que o ella não perdesse mais do sentido" (73,16-18). Em síntese, o progresso do relacionamento do par amoroso ocorre todo no interior da figura feminina, que apresenta um grau de complexidade e sutileza incomum nos livros de cavalarias.

O talento exibido pelo autor da Crônica de D. Duardos na criação do universo interior de D. Floris, Braceliano e Carmélia, contudo, não é secundado por seus dotes estilísticos. Nas ocasiões em que se põe a analisar os sentimentos e as motivações dos personagens, o texto torna-se o mais das vezes prolixo e obscuro. Embora utilize vocabulário amplo e preciso, o autor não se mostra capaz de organizar satisfatoriamente os períodos excessivamente longos de que se serve com freqüência ${ }^{118}$. Eis um exemplo:

revolvendo na fantezia as palavras de Carmellia, a ira com que lhas dicera, a rezão que tivera para dizerlhas, da qual julgava as mais das vezes como parcial da propria Carmellia, tornandoce a si aculpa da Occazião que lhe dera, outras acodia a natureza a seu ser, e parecialhe que não fora grande a de obedecerlhe, porem quando se sentia inclinado a o Amor proprio, e apertado da rezão la guardava sempre seu lugar a o respeito de Carmellia de maneira, que quando se não via asi cõ culpas, por fe prosupunha que não faltarião nella cauzas secrettas para ademonstração que com elle fizera ser arrezoada, e justa $(31,70-78)$.

D. Gonçalo Coutinho dá mostras de ser um escritor diletante, que compôs esta sua Crônica de D. Duardos pelo simples prazer de imaginar aventuras e narrá-las, sem grande preocupação com acabamento final do trabalho. $\mathrm{O}$ fato não impede, contudo, o reconhecimento dos méritos desta obra em que, ao lado da repetição de velhos motivos e recursos comuns à maioria dos livros de cavalarias, há certa originalidade prenunciadora de tendências futuras da literatura, em particular quanto à caracterização dos personagens. Por isso, estamos convencidos da necessidade de divulgar este e

${ }^{118}$ O vocabulário da Crônica de D. Duardos é mais extenso que o de obras congêneres. A consulta ao glossário do texto (volume 2 deste trabalho, apêndice) demonstra a quantidade de termos concernentes a objetos de uso doméstico (aldabra, cassoula etc), instrumentos marítimos (moneta, coxia, enxárcia etc), acidentes geográficos (abra, calheta etc), além de muitíssimas expressões de sabor popular ("dar coices no aguilhão", "cospir para o céu" etc), incomuns em livros de cavalarias. Isabel Adelaide de Lima e Almeida também observou a interferência do registro popular da linguagem no D. Duardos Segundo (op. cit., p. 309) embora na Crônica de D. Duardos o fenômeno adquira maior relevância, visto que não está confinado a certos episódios, como na obra de Fernandes. Sobre a tendência de incorporar a linguagem irônica e humorística nos livros de cavalarias da segunda metade de Quinhentos, cf. Lucía Megías. Libros de caballerías castellanos: un género recuperado, in: Letras. Revista de la Facultad de Filosofía y Letras de la Universidad Católica Argentina, no 50-51, 2004-2005, p. 227. 
outros livros de cavalarias portugueses inéditos (em particular as duas partes restantes da Crônica de D. Duardos, como ainda o D. Belindo, de D. Leonor Coutinho), a fim de permitir nova avaliação da importância do gênero cavaleiresco nas letras lusobrasileiras, com olhar isento dos velhos preconceitos que justificaram o esquecimento dessas obras por demasiado tempo. 


\title{
CAPÍtULO 2
}

\section{A TRADIÇÃO MANUSCRITA}

\section{Descrição dos códices}

Da primeira parte da Crônica de D. Duardos conhecem-se hoje 7 cópias: número nada desprezível, embora não se aproxime dos 33 manuscritos da Crônica de $D$. Belindo, de D. Leonor Coutinho. Ainda assim, a quantidade de cópias que sobreviveu até hoje permite supor que a Crônica de D. Duardos tenha gozado de certo prestígio e aceitação junto ao público, visto que a maioria dos livros de cavalaria manuscritos da época encontra-se conservada em cópia única.

Os 7 manuscritos que conservam a primeira parte da Crônica de D. Duardos encontram-se em Lisboa: um deles na Torre do Tombo e os outros, na seção de Reservados da Biblioteca Nacional. São cópias do século XVII e de modo geral estão bem conservadas. Os códices, acompanhados das respectivas siglas com que serão designados doravante, são os seguintes:

\author{
A - Lisboa, BNL: cód. 12904 \\ B - Lisboa, BNL: cód. 620 \\ C - Lisboa, BNL: cód. 658 \\ D - Lisboa, BNL: cód. 6828 \\ E - Lisboa, TT: Manuscritos da Livraria: cód. 1773 (1ª parte) \\ F - Lisboa, BNL: cód. 483 \\ G - Lisboa, BNL: cód. 619
}

As bibliografia em que se mencionam tais manuscritos é muito escassa e, conforme já tivemos oportunidade de ressaltar anteriormente, resume-se em sua quase 
totalidade apenas à notícia de sua existência. Em síntese, a história da descoberta e identificação dos testemunhos da Crônica de D. Duardos é a que se segue.

João Franco Barreto atribui a Fernão Rodrigues Lobo, o Soropita, a autoria ou a revisão do texto da Terceira e Quarta Partes do Palmeirim de Inglaterra, relativas a D. Duardos, que "andão impressas" em nome de Diogo Fernandes. Já vimos que a informação não permite inferir conclusões sobre as continuações manuscritas do Palmeirim, que o bibliógrafo provavelmente não conheceu ${ }^{119}$.

Barbosa Machado atribui a D. Gonçalo Coutinho a autoria de uma Historia de Palmeirim de Inglaterra e de D. Duardos, em 3 tomos; trata-se, com toda a probabilidade, das 3 partes do livro que apelidamos de Crônica de D. Duardos, cuja atribuição a D. Gonçalo Coutinho julgamos digna de crédito ${ }^{120}$.

Fidelino de Figueiredo informa a localização de cinco dos códices da Crônica de D. Duardos, Primeira Parte (os manuscritos B, C, D, F e G) mas, enganado pela discrepância dos títulos, não notou que se tratavam de cópias de um mesmo texto. Massaud Moisés corrige o equívoco e acrescenta à lista de Figueiredo o códice E, o único que não se encontra na Biblioteca Nacional de Lisboa. A organização dos textos proposta por Massaud Moisés foi reproduzida em todos os estudos posteriores que mencionam os referidos manuscritos, como os de Ettore Finazzi-Agrò e Luciana Stegagno Picchio, entre outros ${ }^{121}$.

João Palma-Ferreira apresenta descrição mais detalhada dos cinco manuscritos já localizados por Figueiredo na Biblioteca Nacional, considerando que seu autor deve ser D. Gonçalo Coutinho ${ }^{122}$.

Foi apenas muito recentemente que surgiu a primeira notícia sobre a existência do cód. BNL 12904 (A), encontrado por Aurelio Vargas Díaz-Toledo no decurso de suas pesquisas sobre os livros de cavalarias manuscritos em Portugal $^{123}$.

\footnotetext{
${ }^{119}$ Bibliotheca Luzitana, op. cit., tomo III, p. 423.

${ }^{120}$ Bibliotheca Lusitana, op. cit., tomo II, $1^{\text {a }}$ parte, p. 360.

${ }^{121}$ Figueiredo, História da Literatura Clássica, op. cit., v. III, p. 29-33; Moisés, A novela de cavalaria portuguesa: achega bibliográfica, op. cit.; Finazzi-Agrò, op. cit., p. 65-71; Picchio, op. cit., p. 205-206.

${ }^{122}$ Palma-Ferreira. Prefácio, in: Crônica do Imperador Maximiliano, op. cit., p. 9-33.

${ }^{123}$ Vargas Díaz-Toledo, A. Os livros de cavalarias em Castela e Portugal, op. cit.
} 


\subsection{Códice A (BNL, cód. 12904)}

Crônica de Primaleão, Emperador de Grecia. Primeira Parte. Texto composto por 80 capítulos.

\section{Descrição externa}

1. O códice encontra-se na Biblioteca Nacional de Lisboa, onde está registrado sob o número 12904. A capa é dura e está em mau estado de conservação; a parte da frente está solta. Na lombada, onde seria o título, vêem-se apenas algumas letras gravadas, sem que seja possível identificar o que estaria escrito.

Na contra-capa da frente, há duas etiquetas: a do canto superior esquerdo contém: "No ... | Estante 53 | Prateleira 163"; a outra, no meio da contra-capa, apresenta o ex-libris dos Condes do Bomfim. Abaixo da primeira etiqueta, foi anotado "cod | 12904" e próximo à segunda etiqueta há anotação a lápis, que diz: "aa.v.chu | \pm bjjjjo", inscrição cujo significado não pudemos descobrir. No alto da contra-capa, centralizado, há outra anotação a lápis, onde se lê: "José Mª Rodrigues | Leilão 20, n 624"124.

O fólio inicial está rasgado, e há um remendo no canto inferior direito. É neste fólio que está registrado o título: "Chronica | de | Primaleão Emperador | de Grecia | Primeira Parte | Em que se da conta das façanhas, que obrou o Prin|cepe D. Duardos, e os mais Princepes | que com elle se criarão, na Ilha Perigoza | do Sabio Daliarte | Composta | Por Guilherme Frusto, Author Hi|bernio, e copiada, por Simisbero | Pachorro, em quanto esteve occupado, ou | encantado no Cume da Penha Riguro|za, da Serra da Lua, pello odio do | Sabio Bragamante”.

Embaixo, há uma inscrição em que se lê: "M. Barb ${ }^{a}$ Bibliot. Lusit. tom. $2^{\circ}$ pag. 289 | col. $2^{\mathrm{o}}$ Francisco de Moraes, a quem fas Autor $\mid$ da $1^{\mathrm{a}}$ e $2^{\mathrm{a}}$ pe. do Palmeirim de Inglaterra, e | de los valerosos y esforçados hechos [rasura] | [rasura] en Armas de Primaleon hijo del Empera|dor Palmerim y de su hermano Polendos y D. | Duarde,

\footnotetext{
${ }^{124} \mathrm{Na}$ descrição codicológica, as informações não redigidas pelo copista (ou as que julgarmos ter sido acrescentadas posteriormente) serão reproduzidas segundo as normas tradicionais das transcrições diplomáticas. O título e as partes do texto redigidas pelo amanuense responsável pela cópia são transcritas de acordo com as normas definidas no cap. 3.
} 
Princepe de Inglaterra. Lisboa, por Simão Lopes 1598 fol. 1"125. Esta anotação deve ter sido feita depois de o fólio ter sido rasgado, pois a escrita se adapta ao pedaço que falta e o remendo não a afeta. Ao final da inscrição, há carimbo da Biblioteca Nacional de Lisboa. No verso do fólio de título, há um carimbo: “compra | 287921” e novamente uma anotação a lápis “cod | 12904”.

2. Os fólios medem 294 x 207 mm e o códice é composto por 262 fólios, mais a folha de título e uma folha de guarda ao final. O texto termina no f. $258 \mathrm{r}$, e entre os fols. 259r a 262v há um "index" dos capítulos da obra.

A numeração, feita pelo próprio copista no canto superior dos fólios retos, é registrada com algarismos arábigos. Começa no f. 1r, onde se inicia o texto, e segue até o f. 258r, sem qualquer erro. A numeração dos fols. do índice foi feita por mão mais recente, e segue o mesmo critério do resto do códice, com a diferença que a contagem começa novamente e o primeiro fólio do índice não foi numerado.

Não foi possível identificar os cadernos originais que formariam o códice antes de sua encadernação.

3. De modo geral, os fólios estão bem conservados. Há alguns trechos com tinta repassada, mas não a ponto de impedir a compreensão do texto, fato que ocorre principalmente nos fols. 6v, 17v-30v, 44v-47v, 52v, 61r-62r, 66v-74v, 89v, 96r-v, 103v, 129v, 131v-134r, 163v-164v,167v-179v, 185v, 188r-v, 197r-v, 200r-v, 206v, 208r-v, 209v e 224r-238r (sendo que neste caso o repasse da tinta parece ter sido ocasionado por uma mancha de água que atingiu principalmente a parte inferior dos fols.). Há borrões de tinta nos fols. 38r-v e 196r-v.

O mesmo dano sofrido pela capa da frente atingiu também os cantos inferiores da junção entre os fólios no início do códice. Apenas a folha de título e os fols. 1 e 2 estão atingidos, mas em nenhum deles o texto foi afetado.

\footnotetext{
${ }^{125}$ A anotação no manuscrito reproduz a informação errônea registrada por Diogo Barbosa Machado, que atribui equivocadamente o Primaleón a Francisco de Morais. Cf. Bibliotheca Lusitana, op. cit., tomo II (1 $1^{\mathrm{a}}$ parte), p. 192.
} 
4. O códice foi escrito por um único copista e não apresenta decoração. A letra aparenta ser do séc. XVII e é bastante clara ${ }^{126}$.

Todo fólio reto e verso apresenta reclames.

5. O manuscrito foi adquirido pela Biblioteca Nacional em 1987, em leilão promovido pelo livreiro José Manuel Rodrigues, conforme inscrição da contra-capa. O catálogo do leilão, por nós consultado, não traz qualquer indicação sobre a origem do códice, embora se saiba que pertenceu à família dos Condes do Bomfim, como testemunha o ex-libris encontrado ${ }^{127}$.

\section{Descrição interna}

[1r: início do texto] Capitulo $1^{\circ} \mid$ Em que se da conta da vida, que fazia | o Emperador Primaleão, e os outros | Principes e como Daliarte detreminou | de trazer os Donzeis, que criava à corte. | Reedificado tinha o Emperador Primaleão | os muros de Constantinopla, e reduzido aquel|la cidade quanto aos edifficios, não só ao esplendor

[258r: fim do texto] queria com as palavras de confiança que | pedia a materia. | Publicouce a jornada para breves | dias com grande alvoroço do Reyno, e dos | Princepes, que logo se offerecerão ao acõ|panhamento, do qual a seu tempo | daremos conta.

[258v: em branco]

[259r] Index | Capitulo $1^{\circ}$ em que se da conta da vida | que fazia o Emperador Primaleão, e os ou|tros Princepes, e como Daliarte detremi|nou de trazer os Donzeis, que criava á Cor|te. fol. 1 .

\footnotetext{
${ }^{126}$ Este é o único códice para o qual não dispúnhamos de quaisquer estimativas de datação, por ter sido descoberto há poucos anos. Embora não tenhamos prática em exames paleográficos, a comparação com outros textos da época parece indicar a segunda metade do séc. XVII como data provável da cópia.

${ }^{127}$ Embora não haja informações seguras a respeito, o catálogo do leilão no qual o códice foi adquirido pela Biblioteca informa que boa parte dos livros leiloados pertencia a Arnaldo H. Oliveira, de quem não conseguimos outras informações.
} 
[262v: fim do index] Capitulo 80. Da Entrada do Embaixador na | cidade, e de como ElRey depois de o ouvir de conta | á Princeza, e do que ella Respondeu, e de como se decla|rou sua jornada para Constantinopla fol. 255.

\subsection{Códice B (BNL 620)}

Crônica de Primaleão, Emperador de Grecia. Primeira Parte. Texto composto por 80 capítulos.

\section{Descrição externa}

1. O códice está na Biblioteca Nacional de Lisboa, registrado sob o número 620. A capa é dura e está um pouco corroída por traças. Na lombada, que está muito danificada, é possível ler: CHRÕ | DE | PRIMAL. Em um dos remendos da lombada, há selo com o número 620.

$\mathrm{Na}$ contra-capa inicial, há anotação a lápis com o código antigo com que o códice estava catalogado na BNL: "B | 10 |7”. Na folha de guarda, foi anotado com giz azul o número 620 e, abaixo, a lápis, a inscrição: "igual ao 483”, numa referência ao códice que será descrito abaixo $(\mathrm{F})$.

Na folha de título, está registrado: "Chronica | de | Primaleão Emperador | de Grecia | Primeira parte | Em que se da conta das façanhas, que obrou | o Principe D. Duardos, e os mais Principes | que com elle se criarão na Ilha Perigoza do | Sabio Daliarte. | Composta | Por Guilherme Frusto Author Hibernio, e | copiada, por Simisberto Pachorro, emquanto esteve | occupado, ou encantado no cume da Penha Riguroza, | da Serra da Lua, pello odio do Sabio Bragamante”.

2. A capa mede 334 × 219 mm e a dimensão dos fólios é de 320 × $214 \mathrm{~mm}$. O códice é composto por 179 fólios de texto, numerados pelo copista, mais uma folha de guarda ao início, a folha de título e, depois do texto, o índice (que ocupa 3 fols) e as duas folhas de guarda ao final.

A numeração dos fólios foi feita pelo próprio copista e consiste na anotação de numeração arábiga corrente nos fólios rectos (canto superior direito) e versos (canto 
superior esquerdo). A numeração segue sem erro desde o f. 1r até o f. $65 \mathrm{v}$ onde, ao invés de anotar o número 130, foi registrado 120. O erro persiste, sempre com a marcação de 10 números abaixo da contagem correta, por exatamente 100 fólios, até o f. $165 \mathrm{r}$, onde o copista registrou corretamente o número 333. Ao longo de todo o intervalo, porém, os números estão corrigidos, aparentemente pelo próprio copista, mas de modo que muitas vezes torna difícil a leitura correta. A partir do f. 165r, a numeração prossegue sem erros até o final do texto, no f. 179v (358, na numeração do copista). Entre os fols. 180r e 182v há o índice dos capítulos, que não foi numerado.

Não foi possível identificar os cadernos que compunham o códice antes de sua encadernação.

3. O códice está muito bem conservado e não há passagens com borrões de tinta que dificultem a leitura. O único dano significativo foi, como se disse, devido à ação das traças, que corroeram parte da capa da frente e fizeram um furo nos 5 fólios iniciais, ou seja, na folha de guarda, na folha de título (onde há um furo que não impede a leitura) e nos 3 primeiros fols. do texto. Dado, contudo, que o furo diminui a cada novo fólio, o texto praticamente não foi afetado.

4. O códice foi escrito por uma única mão, e a letra, excepcionalmente clara e legível, aparenta remontar ao século XVII ${ }^{128}$. Não há decoração.

As margens são bastante regulares e o códice apresenta reclames ao final dos fols. retos e versos.

5. Não foi possível descobrir qualquer indicação sobre os antigos proprietários do códice ou quando ele foi adquirido pela Biblitoteca Nacional de Lisboa.

Descrição interna

${ }^{128}$ João Palma-Ferreira afirma tratar-se de códice "bem caligrafado, provavelmente em meados do século XVII"(op. cit., p. 33). Figueiredo diz acreditar que o códice seria do séc. XVII, embora Esteves Pereira tenha sugerido a datação do séc. XVIII (História da Literatura Clássica, op. cit., vol. III, p. 32). Não descobrimos a que textos de Esteves Pereira e Xavier da Cunha o autor se refere nesta passagem. 
[1r: início do texto] Capitulo $1^{\circ} \mid$ Em que se da conta da vida, que fazia $\mid$ o Emperador Primaleão, e os outros Princepes, | e como Daliarte de triminou de trazer | os Donzeis, que criava á Corte. | Reedificado tinha o Emperador Primaleão os muros $\mid$ de Constantinopla e Reduzido aquella Cidade quanto | aos edifficios, não só ao esplendor e sumptuozidade

[179v: fim do texto] Ao outro dia dando Reposta ao em|baixador, e a Dramusiando na conformidade doque o | Emperador queria com as palavras de confiança que | pedia amateria. | Publicouce a jornada para breves dias | comgrande alvoroço do Reyno e dos Pincepes $^{129}$, que $\operatorname{logo}$ | se offerecerão ao acompanhamento, do qual aseu tem|po daremos conta.

[180r] Index | Capitulo 1. Em que se dà conta davida, o ${ }^{130}$ Emperador Primaleão, eos outros | Principes, ecomo Daliarte determinou detrazer os Donzeis, que | criava á Corte ... f 1 .

[182v: fim do índice] Capitulo 80. Da Entrada do Embaixador na Cidade, e de | como ElRey depois de o ouvir deu conta á Prin|ceza do que vinha, e oque ella respondeu, edecomo | se declarou sua jornada para Constantinopla. Fl. 354 | Fim.

\subsection{Códice C (BNL 658)}

Chronica do Emperador Primaleão e outros Principes. Texto composto por 80 capítulos.

\section{Descrição interna}

1. O códice está na Biblioteca Nacional de Lisboa, registrado sob o número 658. A capa é dura, e não traz qualquer inscrição. A lombada foi restaurada e possui apenas a inscrição 658 .

\footnotetext{
${ }^{129}$ Pincepes por Princepes.

${ }^{130} \mathrm{O}$ por $d o$.
} 
Na contra-capa da frente, há inscrição com giz azul, com o número 658, e a lápis o registro do código com que a obra anteriormente havia sido catalogada na Biblioteca: "B, 10, 45" (havia sido anotado "B, 5, 39" por engano, mas a anotação foi riscada e corrigida). No centro, há um selo da "Biblioteca de historia nacional, e bellas letras de António Lourenço Caminha" e, abaixo, duas inscrições a lápis: "He a continuação do | Palmeirim d'Inglaterra | em 2 vol. Do Primº ha ja na | Bibliotheca 2 exem|plares; porem do $2^{\circ}$ não | há nenhum. | O $2^{\circ}$ vol. [ilegível]”. A outra inscrição é idêntica à presente no códice B: "ver cod. 483".

$\mathrm{Na}$ folha de guarda ao final do códice, há outra inscrição a lápis, certamente posterior à cópia: "Segue-se $2^{\mathrm{a}}$ parte chamada de D. Duardos”.

A folha de título possui nova inscrição com o número 658 em giz azul e o título da obra: "Chronica do Em|perador Primalião, | e | outros Principes".

2. A dimensão da capa é de 302 x 210 mm e os fólios medem 207 x $191 \mathrm{~mm}$. O códice é composto por 202 fólios de texto, mais a folha de título no início e uma de guarda ao final.

A cópia doi realizada por dois copistas e há igualmente duas numerações dos fólios. Uma delas, aparentemente feita pelo primeiro copista, consiste em marcar o canto superior dos fólios retos com numeração arábiga crescente, agrupando-os dois a dois, sem contar a folha de título. Assim, o f. 1r recebe o número 1, o número 2 aparece apenas no f. 3r e assim por diante. Boa parte dos números não podem ser vistos, provavelmente porque os fólios foram cortados para a encadernação. O número 12 é contado duas vezes (na primeira, o número não aparece, mas na segunda vez - onde deveria estar o número 13 - vê-se claramente o número 12, e a contagem continua daí). O numero 22 é pulado: no fólio em que deveria aparecer o 22, há o número 23. Esta numeração segue até o 84, quando muda o copista. Esta numeração pode indicar que pelo menos a porção inicial do códice, que corresponde ao trabalho do primeiro copista, foi formado por cadernos constituídos por 2 fólios.

O copista da porção final do texto não numerou os fólios. Há, contudo, uma outra numeração mais recente, que anota apenas algumas dezenas a lápis e que, diferentemente do copista original, leva em conta a folha de título para a numeração. 
Durante a encadernação alguns fólios saíram da ordem primitiva: identificamos ao menos um trecho (entre os fols. 159 e 161) em que eles estão na posição errada.

O códice não apresenta índice dos capítulos.

3. De maneira geral, o códice está bem conservado e a cópia é clara e bem redigida. Infelizmente, há numerosos fólios com manchas de tinta, o que por vezes dificulta bastante a leitura, em particular nos fols. 1r, 11v, 14r-v, 17r-18v; 20r-21v; 22v-31v; 36r$\mathrm{v} ; 37 \mathrm{r}-\mathrm{v}, 39 \mathrm{v}-41 \mathrm{v} ; 42 \mathrm{r}-\mathrm{v}, 44 \mathrm{v}-50 \mathrm{v} ; 53 \mathrm{r}-60 \mathrm{v} ; 63 \mathrm{v}, 67 \mathrm{r}-69 \mathrm{v} ; 72 \mathrm{r}-73 \mathrm{v} ; 79 \mathrm{r}-82 \mathrm{v} ; 89 \mathrm{r}, 92 \mathrm{r}-$ 93v; 100r; 102r-103v; 111r, 112v-133v; 140r-v; 154r-v; 158v; 170r-v, 176v; 178v-181r; 198r-202r. Algumas palavras riscadas pelo copista ocasionaram manchas no verso do fól., como é o caso dos fols. 138r e 154r.

4. Como os demais, este códice não apresenta decoração. A singularidade deste manuscrito é que o texto foi copiado por duas mãos diferentes: o segundo copista inicia no f. 169r, em meio ao cap. 64. A letra dos dois copistas aparenta ser da segunda metade do séc. XVII ${ }^{131}$.

$\mathrm{Na}$ parte do primeiro copista, a tonalidade da tinta, o espaço entre as linhas e o tamanho da letra vai se modificando sensivelmente. No entanto, não parece haver uma troca de copista e sim ser o mesmo copista que vai progressivamente escrevendo com letra maior e dando mais espaço entre as linhas. Por exemplo:

Fl. 1v = 32 linhas; caixa de texto: $143 \times 133 \mathrm{~mm}$.

Fl. $32 \mathrm{r}=26$ linhas; caixa de texto: $154 \times 130 \mathrm{~mm}$.

Fl. $137 \mathrm{r}=25$ linhas; caixa de texto: $162 \times 143 \mathrm{~mm}$.

Foram usados diversos tipos de papéis, com marcas d’água muito distintas. Em um trecho (fols. 115 a 120), o papel é realmente de qualidade, textura e cor diferentes, o que motiva mudança acentuada de comportamento do copista: quase não há margens, o papel é todo preenchido. Ao voltar ao tipo de papel anterior, as margens retornam ao padrão normal.

O fl. 78r está em branco, o que não acarreta perda de parte do texto; o final do f. $77 \mathrm{v}$ é, inclusive, o único que apresenta reclame, porque o copista provavelmente quis assegurar aos leitores a integridade do texto.

${ }^{131}$ É a opinião de Fidelino de Figueiredo (História da Literatura Clássica, op. cit., vol. III, p. 33). 
O segundo copista ocupa os 33 fólios finais do texto (fols. 169-202). A partir do f. 189, o canto inferior direito dos fólios retos está gasto e se perdeu, o que chega, sobretudo nos últimos fólios, a danificar ligeiramente o texto.

$\mathrm{O}$ códice não apresenta reclames, a menos no fl. 77v.

5. O códice pertenceu a António Lourenço Caminha, de quem Inocêncio Francisco da Silva diz que "obteve de Elrei o senhor D. João VI a nomeação de Official da Bibliotheca Publica d'esta cidade [Lisboa], com o ordenado de tresentos mil réis, como remuneração (diz-se) do donativo que fizera áquelle estabelecimento de uma porção de livros velhos, e alguns manuscriptos, que elle qualificava de raríssimos. Morreu em edade muito provecta (...) no mez de Julho de 1831", além de atribuir-lhe obras poéticas e uma série de opúsculos históricos, traduções e edições de textos antigos ${ }^{132}$.

\section{Descrição interna}

[1r] Chronica $\left|\mathrm{e}^{133}\right|$ Capitulo primeiro emqueseda conta da | vida que fasia oemperador pri|malião eosoutros principes | e como daliarte determinou | detraser os donseis que criava | a corte | Reedificado tinha oemperador primaleão os muros de Constantinopla | eredusida aquella cidade quanto aos edifficios não so aoesplendor | esumptuosidade

[Fl. 78: em branco]

[Fls. 168v - 169r.: mudança de copista] que me digais se sabeis | adevação das meninas de santo Erasmo eadascan|deias de São Pedro por que deseio tirar hũa alma com | que me ejde Casar. A outra companheira que nunca fallou | pallavra selevantou epuxando pella das praticas $\|$ [169r: novo punho] A outra companheira que nunqua fallou pallavra selevantou | e puxando pella das praticas recolherãseambas rebentanto | com riso sem falarem mais pallavra algũa

132 Diccionario bibliographico portuguez: estudos de Innocencio Francisco da Silva applicaveis a Portugal e ao Brasil. Lisboa: Imprensa Nacional / Casa da Moeda, 1973, vol. I, p. 188-190.

133 A inscrição, feita por mão diferente da do copista, ficou incompleta. 
[Fl. 202v: fim do texto] Tras disto chamando os grandes desua corte deulhes | conta do emque estava detreminado, que todos appro|varão como cousa quelhes melhor estava. Então dando | ao outro dia resposta ao Embaxador, e a Dramusiando, | na conformidade que o Emperador queria com as pala|vras deconfiança, que a materia pedia, publicouse a jornada | parabreves dias com grande alvoroço do Reino e dos Princi|pes que logo se offerecerão ao acompanhamento doqual a seu | tempo trataremos. | Fim da primeira parte.

\subsection{Códice D (BNL 6828)}

Crônica do Invicto D. Duardos de Bretalha. Composta por 80 capítulos.

\section{Descrição externa}

1. O códice está na Biblioteca Nacional de Lisboa, registrado sob o número 6828. A capa é mole e foi recoberta com um papel amarelado, no qual foi registrado duas vezes " 1 a parte", uma a tinta e outra a lápis, por mãos diferentes. Na lombada há apenas selo com o número 6828.

Há duas folhas de guarda. Na segunda, há várias inscrições a lápis: "Ordenados e Decima ou ordenados" 134 e o registro do código antigo com que o códice estava catalogado na BNL: U | 2 | 100. Com giz azul, há o número 6828. Embaixo, a lápis novamente: "microfilmado F.R. 1156. 07-05-04", seguido de uma rubrica.

Antes do $1^{\circ}$ fólio, há uma carta de 2 páginas colada, datada de 14/02/1875, de Inocêncio Francisco da Silva, que diz:

"Mmo; e Exmo. Sr. Visconde de Fonte Arcada

Meu respeitável $\mathrm{am}^{\mathrm{o}}$ e sñr. - Grande e | importante achado me noticia V. E. na | carta com que me honrou em 10 do corrente, | dando-me a saber que existe em seu poder | uma chronica inedita de D. Duardos de | Bretanha, attribuida ao nosso velho chronista | Gomes Eannes d'Azurara. É em verdade | uma obra desconhecida, não só de mim, | mas de todos os nossos bibliographos antigos | e modernos, pois não sei que

${ }^{134}$ Não pudemos compreender o significado da anotação. 
algum delles | acusasse até hoje a existencia de simi|lhante escripto: e o indagador e laborioso | Barbosa Machado não dá na Bibliotheca | Lusitana uma única palavra a tal respeito, | ao descrever as composições, quer impressas | quer manuscriptas de Gomes d'Azurara. | Sem duvida que bem valia a pena de entrar | sobre o assumpto em minhas averiguações; in|felizmente $\mathrm{p}^{\mathrm{a}}$ mim, já pouco ou nada posso | fazer. A enfermidade ${ }^{135}$ que ha seis ou sete $\mid$ annos me tomou o olho direito, communi|cou-se agora ao esquerdo, com o qual posso | apenas ler e escrever a mto. custo, e provavel|mente cegarei de todo em breves dias. Como $\mid \mathrm{p}^{\mathrm{a}}$ esta enfermi.de ainda a Medicina | não descobriu cura, será forçoso resig|nar-me a soffrer com paciencia mais esta adversidade.

Tenha V. E. a saude e venturas que | devéras lhe appetece que é com a mais | affectuosa consideração.

De V.E.

$\mathrm{am}^{\mathrm{o}}$ respeitador e vosso obri ${ }^{\mathrm{o}}$

Innocencio $\operatorname{Fran}^{\mathrm{o}}$ da Silva

L. 14 de Fev.

de $1875 "$.

Na folha de título, lê-se: "Chronica do Invicto D. Duar|dos de Bretanha Princepe de Inga|laterra filho de Palmeiry, e da|Princeza Polinarda, daqual se|conta seus estremados feitos | em Armas, e purisimos A|mores, Com outros de outros Cavalleiros que en|seu tempo Concorre|rão.” E abaixo: “ComPosta por Henrrique Frusto | Chronista ingres, etresladada em|Portugues por Gomes Ennes de|Zurara que fes a Chronica | del Rey Dom Afonço | Henrriques dePortugal | achada denovo entre | seus Papeis”.

2. A dimensão dos fólios é de 292 x $200 \mathrm{~mm}$. O códice consta de 175 fols. numerados, sem contar as folhas de guarda (duas no início e uma ao final) e título.

Há numeração arábiga crescente no canto superior dos fols. retos, começando a contar depois da folha de título, quando inicia o texto propriamente dito. O texto termina no f. 167v. A partir do f. 168r, começa o "index dos Capitulos que comtem este

${ }^{135}$ O termo está quase ilegível no original, onde se lê algo como asnaura. A lição apresentada aqui corresponde à transcrição da carta realizada por Palma-Ferrera (op. cit., p. 28). 
Livro", que vai até o fólio 170v. Depois, há 5 cinco fols. numerados, mas em branco: isso significa que a numeração do copista segue até o f. 175.

Não foi possível identificar os cadernos originais que formavam o códice antes de sua encadernação.

3. De modo geral, o códice está bem conservado e é bem legível, apesar dos vestígios da ação de traças, principalmente na região da junção das páginas, sem afetar o texto. Há trechos um pouco borrados, como por exemplo os fols. 100v e 101r, o que prejudica a leitura.

4. O códice foi copiado por um único amanuense e não apresenta decoração. De acordo com Figueiredo, a cópia deve remontar ao séc. XVII, embora ele mesmo diga que há quem discorde de sua opinião, afirmando tratar-se de caligrafia do séc. XVIII ${ }^{136}$. Todos os fólios apresentam reclames, mas em alguns casos eles parecem ter sido atingidos pelo corte do papel, provavelmente feito quando da encadernação do códice.

5. Conforme testemunha a carta de Inocêncio Francisco da Silva, o códice deve ter pertencido ao Visconde de Fonte Arcada. A julgar pela data da carta, trata-se de António Francisco Jacques de Magalhães, o $5^{\circ}$ Visconde de Fonte Arcada (1793-1880), conforme já ficou dito.

\section{Descrição interna}

[1r: início do texto] Capitulo $1^{\circ}$. | Em que se da Comta da vida que fazia Oem|Perador primalião eos outros Princepes e | Como Daliarte detreminou detrazer os|donzeis que Criava aCorte. | Reedificado tinha oemPerador primalião os muros de | Constantinopla e Reduzido aquela cidade quanto aose|difficios não so aoesplendor ${ }^{137}$ asumptouzidade antigaM|as melhorandoa de maneira

[167v: fim do texto] de Alvoroso do Reyno e dos Prinçepes, que logo seofereçerão ao|aCompanhamento, do qual aseu tempo trataremos. | Finis laus deo".

\footnotetext{
${ }^{136}$ Figueiredo, História da Literatura Clássica, vol. III, p. 32.

${ }^{137}$ Falta $e$.
} 
[168r] Index dos Capitulos que comtem | este livro. | Capitulo $1^{\circ}$. Enque se dá Conta da Vida que fazia o Emperador Primalião | $\operatorname{aos}^{138}$ outros Prinçepes, eComo Daliarte detriminou detrazer os Donze|is que Criava aCorte.

[170v: fim do index] Capitulo 80 da Entrada do Embaxador na Cidade, e deComo ElRey | dipois de o Ouvir deu Conta aPrinceza do que vinha e do que lheres|pondeo, e de Como se deClarou a sua Jornada para Constantinopla. | f 166 verso. | Finis.

\subsection{Códice E (TT, Manuscritos da Livraria, $1773-1^{a}$ parte)}

Vida de Primaleão, Emperador de Grecia. Primeira Parte. Texto composto por 80 capítulos. O manuscrito apresenta depois a Terceira Parte da Crônica do Príncipe D. Duardos, com 35 capítulos.

Descrição externa

1. O códice está no Arquivo Nacional da Torre do Tombo, em Lisboa. Trata-se do Manuscrito da Livraria, número 1773 ( $1^{\mathrm{a}}$ parte). A encadernação é relativamente luxuosa, com capa em couro e lombada decorada, onde se lê: "CORONIC. | DOEMPAR. | PRIMAL. | TOM. 32”. No f. 1r (sem contar a folha de guarda), há uma anotação feita a tinta, com o número do códice (1773), e, abaixo, um carimbo: “ANTT

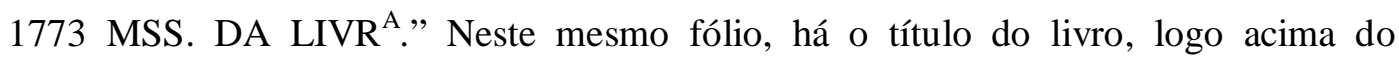
primeiro capítulo: "Primeira parte da vida de Prima|lião Emperador de Cons|tantinopla e de | outros Prince|pes daque|le tempo". No verso da folha de guarda, há uma única inscrição a lápis, com o número 128.

Ao final da primeira Primeira Parte está escrito: "Este livro he daSenhora D. Britis de Lima. | Foi acabado em doze dejulho de 1668".

2. O códice é composto por 317 fols., contando com uma folha de guarda ao início do códice, uma folha de título no início da Terceira Parte da chronica do Principe Dom

\footnotetext{
${ }^{138}$ Aos por $e$ os.
} 
Duardos e 17 fols. em branco ao final do códice. O primeiro livro ocupa os fols. 1r a 154v (sem contar com a folha de guarda inicial); o f. 155 é a folha de título da Terceira Parte, cujo texto começa propriamente no f. 156r e vai até o f. 299v. A partir daí, começam os fólios em branco, talvez reservados para a cópia do índice dos capítulos.

O tamanho dos fols. é 283 x $189 \mathrm{~mm}$. Há evidências claras de que boa parte dos fólios foi cortada quando da encadernação, pois a numeração de vários fols. e as inicias grandes que marcam o início de alguns capítulos foram cortadas (por exemplo, no f. 4v). O primeiro f. em que aparece a numeração é o 5 r.

Há vestígios de numeração arábiga corrente nos cantos superiores direitos dos fols. retos, mas em numerosos fols. ela foi cortada. Nos fols. 107r e 120r há papéis colados com correções, aparentemente feitas pelo próprio copista.

É provável que a Terceira Parte da Crônica haja sido inicialmente encardenada em separado, pois o papel está ligeiramente mais amarelado (o que, no entanto, já ocorre com os últimos fols. da Primeira Parte), além do fato de o canto inferior direito dos primeiros fols. retos da Terceira Parte estarem bastante gastos e amassados, o que não ocorre nos fols. da Primeira Parte. De qualquer modo, os danos no papel atingem, quando muito, apenas a área reservada aos reclames, sem comprometer o texto propriamente dito.

Há dois fols. rasgados, ambos na Terceira Parte: os fols. 169 e o $226\left(72^{\circ}\right.$ desta parte), sendo que este último está remendado e o defeito não atinge ao texto.

3. O códice é de difícil leitura, devido ao escurecimento dos fólios e da pequena letra do amanuense. Além de diversas manchas ocasionadas pela umidade, em praticamente toda a extensão do códice verifica-se a existência de borrões de tinta repassada do verso dos fols., o que em muitas passagens torna a leitura do texto trabalhosa, sobretudo na porção correspondente à Primeira Parte da Crônica.

4. Aparentemente, as duas partes do texto foram copiadas pela mesma mão, apesar de ligeiras diferenças de letra. A letra, em especial na Primeira Parte, é difícil e pequena; na Terceira Parte, embora o copista pareça mais apressado e menos caprichoso, como a letra é maior, lê-se com menos dificuldade. 
5. Segundo informações fornecidas pelo próprio códice, referentes apenas à Primeira Parte da Crônica de D. Duardos, a cópia foi realizada em $1668^{139}$ e pertenceu a D. Britis de Lima - que, conforme já tivemos oportunidade de ressaltar anteriormente (cf. cap. 1, item 3), provavelmente seja uma sobrinha de D. Leonor Coutinho, autora da Crônica de D. Belindo. Se, como cremos, o copista das duas partes do texto atualmente encadernadas em conjunto for o mesmo, é provável que também a Terceira Parte do D. Duardos tenha sido copiada na mesma época e pertencido à mesma D. Britis de Lima.

Descrição interna ${ }^{140}$

[1r: início da Primeira Parte] Capitollo primeiro, em que se da contada | vida que fazia o empe|rador e os outros Prin|cepes e como daLi|arte detrimi|nou de trazer | os donzeis | que criava | a Corte. | Redificado tinha o emperador Primalião os | Muros de Constantinopla, e reduzido aquella | Cidade, quanto aos edificios, não so ao esplan|dor, e suntuuzidade antiga, mas melhorada de | maneira

[154v: fim da Primeira Parte] Então dando ao outro dia | reposta ao Embaixador de Dramusiando, na conformi|dade deque o Emperador queria, com as palavras deconfiança que amateria pidia publicouçe a jornada para breves dias | com grande alvoroço do Reino E dos Princepes que logo seofere|çeram ao acompanhamento doqual a seu tenpo trataremos. | Fim da primeira parte da vida de Primaliam | Este livro he dasenhora D. Britis de Lima. | Foi acabado em doze dejulho de 1668.

\subsection{Códice F (BNL 483)}

Vida de Primaleão, Imperador de Constantinopla. Primeira parte. Texto composto por 80 capítulos.

\footnotetext{
${ }^{139}$ Não há motivos para duvidar da informação. Por outro lado, não conhecemos estimativas de datação da caligrafia deste códice: sendo o único testemunho da primeira parte da Crônica de D. Duardos que não pertence à Biblioteca Nacional, não foi objeto de comentários de Figueiredo e Palma-Ferreira.

${ }^{140}$ Restringimo-nos aqui à Primeira Parte do texto, com a qual este trabalho se ocupa.
} 


\section{Descrição externa}

1. O códice está na Biblioteca Nacional de Lisboa, onde está registrado sob o número 483. Na contra-capa está colado um impresso onde se lê: "Vida de Premelião Emperador de Constantinopla, e de outros Principes daquelle | tempo (Primeira parte). | É novella de cavallaria, contendo 80 capítulos. No fim do texto tem a | data '30 de junho 1449’. | Cópia do séc. XVIII - 1 vol., in-fol. de 211 fl., encad. perg. - Doação | do Dr. A. Ribeiro dos Santos. (B. 6 - 35) 483" Há também anotação a lápis: e "v. cod. 65859", referindo-se ao códice C, descrito acima, e a uma das cópias da Segunda Parte da Crônica de D. Duardos presente na Biblioteca Nacional (cód. 659). Embaixo, há anotação a tinta, onde se lê: "Da doação | Do Dr. Antonio Ribeiro". No f. 1r, há outra anotação a lápis: "igual ao n ${ }^{\circ} 620$ " (que é o códice B, já descrito anteriormente), e um carimbo com aquilo que parece ser as letras "RB".

No f. 1r, antes do primeiro capítulo, próximo a dois novos carimbos (uma da Biblioteca Nacional e outro com a inscrição "RB"), lê-se "Primeira Parte | Da vida de Premelião Emperador de Constanti|nopla, e de outros Principes da quelle tempo".

Ao final do texto, no f. 211r, de fato, lê-se a data "30 de junho de 1449", certamente falsa. Foi acrescentada posteriormente, a lápis, a anotação: "Fim da $1^{\text {a }}$ parte". Na primeira folha de guarda do final, lê-se ainda outra inscrição a lápis: "Seguese $2^{\text {a }}$ parte | Cham. de D. Duardos”.

A encadernação foi feita com capa grossa e na lombada está gravado: "Vida de | Primaleão |E | Outros | Principes”.

2. A dimensão dos fólios é de 312 x $221 \mathrm{~mm}$. O códice consta de 211 fols. numerados, mais as folhas de guarda não numeradas: uma no início e duas ao final. A numeração arábiga no canto superior direito dos fols. retos segue até o número 211 sem erros, salvo enganos nos fols. 93 a 96 (em ambas o copista havia anotado um número a mais, corrigindo-o posteriormente) e nos fols. 137 e 139 (em que o copista havia anotado um número a menos, corrigindo-o posteriormente).

A cada 4 fols., há anotações com letras no canto inferior direito dos lados retos, seguindo a ordem alfabética. Assim, no f. 1r, há a letra "A" maiúscula; no f. 5r, a letra "B"; e assim sucessivamente. O alfabeto usado compõe-se pelas letras A, B, C, D, E, F, 
G, H, I, L, M, N, O, P, Q, R, S, T, V (u), X e Z. Quando terminam as letras do alfabeto, o copista começa a repeti-las dobradas, combinando maiúsculas e minúsculas: com efeito, no f. 85r, vê-se a anotação "Aa"; no f. 169r, começa nova seqüência, com "Aaa". O texto termina no meio do grupo "Mmm". Tais anotações, que se sucedem sem qualquer erro ao longo de todo o códice, indicam que originalmente ele estava organizado em cadernos compostos por 4 fols.

3. De modo geral, o códice está bem conservado e é bem legível. Há alguns borrões de tinta que começa a corroer o papel, nomeadamente nos fols. 104r e v, 157v e 174v, mas não impedem a leitura do texto.

4. A cópia foi feita por um único punho, com letra do séc. XVIII, e carece de toda decoração ${ }^{141}$. Há reclames ao final de todos os fols., tanto no reto como no verso. $\mathrm{O}$ códice não possui índice dos capítulos da obra copiada.

5. O códice pertenceu a António Ribeiro dos Santos, que foi o primeiro bibliotecário mor da então Biblioteca Pública de Lisboa (que mais tarde passou a chamar-se Biblioteca Nacional de Lisboa), a partir de 1796, período no qual deve ter feito a doação do manuscrito ao acervo da instituição. A respeito disso, Inocêncio Francisco da Silva reproduz uma informação alheia, segundo a qual os manuscritos por ele doados à instituição "excediam entre livros e folhetos o número de oitocentos" 142 .

\section{Descrição interna}

[1r: início do texto] Primeira Parte | Da vida de Premelião Emperador de Constanti|nopla, e de outros Principes da quelle tempo. | capitulo $1^{\circ}$. | Em que se dá conta da vida, que fazia o Empe|rador, eos outros Principes; e como Dalearte detre|minou de trazer os Donzeis, que criava à Corte. | Redeificado tinha o Emperador Premelião os muros $\mid$ de Constantinopla, e reduzido aquella cidade, quanto a $\mid$ os edificios não so ào esplandor, e sumptuozidade antiga;

\footnotetext{
${ }^{141}$ Figueiredo (História da Literatura Clássica, vol. III, p. 33) e Palma-Ferreira (op. cit., p. 33) são concordes em estimar a datação da cópia.

${ }^{142}$ Diccionario bibliographico, op. cit., vol. I, p. 249.
} 
[211r: fim do texto] Então dando ào outro dia | resposta ao Embayxador deDramoziando na con|formidade doque o Emperador queria com as pala|vras deconfiança, que amateria pedia; publicou | se a jornada para breves dias, com grande alvorco $^{143}$ do | Reyno, dos Principes, que logo se offerecerão ao acom|panhamento do qual a seu tempo trataremos. | 30 de junho 1449. | Fim da $1^{\mathrm{a}}$ parte.

\subsection{Códice G(BNL 619)}

Crônica de D. Duardos. Primeira parte. Texto composto por 76 capítulos $^{144}$.

Descrição externa

1. O códice está na Biblioteca Nacional de Lisboa, registrado sob o número 619. $\mathrm{Na}$ contra-capa está anotado a lápis: "B | 10 |6". Na folha de guarda inicial foi registrado com giz azul o número 619.

O papel usado parece ter sido especialmente fabricado para a cópia em duas colunas, pois há uma espécie de vinco vertical no meio, com textura ligeiramente mais grossa.

A capa é grossa e na lombada há apenas um selo com o número do códice: 619.

Há sinais de que a parte superior do códice tenha sido acidentalmente molhada: as manchas de água são visíveis sobretudo nos primeiros fols., mas elas não afetam o texto.

2. A dimensão dos fólios é de 290 x $197 \mathrm{~mm}$, e a da capa é de 299 x 206 mm. O códice consta de 201 fols. de texto, mais uma folha de guarda inicial e duas finais, não numeradas. No canto superior direito dos fólios retos há sinais de três numerações realizadas em épocas diferentes e seguindo critérios distintos.

A que parece ser mais antiga, feita pelo próprio copista, consiste em numerar aquilo que talvez fossem os cadernos em que se divide o códice. É numeração arábiga e

\footnotetext{
${ }^{143}$ Alvorco por alvoroço.

${ }^{144}$ Embora a numeração prossiga até o número 76, o códice possui apenas 74 capítulos, visto que faltam os de número 56 e 57.
} 
crescente, que atribui um número a cada grupo de 6 fols., anotando-o apenas no primeiro f. reto do caderno. Assim, o f. 1r (sem contar a folha de guarda) receberia o número 1; o f. 7r receberia o número 2; e assim por diante. Entretanto, é provável que, quando da encadernação do códice, tenha havido um corte dos fols., pois não se vêem os números 1 a 4, ao passo que todos os outros números, a partir do 5, são perfeitamente visíveis. A numeração segue, sem qualquer equívoco na contagem, até o caderno 34.

Além dessa, há vestígios de duas outras numerações mais recentes, feitas a lápis, por mãos evidentemente distintas, também no canto superior direito dos fols. retos. Nos dois casos, os autores das contagens tiveram a intenção de verificar qual o número total de fólios do códice, e não apenas marcar os cadernos, como fez o copista. No entanto, nenhum dos dois punhos anota os números em todos os fols.; normalmente eles marcam preferencialmente (mas com exceções) as dezenas. Ainda assim, o resultado destas duas contagens não é igual, pois um dos punhos saltou uma página por volta do f. 140. O engano acaba por gerar alguma confusão, pois as contagens deixam de coincidir e passam a aparecer números iguais em fls. diferentes. Tanto é verdade, que o f. 201r, onde o texto termina, foi marcado com o número 200.

3. O estado de conservação do códice é bom, apesar de haver pequenas partes do texto que foram cortadas, como se dirá. Há indícios de que o códice tenha sido molhado, pois o tom do papel é ligeiramente mais escuro nas extremidades superior e inferior, sobretudo nos fólios finais. A um grande borrão de tinta no f. 145 e diversas manchas, provavelmente resultadas da umidade, principalmente nos fols. 27, 34, 39, 53, $54,88,99,101,102,127,130,131,194$ e 195, mas que não impedem a leitura do texto. A tinta apresenta um tom claro, sobretudo no início e por volta do f. 170, há nítida mudança no tom, que se torna mais escuro.

Dois fols. do códice possuem remendos. No f. 46, o pedaço danificado fica nas margens do texto e não prejudica a leitura; no f. 55, ao contrário, pequenas partes do texto foram comprometidas. 
4. A letra do único copista é clara e regular, embora ele faça uso abundante de abreviações, e aparenta ser do séc. XVII ${ }^{145}$. A cópia não apresenta qualquer tipo de decoração e foi realizada em duas colunas. A quantidade de linhas por coluna varia entre 26 a 35, notando-se uma clara tendência para a diminuição do número de linhas por coluna conforme o texto avança, na medida em que a letra apresenta um ligeiro aumento de tamanho.

As margens são relativamente bem delimitadas, embora nos fols. iniciais o copista mostre a tendência de preencher mais completamente o fólio. O corte no papel para fins de encadernação, que como foi dito provavelmente eliminou a numeração dos primeiros cadernos, também afeta as linhas finais de alguns dos fls. iniciais, impedindo sua leitura: é o caso dos fols. 1v, 2v, 3r, 3v, 4v, 5v e 8r. A partir do f. 15, as margens inferiores começam a aumentar e o texto não é mais afetado.

Há alguns capítulos sem título, embora o copista tenha deixado espaço reservado para ele: são os de número $18,20,21,23,25$ e 26. O copista também havia deixado o capítulo 17 sem título, mas ele foi posteriormente acrescentado por outro punho: nota-se que a letra e a tinta utilizadas são diferentes. O fato deve estar relacionado à peculiar distribuição da matéria narrativa que caracteriza esta cópia, como veremos adiante.

Há presença de reclames apenas nos fols. versos que terminam os cadernos originais do códice.

5. Não foi possível descobrir quaisquer informações acerca dos antigos proprietários do códice ou quando ele passou a integrar o acervo da Biblioteca Nacional de Lisboa.

\section{Descrição interna}

[1r: início do texto] Chronica do Invicto dom | Duardos de Bretanha Prin|cipe de Inglaterra filho de | Palmeirim; eda Princeza Po|linarda naqual secontão se|us estremados feittos em armas, | e purissimos amores, com os de | outros Cavaleiros que emseu | tempo concorrerão, composta por | Henrique Frustu Chronista Ingres | e

\footnotetext{
${ }^{145}$ Palma-Ferreira declara que sua letra "é indubitavelmente do século XVII" (op. cit., p. 32); Figueiredo crê que este códice é mais antigo que os de número 620 e 6828 (História da Literatura Clássica, v. III, p. $32)$.
} 
tresladada emPortuguez por | Guomes annes deZurarra, e | achada de novo entre seus papeis. | Cappitulo i. Emque seda | conta da vida quefazia | o emperador Primale|ão, e os outros Principes, | e como Daliarte deter|minou detrazer os Dõ|zeis que criava à Corte. || [col. a] Redificado tinha oem|perador Primaleão os mu|ros deConstantinopla, eRe ||[col. b]duzido aquella Cidade quanto | aos edificios, não só ${ }^{146}$ ao es|plendor e sumptuozidade || [fl. 1v] antiga mas me|lhoradade | maneira

[201r: fim do texto] então dando ao ou|tro dia Reposta ao em|baixador, ea Dramuziando naconformida||[col. b]de doque o Emperador q|ueria com aspalavras de | confiança, quea Materia | pedia, publicouse a jor|nada parabreves dias cõ | grande allvoroço do Rei, | e dos Principes, quelogo seofferecerão ao acompa|nhamento, doqualaseu | tempo trataremos.

\section{Colação dos códices.}

Os códices da primeira parte da Crônica de D. Duardos apresentam enorme quantidade de discrepâncias textuais. Ainda que muitas delas não sejam significativas, resumindo-se a pequenos erros de cópia ou a ligeiras alterações introduzidas pelos copistas, outras variantes há que permitiram formular algumas hipóteses acerca da tradição manuscrita do texto.

Posto que o objetivo deste trabalho não é o de apresentar a edição crítica da Crônica de D. Duardos, restringimos a colação de todos os testemunhos a certos trechos, apenas com o intuito de colher subsídios para decidir qual códice utilizar como base para nossa transcrição. Além dos capítulos inicial e final, foram cotejados os capítulos 11-12 e 59-62 (por constituírem "lugares críticos", uma vez que, como veremos, correspondem a trechos em que a lição de $G$ poderia apresentar mais divergências) e ainda o capítulo 64 (onde há mudança de copista em C), perfazendo um total de 9 capítulos, ou mais de $10 \%$ do total da obra ${ }^{147}$.

\footnotetext{
${ }^{146}$ A palavra foi grafada com um sinal que se parece com um $£$.

${ }^{147}$ Seguimos o método recomendado para textos como a Crônica de D. Duardos: "No caso de termos uma obra, ao mesmo tempo, muito extensa, e transmitida por muitos mss., é geralmente admitido que a 'collatio' não cubra a totalidade do texto, limitando-se a um cóngruo número de trechos, escolhidos seja de forma mecânica (aleatória), seja com base na sua notória dificuldade” (Barbara Spaggiari e Maurizio Perugi. Fundamentos da crítica textual. Rio de Janeiro: Lucerna, 2004, p. 33). Acerca da definição dos
} 
Dada a quantidade de variantes existentes entre os diferentes testemunhos, a colação permitiu colher material abundante. Com efeito, os copistas dos manuscritos analisados demonstram relativa liberdade para introduzir alterações no texto, além do fato de, em certas passagens, darem mostras de não compreender perfeitamente aquilo que transcreviam ${ }^{148}$. No entanto, visto que grande parte das discrepâncias são atribuíveis a meros lapsos mecânicos ou a preferências dos amanuenses (como é o caso de variantes ortográficas, omissões ou interpolações de artigos ou pronomes, presença ou ausência de sinais de pontuação etc), na exposição que se segue restringiremos os exemplos aos casos mais significativos, sem pretensão de apresentar uma lista exaustiva das variantes.

Ainda que preliminar (pois as conclusões da colação não apontam para um stemma codicum isento de dúvidas e lacunas), o exame permitiu identificar com segurança o parentesco entre algumas das cópias, fornecendo embasamento para a escolha do códice que será utilizado como base para a transcrição do texto.

\subsection{Ramo A/B}

O resultado da colação demonstrou que os manuscritos A e B (BNL 12904 e 620, respectivamente) são estreitamente aparentados, constituindo um primeiro ramo da tradição manuscrita da Crônica de D. Duardos, Primeira Parte. Os dois códices se distingues dos restantes, antes de mais nada, pela lera exepcionalmente clara e uniforme dos amanuenses e pela utilização mais abundante e regular de sinais de pontuação, que facilitam sobremaneira a compreensão do texto. A divisão dos períodos em frases mais curtas, o emprego mais constante (ainda que distante dos padrões modernos) de sinais de pontuação, além da separação do texto em parágrafos menos longos que os das demais cópias são fatores responsáveis pelo surgimento de grande quantidade de

\footnotetext{
"lugares críticos", adotamos a sugestão de Spina: "Obras de certa extensão exigem um confronto mais demorado (...). Daí o recurso ao confronto dos chamados 'lugares críticos' (ou 'pontos críticos'), que ajudam a estabelecer não só a dependência de um manuscrito a outro, mas a afinidade ou parentesco de todos os manuscritos da tradição - quando estes manuscritos são numerosos" (Introdução à edótica. São Paulo: Cultrix, 1977, p. 93).

148 "Nos séculos XVI e XVII, como é sabido, a tradição textual portuguesa é caracterizada (mais do que qualquer outra tradição européia) pela desenvolta moda das edições 'piratas' ou por uma tendência para as remodelações, ou ainda para os acréscimos subreptícios: o que complica notavelmente o trabalho do editor crítico" (Giulia Lanciani. Textos portugueses dos séculos XVI a XVIII. Problemas ecdóticos, in: Separata de Critique textuelle portugaise: Actes du colloque. Paris: Fondation Calouste Gulbenkian, 1986, p. 279).
} 
variantes textuais em A e B. Exemplo disso pode ser notado em trecho do capítulo 80: o confronto entre as lições de A e B em oposição às de D e G ilustra claramente as adaptações que resultam do uso de sinais de pontuação ${ }^{149}$.

Tabela 1.1: Exemplo de pontuação em A/B (80, 77-81).

\begin{tabular}{|l|l|}
\hline \multicolumn{1}{|c|}{ A/B } & \multicolumn{1}{c|}{ D, G } \\
\hline $\begin{array}{l}\text {.. couzas do mundo. } \\
\text { Depois chamando os grandes de sua Corte } \\
\text { deulhes conta do que em que estava detreminado, } \\
\text { que todos aprovarão, como a couza que lhe estava } \\
\text { melhor. }\end{array}$ & $\begin{array}{l}\text {.. couzas do mundo tras isto chamando os grandes } \\
\text { detreminado, que todos aprovarão como a couza } \\
\text { que outro dia, dando reposta ao Embaixador ... } \\
\text { reposta ao Embaixador... }\end{array}$ \\
\hline
\end{tabular}

Em alguns casos, a pontuação resulta em frases truncadas, como por exemplo no início do capítulo 11:

Tabela 1.2: Exemplo de pontuação em A/B (11, 05-07).

\begin{tabular}{|l|l|}
\hline \multicolumn{1}{|c|}{ A/B } & \multicolumn{1}{|c|}{ C, D, E } \\
\hline $\begin{array}{l}\text { Quatro dias antes da festa do Spirito Sancto, que } \\
\text { era a em que se havia de celebrar aquelle torneo, a } \\
\text { cuja fama se abalara o mundo. Tinhão concorrido } \\
\text { ja tantas gentes Estrangeiras... }\end{array}$ & $\begin{array}{l}\text { Quatro dias antes da festa do Spirito Sancto, que } \\
\text { era a em que se havia de celebrar aquelle torneo, a } \\
\text { cuja fama se abalara o mundo, tinhão concorrido ja } \\
\text { tantas gentes Estrangeiras... }\end{array}$ \\
\hline
\end{tabular}

Além dos casos já mencionados, há uma série de outras variantes textuais que comprovam o parentesco entre A e B. Vejamos em primeiro lugar os traços que unem os dois códices, em contraste com as outras cópias do texto.

\footnotetext{
${ }^{149}$ Nas tabelas que se seguem a ortografia dos diversos testemunhos foi uniformizada a partir da lição de A. A transcrição obedece às normas descritas no capítulo 3, exceto pela eliminação das marcas de mudança de linha e de desenvolvimento das abreviaturas. Foram ressaltados em itálico os elementos divergentes entre as lições. Em certos casos foram desconsideradas as pequenas variantes textuais que não alteram o elemento que desejamos destacar na colação entre os grupos de manuscritos. Além disso, nos exemplos retirados dos capítulos 11 e 12, as lições de $\mathrm{G}$ foram freqüentemente omitidas, por serem completamente divergentes. Sobre as peculiaridades deste manuscrito, cf. o item 4 deste capítulo.
} 
Tabela 1.3: Variantes textuais do ramo A/B.

\begin{tabular}{|c|l|l|l|}
\hline No. & Localiz. & \multicolumn{1}{|c|}{ A/B } & \multicolumn{1}{|c|}{ C, D, E, F, G } \\
\hline 1 & 01,34 & Via sua caza despojada dos cavaleiros & Via sua caza despovoada dos cavaleiros \\
\hline 2 & 11,11 & como se se temerão de grandes males & como se se temerão de males grandes \\
\hline 3 & $11,80-81$ & o que no outro capitulo se segue. & o que para o outro capitulo rezervamos. \\
\hline 4 & $59,100-101$ & folgava toda via de o ver armado & folgara toda via de o ver armado \\
\hline 5 & 60,32 & castello meu a onde agora vamos & castello meu a onde agora himos \\
\hline 6 & 60,112 & o que nelle vos prometto & o que nelle vos digo \\
\hline 7 & 61,67 & daremce os Ultimos abraços & daremce os derradeyros abraços \\
\hline 8 & 64,13 & Não havia na tribuna mais & Não havia nella mais \\
\hline 9 & $64,86-87$ & $\begin{array}{l}\text { a o outro dia succedeo ao cavalleiro o } \\
\text { que veremos no capitulo seguinte. }\end{array}$ & $\begin{array}{l}\text { ao qual ao outro dia aconteceo o que no } \\
\text { capitulo seguinte veremos. }\end{array}$ \\
\hline 10 & 80,77 & porque era senhora retirada & porque ella era mulher retirada \\
\hline 11 & $80,85-86$ & do qual a seu tempo daremos conta. & do qual a seu tempo trataremos. \\
\hline
\end{tabular}

Os exemplos citados acima constituem variantes textuais que não alteram o significado das passagens; sua relevância é apenas a de demonstrar o parentesco entre A e B, em contraste com as outras cópias. Trata-se da substituição de palavras por termos sinônimos ou equivalentes (como em 1, 5, 6 e 7), da inversão da ordem das palavras (exemplo 2) ou de redações alternativas para sintagmas que compreendem grupos de palavras (8 e 10), o que ocorre com freqüência maior nas conclusões dos capítulos (exemplos 3, 9 e 11). No caso do exemplo 4, observa-se que a mudança do tempo verbal é ocasionada pela troca das letras r/v: como são parecidas, elas muitas vezes são objeto de hesitação por parte dos copistas da Crônica de D. Duardos.

Uma vez que as variantes textuais aqui exemplificadas não prejudicam o sentido das passagens, nesses casos a decisão sobre qual será a melhor lição dependerá de uma escolha do editor ${ }^{150}$.

\footnotetext{
${ }^{150}$ Ou seja, tais variantes podem ser consideradas lições neutras ou adiáforas (cf. Spaggiari e Perugi, op. cit., p. 37). De qualquer modo, ao menos nos exemplos 5 e 7, a lição de A/B pode ser considerada resultado de uma simplificação. Nestes casos, o conhecido princípio da conveniência de adotar a lectio difficilior aconselharia descartar a lição de A/B em favor da dos outros testemunhos (cf. Spina, op. cit., p. 67). Porém, dado que não almejamos realizar o estabelecimento crítico do texto, não será necessário submeter os resultados da colação a este tipo de consideração.
} 
Tabela 1.4: Omissões no ramo A/B.

\begin{tabular}{|c|c|l|l|}
\hline No. & Localiz. & \multicolumn{1}{|c|}{ A/B } & C, D, E, F, G \\
\hline 1 & $59,43-44$ & não se hade fazer mais que o que basta & não se hade fazer nunca mais que o que basta \\
\hline 2 & 61,82 & não podia Trineo saber & não podia como dizemos Trineo saber \\
\hline
\end{tabular}

As omissões de trechos do texto parecem não ser comuns no ramo A/B. Em quase todos os casos encontrados, a omissão se restringe à supressão de uma única palavra, normalmente curta e não essencial, como ocorre em 1; quando a omissão abrange expressões ou grupos de palavras, na maior parte dos casos o sentido da passagem também não é afetado, como no exemplo 2.

Tabela 1.5: Interpolações no ramo A/B.

\begin{tabular}{|c|c|l|l|}
\hline No. & Localiz & \multicolumn{1}{|c|}{ A/B } & \multicolumn{1}{|c|}{ C, D, E, F, G } \\
\hline 1 & $12,83-84$ & $\begin{array}{l}\text { obedecendo à força superior e interior } \\
\text { com que Daliarte os obrigara }\end{array}$ & $\begin{array}{l}\text { obecendo àquella força interior com } \\
\text { que Daliarte os obrigava }\end{array}$ \\
\hline 2 & 59,122 & $\begin{array}{l}\text { das que se alcanção com a experiencia, } \\
\text { especulação, e coriozidade. }\end{array}$ & $\begin{array}{l}\text { das que se alcanção com a especulação e } \\
\text { coriozidade. }\end{array}$ \\
\hline 3 & $64,09-10$ & $\begin{array}{l}\text { pouco sitio que occupava na coroa } \\
\text { daquelle Monte } e \text { no cume da quelle } \\
\text { penedo. Levouo Pleonido }\end{array}$ & $\begin{array}{l}\text { Monte. Levouo Pleonido } \\
\text { pouco sitio que occupava daquelle }\end{array}$ \\
\hline 4 & $64,46-47$ & $\begin{array}{l}\text { Melhor quizera eu sahir das minhas } \\
\text { Aventuras, do que vos tendes sahido } \\
\text { desta }\end{array}$ & $\begin{array}{l}\text { Melhor quizera eu sahir das minhas, do } \\
\text { que tendes sahido desta }\end{array}$ \\
\hline
\end{tabular}

Além de não serem numerosas, as interpolações encontradas nos manuscritos A e B também não se revestem de outro significado que não o de atestar, uma vez mais, a afinidade entre estes testemunhos. Em 1, 2 e 3, verifica-se a interpolação de glosas que reforçam o sentido já explicitado na passagem; note-se que em 1, além da interpolação de "superior", o ramo A/B caracteriza-se pelo uso de "obrigara" onde nas demais cópias há "obrigava". No exemplo 4, a lição de A/B apenas resolve a elipse, pois o termo "aventura" estava subentendido. 
Tabela 1.6: Erros no ramo A/B

\begin{tabular}{|c|l|l|l|}
\hline No. & Localiz. & \multicolumn{1}{|c|}{ A/B } & \multicolumn{1}{|c|}{ C, D, E, F, G } \\
\hline 1 & $01,14-15$ & $\begin{array}{l}\text { igualdade, e justiça, com que era } \\
\text { governado, tão semelhante á igualdade, e } \\
\text { brandura do Emperador }\end{array}$ & $\begin{array}{l}\text { igualdade, e justiça, com que era } \\
\text { governado, tão semelhante á bondade, e } \\
\text { brandura do Emperador }\end{array}$ \\
\hline 2 & $11,41-42$ & $\begin{array}{l}\text { borcados cramezins, que se parecião ou } \\
\text { se fazião parecer de fogo }\end{array}$ & $\begin{array}{l}\text { borcados cramezins, que } \text { ofazião parecer } \\
\text { de fogo }\end{array}$ \\
\hline 3 & $12,42-43$ & $\begin{array}{l}\text { tornou a dizer a Daliarte: Que não sei } \\
\text { tornou a dizer para Daliarte: por certo } \\
\text { Daliarte que não sei }\end{array}$ \\
\hline 5 & 62,34 & $\begin{array}{l}\text { tirando os Elmos hũns eoutros ouve algũ } \\
\text { que não festejasse }\end{array}$ & $\begin{array}{l}\text { tirando os Elmos hũns eoutros não ouve } \\
\text { algũ que não festejasse } \\
\text { da quelle trabalho lhe não podia a ella vir } \\
\text { senão danno tanno }\end{array}$ \\
\hline 6 & 64,25 & vos não sois tão christã & nõo podia a ella vir \\
\hline
\end{tabular}

A tabela 1.6 apresenta os casos mais evidentes em que as variantes do ramo $\mathrm{A} / \mathrm{B}$ não devem ser consideradas como adiáforas ou indiferentes, mas sim como erros ${ }^{151}$. Em 1, houve a troca da palavra "bondade", certamente ecoando a ocorrência do termo "igualdade" pouco antes. Em 2, a lição de A/B parece ser decorrência de um erro de transcrição que, notado a tempo pelo copista, gerou uma adaptação do texto, com o intuito de corrigi-lo sem necessidade de rasuras: por isso, a versão de A/B resulta mais confusa que a dos demais testemunhos. Em 4, houve a substituição do termo "trato" por "trabalho", que não se adequa perfeitamente ao contexto. Nos exemplos 5 e 6, os erros devem-se à interpolação ou supressão da palavra "não", que nos dois casos ocasiona alteração do sentido do texto. Em 3, a presença do pronome "que" não se justifica sem o trecho omitido. Ao que tudo indica, este caso representa um saut du même au même, motivado pela repetição do nome de Daliarte ${ }^{152}$.

${ }^{151}$ A noção de erro no âmbito do trabalho edótico deve ser precisada. Em princípio, qualquer desvio ou variante textual que divirja do autógrafo ou do que se supõe ser o arquétipo poderia ser tida como errônea. Contudo, uma vez que tais reflexões escapam ao âmbito deste trabalho, qualificaremos como erradas apenas lições que resultarem confusas ou incompreensíveis devido a falhas mecânicas na transmissão do texto. Claro está que, em certos casos, é impossível definir com rigor absoluto a fronteira entre uma lição aceitável e um erro: não há como evitar certo grau de subjetividade nesta matéria. Sobre a revisão do conceito de erro pela edótica moderna, cf. Spaggiari e Perugi, op. cit., 69-71.

${ }^{152} \mathrm{O}$ saut du même au même é um tipo de omissão que se explica por uma causa mecânica: a repetição de palavras ou expressões em áreas próximas do texto de base pode levar o copista a saltar o trecho que permeia as duas ocorrências do termo repetido. Cf. Martin L. West. Crítica textual e técnica editorial. Lisboa: Calouste Gulbenkian, 2002, p. 29. 
Os exemplos das tabelas 1.3 a 1.6 demonstram claramente a afinidade dos códices A e B. Além disso, é oportuno observar que são relativamente poucos os casos em que as variantes caracterizadoras deste ramo podem ser qualificadas seguramente como erros: na grande maioria dos casos, elas representam lições alternativas que não prejudicam a compreensão do texto.

No entanto, embora sejam estreitamente aparentados, A e B também apresentam discrepâncias entre si. Nas tabelas que se seguem, os trechos em que a lição de A e B divergem serão confrontados também com a dos outros manuscritos, a fim de verificar as possíveis origens de tais variantes.

Tabela 1.7: Licões únicas em A e B.

\begin{tabular}{|c|c|c|c|l|}
\hline $\mathbf{N}^{\mathbf{0}}$ & Localiz. & \multicolumn{1}{|c|}{ A } & \multicolumn{1}{c|}{ B } & \multicolumn{1}{c|}{ C, D, E, F, G } \\
\hline 1 & 01,79 & $\begin{array}{l}\text { todos aquelles senhores } \\
\text { como Oraculos }\end{array}$ & $\begin{array}{l}\text { todos aquelles principes } \\
\text { senhores como Oraculos }\end{array}$ & $\begin{array}{l}\text { todos aquelles homens } \\
\text { como Oraculos }\end{array}$ \\
\hline 2 & $60,65-66$ & no principio ainda estava? & no principio estava? & no principio estava ainda? \\
\hline
\end{tabular}

Foram encontrados apenas dois casos em que ambas as lições de A e B são únicas, isto é, divergem entre si e também da apresentada pelos outros testemunhos. Nessas passagens, nota-se que a versão de A é a que mais se aproxima das restantes: no primeiro exemplo, o termo "homens" das cópias restantes foi substituído por "senhores" em A, a que o copista de B acrescenta ainda a palavra "príncipes". Em 2, A preserva a palavra "ainda", posto que deslocada, ao passo que B a omite.

Tabela 1.8: Variantes exclusivas a B.

\begin{tabular}{|c|c|l|l|l|}
\hline $\mathbf{N}^{\mathbf{0}}$ & Localiz. & \multicolumn{1}{|c|}{ A } & \multicolumn{1}{|c|}{ B } & \multicolumn{1}{|c|}{ C, D, E, F, G } \\
\hline 1 & 12,93 & os acompanharão & os acompanhavão & os acompanharão \\
\hline 2 & 60,97 & $\begin{array}{l}\text { Aproveitou pouco com } \\
\text { tudo }\end{array}$ & $\begin{array}{l}\text { Aproveitou-me pouco com } \\
\text { tudo }\end{array}$ & $\begin{array}{l}\text { Aproveitou pouco com } \\
\text { tudo }\end{array}$ \\
\hline 3 & 62,92 & sẽ replicarẽ mais & sẽ replicar mais & sẽ replicarẽ mais \\
\hline 4 & 80,28 & de que sua filha era natural & de que era sua filha natural & de que sua filha era natural \\
\hline
\end{tabular}

$\mathrm{Na}$ tabela 1.8 figuram os casos em que B apresenta pequenas variantes que não constam em A e nos outros códices. Nenhum dos exemplos acima constitui, no entanto, 
erros que prejudiquem a compreensão do texto. Em 1 e 3, há variações na conjugação verbal, sendo que a primeira ocorrência se explica pela troca das letras r/v já comentada acima. O exemplo 2 consiste em interpolação de pronome pleonástico. No caso de 4 , verifica-se apenas a inversão da ordem das palavras.

Tabela 1.9: Omissões exclusivas a B.

\begin{tabular}{|c|c|c|c|c|}
\hline $\mathbf{N}^{\mathbf{o}}$ & Localiz. & $\mathbf{A}$ & B & $\mathrm{C}, \mathrm{D}, \mathbf{E}, \mathbf{F}, \mathbf{G}$ \\
\hline 1 & $12,18-19$ & $\begin{array}{l}\text { as Raynhas de Hespanha, e } \\
\text { França a Recindos, } e \\
\text { Arnedos, Sidella a Palmeirim }\end{array}$ & $\begin{array}{l}\text { as Raynhas de Hespanha, e } \\
\text { França a Recindos, Sidella } \\
\text { a Palmeirim }\end{array}$ & $\begin{array}{l}\text { as Raynhas de Hespanha, e } \\
\text { França a Recindos, } e \\
\text { Arnedos, Sidella a Palmeirim }\end{array}$ \\
\hline 2 & $59,09-10$ & $\begin{array}{l}\text { Ás avessas entendo eu isso } \\
\text { (tornou o outro) porque }\end{array}$ & $\begin{array}{l}\text { Ás avessas entendo eu isso) } \\
\text { porque }\end{array}$ & $\begin{array}{l}\text { Ás avessas entendo eu isso } \\
\text { tornou o outro porque }\end{array}$ \\
\hline 3 & $59,47-48$ & $\begin{array}{l}\text { melhores dezenganos com } \\
\text { hũa mentira mais, ou } \\
\text { menos. Essoutro que dizeis }\end{array}$ & $\begin{array}{l}\text { melhores dezenganos. } \\
\text { Essoutro que dizeis }\end{array}$ & $\begin{array}{l}\text { melhores dezenganos com } \\
\text { hũa mentira mais, ou } \\
\text { menos. Essoutro que dizeis }\end{array}$ \\
\hline 4 & $59,73-74$ & $\begin{array}{l}\text { espreitando, a fora que mal } \\
\text { poderia deixar de ser } \\
\text { sentido, não lhe ficava } \\
\text { esperança }\end{array}$ & $\begin{array}{l}\text { espreitando não lhe ficava } \\
\text { esperança }\end{array}$ & $\begin{array}{l}\text { espreitando, afora que mal } \\
\text { poderia deixar de ser } \\
\text { sentido, não lhe ficava } \\
\text { esperança }\end{array}$ \\
\hline 5 & $62,51-52$ & $\begin{array}{l}\text { partirão de sua caza todos tres } \\
\text { juntos para Constantinopla }\end{array}$ & partirão para Constantinopla & $\begin{array}{l}\text { partirão de sua caza todos tres } \\
\text { juntos para Constantinopla }\end{array}$ \\
\hline 6 & $64,74-75$ & $\begin{array}{l}\text { custandolhe a elle seus } \\
\text { revezes, } e \text { justar com algũns } \\
\text { mais que hũa vez porque erão } \\
\text { todos escolhidos }\end{array}$ & $\begin{array}{l}\text { custandolhe a elle seus } \\
\text { revezes, porque erão todos } \\
\text { escolhidos }\end{array}$ & $\begin{array}{l}\text { custandolhe a elle seus } \\
\text { revezes, e justar com algüm } \\
\text { mais que hũa vez, porque erão } \\
\text { todos escolhidos }\end{array}$ \\
\hline
\end{tabular}

Nos capítulos cotejados, não há passagens em que A apresente lacunas no texto em comparação com B; foram encontrados apenas exemplos de omissões de partes do texto exclusivas a B. Ainda que em nenhum dos casos o trecho omitido seja essencial para a inteligibilidade da frase ${ }^{153}$, os exemplos acima permitem concluir que: a) entre A e B, o primeiro apresenta lição mais próxima à das demais cópias, conforme foi sugerido acima; b) A não pode ter sido copiado de B.

\footnotetext{
${ }^{153} \mathrm{O}$ único exemplo em que a lição de B resulta errada é o segundo, em que o copista manteve apenas um dos parênteses do trecho que saltou. A presença do parêntese pode indicar que B foi copiado de A ou de um outro manuscrito perdido em que a expressão "tornou o outro" também estaria entre parênteses.
} 
Tabela 1.10: Erros exclusivos a B.

\begin{tabular}{|c|c|c|c|c|}
\hline $\mathbf{N}^{\mathbf{o}}$ & Localiz. & $\mathbf{A}$ & $\mathbf{B}$ & $\mathbf{C}, \mathbf{D}, \mathbf{E}, \mathbf{F}, \mathbf{G}$ \\
\hline 1 & 11,44 & $\begin{array}{l}\text { não se vião muy } \\
\text { distintamente }\end{array}$ & $\begin{array}{l}\text { não se vião muy } \\
\text { distantemente }\end{array}$ & $\begin{array}{l}\text { não se vião muy } \\
\text { distintamente }\end{array}$ \\
\hline 2 & $12,30-31$ & $\begin{array}{l}\text { querendolhe hũns, e outros } \\
\text { bejar a mão, não a deu } \\
\text { senão a os nettos }\end{array}$ & $\begin{array}{l}\text { querendolhe hũns, e outros } \\
\text { bejar a mão, a deu senão } \\
\text { dos nettos }\end{array}$ & $\begin{array}{l}\text { querendolhe hũns, e outros } \\
\text { bejar a mão, não a deu } \\
\text { senão a os nettos }\end{array}$ \\
\hline 3 & 60,99 & porque vou vendo que vos & porque vos vendo que vos & porque vou vendo que vos \\
\hline 4 & 60,107 & de quem me exercita nella & de quem me excita nella & de quem me exercita nella \\
\hline 5 & 61,54 & não podẽ ser bons juizes & não podẽ ser bons juizos & não podẽ ser bons juizes \\
\hline 6 & $62,74-75$ & $\begin{array}{l}\text { Resoluto nisto chamou } \\
\text { Ardellio, e disselhe: } \\
\text { Ardellio amigo, mal me } \\
\text { ouzaria eu }\end{array}$ & $\begin{array}{l}\text { Resultou nisto chamou } \\
\text { Ardellio, amigo e disselhe } \\
\text { mal me ouzaria eu }\end{array}$ & $\begin{array}{l}\text { Resoluto nisto chamou } \\
\text { Ardellio, e disselhe: } \\
\text { Ardellio amigo, mal me } \\
\text { ouzaria eu }\end{array}$ \\
\hline
\end{tabular}

O códice B também apresenta alguns erros que não se encontram em A. Trata-se da troca de palavras por outras que, embora semelhantes, não fazem sentido no contexto (exemplos 1, 3, 4, 5 e no início do exemplo 6), da omissão da palavra "não", que gera uma tentativa de adaptação mal sucedida (2) e de um salto provavelmente motivado pela repetição do nome de Ardélio (exemplo 6) ${ }^{154}$.

Embora pouco numerosos, os erros exclusivos a B são mais freqüentes que os do códice A, que constam da tabela abaixo.

Tabela 1.11: Erros exclusivos a A.

\begin{tabular}{|c|c|l|c|l|}
\hline $\mathbf{N}^{\mathbf{0}}$ & Localiz. & \multicolumn{1}{|c|}{ A } & \multicolumn{1}{|c|}{ B } & C, D, E, F, G \\
\hline 1 & 12,14 & aquellas senhores estavão & aquellas senhoras estavão & aquellas senhoras estavão \\
\hline 2 & 60,63 & $\begin{array}{l}\text { ás dividas em que à } \\
\text { primeira confiança }\end{array}$ & $\begin{array}{l}\text { ás duvidas em que à } \\
\text { primeira confiança }\end{array}$ & $\begin{array}{l}\text { ás duvidas em que à } \\
\text { primeira confiança }\end{array}$ \\
\hline
\end{tabular}

\footnotetext{
${ }^{154}$ Encontra-se em B ainda outro gênero de erro, que não foi registrado na tabela acima. Trata-se dos erros percebidos e corrigidos pelo copista, que antepõe à correção o verbo "digo", como nestes exemplos: "tratando-a com mais brandura, e regalo do que elle digo do que se podia crer de sua antiga natureza" (cap. 01); "à custa de perder o merecimento da restituição digo da rezistencia que se fazia a si proprio" (cap. 61). Este tipo de erro é relativamente comum em B (a menos na porção do texto em que empreendemos a colação dos testemunhos), mas é quase inexistente em A.
} 
A tabela 1.11 apresenta os dois únicos casos encontrados de erros do códice A que não se repetem em B. Admitindo a hipótese de que B tenha sido copiado de $A, o$ primeiro exemplo poderia facilmente ter sido notado e corrigido pelo copista de B, inclusive pela presença do pronome feminino "aquellas", que foi mantido em A. No entanto, em 2 é menos provável que isto tenha ocorrido, pois a troca de "dúvidas" por “dívidas” seria um erro dificilmente identificável pelo copista de $\mathrm{B}^{155}$.

Findo o exame do ramo $\mathrm{A} / \mathrm{B}$, estamos em condições de sistematizar algumas conclusões. Em primeiro lugar, nota-se que as numerosas variantes comuns e exclusivas a A e B (cf. as tabelas 1.3 a 1.6) caracterizam a afinidade entre ambos, sendo que a maior parte delas consiste em lições adiáforas. Por outro lado, a quantidade de discrepâncias exclusivas a B permite supor que a lição de A seja a mais confiável, hipótese reforçada pela constatação da impossibilidade de A ter sido copiado a partir de $B$, visto que este manuscrito apresenta lacunas em comparação com aquele. Embora as evidências analisadas permitam supor A seja o antígrafo de B (ou seja, que A tenha sido o texto de base a partir da qual B foi copiado), o último exemplo da tabela 1.11 parece desautorizar tal conclusão, a menos que estejamos diante de um caso de contaminação $^{156}$. Assim, embora inclinados a admitir a tese de B ser cópia de A, por prudência adotamos como possível também a hipótese de ambos os códices procederem de um antecedente comum perdido.

Em síntese, as duas possibilidades relativas ao ramo $\mathrm{A} / \mathrm{B}$ poderiam ser representadas das seguintes formas:

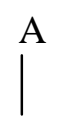

B
$\mathrm{Ou}$

A

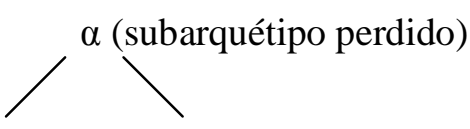

B

\footnotetext{
${ }^{155}$ Note-se que D apresenta o mesmo erro. Trata-se, no entanto, de uma provável coincidência, uma vez que, conforme veremos adiante, D não apresenta afinidades significativas com A.

156 Não é incomum que amanuenses compulsassem mais de um manuscrito ao realizar sua cópia, selecionando as lições que lhes parecessem melhores. É possível que o copista de B tenha suspeitado que naquela passagem haveria equívoco e tenha recorrido a outra cópia para sanar a dúvida. De qualquer modo, para sustentar adequadamente esta hipótese seria preciso reunir mais elementos. Sobre a contaminação, cf. Spaggiari e Perugi, op. cit., p. 41-42.
} 


\subsection{Ramo $E / F$}

Outro ramo bem caracterizado na tradição manuscrita da Crônica de D. Duardos é o composto pelos códices E e F. Diferentemente do que sucedeu no ramo A/B, no entanto, o parentesco entre $\mathrm{E}$ e $\mathrm{F}$ é caracterizado por um número maior de erros comuns a ambos testemunhos. O manuscrito E (TT 1773, $1^{\mathrm{a}}$ parte), dentre todos, é o de mais difícil leitura, não apenas pelo tamanho reduzido da letra, como também pelo estado do códice, cujos fólios se encontram muito escurecidos. O amanuense que o copiou utiliza grande quantidade de abreviações e possui hábitos ortográficos arcaizantes que o singularizam, visíveis sobretudo nas terminações em -ão, sempre grafadas por ele com -am: é o caso de nam (= não) e rezam (= razão), por exemplo, mas também de poderiam (= poderião, nos outros códices) ${ }^{157}$. Já o códice $\mathrm{F}$ (BNL 483), embora seja redigido com letra muito clara e esteja melhor conservado, apresenta numerosos erros de cópia.

Conforme procedimento adotado para o exame do ramo A/B, inciaremos pelos exemplos das variantes comuns a E e F.

Tabela 2.1: Variantes textuais do ramo E/F.

\begin{tabular}{|c|c|l|l|}
\hline No. & Localiz & \multicolumn{1}{|c|}{ E/F } & \multicolumn{1}{|c|}{ A, B, C, D, G } \\
\hline 1 & 01,23 & em quanto os animos se socegão & em quanto os animos se assegurão \\
\hline 2 & $01,80-82$ & $\begin{array}{l}\text { se começarão a fazer prestes com suas } \\
\text { mulheres e filhas os que os tinhão para } \\
\text { Constantinopla }\end{array}$ & $\begin{array}{l}\text { se começarão a fazer prestes para } \\
\text { filhas }(\text { os que os tinhão })\end{array}$ \\
\hline 3 & $11,64-65$ & onde a cerpe se sumira & onde a cerpe se sumergira \\
\hline 4 & 59,77 & passavão a vala & passavão o vallado \\
\hline 5 & 60,50 & mas houve o peor sucesso & mas teve o peor sucesso \\
\hline 6 & 62,40 & he pequeno castigo de minha innocencia & he pequeno castigo de minha ignorancia \\
\hline 8 & 62,67 & vierão ter com Barciliano, $e$ Trineo & vierão ter com Trineo, e Barciliano \\
\hline
\end{tabular}

${ }^{157}$ É preciso observar que as peculiaridades ortográficas de E devem ser imputadas a causas meramente acidentais, como a hábitos do amanuense, e não podem servir para suposições quanto à possível antigüidade da cópia, visto que o códice está datado de 1668 - informação cuja autenticidade não há motivos para questionar. 
As variantes textuais de E/F são de tipos semelhantes às analisadas no ramo A/B: em grande parte dos casos resumem-se à substituição de palavras por outras, sinônimas ou equivalentes (exemplos 1, 3, 4, 5 e 6). Em 2, 7 e 8 ocorre a simples alteração da ordem das palavras. São variações pouco significativas para além do fato de atestarem a afinidade entre E e F.

Tabela 2.2: Omissões no ramo E/F.

\begin{tabular}{|c|c|l|l|}
\hline No. & Localiz & \multicolumn{1}{|c|}{ E/F } & \multicolumn{1}{|c|}{ A, B, C, D, G } \\
\hline 1 & $01,02-03$ & $\begin{array}{l}\text { Em que se da conta da vida, que fazia o } \\
\text { Emperador e os outros Principes }\end{array}$ & $\begin{array}{l}\text { Em que se da conta da vida, que fazia o } \\
\text { Emperador Primaleão es outros Principes }\end{array}$ \\
\hline 2 & 11,30 & aquelle extraordinario incendio & aquelle tão extraordinario incendio \\
\hline 3 & 59,02 & do que Trineo passou com hum delles & do que Trineo passou depois com hum delles \\
\hline 4 & 60,98 & $\begin{array}{l}\text { escreveume hũa carta, e tantas outras } \\
\text { escreveume hũa carta, eutra carta e } \\
\text { tantas outras }\end{array}$ \\
\hline 6 & 64,70 & e fazer dezairoso reves na sella & $\begin{array}{l}\text { culpa, aquẽ na quelles cazos a tem, que na quelles cazos a tem } \\
\text { sempre, que são aquellas violencias }\end{array}$ \\
\hline
\end{tabular}

Outro tipo de variantes conjuntivas, que comprovam a consangüinidade dos códices E e F, são as omissões de palavras ou expressões breves. Como é compreensível, as palavras omitidas são normalmente curtas (principalmente nos exemplos 2 e 6) ou dispensáveis para a intelecção da passagem em questão (1, 3 e 5). $O$ mesmo sucede com a omissão de sintagmas ou expressões: é o caso do exemplo 4, que pode ser explicado pela repetição do termo "carta", configurando outro caso do saut du même au même.

Tabela 2.3: Erros no ramo E/F.

\begin{tabular}{|c|c|l|l|}
\hline No. & Localiz & \multicolumn{1}{|c|}{ E/F } & \multicolumn{1}{c|}{ A, B, C, D, G } \\
\hline 1 & $12,32-33$ & querẽdo Polynardo seu bejarlha logo & querẽdo Polynardo seu tio bejarlha logo \\
\hline 2 & $59,28-29$ & esperando achalla de todo sem culpa & esperando achalla de todo sem desculpa \\
\hline
\end{tabular}




\begin{tabular}{|c|c|c|c|}
\hline 3 & $59,117-118$ & $\begin{array}{l}\text { começou a caminhar por aquelles campos } \\
\text { seguindo os dos Gabões, seguramente } \\
\text { delle entrarão na charneca }\end{array}$ & $\begin{array}{l}\text { começou a caminhar por aquelle campo } \\
\text { seguindo os dos Gabões, e sahindo } \\
\text { seguramente delle entrarão na charneca }\end{array}$ \\
\hline 4 & 60,36 & $\begin{array}{l}\text { Thomeime eu então com esta reposta } \\
\text { contra mim mesmo }\end{array}$ & $\begin{array}{l}\text { Thomeime eu então com esta reposta } \\
\text { conta } a \text { mim mesmo }\end{array}$ \\
\hline 5 & 60,39 & nesta conformidade detive repostas & nesta conformidade tive reposta \\
\hline 6 & 60,87 & àquillo de que a preçoadia antes & àquillo de que a antes a dissuadia \\
\hline 7 & 61,09 & $\begin{array}{l}\text { lhe declarava quam entregue } e \text { pobre } \\
\text { homem vivia }\end{array}$ & $\begin{array}{l}\text { lhe declarava quam entregue } o \text { pobre } \\
\text { homem vivia }\end{array}$ \\
\hline 8 & $62,09-11$ & $\begin{array}{l}\text { e elles a sentir nas carnes a força daquillo } \\
\text { na sua. Trineo era mui bom cavaleiro } \\
\text { mas não lhe devia nada o com que se } \\
\text { combatia. O com que o Hospede se } \\
\text { combatia e estava embaraçado }\end{array}$ & $\begin{array}{l}\text { e elles a sentir nas carnes a força de que } \\
\text { aquillo nascia. Trineo era mui bom } \\
\text { cavaleiro mas não lhe devia nada o com } \\
\text { que se combatia. O com que o Hospede } \\
\text { estava embaraçado }\end{array}$ \\
\hline 9 & 62,85 & athe chegar á raiz do outro & athe chegar á raiz do outeiro \\
\hline 10 & $64,42-43$ & $\begin{array}{l}\text { será razão que } o \text { vio desta tribuna } e \text { da } \\
\text { camareira Mor }\end{array}$ & $\begin{array}{l}\text { será razão que saibais que o uzo desta } \\
\text { tribuna he da camareira Mor }\end{array}$ \\
\hline 11 & 80,22 & Embaixador de Dramuziando & Embaixador, $e$ Dramuziando \\
\hline
\end{tabular}

Como pode-se notar pelos exemplos da tabela 2.3, os erros comuns ao grupo E/F são mais freqüentes que os do ramo anterior. Em 1, E e F omitem a palavra "tio", sem a qual a frase fica sem sentido. Em 3, além do plural em "aquelles campos", que seria uma variação pouco significativa, omitiu-se "e sahindo", com o que se compromete o significado do resto da frase. A troca de palavras em 4, 6, 7, 9, 10 e 11 (algumas delas simples preposições) também resulta em frases incompreensíveis ${ }^{158}$. No caso dos exemplos 2 e 5, embora as modificações introduzidas em E/F não cheguem a prejudicar completamente o sentido da passagem, podem ser consideradas errôneas, pois a lição dos demais testemunhos se ajusta melhor ao contexto. E, finalmente, o exemplo 8 apresenta um erro de leitura no início do trecho em destaque e uma repetição indevida da palavra "combatia" ao final, tornando-o confuso.

Em suma, os exemplos das tabelas 2.1 a 2.3 são suficientes para comprovar o parentesco entre E e F. Mas, assim como ocorre no caso do ramo A/B, os códices E e F

\footnotetext{
${ }^{158}$ No exemplo 9, é possível que a origem do erro seja uma abreviação da palavra "outeiro" no antígrafo, não percebida pelo copista. Em 6, os ms. C e D apresentam ordem das palavras mais próxima da do ramo $\mathrm{E} / \mathrm{F}$, ainda que não compartilhem o erro deste ramo: "aquillo de que a dissuadia antes".
} 
não são idênticos. A fim de compreender a relação entre eles, será preciso analisar brevemente as discrepâncias que os diferenciam. Sendo que a maioria das variantes são exclusivas a F, é pelo exame delas que iniciaremos.

Tabela 2.4: Variantes exclusivas a F.

\begin{tabular}{|c|c|c|c|c|}
\hline $\mathbf{N}^{\mathbf{o}}$ & Localiz. & $\mathbf{E}$ & $\mathbf{F}$ & $\mathbf{A}, \mathbf{B}, \mathbf{C}, \mathbf{D}, \mathbf{G}$ \\
\hline 1 & $01,31-32$ & $\begin{array}{l}\text { os corações de Primaleão e } \\
\text { de seus vassallos }\end{array}$ & $\begin{array}{l}o \text { coração de Primaleão e } \\
\text { de seus vassallos }\end{array}$ & $\begin{array}{l}\text { os corações de Primaleão e } \\
\text { de seus vassallos }\end{array}$ \\
\hline 2 & $12,10-11$ & $\begin{array}{l}\text { parecendome que me } \\
\text { levaveis outra ves estas } \\
\text { Senhoras, sem quem ja não } \\
\text { puderamos viver. }\end{array}$ & $\begin{array}{l}\text { parecendome que me } \\
\text { levareis outra ves estas } \\
\text { Senhoras, sem quem ja não } \\
\text { poderemos viver. }\end{array}$ & $\begin{array}{l}\text { parecendome que me } \\
\text { levaveis outra ves estas } \\
\text { Senhoras, sem quem ja não } \\
\text { puderamos viver. }\end{array}$ \\
\hline 3 & $12,25-27$ & $\begin{array}{l}\text { pois no sobresalto deste dia } \\
\text { vos temos sido } \\
\text { companheiros, e no trabalho } \\
\text { de vir aqui buscallos nos fas } \\
\text { nos não fas nimguem } \\
\text { companhia. }\end{array}$ & $\begin{array}{l}\text { pois nos sobresaltos deste } \\
\text { dia vos temos feito } \\
\text { companhia, e no trabalho } \\
\text { de vir aqui buscallos nos } \\
\text { não fas nimguem } \\
\text { companhia. }\end{array}$ & $\begin{array}{l}\text { pois no sobresalto deste dia } \\
\text { vos temos sido } \\
\text { companheiros, e no trabalho } \\
\text { de vir aqui buscallos nos não } \\
\text { fas nimguem companhia. }\end{array}$ \\
\hline 4 & 59,62 & quando estava na $a g o a$ & quando estava na lagoa & quando estava na agoa \\
\hline 5 & $60,67-68$ & $\begin{array}{l}\text { não era tão pouco o que lhe } \\
\text { eu divia }\end{array}$ & $\begin{array}{l}\text { não era tão pouco o que lhe } \\
\text { eu dizia }\end{array}$ & $\begin{array}{l}\text { não era tão pouco o que lhe } \\
\text { eu divia }\end{array}$ \\
\hline 6 & 80,42 & $\begin{array}{l}\text { de se Mostrarem quando } \\
\text { cuidão }\end{array}$ & $\begin{array}{l}\text { de demonstrarem quando } \\
\text { cuidão }\end{array}$ & $\begin{array}{l}\text { de se Mostrarem quando } \\
\text { cuidão }\end{array}$ \\
\hline
\end{tabular}

As alterações exemplificadas acima foram introduzidas pelo copista de F, uma vez que não correspondem à lição de $\mathrm{E}$, que nestes casos é idêntica à dos demais códices. A única exceção é a do exemplo 3, onde há uma repetição indevida em E ("nos fas nos não fas”), que aliás seria facilmente identificável pelo copista de F, caso ele tenha utilizado E como base para sua cópia ${ }^{159}$. De resto, as variantes registradas na tabela 2.4 podem ser consideradas neutras, apesar de provavelmente não remontarem ao arquétipo. ${ }^{159} \mathrm{Na}$ passagem referente ao exemplo 3, A apresente uma repetição indevida da palavra "deste": "no
sobresalto deste [[deste]] dia". 
Tabela 2.5: Erros exclusivos a F.

\begin{tabular}{|c|c|c|c|c|}
\hline $\mathbf{N}^{\mathbf{o}}$ & Localiz. & $\mathbf{E}$ & $\mathbf{F}$ & $\mathbf{A}, \mathbf{B}, \mathbf{C}, \mathbf{D}, \mathbf{G}$ \\
\hline 1 & $01,18-19$ & $\begin{array}{l}\text { couza que os Princepes, } \\
\text { que entrão de novo em seus } \\
\text { estados necessariamente } \\
\text { ande fazer. Acomodar-se, } \\
\text { digo, ao governo }\end{array}$ & $\begin{array}{l}\text { couza que os Princepes, } \\
\text { que entrão de novo em seus } \\
\text { estados necessariamente } \\
\text { ande acomodar-se ao } \\
\text { governo }\end{array}$ & $\begin{array}{l}\text { couza que os Princepes, } \\
\text { que entrão de novo em seus } \\
\text { estados necessariamente } \\
\text { ande fazer. Acomodar-se, } \\
\text { digo, ao governo }\end{array}$ \\
\hline 2 & $01,71-72$ & $\begin{array}{l}\text { o animo, e força, de que se } \\
\text { sentião dotados }\end{array}$ & $\begin{array}{l}\text { o animo, e força, de que se } \\
\text { sentião notados }\end{array}$ & $\begin{array}{l}\text { o animo, e força, de que se } \\
\text { sentião dotados }\end{array}$ \\
\hline 3 & 12,82 & $\begin{array}{l}\text { que lhe entretinha o } \\
\text { cuidado de Sua Alteja }\end{array}$ & $\begin{array}{l}\text { que lhe entretinha o } \\
\text { cuidado de } S . A \text {. }\end{array}$ & $\begin{array}{l}\text { que lhe entretinha o } \\
\text { cuidado de sua Altea }\end{array}$ \\
\hline 4 & 59,12 & $e u$ lhe respondeu elle & hum lhe respondeu elle & $E u$ (lhe respondeu elle) \\
\hline 5 & 59,49 & $\begin{array}{l}\text { pudera ficar Daraja menos } \\
\text { desculpada }\end{array}$ & $\begin{array}{l}\text { pudera ficar fora ja menos } \\
\text { desculpada }\end{array}$ & $\begin{array}{l}\text { pudera ficar Daraja menos } \\
\text { desculpada }\end{array}$ \\
\hline 6 & 59,60 & vamos buscar os rocĩns & vamos buscar as razões & vamos buscar os rocĩns \\
\hline 7 & 60,75 & $\begin{array}{l}\text { cazarãome meus Pais com } \\
\text { vosco }\end{array}$ & $\begin{array}{l}\text { cauzarãome meus Pais } \\
\text { com vosco }\end{array}$ & $\begin{array}{l}\text { cazarãome meus Pais com } \\
\text { vosco }\end{array}$ \\
\hline 8 & $61,19-20$ & $\begin{array}{llr}\text { com o credito } & \text { tão } \\
\text { aventurado } & \text { como } & \text { nelle } \\
\text { tinha } & & \end{array}$ & $\begin{array}{l}\text { com o credito tão } \\
\text { aventurado como elle tinha }\end{array}$ & $\begin{array}{llr}\text { com o } & \text { credito } & \text { tão } \\
\text { aventurado } & \text { como } & \text { nelle } \\
\text { tinha } & & \end{array}$ \\
\hline 9 & $61,65-67$ & $\begin{array}{l}\text { hia mais bem contente delle } \\
\text { na quelle habito, que no } \\
\text { outro, em que anoite } \\
\text { passada o vira. E depois de } \\
\text { terem caminhado mais de } \\
\text { Mea legoa }\end{array}$ & $\begin{array}{l}\text { hia bem contente, mais na } \\
\text { quelle habito, que no outro, } \\
\text { em que anoite passada o } \\
\text { vira. E depois de o ter } \\
\text { encaminhado mais de Mea } \\
\text { legoa }\end{array}$ & $\begin{array}{l}\text { hia bem mais contente delle } \\
\text { na quelle habito, que no } \\
\text { outro, em que anoite } \\
\text { passada o vira. E depois de } \\
\text { terem caminhado mais de } \\
\text { Mea legoa }\end{array}$ \\
\hline 10 & 62,06 & mas deixandoo logo & mas deitandoo logo & mas deixandoo logo \\
\hline 11 & 64,15 & dissimulando a falla & dissimulando a falta & dissimulando a falla \\
\hline 12 & 64,35 & $\begin{array}{l}\text { porque com tudo tornou a } \\
\text { dizer }\end{array}$ & $\begin{array}{l}\text { porem com tudo tornou a } \\
\text { dizer }\end{array}$ & $\begin{array}{l}\text { porque com tudo tornou a } \\
\text { dizer }\end{array}$ \\
\hline 13 & 64,40 & puxando pella das praticas & puxando pellas praticas & puxando pella das praticas \\
\hline 14 & $64,76-77$ & $\begin{array}{l}\text { ás tendas de ElRey que } a \\
\text { porta de hũa dellas }\end{array}$ & $\begin{array}{l}\text { ás tendas de ElRey que } \\
\text { apartada de hũa dellas }\end{array}$ & $\begin{array}{l}\text { ás tendas de ElRey que } a \\
\text { porta de hũa dellas }\end{array}$ \\
\hline 15 & 80,10 & a quelle dia guardou & a quelle dia ganhou & a quelle dia guardou \\
\hline
\end{tabular}

São numerosos os erros de cópia de F que não estão presentes em E. Na maioria dos casos, trata-se de uma troca indevida de palavras (exemplos 2, 4, 5, 6, 7, 8, 10, 11, 12, 14 e 15) ou da omissão de uma palavra a prejudicar a clareza do texto (13). Em 9, 
nota-se que a lição de $\mathrm{E}$ também apresenta pequenas alterações com relação às demais, sem prejuízo do sentido do trecho, ao passo que a redação de F é confusa.

No exemplo 3, o nome da personagem Altea foi confundido com a palavra "Alteza": daí a abreviação em F ("S. A." é abreviação comum de "Sua Alteza"). Caso F tenha sido copiado de E, o equívoco poderia ser explicado pelo fato de este códice grafar o nome com a semivogal $j$.

Na tabela acima merece atenção particular o exemplo 1, em que a omissão do verbo "fazer" em F torna a frase incompreensível; é preciso notar, contudo, que quanto à falta do verbo "digo", parece ter havido uma correção por parte do amanuense, posto que a inclusão de glosa iniciada por "digo" era modo habitual com que os copistas da época faziam correções evitando a rasura do texto. O que parece ter ocorrido neste caso é que uma emenda feita em nível muito alto da tradição manuscrita (talvez no próprio autógrafo) acabou por ser inadvertidamente incorporada ao texto, transmitindo-se a todos os testemunhos conhecidos. As únicas exceções são os manuscritos F e G: no caso do primeiro, pelo que a esta altura já é possível concluir dos exemplos analisados, não é provável que se trate de um representante de nível mais alto da tradição, ou mesmo de cópia direta de códice que não contivesse a emenda. Quanto a G, sua situação no estema será discutida adiante.

Tabela 2.6: Lições únicas em E e F.

\begin{tabular}{|c|c|c|c|c|}
\hline $\mathbf{N}^{\mathbf{o}}$ & Localiz. & $\mathbf{E}$ & $\mathbf{F}$ & $\mathbf{A}, \mathbf{B}, \mathbf{C}, \mathbf{D}, \mathbf{G}$ \\
\hline 1 & 12,60 & $\begin{array}{l}\text { pois não pode deixar de ser a } \\
\text { criação este Donzel Floris }\end{array}$ & $\begin{array}{l}\text { pois não pode deixar de ser } \\
\text { a criação este de } D \text {. Floris }\end{array}$ & $\begin{array}{l}\text { pois não pode deixar de ser } \\
\text { a criação. Este he } D \text {. Floris }\end{array}$ \\
\hline 2 & 12,89 & $\begin{array}{l}\text { velassem as armas para que } \\
\text { a } o \text { fossẽ }\end{array}$ & $\begin{array}{l}\text { velassem as armas para que } \\
o \text { fossẽ }\end{array}$ & $\begin{array}{l}\text { velassem as armas para que } \\
\text { a o outro dia o fossẽ }\end{array}$ \\
\hline 3 & $60,08-09$ & $\begin{array}{l}\text { deixe de vos obedecer, } \\
\text { digo offerecer a obediencia }\end{array}$ & $\begin{array}{l}\text { deixe de vos obedecer, ou } \\
\text { offerecer a obediencia }\end{array}$ & $\begin{array}{l}\text { deixe de vos offerecer a } \\
\text { obediencia }\end{array}$ \\
\hline 4 & 60,47 & $\begin{array}{l}\text { mal persuadida e peor dos } \\
\text { exemplos }\end{array}$ & $\begin{array}{l}\text { mal persuadida de si e peor } \\
\text { dos exemplos }\end{array}$ & $\begin{array}{l}\text { mal persuadida de minhas } \\
\text { palavras, pouco ajudada de } \\
\text { sua idade e peor dos } \\
\text { exemplos }\end{array}$ \\
\hline 5 & $61,41-43$ & $\begin{array}{l}\text { perdeu a desculpa que } \\
\text { podia ter dando, porque a } \\
\text { emsesão foy acto da } \\
\text { liberdade forçada, e a } \\
\text { promessa da vontade livre, } \\
\text { e dada esta deffença }\end{array}$ & $\begin{array}{l}\text { perdeu a desculpa que } \\
\text { podia tardando, porque a } \\
\text { inceção foy acto da } \\
\text { liberdade forçada, e a } \\
\text { promessa da vontade livre, } \\
\text { e dada esta deffença }\end{array}$ & $\begin{array}{l}\text { perdeu a desculpa que } \\
\text { podia ter dando, porque a } \\
\text { concecção foy acto da } \\
\text { liberdade forçada, e a } \\
\text { promessa da vontade livre, } \\
\text { e dada esta differença }\end{array}$ \\
\hline
\end{tabular}




\begin{tabular}{|c|c|l|l|l|}
\hline 6 & 64,29 & $\begin{array}{l}\text { com apessa não haveis de } \\
\text { me enganar }\end{array}$ & $\begin{array}{l}\text { com apessa não haveis de } \\
\text { enganar }\end{array}$ & $\begin{array}{l}\text { com apessa não haveis de } \\
\text { enganar niguẽ }\end{array}$ \\
\hline 7 & $80,24-25$ & $\begin{array}{l}\text { o que mais convinha á } \\
\text { honrra de sua filha, e } \\
\text { autolidade de seus } \\
\text { vassallos }\end{array}$ & $\begin{array}{l}\text { o que mais convinha á } \\
\text { honrra de sua filha, e } \\
\text { autoridade de seus } \\
\text { vassallos }\end{array}$ & $\begin{array}{l}\text { o que mais convinha á } \\
\text { honra de sua filha, e á } \\
\text { utidade de seus vassallos }\end{array}$ \\
\hline
\end{tabular}

A tabela 2.6 apresenta os casos em que as variantes dos códices em questão divergem entre si. De modo geral, são possíveis duas explicações para a presença desses erros: se admitirmos que $\mathrm{F}$ tenha sido copiado de $\mathrm{E}$ - como sugere a maior quantidade de erros de cópia em $\mathrm{F}$-, as variantes poderiam ser explicadas por equívocos cometidos pelo amanuense do códice $\mathrm{E}$ a que se seguiram em certos casos emendas nem sempre bem sucedidas por parte do copista de F; por outro lado, caso E e F sejam copiados a partir de um mesmo manuscrito, as lições destes códices poderiam ser resultado de falhas existentes no antecedente comum. Uma vez que, como já foi ressaltado, E apresenta menos variantes e erros, a hipótese mais provável é a primeira - ou seja, que E seja o antígrafo de F.

O único exemplo que não parece confirmar esta afirmação é o primeiro, pois neste caso a lição de F é a que mais se aproxima da dos outros testemunhos. Em 2, o salto de trecho do texto é mais visível em E, ao passo que o copista de $\mathrm{F}$ parece ter notado o problema e ter tentado corrigi-lo. Algo semelhante pode ter ocorrido em 4. O exemplo 3 retrata novamente o uso de "digo" exercendo a função de introduzir a correção de um erro de cópia em $\mathrm{E}$ ou no subarquétipo do ramo $\mathrm{E} / \mathrm{F}$, o que deve ter sido notado pelo copista de F. Em todo caso, a versão de E e F é resultado de um erro evidente, em que o amanuense trocou "offerecer" por “obedecer", mas notou o equívoco e procurou corrigi-lo. Em 5, a lição de E é a mais próxima da dos demais códices, embora ela também apresente problemas: "emsesão" no lugar de "concessão" e "deffença" ao invés de "differença" 160 . O exemplo 7 também parece se explicar por um erro de cópia ocorrido em E e transmitido a $\mathrm{F}$ : neste caso, a união do artigo com a palavra "utilidade" grafada incorretamente pode ter sido o motivo da emenda por parte do amanuense de F.

${ }^{160}$ Este erro entra na categoria da haplografia: cf. Spina, op. cit., p. 115. 
Tabela 2.7: Erros exclusivos a E.

\begin{tabular}{|c|c|l|l|l|}
\hline $\mathbf{N}^{\mathbf{0}}$ & Localiz. & \multicolumn{1}{|c|}{$\mathbf{E}$} & $\mathbf{F}$ & \multicolumn{1}{c|}{ A, B, C, D, G } \\
\hline 1 & 60,15 & filhos, entre os que dais & filhos, entre os quais & filhos, entre os quais \\
\hline 2 & $60,93-94$ & $\begin{array}{l}\text { a the para não ser mais } \\
\text { julgado de Daraja mostrar hũ } \\
\text { pouco de mais sentimento }\end{array}$ & $\begin{array}{l}\text { a the para não ser mal julgado } \\
\text { de Daraja mostrar hũ pouco } \\
\text { de sentimento mais }\end{array}$ & $\begin{array}{l}\text { a the para não ser mal julgado } \\
\text { de Daraja mostrar hũ pouco } \\
\text { de mais sentimento }\end{array}$ \\
\hline
\end{tabular}

Os erros de transcrição exclusivos a E encontrados foram apenas dois, ambos no capítulo 60. Ainda que o primeiro pudesse ser identificado pelo copista de F, caso ele estivesse utilizando como base o códice E (e, com efeito, a passagem parece corrigida em F), é menos provável que o mesmo sucedesse com o segundo exemplo ${ }^{161}$.

Assim, nos encontramos em situação semelhante à verificada com relação ao ramo $\mathrm{A} / \mathrm{B}$ : embora sejam vários os indícios que apontem para a hipótese de $\mathrm{E}$ ser $\mathrm{o}$ antígrafo de F, dois detalhes de caráter duvidoso (ex. 1 da tabela 2.6 e ex. 2 da tabela 2.7) parecem desaconselhar essa conclusão. Dessa forma, por cautela admitimos a possibilidade de E e F serem cópias de um mesmo subarquétipo perdido, embora estejamos inclinados a considerar $\mathrm{F}$ como cópia de $\mathrm{E}$, pelos diversos motivos anteriormente apontados. Formulamos mais uma vez, portanto, duas hipóteses para a representação do estema deste ramo:

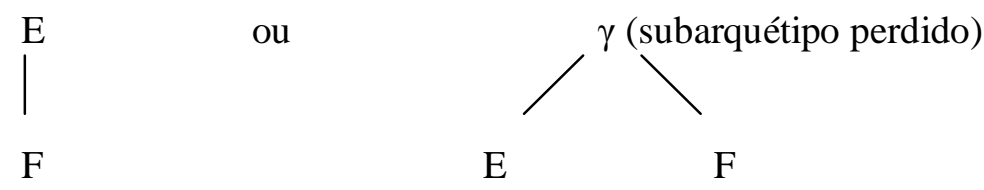

Apesar das semelhanças entre as posições ocupadas por A e E nos respectivos estemas, a comparação entre os dois manuscritos atesta a clara superioridade de A relativamente a E. Conforme já foi ressaltado, para além das dificuldades de leitura que este códice apresenta, A possui menor quantidade de erros que E.

${ }^{161}$ É preciso notar que a lição de B apresenta um erro nesta passagem, pois falta-lhe a palavra "não", o que deixa a frase sem sentido: trata-se de mais um elemento a reforçar as conclusões anteriormente expostas acerca desta cópia. 


\section{Os códices C e D}

Afora os códices já examinados, os demais não apresentam afinidades tão estreitas que permitam concluir pela existência de novos ramos da tradição manuscrita. Com efeito, as evidências de uma suposta proximidade entre C e D são muito mais tênues do que as existentes entre A e B ou entre E e F.

Do que foi exposto até o momento, nota-se que as lições de C e D ora se aproximam do ramo $\mathrm{A} / \mathrm{B}$ (quando foram encontradas variantes exclusivas a $\mathrm{E}$ e $\mathrm{F}$ ), ora do ramo $\mathrm{E} / \mathrm{F}$ (nos casos das variantes que caracterizam A e B). No entanto, apesar de C e D ocuparem a mesma posição "intermediária" entre os ramos acima descritos, foram encontradas numerosas variantes exclusivas a cada um dos códices em questão. Por isso, eles serão examinados em separado, antes de verificarmos os indícios que apontam para a ligação entre ambos.

O códice BNL 658 (C) é o único que foi copiado por duas mãos. A letra dos dois amanuenses é bastante clara, mas o manuscrito possui numerosos fólios com tinta repassada do verso, o que por vezes torna a leitura trabalhosa. A mudança de punho (que ocorre, como já observamos, no início do f. 169r, em meio ao capítulo 64) levanta questões que não podem ser ignoradas para a correta avaliação das variantes apresentadas no códice. Qual o motivo da troca de copistas: trata-se simplesmente de uma substituição ocorrida no decorrer do trabalho ou o manuscrito atual é resultado da junção de partes de dois códices originalmente independentes? Neste caso, os amanuenses basearam-se num mesmo antígrafo ou tomaram por base manuscritos diferentes?

O exame das marcas d’água demonstra que na confecção deste códice foram utilizados papéis de procedência variada; há inclusive um trecho (fols. 115 a 120) em que foi aproveitado um papel de qualidade inferior e completamente diversa da dos demais. Isso pode indicar que o manuscrito tenha sido redigido para uso privado e que, por isso, não foi dada grande atenção à apresentação do texto; numa cópia como esta, presumivelmente feita com pressa e valendo-se dos recursos mais à mão, não estranha a mudança de letra. Além disso, o fato de alguns fólios do trecho copiado pelo segundo

punho apresentarem marcas d’água iguais a algumas das encontradas nos fólios utilizados pelo primeiro copista sugere que os dois amanuenses trabalharam em 
períodos e regiões aproximados. Tudo indica, portanto, não ter havido a junção de partes de dois manuscritos preexistentes; o códice C parece ser cópia feita sem grande esmero e que, por motivo desconhecido, foi concluída por um amanuense diferente daquele que havia iniciado o trabalho ${ }^{162}$. Com efeito, ao menos no trecho analisado, não foram encontrados elementos relevantes que permitissem supor a utilização de outro antígrafo por parte do segundo amanuense. Ainda assim, por motivo de clareza, nas tabelas que se seguem os exemplos retirados do trecho transcrito pelo segundo punho (todos pertencentes ao final do capítulo 64 e ao capítulo 80) foram assinalados com um asterisco.

Tabela 3.1: Lições Adiáforas de C.

\begin{tabular}{|c|l|l|l|}
\hline No. & Loliz. & \multicolumn{1}{|c|}{$\mathbf{C}$} & \multicolumn{1}{|c|}{ A, B, D, E, F, G } \\
\hline 1 & 01,06 & reduzida aquella cidade & reduzido aquella cidade \\
\hline 2 & $11,39-40$ & $\begin{array}{l}\text { que se não vião huns a os Outros, } \text { acabado } \\
\text { acal }\end{array}$ & $\begin{array}{l}\text { que se não vião huns a os Outros, } \\
\text { acabado o qual }\end{array}$ \\
\hline 3 & $12,22-23$ & os com que serrava o numero & os com que se serrava o numero \\
\hline 4 & $59,15-16$ & $\begin{array}{l}\text { que nenhũa que me prometta deixarà de } \\
\text { cumprir }\end{array}$ & $\begin{array}{l}\text { que nenhũa que prometta deixarà de } \\
\text { cumprir }\end{array}$ \\
\hline 5 & 61,75 & $\begin{array}{l}\text { em campo das mesmas cores hũns cinquo } \\
\text { troncos }\end{array}$ & $\begin{array}{l}\text { em campo das mesmas cores hũns } \\
\text { troncos }\end{array}$ \\
\hline 6 & $62,46-47$ & tendo Barceliano outros & tendo Barceliano depois outros \\
\hline $7^{*}$ & 64,68 & e remetendo a o do Sol & e remeteu a do Sol \\
\hline Cap. 80 & ponderasse Sua Alteza se convinha & ponderasse Sua Alteza bem se convinha \\
\hline
\end{tabular}

$\mathrm{O}$ manuscrito $\mathrm{C}$ distingue-se pela pequena quantidade de variantes que lhe são exclusivas, em comparação com os ramos anteriormente examinados. O exemplo 1 consiste na concordância do particípio com o objeto, que ainda era comum na transição dos séculos XVI e XVII ${ }^{163}$ e em 2, há inversão da ordem das palavras. Os exemplos

\footnotetext{
$162 \mathrm{O}$ fato de o segundo punho iniciar o fol. 169r repetindo a última frase transcrita pela primeira mão (cf. a descrição do códice, feita acima) não invalida a conclusão.

163 "Os particípios, que, com os verbos ter e haver, constituem locuções verbais ativas, concordavam em gênero e número com o objeto direto do verbo; esta prática parece perdurar durante todo o século XVI" (Dulce de Faria Paiva. História da língua portuguesa. II: Século XV e meados do século XVI. São Paulo: Ática, 1988, p. 59-60). Note-se que é este o caso em questão, pois a frase completa (que é a primeira do
} 
restantes consistem na troca de formas verbais por outras igualmente possíveis nos respectivos contextos (7) ou em pequenas omissões ou interpolações (em 3, 4, 5, 6, e 8).

Tabela 3.2: Erros do códice C.

\begin{tabular}{|c|c|l|l|}
\hline No. & Loliz. & \multicolumn{1}{|c|}{ C } & \multicolumn{1}{|c|}{ A, B, D, E, F, G } \\
\hline 1 & 12,13 & então levandoo & então levantandoo \\
\hline 2 & 59,68 & tirarlho por força, aforça que & tirarlho por força, a fóra que \\
\hline 3 & $60,66-67$ & que nos mostrou a ambos & que nos matou a ambos \\
\hline 4 & 60,96 & hia passando forrado na honrra & hia passando ferrado na honrra \\
\hline 5 & 62,37 & acontecer al $\|$ a Recindos & acontecer algũ dezastre a Recindos \\
\hline 6 & $64,37-38$ & devação das meninas de Santo Erasmo & devação das Missas de Santo Erasmo \\
\hline $7 *$ & Cap. 80 & Dramusiando, Arnelio, Palmeirim Frenellio & $\begin{array}{l}\text { Dramusiando, } \\
\text { Palmeirim Frenellio }\end{array}$ \\
\hline
\end{tabular}

Foram encontrados também poucos erros em C. A troca de "levantando-o" por "levando-o" em 1 é caso de haplografia. Em 2, 3, 4 e 6 ocorrem trocas de palavras por erros de leitura ou por associações mentais do copista ${ }^{164}$. No exemplo 7 o nome de Arnedos é grafado incorretamente, devido à proximidade com o nome de Frenélio ${ }^{165}$; algo parecido ocorreu em 2, onde a palavra "força" ecoa na seguinte. E, finalmente, o exemplo 5 explica-se pela mudança de fólio, que gerou um pequeno salto no texto (assinalado por duas barras).

O códice D (BNL 6828), ao contrário de C, apresenta numerosas variantes e erros do amanuense, apesar de ser redigido com letra clara e uniforme. O traço distintivo desta cópia é o uso de sinais de pontuação incomuns: dois traços perpendiculares (//) para indicar o fim de frase ou mudança de parágrafo e outro sinal, assemelhado a um til ( ) ou a um ponto de interrogação deitado, para indicar a

capítulo 01), diz: "Redificado tinha o Emperador Primaleão os muros de Constantinopla e reduzido aquella cidade..."

${ }^{164}$ Note-se que no caso do exemplo 3, o termo matou foi corrigido pelo copista, que anteriormente havia grafado outra coisa. Isto pode ser indicativo do fato desta passagem apresentar algum problema de transmissão também no antígrafo de A, o que pode sugerir a existência de alguma emenda ou correção em nível mais alto da tradição, comum ao ramo A/B e a C. As possíveis relações entre A/B e $\mathrm{C}$ serão discutidas a seguir.

${ }^{165}$ Note-se que há erro nesta mesma passagem em D: "Dramusiando, Recindos, e Arnaldo, Arnedos...”: o nome acrescentado não corresponde a nenhum personagem na obra. 
interrogação. Pelo que verificamos, contudo, o emprego desses sinais, além de parcimonioso, não abrange a totalidade da cópia.

Tabela 3.3: Lições Adiáforas de D.

\begin{tabular}{|c|c|c|c|}
\hline No. & Localiz. & $\mathbf{D}$ & $A, B, C, E, F, G$ \\
\hline 1 & $01,38-39$ & pezavalhe de $o s$ ter deixado & pezavalhe de lhos ter deixado \\
\hline 2 & $01,75-76$ & Despachou Donzellas às cortes & Despachou Donzellas a todas as cortes \\
\hline 3 & 11,22 & onde se juntarão os mais & onde se juntarão com os mais \\
\hline 4 & 59,100 & o habito manifestava & o habito lhe grangeava \\
\hline 5 & $60,15-16$ & entra hua filha fermoza muito & $\begin{array}{l}\text { entra hua filha de pouca idade, fermoza } \\
\text { muito }\end{array}$ \\
\hline 6 & Cap. 60 & $\begin{array}{l}\text { cõ eu ter vindo de partes mui remotas que } \\
\text { nos vizinhos he cauza ainda de melhor } \\
\text { recebimento, se me fizeram alli muitos } \\
\text { gazalhados. Vi Daraya }\end{array}$ & $\begin{array}{l}\text { cõ eu ser vindo de partes mui remotas } \\
\text { que nos vizinhos he cauza ainda de } \\
\text { melhor recebimento, se me fizeram alli } \\
\text { muitos gazalhados em verdade. Vi Daraja }\end{array}$ \\
\hline 7 & 60,25 & com estas licenças & com estas lizonjas \\
\hline 8 & 61,47 & se arrojava comoopprimida $a$ força & se arrojava comoopprimida, e forçada \\
\hline 9 & $61,81-82$ & $\begin{array}{l}\text { os moradores della ficarão quietos } e \\
\text { ficarão contentes como temos contado }\end{array}$ & $\begin{array}{l}\text { os Moradores della ficarão quietos como } \\
\text { temos contado }\end{array}$ \\
\hline 10 & 62,05 & Encontrarão-se aquelles Cavalleiros & $\begin{array}{l}\text { Em cheio se encontrarão aquelles } \\
\text { Cavalleiros }\end{array}$ \\
\hline 11 & $64,29-30$ & $\begin{array}{l}\text { A fé e por esta cruz que sois vos mui } \\
\text { letrada }\end{array}$ & A fé que sois vos muy letrada \\
\hline 12 & $64,67-68$ & hũ de seus companheiros & hũ dos seis companheiros \\
\hline 13 & 80,41 & Ponderando tambẽ o seu & Poderava tambẽ o seu \\
\hline
\end{tabular}

Os exemplos referidos na tabela 3.3 ilustram alguns dos numerosos casos em que o manuscrito D apresenta variantes adiáforas: trata-se da substituição de palavras ou da redação divergente de trechos curtos, sem prejuízo do sentido da passagem (exemplos 1, 4, 7, 8, 10, 12 e 13), ou de pequenas omissões e interpolações (em 2, 3, 5, 9 e 11). No ex. 6, ocorrem os dois fenômenos: uma variação pouco significativa (ser/ter) seguida da omissão de uma expressão não essencial. A glosa interpolada pelo copista no 
exemplo 11 consiste provavelmente numa fórmula então corrente de juramento, que o amanuense registra recorrendo a um símbolo abreviador (“à fe e por esta †”).

Tabela 3.4: Erros do códice D.

\begin{tabular}{|c|c|c|c|}
\hline No. & Localiz. & $\mathbf{D}$ & $\mathrm{A}, \mathrm{B}, \mathrm{C}, \mathbf{E}, \mathbf{F}, \mathbf{G}$ \\
\hline 1 & 01, 08-09 & por que elle com cruzidade, em que vivia & $\begin{array}{l}\text { por que elle com a Occiozidade, em que } \\
\text { vivia }\end{array}$ \\
\hline 2 & $01,27-28$ & $\begin{array}{l}\text { nem elle teve trabalho, nẽ os deu a seus } \\
\text { povos }\end{array}$ & $\begin{array}{l}\text { nem elle teve trabalho, nẽ } o \text { deu a seus } \\
\text { povos }\end{array}$ \\
\hline 3 & 01,40 & hũa cidade a ser parecer & hũa cidade a seu parecer \\
\hline 4 & 11,49 & ja tão estendida que chegava a falar & ja tão estendida que chegava a terra \\
\hline 5 & $12,08-09$ & porque juntas tantas a tardança & porque juntastes à tardança \\
\hline 6 & $59,10-11$ & e ella menos de que se honrar & e ella menos de que se correr \\
\hline 7 & $59,66-67$ & dezejando saber o mais que não entendião & dezejando saber o mais que não entendia \\
\hline 8 & 60,10 & Eu senhor cavalleyro & Eu senhor sou cavalleyro \\
\hline 9 & $60,59-60$ & $\begin{array}{l}\text { polido o engenho, e exercitar o } \\
\text { Entendimento }\end{array}$ & polir o engenho, e exercitar o Entendimento \\
\hline 10 & 61,08 & $\begin{array}{l}\text { as lagrimas que em muitos pasados dellas } \\
\text { engolia }\end{array}$ & $\begin{array}{l}\text { as lagrimas que em muitos passos dellas } \\
\text { engolia }\end{array}$ \\
\hline 11 & 61,24 & Via o outro perigo de primor & Via o outro prodigio de primor \\
\hline 12 & 61,78 & $\begin{array}{l}\text { lhes deu novas da perdição dos Reys } \\
\text { descontou tãbẽ }\end{array}$ & $\begin{array}{l}\text { lhe deu novas da perdição dos Reys lhe } \\
\text { contou tãbẽ }\end{array}$ \\
\hline 13 & 64,26 & suprireis com calidade os deffeitos & suprireis com charidade os deffeitos \\
\hline 14 & 80,17 & parecer, e Conselho de Dramusiando & parecer, e Conselho. Dramusiando \\
\hline 15 & $80,54-55$ & $\begin{array}{l}\text { nem quando o não fizesse para de quẽ } \\
\text { elle tivesse muita satisfação }\end{array}$ & $\begin{array}{l}\text { nem quando o não fizesse pessoa, de quẽ } \\
\text { elle tivesse muita satisfação }\end{array}$ \\
\hline
\end{tabular}

O manuscrito D apresenta também mais erros que C, como demonstra a tabela 3.4. São várias as trocas de palavras que prejudicam a compreensão da frase (como em $1,3,4,5,6,9,10,11,12,13$ e 15), sendo que em alguns casos os erros podem ser atribuídos a meras falhas de leituras ou a erros mecânicos de transcrição. Não faltam erros de concordância, como os verificados nos exemplos 2, 7 e 12. Em 8 omitiu-se o 
verbo "sou", sem o qual a frase perde o sentido. No exemplo 15 houve a interpolação indevida de uma preposição.

Em suma, o breve exame realizado é suficiente para atestar a superioridade da lição de C em comparação com a de D. Vejamos agora os pontos de contato entre os dois manuscritos.

Tabela 3.5: Variantes comuns a C e D.

\begin{tabular}{|c|c|c|c|c|}
\hline $\mathbf{N}^{\mathbf{o}}$ & Localiz. & $\mathbf{C}$ & D & $\mathbf{A}, \mathbf{B}, \mathbf{E}, \mathbf{F}, \mathbf{G}$ \\
\hline 1 & 01,45 & $\begin{array}{l}\text { a qual hia crescendo em } \\
\text { fermozura, e boas partes } \\
\text { outras de maneira, que }\end{array}$ & $\begin{array}{l}\text { a qual hia crescendo em } \\
\text { fermozura, e boas partes } \\
\text { outras de maneira, que }\end{array}$ & $\begin{array}{l}\text { a qual hia crescendo em } \\
\text { fermozura, e boas partes de } \\
\text { maneira, que }\end{array}$ \\
\hline 2 & 11,47 & $\begin{array}{l}\text { delphĩns, que atopondoce a } \\
\text { ella }\end{array}$ & $\begin{array}{l}\text { delphĩns, que trepandoce a } \\
\text { ella }\end{array}$ & $\begin{array}{l}\text { delphĩs, que sotopondoce a } \\
\text { ella }\end{array}$ \\
\hline 3 & Cap. 11 & $\begin{array}{l}\text { mas ja quando chegarão } \\
\text { áquellas Princezas, (que de } \\
\text { todo se tinhão contado por } \\
\text { acabadas quando virão } \\
\text { lançar a Ponte, e } \\
\text { desmaiadas todas estavão } \\
\text { esperando o que a fortuna } \\
\text { quereria dispor dellas) } \\
\text { acharão que tornadas em } \\
\text { seu acordo }\end{array}$ & $\begin{array}{l}\text { mas ja quando chegarão } \\
\text { áquellas Princezas, (que de } \\
\text { todo se tinhão contado por } \\
\text { acabadas quando virão } \\
\text { lançar a Ponte, e } \\
\text { desmaiadas todas estavão } \\
\text { esperando o que a fortuna } \\
\text { quereria dispor dellas), e } \\
\text { tanto que tornarão em seu } \\
\text { acordo }\end{array}$ & $\begin{array}{l}\text { mas ja quando chegarão } \\
\text { áquellas Princezas, (que de } \\
\text { todo se tinhão contado por } \\
\text { acabadas quando virão } \\
\text { lançar a Ponte, e } \\
\text { desmaiadas todas estavão } \\
\text { esperando o que a fortuna } \\
\text { queria dispor dellas) } \\
\text { acharão que tornadas em } \\
\text { seu acordo }\end{array}$ \\
\hline 4 & 59,38 & esperar hũ largo termo & esperar hũ largo termo & esperar hũ largo tempo \\
\hline 5 & $60,81-84$ & $\begin{array}{l}\text { parecevos que ficava retirada } \\
\text { algũa a hũ homem que nem } \\
\text { he de pedra, nem nasceu de } \\
\text { pedras? parecevos que podia } \\
\text { eu deixar de seguir a Daraja } \\
\text { os passos por onde me ella } \\
\text { encaminhava? parecevos que } \\
\text { podia eu deixar de crer hũa } \\
\text { Mulher não obrigada a the } \\
\text { então mais }\end{array}$ & $\begin{array}{l}\text { parecevos que ficava retirada } \\
\text { algũa a hũ homem que não } \\
\text { he de pedra nem nasceu de } \\
\text { pedras? parecevos que podia } \\
\text { eu deixar de seguir a Daraja } \\
\text { os passos por onde ella me } \\
\text { encaminhava? parecevos que } \\
\text { podia eu deixar de querer hũa } \\
\text { Mulher não obrigada a the } \\
\text { então mais }\end{array}$ & $\begin{array}{l}\text { parecevos que ficava retirada } \\
\text { algũa a hũ homem que não } \\
\text { he de pedra, nem dellas } \\
\text { nasceu (E/F: que nem he de } \\
\text { pedra nem nasceu de pedra)? } \\
\text { parecevos que podia eu } \\
\text { deixar de seguir a Daraja os } \\
\text { (E/F: pellos) passos por onde } \\
\text { me ella encaminhava? } \\
\text { parecevos que podia eu } \\
\text { deixar de crer (querer em } \\
\text { E/F) hũa Mulher não } \\
\text { obrigada (que não obrigava } \\
\text { em E/F) a the então mais }\end{array}$ \\
\hline
\end{tabular}

Embora poucos, os exemplos acima podem sugerir a existência de certo grau de afinidade entre C e D. Em 2, as lições dos manuscritos em questão são divergentes entre si, mas podem indicar que ambos sejam provenientes de um ramo da tradição em que a passagem apresentava algum tipo de corrupção ou dificuldade de leitura, pelo que os 
copistas de C e D a emendaram, cada um à sua maneira. Em 1 e 4, as variantes apresentadas são pouco significativas e são comuns também ao manuscrito G. Os exemplos 3 e 5 estão situados em pontos críticos do texto, em que há grande quantidade de variantes em todos os códices ${ }^{166}$. No exemplo 3, importa notar que C e D são os únicos a trazer "quereria", ao invés de "queria"; quanto ao uso de "tornarão" em D, trata-se de uma variante que não prejudica o sentido da frase. No exemplo 5, as lições de $\mathrm{C}$ e $\mathrm{D}$ apresentam algumas variantes únicas e outras que os aproximam ora de um ora de outro dos ramos já descritos; quanto à variação crer/querer, $\mathrm{C}$ aproxima-se do ramo $\mathrm{A} / \mathrm{B}$, ao passo que $\mathrm{D}$ apresenta a mesma lição de $\mathrm{E} / \mathrm{F}^{167}$. Em suma, embora bastante frágeis, os indícios da existência de alguma ligação entre C e D não podem ser negligenciados.

Quanto à relação dos manuscritos C e D com os outros ramos da tradição, verifica-se mais uma vez que a lição de $C$ em algumas passagens coincide com a de A/B, conforme a tabela acima (ex. 5). Os outros casos de concordância encontrados são os seguintes:

Tabela 3.6: Variantes comuns a A/B e C.

\begin{tabular}{|c|c|l|l|}
\hline No. & Localiz & \multicolumn{1}{|c|}{ A/B e C } & \multicolumn{1}{|c|}{ D, E, F, G } \\
\hline 1 & $11,66-67$ & $\begin{array}{l}\text { do Arco de Iris, (a que vulgarmente } \\
\text { chamamos arco da velha) }\end{array}$ & $\begin{array}{l}\text { do Arco de Iris, (a que vulgarmente } \\
\text { chamamos da velha) }\end{array}$ \\
\hline 2 & $59,88-89$ & $\begin{array}{l}\text { Com menos ira se costumão receber os } \\
\text { hospedes }\end{array}$ & $\begin{array}{l}\text { Com menos ira se costuma receber os } \\
\text { hospedes }\end{array}$ \\
\hline 3 & 60,112 & $\begin{array}{l}\text { se não estais de todo entregue a não crer } \\
\text { nada }\end{array}$ & $\begin{array}{l}\text { se não estais de todo entregue a não querer } \\
\text { nada }\end{array}$ \\
\hline $5 *$ & $80,43-44$ & $\begin{array}{l}\text { jomeçarão hũa assas notavel e perigoza } \\
\text { batalha }\end{array}$ & $\begin{array}{l}\text { começarão hũa assas notavel batalha } \\
\text { jornada à quelles Reynos }\end{array}$ \\
\hline
\end{tabular}

\footnotetext{
${ }^{166} \mathrm{Na}$ passagem correspondente ao exemplo 3, os manuscritos E e F apresentam erros que tornam a frase incompreensível: "quando chegarão aquelles principes que tudo (F: todo) se tinha contado por acabadas". Também o códice B apresenta problemas nesta passagem: é omitido o verbo "chegarão" e, ao final, a palavra "tornadas" é substituída por "todas", o que também prejudica a compreensão deste trecho. São dados que só fazem reforçar as conclusões relativas aos ramos A/B e E/F expostas anteriormente. Quanto ao ex. 5, além das numerosas variantes já apontadas no quadro, falta notar que o copista de B atrapalhouse com as diversas repetições da frase, apresentando uma lição confusa.

167 A passagem em questão não consta do manuscrito $G$ pois, como veremos adiante, este códice apresenta uma lacuna que abrange todo o capítulo 60.
} 
Os exemplos em que a lição de $\mathrm{C}$ diverge da de $\mathrm{D}$ e concorda com a do ramo A/B são, como se pode ver acima, pouco significativos. Em 1, há uma interpolação do termo "arco", que estava subentendido; no exemplo 2 a mudança limita-se à conjugação verbal, sem acarretar erro; em 3 verifica-se novamente a variação querer/crer, já observada no exemplo 5 da tabela anterior (e aqui, como antes, A, B e C apresentam "crer" onde os demais testemunhos trazem "querer"); no exemplo 5 a variação entre plural e singular é pouco relevante: digna de nota é apenas a circunstância de o trecho ter sido copiado pelo segundo punho do códice C. A passagem reproduzida no exemplo 4 é das que mais apresentam variantes nas diferentes cópias: além das lições reproduzidas acima, em D lê-se "hũa lastimoza e perigoza batalha" e G apresenta "hũa notavel e perigoza batalha" (omitindo a palavra "assas") ${ }^{168}$.

Pelos exemplos apresentados, nota-se que as concordâncias descobertas entre as lições de $\mathrm{C}$ e $\mathrm{A} / \mathrm{B}$ não são suficientemente numerosas ou relevantes para fundamentar hipóteses acerca da existência de possíveis pontos de contato entre os manuscritos em zonas mais altas da tradição. $\mathrm{O}$ exame das concordâncias sugere, inclusive, que em alguns casos elas podem ser fruto de meras coincidências (principalmente nos exemplos $1,2$ e 5$)$.

Menos numerosas e mais inconsistentes ainda são as coincidências encontradas entre os manuscritos $\mathrm{C}$ ou $\mathrm{D}$ e os outros códices (E, F e G). Devido à enorme quantidade de variantes existentes nos manuscritos, seria possível elaborar listas de concordâncias entre todos os testemunhos; na maioria dos casos, entretanto, as ocorrências devem ser caracterizadas como simples lições adiáforas ou erros poligenéticos, isto é, provavelmente introduzidos em ramos independentes da tradição, casualmente equivalentes e por isso mesmo pouco significativos ${ }^{169}$.

Em síntese, os elementos colhidos na colação não permitem inferir conclusões definitivas a respeito dos manuscritos C e D. Embora haja indícios da existência de certo grau de parentesco entre eles, sua afinidade está longe de ser vinculante como a verificada entre A e B ou E e F - pelo que não os consideramos representantes de um novo ramo da tradição manuscrita da Crônica de D. Duardos, Primeira Parte. Cópias independentes, de qualidade desigual (pois, como já foi dito, a lição de C é mais

\footnotetext{
${ }^{168}$ A estes casos, deve-se somar o possível parententesco entre A/B e C apontado no comentário feito acima ao exemplo 3 da tabela 3.2 e ao exemplo 5 da tabela 3.5 .

${ }^{169}$ Sobre os erros poligenéticos, cf. Spaggiari e Perugi, op. cit., p. 34.
} 
próxima da dos demais testemunhos, apresentando menos variantes e erros), os manuscritos C e D ocupam posição intermediária em relação aos ramos descritos anteriormente, visto que ora se aproximam do ramo A/B (nos casos em que E e F apresentam variantes que lhes são exclusivas: cf. tabelas 2.1 a 2.3), ora concordam com $\mathrm{E} / \mathrm{F}$ (nas passagens em que há variantes caracterizadoras do parentesco entre A e B: cf. tabelas 1.3 a 1.6).

Com base nas informações disponíveis, contudo, é impossível precisar com segurança a posição dos códices C e D na tradição manuscrita. Admitimos provisoriamente a hipótese de ambos derivarem direta ou indiretamente de um subarquétipo comum, hoje perdido, como sugerem os exemplos da tabela 3.5, apesar de estarmos conscientes da fragilidade de tais indícios. A maior proximidade de $\mathrm{C}$ com relação ao ramo A/B (para a qual parecem apontar s igualmente frágeis exemplos da tabela 3.6), entretanto, levanta problemas cuja solução exigiria a colação de outros trechos da Crônica. Três são as suposições plausíveis: a) esta afinidade deve-se a parentesco mais distante, num hipotético nível intermediário situado em área mais alta da tradição; b) ela é resultado de uma contaminação; ou c) as concordâncias entre as lições de $\mathrm{C}$ e do ramo A/B são resultado de meras coincidências. Por ora, na falta de mais elementos, restringimo-nos a propor uma solução conjectural, que atenda aos critérios de simplicidade e de economia quanto à suposição da existência de testemunhos intermediários perdidos. A linha segmentada representa um possível caso de contaminação ${ }^{170}$.

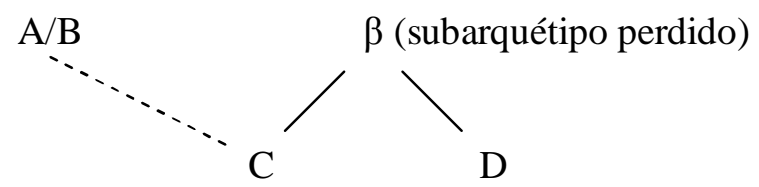

\footnotetext{
${ }^{170}$ A existência de um antecedente comum a $\mathrm{C}$ e o ramo $\mathrm{A} / \mathrm{B}$ aparentemente contradiz a hipótese de C e D derivarem de um subarquétipo comum, tendo em vista a falta de elementos comprobatórios da proximidade entre as lições de A/B e D. Além disso, a especulação sobre o suposto codex interpositus criaria dificuldades para explicar as concordâncias existentes entre $\mathrm{C}$ e $\mathrm{D}$ e o ramo E/F, que são relevantes (cf. tabelas 1.3 a 1.6). Por fim, conforme veremos adiante, seria preciso encontrar ainda subarquétipos que explicassem a posição de $\mathrm{G}$, que também ocupa posição intermediária entre os ramos A/B e E/F, mas apresenta lição muito distinta da dos códices $\mathrm{C}$ e D.
} 


\subsection{Códice $G$}

O códice BNL 619 (G) é o que mais se diferencia dos restantes testumunhos. Único manuscrito a ser redigido em duas colunas, apresenta texto bem legível mas repleto de erros e variantes - tantas e tão significativas, que o situam em posição à parte na tradição manuscrita.

A primeira que salta aos olhos é relativa à discrepância do número de capítulos deste códice em comparação com as outras cópias conhecidas do texto: com efeito, se em todos os outros testemunhos a Crônica de D. Duardos, Primeira Parte possui 80 capítulos, em G ela é composta por apenas $74^{171}$. Da comparação entre os títulos, as frases iniciais e finais dos capítulos dos códices A e G, pudemos concluir pela existência de quatro zonas em que a matéria narrativa é submetida a subdivisões discrepantes: entre os capítulos 10-18, 22-23, 26-30 e 59-61 da versão do manuscrito $\mathrm{A}^{172}$. Em alguns casos, a matéria de um único capítulo de $\mathrm{A}$ foi distribuída por dois capítulos em G (como ocorre com o capítulo 10, que corresponde grosso modo aos capítulos 10 e 11 de G); em outros casos verifica-se o contrário, isto é, que a matéria de um único capítulo de $\mathrm{G}$ corresponde à de dois ou mais capítulos de $\mathrm{A}$ (é o caso dos capítulos 11 e 12 de A, que foram condensados no capítulo 12 de G). A tabela abaixo apresenta a correspondência entre os capítulos dos dois códices. As zonas em que há divergências foram assinaladas com asterisco.

\footnotetext{
${ }^{171}$ Embora a numeração prossiga até o número 76, o texto apresenta apenas 74 capítulos, visto que o códice não possui os capítulos 56 e 57.

172 Tomamos a lição de A como representativa dos capituleiros dos demais testemunhos, pois eles não apresentam variantes significativas entre si, conforme atesta também Palma-Ferreira, op. cit., p. 9-33. A identificação destas zonas discrepantes foi utilizada como critério para definir quais trechos da obra seriam submetidos à colação, conforme declaramos anteriormente (cf. o início do item 2 deste capítulo).
} 
Tabela 4.1: Capituleiros de A e G.

\begin{tabular}{|l|l|}
\hline \multicolumn{1}{|c|}{ A } & \multicolumn{1}{|c|}{ G } \\
\hline Capítulos 1-9 & Capítulos 1-9 \\
\hline$*$ Capítulo 10 & *Capítulos 10-11 \\
\hline$*$ Capítulos 11-12 & *Capítulo 12 \\
\hline$*$ Capítulos 13-14 & * Capítulo 13 \\
\hline$*$ Capítulos 15-16 & $*$ Capítulo 14 \\
\hline$*$ Capítulos 17-18 & $*$ Capítulo 15 \\
\hline Capítulos 19-21 & Capítulos 16-18 \\
\hline$*$ Capítulos 22-23 & $*$ Capítulos 19-21 \\
\hline Capítulos 24-25 & Capítulos 22-23 \\
\hline$*$ Capítulos 26-30 & $*$ Capítulos 24-26 \\
\hline Capítulos 31-58 & Capítulos 27-54 \\
\hline$*$ Capítulos 59-61 & *apítulo 55 \\
\hline Capítulos 62-80 & \\
\hline
\end{tabular}

Além das diferenças apontadas na tabela, há outras discrepâncias. Em G, os capítulos 18, 20, 21, 23, 25 e 26 não apresentam título, embora o copista tenha deixado o espaço reservado para anotá-lo. No caso do capítulo 17, o título foi acrescentado posteriormente, por outra mão.

A maior anomalia do texto parece ser a do capítulo 55 de G (= capítulos 59 a 61 de A). Ali, não ocorre apenas a reunião de três capítulos em um só; na realidade, a versão de $\mathrm{G}$ apresenta uma lacuna de porção significativa do trecho correspondente em A. Dado que a falha, como veremos, provavelmente remonta ao antecedente de $\mathrm{G}$, fato que o copista não notou, une-se uma frase da metade do capítulo 59 de A a outra do meio do capítulo 61, sem qualquer anotação, o que resulta numa lição incompreensível, conforme se pode verificar na tabela abaixo ${ }^{173}$.

${ }^{173} \mathrm{O}$ salto ocorre no f. $147 \mathrm{v}$, col. a de G. Na tabela abaixo, são destacadas as divisões de linhas do manuscrito G, de modo que é possível verificar que a união dos trechos pertencentes aos capítulos 59 e 61 das outras cópias de fato ocorre numa mesma linha de G, sem qualquer anotação por parte do copista. No 
Tabela 4.2: Lacuna em G (caps. 59-61).

\begin{tabular}{|c|c|c|c|}
\hline Local. & $\mathbf{G}$ & Local. & $\mathrm{A}, \mathrm{B}, \mathrm{C}, \mathrm{D}, \mathbf{E}, \mathbf{F}$ \\
\hline \multirow[t]{2}{*}{ Cap. 55} & \multirow{2}{*}{$\begin{array}{l}\text { fazen|do mais concideração não | o } \\
\text { tinha por couza facil, porque | se os } \\
\text { homẽns erão honrrados co|mo a elle } \\
\text { lhe parecião perdia | mais em faze- } \\
\text { las, que em obser|va-las e a razão } \\
\text { era que andar | perderia o que } \\
\text { desencarregan|do a culpa a quem } \\
\text { naquelles | cazos a tem sempre que } \\
\text { são a||[col. b]quellas violencias } \\
\text { gran|des, com que o amor cega o | } \\
\text { Entendimento }\end{array}$} & $\begin{array}{c}59, \\
69-71\end{array}$ & $\begin{array}{l}\text { fazendo mais concideração não o tinha por } \\
\text { couza facil, porque se os homẽns erão } \\
\text { honrados como lhe a elle parecião, quando } \\
\text { não tivessẽ força para se deffender, terião } \\
\text { animo para não confessar, e se o não fossem } \\
\text { em remettendo a elles lhe fogirião... }\end{array}$ \\
\hline & & $\begin{array}{c}61 \\
34-38\end{array}$ & $\begin{array}{l}\text { mais tinha de que se contentar na quebra } \\
\text { daquellas promessas, que no comprimento } \\
\text { dellas como ella perdia mais em fazellas e } \\
\text { cumprillas, do que em observallas, e a razão } \\
\text { era que em dar perderia o desse carregando a } \\
\text { culpa, aquẽ na quelles cazos a tem sempre, } \\
\text { que são aquellas violencias grandes, com que } \\
\text { o amor cega o Entendimento }\end{array}$ \\
\hline
\end{tabular}

Além disso, o capítulo seguinte em G recebeu o número 58, e não 56 como seria de esperar, o que reforça a hipótese de que a lacuna remonta ao antígrafo de G. Tal lacuna abrangeria o final do capítulo 55 (=59 de A), o capítulo 56 inteiro (=60 de A) e a porção inicial do capítulo 57 (=61 de A). Assim, explica-se também o motivo de o salto na numeração dos capítulos de $\mathrm{G}$ não corresponder a nova lacuna do texto.

Se é verdade que as anomalias do capítulo 55 de $\mathrm{G}$ são explicáveis pela existência de uma lacuna em seu antecedente, conclui-se que as zonas do texto em que o copista de G (ou de seu antecedente) o submeteu a novo arranjo dos capítulos restringese ao primeiro terço do livro - ou, mais precisamente, entre os capítulos 10 e 30 da versão de A, conforme é possível verificar pela tabela 4.1. E, com efeito, dentre os capítulos examinados na colação, foram nos de número 11 e 12 que encontramos as maiores discrepâncias entre a versão de $\mathrm{G}$ e a lição dos outros manuscritos ${ }^{174}$. Por isso, as variantes de $\mathrm{G}$ nestes capítulos serão examinadas à parte.

Vejamos primeiramente alguns exemplos encontrados das numerosas lições adiáforas que $\mathrm{G}$ apresenta fora da área em que há divergências quanto à estrutura dos capítulos (ou seja, nos capítulos 01, 59-62, 64 e 80).

quadro em que se apresenta o texto de G, a parte correspondente ao capítulo 61 está em itálico; nos quadros com o texto dos outros testemunhos, estão em itálico o início e o final do trecho omitido em G.

${ }_{174}$ Note-se que, conforme foi dito anteriormente, os capítulos cotejados foram os de número $01,11,12$, 59-62, 64 e 80. Excluídos os capítulos 59-62 da zona em que a versão de G distribui a matéria narrativa a outra divisão, restam apenas os capítulos 11-12. 
Tabela 4.3: Lições adiáforas de $\mathrm{G}$.

\begin{tabular}{|c|c|c|c|}
\hline No. & Localiz. & $\mathbf{G}$ & $\mathrm{A}, \mathrm{B}, \mathrm{C}, \mathrm{D}, \mathbf{E}, \mathbf{F}$ \\
\hline 1 & $01,36-38$ & $\begin{array}{l}\text { de quem havia muito não tivera novas, } \\
\text { porque nimguem (como na Cronica de } \\
\text { Palmeirim de conta) sabia delles se não } \\
\text { quem elle queria. E parecendolhe que } \\
\text { podião ja ser cavalleiros, e tornarem a } \\
\text { encher o mundo }\end{array}$ & $\begin{array}{l}\text { de quem havia muito que não tivera } \\
\text { novas, porque nimguem (como na } \\
\text { Cronica de Palmeirim se conta) sabia } \\
\text { della se não quem elle queria. E } \\
\text { parecendolhe que podião ja ser } \\
\text { cavalleiros, e tornar a encher o mundo }\end{array}$ \\
\hline 2 & 01,49 & Mandando embaixadores frequentes & Mandando embaxadas frequentes \\
\hline 3 & $59,07-08$ & $\begin{array}{l}\text { Bem empregado serà tudo pois vos por } \\
\text { teima (respondeu o companheiro), não } \\
\text { quizestes esperar }\end{array}$ & $\begin{array}{l}\text { Bem empregado serà tudo (respondeu o } \\
\text { companheiro) pois vos por teima não } \\
\text { quizestes esperar }\end{array}$ \\
\hline 4 & $59,51-54$ & $\begin{array}{l}\text { respeitei a ella mais que amim, mas agora } \\
\text { que ja viverei com os demais enganos, não } \\
\text { vos parecerá sem razão que seja isto a o } \\
\text { contrario depois não se pode negar, que } \\
\text { ainda pella liberdade das mentiras }\end{array}$ & $\begin{array}{l}\text { respeitei a ella muito mais que amim, mas } \\
\text { agora que ja viverei com os dezenganos, } \\
\text { não vos parecerá sem razão que seja isto a o } \\
\text { contrario. E pois não se pode negar, que } \\
\text { ainda pela liberalidade das mentiras }\end{array}$ \\
\hline 5 & $59,62-63$ & forão para onde estava Trineo & forão indireitando para onde estava Trineo \\
\hline 6 & 61,39 & pouco mais Mõtão os fruitos & pouco mais Mõtão os triumfos \\
\hline 7 & 62,14 & paixão com que se combatião & paixão com que se accometião \\
\hline 8 & 64,05 & Não era passado muito da menhã & Não era gastado muito da menhã \\
\hline 9 & $80,25-26$ & $\begin{array}{l}\text { vendo que guiava Deus os negocios } \\
\text { pellos meios }\end{array}$ & $\begin{array}{l}\text { vendo que guiava Deus o negocio pellos } \\
\text { meios }\end{array}$ \\
\hline
\end{tabular}

Na maior parte dos casos, as variantes são resultado da substituição de palavras por termos sinônimos ou próximos, sem prejuízo da inteligibilidade da frase, como nos exemplos 2, 6, 7 e 8. Em 1 e 4 são várias as palavras trocadas num trecho próximo do texto, mas ainda assim o sentido da passagem é preservado. Em outro caso, a variação consiste numa simples troca entre plural e singular (em 9). Omissões ou interpolações de palavras não essenciais também são comuns, como no exemplo 5. Por fim, a ordem das palavras na frase foi alterada em 3 . 
Tabela 4.4: Erros de G.

\begin{tabular}{|c|c|c|c|}
\hline No. & Localiz. & $\mathbf{G}$ & $\mathrm{A}, \mathrm{B}, \mathrm{C}, \mathrm{D}, \mathbf{E}, \mathbf{F}$ \\
\hline 1 & $01,52-53$ & $\begin{array}{l}\text { posto que em algũns podião menos as } \\
\text { saudades, que nos outros, mais que } \\
\text { Palmeirim, Floriano, e os mais }\end{array}$ & $\begin{array}{l}\text { posto que em algũns podião menos as } \\
\text { saudades, que nos outros, porque } \\
\text { Palmeirim, Floriano, e os mais }\end{array}$ \\
\hline 2 & 01,70 & vendo que os moços desobedecião já & vendo que os moços obedecião já \\
\hline 3 & 61,70 & em campo sanguinho e nas de Midas & $\begin{array}{l}\text { em campo sanguineo o jugo e Nós de } \\
\text { Midas }\end{array}$ \\
\hline 4 & $62,81-82$ & $\begin{array}{l}\text { tempo que as memorias da senhora } \\
\text { Fidellia me deixarem devir }\end{array}$ & $\begin{array}{l}\text { tempo que as memorias da senhora } \\
\text { Fidellia me deixarem de vida }\end{array}$ \\
\hline 5 & 62,88 & $\begin{array}{l}\text { Assi o deixaremos por o que sentia a } \\
\text { Princeza }\end{array}$ & $\begin{array}{l}\text { Assi o deixaremos por dizer o que sentia } \\
\text { a Princeza }\end{array}$ \\
\hline 6 & $64,37-38$ & $\begin{array}{l}\text { se sabeis a devação de Santo Erasmo das } \\
\text { suas missas }\end{array}$ & $\begin{array}{l}\text { se sabeis a devação das Missas de Santo } \\
\text { Erasmo }\end{array}$ \\
\hline 7 & $64,73-74$ & mas custandolhes a elles seus revezes & mas custandolhe a elle seus revezes \\
\hline 8 & 80,10 & que a quelle guardou & que a quelle dia guardou \\
\hline
\end{tabular}

Quanto aos erros identificados em G, são de tipos semelhantes aos encontrados nos outros manuscritos. Vários são os casos de troca de palavras, prejudicando o sentido da frase, motivados seja por associações mentais (como parece ser o caso de 1) ou por erros de leitura (provavelmente em 2 e 4). No exemplo 7, a troca entre o singular e o plural compromete a inteligibilidade do trecho. Em 3, 5 e 8 o erro se deve à omissão de palavras curtas. O único caso em que o erro não gera distorção no sentido da passagem é o do exemplo 6; consideramo-lo errado, contudo, porque a troca da ordem das palavras parece ser resultado de um lapso do copista ${ }^{175}$.

Como dissemos, é nos capítulos 11 e 12 (=12 em G) que se concentra a maior quantidade de variantes significativas encontradas na colação. Apresentamos abaixo o confronto entre algumas das passagens desses capítulos em que a lição de $\mathrm{G}$ mais se distancia das dos demais testemunhos. Além disso, constam da tabela também os

\footnotetext{
${ }^{175}$ Note-se que este exemplo já havia sido referido anteriormente, sem contudo ressaltar a diferença entre a lição de $\mathrm{G}$ e a dos demais manuscritos (cf. tabela 3.2., ex. 6). O mesmo acontece com o ex. 7 (cf. tabela 1.0 , ex. 6) e com o ex. 8 (cf. tabela 2.5, ex. 15).
} 
trechos iniciais e finais dos capítulos, comprovando que o capítulo 12 de G corresponde exatemente aos capítulos 11 e 12 dos outros manuscritos ${ }^{176}$.

Tabela 4.5: Variações nos capítulos 11 e 12 (=12 de G).

\begin{tabular}{|c|c|c|c|}
\hline No. & Localiz. & $\mathbf{G}$ & $\mathrm{A}, \mathrm{B}, \mathrm{C}, \mathrm{D}, \mathbf{E}, \mathbf{F}$ \\
\hline 1 & $\begin{array}{l}\text { 11, 05-06 } \\
\text { (início cap.) }\end{array}$ & $\begin{array}{l}\text { Quatro dias antes das festas do Spirito } \\
\text { Sancto, que era } o \text { em que havia cellebrar- } \\
\text { se aquelle torneio }\end{array}$ & $\begin{array}{l}\text { Quatro dias antes da festa do Spirito } \\
\text { Sancto, que era } a \text { em que se havia de } \\
\text { celebrar aquelle torneio }\end{array}$ \\
\hline 2 & $11,12-13$ & $\begin{array}{l}\text { estando ja Floriano e Floris sãos de suas } \\
\text { feridas e Dramuziando da sua perna }\end{array}$ & $\begin{array}{l}\text { estando ja Floriano, D. Floris } e \\
\text { Dramuziando, bem sãos de suas feridas, } \\
\text { e perna }\end{array}$ \\
\hline 3 & $11,40-46$ & $\begin{array}{l}\text { se vio a quelle globo ser de hũa Maça } \\
\text { cristalina e tão transparente } e \text { divizava-se } \\
\text { dentro delle hũa caza grande armada de } \\
\text { borcados cramezins que erão os que o } \\
\text { fazião parecer de fogo. E sentado em } \\
\text { cadeira o mesmo Daliarte, e Floramão } \\
\text { com todos aquelles Princepes armados de } \\
\text { armas brancas, sem elmos, espadas, nem } \\
\text { esporas, mas ainda se divizavão mal nem } \\
\text { se poderão conhecer se ja todos não } \\
\text { sospeitarão o que era. }\end{array}$ & $\begin{array}{l}\text { se vio que a Materia da quelle globo era } \\
\text { hũa Maça cristalina tão transparente, que se } \\
\text { divizava dentro delle hũa caza grande } \\
\text { armada de borcados cramezins que ofazião } \\
\text { parecer de fogo. E sentados nella em } \\
\text { cadeiras do mesmo borcado Daliarte, e } \\
\text { Floramão com todos aquelles Princepes } \\
\text { armados de armas brancas, sem elmos, } \\
\text { espadas, nem esporas, mas não se vião mui } \\
\text { distintamente estas miudezas, nem elles } \\
\text { poderão ser conhecidos, se ja todos não } \\
\text { sospeitarão que o erão. }\end{array}$ \\
\hline 4 & $11,65-67$ & $\begin{array}{l}\text { se foi levantando pouco a pouco hũa } \\
\text { pyramide oitavada, e composta de muitas } \\
\text { cores, semelhantes às que se vêm nas } \\
\text { nuvens ao por do Sol nas tardes do verão }\end{array}$ & $\begin{array}{l}\text { se foi levantando pouco a pouco hũa } \\
\text { como pyramide oitavada, composta de } \\
\text { varias cores, em materia não conhecida, } \\
\text { semelhantes entre si às do Arco de Iris, } \\
\text { (a que vulgarmente chamamos arco da } \\
\text { velha) }\end{array}$ \\
\hline 5 & $\begin{array}{c}11,79 \text { - } \\
12,07 \\
\text { (mudança } \\
\text { cap. 11-12) }\end{array}$ & $\begin{array}{l}\text { posto de giolhos diante delles, tendo } \\
\text { tirado o elmo ja quando entrara na torre, } \\
\text { e dice: Bem sei que eide ser perdoado }\end{array}$ & $\begin{array}{l}\text { posto de giolhos diante delle tendo tirado } \\
\text { o elmo ja quando entrara na torre e } \\
\text { dicelhes o que no outro capítulo se segue. } \\
\text { // [cap. 12] Posto de giolhos Daliarte, } \\
\text { como no capitulo passado diziamos, } \\
\text { diante de seu Pay, e daquelles Princepes, } \\
\text { que pella varanda vinhão, dicelhes: Bem } \\
\text { sei que eide ser perdoado }\end{array}$ \\
\hline 6 & $\begin{array}{l}12,91-93 \\
\text { (fim) }\end{array}$ & $\begin{array}{l}\text { forão todos assi como vinhão á capella do } \\
\text { Emperador a velar as armas, aonde as } \\
\text { mais da quellas senhoras cazadas os } \\
\text { acompanharão, athe o outro dia, no qual } \\
\text { forão armados do modo que no capitulo } \\
\text { seguinte Mostraremos. }\end{array}$ & $\begin{array}{l}\text { forão todos assi como vinhão á capella, } \\
\text { que nos Paços estava a velar as armas, } \\
\text { onde as mais da quellas senhoras cazadas } \\
\text { os acompanharão athe o outro dia, no } \\
\text { qual forão armados cavalleiros, como no } \\
\text { capitulo seguinte Mostraremos. }\end{array}$ \\
\hline
\end{tabular}

${ }^{176}$ Alguns dos exemplos da tabela 4.5 compreendem trechos que já foram utilizados em exemplos de tabelas anteriores, como é o caso de 3 (em parte na tabela 1.6, ex. 2 e por outra parte na tabela 1.10, ex. 1), 4 (tabela 3.6, ex. 1) e 6 (tabela 1.8, ex. 1); em todos, desconsideramos aqui as diferenças então apontadas entre os manuscritos agora agrupados. 
De modo geral, nota-se a tendência ligeiramente mais sintética da lição de $\mathrm{G}$ em comparação com a dos outros códices: são eliminados alguns detalhes (em especial nos exemplos 3 e 6) ou realizadas alterações simplificadoras na redação de certos trechos (como em 2 e 4). Em ao menos um dos exemplos, a versão de G supera em clareza a das outras cópias (exemplo 2). A mudança de capítulo foi assinalada no exemplo 5 com dois traços oblíquos; o título do novo capítulo em A não foi reproduzido, a fim de facilitar a identificação das adaptações realizadas pelo copista de $G$ (ou de seu antígrafo) na junção dos capítulos 11 e 12.

Em relação aos ramos e aos outros códices descritos, a lição dos capítulos 11 e 12 de G não possui semelhanças significativas. O confronto com algumas das variantes caracterizadoras do ramo A/B demonstra que nestas passagens a lição de $\mathrm{G}$ concorda com a de C, D e E/F, conforme é possível verificar pelos exemplos abaixo ${ }^{177}$ :

Tabela 4.6: Capítulos 11 e 12 (= 12 de G): contraste entre G e A/B.

\begin{tabular}{|c|c|c|c|c|}
\hline $\mathbf{N}^{\mathbf{o}}$ & Localiz. & $\mathbf{G}$ & $\mathbf{A} / \mathbf{B}$ & $\mathrm{C}, \mathrm{D}, \mathbf{E}, \mathbf{F}$ \\
\hline 1 & 11,11 & $\begin{array}{l}\text { como se se temerão de males } \\
\text { grandes }\end{array}$ & $\begin{array}{l}\text { como se se temerão de } \\
\text { grandes males }\end{array}$ & $\begin{array}{l}\text { como se se temerão de males } \\
\text { grandes }\end{array}$ \\
\hline 2 & $12,42-43$ & $\begin{array}{l}\text { tornou a dizer para Daliarte. } \\
\text { Por certo senhor Daliarte } \\
\text { que não sei }\end{array}$ & $\begin{array}{l}\text { tornou a dizer para Daliarte: } \\
\text { Que não sei }\end{array}$ & $\begin{array}{l}\text { tornou a dizer para Daliarte, } \\
\text { por certo senhor Daliarte } \\
\text { que não sei }\end{array}$ \\
\hline 3 & Cap. 12 & $\begin{array}{l}\text { obedecendo à força } \\
\text { interior, com que Daliarte } \\
\text { os obrigava }\end{array}$ & $\begin{array}{l}\text { obedecendo à força superior } \\
e \text { interior, com que Daliarte } \\
\text { os obrigara }\end{array}$ & $\begin{array}{l}\text { obedecendo à força interior } \\
\text {,com que Daliarte os } \\
\text { obrigava }\end{array}$ \\
\hline
\end{tabular}

A lição de G não partilha a inversão da ordem das palavras (exemplo 1), nem a interpolação e da alternância entre r/v (em 3) que caracterizam a lição de A e B. A pequena lacuna do texto na lição do ramo A/B também não é reproduzida em G (ex. 2), o que significa que nenhum daqueles códices pode ter sido o antígrafo de $\mathrm{G}$ ou de seu antecedente.

${ }^{177}$ Os exemplos abaixo já haviam sido comentados anteriormente, quando da apresentação das variantes do ramo A/B: cf. tabela 1.3 (ex. 2); tabela 1.6 (ex. 3) e tabela 1.5 (ex. 1). Posto que a lição de G nos capítulos 11 e 12 diverge bastante das demais, nem todas as variantes caracterizadoras dos ramos anteriores possuem correspondência precisa em $\mathrm{G}$. 
Com relação aos manuscritos $\mathrm{C}$ e $\mathrm{D}$, raras foram as variantes exclusivas destes códices nos capítulos 11 e 12 que permitiram o confronto com a lição de G. Afora os casos pouco significativos de erros exclusivos a $\mathrm{C}$ ou $\mathrm{D}$, que nunca são reproduzidos em G, resta apenas um exemplo (tabela 3.5, ex. 3). Nesta passagem, reproduzida abaixo, a lição de G não concorda com a de C e D.

Tabela 4.7: Capítulos 11 e 12 (= 12 de G): contraste entre G e os manuscritos C e D.

\begin{tabular}{|c|c|c|c|c|}
\hline $\mathbf{N}^{\mathbf{1}}$ & Localiz. & \multicolumn{1}{|c|}{ G } & \multicolumn{1}{|c|}{ C e D } & \multicolumn{1}{c|}{ A, B, E, F } \\
\hline 1 & 11,73 & $\begin{array}{l}\text { o que a fortuna queria } \\
\text { dispor dellas }\end{array}$ & $\begin{array}{l}\text { o que a fortuna quereria } \\
\text { dispor dellas }\end{array}$ & $\begin{array}{l}\text { o que a fortuna queria } \\
\text { dispor dellas }\end{array}$ \\
\hline
\end{tabular}

Com a quase totalidade das variantes caracterizadoras do ramo $\mathrm{E} / \mathrm{F}$ verifica-se o mesmo $^{178}$ :

Tabela 4.8: Capítulos 11 e 12 (= 12 de G): contraste entre G e E/F.

\begin{tabular}{|c|c|c|c|c|}
\hline $\mathbf{N}^{\mathbf{o}}$ & Localiz. & $\mathbf{G}$ & $\mathbf{E} / \mathbf{F}$ & A, B, C, D \\
\hline 1 & 11,30 & $\begin{array}{l}\text { aquelle tão extraordinario } \\
\text { incendio }\end{array}$ & $\begin{array}{l}\text { aquelle } \quad \text { extraordinario } \\
\text { incendio }\end{array}$ & $\begin{array}{l}\text { aquelle tão extraordinario } \\
\text { incendio }\end{array}$ \\
\hline 2 & $11,64-65$ & lugar onde a cerpe se sumira & $\begin{array}{l}\text { lugar onde a serpente se } \\
\text { sumira }\end{array}$ & $\begin{array}{l}\text { lugar onde a serpente se } \\
\text { sumergira }\end{array}$ \\
\hline 3 & Cap. 12 & $\begin{array}{l}\text { eu quis que estes Donzeis } \\
\text { vissẽ primeiro porque pois } \\
\text { tem todos hũa mesma idade, } \\
\text { tivessem hũa conversação. } \\
\text { Este he Dom Floris }\end{array}$ & $\begin{array}{l}\text { eu quis que estes Donzeis } \\
\text { vissẽ e conhecessem primeiro } \\
\text { que animgue desta terra, para } \\
\text { que depois com hua mesma } \\
\text { idade ande correr todos } \\
\text { quazi hũa mesma fortuna, } \\
\text { não lhes faltasse este } \\
\text { conhecimento pois não pode } \\
\text { deixar de ser a criação este } \\
\text { de Dom Floris (F: este } \\
\text { donzel Floris) }\end{array}$ & $\begin{array}{l}\text { eu quis que estes Donzeis } \\
\text { vissẽ e conhecessem primeiro } \\
\text { que animguẽ desta terra, para } \\
\text { que pois com hua mesma } \\
\text { idade ande correr todos } \\
\text { quazi hũa mesma fortuna, } \\
\text { não lhes faltasse este } \\
\text { conhecimento pois não pode } \\
\text { deixar de ser a criação. Este } \\
\text { he Dom Floris }\end{array}$ \\
\hline 4 & 12,89 & $\begin{array}{l}\text { velassem as armas para que } a \\
\text { o outro dia } o \text { fossẽ }\end{array}$ & $\begin{array}{l}\text { velassem as armas para que } \\
a o(F: o) \text { fossẽ }\end{array}$ & $\begin{array}{l}\text { velassem armas para que } a o \\
\text { outro dia } o \text { fossẽ }\end{array}$ \\
\hline
\end{tabular}

A maioria das variantes caracterizadoras do ramo $\mathrm{E} / \mathrm{F}$ também não são partilhadas por $\mathrm{G}$ que, nestes casos, aproxima-se mais do ramo $\mathrm{A} / \mathrm{B}$ e dos códices $\mathrm{C}$ e

${ }^{178}$ Os exemplos abaixo também se encontram em tabelas anteriores, quando foram apresentadas as características do ramo E/F: cf. tabela 2.2 (ex. 2); tabela 2.1 (ex. 3); tabela 2.6 (exs. 1 e 2). 
D. No exemplo 3, em que é mais uma vez perceptível a tendência à síntese de G, é importante notar que este manuscrito não apresenta o mesmo erro de $\mathrm{E} / \mathrm{F}$ ao final do trecho ("este de Dom Floris" ou "este donzel Floris"), mas segue a lição dos outros testemunhos, que é mais clara. Da mesma forma, G não apresenta as pequenas omissões dos códices $\mathrm{E}$ e $\mathrm{F}$ nos exemplos 1 e 4, comprovando que nenhum deles pode ser considerado seu antecedente.

O caso do exemplo 2, no entanto, propõe novos problemas. A coincidência da substituição de "sumergira" por "sumira", que seria pouco provável em ramos independentes da tradição, pode indicar a existência de algum grau de parentesco entre $\mathrm{G}$ e o ramo E/F. Se, como dissemos acima, estes códices não podem ser antecedentes de G, a confluência entre eles só pode ser procurada em nível mais alto da tradição. A identificação precisa do grau de parentesco, contudo, demandaria a colação de outras partes do texto, pois a simples suposição de um antecedente comum entre G e o ramo E/F não seria suficiente para justificar as numerosas diferenças entre eles, bem como os casos em que $\mathrm{G}$ partilha de lições comuns com os ramos $\mathrm{A} / \mathrm{B}$ e com os códices $\mathrm{C}$ e $\mathrm{D}^{179}$. Posto que, na falta de novas evidências, não há como avançar com segurança na especulação acerca de supostos intermediários perdidos, a questão terá de aguardar novos estudos para ser respondida.

Em suma, o exame do códice BNL 619 (G) revela que em tese ele apresentaria uma versão integral da Crônica de D. Duardos, apesar da discrepância do número de capítulos que o compõem. A grande lacuna existente no capítulo 55 (= 59 a 61 dos outros testemunhos) não foi intencional, mas é resultado da provável perda de alguns fólios do manuscrito que serviu de base para a cópia (a que chamaremos $\delta$ ), como dá a entender o salto na numeração dos capítulos em G. As informações de que dispomos não permitem dirimir, contudo, outras dúvidas: as discrepâncias quanto à estrutura dos capítulos já constavam de $\delta$ ou são de responsabilidade do copista de G? Por que foram introduzidas alterações tão significativas no texto: elas corresponderiam ao desejo do autor ou foram emendas feitas por um copista mais "rebelde"? Como explicar as convergências entre $\mathrm{G}$ e as demais cópias, raras em meio à quantidade de diferenças que

${ }^{179}$ As convergências de $\mathrm{G}$ com o ramo A/B em contraste com E/F são particularmente visíveis nas tabelas 2.1 a 2.3. Com relação às concordâncias com os códices $\mathrm{C}$ e $\mathrm{D}$, algumas já foram apontadas em observações anteriores, como por exemplo nos comentários à tabela 3.5 (exemplos 1 e 4). Entretanto, nos capítulos 11 e 12, com que nos ocupamos no momento, não foram encontrados traços significativos para o cotejo com as lições de C e D. 
o distanciam de todos os outros testemunhos? As perguntas só poderão ser respondidas com a colação de outros trechos da obra. Limitamo-nos por enquanto a indicar a existência do antecedente de G, cuja existência fica comprovada pelas reflexões anteriores, e a sugerir um possível caso de contaminação com o ramo E/F, de modo a justificar a coincidência registrada no ex. 2 da tabela 4.8 .

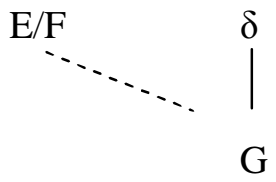

\section{A tradição manuscrita: conclusões}

Embora tenha fornecido elementos preciosos para a escolha do manuscrito a ser utilizado como base para a transcrição, a colação dos códices da primeira parte da Crônica de D. Duardos não revelou dados suficientes para o desenho de um stemma codicum completo - o que não chega a surpreender, dada a extensão do texto e a quantidade de cópias. Algumas das hipóteses propostas ao longo do exame dos diferentes ramos da tradição manuscrita poderão ser verificadas em pesquisas futuras, caso outras partes do texto venham a ser cotejadas. Certas dúvidas, porém, talvez permaneçam sem resposta, a menos que sejam descobertas novas peças do quebracabeças; pois não é de todo impossível que ainda haja cópias da Crônica de D. Duardos esquecidas em bibliotecas ou coleções particulares. Com base nas informações disponíveis, por ora é possível apenas estabelecer com segurança o parentesco entre alguns testemunhos e conjecturar acerca de outros.

Dessa forma, o estema que vimos montando aos poucos nas últimas páginas representa um simples ponto de partida, uma primeira hipótese de trilha a seguir no labirinto da infinidade de variantes oferecidas por estes manuscritos até hoje praticamente intocados. Assim, esperamos que nossas perplexidades e equívocos sirvam de convite para que outros pesquisadores alterem e aprofundem o que agora está apenas esboçado.

O estema aqui proposto pretende simplesmente indicar os vários ramos e grupos em que a tradição manuscrita da Crônica de D. Duardos, Primeira Parte se subdivide. Quanto a possíveis intermediários desaparecidos, não arrisca conjecturas; alguns 
certamente terão existido, mas é impossível determinar por ora quantos e que posição deveriam ocupar no estema.

Estamos convencidos, entretanto, que tais intermediários não devem ter sido numerosos. Em primeiro lugar, porque a tradição textual portuguesa normalmente se apresenta "escassamente articulada e, muitas vezes, confiada a um único testemunho" e quanto a essa tendência os textos dos séculos XVI e XVII não constituem exceção, de acordo com Giulia Lanciani ${ }^{180}$. Assim, o fato de serem conhecidas hoje sete cópias da parte inicial da Crônica de D. Duardos já configura um caso excepcional no panorama dos livros de mão em Portugal. Acresce a isto que, dentre os testemunhos remanescentes da Crônica de D. Duardos, Primeira Parte, cinco certamente não deixaram descendência conhecida ( $\mathrm{B}, \mathrm{C}, \mathrm{D}, \mathrm{F}$ e G) e apenas dois (os códices A e E) provavelmente tenham sido utilizados como base para a elaboração de novas cópias, o que parece indicar uma tradição pobre em níveis intermediários, em que a transmissão do texto ocorreu prioritariamente em sentido horizontal, a partir de um número reduzido de textos-base.

Além disso, a aventura de imaginar códices perdidos e contaminações múltiplas entre os diversos manuscritos talvez não seja o único meio para explicar o intrincado cruzamento de convergências e discrepâncias das variantes que caracterizam os testemunhos conhecidos do livro. Sabe-se que nos séculos XVI e XVII é comum que o autor submeta sua obra a uma revisão mesmo depois que ela tenha começado a circular: é o caso de António Ribeiro Chiado, objeto do trabalho já citado de Giulia Lanciani. O fenômeno é tão freqüente no domínio da literatura portuguesa quinhentista que Spaggiari e Perugi, lembrando os exemplos de Camões, Sá de Miranda e António Ferreira, afirmam que "a filologia portuguesa da época renascentista é, na sua maioria, uma filologia de variantes autorais, distribuídas, muitas vezes, sob a forma de redações diferentes" ${ }^{181}$. Assim, os diferentes ramos e grupos em que se divide a tradição da Crônica de D. Duardos, Primeira Parte podem indicar não exatamente famílias de manuscritos, mas sim registros das diversas etapas de correção e revisão autoral do texto, o que explicaria a dificuldade de representar num estema as múltiplas convergências de variantes que não parecem se distribuir de maneira homogênea entre os sete testemunhos remanescentes.

\footnotetext{
${ }^{180}$ Op. cit., p. 279.

${ }^{181}$ Op. cit., p. 157.
} 
Trata-se, como é evidente, de mais uma hipótese a ser verificada em ulteriores aprofundamentos e pesquisas, caso outras partes do texto que venham a ser cotejadas confirmem as conclusões aqui expostas. Na elaboração do estema, contudo, utilizou-se o modelo convencional em que todos os testemunhos remontam a um único arquétipo, sem preocupação com a representação gráfica da possibilidade da existência de redações múltiplas.

De acordo com os dados revelados pela colação, em suma, o estema da tradição manuscrita do pode ser representado de duas formas ligeiramente distintas, tendo em vista as dúvidas relativas aos ramos $\mathrm{A} / \mathrm{B}$ e E/F já expostas acima. Na primeira hipótese, que julgamos ser a mais provável, $\mathrm{B}$ e $\mathrm{F}$ figuram como cópias de $\mathrm{A}$ e $\mathrm{E}$, respectivamente. Dentre as diversas possíveis contaminações de manuscritos pertencentes a ramos distintos, representamos apenas a provável ligação entre $\mathrm{C}$ e o ramo $\mathrm{A} / \mathrm{B}$ e as coincidências entre $\mathrm{G}$ e o ramo $\mathrm{E} / \mathrm{F}$, por serem as que possuem indícios mais relevantes no texto ${ }^{182}$.

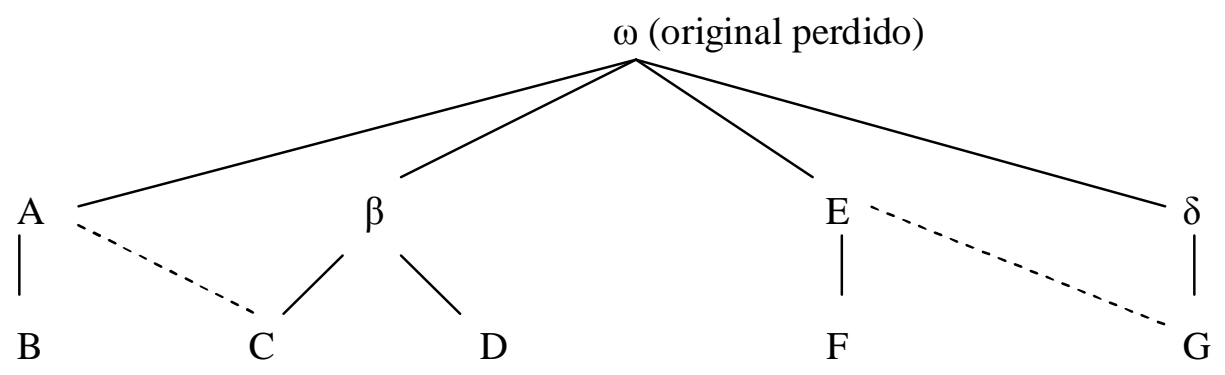

A segunda hipótese para o estema prevê um número maior de códices intermediários desaparecidos, que ocupariam a posição de subarquétipos dos ramos A/B e E/F:

\footnotetext{
${ }^{182}$ Ver a propósito a tabela 3.6 (relações entre C e A/B) e o ex. 2 da tabela 4.8 (relação entre G e E/F). Outro provável caso de contaminação, não representado no estema por estar baseado em indícios menos seguros, seria o possível contato entre G e os códices C e D (cf. tabela 3.5, exemplos 1 e 4), entre outros.
} 


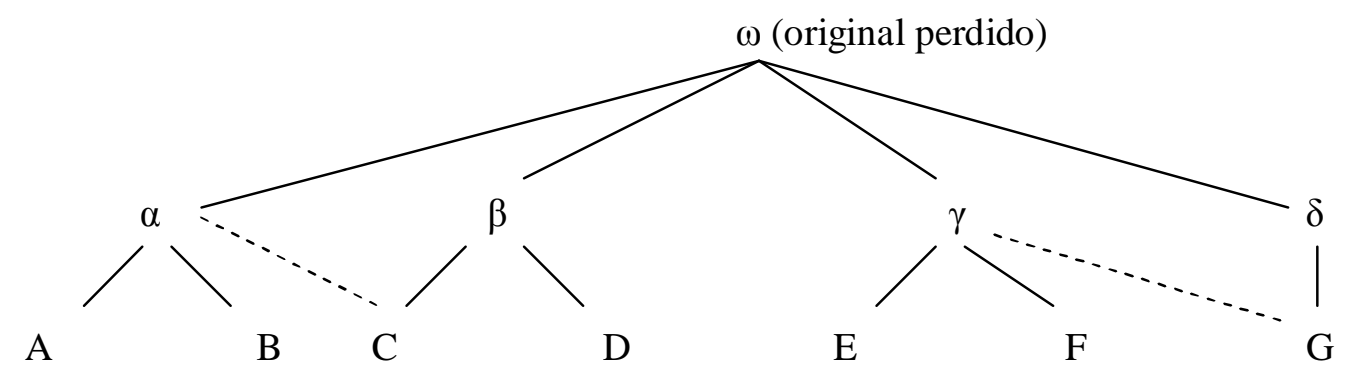

Os resultados da colação parecem confirmados ainda pela variação dos títulos que a obra recebe nos diversos manuscritos. Com efeito, as cópias do ramo A/B apresentam exatamente o mesmo título: Chronica de Primaleão Emperador de Grecia. Primeira Parte, em que se da conta das façanhas, que obrou o Princepe D. Duardos, e os mais Princepes que com elle se criarão, na Ilha Perigoza do Sabio Daliarte. Composta por Guilherme Frusto, Author Hibernio, e copiada por Simisberto Pachorro, em quanto esteve occupado, ou encantado no Cume da Penha Riguroza, da Serra da Lua, pello odio do Sabio Bragamante. Os códices E e F, que também julgamos estreitamente aparentados, apresentam igualmente títulos idênticos: Primeira parte da vida de Primalião Emperador de Constantinopla e de outros Princepes daquelle tempo. Já entre os códices $\mathrm{C}$ e $\mathrm{D}$, cujas relações não são significativas a ponto de autorizar descrevê-los como um novo ramo da tradição manuscrita, não há coincidência de títulos. Em C lê-se apenas Chronica do Emperador Primalião, e outros Principes; em D o título é mais longo: Chronica do Invicto D. Duardos de Bretanha Princepe de Ingalaterra filho de Palmeiry, e da Princeza Polinarda, daqual se conta seus estremados feitos em Armas, e purisimos amores, com outros de outros Cavalleiros que en seu tempo Concorrerão. Composta por Henrique Frusto Chorista ingres, e tresladada em Portugues por Gomes Ennes de Zurara, que fes a Chronica del Rey Dom Afonso Henrriques de Portugal achada denovo entre seus Papeis. O título atribuído ao texto pelo amanuense de $\mathrm{G}$ é muito próximo ao do códice $\mathrm{D}$, inclusive pelo fato de atribuir a autoria do texto a Zurara, mas sem mencionar a Crônica de Afonso Henriques.

Por fim, quanto à escolha do testemunho que serviu de base para a transcrição, as observações feitas ao longo da análise dos resultados da colação reduzem grandemente o leque de possibilidades. Ainda que não seja possível afirmar com toda 
certeza que B e F sejam cópias dos manuscritos A e E (o que justificaria eliminá-los como códices descripti), o exame realizado mostrou serem aqueles manuscritos cópias de qualidade inferior às outras do ramo a que pertencem, pelo que se conclui que B e F não devem ser utilizados para a transcrição ${ }^{183}$. Critério semelhante leva a descartar também o manuscrito $\mathrm{D}$, uma vez que ele apresenta maior número de erros que $\mathrm{C}$, o códice com que tem mais afinidade (cf. as tabelas 3.2 e 3.4). Quanto a G, as significativas diferenças com relação à divisão dos capítulos, a enorme lacuna do capítulo 55 e a posição excêntrica que o códice ocupa no estema desaconselham a considerá-lo como testemunho mais representativo e confiável que os demais.

Dentre as opções restantes, os códices A, C e E, este é o que possui maior número de erros, conforme ficou demonstrado acima (cf. as tabelas 2.3, 2.6 e 2.7). Entre os manuscritos A (BNL 12904) e C (BNL 658) não há muita diferença. A favor do segundo pesaria sua posição intermediária, que o faz compartilhar elementos comuns com os ramos A/B e E/F. Por outro lado, o códice A está redigido com letra mais legível e está melhor conservado que C. O fator determinante para a escolha do códice BNL 12904 como base para a transcrição foi, contudo, o fato de ele oferecer uma versão mais clara do texto, principalmente por estar melhor pontuado que os demais ${ }^{184}$.

Assim, a transcrição do texto seguiu a lição do códice BNL 12904 (A); recorreuse aos manuscritos BNL 620 (B) e 658 (C) apenas para esclarecer passagens duvidosas ou ilegíveis de A.

\footnotetext{
${ }^{183}$ A inferioridade de B em relação a A e de F em relação a E ficou demonstrada nas tabelas 1.7 a 1.11 e 2.4 a 2.7, respectivamente, em que se verificam que B e F possuem quantidade muito superior de erros que os códices que lhe são aparentados (A e E).

${ }^{184}$ Estamos conscientes que a pontuação pode ser indicativa de maior modernidade de A. Para uma transcrição semi-diplomática do texto, como a que apresentamos neste trabalho, entretanto, a escolha de uma lição mal pontuada levantaria dificuldades desnecessárias para os leitores.
} 


\section{CAPÍTULO 3}

\section{CRITÉRIOS DE EDIÇÃO}

\section{Tipo de edição}

Optamos por realizar uma transcrição semidiplomática do texto. Tal escolha justifica-se por diversos motivos.

Em se tratando de obra trazida a lume pela primeira vez, será útil relembrar as observações feitas Heitor Megale a propósito da edição do manuscrito vienense da Demanda do Santo Graal: “Tecnicamente falando, a seqüência esperada de gerações na história da edição de um manuscrito como este (...) seria a seguinte: primeira geração, edição paleográfica; segunda geração, edição crítica, e terceira, edição modernizada" ${ }^{185}$. Opinião semelhante é a de César Nardelli Cambraia, ao recomendar que "se se pensar no próprio processo de preparação de edições, certamente o preenchimento desse campo deveria começar com as mais conservadoras e caminhar sucessivamente para as mais modernizadoras", observando ainda que "por razões metodológicas as edições críticas devem ser precedidas pelas diplomáticas" ${ }^{186}$. De fato (e sem levar em consideração a possibilidade da edição modernizada, etapa ulterior), a edição crítica de um texto deve ser considerada a conclusão do processo de estudo e conhecimento do texto em si e das cópias que o preservaram - especialmente no caso de obra manuscrita, extensa e com numerosas cópias, como é o caso da Crônica de D. Duardos.

Descartadas portanto as opções de edição crítica ou modernizada, decidimo-nos pela semidiplomática. No entanto, embora este tipo de edição (também chamada de diplomática-interpretativa) normalmente permita a introdução de alterações na

\footnotetext{
${ }^{185}$ Heitor Megale. A Demanda do santo Graal: do manuscrito ao texto modernizado, in: II Encontro de edição crítica e crítica genética: eclosão do manuscrito. São Paulo: Faculdade de Filosofia, Letras e Ciências Humanas da Universidade de São Paulo, 1989, p. 29.

${ }^{186}$ Cèsar Nardelli Cambraia. Livro de Isaac: edição e glossário (Cód. Alc. 461). Tese de doutorado apresentada à Faculdade de Filosofia, Letras e Ciências Humanas da Universidade de São Paulo. São Paulo: 2000, p. 147.
} 
pontuação, ortografia e separação vocabular do manuscrito ${ }^{187}$, optamos por atitude conservadora também com relação a esses quesitos. Assim, em nossa transcrição o grau de intervenção no texto foi o mínimo possível. Além da solução de casos duvidosos (sobretudo quanto à capitalização e a separação vocabular, aspectos nos quais, conforme será dito a seguir, o manuscrito é menos claro), nossa intervenção restringiu-se a pouco mais que o desenvolvimento das abreviaturas (não sem ressaltá-las em itálico) e indicações acerca erros ou de palavras repetidas, interpoladas e corrigidas pelo copista.

Vários foram os motivos dessas escolhas: em primeiro lugar, o manuscrito utilizado como base para a transcrição (BNL 12904) apresenta texto bastante claro e compreensível, tornando desnecessária a intervenção constante do editor. Além disso, decidimos adaptar nosso trabalho às Normas para a Transcrição de Documentos Manuscritos para a História do Português do Brasil (NHPB), que prevêem condutas conservadoras com relação aos aspectos mencionados ${ }^{188}$. Dessa forma esperamos que este trabalho possa ser útil também para outros estudiosos que desejarem valer-se do texto para finalidades distintas das perseguidas aqui, como o estudo da história da língua.

\section{Critérios de transcrição}

Conforme já foi observado, buscamos a maior fidelidade possível à lição do manuscrito BNL 12904, baseando o estabelecimento dos critérios de transcrição nos procedimentos recomendados pelas NHPB.

\subsection{Grafia}

A grafia do manuscrito foi respeitada, inclusive nos casos em que a mesma palavra apresenta diferentes formas ao longo do texto. O fenômeno é particularmente

\footnotetext{
187 “Assim, uma edição diplomático-interpretativa pode recorrer a sinais de pontuação e pode adaptar o texto à ortografia atual, juntando partes separadas de um só vocábulo e separando elementos vocabulares conglomerados" (Leodegário A. de Azevedo Filho. Iniciação em crítica textual. Rio de Janeiro: Presença / São Paulo: Edusp, 1987, p. 30). Cf. também Spina, op. cit., p. 79 e Spaggiari e Perugi, op. cit., p. 25.

${ }^{188}$ As NHPB foram definidas por um grupo de pesquisadores reunidos no II Seminário para a História do Português Brasileiro, em 1998 e publicadas em apêndice à edição de A Carta de Pero Vaz de Caminha, elaborada por A. G. Cunha, César N. Cambraia e Heitor Megale (São Paulo: Humanitas, 1999, p. 23-26).
} 
perceptível nas hesitações quanto à utilização de $\mathrm{s} / \mathrm{z}$ ou aos modos de assinalar as nasais. Assim, por exemplo, entre as linhas 17 a 19 do fl. 1r, onde se lê

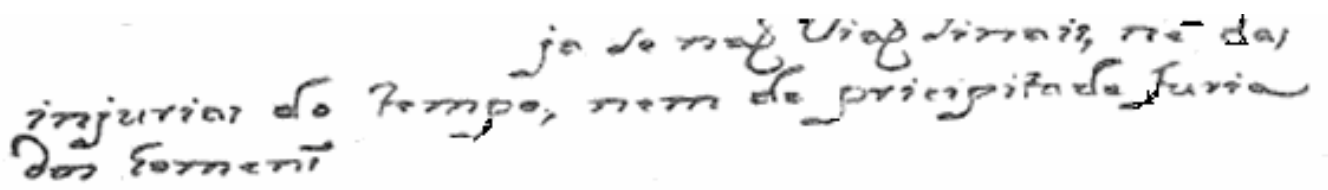

o trecho foi transcrito "ja se não vião sinais, nẽ das | injurias do tempo, nem da pricipitada furia | dos homẽns".

Foi mantida também a acentuação das palavras, procurando respeitar inclusive a presença de acentos graves e agudos - nem sempre fáceis de identificar -, conforme os exemplos abaixo (fl.4v, 1.8 e fl. $18 \mathrm{v}, 1.31)$,

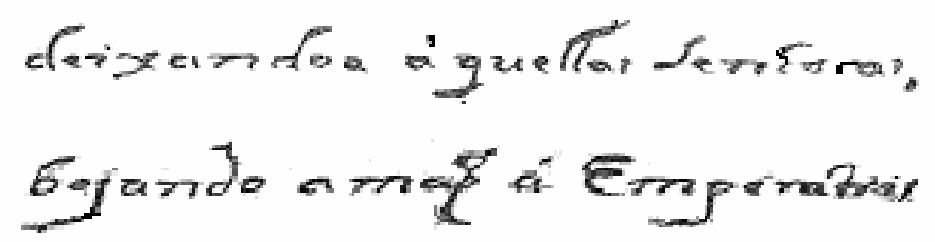

que foram transcritos, respectivamente, como "deixandoa à quellas senhoras" e "bejando a mão á Emperatris".

Raros são os casos em que o til em palavras terminadas em -ão não foi posicionado sobre a letra "a", como é o caso da ocorrência de "tardaráõ"189 (fl. 3v, 1. $31)$.

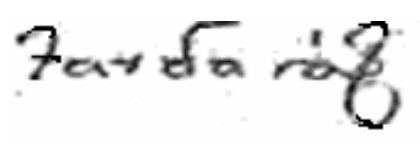

\subsection{Abreviaturas}

As abreviaturas foram desenvolvidas, indicando-se em itálico as letras acrescentadas. Embora sejam numerosas, as abreviaturas utilizadas pelo copista são restritas a pequena variedade de palavras, pelo que não houve necessidade de pôr em

\footnotetext{
${ }^{189}$ Casos como este são raros no manuscrito por nós utilizado. A forma tardaráõ explica-se pelo fato de o verbo em questão estar no futuro (tardarão, na forma moderna). Uma vez que todas as formas pretéritas que hoje são grafadas com final -am (tardaram, falaram, eram) assumiam freqüentemente a terminação ão (tardarão, falarão, erão) no período em que a cópia foi realizada, o acento utilizado no caso que estamos comentando serviria para marcar a tonicidade da última sílaba de forma a evitar a ambigüidade com a forma verbal do pretérito perfeito (tardarão / tardaram, na grafia atual).
} 
questão a grafia a ser adotada no seu desenvolvimento. Os exemplos mais comuns constam do quadro abaixo: 


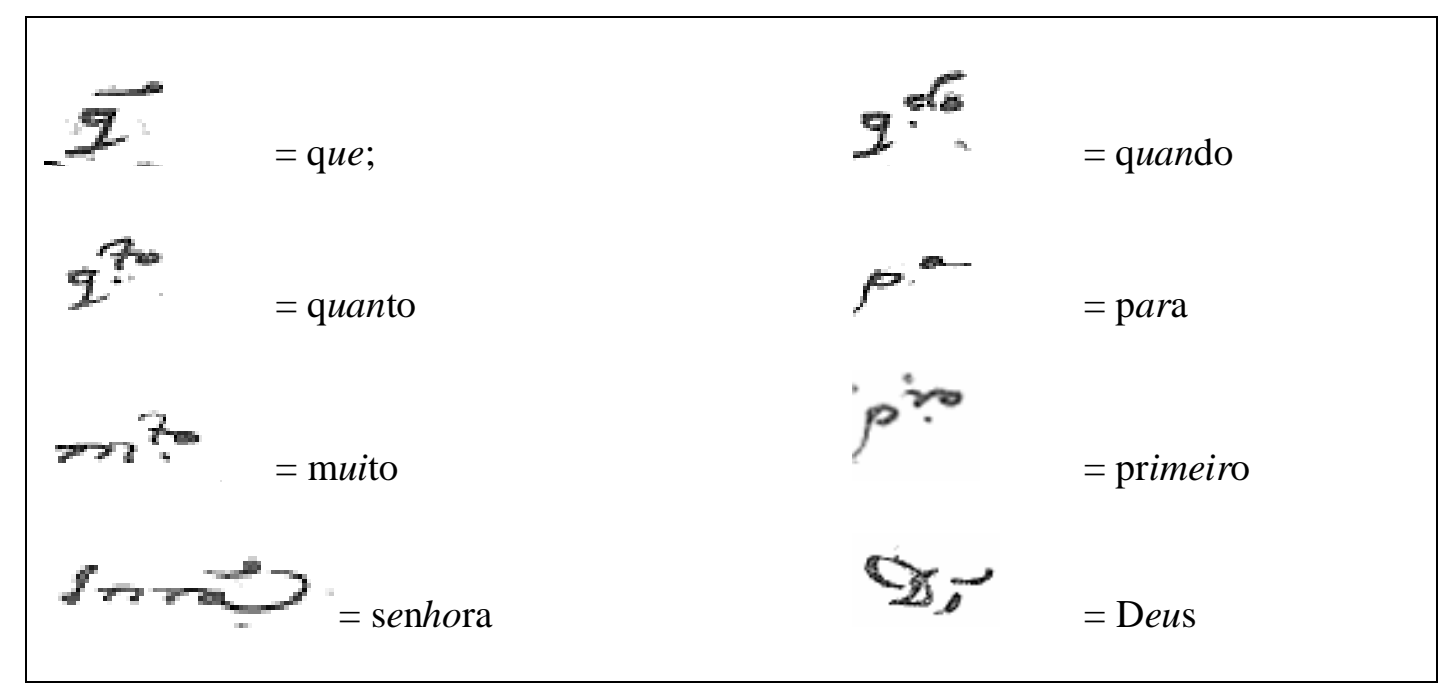

\subsection{Divisão das linhas e mudança de fólio}

A divisão das linhas do texto foi marcada com uma barra vertical: | . A mudança de fólio foi assinalada por duas barras verticais, seguidas do número do fólio que se inicia entre colchetes: $\|[1 \mathrm{r}]\|,[1 \mathrm{v}]$ etc.

\subsection{Separação vocabular}

Quanto à separação vocabular, procuraram-se respeitar as opções do copista, inclusive nos casos em que o amanuense adota diferentes soluções para o mesmo vocábulo (ou grupo de vocábulos) ao longo da cópia. É o caso, por exemplo, dos advérbios terminados em -mente, que podem aparecer juntos ou separados, ou de pronomes como "aquelle", às vezes separados em "a quelle", como nos exemplos abaixo (fl. 123r, 1.11 e fl. 157r, 1. 27):

$$
\begin{aligned}
& \text { - ğ aguele rfia ("o que aquelle dia") } \\
& \text { aguefler Eome } \overrightarrow{5} \text { ("a quelles homẽns") }
\end{aligned}
$$


Nem sempre é fácil determinar com precisão a intenção do copista quanto ao espaço intervocabular. Em certos momentos, o próprio amanuense parece hesitar. Nestes casos, procedeu-se à comparação com outros espaços intervocabulares na mesma linha para determinar qual opção adotar.

A ocorrência de espaço maior que o habitual entre dois vocábulos (normalmente depois de ponto final ou de dois pontos) foi marcado com o sinal: [espaço]. Neste aspecto, como nos demais, o comportamento do amanuense não é uniforme; casos em que o espaço antes do início de nova frase é pouco maior que o de separação das palavras não foram considerados. Por outro lado, nos casos em que a marca de espaço foi utilizada, não se fez distinção quanto ao tamanho do intervalo, que apresenta grandes variações.

Nas ocorrências de palavras separadas pela troca de linhas, adotou-se como critério mantê-las juntas (sem espaço antes e depois do sinal “|”, utilizado para indicar a mudança de linha) nos casos em que o copista assinala a divisão da palavra com hífen, o que é bastante comum, ou quando, na ausência do hífen, consideramos não haver dúvida quanto à intenção de manter a palavra unida. Quando se trata de palavras em que o procedimento do copista não é uniforme e não há hífen, optou-se por separar a palavra. Exemplo disso ocorre com o termo facilmente entre as linhas 2 e 3 do fl. $27 \mathrm{r}$,

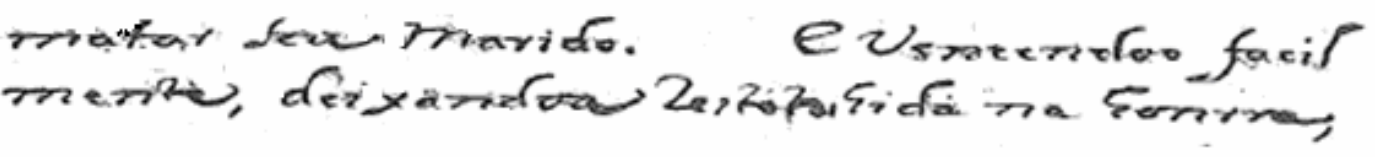

trecho que foi transcrito do seguinte modo: "matar seu Marido. [espaço] E vencendoo facil | mente, deixandoa restetuhida na honrra,".

\subsection{Pontuação}

A pontuação e a paragrafação originais foram mantidas, inclusive nos casos em que há evidente omissão do ponto, como sucede não raro nas abreviaturas de "D." e, com menor freqüência, antes do início de novas frases.

Respeitamos rigorosamente a pontuação do original também no tocante ao emprego dos demais sinais de pontuação: vírgulas, dois pontos, ponto e vírgula, ponto de interrogação, de exclamação e parênteses. 


\subsection{Capitalização}

Quanto à capitalização, manteve-se o emprego de maiúsculas e minúsculas tal como no original, desconsiderando-se a ornamentação típica das maiúsculas de início de capítulo. No entanto, devido a particularidades da escrita do copista, nem sempre é fácil distinguir as maiúsculas das minúsculas. Também com relação a este aspecto o amanuense parece hesitar em alguns casos, ainda que não numerosos.

Conforme o quadro com o alfabeto do manuscrito, apresentado a seguir, é possível notar que no caso das letras "g" e "o", o traçado das maiúsculas não difere significativamente do das minúsculas a não ser no tamanho do grafema. No caso da letra "s" a diferença de traçado é sutil e às vezes difícil de identificar.

Algumas letras apresentam mais de um traçado possível para as maiúsculas. Em particular, as letras "a", “e”, "m” e "n”, quando maiúsculas, às vezes se diferenciam das minúsculas apenas pelo seu tamanho. Quando são um pouco maiores que as letras restantes da palavra, foram grafadas como maiúsculas ${ }^{190}$.

Quanto às letras "c", "u" e "v", elas normalmente assumem formato maior quando ocorrem em início de palavra, além de em muitos casos não apresentarem diferenças significativas de traçado entre maiúsculas e minúsculas. Dada a impossibilidade de diferenciá-las na grande maioria dos casos, optou-se por grafá-las maiúsculas de acordo com sua posição na frase (ou seja, quando em início de frase ou em nomes próprios), além das poucas ocasiões em que apresentam nitidamente traçado de letras maiúsculas ${ }^{191}$.

\subsection{Erros, repetições e interpolações}

Erros do copista, quando identificados, são destacados em nota de rodapé e confirmados pelo cotejo com os manuscritos B e C (BNL 620 e 658), conforme

${ }^{190} \mathrm{O}$ copista parece muito hesitante quanto à forma e ao emprego das maiúsculas nestes casos. No entanto, dado que em diversas passagens pode-se presumir um desejo de ressaltar a palavra iniciada com alguma dessas letras (como é o caso de "Amor", "Aventura", "Escudo", "May”, "Mandar", "Navio"), quando a letra é maior que as outras foi registrada como maiúscula.

${ }^{191}$ As letras "c" e "v" apresentam por vezes traçado nitidamente caracterizador de maiúscula. No entanto, como o copista o emprega poucas vezes, na maioria dos casos a distinção entre maiúsculas e minúsculas é praticamente impossível. 
justificado anteriormente. Correções ou supressões feitas pelo copista são igualmente remetidas para nota de rodapé.

Nos casos de repetição não intencional por parte do copista, raríssimos em nosso manuscrito, ela será assinalada com colchetes duplos, como ocorre no fl. 32r, 1. 12, onde se lê Grostab derze deste frial (fl. 32r, 1. 12), trecho que transcrevemos "so|bresalto deste [[deste]] dia".

Os acréscimos feitos pelo copista nas entrelinhas do texto são indicados entre os sinais $<>$, como é o caso da sílaba "re" posta sobre um sinal em forma de ${ }^{\wedge}$ no local em que o segmento deve ser inserido:

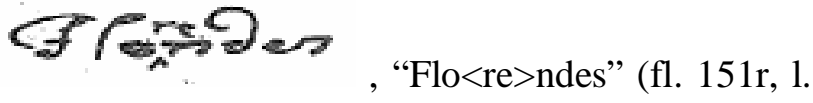
$10)$.

Além disso, as rasuras e os trechos ilegíveis, também pouquíssimo freqüentes no códice transcrito, são assinalados com os seguintes sinais: [rasura] e [ilegível].

\subsection{Anexos ao texto}

Ao final do texto, apresentamos glossário e índices de personagens, localidades e obras citadas.

\subsection{Alfabeto da Crônica de D. Duardos (Cód. BNL 12904)}

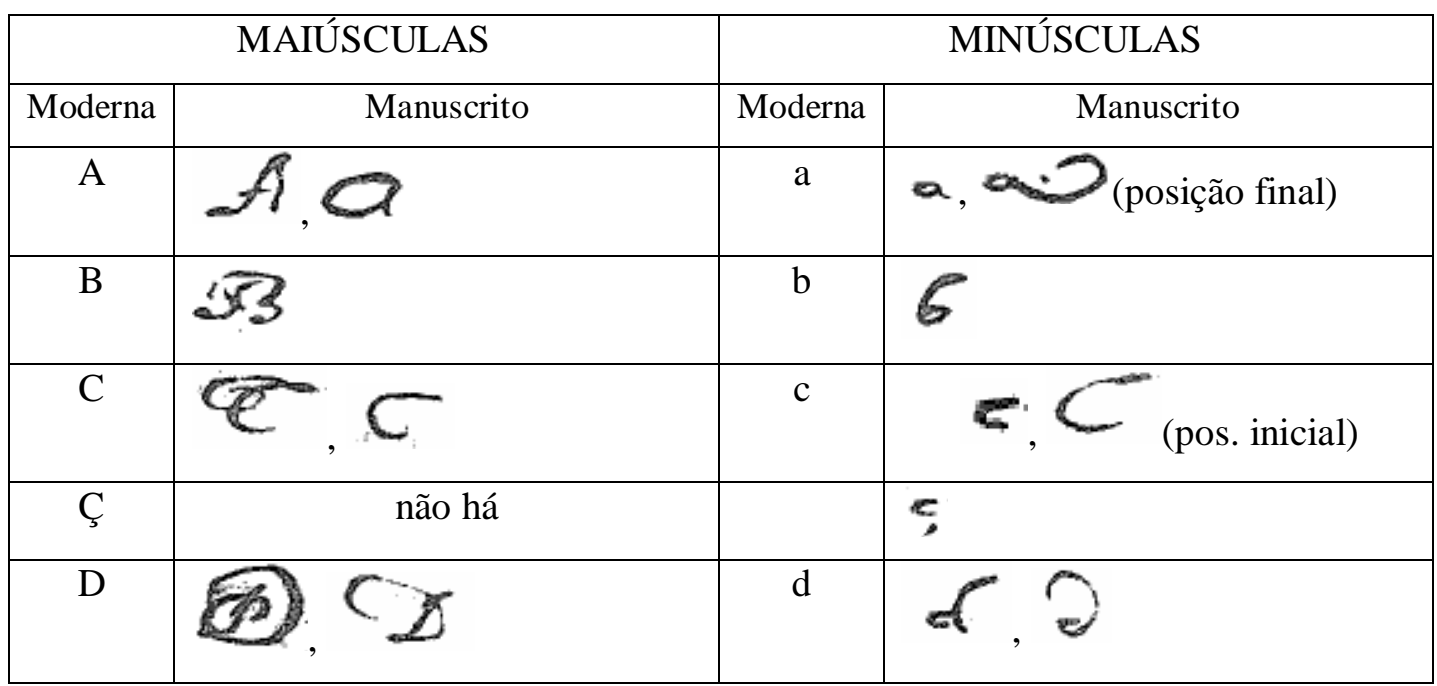


131

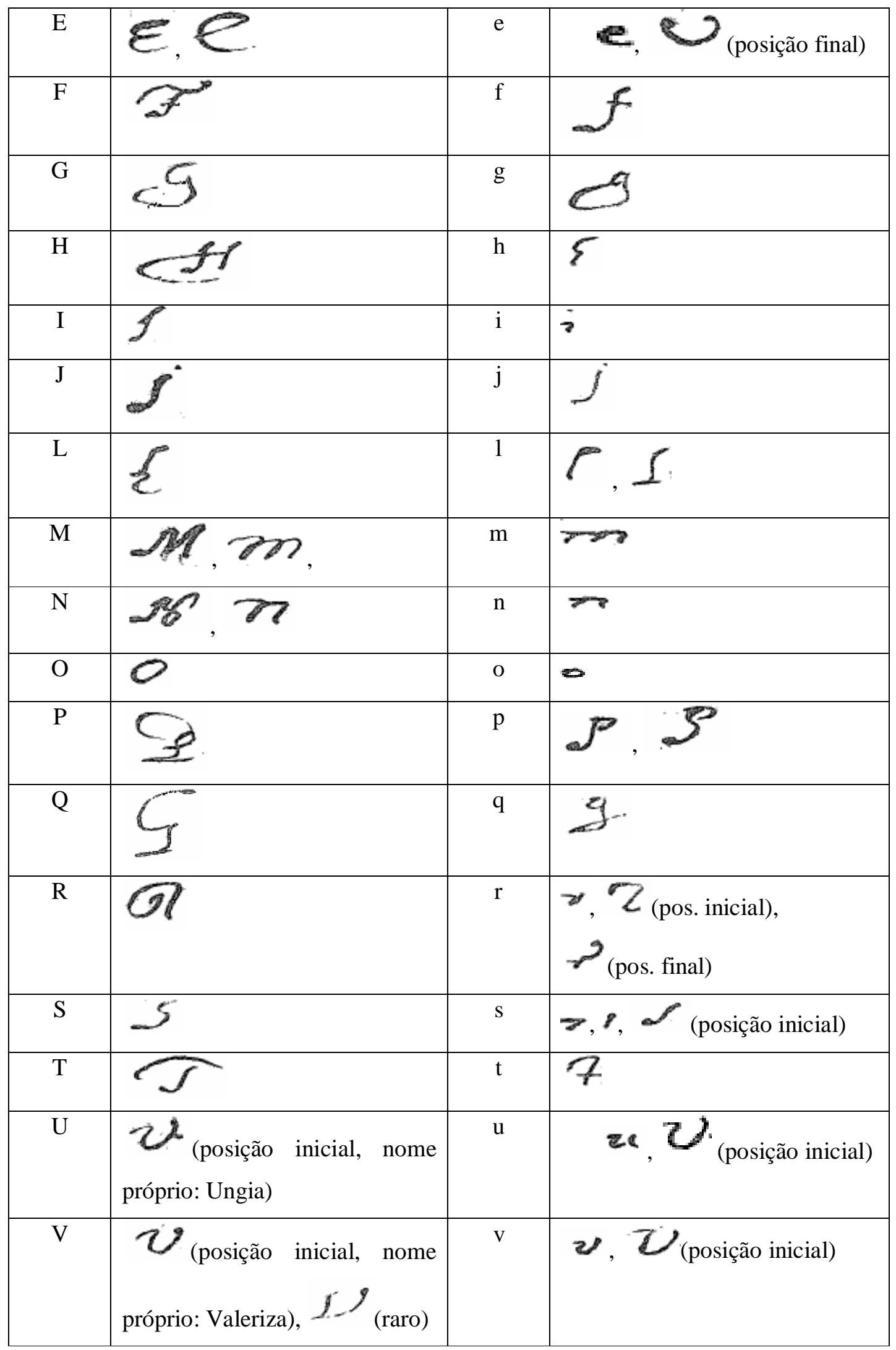




\begin{tabular}{|c|c|c|l|}
\hline $\mathrm{X}$ & $\mathcal{X}$ & $\mathrm{x}$ & $\mathcal{X}$ \\
\hline $\mathrm{Y}$ & não há & $\mathrm{y}$ & $\mathcal{X}$ \\
\hline $\mathrm{Z}$ & não há & $\mathrm{z}$ & $\boldsymbol{Z}$ \\
\hline
\end{tabular}

\subsection{Exemplos dos sinais de pontuação empregados pelo copista}

\begin{tabular}{|c|c|c|}
\hline Tipo de Sinal & Transcrição & Manuscrito \\
\hline ponto final & acha. , pessoas. & aztal pettoal. \\
\hline dois pontos & dizião: & fiziof: \\
\hline vírgula & isso, & $i \pi / o_{p}$ \\
\hline ponto e vírgula & dar; & farp. \\
\hline interrogação & nelle? & mere? \\
\hline exclamação & fante|zia! & zia.'s \\
\hline parêntese & cabeça (que & $\pi$ Geras/a \\
\hline parêntese & acordo) revolvendo & aroido) Zuvofuenelo \\
\hline hífen ${ }^{192}$ & $\begin{array}{l}\text { separou-a } \\
\text { reçussitar - hũ }\end{array}$ & $\begin{array}{l}\text { Separoie- } \\
\text { Lezurritart Su }\end{array}$ \\
\hline
\end{tabular}

Além dos sinais de pontuação apresentados na tabela acima, há ainda outro, muito comum: hífen de separação de palavras ao final da linha, como no exemplo abaixo (fl. 112r, 1. 15-16):

$$
\begin{aligned}
& \text { Fenvelo obraio eitar meravilfal, e erianta- } \\
& \text { clo a Ilsa } p \text { an the roof purfelle artar Sem }
\end{aligned}
$$

${ }^{192}$ A utilização do hífen como elemento separador entre verbo e pronome é extremamente rara no manuscrito. Em alguns pouquíssimos casos, como o de "reçussitar - hũ" aqui apresentado (fl. 102v, 1 . 12), há um traço separando duas palavras. Na dúvida se ele é ou não intencional, todas as vezes em que há este tipo de traço, ele foi reproduzido na transcrição. 
transcrito da seguinte forma: "tendo obrado estas maravilhas, e encanta|do a Ilha para que se não pudesse achar sem”. 


\section{APÊNDICES}




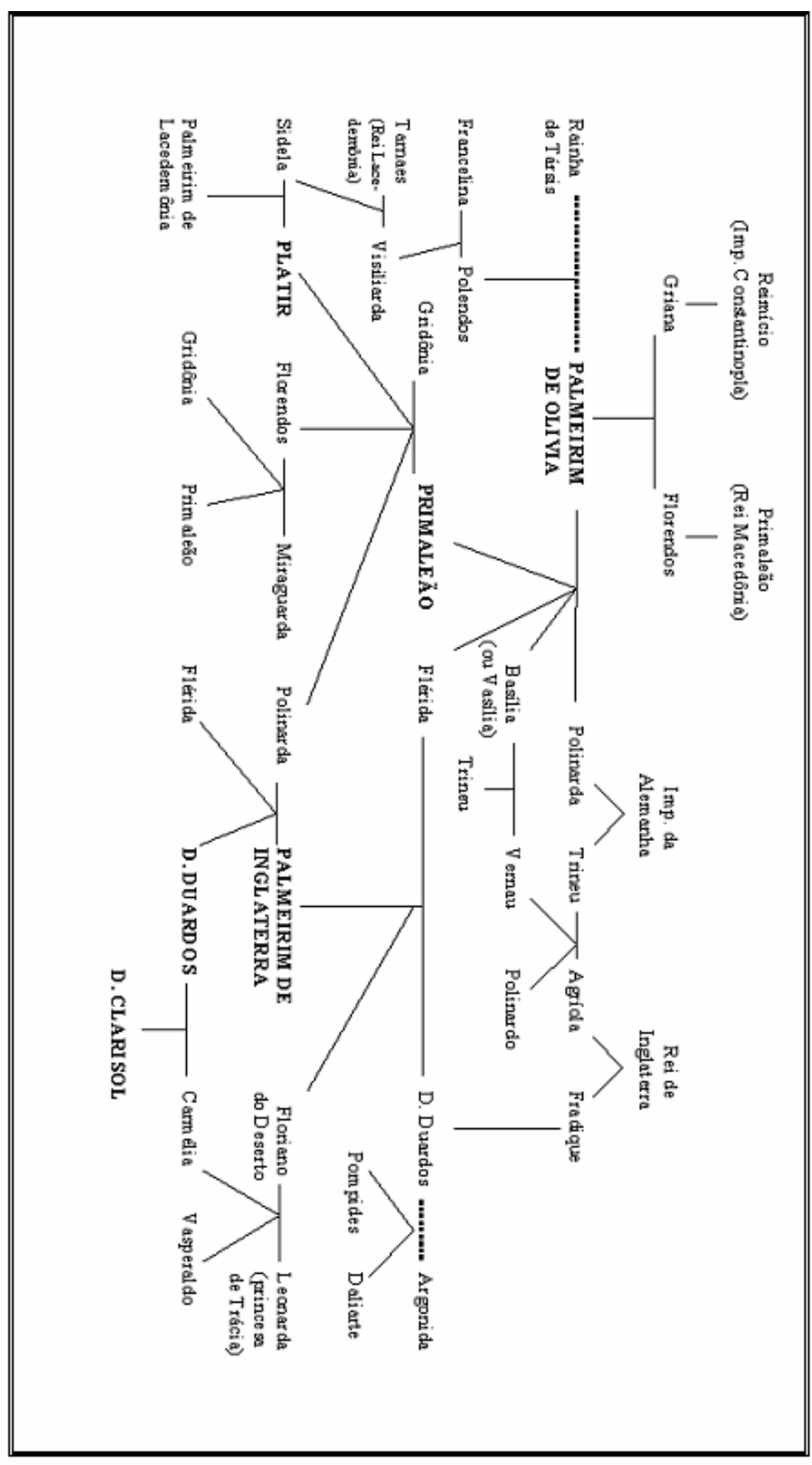

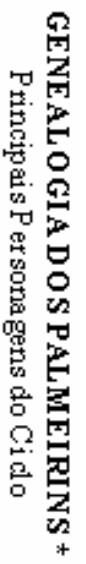




\section{APÊNDICE 2}

\section{RESUMO DO CICLO DOS PALMEIRINS}

Apresentamos a seguir o resumo do ciclo dos Palmeirins, restringindo-nos aos livros indispensáveis para a satisfatória compreensão da Crônica de D. Duardos: Palmerín de Olivia (1511), Primaleón (1512) e Palmeirim de Inglaterra (c. 1544). Não incluímos aqui o Platir (1533), pelos motivos apontados acima (cf. capítulo 1 deste volume, item 2).

\section{Palmerín de Olivia}

Griana, filha do Imperador Reimício de Constantinopla (o oitavo desde a fundação da cidade), estava prometida a seu primo Tarísio, príncipe de Hungria. Ela, no entanto, conhece o príncipe Florendos da Macedônia, com quem se casa em segredo e pretende fugir para evitar a punição pela desobediência ao pai. O plano de fuga é descoberto e o Imperador, furioso, ordena que a filha seja encerrada na prisão até que aceite casar-se com o primo. Confinada numa torre, a princesa conseguiu ocultar de todos o fato de estar grávida de Florendos. Logo que nasce, seu filho é abandonado numa montanha; a mãe só teve tempo de notar que a criança possuía um lunar no rosto. Depois disso, Griana reconhece não ter outra alternativa senão aceitar Tarísio como esposo, e ambos vão viver no reino de Hungria.

O recém-nascido é encontrado na montanha de Oliva, entre as palmas de uma árvore (daí ser batizado de Palmeirim de Oliva) e é criado por Geraldo e Marcela, um casal de rústicos vilãos. Aos 15 anos, o jovem sonha com uma donzela muito formosa, que possuía na mão esquerda um sinal semelhante ao de seu rosto. Ela diz a Palmeirim que ele descende de linhagem nobre, incitando-o a abandonar a vida de vilão que levava. Dessa forma, o rapaz deixa sua casa e segue para o reino de Macedônia. No caminho, conhece o anão Urbanil, que lhe informa da doença do rei Primaleão (pai de Florendos), cuja cura só poderia ser alcançada com água da fonte da montanha Artifária, guardada por terrível serpente. Chegando à corte, o rapaz pede a Florendos que o arme cavaleiro, pois deseja experimentar a aventura da fonte. Florendos fica surpreso com a 
ousadia do jovem, mas não suspeita ser ele seu filho. Palmeirim consegue matar a serpente da montanha, mas é gravemente ferido e só sobrevive graças à intervenção de três fadas, que vaticinam diversos acidentes em sua vida futura.

Depois de proporcionar a cura do rei Primaleão, seu avô, o jovem cavaleiro parte em busca de sua identidade e da donzela de seus sonhos. Entre outras aventuras, Palmeirim consegue derrotar o cavaleiro encantado que assolava a região onde vivia o Imperador da Alemanha. Assim, ele conquista a amizade do Imperador e de seus filhos: Polinarda (que o jovem reconhece como sendo aquela que lhe aparecera em sonhos) e Trineu. Com a divulgação da notícia de que um filho do rei de França convocava cavaleiros a justarem para provar a beleza de suas amigas, Palmeirim viaja a Paris com anuência de Polinarda e ali vence todos os oponentes, com exceção de um: o Cavaleiro do Sol, que também justava por Polinarda. A batalha é muito equilibrada e os dois são forçados a abandonar o combate com a chegada da noite. O misterioso cavaleiro é sobrinho de Tarísio e chama-se Frisol. Seu pai havia sido injustamente exilado de Hungria e sonhara que seria reconduzido à corte húngara através deste seu filho.

De volta à Alemanha, Palmeirim contrai matrimônio secreto com Polinarda, mas logo eles serão forçados a se separar novamente. Trineu apaixonara-se pela filha do rei de Inglaterra, Agríola, que ele havia visto retratada no estandarte de um cavaleiro durante as justas em Paris, e pede a Palmeirim que o acompanhe até Inglaterra, onde poderia conhecer Agríola pessoalmente e servir a seu pai na guerra que então havia entre ingleses e escoceses. O plano era muito arriscado, pois levaria Trineu a favorecer um inimigo de seu pai, visto que os escoceses eram aliados do Imperador da Alemanha.

Quando os ingleses vencem a guerra, todos se perguntam quem seriam os misteriosos cavaleiros estrangeiros que haviam lutado tão bravamente: com efeito, Palmeirim se destacou entre todos os combatentes e Trineu salvou a vida do rei de Inglaterra no meio da batalha. Depois, eles ainda têm oportunidade de libertar Agríola e a rainha sua mãe das mãos do gigante Fanarque, o que só faz confirmar o prestígio deles na corte inglesa e, em particular, a simpatia da princesa. Palmeirim revela a Agríola a identidade de Trineu e ela aceita fugir de Londres com os dois estrangeiros.

Durante a viagem de retorno à Alemanha, uma tempestade no mar os lança nas proximidades da Turquia. Ali, Agríola e Trineu são raptados: ele é levado para a Ilha de Malfado, onde um encantamento fazia com que todos os homens fossem transformados 
em cães; Agríola é entregue ao Grão-Turco, que se encanta com sua beleza e decide desposá-la (e ainda assim ela se conserva casta em virtude da força de um anel mágico que trazia consigo). Palmeirim, por sua vez, é conduzido à Babilônia, onde, passando-se por mudo a fim de ocultar o fato de ser cristão, realiza uma série de proezas que lhe permitem conquistar a confiança do Sultão e o amor de Alchidiana, sua filha. Ela confessa seus amores e Palmeirim (que a esta altura já havia aprendido a língua da terra e simula estar curado da mudez) promete que a desposará assim que voltar de Constantinopla, para onde o Sultão enviaria uma grande armada contra os cristãos. Seu plano era, na verdade, desertar do exército turco assim que aportasse em terras cristãs. Antes de ir a Constantinopla, contudo, Palmeirim deve ajudar o Sultão em outra guerra e parte para o reino de Trácia. Naquela terra ele não apenas se destaca nos combates, como também é seduzido pela rainha de Társis, uma encantadora que faz Palmeirim cair em profunda letargia a fim de ter um filho dele, que se chamará Polendos.

Durante o trajeto para Constaninopla, Palmeirim afasta-se da armada turca acompanhado por Olorique, cavaleiro mouro de quem se tornara amigo durante a permanência no Oriente. Após breve passagem pela corte alemã para rever Polinarda, que não recebia notícias suas há dois anos, Palmeirim avista uma das fadas da montanha Artifária, de quem ouve que seria salvo por seu maior inimigo. Com efeito, pouco tempo depois, Frisol salva-o de uma emboscada. Tornam-se amigos e decidem seguir juntos para resgatar Trineu e Agríola dos mouros.

Antes disso, porém, passam pela corte de Constantinopla para defender Florendos e Griana, presos sob acusação de tramar a morte de Tarísio. Provada a inocência de ambos, Griana reconhece o filho graças ao sinal que possuía no rosto. $\mathrm{O}$ velho Reimício perdoa Griana e finalmente são celebradas as bodas dela com Florendos. Na mesma ocasião, Frisol revela ser sobrinho de Tarísio e casa-se com Armida (filha de Griana e Tarísio), reconduzindo seu pai ao trono húngaro e cumprindo a antiga profecia.

Depois dos festejos em Constantinopla, Palmeirim parte rumo ao Oriente acompanhado de Frisol, Olorique e mais três cavaleiros. A embarcação em que iam é novamente interceptada por mouros e, a fim de não serem presos, decidem auxiliar o capitão turco nas incursões contra os cristãos. Depois disso, são levados à presença do Grão Turco, que os recebe com muita honra, pois Palmeirim diz ser irmão de Agríola. Um plano urdido por outra cristã cativa permite o assassinato do Grão Turco e a fuga de 
Palmeirim e seus companheiros, que logo aportam na Ilha de Malfado e sofrem o mesmo castigo de Trineu: Frisol e os demais cavaleiros são transformados em cães, ao passo que Agríola vira uma cerva. O único poupado é Palmeirim, graças à proteção das fadas da montanha Artifária. De lá, ele parte em busca de socorro para desencantar os amigos.

No caminho, Palmeirim passa pelo castelo da Infanta Zérfira, que sofria de terrível doença e soltava vermes pelas narinas. Zérfira, que havia estado na Ilha de Malfado em busca de cura para seu mal, trouxera Trineu para junto de si. Ao ver Palmeirim, Trineu expressa grande contentamento e não mais se separa do amigo, embora não seja reconhecido, visto que permanecia com a aparência de um cão. Zérfira acompanha Palmeirim para o reino de Rumata, onde vivia o sábio Muça Belín. Ali, Palmeirim dá cabo à aventura do Castelo dos Dez Padrões, em que consegue colher as flores para a cura a Zérfira e onde Trineu reassume a forma humana.

Antes de socorrer os amigos na Ilha de Malfado, no entanto, Palmeirim e Trineu devem auxiliar o rei de Rumata na guerra contra o Sultão da Pérsia. Palmeirim consegue capturar o Sultão em pessoa e um tratado de paz é firmado. Impressionado com os cavaleiros cristãos, o Sultão deseja que abandonem a fé cristã e permaneçam em seu reino. Para isso, ele pede a suas duas irmãs que convençam os estrangeiros a se casar com elas. Liçadra tem pouco sucesso com Palmeirim, mas Aurencida consegue seduzir Trineu, de quem terá um filho chamado Rifarán. Quando o Sultão toma ciência de que sua irmã havia sido desonrada por Trineu, manda prendê-lo e condena-o à morte. No momento em que o príncipe alemão ia ser queimado, contudo, ele é salvo pela magia do sábio Muça Belín e só então Trineu e Palmeirim podem finalmente se dirigir à Ilha de Malfado. Ali, graças às instruções do sábio mouro e à coragem de Palmeirim de Oliva, os encantamentos são desfeitos: Agríola, Frisol e os demais retomam a forma humana e todos retornam a salvo para Constantinopla.

Pouco depois das festas nas cortes grega e alemã por ocasião do retorno dos príncipes e das bodas entre Palmeirim e Polinarda e de Trineu e Agríola, o Imperador Reimício, já muito velho, morre. Visto que Florendos e Griana, seus naturais sucessores, desejam permanecer em Macedônia, Palmeirim é coroado Imperador de Constantinopla. Com o passar dos anos, nascem-lhe dois filhos: Primaleão e Polícia, que fazem companhia aos gêmeos de Frisol, nascidos pouco antes: Ditreu e Belcar. 
Quando imaginava poder descansar dos trabalhos passados, um novo perigo ameaça a vida de Palmeirim: dois cavaleiros, um cristão e outro mouro, ambos desejosos de reparar antigas desavenças, planejam assassiná-lo. Com ajuda de um encantador, eles adentram o palácio e conseguem ferir gravemente o Imperador, que é salvo pelo socorro de seus amigos e sobretudo por causa de mais uma aparição de Muça Belín.

O livro termina com o prenúncio de novas aventuras: vem à corte uma mensageira anunciando que em breve o Imperador conhecerá novos cavaleiros, que farão escurecer a fama de todos os presentes em Constantinopla.

\section{Primaleón}

Polendos crescia sem saber que era filho de Palmeirim de Oliva, pois sua mãe, a rainha de Társis, temia que, uma vez descoberta a verdade, ele abandonasse sua terra e se tornasse cristão. Certo dia, porém, uma velha revela a verdade ao rapaz, acrescentando que ele passaria muitos trabalhos por amor de uma donzela chamada Francelina. Com indizível tristeza de sua mãe, Polendos parte em busca do pai e daquela que começava a amar mesmo sem conhecer. Logo na primeira aventura, o jovem vence o gigante Baledón e liberta os cavaleiros que permaneciam cativos em sua ilha, entre os quais Rifarán, filho de Trineu e Aurencida, que também partira em busca do pai. Depois de várias outras peripécias, Polendos chega à Ilha de Cardéria, onde ficava a torre encantada em que estava Francelina, e consegue libertá-la. Antes que se casem, entretanto, Francelina pede que Polendos resgate seu pai, o rei de Tessália, em poder do Grão Turco. Para libertá-lo, Polendos conquista o coração de Leifida, filha do alcaide do castelo onde o rei estava preso; uma vez dentro do castelo, não poupa sequer o pai de Leifida, motivo pelo qual ela se suicida. O episódio "acrecentó la gran enemistad de los turcos con los grecianos, que turó desde entonces fasta que los turcos ovieron a toda Grecia en poder. Mas mientra que el emperador Palmerín fue bivo, no tuvo el Gran Turco osadía de començar guerra" (p. 93).

Quando Polendos volta a Constantinopla, ele revela ser filho de Palmeirim e é recebido com grande alegria. Antes que seja batizado e se case com Francelina, sua trajetória cruza com a dos filhos dos companheiros de Palmeirim. Ditreu, filho de 
Frisol, casa-se com Esquivela (filha de Alchidiana e Olorique); Belcar, irmão de Ditreu, vive muitas aventuras até casar-se com Alderina, filha do Duque de Duraço; Arnedos e seu primo Recindos (príncipes de França e Espanha, respectivamente) demonstram seu valor antes de desposar Polícia, filha de Palmeirim, e Melisa, filha de Frisol. Cavaleiros mouros também protagonizam várias aventuras, entre as quais sobressaem relações adulterinas: Rifarán envolve-se com a Condessa de Islanda, que se descobre grávida depois da partida dele; Lecefín (filho de Zérfira com o Sultão de Pérsia) seduz diversas mulheres, entre as quais uma religiosa. Mais tarde, quando ambos já estiverem convertidos à lei cristã, Rifarán (que passou a chamar-se Triolo) tornar-se-á duque de Bolonha e Lecefín desposará Valarisa, filha de Trineu e Agríola.

Aos poucos, a narrativa passa a se concentrar em torno de dois outros filhos de Palmeirim e Polinarda: Primaleão e Flérida, cuja beleza superava a de sua irmã Polícia. Durante os torneios celebrados em Constantinopla por ocasião do matrimonio de Polícia e Arnedos, Primaleão recebe a ordem da cavalaria e um sábio, o Cavaleiro da Ilha Cerrada, envia-lhe um escudo em que havia a representação do castelo da Roca Partida, onde vivia aquela por quem Primaleão sofreria penas de amor. As primeiras aventuras do jovem prendem-se a um episódio narrado no Palmerín de Olivia: a morte dos que acusavam Florendos de haver premeditado o assassinato de Tarísio, marido de Griana. A duquesa de Ormedes, esposa de um dos acusadores mortos por Palmeirim e Frisol, promete oferecer a mão de sua filha Gridônia a quem matar o Imperador ou seu filho. Movidos pela beleza de Gridônia, diversos cavaleiros desafiam Primaleão e são derrotados, entre os quais o príncipe de Apolônia, Perequín de Duaces, sobrinho da duquesa. Dessa forma, cresce o ódio de Gridônia pelo príncipe de Constantinopla.

A fama da beleza de Gridônia chega aos ouvidos de D. Duardos, filho do rei Fradique de Inglaterra e sobrinho de Agríola. Ele parte de Londres, acompanhado de seu cão (que, embora D. Duardos não o soubesse, era um gigante chamado Maiortes, encantado na ilha de Malfado) e do escudeiro Clódio. Sua primeira aventura é desfazer o encantamento de um mosteiro, cuja recompensa é uma espada que o protegeria de todos os sortilégios nefastos. Depois, ele captura a infanta Zérfira (filha da mãe de mesmo nome que figurara entre os personagens do livro anterior e irmã de Lecefín) e a envia para Gridônia. Além disso, ele ajuda Olimba e Belagriz, filhos do Sultão de Niquea, a retomar a coroa do pai, que havia sido assassinado. 
Quando D. Duardos finalmente chega a Constantinopla, apaixona-se por Flérida, mas ainda assim não deixa de acusar Primaleão pela morte dos parentes de Gridônia. Diferentemente do que ocorrera com todos os outros que haviam feito a mesma acusação, D. Duardos não foi vencido pelo príncipe de Constantinopla: a batalha entre os dois é muito equilibrada, e eles se separam a pedido de Flérida. Primaleão fica furioso por não ter vencido aquele misterioso oponente (que é conhecido como “Cavaleiro do Cão", por estar sempre acompanhado de Maiortes) e parte em seu encalço. D. Duardos segue para Niquea e ali recebe de Olimba uma copa encantada, que o ajudaria a conquistar o amor de Flérida.

Primaleão busca notícias de D. Duardos, acompanhado de seu anão Risdeno (filho de Urbanil, que servira Palmeirim) e do escudeiro Purente, filho do Cavaleiro da Ilha Cerrada. No caminho, contam-lhe que Gridônia se refugiara no castelo da Roca Partida (o mesmo retratado em seu escudo), onde vivia com a mãe e um leão que sempre a acompanhava, a fim de proteger-se do príncipe de Clarência, que desejava tomá-la por esposa à força. Oculto sob a alcunha de "Cavaleiro da Roca Partida", Primaleão vai a Gridônia oferecer-lhe ajuda e, ao vê-la, apaixona-se imediatamente. $\mathrm{O}$ leão de Gridônia, que se mostrava hostil a todo homem que se aproximasse dela, fica manso diante de Primaleão: afinal, ele havia sido enviado pelo Cavaleiro da Ilha Cerrada para que Gridônia entendesse "que el león más fuerte, que era Primaleón, avía de ser d'ella señor" (p. 206). Derrotado o príncipe de Clarência, Primaleão conquista o coração daquela que tanto o odiava: Gridônia começa a amá-lo, mas diz que só se casará se ele lhe trouxer a cabeça de Primaleão como dote, o que o próprio Cavaleiro da Roca Partida promete fazer.

Mas ele deverá enfrentar muitas outras aventuras a serviço de sua amada. Em primeiro lugar, Primaleão derrota o exército de Grístamo, que contestava a nomeação da duquesa de Ormedes, mãe de Gridônia, como rainha de Apolônia. Durante a perseguição às naus de Grestes, irmão de Grístamo, Primaleão aporta na Ilha de Cíntara, onde o gigante Gataru o mantém encantado numa cova. Antes de ser libertado por D. Duardos (que Primaleão não sabe ser o cavaleiro que perseguia), durante o período em que esteve fora de seu juízo, o príncipe de Constantinopla engravida Curoya, antiga senhora da ilha, que também permanecia encantada ali. Depois de partir de Cíntara, Primaleão ainda conseguirá capturar um monstro chamado Patagón, num episódio 
celebrizado pelo fato de ter sugerido aos navegantes espanhóis o nome dado a uma região do Novo Mundo. O Cavaleiro da Roca Partida retorna vitorioso de todas as aventuras, mas pouco depois de sua chegada Gridônia é raptada por Grestes.

Enquanto isso, D. Duardos volta a Constantinopla por amor de Flérida. Dizendo chamar-se Julião e passando-se por filho do hortelão que cuidava dos jardins da princesa, D. Duardos consegue fazê-la beber da copa mágica dada por Olimba e, assim, Flérida começa a amar aquele que pensava ser um simples jardineiro. Os dois passam a manter encontros noturnos, nos quais Julião garante ser cavaleiro "de alta guisa" mantendo oculta, no entanto, sua verdadeira identidade. Para provar que dizia a verdade, Julião se apresenta diante do Imperador como o Cavaleiro do Cão, e resolve duas aventuras em que nenhum outro cavaleiro da corte conseguira ter sucesso: conquistar a guirlanda de flores das mãos do fortíssimo Camilote e fazer um espelho encantado refletir o rosto do amado de quem o mirasse.

Diante da bravura de Julião, a infanta Flérida aceita casar-se com ele em segredo. Pouco depois, no entanto, D. Duardos é forçado a partir de Constantinopla para atender ao rogo de uma donzela. Após libertar Primaleão na ilha de Cíntara, o Cavaleiro do Cão ajuda a desfazer outro encantamento, libertando o príncipe Tarnais de Lacedemônia do cruel castigo imposto por seu pai que, movido por ciúmes, o encantara numa montanha. A coragem de D. Duardos cativa o coração de Paudrícia, irmã de Tarnais, que confessa seus sentimentos a Belagriz, o cavaleiro mouro que acompanhava o príncipe de Inglaterra em suas aventuras. Fazendo-se passar pelo amigo, Belagriz dorme com Paudrícia e desta união nascerá Blandidón. Mas D. Duardos também estava destinado a ter um filho fora do casamento: uma sábia encantadora, senhora da ilha de Ircana, fará com que ele seja seduzido por Argonida, sua filha, gerando Pompides.

Acabadas essas aventuras, D. Duardos volta a Constantinopla, onde Flérida o aguardava, temerosa por ser-lhe cada dia mais difícil ocultar sua gravidez. D. Duardos decide levá-la em segredo para a Inglaterra. Durante o trajeto, contudo, eles cruzam com a nau em que Gridônia estava aprisionada por Grestes. Mesmo sem saber quem era aquela donzela (D. Duardos nunca a vira), ele mata o raptor no exato momento em que se aproxima a nau de Primaleão, que também vinha em busca de Gridônia. Pensando que D. Duardos fosse o raptor de Gridônia, Primaleão é tomado por fúria cega e ataca-o. A batalha entre os dois é cruel e, se não fosse interrompida pelo Cavaleiro da Ilha 
Cerrada, ambos morreriam. Para evitar desastre tão grande, aquele sábio os leva para sua ilha, onde Primaleão é informado da identidade de D. Duardos e a paz entre eles é selada. Flérida, tendo perdido o filho que esperava, cede aos rogos do irmão e decide voltar à corte de Constantinopla para se desculpar com o Imperador Palmeirim.

Antes de sua partida, o Cavaleiro da Ilha Cerrada pede que eles o ajudem a reconquistar a ilha de Ordán, furtada por seu cunhado. A batalha entretanto, será mais difícil do que se imaginava, porque, com informações enganosas, o Imperador Palmeirim em pessoa, acompanhado de seu filho Polendos, lutariam contra o exército do Cavaleiro da Ilha Cerrada. Inconscientes de combater seus amigos e familiares, os exércitos encontram-se em choque crudelíssimo, no qual o velho Palmeirim de Oliva demonstrou não ter perdido a antiga força, pois D. Duardos e Primaleão quedam feridos por seus fortes golpes. Felizmente a verdade foi descoberta antes que se fizesse um dano irreparável e firmou-se um acordo de paz.

Quando Primaleão volta a Constantinopla com seus companheiros, finalmente revela sua verdadeira identidade a Gridônia: dando-lhe sua espada e oferecendo a cabeça nas mãos dela, cumpre a promessa que fizera a sua amada. Gridônia fica transtornada, mas termina por perdoá-lo e aceita casar-se com ele. As bodas de Primaleão e D. Duardos são celebradas com grandes festas na corte e, aproveitando a reunião de todos os reis e príncipes amigos, diversos companheiros dos dois protagonistas também se desposam: Vernau (filho de Trineu e Agríola) é armado cavaleiro e casa-se com Vasília, filha do Imperador Palmeirim; a rei Tarnais de Lacedemônia é oferecida a mão da filha de Polendos, Visiliarda; Pridos, filho do conde de Gales e primo de D. Duardos, desposa Artada, donzela que acompanhou Polinarda em todas as aventuras. Também são arranjados os casamentos dos cavaleiros mouros presentes à corte: Belagriz, Sultão de Niquea, casa-se com Zérfira e Torques, príncipe de Rumata, com Olimba. Maiortes, que todos pensavam ser um cão, foi desencantado pelo Cavaleiro da Ilha Cerrada, casa-se com a infanta Campora e segue com seu irmão, o gigante Gataru, para o reino de Perez.

D. Duardos e Flérida partem para Inglaterra e, segundo o narrador, "bivieron mucho tiempo muy sabrosa vida amándose estrañamente y uvieron fijos y fijas, mas ninguno de sus fijos igualó a la bondad de Pompides" (p. 521). Primaleão e Gridônia tiveram quatro filhos e, nos capítulos finais da obra, é apresentada em breves traços a 
biografia do caçula, chamado Platir. Este, que se sobressaiu aos demais, partiu de Constantinopla pouco depois de ser armado cavaleiro para servir Sidela, filha de Tarnais e Visiliarda. Tendo vencido os torneios que se apregoavam no reino de Lacedemônia, conquistou o coração da princesa e, depois de algumas aventuras no reino de França, casou-se com Sidela, herdando a coroa do rei Tarnais.

Já muito velho, o Imperador Palmeirim é ferido por misterioso gigante e, por ocasião de seu falecimento, ocorreram diversas maravilhas.

\section{Palmeirim de Inglaterra}

Certo dia, enquanto caçava em uma floresta próxima a Londres, D. Duardos é preso no castelo da maga Eutropa, que o atraíra traiçoeiramente a fim de vingar seu irmão, o gigante Farnaque, cuja morte é narrada no Palmerín de Olivia. Eutropa havia encantado o castelo, de sorte que ninguém poderia encontrá-lo sem seu conhecimento; além disso, guardavam a fortaleza três temíveis gigantes: Pândaro, Daliagão e Dramusiando, filho de Farnaque.

Flérida recebe a notícia do desaparecimento de seu marido pouco antes de dar à luz a dois gêmeos, batizados de Palmeirim de Inglaterra e Floriano do Deserto. Logo após o nascimento, contudo, os bebês são levados por um selvagem que andava por aquela floresta à busca de alimento para seus dois leões. Felizmente, a esposa do selvagem se compadece das crianças e decide criá-las em companhia de Selvião, seu filho.

A notícia da prisão de D. Duardos chega a Constantinopla quando se comemorava na corte o nascimento de Polinarda, filha de Primaleão. Lembrando-se da amizade que tinham com o príncipe inglês, vários cavaleiros partem em busca de notícias sobre seu paradeiro. O primeiro a chegar à fortaleza de Dramusiando foi Primaleão; dado, porém, que nem ele conseguiu vencer os gigantes que a protegiam, aos poucos todos os principais cavaleiros da cristandade (Vernau, Belcar, Polendos, Recindos, Arnedos e muitos outros) foram sendo presos em companhia de D. Duardos.

Enquanto isso, Palmeirim e Floriano cresciam com a família do selvagem. Um dia, Floriano é encontrado na floresta por Pridos, primo de D. Duardos, que o leva a Londres. Ali, Flérida (sem saber que aquele era um de seus filhos) recebe o jovem em 
seu serviço. Pouco depois, Palmeirim é encontrado por Polendos, que o leva para Constantinopla por achá-lo parecido com o Imperador Palmeirim de Oliva. Ali, o rapaz é posto ao serviço de Polinarda, a quem começa a amar imediatamente. Pouco depois de sua chegada, o Imperador recebe uma carta da dona do Lago das Três Fadas anunciando que aquele donzel procedia de sangue real e realizaria grandes maravilhas.

Novas profecias acerca do herói são feitas pelo sábio Daliarte na ocasião em que Palmeirim é armado cavaleiro juntamente com outros novéis, entre os quais Florendos e Platir, filhos de Primaleão. Daliarte, o mago protetor dos heróis do livro, é um segundo filho de D. Duardos com Argonida e é meio irmão de Palmeirim e Floriano. Nas justas dos cavaleiros novéis, Palmeirim leva a honra, vencendo a todos os oponentes; o único a resistir a seus golpes é um misterioso combatente em cujo escudo havia o retrato de um selvagem com dois leões. Depois de muitos desencontros e aventuras, Palmeirim descobrirá que o Cavaleiro do Salvage é seu irmão, Floriano do Deserto.

Pouco depois de ser armado cavaleiro, Palmeirim pede a Polinarda que lhe dê licença para sair da corte em busca de aventuras. Desconfiada dos sentimentos que o rapaz lhe devota, a princesa ordena que ele não volte a aparecer diante dela. Dessa forma, Palmeirim parte de Constantinopla e, ocultando-se sob o nome de Cavaleiro da Fortuna, começa a adquirir grande fama. Suas aventuras cruzam-se com as de vários outros cavaleiros, entre os quais se destaca Floramão, príncipe da Sardenha que vive celebrando a memória de Altéia, sua amiga morta prematuramente. Diversas façanhas de Floriano também são narradas, como a vitória sobre o temível gigante Calfúrnio e sua tentativa de libertar os cavaleiros presos na fortaleza de Dramusiando. Embora os gigantes se espantem com sua força e coragem, a solução desta aventura estava reservada a seu irmão Palmeirim, que é o único a conseguir vencer Dramusiando.

A libertação de D. Duardos e dos demais companheiros presos encerra a primeira parte da obra. Dramusiando, que era de "nobre condição" e havia travado amizade com os cavaleiros que mantinha presos, é perdoado e desde então considera-se vassalo de D. Duardos. Em Londres, Daliarte revela que Palmeirim e Floriano são filhos de D. Duardos e Flérida. O rei Fradique e os demais membros da corte, desejosos de conhecer a fortaleza onde seus parentes haviam permanecido presos por tanto tempo, dirigem-se à torre de Dramusiando. Ali, encontram um misterioso cavaleiro que desafia a todos os outros sobre a beleza de Miraguarda, donzela cuja beleza podia rivalizar com 
a de Polinarda. Vários cavaleiros aceitam o desafio e são derrotados, com exceção de Floriano, com quem a disputa termina empatada. Palmeirim é advertido por Daliarte para não justar. Depois de resolver as aventuras da Ilha Perigosa, que fôra de Urganda, Palmeirim vai ao castelo de Almourol, na Lusitânia, para ver se Miraguarda era tão bela como sua fama apregoava. A luta contra o cavaleiro que guardava o castelo (que, embora Palmeirim não o soubesse, era Florendos, irmão de Polinarda) termina empatada, o que deixa Miraguarda muito agastada. Proibido de usar armas durante um ano por sua senhora, Florendos recolhe-se a uma vida pastoril enquanto Dramusiando toma seu lugar como defensor de Miraguarda. Durante outras aventuras de Palmeirim e Floriano (que começa a demonstrar seu temperamento donjuanesco), chega a Almourol Albaizar, o jovem sultão da Babilônia, desejoso de conquistar o escudo de Miraguarda para oferecê-lo à formosa Targiana, filha do Grão Turco, a quem servia. Sua batalha com Dramusiando termina empatada e ele rouba o escudo de Miraguarda à noite, sem que o gigante perceba. Enquanto isso, Floriano é raptado e levado à corte do Grão Turco, onde vive breve envolvimento com Targiana.

Enquanto Albaizar vence diversos cavaleiros de Constantinopla em defesa da beleza de Targiana, esta se entrega a Floriano que, como de costume, em pouco tempo se desinteressa da amante. A pedido de Targiana, Floriano parte rumo a Constantinopla, levando-a sem consentimento do pai. Depois de deixá-la na corte, Floriano ainda vivenciará muitas outras aventuras amorosas, entre as quais conta-se a retratada no célebre episódio das damas francesas, onde são incorporados elementos autobiográficos da permanência de Francisco de Morais na corte francesa. Palmeirim de Inglaterra, por outro lado, depois de experimentar a aventura da copa do rei Sardamante (objeto mágico que demonstrava o grau de perfeição amorosa de quem a tivesse nas mãos), partiu para libertar Leonarda, neta de Sardamante, de um terrível encantamento.

A tensão com os turcos aumenta, visto que eles exigem reparação do suposto seqüestro de Targiana por Floriano. Belcar, Polendos e diversos outros companheiros são presos em represália, mas Targiana intercede por sua libertação. Floriano apaixonase por Leonarda e pede para ser seu cavaleiro, embora isso não o impeça de continuar cortejando outras mulheres. Antes dos casamentos dos dois irmãos, a tensão com os mouros cresce a níveis insuportáveis: uma embaixada do Grão Turco exige que Floriano seja entregue aos turcos em reparação pelo suposto rapto de Targiana; além disso, 
exige-se que Polinarda seja oferecida como esposa a um potentado mouro. Como as exigências não são atendidas, o Grão Turco, acompanhado do Sultão da Babilônia e de muitos outros senhores, desembarcam próximos a Constantinopla com inumerável exército. Os gregos contam com o apoio de todos os reis cristãos amigos, mas ainda assim o exército mouro é numericamente muito superior. Pouco antes da guerra ser desencadeada, o velho imperador Palmeirim de Oliva morre.

$\mathrm{Na}$ crudelíssima guerra entre mouros e cristãos, as mortes de ambos os lados são incontáveis. Por fim, apesar da vitória dos cristãos, a cidade de Constantinopla é reduzida a escombros e sua nobreza quase dizimada. Os reis e príncipes sobreviventes são levados por Daliarte a uma antiga ilha da maga Urganda, chamada Ilha Perigosa, onde os feridos são curados e os filhos dos heróis cristãos nascem e são criados. Estes serão os protagonistas das continuações (impressas e manuscritas) do Palmeirim de Inglaterra, entre os quais sobressaem D. Duardos (filho de Palmeirim de Inglaterra e Polinarda), Vasperaldo (filho de Floriano e Leonarda) e Primaleão (filho de Florendos e Miraguarda). 


\section{APÊNDICE 3}

\section{REPRODUÇÕES DE FÓLIOS DA CRÔNICA DE D. DUARDOS}

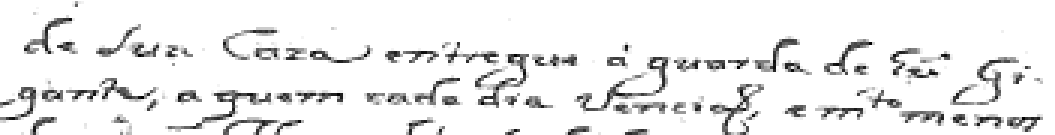

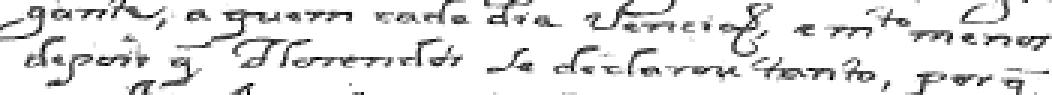

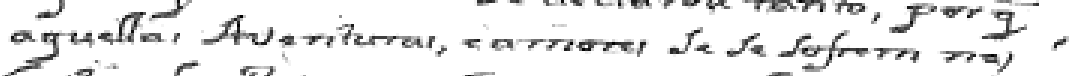

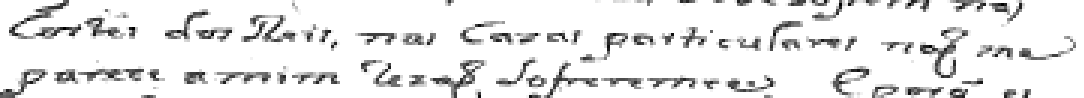

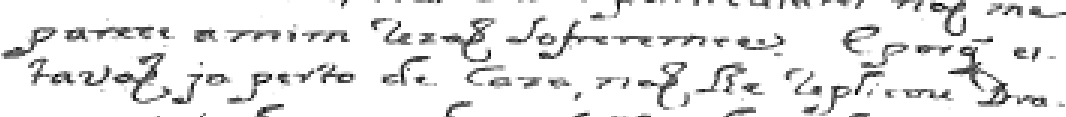

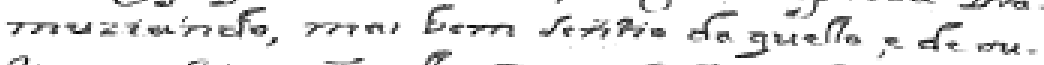

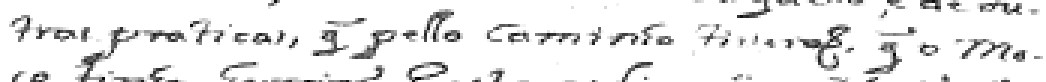
co Timfa Faprior, extrafidimario, = ge viell

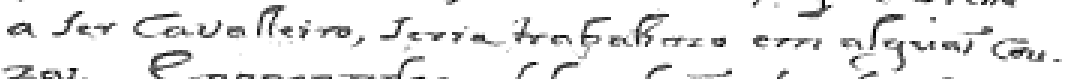

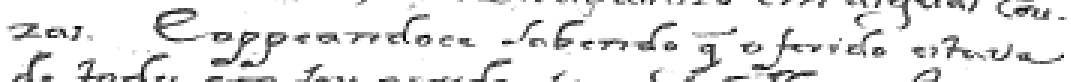

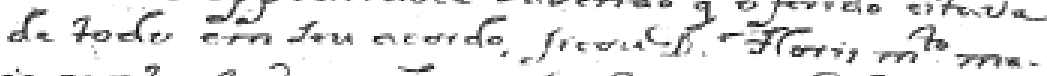

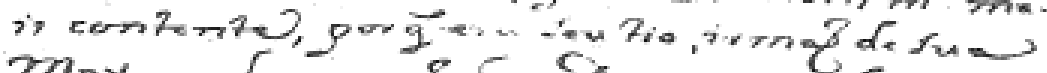

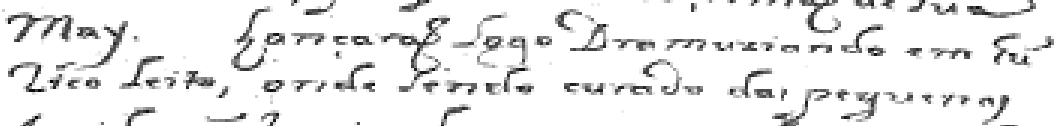

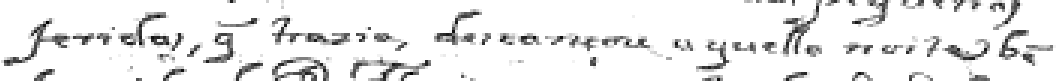

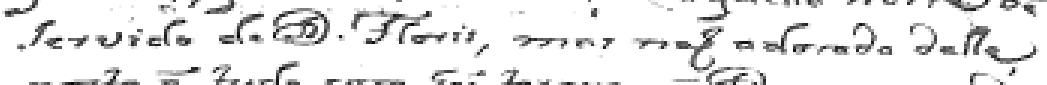

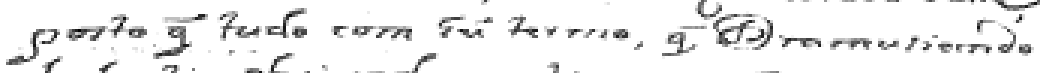
Ja terrio obriggato a ethimat a Corkeria, Zeppeitar apellow?

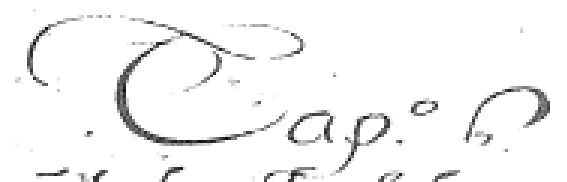

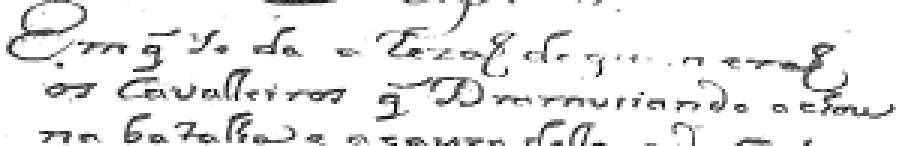

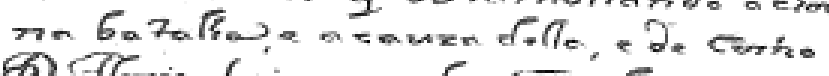
(8) Itoriz foi ormato cavaloin.

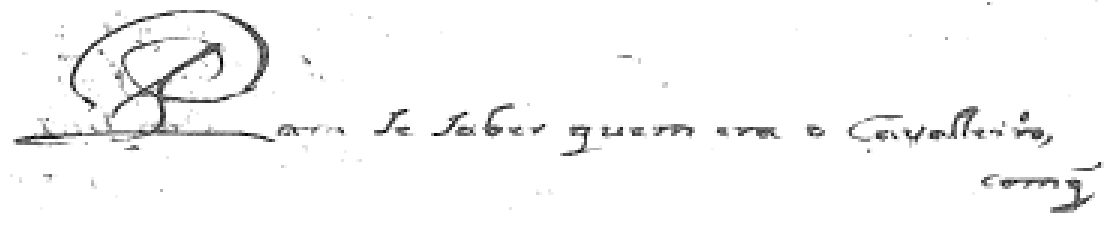

Fólio 13r, Cód. BNL 12904 (A) 
150

Cbronica

de de

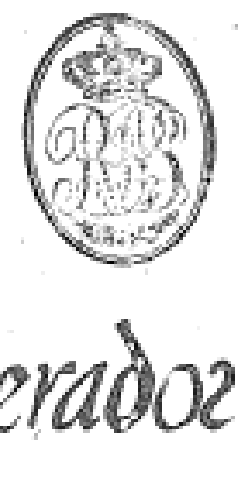

de Grocia

Primeira parte
Em que se conta das facanhas, que obrom - Orincipe Q. Duardos, e os mais Principes que com ellesecriaraó na Stha Perigoza do e Sabio Daliarte.

omposta

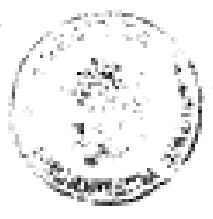

QorGuihermeer on -utor Glybernio, e copiada, por Simisberto 2 ac horro em quanto esteve ouipado, ou encantado no cume da Penha Rigursza, daserráda Lua pelto odio dis Sabio Mragamante

Folha de título, Cód. BNL 620 (B). 


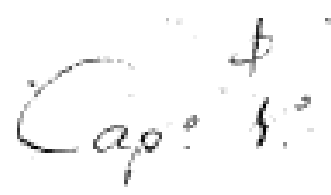

1

Cmane veda cortsa da vida que ravia.

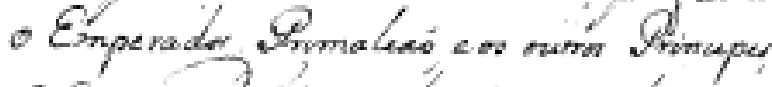
c Como Laversts de trimines de haves or Lorzais pue Crides a Corte.

$\partial$

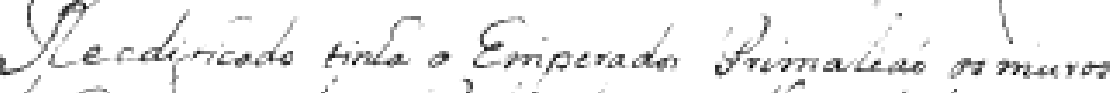

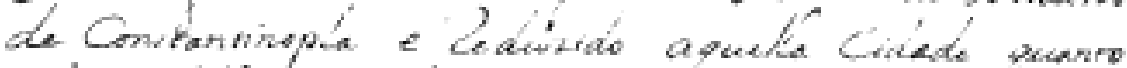

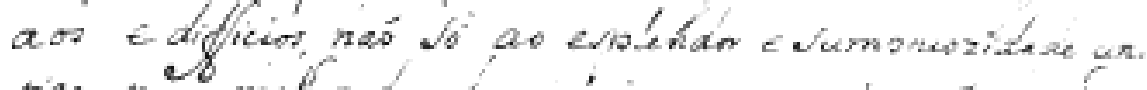

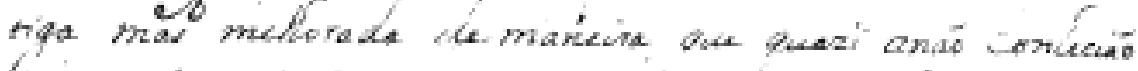

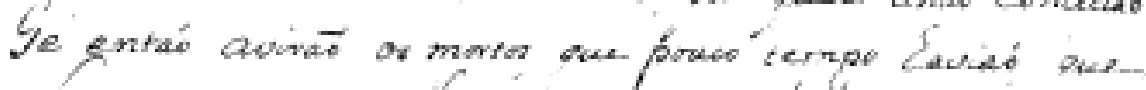

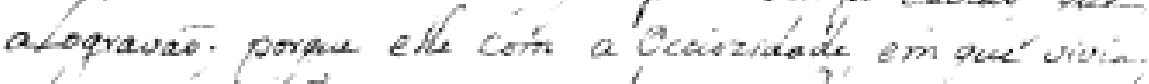

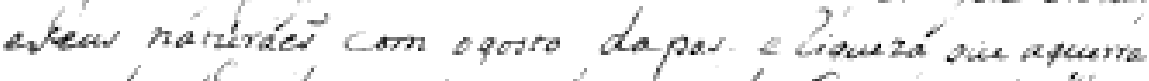

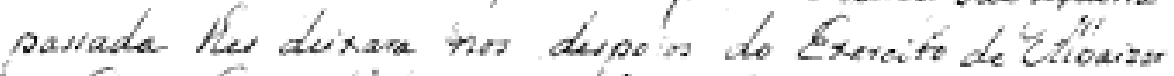

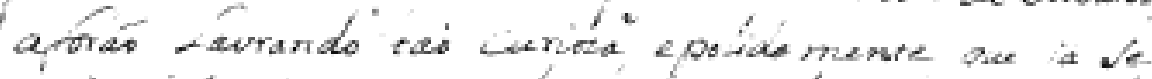

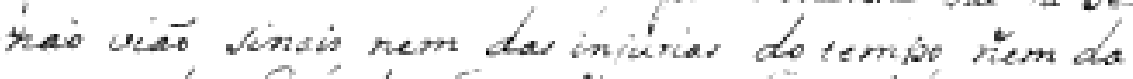

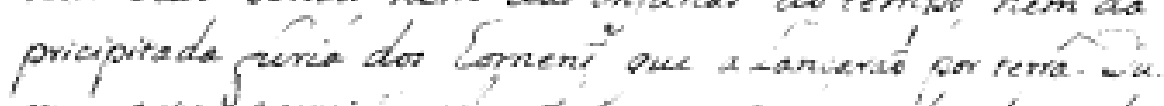

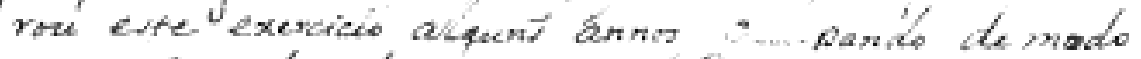

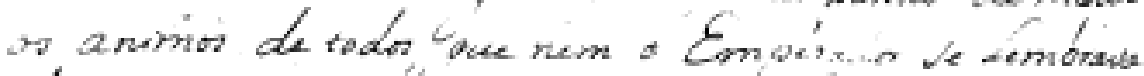

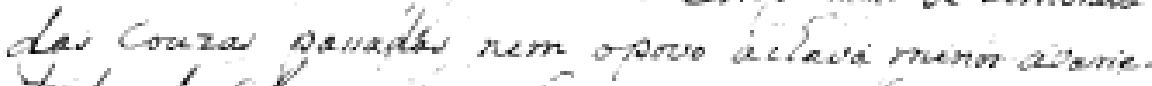

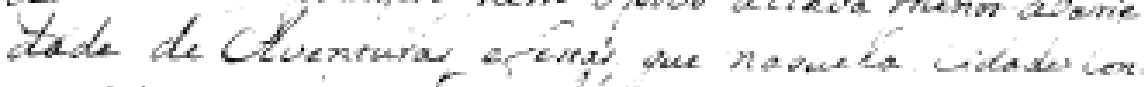

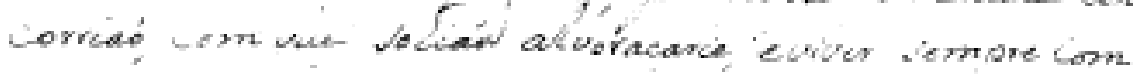
Conperiamento.

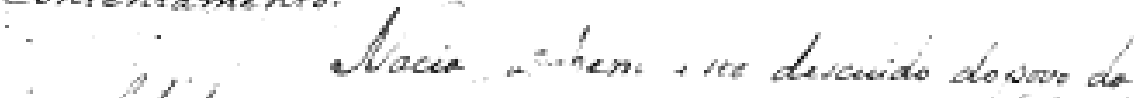

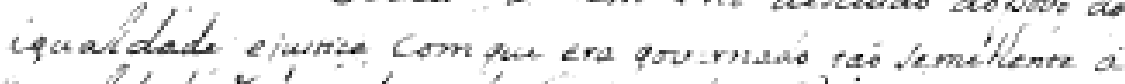

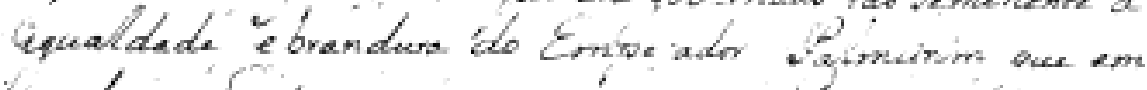

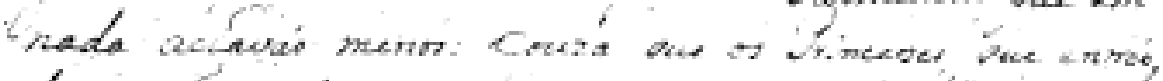

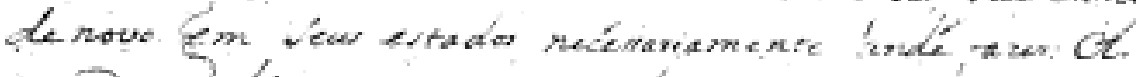

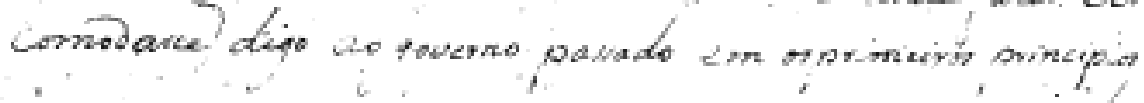

Fólio 1r, Cód. BNL 620 (B). 


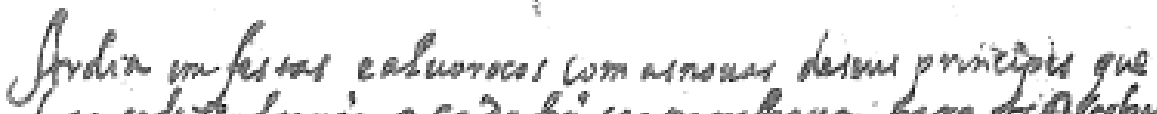

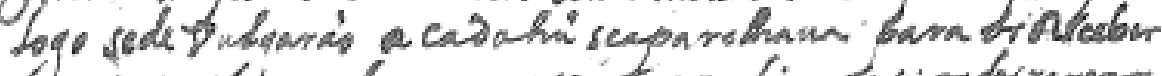

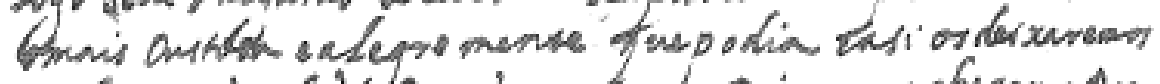

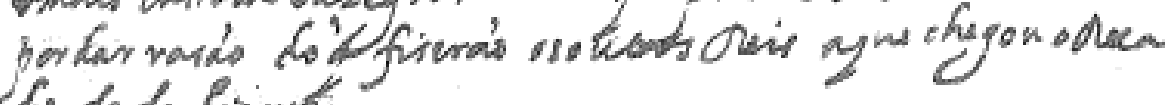
do de da fiarte,

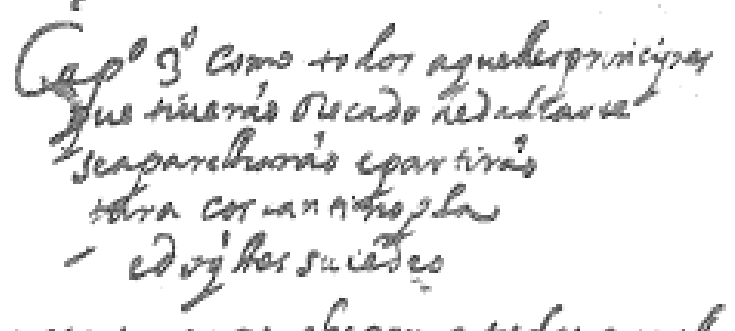

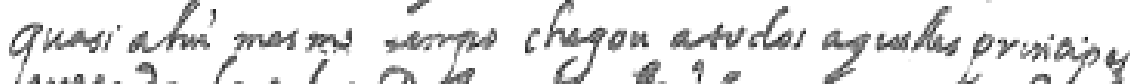

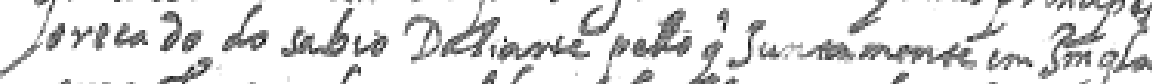

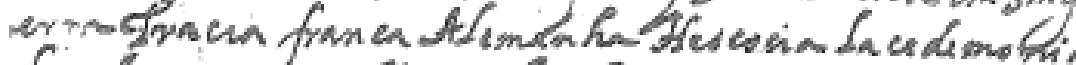

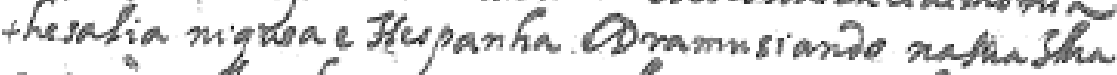
se comecarás a formprostes forlor comestranhorabuoro

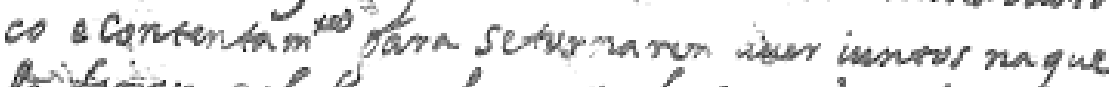

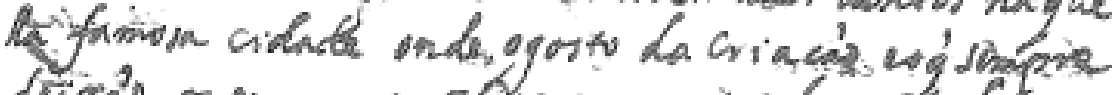

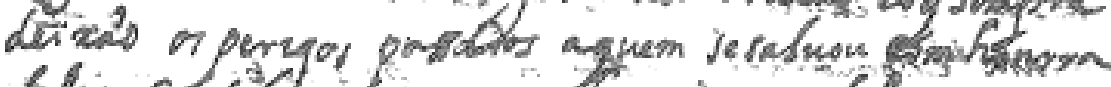

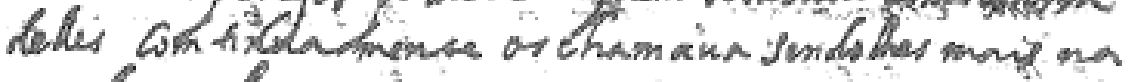
turah aquela ermi que apropir sun no gepromangor

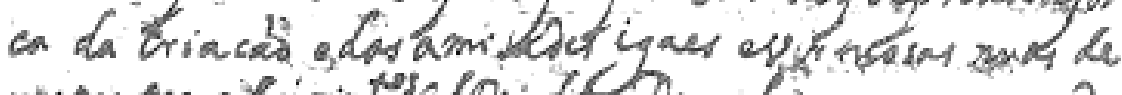

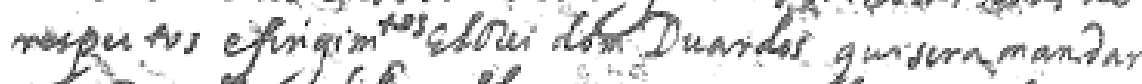

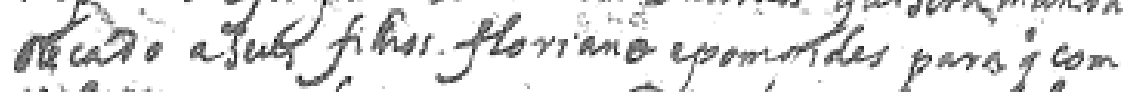

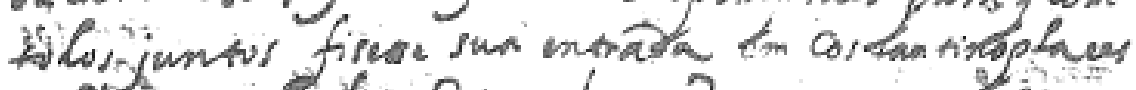

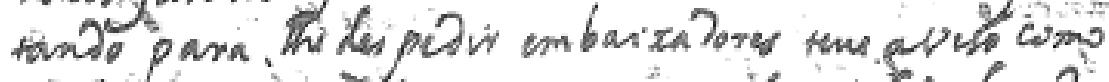

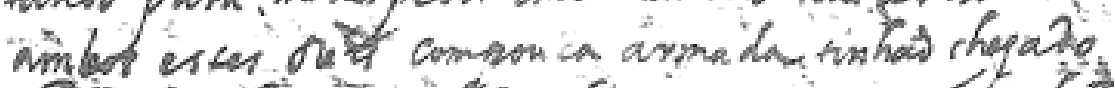

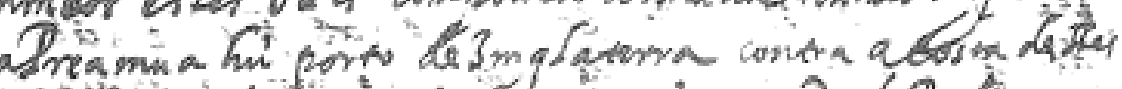

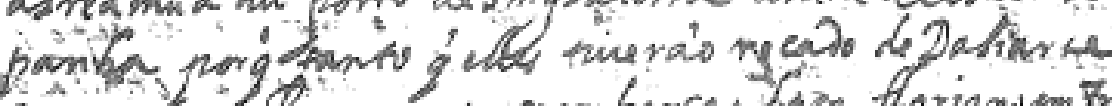

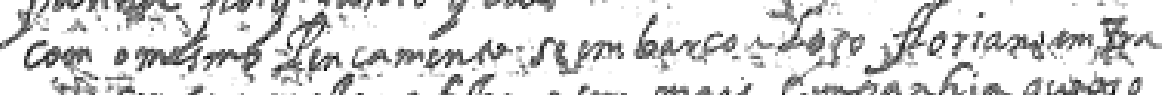

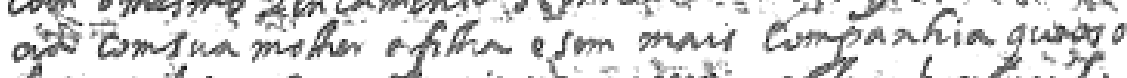

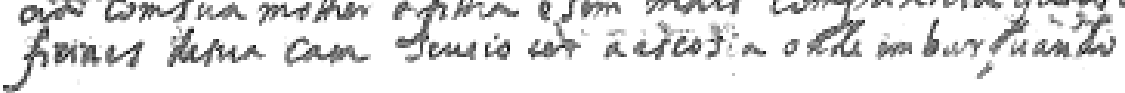

Fólio 4r, Cód. BNL 658 (C) 

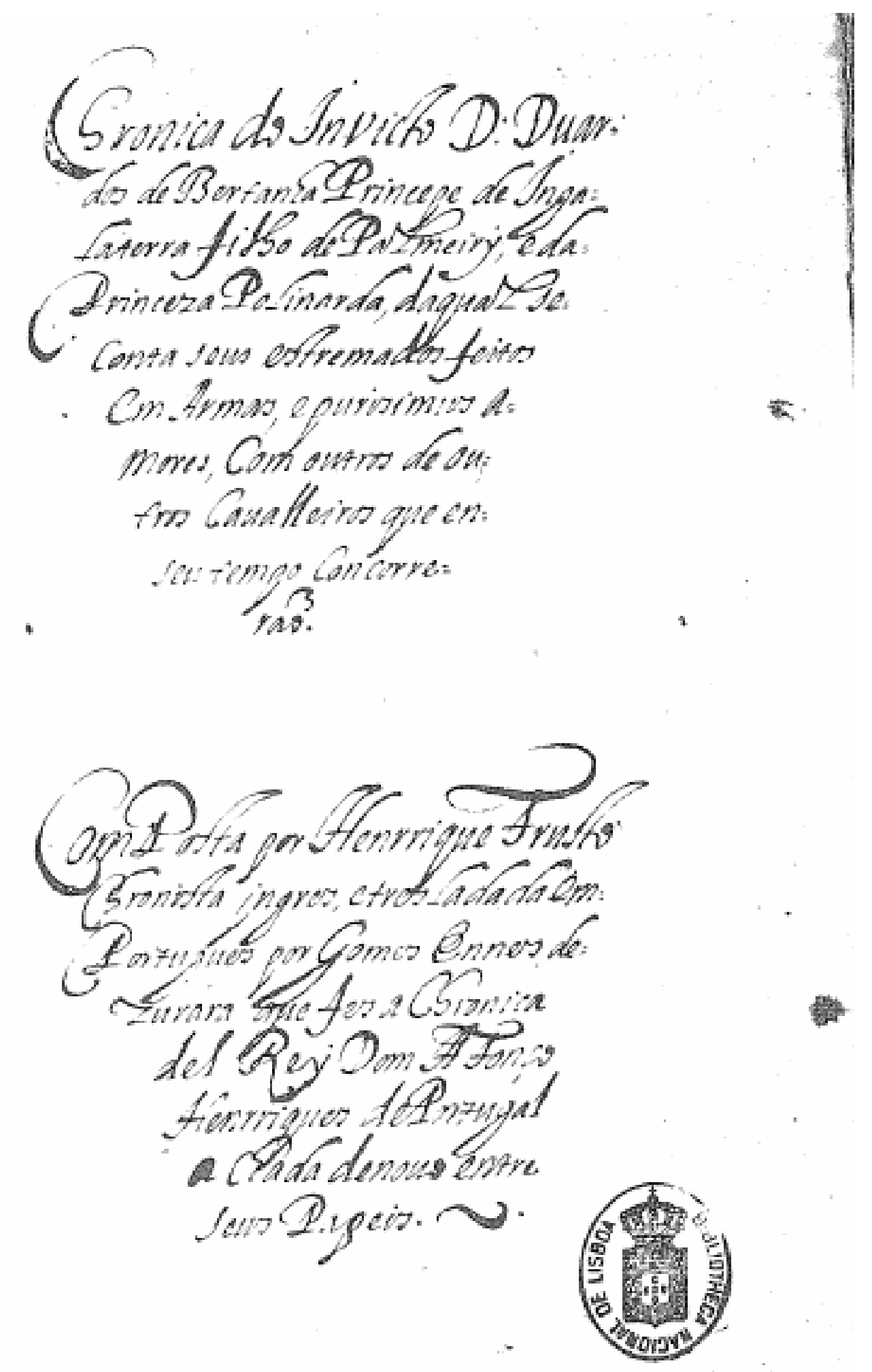

Folha de título, Cód. BNL 6828 (D). 


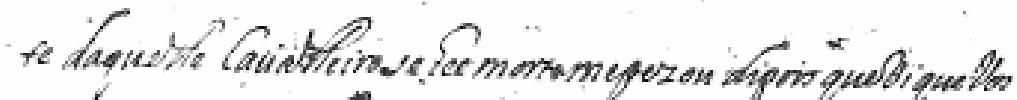

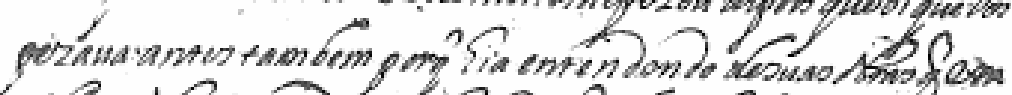

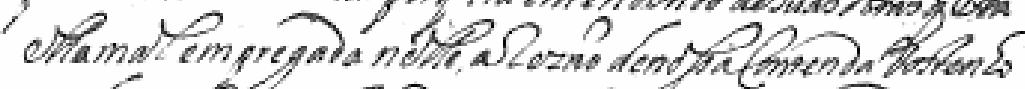

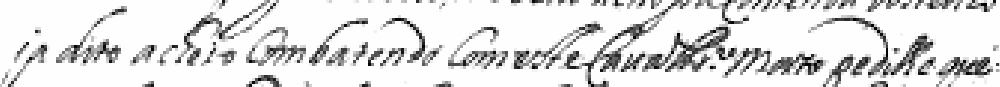

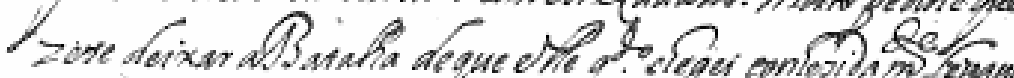

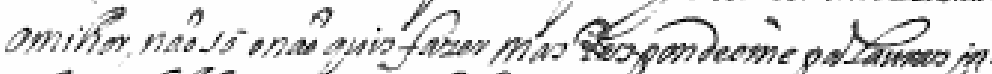

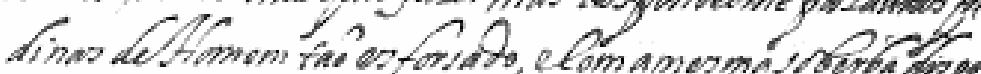
- $>$ D vor

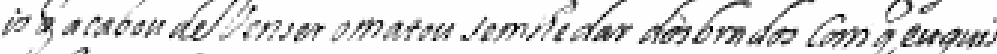

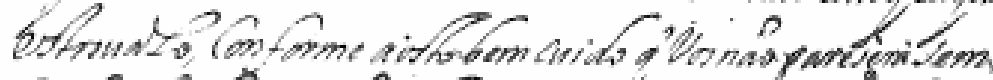

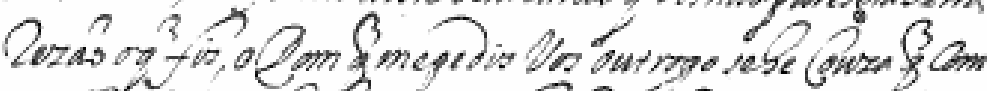

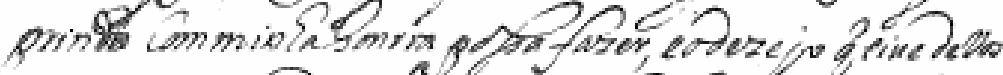

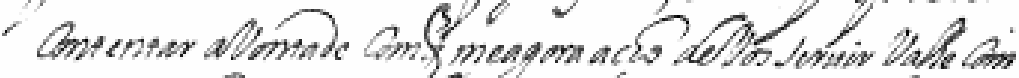

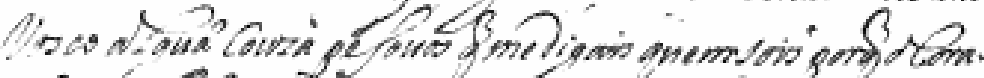

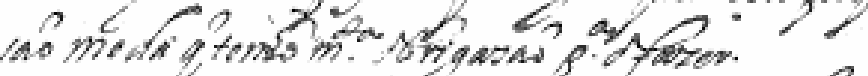

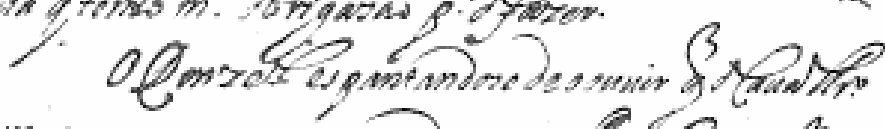

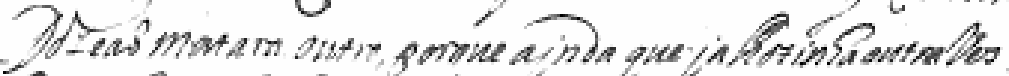

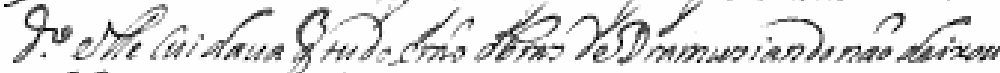

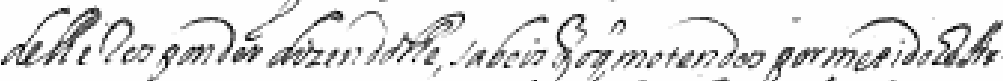

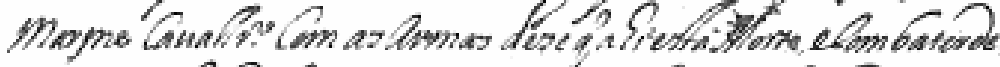

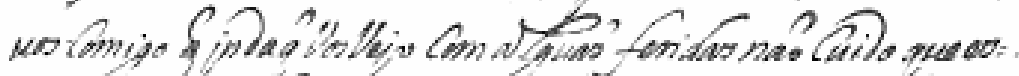

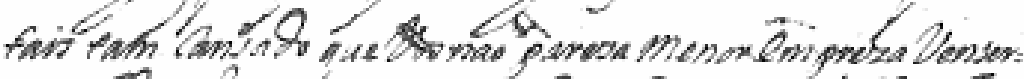

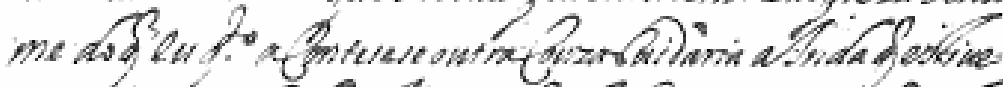

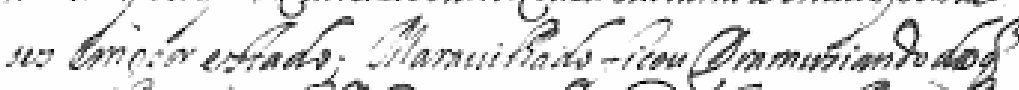

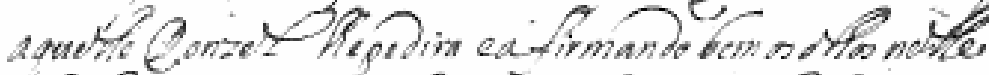

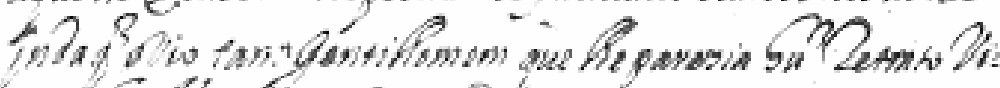

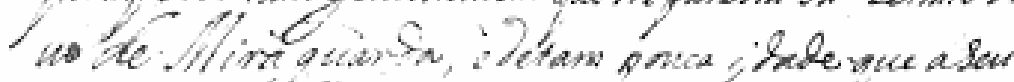

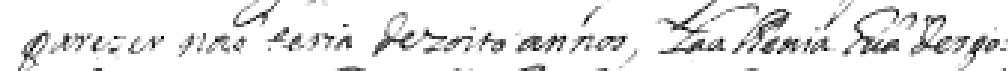

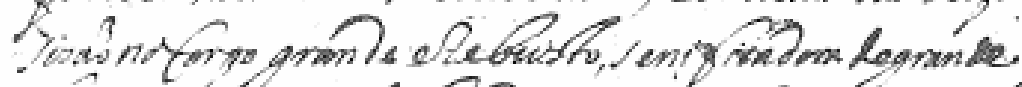

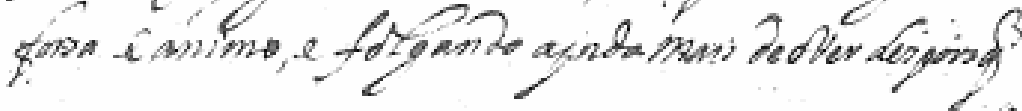

Fólio 10r, Cód. BNL 6828 (D) 


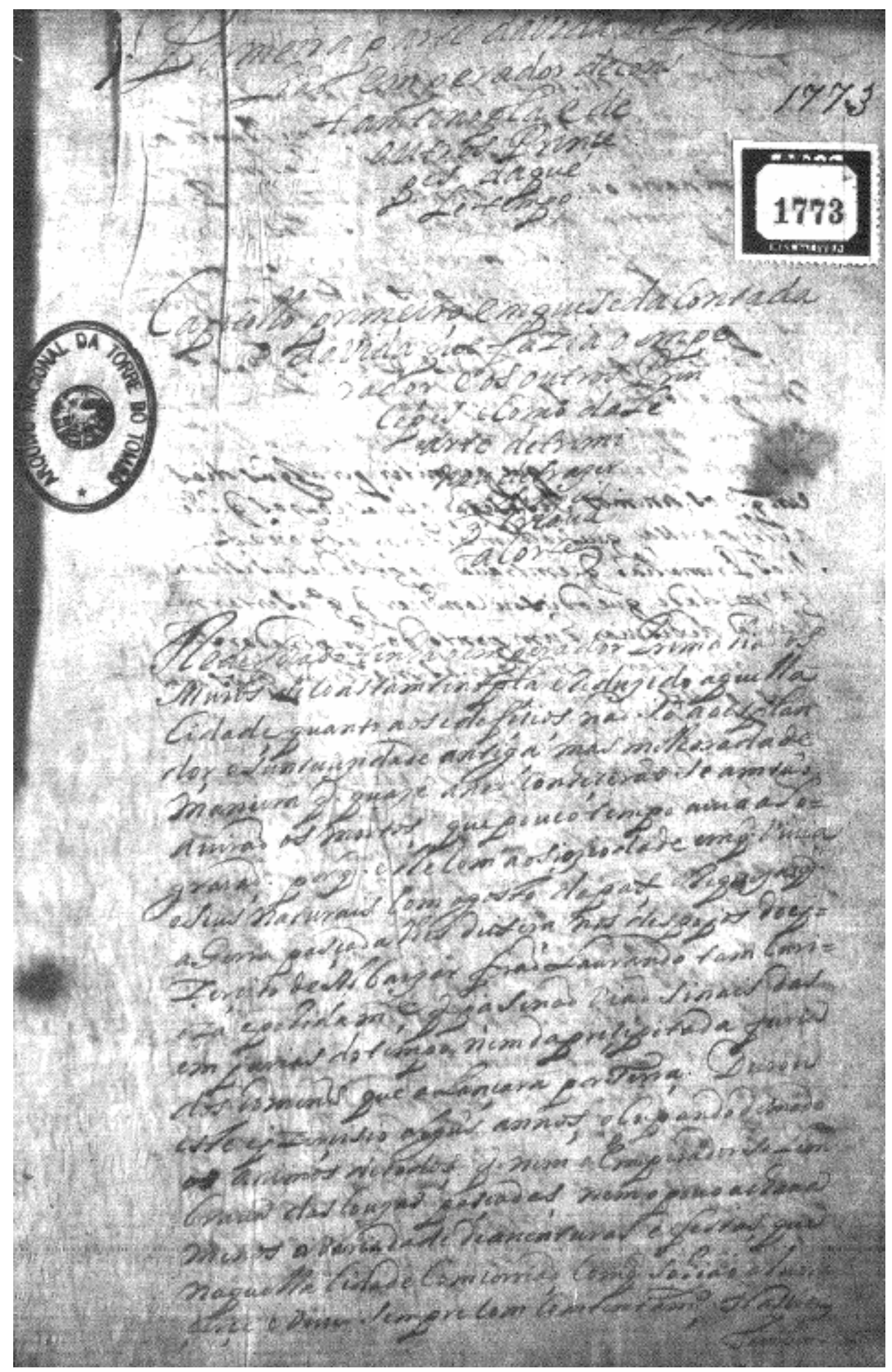

Fólio 1r, Cód. TT 1173 (E) 


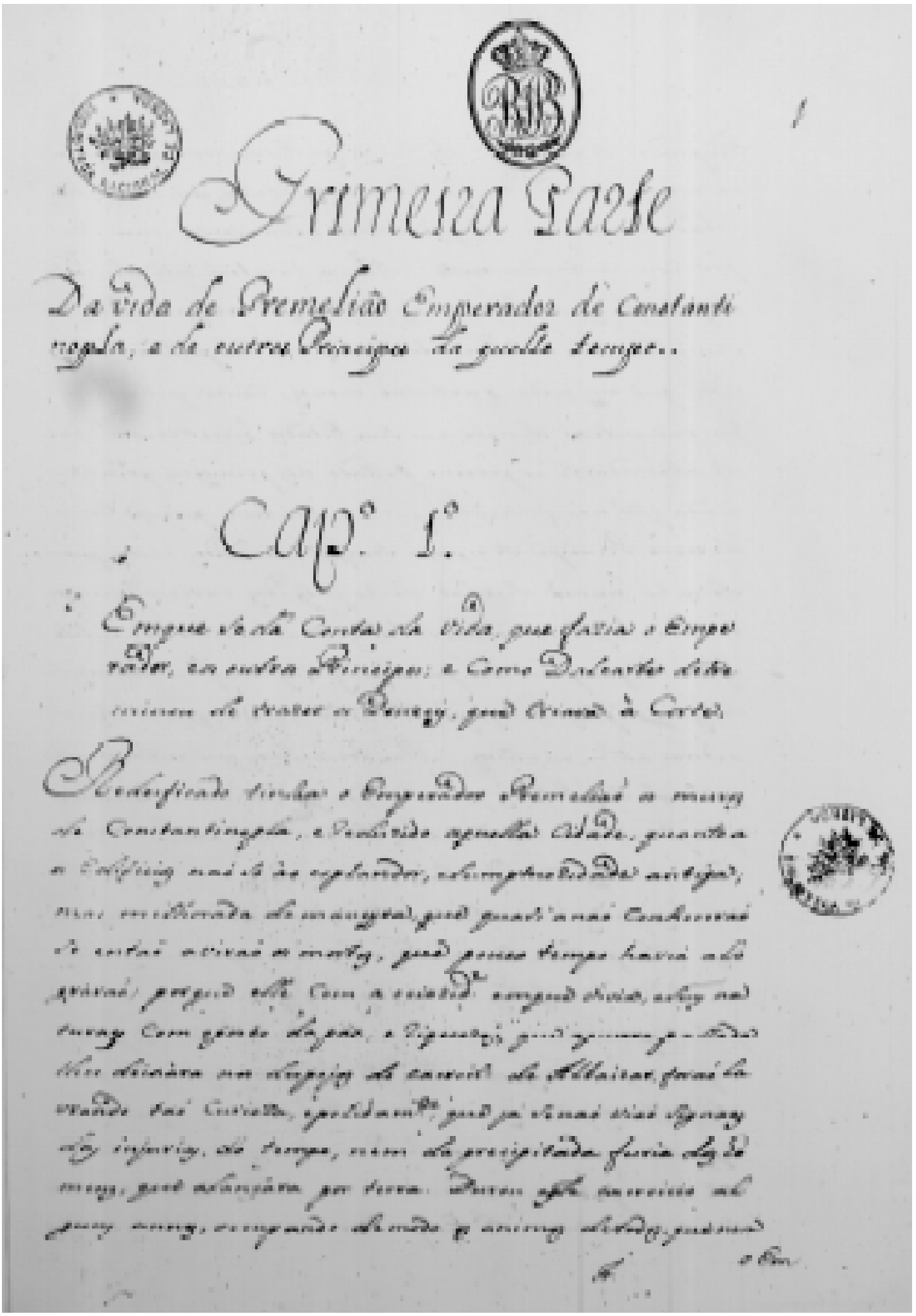

Fólio 1r, Cód. BNL 483 (F) 
umvardo cemprea tretionca iperal iss srometendokes quebrevemente or tenaria dabi, os metteo cen novorat norocor, eef peraincas, edes fiachou donizellas arcoter dor Qrinoifer que alti linhas se nhores pedindolber preare idamente que alwopermo

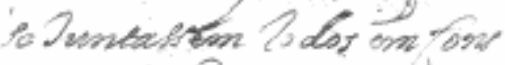
cankinoper forque impor lave afi a conderien on

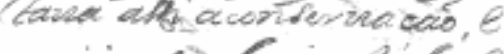
aupinene deveserlálos Qidai 2

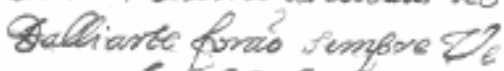

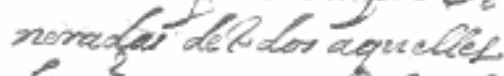
homes como onarelor de Qinor solf da arcoster a queckeqario abuar don leler

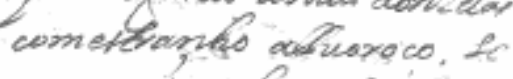

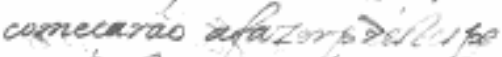
rafoulantroble com mo laver efilkor orque or 2 . whas guedis frownen daso

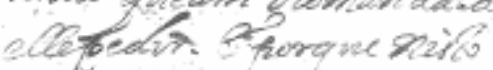
cons nomaes bo sempre omperadox $\leq$ Primelea

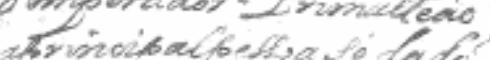

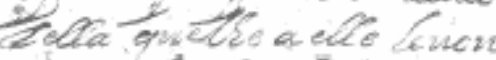
Peirle, le provirla der. Canubria sartinllarlezí como Veremos 920 proxisto cos:

Tapeliz doreca

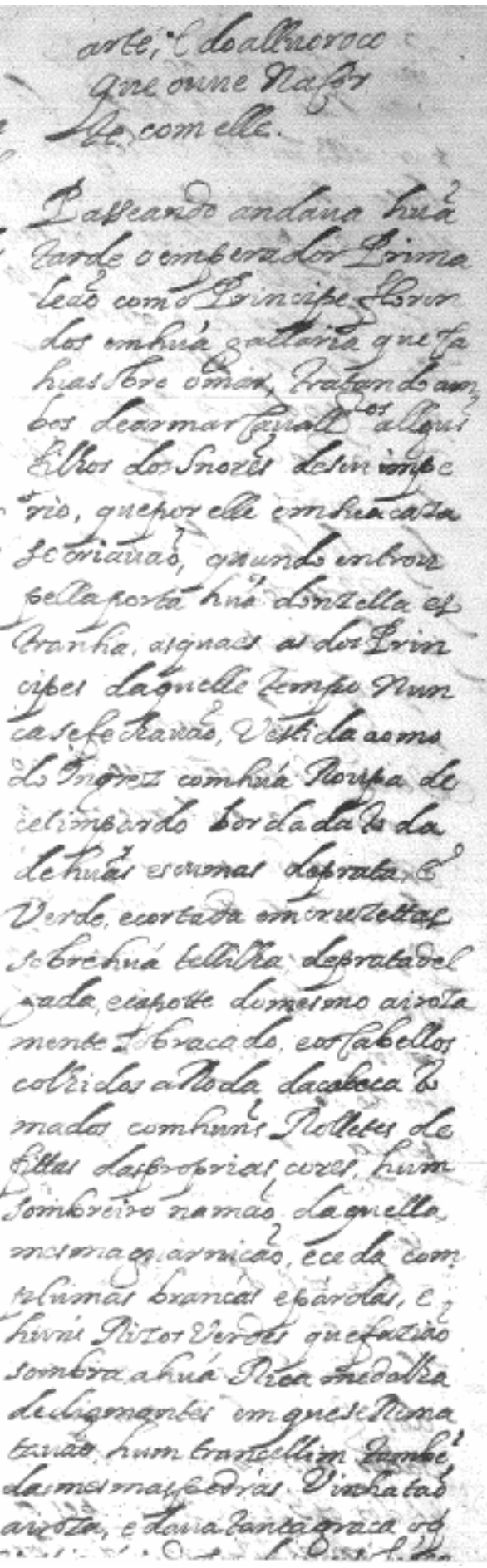

Fólio 3r, Cód. BNL 619 (G) 
UNIVERSIDADE DE SÃO PAULO

FACULDADE DE FILOSOFIA, LETRAS E CIÊNCIAS HUMANAS

DEPARTAMENTO DE LETRAS CLÁSSICAS E VERNÁCULAS

PROGRAMA DE PÓS-GRADUAÇÃO EM LITERATURA PORTUGUESA

\section{CRÔNICA DE D. DUARDOS (PRIMEIRA PARTE) CÓD. BNL 12904 \\ Edição e estudo}

Raúl Cesar Gouveia Fernandes

VOLUME II

São Paulo

2006 
UNIVERSIDADE DE SÃO PAULO

FACULDADE DE FILOSOFIA, LETRAS E CIÊNCIAS HUMANAS

DEPARTAMENTO DE LETRAS CLÁSSICAS E VERNÁCULAS

PROGRAMA DE PÓS-GRADUAÇÃO EM LITERATURA PORTUGUESA

\section{CRÔNICA DE D. DUARDOS (PRIMEIRA PARTE) \\ CÓD. BNL 12904}

Edição e estudo

Raúl Cesar Gouveia Fernandes

Tese apresentada ao Programa de PósGraduação em Literatura Portuguesa, do Departamento de Letras Clássicas e Vernáculas da Faculdade de Filosofia, Letras e Ciências Humanas da Universidade de São Paulo, para obtenção do título de Doutor em Letras.

Orientadora:

Profa. Dra. Lênia Márcia Mongelli

VOLUME II

São Paulo 


\section{SUMÁRIO}

\section{VOLUME I}

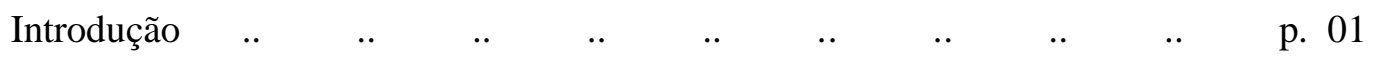

I. A CRÔNICA DE D. DUARDOS (PRIMEIRA PARTE) .. $\quad$.. $\quad$.. $\quad 10$

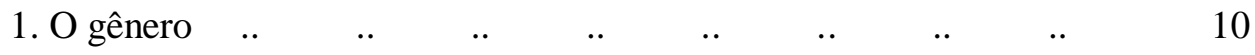

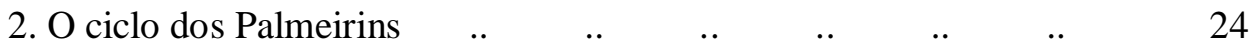

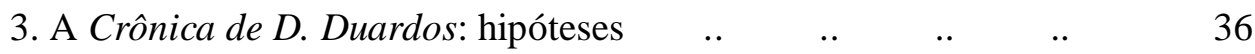

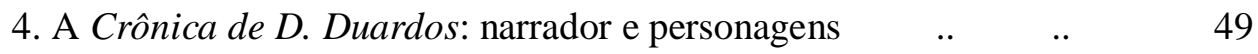

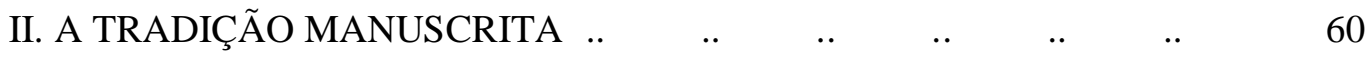

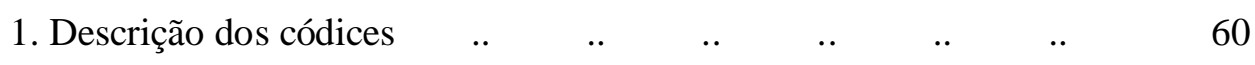

$\begin{array}{lllllllll}\text { 1.1. Códice A .. } & . . & . . & . . & . . & . . & . . & 62\end{array}$

$\begin{array}{lllllllll}\text { 1.2. Códice B .. } & . . & . & . & . . & . . & . . & . . & 65\end{array}$

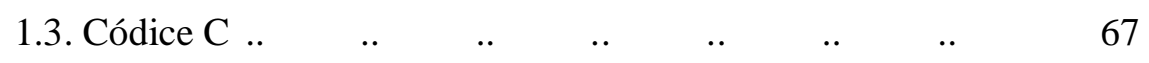

$\begin{array}{lllllllll}\text { 1.4. Códice D .. } & . . & . . & . . & . . & . . & . . & 71\end{array}$

$\begin{array}{lllllllll}\text { 1.5. Códice E .. } & . . & . . & . . & . . & . . & . . & 74\end{array}$

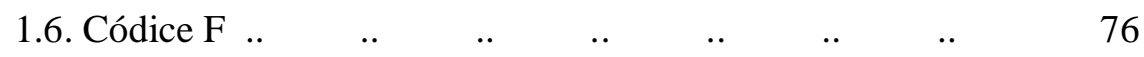

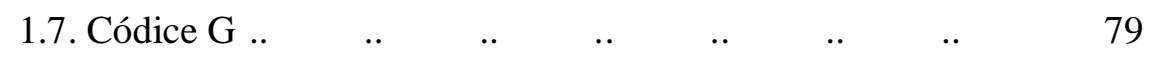

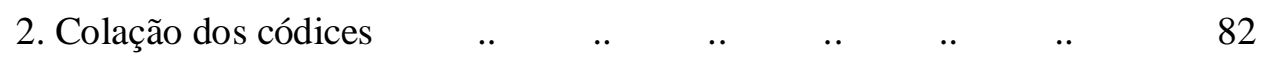

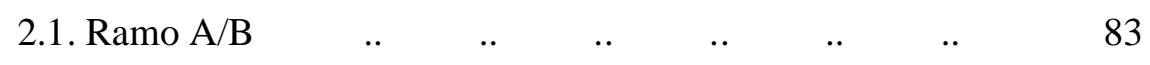

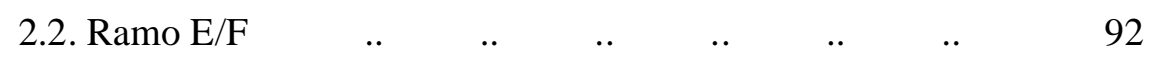

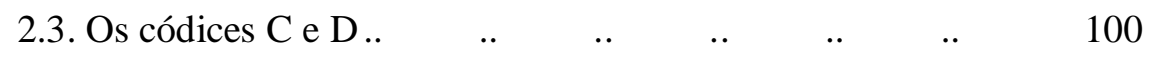

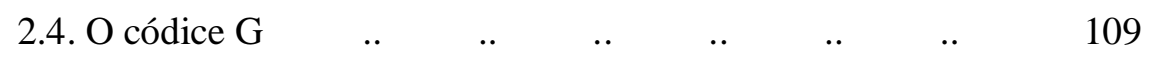

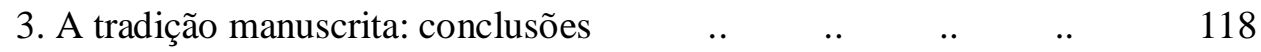

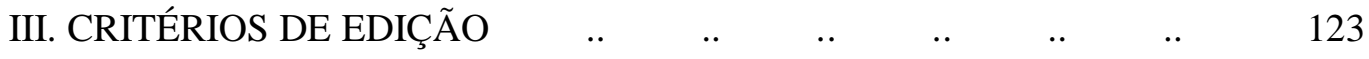

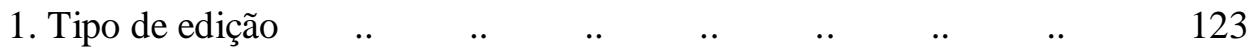

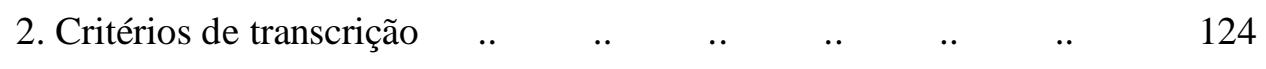

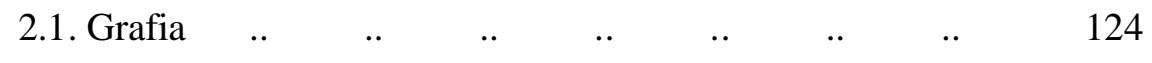

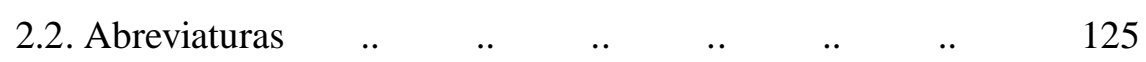

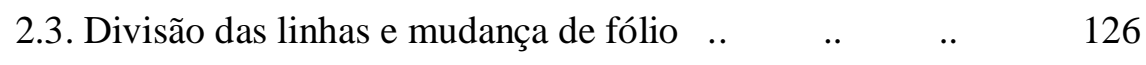

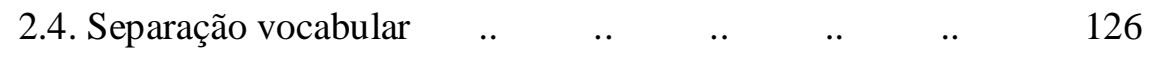




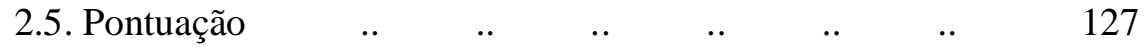

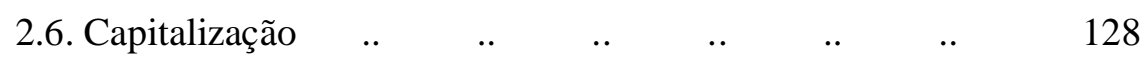

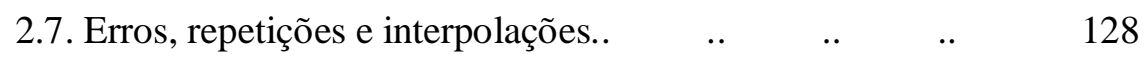

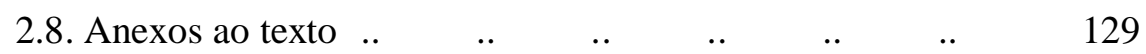

2.9. Alfabeto da Crônica de D. Duardos (Cód. BNL 12904).. 129

2.10. Exemplos dos sinais de pontuação $\quad$.. $\quad$. $\quad$. $\quad$. $\quad$. 131

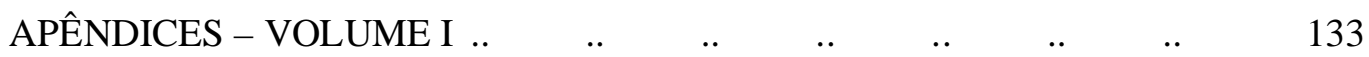

1. Quadro genealógico dos principais personagens do ciclo dos Palmeirins 134

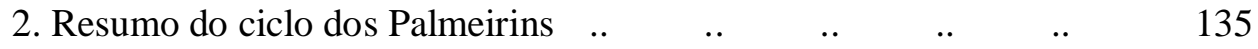

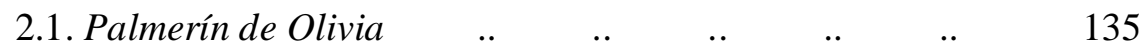

$\begin{array}{llllllll}\text { 2.2. Primaleón } & \text {.. } & \text {.. } & \text {.. } & \text {.. } & \text {.. } & \text {.. } & 139\end{array}$

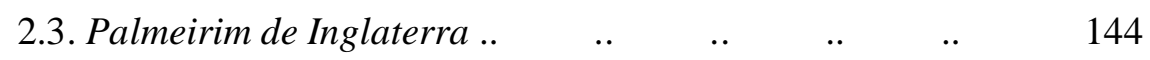

3. Reproduções de fólios dos códices da Crônica de D. Duardos $\quad$.. $\quad 148$

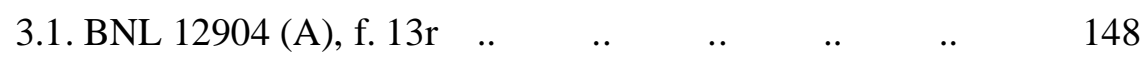

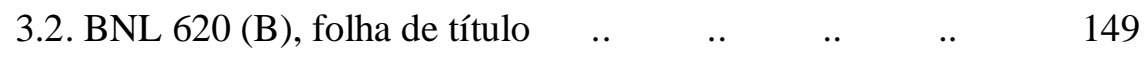

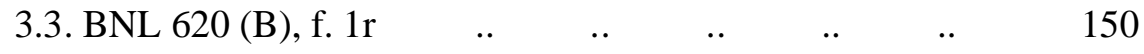

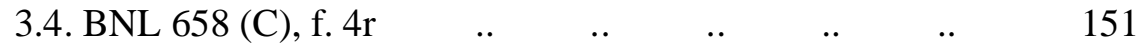

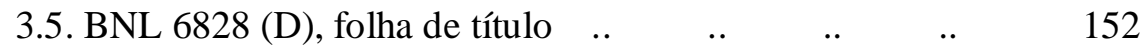

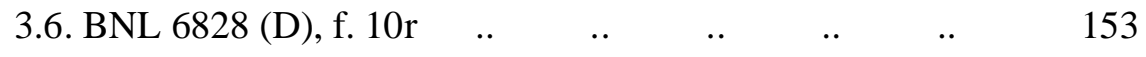

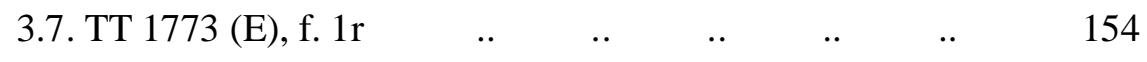

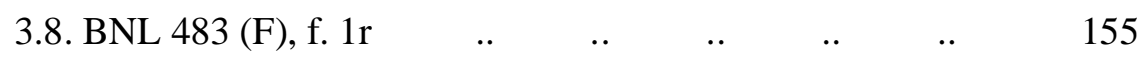

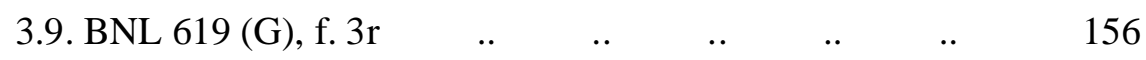

VOLUME II

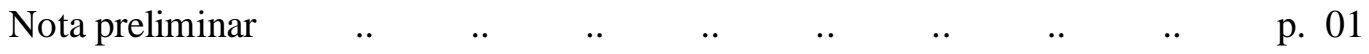

$\begin{array}{lllllllllll}\text { Folha de rosto (cód. BNL 12904) } & \text {.. } & \text {.. } & \text {. } & \text {. } & \text {.. } & \text {.. } & \text {. } & & 02\end{array}$

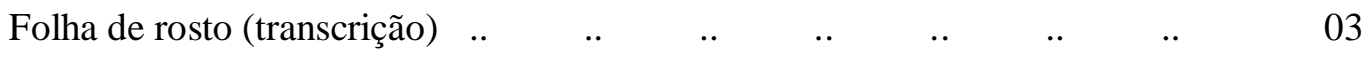

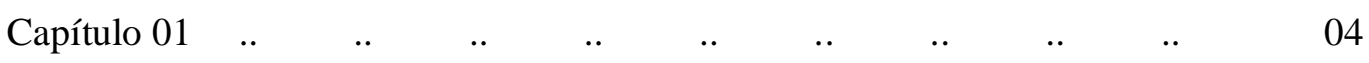

$\begin{array}{llllllllllllll}\text { Capítulo } 02 & . . & . . & . . & . . & . . & . . & . . & . . & . & & 08\end{array}$

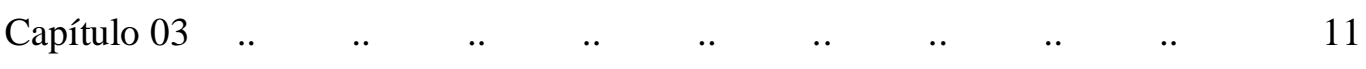

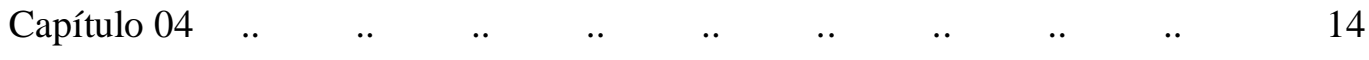


$\begin{array}{lllllllllllll}\text { Capítulo } 05 & . . & . . & . . & . . & . . & . . & . . & . . & . . & & 18\end{array}$

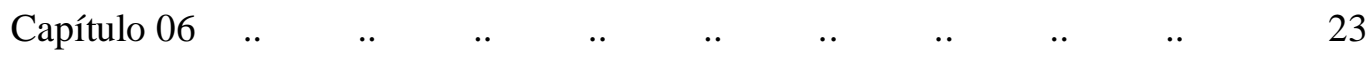

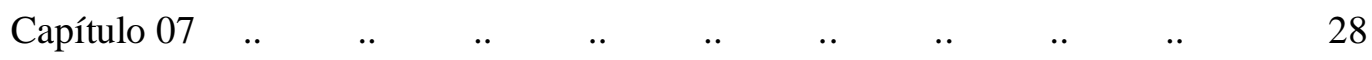

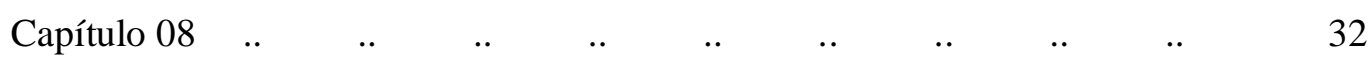

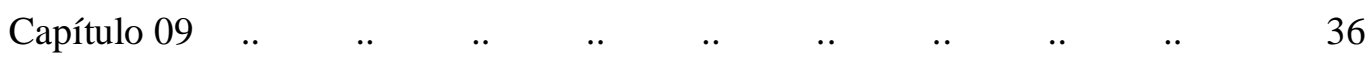

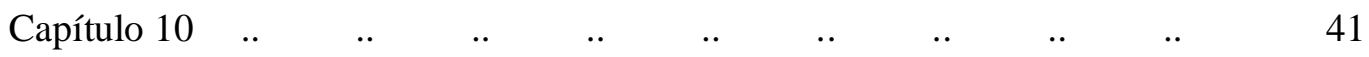

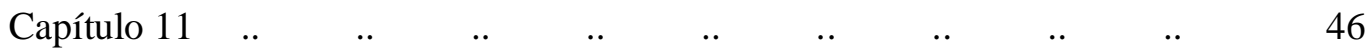

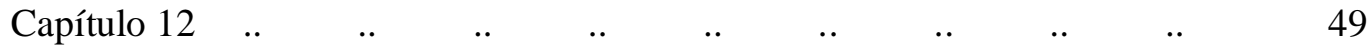

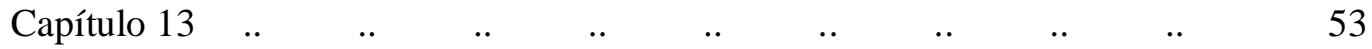

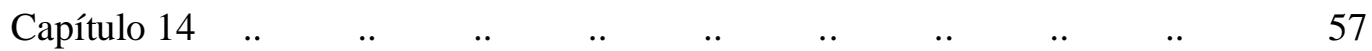

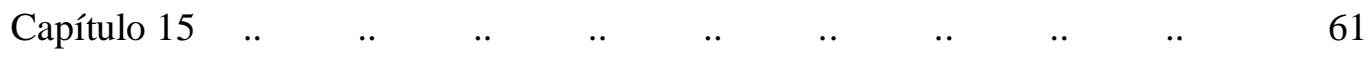

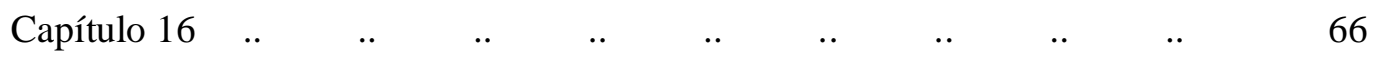

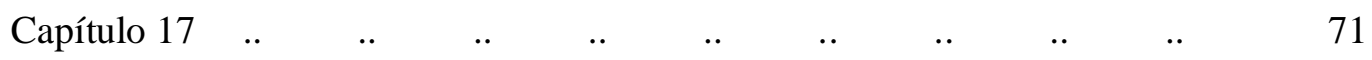

$\begin{array}{llllllllllllll}\text { Capítulo } 18 & . . & . . & . . & . . & . . & . . & . . & . . & . . & & 74\end{array}$

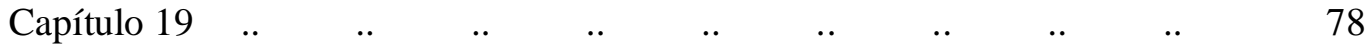

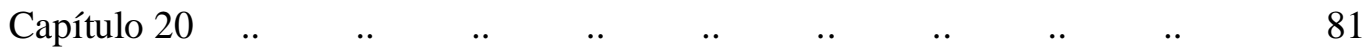

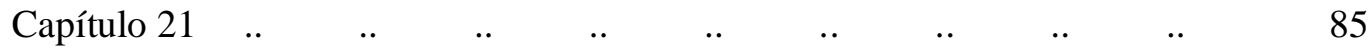

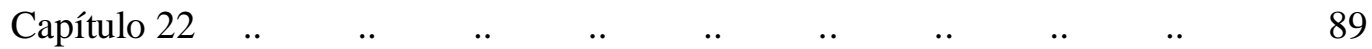

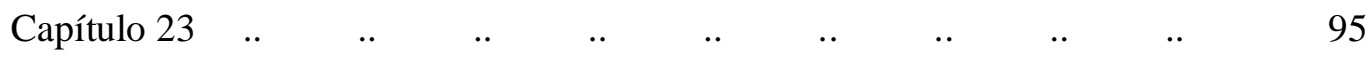

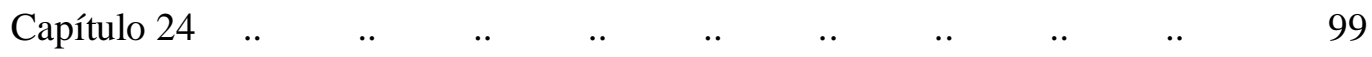

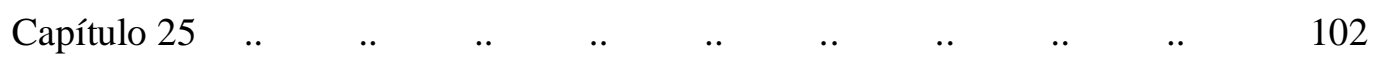

$\begin{array}{llllllllllllll}\text { Capítulo } 26 & . . & . . & . . & . & . & . & . & . . & . . & . . & . & & 106\end{array}$

$\begin{array}{lllllllllllll}\text { Capítulo } 27 & . . & . . & . . & . . & . . & . . & . . & . . & & . & & 110\end{array}$

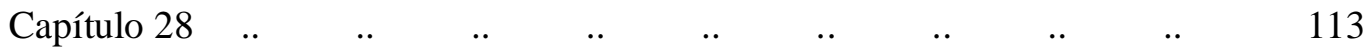

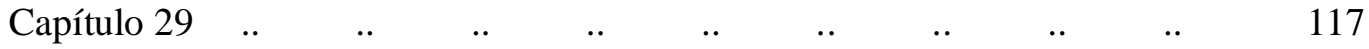

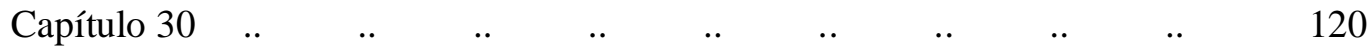

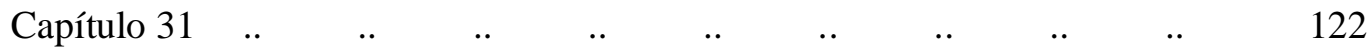

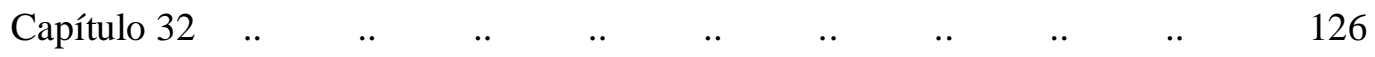

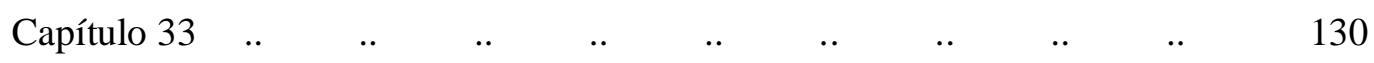

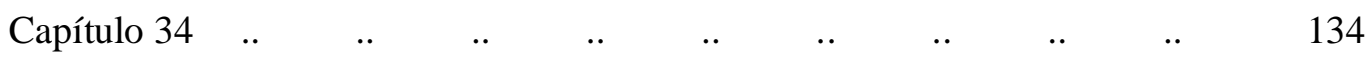

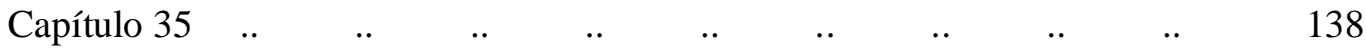

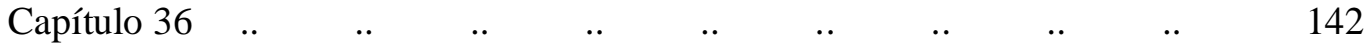




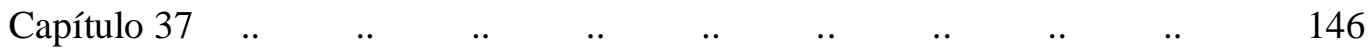

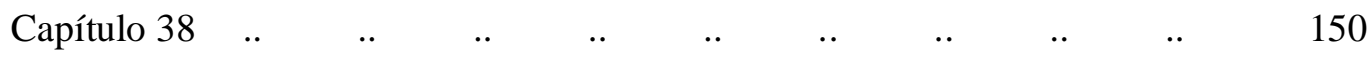

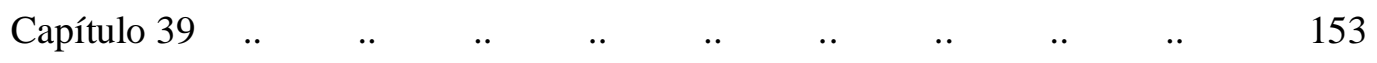

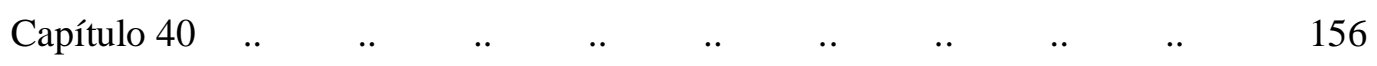

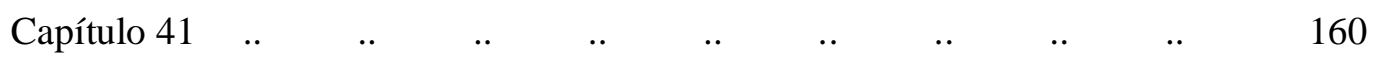

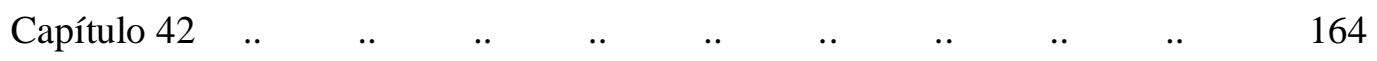

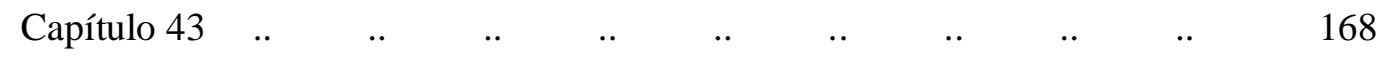

$\begin{array}{lllllllllllll}\text { Capítulo } 44 & . . & . . & . . & . . & . & . & . . & . & . & . . & . . & 172\end{array}$

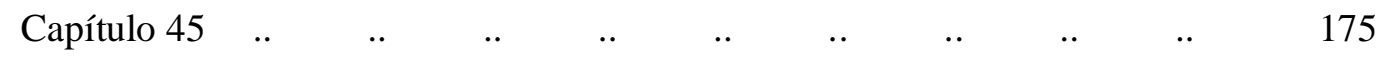

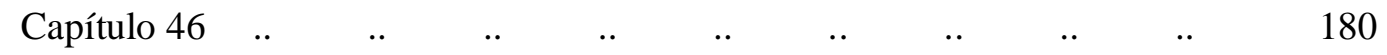

$\begin{array}{llllllllllllll}\text { Capítulo } 47 & . . & . . & . . & . & . & . & . & . & . & . & . . & . . & 184\end{array}$

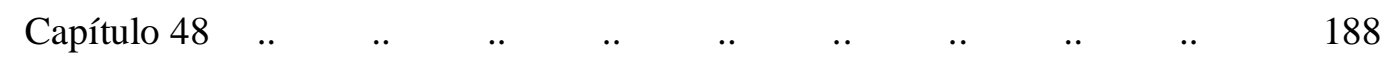

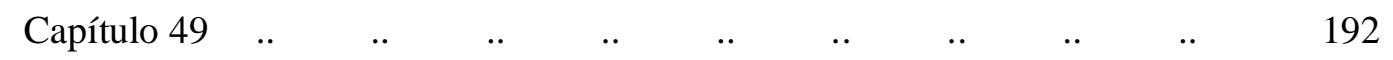

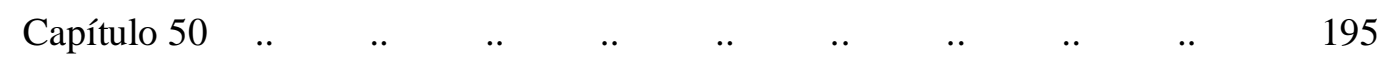

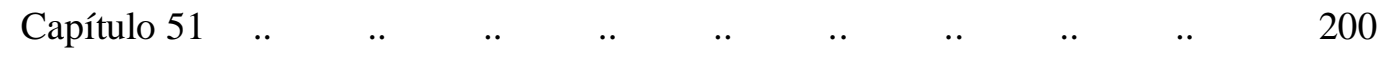

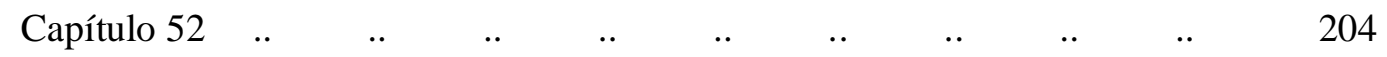

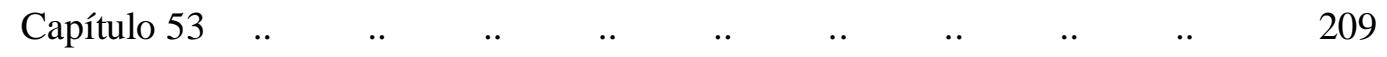

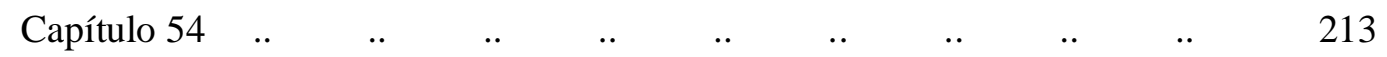

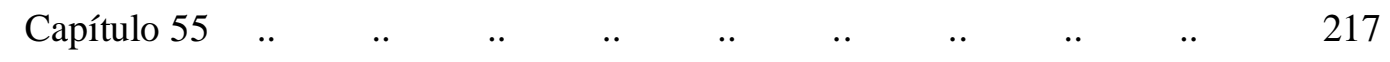

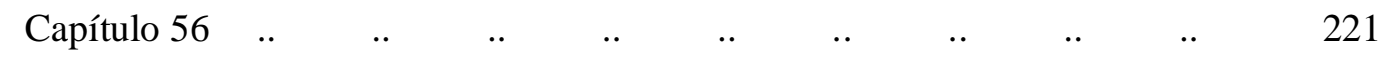

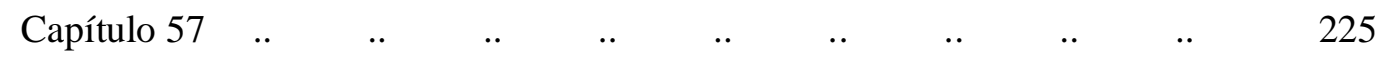

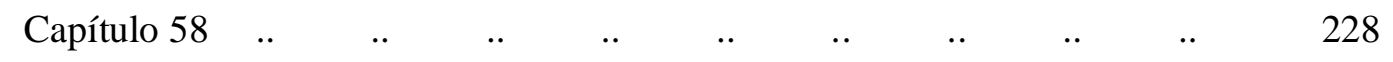

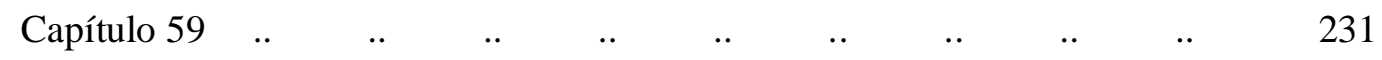

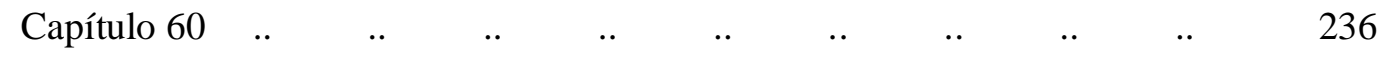

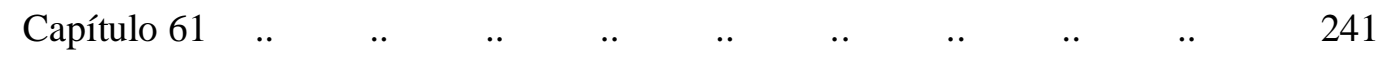

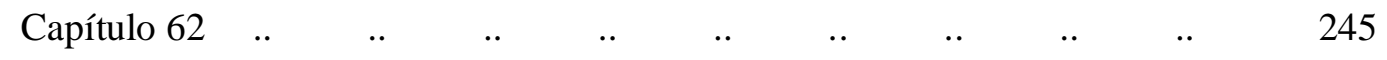

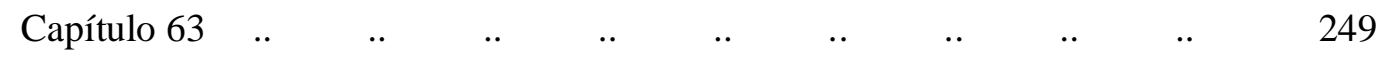

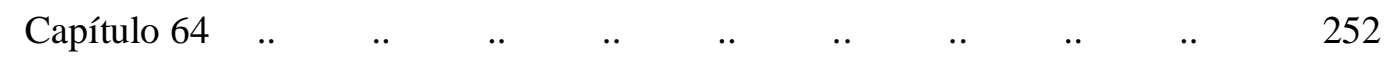

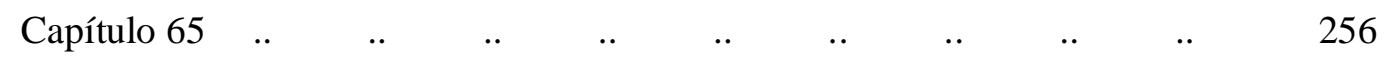

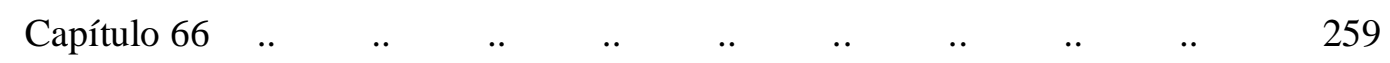

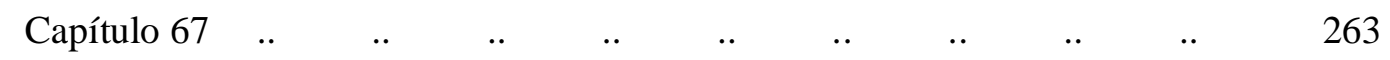

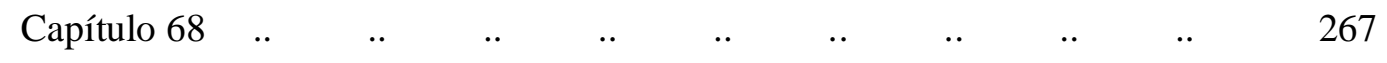




\begin{tabular}{|c|c|c|c|c|c|c|c|c|c|c|}
\hline Capítulo 69 & .. &.. & .. & .. & .. & .. & .. & .. & .. & 271 \\
\hline Capítulo 70 & .. &.. & .. & .. & .. & .. & .. & .. & .. & 275 \\
\hline Capítulo 71 &.. &.. & .. & .. & .. & .. &. & .. & .. & 279 \\
\hline Capítulo 72 &.. &.. & .. & .. & .. & .. & .. & .. & .. & 283 \\
\hline Capítulo 73 &.. &.. & .. & .. & .. & .. & .. & .. & .. & 287 \\
\hline Capítulo 74 &.. &.. & .. &.. & .. & .. & .. & .. & .. & 290 \\
\hline Capítulo 75 &.. &.. & .. & .. & .. & .. & .. & .. & .. & 293 \\
\hline Capítulo 76 & .. &.. & .. & .. & .. & .. & .. & .. & .. & 296 \\
\hline Capítulo 77 &.. &.. & .. &.. & .. & .. & .. & .. & .. & 300 \\
\hline Capítulo 78 &.. &.. & .. & .. & .. & .. & .. & .. & .. & 305 \\
\hline Capítulo 79 & .. &.. & . & .. & $\cdot$ & .. & .. & .. & .. & 308 \\
\hline Capítulo 80 & .. &.. & $\cdot$ & .. & .. & .. & .. & .. & .. & 312 \\
\hline Index ... & .. &.. & .. & .. & .. & .. & .. & .. & .. & 316 \\
\hline \multicolumn{4}{|c|}{ APÊNDICES - VOLUME II. } & .. & .. & .. & • & .. & .. & 322 \\
\hline \multicolumn{2}{|c|}{ 1. Glossário } & .. & . & .. & .. & .. & .. & .. & .. & 323 \\
\hline \multicolumn{2}{|c|}{ 2. Índices } & .. &.. &.. & $\cdot$. & .. &.. & .. & .. & 356 \\
\hline & \multicolumn{4}{|c|}{ 2.1. Índice de personagens } & .. & .. & 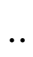 & .. & .. & 357 \\
\hline & \multicolumn{4}{|c|}{ 2.2. Índice geográfico.. } & .. & .. & .. & .. & .. & 365 \\
\hline & \multicolumn{4}{|c|}{ 2.3. Índice de obras citadas } & .. & .. & .. & .. & .. & 367 \\
\hline Bibliografia & .. &.. &.. & .. & .. & .. & .. & .. & .. & 368 \\
\hline
\end{tabular}




\section{Nota preliminar}

Os critérios de transcrição do texto foram descritos anteriormente.

Resta apenas observar que o texto transcrito é acompanhado de notas e anexos, organizados da seguinte forma: na elaboração das notas de rodapé, procuramos atender a três objetivos principais: 1. indicar as variantes textuais mais significativas entre as diferentes cópias examinadas; 2. esclarecer as passagens do texto que oferecem maiores dificuldades de compreensão; 3. ressaltar os elementos de coesão (concordâncias ou discrepâncias) com as demais obras do ciclo dos Palmeirins.

Ao transcrever em notas de rodapé passagens de outros códices, a fim de cotejálas com a lição da cópia transcrita, utilizamos os mesmos critérios de transcrição descritos no capítulo 3 (vol. 1 deste trabalho). Quando a lição alternativa apresentada em rodapé divergir da apresentada pelo manuscrito que transcrevemos, os elementos destoantes serão indicados em itálico.

Após o texto, são apresentados alguns anexos. O primeiro é um glossário; o segundo é composto por índices (de personagens, de localidades e de obras citadas), cujo objetivo é auxiliar o leitor a localizar-se em meio à enorme quantidade de nomes e lugares citados na obra. 


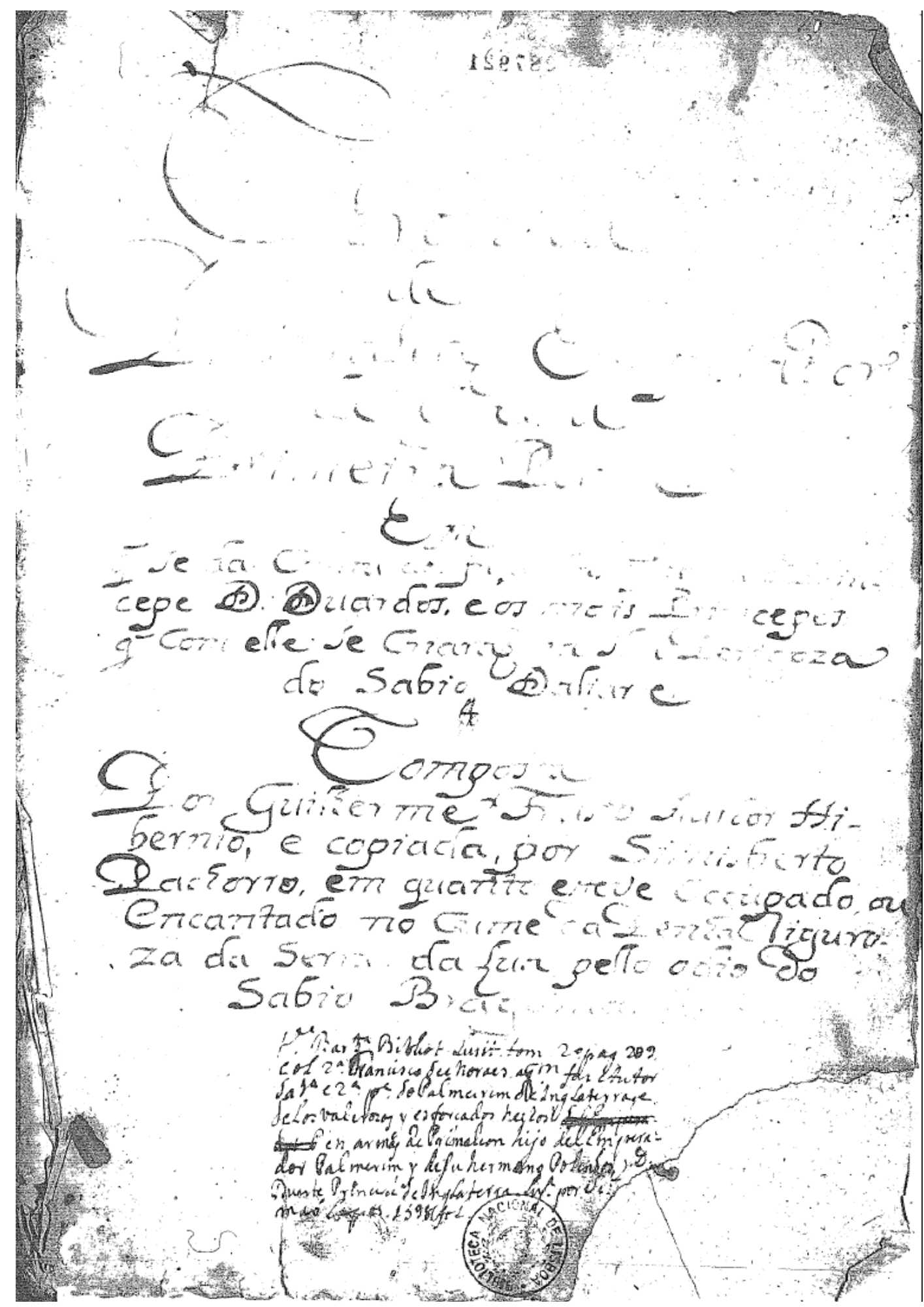

Folha de rosto do cód. BN 12904 


\title{
Chronica
}

\author{
de \\ Primaleão Emperador \\ de Grecia \\ Primeira Parte \\ Em
}

que se da conta das façanhas, que obrou o Prin|cepe D. Duardos, e os mais Princepes $\mid$ que com elle se criarão, na Ilha Perigoza | do Sabio Daliarte.

\section{Composta}

Por Guilherme Frusto, Author Hi|bernio, e copiada, por Simisbero | Pachorro, em quanto esteve occupado, ou | encantado no Cume da Penha Riguro|za, da Serra da Lua, pello odio do Sabio Bragamante.

M. Barb ${ }^{\text {a }}$ Bibliot. Lusit. tom. $2^{\circ}$ pag. $289 \mid$ col. $2^{\circ}$ Francisco de Moraes, a quem fas Autor $\mid$ da $1^{\mathrm{a}}$ e $2^{\mathrm{a}}$ pe. do Palmeirim de Inglaterra, e $\mid$ de los valerosos y esforçados hechos [rasura] | [rasura] en Armas de Primaleon hijo del Empera|dor Palmerim y de su hermano Polendos y D. | Duarte, Princepe de Inglaterra. Lisboa, por Simão Lopes 1598 fol. 1 


\section{[1r] Capitulo $1^{\circ}$}

\section{Em que se da conta da vida, que fazia | o Emperador Primaleão, e os outros | Principes e como Daliarte detreminou | de trazer os Donzeis, que criava à corte.}

Reedificado tinha o Emperador Primaleão | os muros de Constantinopla, e reduzido aquel|la cidade quanto aos edifficios, não só ao esplendor | e sumptuozidade antiga, mas melhorada de | maneira, que quazi a não conhecerão, se então a | virão os mortos, que pouco tempo havião, que a logra|vão ${ }^{1}$; por que elle com a Occiozidade, em que vivia, e | seus naturaes, com o gosto da pas, e riqueza, que a guerra passada lhes

10 deixara, nos despojos do Exer|cito de Abbaisar, a forão lavrando tão curioza, e | polidamente, que ja se não vião sinais, nẽ das | injurias do tempo, nem da pricipitada furia | dos homẽns, que a lançara por terra ${ }^{2}$. Durou este | exercicio algũns annos, occupando de modo | os animos de todos, que nem o Emperador se lem|brava das couzas passadas, nem o povo achava | menos a variedade de aventuras, e festas, que na |

15 quella cidade concorrião, com que sohião alvoroçar|ce, e viver sempre com contentamento. [espaço] | Nascia tambem este descuido do povo, da igual|dade, e justiça, com que era governado, tão seme|lhante á igualdade ${ }^{3}$, e brandura do Emperador | Palmeirim ${ }^{4}$, que em nada o achavão menos: cou|za que os Princepes, que entrão de novo em seus esta|dos, necessariamente ande fazer. Acomodarce, digo ${ }^{5}$, | ao governo

20 passado em os primeiros principios, in|da que não fosse a seu parecer tão bom, porque $\|$ [1v] como do novo Princepe se esperão sempre | novidades, e estas quando as há nunca deixão de ser | julgadas variamente, importa mais à quieta|ção dos subditos o não alterar de subito o go|verno que permitir por algũns dias, em quanto os | animos se assegurão, algũas couzas, que aelle lhe | pareça que se devem alterar assi, ou assi. [espaço] Mas |

25 Primaleão, que entrara na posse de seus estados | ja em idade que o deixou conhecer,

\footnotetext{
${ }^{1} \mathrm{C}, \mathrm{D}, \mathrm{E}, \mathrm{F}$ e G: lograrão.

${ }^{2}$ A obra principia do ponto em que terminou o Palmeirim de Inglaterra: depois da guerra movida por Albaizar, a cidade de Constantinopla ficou reduzida a ruínas. Presume-se, entretanto, que tenham passado alguns anos, pois os filhos dos reis e príncipes que foram deixados na Ilha Perigosa para serem educados por Daliarte já estavam em idade de se tornar cavaleiros, conforme o narrador dirá a seguir.

${ }^{3} \mathrm{C}, \mathrm{D}, \mathrm{E}, \mathrm{F}$ e G: bondade.

${ }^{4}$ Aqui há erro, comum a todas as cópias: o Imperador de Constantinopla é Primaleão. Palmeirim de Oliva, pai de Primaleão, era o antigo Imperador, cuja morte é narrada nos capítulos finais do Palmeirim de Inglaterra.

${ }^{5}$ A passagem, um tanto confusa, parece ser resultado de erro de cópia, como atesta a presença do verbo digo, utilizado para a introdução de correções de amanuenses. Tal erro deve ter ocorrido em nível muito alto da tradição manuscrita, pois as únicas cópias que não apresentam a emenda digo são F e G.
} 
que para acertar | não havia desviar hũ ponto do Emperador | seu pay, com deixar caminhar as Materias pel|los mesmos passos, nem elle teve trabalho, nẽ o | deu a seus povos. [espaço] Mas passada, como diziamos, | a occupação das obras da cidade, e de algũas $\mathrm{Ou}$ |tras a que foi necessario acudir pello Imperio, como | prover os portos de mar,

30 lavrar galés, reparar | fortalezas, dar sucessores aos Mortos nos Magis|trados, e officios politicos, e de guerra ${ }^{6}$. Tornarão os $\mid$ cuidados antigos a occupar os corações de Prima|leão e de seus vassallos, de sorte, que em nenhũ em seu | tanto sevia sinal de contentamento. [espaço] Ao Em|perador lembravãolhe os amigos, e parentes Mor|tos. Via sua caza despojada dos cavaleiros, e cazos | que sohião emnobrecella, e alegralla.

35 [espaço] Vinhãolhe a | memoria seus netos e os outros Princepes que se | criavão na ilha de Daliarte, de quem havia muito | que não tivera novas, porque nimguem (como na | Cronica de Palmeirim se conta) sabia della | senão quem elle queria ${ }^{7}$. [espaço] $\mathrm{E}$ parecendolhe que podião | ja ser cavalleiros, e tornar a encher o mundo | pezavalhe de lhos ter deixado. [espaço] O povo viasse | com hũ Princepe justamente triste, metido |

40 em hũa cidade a seu parecer dezerta. [espaço] Cre|cião seus filhos sem a doutrina, e criação que elles || [2r] tiverão, a cuja falta, inda que com olhos de | pais, não deixavão de ver algũns defeitos, que lhes | dohião muito. E assi rey, e subditos passavão | com differentes cauzas, hũa mesma tristeza. | Se algua couza consolava a Primaleão, era, | ter nascido hũa filha a o Princepe Florendos | da sua Miraguarda, a q ue chamavão Gridonia,

45 | como sua May, a qual hia crecendo em fermo|zura, e boas partes de maneira, que se fazia pouca | duvida, em que deixaria a trás May, e Avó e tu|do o que melhor tivesse sido no mundo. Com | esta netta se consolava, e entretinha Primaleão | tratandoa com mais brandura e regallo do que $\mid$ se podia crer de sua antiga natureza ${ }^{8}$. E desta $\mid$ maneira hia pairando, Mandando embaxa|das frequentes a ElRey D. Duardos, a Palmei|rim, a 50 ElRey de Tracia Floriano, a Beroldo, | a Graciano, a Dramuziando, a Blandindon, | a Pompides, a seu filho Platir, e aos mais Prin|cepes seus amigos, que não passavão melhor vida $\mid$ que elle, posto que em algũns podião menos as sa|udades, que nos outros,

\footnotetext{
${ }^{6}$ A divisão desta frase com o ponto final é um dos casos, comuns no texto, em que a pontuação acaba por prejudicar a estrutura do período, tornando-o confuso.

${ }^{7}$ Veja-se o que diz o cap. 168 do Palmeirim de Inglaterra: Daliarte encantou sua ilha "de maneira (...) que nunca mais se achou, até que o tempo e sua vontade deram lugar a isso". Permaneceram com ele na ilha os filhos dos principais personagens do Palmeirim, muitos dos quais haviam sido mortos pelas tropas de Albaizar.

${ }^{8}$ No Palmeirim de Inglaterra, Primaleão é freqüentemente retratado como irascível. Veja-se, por exemplo, o cap. 122, em que se afirma que "nele nenhuma moderação nem temperança havia"; no cap. 131, diz-se que "Primaleão (...) de seu natural era áspero nas palavras".
} 
porque Palmeirim, Floria|no, e os mais que se tinhão cazado por amores, vi|vião com suas mulheres tão contentes, que a con|cervação da quelle só bem era o que pello menos 55 | the mais lembrava. [espaço] Tinha Palmeirim hũa | filha chamada Flerida tão estremada em fer|mozura, que não parecia que a natureza podia fa|zer mais. [espaço] Tinha Floriano a sua Carmelia, | que resplandeceu entre todas, como a lua entre $\mid$ as estrellas. [espaço] A ElRey Beroldo nasceu em | Espanha outra, chamada Valeriza, tão nota|velmente fermoza, engraçada e entendida, | que foi hũ milagre da quelles tempos. E

60 assim || [2v] na converçação, de suas mulheres e filhas, | hião passando estes princepes comunicando|ce sempre por seus Embaixadores e não des|cuidados nunca com tudo da Ilha Perigoza, | onde cada hũ delles tinha a melhor parte de | sua alma. [espaço] Nem o sabio Daliarte se des|cuidava tambem na criação da quelles mo|ços de que se entregara, nem do serviço da|quellas senhoras viuvas, que lhe ali ficarão ${ }^{9}$. An|tes servindoas e 65 regalandoas a ellas, conforme | a o estado que tinhão thomado, e doutrinandoos | a elles, em todas as boas artes, e disciplinas, | os tinha reduzido a o mais alto ponto de perfei|ção que fóra de sua companhia puderão alcan|çar. [espaço] E vendoos neste estado, sabendo tambem o | em que seus pais estavão com dezejo delles, e o Mun|do, que carecia de suas obras crecendo em necessida|de dellas, pellas licenças, que a desordenada vida dos |

70 máos dezenfreadamente hia thomando, vendo | justamente, que os moços obedecião ja de ma maneira, e que se julgavão por prezos, havendo | por inutil o dom da natureza, o animo, e for|ça, de que se sentião dotados, pois alli entre aquel|las Ondas se gastava so em os Exercicios de | Montear feras; detreminou satisfazellos a el|les, alegrar seus pais, e remedear o mundo cõ | sua prezença. E para isto prometendolhes, que bre|ve mente os 75 levaria dali, os meteu em novos | alvoroços, e esperanças. Despachou Donzellas às | cortes, dos Princepes, que ali tinhão penhores, pe|dindolhes encarecidamente, que a certo prazo se | juntassem todos em Constantinopla, porque | importava assim á conservação, e aumento | de seus estados, e vidas. [espaço] E como as couzas || [3r] de Daliarte forão sempre veneradas de to|dos aquelles senhores como Oraculos divinos | 80 em todas as cortes a que chegarão as suas Don|zellas, com estranho alvoroço se começarão a fazer prestes para Constantinopla, com suas mu|lheres, e filhos (os que os

\footnotetext{
${ }^{9}$ Após a batalha entre gregos e turcos, narrada no final do Palmeirim de Inglaterra, as mulheres que haviam perdido seus maridos na guerra permaneceram na Ilha Perigosa em companhia de Daliarte, conforme é dito no cap. 172: "a imperariz Polinarda e a imperatriz Vasília e as rainhas de Espanha e França, Tesália, todas com as outras princesas e senhoras, cujos maridos ali ficaram sepultados, ficaram na ilha os dias de sua vida".
} 
tinhão) que assi lho mandara $\mid$ o sabio pedir. [espaço] E como nisto, e no mais foy $\mid$ sempre o Emperador Primaleão a princi|pal pessoa só da Donzella que lhe a elle levou | o recado, da o Coronista desta historia prin|cipal rezão, e particular como veremos no 85 pro|ximo capitulo. 


\section{Capitulo 2}

\section{Do recado, que teve o Emperador do | Sabio Daliarte, e do alvoroço que | ouve na corte com elle.}

Passeando andava hũa tarde o Empera|dor Primaleão, com o Princepe Florendós | seu filho, em hũa gallaria, que cahia sobre o mar, | tratando ambos de armar cavalleiros algũns fi|lhos dos senhores de seu Imperio, que por elle, e em | sua caza se criavão, quando entrou pella porta hũa | Donzella estranha, vestida ao modo Ingles, | com hũa roupa de setim pardo, bordada toda | de hũas escamas de prata, e verde, e cortada $\mid$ em

10 cruzetas, sobre hua telilha de prata delgada, | capote do mesmo, airozamente sobraçado, | os cabellos colhidos á roda da cabeça, com | hũns roletes de fitas das proprias cores, sombrei||[3v]ro na mão da quella guarnição mesma, | com plumas brancas, e pardas, e huns rizos | verdes, que fazião sombra a hũa rica medalha | de diamantes, em que se rematava hũ tran|celim, tambem das mesmas pedras. [espaço] Vi|nha tão airoza, e dava

15 tanta graça, ao que ves|tia, que ainda que sendo muito branca, e muito | loura não era fermoza, não podia deixar $\mid$ de parecelo muito [espaço] E chegandoce assim a o | Emperador, que estava occupando os olhos nel|la, folgando de a ver, lhe disse (apos lhe fazer | hũa profundissima reverencia) [espaço] Muito | alto, e muito poderozo Emperador, o Sabio Da|liarte beja vossas reaes mãos, e vos pede que | despedida toda

20 tristeza, de que vosso coração | anda Occupado, o prepareis para novos conten|tamentos, porque he chegado o tempo, em que ve|reis vossa caza, e corte tão emnobrecida, e | alegre, como o nunca foi, com a prezença / de vossos nettos, e de outros Princepes, que na | sua Ilha se crearão, os quais vos detremina tra|zer aqui para a festa do Spirito Sancto proxima, | para que nella os Armeis cavalleiros, e vejais o | principio de suas

25 obras, para o qual acto, vos pede | que rezerveis, o que agora andaveis tratando cõ $\mid$ o Princepe Florendós, fazendovos tambem | saber, que tem avizado ja todos os Reys, e Prin|cepes, que vos mais folgareis de ver, para se acharẽ | com vosco na quelle dia, que vos podeis fazer | prestes para os agazalhar, porque ja algũns delles | não tardaràô ${ }^{1}$ muito [espaço] E porque trago outra Em|baixada para a Emperatris, e Miraguarda, e |

\footnotetext{
${ }^{1}$ Este acento pode se justificar como meio para evitar a confusão com a $3^{\mathrm{a}}$ pessoa do plural do pretérito perfeito, que na época também se grafava com - ão (tardarão / tardaram, de acordo com a grafia moderna). Às vezes, o acento duplo ocorre em formas do pretérito, mas como o mesmo objetivo de evitar a confusão com o futuro: veja-se o faltàrão no cap. 06, linha 53.
} 
30 para a senhora Gridonia, mandeme Vossa Magestade | dar licença, para que as veja. [espaço] || [4r] Donzella (disse Primaleão) são de tanto | gosto meu as novas, que me trazeis, que que|ro eu ser quem vos leve à Emperatris, por|que la me deis particular conta da despozição | do Sabio Daliarte, e de meus filhos, que nesta ${ }^{2} \mid$ tenho eu todos, os que elle cria. [espaço] E levandoa | o Emperador, e Florendós concigo, se forão a o |

35 apozento da Emperatris, onde ja tinhão che|gado em parte as novas, que a Donzella trazia, | com que tudo estava alvoroçado, e revolto, mas so|cegandoce com sua chegada, o Emperador a | prezentou pella mão à Emperatris, e a Mira|guarda dizendolhes: [espaço] Fazeilhe honrra senho|ras, que vem de parte, e com tais novas, que bem a | merece. [espaço] A Donzella então sentandoce | de giolhos, lhe deu hũa Embaixada, que 40 lhes trazia | da Emperatris Vazilia, e das outras veuvas, | que no Mosteiro $^{3}$ vivião, ejuntamente recados | da quelles Princepes. [espaço] Virando para Gridonia, | que estremadamente lhe pareceu fermoza, disse: | O Sabio Daliarte me mandou senhora que $\operatorname{vos} \mid$ dicesse, que vos aparelhaceis vos tambem para estas fes|tas, porque vos fazia saber, que vos não vereis em | menos afronta com as hospedas, que vos verião, | do que 45 os cavalleiros com os perigos, que havião de | passar; porque ainda que vossa fermozura he tal, | como eu agora vejo, eaquem nenhũa outra po|de fazer sombra, que com tudo, não quis a nature|za contentarce de fazer hũ so extremo, e que | o da quellas senhoras he tamanho, que vos não ande | deixar dormir tão socegada, como o agora estais. | Gridonia com hũa cor rozada meia corrida, | pondo os olhos em sua May respondeu à | Donzella:

50 [espaço] Por certo amiga, que não sei eu \|| [4v] afronta, em que se possa ver com essas Prin|cezas quem tanto dezeja de as ver como eu | e tem tanto cuidado dellas, e tão pouco de si. | Comtudo, dizei a o Sabio Daliarte que quando o | vir nesta caza, lhe mostrarei, o quanto estimo es|te seu avizo. [espaço] E depois do Emperador bẽ | informado do mais que quis saber da Donzel|la deixandoa à quellas senhoras, que primeiro que a | 55 despedicem meuda, e curiozamente lhe esti|verão perguntando pella criação, despozição, | e mais partes do Princepes, se sahio para fora | a mandar dar Ordẽ às couzas necessarias ao | gazalhado dos hospedes, que esperava, tão conten|te, e

${ }^{2} \mathrm{C}$ : nesta conta. A lição de A resulta um tanto confusa pela omissão do termo conta, embora ela possa ter sido fruto de uma escolha deliberada do copista.

${ }^{3} \mathrm{O}$ Palmeirim de Inglaterra não faz qualquer menção ao suposto mosteiro onde as viúvas teriam se recolhido na Ilha Perigosa. A referência pode ser resultado de um lapso do autor, visto que antes de serem levadas por Daliarte para sua ilha, aquelas senhoras haviam se refugiado no mosteiro de Santa Clara, em Constantinopla, logo após a morte do Imperador Palmeirim de Oliva (cf. o cap. 167 do Palmeirim de Inglaterra). 
alvoroçado, que quazi esquecida a Autho|ridade tratava com todos mais familiarmente | do que de antes costumava.

60 No Terreiro do Paço não cabia | gente, A cidade ardia em festas, e alvoroços, | com as novas de seus Princepes, que logo se di|vulgarão, e cada hũ se aparelhava para os receber | o mais custoza, e alegremente, que podia. E | assim os deixaremos, por dar razão do que fi|zerão os outros Reys, a que chegou o recado de | Daliarte. 


\section{Capitulo $3^{\circ}$}

\section{Como todos aquelles Princepes, que | tiverão recado de Daliarte se apa|relharão e partirão para Constanti|nopla, e do que lhes succedeu.}

|| [5r] Quazi a hũ mesmo tempo chegarão | a todos aquelles Princepes os recados do sabio | Daliarte, pello que juntamente em Inglaterra | Tracia, França, Alemanha, Escocia, Lacedemo|nia, Thesalia, Niquea, e Hespanha, e Dramu|ziando na sua Ilha se começarão a fazer prestes | todos com estranho alvoroço, e contentamento | para se tornarem a ver juntos na quella famoza | cidade, onde o gosto da criação, e o que sempre

10 dei|xão os perigos passados a quem se salvou com | honrra delles continuamente os chamava sen|dolhes mais natural aquella terra, que a sua propria, no que se prova a força da criação, e das a|mizades iguaes, e virtuozas, nuas de respeitos, | e fingimentos.

ElRey D. Duardos quizera | mandar recado a seus filhos Floriano, e Pompi|des, para que com todos juntos fizesse sua entrada | em Constantinopla, e estando para lhe

15 despedir | Embaixadores, teve avizo como ambos estes | Reys com pouca armada tinhão chegado a Ple|muu ${ }^{1}$ hũ porto de Inglaterra contra a costa de | Hespanha, porque tanto que elles tiverão recado de | Daliarte, com o mesmo pensamento se em|barcarão logo Floriano em Tracia com sua | mulher, e filha, e sem mais companhia que hũns | officiaes de sua caza se veio ter a Escocia, on|de embarcando comcigo a ElRey ${ }^{2}$, e a hũ filho |

20 seu, que lhe nascera depois que viera da Ilha Peri|goza chamado Frenellio, que foi estremado ca|valleiro, como diremos em seu lugar ${ }^{3}$. Parti|rão na volta de Londres, e não podendo com || [5v] O tempo, que lhe correo thomar aquelle porto, | forão ao outro, em que se dezembarcarão, e thoma|rão o caminho da corte por terra, avizando | primeiro a ElRey seu Pay, e a Palmeirim | seu Irmão, os quais mandarão logo andas, e | coches 25 para a Raynha, e sua filha, e suas Damas, e | Donzellas, e se fizerão prestes para as receber com | grande gosto, e menor cerimonia, do que suas | pessoas, e estados requerião, e assim a poucos di|as depois de terem o primeiro recado, tiverão logo ou|tro de que aquelle chegarião a Londres, pello que sa|hindoos a receber não andarão hũa legoa quando | chegarão á dianteira da quella companhia, | na qual ja vinhão os dous

\footnotetext{
${ }^{1}$ Acreditamos tratar-se da atual Plymouth, na costa da Cornualha.

${ }^{2}$ Trata-se de Pompides, rei da Escócia.

${ }^{3} \mathrm{O}$ Palmeirim de Inglaterra (cap. 172) menciona apenas outro filho de Pompides, chamado Doriel, que não é lembrado nesta continuação.
} 
30 irmãos alvoroçados | para bejarem a mão a seu Pay, e abraçarem a | Palmeirim, armados ambos de suas antigas | armas, e divizas do Salvage, e do Touro ${ }^{4}$. [espaço] E | chegandohũns a os outros, Floriano, e Pompi|des se apearão, e depois de bejarem a mão a | D. Duardos, que vestido de campo emcima de | hua pequena faca ingreza os abraçou, e apppertou concigo muito. [espaço] Abraçarão tambẽ estrei|tamente a Palmeirim, que

35 posto a pe estava es|perando que acabacem com seu pay para elle os | levar nos braços, como fes, e assim estiverão | todos apertados tanto espaço, que chegarão os co|ches, em que vinha a Raynha, e sua filha ${ }^{5}$. [espaço] En|tão se deceu D. Duardos por impedir que ellas se | não apeassem como querião fazer, e recebendo | a sua Nora com grande cortezia, e amor, pon|do depois os olhos em Carmelia, que mea fora | do estribo o tinha

40 esperado, e absorto em a quel||[6r]le prodigio de fermozura, e hũ pouco em|baraçado disse para ella: Porcerto filha que se eu | não devera mais a Daliarte que fazer com que a|gora vos visse, que não empregara mal o amor $\mid \mathrm{q} u e$ lhe tenho ${ }^{6}$ : [espaço] $\mathrm{E}$ abraçandoa voltou rindo para a | Raynha sua May dizendo, como em profecia: | Pareceme senhora, que temos nececidade do | Saber de ElRey Sardamante vosso Avó ${ }^{7}$ para nos | livrar dos

45 perigos, em que a fermozura de minha | netta temo que nos hade meter. [espaço] A Raynha lhe | respondeu: [espaço] Bom he dizer Vossa Alteza isso tendo em | caza a senhora Flerida ${ }^{8}$, diante quem segundo | me dizem, e eu creio, nimguem pode aparecer, | quanto mais Carmellia, que so tem de bom ser paren|ta sua, e netta de seu Avó. [espaço] Tras isto recebendo | a Palmeirim que chegara a falarlhe, o qual passando | com ambas muitos comprimentos, e cortezias, es|pantado tambem do parecer das sobrinhas ${ }^{9}$, tho|marão o caminho de Londres vagarozamente, | indo a Raynha de Tracia assás contente de lhe | parecer pellas demonstrações do sogro, que não se|ria pello menos Flerida mais fermoza que Car|mellia, vicio de maneira ordinario nas Mãles, que quazi lhes he tão natural, como serem fle|maticas, ou colericas. E assim andando che|garão a

\footnotetext{
${ }^{4}$ No Palmeirim de Inglaterra, Floriano do Deserto e Pompides são conhecidos respectivamente como Cavaleiro do Salvage e do Touro, segundo as insígnias que trazem em seus escudos.

${ }^{5}$ Trata-se da rainha de Trácia, Leonarda, esposa de Floriano do Deserto, e de sua filha Carmélia.

${ }^{6}$ Ou seja: mesmo que não tivesse outros motivos para amar Daliarte, só o fato de ele os ter convocado para ir a Constantinopla, propiciando a ocasião de conhecer Carmélia, já seria suficiente para justificar o amor que D. Duardos devotava ao Sábio.

${ }^{7} \mathrm{O}$ avô de Leonarda, um antigo rei de Trácia chamado Sardamante, foi "tão grã mágico, que trespassou todos os mágicos, que em seu tempo houve", como esclarece o cap. 90 do Palmeirim de Inglaterra.

${ }^{8}$ Leonarda refere-se à filha de Palmeirim e não a sua avó, esposa de D. Duardos, que tinha o mesmo nome.

${ }^{9} \mathrm{C}$ : da sobrinha.
} 
55 Londres, onde Floriano era estremada|mente amado pella criação, que ali tivera ${ }^{10}$, com que | o recebimento, que lhe fizerão as gentes do povo de | festas e alegrias, foi o maior que se alli nunca vira. | Da mesma maneira foy da Raynha sua May | e de Polynarda, e Flerida, a Raynha sua mulher | e Carmellia ${ }^{11}$, e por escuzarmos o enfado, que seme|lhantes recebimentos costumão dar a os leitores \|| [6v] quando se escrevem 60 particularmente deixamos de di|zer as couzas que neste passarão, podendoce | conjecturar facilmente.

Do mesmo modo partirão todos | os outros Princepes na volta de Constanti|nopla indo juntos tambem Beroldo Rey | de Hespanha, Dragonalte de Navarra ${ }^{12}$, e | Graciano de França. E em outra companhia | Polinardo Conde de Flandes, e Duque de Bor|gonha, 65 que governava o Imperio de Alemanha|por Trineo seu sobrinho ${ }^{13}$, e ElRey Francido de | Thessalia ${ }^{14}$, que se juntou com elle. [espaço] Em outra | tropa hião Blandindon Soldão de Niquea, | D. Rosuel Duque de Ponta, e Duraço, e ElRey de | Ungria, e o de Lacedemonia $^{15}$. Todos estes Prin|cepes chegarão juntos. Dramusiando não, que | chegando da sua Ilha a Inglaterra achando | D. Duardos partido, tornandoce a embarcar

70 para | França, com tempo arribou a Hespanha, aon|de lhe aconteceu o que adiante se dirà.

\footnotetext{
${ }^{10}$ Lembre-se que Floriano foi levado ainda jovem a Londres e criado pela rainha Flérida, embora ela não soubesse então que ele fosse seu filho (cf. Palmeirim de Inglaterra, cap. 07).

${ }^{11}$ A frase, um tanto confusa, é quase idêntica à reproduzida em $\mathrm{C}$, onde se lê: "da mesma maneira $o$ foi daRainha sua maj e depolinarda e flerida a Rainha sua mulher E Carmelia”.

${ }^{12}$ Segundo o Palmeirim de Inglaterra (cap. 169), Dragonalte havia morrido na batalha contra as tropas de Albaizar. Sua presença aqui prova que o autor deste livro não o notou.

13 As informações sobre Polinardo também são incoerentes com as fornecidas pelo Palmeirim de Inglaterra. Ali, no cap. 95, informa-se que ele se torna duque da Saxônia e não de Borgonha, sem mencionar o condado de Flandres; além disso, no cap. 169, é narrada sua morte na guerra contra os turcos.

${ }^{14}$ Sobre Francido não há informações nas obras anteriores do ciclo. O antigo rei de Tessália era Polendos, filho bastardo de Palmeirim de Oliva. No Palmeirim de Inglaterra, menciona-se várias vezes um filho de Polendos, chamado Francião, que se casa com Bernarda, irmã de D. Rosuel. É possível que, por erro de cópia, o nome de Francião tenha sido grafado como Francido, visto que no cap. 07 Francião volta a ser lembrado (cf. nota 6) e o nome de Francido desaparece do texto. De qualquer modo, Francião é um dos cavaleiros dados como mortos na batalha contra os turcos, informação que deve ter passado despercebida ao autor (cf. cap. 169 do Palmeirim).

${ }^{15}$ O rei de Lacedemônia é Platir; o rei de Hungria, ao menos nesta primeira parte das continuações manuscritas do Palmeirim de Inglaterra, nunca é nomeado. No Palmeirim, o reino de Hungria era governado por Estrelante.
} 


\section{Capitulo 4.}

\section{Do que succedeu a Dramuziando | depois que partio de sua Ilha.}

Não ficou Dramuziando sem recado de | Daliarte, porque sua amizade, e 5 conversação foi | sempre tão estimada de todos aquelles Princepes | que como se ja disse na Cronica de Palmeirim | de Inglaterra, nenhua differença fazia delle a || [7r] os com que mais parentesco, e rezão tinhão, o | qual tanto que o recebeu se enbarcou logo, dei|xando sua mulher no governo de sua Ilha, on|de de novo tinha inquietações com hũns Gigan|tes filhos de Calfarneo, e Comboldao seus cunha|dos, que querião

10 conquistalla por herança de seus | Pais ${ }^{1}$. [espaço] E como Dramuziando estivera algum | tempo auzente, e elles não deixassem de ter muita | intelligencia na terra, alterarãona de manei|ra, que quando chegou da Ilha Perigoza sam de suas | feridas (que como se tem dito durarão mais tempo | que as dos outros em $\operatorname{sarar}^{2}$ ) não teve pouco que fa|zer em sucegar os tumultos, que sua auzencia, e a | vezinhança dos Gigantes tinhão movido. E

15 por|que elles de hũns castellos que tinhão dalli perto em ter|ra não davão sinais de estar de todo so|cegados, pareceulhe a Dramuziando que convinha | deixar Arlança, cuja prezença bastaria para con|cervar os ledos, e refrear os que o não fossem. E | fazendoo assim se enbarcou com so hũ escudei|ro armado de huas folhas de asso como cascas de | pinhas verdes, e azuis, apartadas as cores com hũns | perfis de Ouro, no escudo em campo verde a sua $\mid$ torre antiga ${ }^{3}$. Fes vella para Inglaterra a buscar $\mid$ D. Duardos para o acompanhar na quella jorna|da, porque a elle, e a seus filhos tinha, e respeitava | por seus naturaes senhores; Mas teve tantas tor|mentas, e gastou tanto tempo no mar, que quando | la chegou ja elles erão partidos, E voltando a | proa contra França, chegou a Calés, onde da | mesma maneira soube que Garciano, e os mais | se tinhão ja embarcado.

25 [espaço] Então seguindo | sua derrota para Grecia, tornou a achar, e ter a | mesma fortuna, que tanto o tinha perseguido, | com a qual correndo algũns dias foy ver a || [7v] terra de Hespanha nas derradeiras praias | do mar Occeano. [espaço] E fazendo thomar

\footnotetext{
${ }^{1}$ Estes dois gigantes, que no Palmeirim de Inglaterra aparecem com os nomes Calfúrnio e Camboldão, são irmãos de Arlança e foram mortos por Floriano e Palmeirim. A ilha de Dramusiando, aqui não nomeada, no Palmeirim era chamada de Ilha Profunda.

${ }^{2}$ Ao final da guerra com os turcos, quando Daliarte se encarrega da cura dos feridos levando-os à Ilha Perigosa, o narrador do Palmeirim de Inglaterra observa que "Dramusiando e o cavaleiro do Salvage fizeram muitos termos mortais e estiveram mais tempo em cura" (cap. 171).

${ }^{3}$ Trata-se da torre onde mantivera preso D. Duardos e outros príncipes, como se lê na primeira parte do Palmeirim de Inglaterra.
} 
hum | porto da quella costa por vir mui enfadado | do mar, mandou lançar os cavallos em ter|ra, crendo que melhor poderia assi fazer sua jor|nada, e caminhando algũns dias 30 por aquel|la Provincia, não achou nunca em que oc|cupar suas obras, de que hia tão enfadado, como | de lhe parecer que chegaria tarde ao prazo para | que o chamarão. [espaço] Com estas imaginações, | e com as saudades de sua Arlança, que nunca | o desacompanhavão hia gastando o tempo jul|gando o mundo por despovoado, pois havendo | tanto que o passeava por mar, e por terra, não | tinha encontrado nenhũa

35 daquellas Aventu|ras, de que em outros dias as estradas andavão | cheas. [espaço] E assi emvolto hũas horas nesta fante|zia, e outras na contemplação de seus amo|res, achouce hũ dia tão perto do castello de Al|mourol, que poude reconhecer a terra, divizan|do de hũns cabeços altos as areas do Tejo, que | elle tanto tempo com suas lagrimas regara ${ }^{4}, \mid \mathrm{e}$ alvoroçandoo de subito aquella vista pouco | menos que quando a fermozura, e rigor de

40 Miraguar|da tinhão o mundo cheio de acontecimentos | grandes, lançouce pellos outeiros abaixo dezeljozo de ir ver se aquellas paredes concervavão | ainda os sinais de seus suspiros, e visitar Car|diga ${ }^{5}$ se alli estivesse. [espaço] E antes de chegar ahũa | varge, que do pe do monte se começava a esten|der contra o proprio Tejo, ouvio á sua mão di|reita soar golpes, e a seu parecer grandes. E | voltando o cavallo para si com hũ galope apre|çado contente de ouvir aquelle som, que tantos || [8r] dias havia que lhe não tinha chegado às Ore|lhas. [espaço] Não andou muito que não visse na rais | daquelle Outeiro onde a varge se começava | dous cavalleiros a pe grandes, e bem feitos em | hũa aspera batalha, e chegandoce a elles de|tendoce hũ pouco a olhar como perfiavão em | se vencer, conheceu logo que hũ trazia as ar|mas de pardo, e verde a quarteirões, e no 50 es|cudo em campo branco hũ Leão morto em | memoria de outro, que matara, tinha tão conhe|cida ventagem a o com que se combatia, que se | durasse muito a contenda, não poderia escapar | de suas mãos. [espaço] E porque tambem este the pareceu | bom cavalleiro, dezejozo de os apartar se me|teu entre elles dizendo para o do Leão: Peçovos | senhor cavalleiro que queirais deixar esta batalha | se a cauza porque a fazeis vos não obriga muito a levalla adiante, que por ventura outra couza | haverá em que vos sirva mais de vosso gosto. | O cavalleiro, que era soberbo, posto que a prezença, e |

\footnotetext{
${ }^{4}$ Lembre-se que, no Palmeirim de Inglaterra, Dramusiando foi um dos servidores de Miraguarda, defendendo seu escudo enquanto Florendos estava afastado do exercício das armas por ordem dela: cf caps. 62 e seg.

${ }^{5}$ Cardiga era casada com o gigante Almourol, antigo protetor de Miraguarda, morto na batalha contra os turcos.
} 
comedimento de Dramuziando pedissẽ outra | reposta, lhe disse: Cavalleiro, hide vosso cami|nho se vos parece, ou esperai hũ pouco vereis co|mo castigo descortezias, então aprendereis á cus|ta alhea a vos não embaraçar no em que vos | não vai nada. [espaço]

60 Bem quizera Dramuzi|ando responderlhe logo como elle merecia, mas $\mid$ outro $^{6}$, com quẽ fazia a batalha se lhe atravessou | dizendo: [espaço] Inda que senhor me eu pudera quei|xar de que tivestes mais comprimento com esse | cavalleiro, que comigo, toda via, não quero dei|xar de vos agradecer a vontade de que sei vos nas|ceu, que foi doervos de minha dispozição, mas | porque seja so a culpa de ella ser tal da fortuna, || [8v] e não do 65 animo, deixaime acabar minha | batalha, e depois vereis o que vos convem fazer. |E como isto disse, tornouce a ajuntar com o | outro tão maltratado ja que a pouco espasso, que se | andarão ferindo, o cavalleiro das armas ver|des deu com elle no chão sem nenhũ acordo. | Dramuziando então porque vio que lhe dezenlaça|va o Elmo, temendo que o matasse, lhe bradou | que o não fizesse, e apeouce do cavallo para the valer. | Mas o

70 outro que lhe não dava muito de seus brados | antes que elle chegasse lhe cortou a cabeça, de que | Dramuziando ficou com tanta paixão, que sem | lhe falar palavra arrancando da Espada o comes|sou a carregar de tantos, e tão duros golpes, que | ainda que elle fosse estremado cavalleiro, e digno | (senão fora sua soberba) de ser contado por hũ dos $\mid$ bons do mundo, não lhe aproveitando contra ta|manha ${ }^{7}$ inimigo força, nẽ 75 ligeireza. [espaço] Despois | de trabalhar, e sofrer muito mostrando tambẽ a Dra|muziando que não sem cauza confiava muito de si | porque ás vezes o enfadava mais do que elle quizera. | Tirouce hũ pouco para fora dizendo: Por certo cava|leiro que não sei que conhecimento podeis ter com elle | que ahi jas para tomardes tanto à vossa conta querer | vingarlo, que vos ponhais a risco de vos perder tãbẽ | ou de me matar 80 amim sem saber a razão que | para isso tenhaes. [espaço] Dramuziando sentindo don|delhe aquillo nascia, respondeulhe: Descançai em|bora que quanto mais tempo gastardes nisso, mais vos | atromentará o arrependimento de vossa sober|ba, que eu não me contento só com vos cortar | a cabeça em pago da outra que sem me querer | ouvir cortastes. [espaço] Não sei como isso serà | (lhe tornou elle) mas se eu posso o que costumo, || [9r] Eu vos farei arrepender a vos depressa | dessa tão arrogante confiança. E como isto | disse se foi para Dramuziando com a espada | levantada, que da mesma maneira o sahio a $\mid$ receber, e nesta segunda batalha acabou de co|nhecer Dramuziando

\footnotetext{
${ }^{6} \mathrm{~B}, \mathrm{C}$ : mas $o$ outro.

${ }^{7}$ B, C: tamanho.
} 
que senão colhera aquelle | cavalleiro cançado, e encetado ja da batalha | que com o cavalleiro Morto tivera, que lhe não | custara mui barata a victoria, porque ainda as $\mid \operatorname{sim}$ $90 \mathrm{o}^{8}$ necessitou de uzar de toda a sua forsa, | e industria para se guardar de seus golpes, que não | parecião em nada de homem tão mal tratado | como elle andava, e correndoce não so delhe | durar tanto hũ homẽ, que achara naquelle estado, | mas de o trazer ferido em alguas partes, e não | mui descançado, porque com a idade, e descostu|me da quelle exercicio, algua couza se achava | pezado, e floxo. Tornando sobre si começou |a 95 mostrar nas armas, e carne do outro a cole|ra, que de si tivera apartandoo de manera, que | ja não entendia em mais que em se guardar | dos golpes de seu contrario, o que fazia com | tanta fraqueza, que começou Dramuziando | a haver lastima delle. [espaço] Com aquella no|breza, de que seu coração nunca andou dezalcompanhado, e apartandoce a fora lhe disse: | Ja vedes cavalleiro o estado a que a vossa soberba | vos

100 tem trazido, rendeivos em minhas mãos | e por ventura que achareis melhor tratamento | nellas rendido, do que peleijando o tendes achado. |E antes que lhe pudesse responder, chegou á | quelle lugar hum moço de pouca idade vestido | de monte com hũ esmerilhão na mão em || [9v] cima de hũ palafrem bayo grande, e fermozo, | e elle tão airozo, e gentilhomẽ, quanto nunca Dra|muziando vira outro que assim lho parecesse | daquella 105 idade. [espaço] Vinha correndo, porque como | de longe ouvira os golpes, dezejozo de ver o | sucesso delles se apressara, deixando a compa|nhia de Monteiros, e cassadores que trazia, e | tanto que chegou a o lugar donde se fazia a bata|lha conhecendo o cavalleiro morto, e conhecen|do o das armas verdes, pasmado de o ver tão | mal parado, posto que a prezensa de Damuzian|do prometia de si maiores maravilhas, foice | para 110 elle, que o estava olhando vendoo vir, muito mais | espantado de sua gentileza, do que elle o estava de seu | valor. [espaço] E chegandocelhe bem deceuce do palafrem | e disselhe o que no seguinte capitulo se refere.

\footnotetext{
${ }^{8}$ Este $o$, sem qualquer função sintática, também aparece na lição de C.
} 


\section{Capitulo 5}

\section{Do que o Donzel passou com Dramu|ziando, e de quem elle era, e como | Dramuziando se foi curar a sua caza.}

Se esta batalha senhor cavalleiro, que fazeis (dis|se o Donzel a Dramuziando) não he couza, | em que vos va muito, muita merce receberia eu ẽ | que a deixasseis por amor de mim, porque esse caval|leiro (afora o que parece que ganhará nisso) fará o q que lhe eu rogar. [espaço] Fermozo Donzel (respon|deu Dramuziando) nenhũa batalha comecei || [10r] em minha vida com tanto dezejo de a aca|bar, como esta, pella crueza,

10 com que este cavallei|ro matou essoutro, que a hi vedes, sem lhe valer | estar ja no chão, e não se poder deffender, nẽ | rogarlhe eu que o não fizesse; mas se elle me | disser a rezão porque o fes, e vos se tendes algũ | parentesco com a senhora Miraguarda, que daqui | perto viveu hũ tempo, eu sou contente de dei|xar a batalha. [espaço] A isto respondeu o cavalleiro: | Para que he senão acaballa, que será muito mais facil, que |

15 dizervos tanta couza? [espaço] E como o disse se foi | para Dramuziando com tenção de acabar de todo $\mid$ de que ja se não sentia ${ }^{1}$ mui longe. [espaço] Mas o Donzel | se tornou a meter entre elles, e disse ao do Leão: | Melhor serà senhor curardes essas feridas, que porfiar | mais em receber outras. [espaço] Eu satisfarei este ca|valleiro no que me pregunta de mim, epor ven|tura que se contente do que mais quer saber de vos. | Mas o

20 cavalleiro que ja se sostinha mais na vi|veza do coração, que no sangue, nem nas for|ças, esfriando de todo com aquellas detenças, | deu concigo no chão tão dezacordado, como | quem lhe faltava bem pouco para morto. [espaço] E o | Donzel que o vio, deixandoce cahir sobre elle, | dezenlaçandolhe o elmo, e vendoo, de todo | julgou que o estava. [espaço] Então mandandoo | thomar a hũns caçadores seus, que ja alli tinhão | chegado,

25 disse que o levassẽ a caza, que dali perto | era, e viessem pello outro para o sepultarem | tambẽ. [espaço] E depois disto feito virandoce para| Dramusiando (que não estava pouco sentido de $\mid$ aquelle dezastre chegar tanto a o cabo, pare $\|[10 \mathrm{v}]$ cendolhe o cavalleiro pessoa de preço, e man|cebo) lhe disse: [espaço] Vos cavalleiro pudereis fa|zer o que vos pedi com menos condições, mas | fizestes o que vos pareceu, e não foi

30 pouco porque | aquelle cavalleiro, que matastes era hũ dos me|lhores de toda esta terra; Mas pois que para lhe | valer na vida aproveitei pouco com vosco, | pessovos, que me

\footnotetext{
${ }^{1} \mathrm{C}$ : "acabar detodo deque senão sentia". O sentido da frase é que o Cavaleiro do Leão queria acabar a
} batalha, pois percebia (devido a suas feridas) que ela já não poderia ir muito adiante. 
Otorgueis hũ dom para ver se | na morte lhe posso ser bom em algũa couza. | Cuidou Dramusiando que lhe queria perguntar | quem era, e detreminou de lho dizer respon|dendolhe: Da morte da quelle cavalleiro (se he | morto) me pezou, depois que vi,

35 que vos a vos pe|zava, e antes tambẽ, porque hia entendendo|de suas obras, que era ella mal enpregada nelle. | A rezão de nossa contenda vos tenho ja ditto. | Acheio combatendoce com este cavaleiro mor|to, pedilhe que quizesse deixar a batalha, de que | elle quando cheguei conhecidamente levava a me|lhor. Não só o não quis fazer, mas respondeu|me com palavras indignas de homẽ tão esfor|çado, e com a mesma soberba

40 depois que o aca|bou de vencer, e matou ${ }^{2}$, sem lhe dar dos bra|dos, com que eu quis estorvallo. E conforme ais|to bem cuido que vos não parecerá sem razão | o que fis. [espaço] O Dom que me pedis vos Otorgue, se | he couza que cumprindo com minha honrra | possa fazer, e se o dezejo, que tive de vos contẽtar, | e a vontade, com que agora me acho de vos servir, | valem com vosco algũa couza, pessovos que me | digais quem 45 sois, porque o coração me dis que tenho \| [11r] muita obrigação para o fazer. [espaço] O Donzel es|pantandoce de ouvir que o cavalleiro do Leão | matara o outro, porque ainda que ja lho tinha ou|tra ves ditto, imaginava que tudo erão obras | de Dramusiando, não deixou de lhe respon|der dizendo: [espaço] Sabei que o que me tendes prometi|do he armarme cavalleiro com as armas des|se que a hi està morto, e combaterdesvos 50 comigo, | que ainda que vos vejo com alguas feridas, não cui|do que estais tão cançado, que vos não pareça me|nor empreza vencerme, do que eu quando acon|tessa outra couza cuidaria inda que estivesseis | em peor estado ${ }^{3}$. [espaço] Maravilhado ficou Dramu|ziando do que aquelle Donzel lhe pedia, e af|firmando bem os olhos nelle, ainda que o vio tão | gentilhomem que lhe parecia hũ retrato vivo de | Miraguarda, e de tão

55 pouca idade, que a seu | parecer não chegava a dezoito anos, la lhe | via hũa disposição no corpo grande, e robus|ta significadora de grande força, e animo. | E folgando ainda mais de o ver, depois, que O | ouvio the respondeu: [espaço] Fermozo Donzel, | estou tão contente do animo que mostrais nessa / idade, que me haveisde fazer trocar hũa opini|ão em que vivia, de cuidar que era acabada a ra|ça dos cavalleiros, que eu em 60 outro tempo con|vercei, e experimentei, porque ja agora vejo que só | vos quando não

\footnotetext{
${ }^{2} \mathrm{~B}$ : vencer e $o$ matou; $\mathrm{C}$ : vencer $o$ matou.

${ }^{3}$ O jovem diz que é mais provável que Dramusiando o vença do que o contrário ("outra coisa", na linguagem do rapaz) e que Dramusiando dificilmente seria vencido, mesmo se estivesse mais ferido ("em pior estado").
} 
haja mais no mundo resucitareis | nelle todo o valor, de que eu andava com sauda|de. [espaço] O Dom que me pedis não posso eu cũ|prir, porque, como deveis saber, não podeis re|ceber a Ordem de cavallaria, sem ter vella||[11v]do as armas hũa noite inteira, com outras | cerimonias, que neste acto são precizamente | necessarias. [espaço] $\mathrm{E}$ tambẽ inda que o eu fizesse, não | era razão começardes a entrar no mundo | com tanta ingratidão, como fora pagardes | tão mal a quem vos dava essa Ordẽ que pedis. | Fora todas estas razões, vossa idade ainda me | não parece ${ }^{4}$. [espaço] Não vades mais por diante | (respondeu o Donzel) Dizeime como vos | chamais, se sois servido, porque ja agora ar|mado por vos, ou por Outrem, não me tirarà $\mid$ o poder do mundo provarme

70 comvosco, e por | ventura que quando isto for, me julgareis melhor, do | que agora vos pareço. [espaço] Isto dizia o Donzel | com hũ rostro tão assendido, e vivo, que Dramu|ziando o teve em muito e respondeulhe: [espaço] | Não me parece que será rezão deixarvos des|contente em tudo. Amim me chamão | Dramusiando. Pois sois natural desta terra | como vossa falla mostra, algua hora me ouvi|rieis nomear, que muito tempo

75 vivi nella em | companhia de hũ cuidado, que sempre ma fes | bem mà. [espaço] E pois vos tenho dito o que me per|guntastes, rezão serà tambem que me digais $\mid$ o que dezejo saber, e juntamente onde poderei | ser curado das minhas feridas, para que com me|lhor dispozição vos sirva no que me mandar|des. [espaço] Senhor Dramusiando (respondeu o Don|zel) sendo o conhecervos a couza do mundo | que mais dezejei, sempre sinto em 80 extremo | vilo a fazer em tempo que parecerá que medo | de vossas obras me esfrião o animo para proce $\|[12 r]$ guir na vingança da quelle cavalleiro, e | não esta vontade, que para vos servir nasceu | comigo; mas julgueme como quizerẽ, eu sou | vosso servidor, e ja pello menos me não nega|reis armarme cavalleiro em hũa caza, que a|qui está perto, onde podereis tambẽ ser curado | das feridas, que dizeis. [espaço] Amim me chamão D. |

85 Floris de Lusitania. Sou filho do conde Arláo | Pay da senhora Miraguarda de outro Matrimo|nio, o qual não ha muito tempo, que com sua morte $\mid$ me deixou o senhorio de toda esta terra, em que entra | o castello de Almourol, que eu estimo mais porque vos | alli vivestes, que por todas as outras razões que o podem | fazer de estimação. E porque la vos darei mais | particular conta de minhas couzas, vamonos da|qui, e darseha tambẽ 90 Ordem a sepultura dos | Mortos, que amerecem. [espaço] Dramusiando como | o ouvio, tirando primeiro o Elmo, o levou nos braços, | dizendo: [espaço] Bem adevinhava eu

\footnotetext{
${ }^{4}$ A frase, que é transmitida de modo idêntico em B e C, parece truncada, como se D. Floris interrompesse a fala de Dramusiando.
} 
senhor D. | Floris, que não me cumpria a mim ter brigas cõ|vosco, e tervos agora abraçado como amigo, | julgo por milagre da minha fe, que sempre foi | a que devia com as couzas da senhora Miraguar|da. [espaço] Vamos a onde Mandardes, que ja agora |me

95 dou por pago de todos os trabalhos, que o se|guir as armas me tem dado, com vos conhe|cer, e podervos servir em algũa couza. [espaço] $\mathrm{E} \mid$ pondoce ambos a cavallo virão vir hũa tropa $\mid$ de gente de armas a correr, e alguns cavallei|ros armados entre ella, que D. Floris conheceu | logo que erão criados seus, que o vinhão buscar, | pello que lhe ${ }^{5}$ contarão os caçadores, que levarão | o cavalleiro das armas verdes, e chegando ||

$100[12 v]$ hũns a os outros vendo a conformidade, com | que D. Floris estava com aquelle cavalleiro, | conformarãoce elles tambem. [espaço] E dizendolhe | que o outro não era de todo acabado, antes dava | esperanças que viviria, porque em lhe toman|do o sangue tornara a si, levando o corpo $\mid$ do morto, se forão juntamente a the a caza $\mid$ de D. Floris, que era hũ castello roqueiro mui | bem feito, assentado por hũa parte sobre hũa | grande,

105 e fermoza horta, a qual regava hum | rio não de muita agoa, mas de muito arvoredo, e | mui engraçado sitio. [espaço] E por outra banda ti|nha hũ terreiro, ou rocio diante, tamanho, que | podia agazalhar esquadrões armados, e no ca|bo delle, (que se cobria de hũa relva meúda, e | muito verde povoado de boninas azuis, bran|cas e vermelhas) estava hũa Ermida de | Nossa Senhora de mui gentil Obra, e muito devota, que alli | 110 edificarão os senhores daquelle castello, que com a sumptuozidade do edifficio, e graça destes | arredores, era assas fermozo, e tal o pareceu elle | a Dramusiando, que disse a D. Floris: Parece|me senhor, que não era esta habitação peor para lo|grar, que o castello de Almourol. E espantome | como estando tão perto, como mostrão as | prayas do Tejo, que daqui não parecẽ mui dis|tantes, o não vimos nunca nem Almourol | nos 115 deu noticia delle. [espaço] Não sei nada das | couzas desse tempo (disse D. Floris) nem lhe | sou tão afeiçoado, como a vós vos pode pare|cer, antes não julgo que acertou meu Pay | muito em concentir que sua filha estivesse fora || [13r] de sua caza entregue à guarda de hũ Gi|gante, a quem cada dia vencião ${ }^{6}$, e muito menos | depois que Florendós se declarou tanto, porque | aquellas Aventuras, e amores se se sofrem nas | cortes dos

120 Reis, nas cazas particulares não me | parece a mim rezão sofreremce. [espaço] E porque

\footnotetext{
${ }^{5} \mathrm{Na}$ época em que o texto foi escrito, ainda era habitual que o pronome lhe às vezes não fosse flexionado no plural: vejam-se outros exemplos nos caps. 15 (linha 99) e 20 (linha 52). Isto não quer dizer que inexistam no texto ocorrências de lhes: ao contrário, o raro é a falta de concordância do pronome.

${ }^{6}$ Lembre-se que o gigante Almourol, protetor de Miraguarda, foi derrotado por Florendos, Dramusiando e Floriano (Palmeirim de Inglaterra, caps. 53, 62 e 127 respectivamente).
} 
es|tavão ja perto de caza, não lhe replicou Dra|muziando, mas bem sentio da quella, e de ou|tras praticas, que pello caminho tiverão, que o Mo|ço tinha humor Extraordinario, e que se viesse | a ser cavalleiro, seria trabalhozo em algũas coulzas. [espaço] $\mathrm{E}$ appeandoce sabendo que o ferido estava $\mid$ de todo em seu acordo, ficou D. Floris muito 125 ma|is contente, porque era seu tio, irmão de sua | May. [espaço] Lançarão logo Dramuziando em hũ | rico leito, onde sendo curado das pequenas | feridas, que trazia, descançou a quella noite bẽ $\mid$ servido $^{7}$ de D. Floris, mas não adorado delle, | posto que tudo com hũ termo, que Dramusiando | se sentia obrigado a estimar a cortezia, e a | respeitar a pessoa.

\footnotetext{
${ }^{7}$ Falta servido em B.
} 


\section{Capitulo 6.}

\section{Em que se da a rezão de quem erão | os cavalleiros que Dramusiando achou | na batalha, e a cauza della, e de como | D. Floris foi armado cavaleiro.}

Para se saber quem era o cavalleiro, || [13v] comque Dramusiando se combateo, e tudo o | mais que no capitulo passado se contou, dis a His|toria que o Conde Arláo pay de Miraguarda, fi|cou por Governador em Hespanha quando ElRey Re|cindos se foy a Grecia com a Raynha sua mu|lher a acharce em os casamentos de seus filhos ${ }^{1}$, | e dos outros Princepes, que la cazarão, levando | concigo Miraguarda para mulher de

10 Florendós, | aquem o Emperador Palmeirim quis fazer a|quella honrra, assim pello gosto de seu netto, como | por lhe pagar a ella o serviço que lhe fizera na | retenção de Albaizar, como na Choronica de | Palmeirim se conta ${ }^{2}$, na qual se dis tambem | como Recindos, e Arnedos, e os mais Princepes | da quelle tempo, morrerão todos na deffenção | de Constantinopla, e aquellas Princezas fo|rão levadas à Ilha de Daliarte,

15 com o mais $\mid$ que tras isto succedeu ${ }^{3}$.

O Conde Arláo pois em tempos | tão calamitozos para aquelles estados, em quanto se não | soube da vida de ElRey Beroldo, trabalhou de | cumprir na guarda, e administração delles com | a confiança que de sua pessoa se tinha feito, e as|sim lhos entregou quando veio ${ }^{4}$ com tanta satisfa|ção de seus procedimentos, como de suas

20 gran|des calidades se esperava. E recolhendoce de|pois a descançar naquelle seu castello, onde es|tava D. Floris, quis que fosse em companhia | de hũa parenta sua moça, sezuda, fermoza, | e honesta, com quem se cazou, mais para que ella | o regallace, e consolasse da saudade que sua filha | lhe fazia na vida retirada, que para outros fins, || [14r] que na quelle estado se podem sospeitar de ou|tras idades; mas como a della fosse

25 pouca, e | a delle não de todo decrepita, nasceu daquel|la converçação (que não durou muito) D. Floris, de | cujo parto sua may perdeu a vida, deixando o | velho tão magoado

\footnotetext{
${ }^{1}$ No cap. 150 do Palmeirim de Inglaterra, ao narrar esta viagem de Recindos a Constantinopla não se menciona o Conde Arláo. Recindos era pai de Beroldo e sua esposa, cujo nome aqui não se menciona, era casado com Melisa, filha de Frisol (conforme se lê no Primaleón, cap. 64).

${ }^{2}$ Vencido por Florendos em Constantinopla, Albaizar teve de ir a Almourol colocar-se à disposição de Miraguarda. Esta, sabendo que Polendos e Belcar estavam presos pelo Sultão de Babilônia, exige que ele permaneça na corte espanhola até que os prisioneiros sejam libertados (cf. cap. 108 do Palmeirim de Inglaterra).

${ }^{3}$ Recindos e Arnedos são, respectivamente, os dois antigos reis de Espanha e França, ambos mortos na batalha contra Albaizar. Recindos é pai de Beroldo e Arnedos é pai de Graciano. Os dois reis não devem ser confundidos com seus netos, que receberam os mesmos nomes dos avôs.

${ }^{4}$ Isto é, quando Beroldo voltou da Ilha Perigosa, o Conde Arláo lhe devolveu o governo do reino.
} 
que nem com se ver com suc|cessor, que não esperava, nem com a fermozura do | menino ser admiravel, se podia consolar, Eas|sim foi passando algũns annos mais namo|rado, e triste, do que sua idade, e prudencia o re|querião, não deixando com tudo

30 de tratar da | criação do filho, que hia crecendo em partes na|turaes fora de toda a Estimação dos homẽns, | porque sem nenhũa proporção excedia sua idade | em todo o que lhe ensinavão, que erão todos aquel|les exercicios, com que se ella conformava muito | No parecer dos primeiros annos foi tão se|melhante a Miraguarda, que ainda que com a | idade, e com os trabalhos, que depois teve se fes $\mid$ mais robusto, e se lhe

35 engroçarão as feições, | em muitas partes era conhecido, contra sua von|tade, por seu irmão della. [espaço] Nas primeiras letras, | muzica, e mais artes liberaes, que aprendeu, e | depois na esgrima, em fazer mal a os cavallos, | em lutar, em tirar a barra ${ }^{5}$, sahio tão extre|mado, que entre os moços da quelle tempo era | havido por maravilha grande da natureza, | E entre os cavalleiros depois que chegou a sello, fes | ventagem em algũas

40 daquellas couzas, a todos $\mid$ os que com elle concorrerão, como foi em jugar | as armas, em lutar, e na agilidade dos mem $\|[14 \mathrm{v}]$ bros, porque igualando elle a todos em tudo (co|mo no discurso desta historia veremos) na |quillo, o não igualou nimguẽ.

Com estas boas partes, que D. Floris | hia mostrando se consolava o velho, sem o que|rer nunca mandar a Miraguarda, que o impor|tunava por isso com estranho dezejo

45 de o ver, pel|los extremos, que delle lhe escrevião. Nem ElRey | Beroldo (em cuja caza se elle criava) poude aca|bar com Arláo que lhe deixasse mandar a o Em|perador Primaleão, e a Florendós, que o dezeja|vão na sua, pellas mesmas razões que Mira|guarda.

Chegou emfim a hora a o Conde | seu Pay, como a tudo, e foice desta vida 50 deixã|do o filho de doze annos herdeiro de seu estado, | que para de vassalo não era pequeno, porem tanto | melhor herdado da natureza, que pellas partes de | sua pessoa, foy hũ dos excellentes princepes do | Mundo, [espaço] Mas porque nas perfeições huma|nas não se achão nunca virtudes puras, não | lhe faltàrão a D. Floris couzas, que o fizerão ser | menos amado de algũns, do que se as não tive|ra acontecera, porque 55 primeiramente sendo tão bẽ | nascido, que incluhia em si dos melhores san|gues de Hespanha, sendo tão esforçado, e tão | entendido, como no discurso desta Historia

\footnotetext{
${ }^{5}$ Em que consisitiria o exercício de "fazer mal aos cavalos": seria domar cavalos? Quanto à expressão "tirar a barra", o Vocabulario de Bluteau esclarece: "antigamente era um jogo, em que os que lançavam mais longe um varão de ferro davam mais prova de suas forças e venciam".
} 
ve|remos, la teve hũa desconfiança natural, que | o fazia não converçar ${ }^{6}$ com os Princepes de | seu tempo de boa vontade, particularmente | com os da caza de Grecia, dos quais se aborre|cia de maneira, que athe de seu proprio so||[15r]brinho Primaleão ${ }^{7}$ se apartava, e de Floren|dós ainda mais, dando por razão desta esqui|vança, que porque elles não cuidassem que folgava | elle com aquelles parentescos. [espaço] E sendo por | outra parte de condição humana affeiçoada, | e brandissima, e entretendoce muito de tratar | com mulheres com grande limpeza, e decencia, | era tão ciozo dellas, que ainda as em que lhenão hia na|da lhe davão trabalho, e assim teve algũns a esta conta.

65 Com esta idade, e com estas inclina|ções ficou D. Floris, por morte de seu Pay entregue | a hũ tio seu irmão de sua May, muito mancebo, e | muito bom cavalleiro, chamado Lisanio, a quem o | Conde Arláo o deixou encomendado. O qual sen|do dotado de grandes excelencias, era em tanta |demazia soberbo, e confiado de si, que maculava | notavelmente com estas, as outras boas partes, que | tinha, e sobre este seu termo hião ja

70 D. Floris, e | elle tendo disgostos domesticos, porque ao sobri|nho não the parecia bem a arte do tio, a fora que | como era tutor, e elle hia crescendo, a obedien|cia, lha fazia parecer mais pezada. E o tio, | como nimguem se conhece a si proprio, tam|bem cuidava que tinha que repreender no sobri|nho o mesmo vicio disfarçado, porẽ cõ nome | de altives. [espaço] D. Floris que entre estas couzas | tinha chegado a despozição, e força,

75 que ja lhe pa|recia que lhe tardava a Ordem da cavallaria | dezejandoa muito, e andando tratando com Li|sanio seu Tio do modo, e mão de quẽ a rece|beria, publicouce a jornada da quelles Prin||[15v]cepes a Constantinopla, e querendo El|Rey Beroldo levallo concigo, para que juntamente | com os outros moços, que havia trazer Daliarte | fosse armado cavalleiro (couza que ja todos entẽ|dião que elle dezejava tanto) como no seu 80 cora|ção ardesse juntamente com este dezejo outro | de se assinalar porcima dos outros homẽns | detreminando acharce naquellas festas, e no | Torneio dos Noveis sem ser conhecido para se | poder provar com elles, não querendo acompa|nhar a ElRey por este respeito, fingiose doen|te de maneira, que ouve de ficar. E vindoce | depois de partido ElRey à quelle seu castello | para dali dar Ordem a o que tinha no pensamen|to, 85 succedeu que indo hũ dia à cassa das lebres, | de que por alli havia muitas levou tambẽ esmeri|lhões para as cotovias, e andando la, vindo Li|sanio defora, e não achando o

\footnotetext{
${ }^{6}$ Ao final da palavra converçar, há o complemento -ção riscado pelo copista, que provavelmente havia escrito converçação inicialmente.

${ }^{7}$ Trata-se do príncipe Primaleão, filho de Florendos e Miraguarda.
} 
sobrinho, in|formado daparte para que dissera que hia, foise em | sua busca para ver tambem voar os esmirilhões, | e topandoce antes de chegar onde elle andava | com aquelle cavalleiro, com que Dramusian|do o achou em batalha, que era vizinho em | hũ castello alli perto, no qual tinha hũa cunha|da sua, com quem Lisanio tratava menos ho|nestamente, do que o outro quizera. Sobre | aquella materia ouverão as brigas em que Dra|musiando os achou, das quais succedeu o que te|mos contado.

D. Floris pois que pellas couzas que | tinha ouvido de Dramuziando the era mais || [16r] affeiçoado que a homem algum daquelle tempo, pa|recendolhe melhor o 95 procedimento que tivera | com Miraguarda, que todo o outro por menos in|tereçado. Em nenhũa maneira quis deixar | de ser cavalleiro de sua mão, e bem folgara de se | experimentar com elle, mas parecialhe que ja o fa|zello, ou tentallo, seria julgado mais a rusticida|de de natureza que a brio de coração. E assim | tanto que amanheceu como soube que Dramusian|do estava acordado, foice a sua camara, e depois | de saber delle,

100 que estava mais descançado do tra|balho, e com menos sentimento das feridas, dizen|dolhe como Lisanio mostrava tambẽ algũa melho|ria nas suas, e quem elle era, e a razão da morte | do outro, lhe tornou a pedir que o quizesse armar | cavalleiro, e sem admitir escuza algũa trouxe | Dramusiando alho prometer. E assi dali a tres | dias, que se achou em dispozição de poder caminhar | tendo D. Floris vellado as armas na quella 105 Er|mida, que dissemos, o armou cavalleiro Dramusi|ando, com grande gosto de ambos, posto que tem|perado com as feridas de Lisanio irem peoran|do, ao qual não foi bom remedio saber que era | Dramusiando quem lhas dera, como algũns | cuidarião, antes veneno mortal, porque elle se / estimava em tanto, e cuidava tanto de si, que | tinha crido que o não venceria Palmeirim se se | encontrassem, e verce vencido de quem o fora | 110 delle $^{8}$, inda que o tomara ja cançado, e ferido da | batalha em que o achara, acrecentoulhe o mal de | maneira, que ou disso, ou de que as feridas não erão | medicaveis, pouco depois de Dramusiando \| [16v] partido espirou de todo, o qual em armando | cavalleiro D. Floris não tardou mais despe|dindoce delle com mostras de verdadeiro A|mor, e assim lho teve sempre igualmente, que a $\mid$ os filhos de D. Duardos.

115 [espaço] $\mathrm{E}$ aconcelhandoo, e | dandolhe muitos e proveitozos documentos para se | governar bem na nova Ordem, em que entrava, | abraçandoo, ultimamente thomou seu

\footnotetext{
${ }^{8}$ Com efeito, Palmeirim venceu Dramusiando (e só lhe poupou a vida a pedido de D. Duardos, acrescenta o narrador) por ocasião da libertação dos príncipes que estavam presos na fortaleza do gigante (cf. cap. 49 do Palmeirim de Inglaterra).
} 
cami|nho para o primeiro porto de mar, que toda via lhe pare|ceu que para chegar a tempo a Constantinopla | convinha embarcarce. E D. Floris, que ficou | em sua caza não poude sahir logo della como | quizera, porque a despozição de seu tio não da|va lugar a 120 o largarem. [espaço] Enfim morto elle | fazendoo enterrar como a sua pessoa convi|nha, e deixando suas couzas a bom recado, tho|mou o caminho de Grecia, armado de hũas | armas negras, com lagrimas de prata, em | sinal da tristeza que levava, dezejando acharse | na quellas festas sem ser conhecido, como temos | contado, e assi o deixaremos athe seu tempo. 


\section{Capitulo 7.}

\section{Em que se da conta como todos aquelles | Reys, e Princepes chegarão a Cons|tantinopla, e do mais que nisto succedeu.}

Ja começava a dar cuidado a Primaleão | a tardança de seus hospedes porque se chegava || [17r] o dia prescripto às festas, para as quais tinha pres|tes tudo, o que lhes parecia necessario, e não vinha | recado de nenhũ delles, ${ }^{1}$ com o que hia o affeito na|tural (que fas sempre recear o que se muito dezeja) | começando a inquietar o animo do Empera|dor, temendo, ou os ordinarios accidentes da | fortuna, ou as invenções da

10 malicia humana, | parecendolhe que crera depreça a Donzella, e que | poderia não ser de Daliarte, mas não tardou muito | que o livrou desta imaginação dizeremlhe, que seu | filho Platir era entrado no Porto, com a Ra|ynha sua Mulher ${ }^{2}$, apos o qual dentro de poucos | dias chegarão os outros Reys, que se esperavão, com | tanto alvoroço de todos, como se de novo então | começarão a viver no mundo. Os compri|mentos, e cirimonias

15 dos recebimentos não | particulariza o choronista, havendo que onde | tudo era tão perfeito, poderia ser o juizo de cada | hũ dos leitores amedida do que quizesse imaginar. | So dis, que D. Duardos, e Flerida, forão apo|zentados na quelle quarto, que inda concercava | o seu nome ${ }^{3}$, e todos os mais Reys nos passos, | que os bem podião sofrer, porque afora serẽ muy | sumptuozos, o Emperador, como dissemos, tinha | lavrado tão

20 magnificamente nelles, como se | adevinhara que os havia de haver mister para aquel|le tempo. [espaço] Valeriza, Flerida, e Carmelia, | forão dadas por hospedas à Princeza Gridonia, | que por mais que trabalhou por enfraquecer o juizo | de Daliarte, não poude fazer tanto que se livra|ce pello menos de hũ muito justo espanto de | fermozura de cada hũa dellas, principalmente $\|[17 \mathrm{v}]$ de Carmellia, a qual, sem se entender o porque | foi 25 julgada dos desapaixonados da quelle tempo, por mais fermoza que todas, mas demaneira | o era cada hũa destas quatro Princezas, que | quem quizera atribuir o primeiro lugar aqualquer| dellas, não lhe faltaria por ventura razão, e ra|zões para o

\footnotetext{
${ }^{1}$ Neste ponto, há um parêntese riscado pelo copista.

2 A esposa de Platir é Sidela, filha do rei Tarnais de Lacedemônia.

${ }^{3}$ No Palmeirim de Inglaterra também se faz referência aos antigos aposentos de Flérida: quando ela e o marido chegam a Constantinopla por ocasião do casamento dos príncipes, o narrador diz: "Foi D. Duardos e Flerida apousentados no próprio apousento, que ainda tinha o seu nome” (cap. 150).
} 
poder fazer ${ }^{4}$, e assi vivião todas com | tamanhos ciumes de si mesmas nos primeiros dias, | que não era necessario menos que seus juizos, e des|crições, para encobrirem o 30 que cada hũa sentia. | A Princeza Polynarda, Miraguarda, e a Ray|nha de Tracia, estavão ainda tão frescas, e in|teiras em seu parecer, que puderão mui bem | fazer inveja a suas filhas, se o costume de as | tratarem, e saberce que erão Mãis não fizera con|tra ellas nesta parte. [espaço] Gridonia, e Flerida | não concercavão ja do que forão, mais que hũns | pequenos vestigios no gesto, e ar, que ainda davão | assi mesmas ${ }^{5}$. [espaço] D.

35 Duardos, e Primaleão | da mesma maneira estavão carregados nas | pessoas, brancos nos cabellos, e impedidos dos $\mid$ achaques que a idade tras concigo, mas ainda $\mid$ com o gosto de se verẽ juntos trazendo à me|moria suas couzas passadas, criavão em si hu|as vezes espiritos militares, e outras magoas, | que tem so o sofrimento por remedio. [espaço] Todos | os mais Princepes, Palmeirim, Floriano, Flo|rendós, Platir, Graciano, Beroldo, 40 Polinardo, | Francião ${ }^{6}$, Pompides, Dragonalte, Blandindon, | e D. Rosuel, estavão no melhor de sua idade, in|teiros nas forças, sãos nas pessoas, alegres no ani|mo, e promptissimos para se cumprisse tornar $\|$ [18r] Aos $^{7}$ trabalhos do mundo, como nos primeiros dias, | em que o tratarão. [espaço] Floriano so tinha algũas | cãns, que o fazião mais gentilhomem, annunci|adores ${ }^{8}$ de seus antigos exercicios, que sempre em | quem

45 os assim teve, se costumão antecipar. | Acharão em tão todos menos a Dramuzian|do, com que o prazer não era de todo cumprido, | porque (como muitas vezes temos ditto) este foi o | homem cuja converçação, e amizade mais | se estimava na quelles tempos; Mas parecen|dolhe impossivel que deixasse de ter recado de Da|liarte, conçolavãoce com entederẽ que não po|deria tardar muito, e quando não viesse, que depressa | lhe mandarião avizo, a o menos para o verem.

Assi hião passando estes cavalleiros | conversandoce com grande familiaridade fa|lando nas couzas passadas, no trabalho, em que os | metera Albaizar, na bondade de

\footnotetext{
${ }^{4}$ Esta frase, que possui estrutura sintática confusa, está igual em B; em C, apresenta ligeiras variações: "mas demaneira oera cada húa destas quatro princesas que quem quisera atribuir oprimeiro lugar aqualquer dellas não lhefaltara por ventura rasões nem rasão para opoder faser".

5 O narrador se refere aqui à Imperatriz Gridônia (mãe de Florendos e Platir) e à rainha Flérida (mãe de Palmeirim e Floriano), que não devem ser confundidas com suas netas.

${ }^{6}$ Sobre Francião, ver acima, cap. 03, nota 14.

${ }^{7}$ A letra $A$ foi escrita sobre um $t$, pois provavelmente o copista iniciaria o fólio com a próxima palavra (trabalhos).

${ }^{8} \mathrm{~B}$ e C: anunciadoras.
} 
Targiana $^{9}$, que | ainda veuva governando seus estados, e os de seu | filho, não deixava de correr com aquellas Prin|cezas, aguardando por Daliarte para poderem | ver seus filhos, 55 aquem quazi não conhecião, e | dequem nunca perderão o cuidado. [espaço] Hũ dia | pois pouco antes da festa do Spirito Sancto, que se / esperava, estando o Emperador com todos el|les, e com aquellas senhoras, e Princezas na | Orta de Flerida ${ }^{10}$, onde tinha jantado, entrou | pella porta aquelle valente Dramuziando, arma|do das duas folhas de asso, rotas por algũas partes, | e o Escudo falsado em algũns lugares, e elle algũ | tanto

60 mais groço, do que o alli virão, que deu azo a o | não conhecerẽ na despozição, e continencia | do corpo. [espaço] Mas na quella ${ }^{11}$ tão airoza, e bẽ posto | como quem ainda se sentia para correr hũ $\|$ [18v] par de lanças com todos os Princepes | da Ilha Perigoza. [espaço] Desta maneira foy | andando para o Emperador, descontente de o | ver tão quebrado a elle, e a D. Duardos, e sem | fallar palavra pondo os giolhos no chão 65 dezen|laçando o Elmo disse: Ainda senhor venho | a tempo que me pode vossa Magestade Mandar | dar o castigo da minha tardança. Já D. | Duardos, e seus filhos o tinhão tão apertado cõ|cigo, que não davão lugar a os outros, que querião | fazer o mesmo. [espaço] O Emperador o levantou | e abraçou muito estreitamente dizendo: Por|certo Dramusiando, que vossa tardança nos da|va tanto cuidado a todos vossos 70 amigos, que | nos não deixava lograr o gosto de nos vermos | juntos, mas pois vos tenho nesta caza a vos, e a | elles, não sei ja mal que possa vir que me doa muito | nem bem, que me faça mais contente. [espaço] Nisto | voltou Dramusiando para o estrado das Princezas, | donde se ouvio chamar, e vio que Miraguarda lhe | dizia: [espaço] Não sei Dramusiando quem tem | a culpa de me não veres, se Florendós so, se to|dos estes

75 Princepes juntos, mas demola ao tem|po, que me tem feito velha, e a vós descuidado, e | com tudo me dizei como vindes, que todas folgare|mos seja bem. [espaço] Dramusiando lhe respondeu: | Se falar senhora a o Emperador foy erro, impos|sivel será arrependerme delle, pois me foi occa|zião desta merce que me fizestes, Mas hũas novas | vos trago, com que me podereis perdoar. [espaço] Então | bejando a mão á Emperatris, fallou a 80 todas aquel|las senhoras, de quem foi extraordinaria mente | favorecido. E informandoce

\footnotetext{
${ }^{9}$ A figura de Targiana é um tanto ambígua no Palmeirim de Inglaterra: se, por um lado, ela avisa o Imperador Palmeirim de Oliva das intenções duvidosas de uma embaixada do Grão Turco (cap. 112) e se opõe à tentativa de invasão de Constantinopla (cf. caps. 157 e 164), por outro lado, ela também foi a responsável pelo rapto de Leonarda, para se vingar de Floriano (cf. cap. 155).

${ }^{10}$ No Palmeirim de Inglaterra, a horta de Flérida parece ser um dos locais preferidos pelos membros da corte (cf., por exemplo, os caps. 112 e 151).

${ }^{11}$ Isto é, na "despozição" do corpo.
} 
de quem erão as $\|$ [19r] moças, pasmado do parecer dellas, disse para Gri|donia: [espaço] Espantece senhora quem não souber | cuja filha sois, e quem o sabe, comece a fazerce | prestes para ser martirizado, que não cuido que donde | ha tanta conformidade no parecer, haja differen|ça na condição ${ }^{12}$. [espaço] Seguindo isso (disse Miraguar|da) mal tornareis vos aguardar o castello de $\mid$ Almourol por amor de mim. [espaço] Ao menos senhora |quando o fizesse (respondeu elle) agora, me devereis | mais que nunca, porque tendes la hũ parente tão | agastado, que emprestava eu fortes trabalhos a o se|nhor Florendós, se elle viera na quelle tempo. [espaço] | Então lhes contou tudo o que com D. Floris lhe aconte|cera, de que todos ficarão em extremo alvoraçados, | e 90 Florendos, e o Emperador mais, que nunca puderão | havello á mão. [espaço] ElRey Beroldo perguntou a | Dramuziando, se ficava com detreminação de | vir as festas, porque elle o não pudera armar à quella | jornada. [espaço] Muito lhe deverá (disse Dramuzian|do) a quem elle der conta das suas detreminações | por sua vontade, e contra ella, não tenho por cou|za facil sabello nimguem delle. [espaço] Igual|mente sentida, que

95 alvoraçada, estava Miraguarda | com o que ouvia de seu irmão, e o Emperador | que lhe sentio aquillo lhe disse rindo: Não vos a|gasteis filha, que não he possivel que deixemos de o colher | aqui algũ dia, e se vem, nesse estrado está | gente, que o fará mais brando que hũ cordeiro, que | bem sabeis vos que na caza de Grecia não faltarão | nunca remedios para condições izentas. [espaço] Ella | se atalhou hũ pouco com o que o 100 Emperador lhe dizia | e antes de lhe responder entrou pella porta hua Aven|tura, que detodo lhe impedio fazello, como veremos | no capitulo seguinte.

12 Dramusiando refere-se às duas principais características de Miraguarda, mãe de Gridônia: sua extremada beleza e a crueldade com que tratava seus servidores, entre os quais contava-se o próprio Dramusiando. Acerca de Miraguarda, diz o Palmeirim de Inglaterra: ela era "tão confiada e altiva, que cria que tudo se devia a seu merecimento, sem ela dever nada a ninguém” (cap. 109). 


\section{|| [19v] Capitulo 8}

\section{Do mais que succedeu estando aquelles | Reys na Orta.}

Querendo Miraguarda responder ao Empera|dor entrou pella porta hũ Escudeiro,

5 que sentã|doce de giolhos diante delle disselhe: Senhor, hũ | cavalleiro Estranho, que alli fora está, beja vossas | Reaes Mãos, e vos fas a saber como he vindo | a esta corte á fama das festas que mandastes pre|goar, para vos servir nellas. [espaço] E porque acha que inda | não são começadas quer se lhe derdes licença | exprimentarce com os cavaleiros de vossa ca|za em quanto não ha outra couza que fazer, para o que | os dezafia a todos a

10 justar so mente, porque não | queria darvos nenhũ disgosto; mas que se algum | lhe for igual na justa, que então o aggravado po|dera fazer o que quizer. [espaço] Estranha pareceu | a confiança do cavalleiro a todos aquelles Prin|cepes, E as Damas se começarão a alvoraçar | com aquelle principio de festa. [espaço] Estando | todos com os olhos no Emperador, virão que res|pondia dizendo: [espaço] Escudeiro, dizei a vosso |

15 Senhor que elle seja mui bem vindo, que a licen|ça, que me pede lhe dou a elle, e a todos os meus, | que com elle se quizerẽ exprimentar, mas que | me parecia melhor pouparce para o Torneio, que | não pode tardar ja muito, onde acharia mais | gente, em que empregar suas forças, que não de|vem ser poucas, segundo a muita confiança, que | de si mostra. [espaço] O Escudeiro se tornou | com esta Embaixada, e Dramusiando, que

20 || [20r] estava armado disse para o Emperador: Pa|receme senhor, que a mim so dezafia este ca|valleiro, pois eu só dos vossos sou o que aqui | mais depressa lhe posso responder, pello que | pois Vossa Magestade nos deu licença a todos, an|tes que se elle enfade mais me parece razão ir|molo a entreter. [espaço] Pois assi o quereis (disse $\mid$ o Emperador) estreareis esta praça, que está | as vossas costas, que para hũ cazo destes,

25 mandei | aqui lavrar de novo. [espaço] E assi era, que onde se | cruzavão hũas ruas de louros, choupos muito | altos, se fazia hũa praça coadrada, capás de | se combaterem oito cavalleiros nella, cercada | de muro de altura de hũ homem, e cuberto por | dentro de arvores de Espinho, que enconstadas nas | paredes não deixavão ver nada dellas, e deste | muro para cima nelle proprio, estavão situadas | tantas cadeiras de azulejos,

30 quantas podião | caber em seu diametro, ás quais se sobia por | dentro da quelle cerco, que tinha quatro portas | fronteiras hũas de outras, que sahião a quatro ru|as differentes, mas todas compridas, e direitas, | e em extremo bem assombradas. [espaço] Áquelles | 
assentos se passarão logo todos aquelles Prince|pes, e senhoras, mandando recado a o cava|leiro Estranho que entrasse. E tendo trazido | o cavallo a Dramusiando, Floriano

35 lhe en|laçou o elmo, e lhe disse: Pareceme que não foi | ditozo este cavalleiro em vos achar tão apre|cebido, se ja não julgar por dita forrardelo de $\mid$ muito encontros ${ }^{1}$. [espaço] Não estou ja para nada senhor | Floriano (lhe disse Dramuziando) mas com || [20v] este vosso favor veremos o que nos acontesse.

Nisto entrou o cavalleiro Es|tranho na praça emcima de hũ cavallo | Murzello 40 grande, e fermozo, e elle tão airozo, | e bem posto, que deu de si grande contentamen|to a todos aquelles Mestres de guerra, que alli es|tavão. [espaço] Vinha armado de hũas Armas de | Ouro, e leonado, misturadas as cores de ma|neira, que se davão muita graça hua à outra. | No escudo Em campo verde hũa Hidra cõ $\mid$ muitas cabeças mortas, e outras que mostravão es|tar vivas, e hũa letra em lingoa Latina, que | dizia assi: Magis, magis ${ }^{2}$.

45 [espaço] A dispozição do | cavalleiro, a louçania das armas, a novidade | da diviza, e letra, encherão de alvoroço a to|das aquellas senhoras, e a muitas começava a pe|zar de se achar alli Dramuziando tão a pon|to, contra cujas forças não lhe parecia que o | outro se poderia deffender, a o qual quando ja não | dezejassem a victoria, pello menos não que|rião que tão depressa fora vencido.

50 Os cavalleiros que ja estavão sos | na praça a o som de hũa trombeta (que o | Emperador mandou tocar por fazer essa honr|ra a Dramuziando) remeterão hũ ao ou|tro a todo o correr de seus cavallos, e encon|trandoce em cheio, no meio dos escudos, foi | com tanta força, que o cavallo de Dramu|ziando que vinha fraco e cançado, deu comci|go no chão, levandolhe hũa perna de baixo | de que ficou tão impedido, que não

55 poude mais || [21r] fazer batalha. A o cavalleiro Estranho | rebentarão as cilhas, e com a sella entre as per|nas se achou em pe no campo. [espaço] Entrarão $\mid \operatorname{logo}$ todos aquelles Princepes na praça pou|co contentes do desastre de Dramusiando, e | não pouco espantados da força do cavalleiro. | E Floriano, que foi o primeiro que chegou achou ja que o Es|tranho lhe tinha tirado o cavallo de cima, e | trabalhava pello levantar, porque o 60 pezo do corpo | e a fraqueza do cavallo ajudarão a fazer a que|da de maior perigo. Então disse Floriano | contra Dramuziando: Não sei senhor porque | trazendo o cavallo tão

\footnotetext{
${ }^{1}$ Isto é: Floriano diz que o cavaleiro estranho teve pouca sorte em achar Dramusiando pronto para combatê-lo, pois perderia a oportunidade de experimentar-se com os demais cavaleiros da corte caso fosse vencido rapidamente por Dramusiando.

${ }^{2}$ Do lat., "mais, mais".
} 
cançado não quizestes | thomar outro para vos ver agora por falta sua | neste dezastre. [espaço] O cavalleiro Estranho, que | o ouvio the respondeu: Como senhor, falta | do cavallo vos parece a vós que tem neste estado | a esse cavalleiro? [espaço] Si por certo

65 (disse Flori|ano) e se o vos conhecereis facilmente o con|fessareis. [espaço] Não sei o que eu confessarei (disse o | Estranho) mas se vós tendes algũ muito poupa|do pondevos nelle, que eu nesse que cahio vos mos|trarei bem depreça onde a falta esteve. [espaço] | Dramuziando, que em extremo estava enfada|do do que lhe tinha acontecido, lhe disse: [espaço] Ca|valleiro, conforme a postura do vosso deza|fio, com que sou o aggravado

70 posso pedir batalha, | peçovos que a façamos, que ainda que estou com me|nos hua perna, por ventura que se vos não a|partardes muito de mim, que ou me deixeis com | menos saude, ou com menor magoa. Fa|cilmente vos fizera a vontade (respondeu o | Estranho) inda que não sei se me podeis o\|[21v]brigar pello que continha o meu recado, mas | tendes aqui tantos padrinhos que ei medo se vos | acontecer algũa couza, que vos

75 não $\mathrm{de}^{3}$ gosto, que | digão que estaveis maltratado. [espaço] Floriano que | estava ardendo em colera, ouvindo a resposta | do cavalleiro, thomouo pello braço, e disselhe: | Todos os que aqui estamos cavalleiro, somos ami|gos do Senhor Dramuziando, mas nem elle tẽ | necessidade de nos para se satisfazer das faltas | de seu cavallo, nem vós vos ireis sem pagares | a soberba, de que são cheas vossas palavras, que eu | que entre 80 todos os que vedes sou o que menos posso | volo mostrarei logo como vierem as armas, | que para o fazer tenho ja mandado buscar.

A o Emperador pezou muito da pai|xão de Floriano parecendolhe particularmente | que não tinha muita razão, e voltando para o cavallei|ro, que hia respondendo, lhe disse: Cavaleiro, não vos | espanteis de nos pezar dos dezastres de

85 Dramusi|ando, que quando soubereis as razões que para isso ha, bẽ | vereis que nos não faltão. Vós haveivos por segu|ro de todos, senão dos com que vos combaterdes, | e não tendes que responder, porque os cavalleiros cõ | as obras, e não com as palavras respondẽ. [espaço] O | cavalleiro Estranho espantado da quella man|cidão, e benignidade do Emperador, se pos | em giolhos, e disselhe: Senhor fassa Vossa

90 Magestade jus|tiça igual pois he Ministro de Deus na terra | e foi ja tambẽ cavalleiro Andante. E no | mais eu trabalharei de maneira de cumprir | com o que me manda, que

\footnotetext{
${ }^{3}$ Para compreender a frase, é preciso considerar este de como sendo forma verbal tônica (dê). Poucas linhas à frente, o copista acentua a mesma forma verbal (dé), a fim de evitar ambigüidade com a preposição (cf. linha 8,92).
} 
dé mais satisfação | com as obras, do que a da qui levo das palavras. || [22r] A este ponto estava ja Floriano armado, e | tão apaxonado, que nem quis ouvir nada do que | lhe dizia Palmeirim seu irmão, nem a Ra|ynha sua Mulher, que o mandava chamar de / parte 95 daquellas senhoras, que lhe querião fallar an|tes que entrasse na batalha, da qual daremos | razão no capitulo que se segue, para enfiar melhor | o curso da historia, que himos tecendo. 


\section{Capitulo 9}

\section{Da batalha, que estes cavalleiros houverão | e do que della succedeu.}

Tanto que Floriano se acabou de armar assim a | pe como estava moveo para seu 5 contrario, que o espe|rava dezejozo de lhe mostrar que não fora a queda | de Dramuziando de todo falta do seu cavallo. E | embraçando ambos os escudos levando das espa|das sẽ falarem palavra começarão a se ferir de | tão duros e pezados golpes que em pouco espaço | ficou aquelle terreiro semeado de rachas dos escu|dos, e pedaços das armas que à furia delles erão pequena | rezistencia. [espaço] Floriano ao principio com a

10 pai|xão de que se deixava senhorear descuidandose da | arte pelleijava mais como colerico, que como sciente. | Mas o outro, que alli mais que em nenhũa parte do mũ|do dezejava mostrar o para que era ${ }^{1}$, estando recolhido | em si sem perder nada do campo, ferio em duas | ou tres partes primeiro a seu contrario, o que na quellas senho|ras, que os vião cauzou tanta turbação, principal||[22v]mente em sua may, em sua mulher, e filha,

15 que | com lagrimas sahidas dalma começarão a | solemnizar aquella cruel tragedia. Mas | em Floriano não servirão as feridas de mais $\mid$ que de o espertar $\mathrm{a}^{2}$ fazer tornar sobre si, aprovei|tandoce de toda sua industria, e ligeireza, | com que a batalha começou a ser a mais notavel | a juizo da quelles que a vião, que de dous cavalleiros | sos se tinha visto, os quais sem mostrarẽ hũ | ponto de fraqueza se andarão ferindo por hũ | grande espaço

20 sem se conhecer em nada me|lhoria, porque ambos andavão ja cubertos de | seu sangue, E quazi que de todo desarmados, | e tão vivos, e tão ligeiros, que não parecia que tinhão | feito nada. [espaço] O Emperador benziase. | Palmeirim, e os outros pasmavão. Dramu|siando, que nunca se dalli quizera ir por mais | necessidade que disso tinha, pezavalhe de ver ta|manhas obras no cavalleiro, porque lhe hia ja pa|recendo que mais

25 culpado era no seu dezastre, | a força delle, que a fraqueza do seu cavallo. E | vendo alli prezentes todos os cavalleiros do mũ|do, de quem se podião sospeitar tamanhas cou|zas, não sabia que dizer, senão que anatureza $\mid$ em todas as idades dava homens de novo. |A este tempo os cavalleiros se afastarão cada | hũ para sua parte por thomarem algũ alento, | e Floriano vendoce tão mal tratado, o escu|do desfeito, as armas rottas, e elle

30 ferido em | tantas partes começou a dizer concigo: [espaço] Se | para acabar á vista do mundo todo, que aqui ve|jo junto por mãos de hũ so cavalleiro, e não || [23r] conhecido,

\footnotetext{
${ }^{1}$ Isto é: desejava mostrar do que era capaz.

${ }^{2} \mathrm{C}$ : "espertar $e$ fazer".
} 
me guardou a fortuna de tantos | acontecimentos grandes, cumpramos com | o que ella tem ordenado, e façamola ${ }^{3}$ muito embo|ra rica com nossos desastres, mas pello me|nos folgo que verão estes cavalleiros, a quem | mais que animguem dezejei sempre dar satis|fação de mim, que quando perder a victoria, não | ficarei com vida para sentir a vergonha. E | pondo os olhos onde aquellas senhoras estavão | vendo sua mulher, e filha sem cor, e todas tão | tristes como quem sentia nalma a dor de su|as feridas, vindolhe hũa nova força, e hũ novo | alento, não o quis dispender em mais imagi|nações, e tornandoce a ajuntar com o cavalleiro, | que athe então estivera dizendo entre si:

40 [espaço] $\mathrm{Eu} \mid$ morro no melhor da minha idade, e so o sinto | pello pouco que tenho aproveitado no mundo, | a que parece que vim inutilmente, pois acabo | antes de começar. Mas forte couza he que não | criasse a natureza homẽns senão para serem | vencidos destes Gregos, porem isto não verão | elles em mim, se he verdade que onão fica $\mid$ quem fazendo tudo o que pode paga com a vi|da o que deve à sua honrra ${ }^{4}$. [espaço]

45 E acabadas estas | palavras vendo como Floriano se vinha para | elle, se tornarão a receber com tamanha|tempestade de golpes, que mais parecião de | Martellos robustos, e pezados, que de espadas leves, | e cortadoras. [espaço] Desta segunda ves se chegarão | a estado, que ja não havia em nenhũ delles espe|rança de vida, nem de remedio algum | com que todos aquelles Princepes estavão os || [23v] mais descontentes homẽns do 50 mundo, E co|mo a virtude nunca està Ocioza nos pei|tos, em que se cria, não havia alli algũ que não | sentisse tambem muito a morte do cavalleiro | Estranho, que em extremo tinha contentado | a todos. [espaço] Verdadeiramente (disse ElRey | D. Duardos para o Emperador) que se me não | fora tanto Floriano, ou se o não vira tão mal | tratado que por nenhũa couza deixara de estorvar ${ }^{5}$ | esta batalha, mas ainda que estivera ${ }^{6}$ Palmeirim | 55 no mesmo estado o não fizera pellos respeitos $\mid \mathrm{q} u e$ digo $^{7}$. [espaço] $\mathrm{Eu}$ (lhe respondeu elle) comprara ho|je com toda a valia do meu senhorio não ter | officio de fazer justiça, porque este so he o que me detẽ, | que não vi nunca lastima igual a morrerem | assim estes homẽns com tão pequena cauza. | A este tempo ja as mais da quellas Princezas

\footnotetext{
${ }^{3}$ B: façamolo.

${ }^{4}$ Leia-se: "Mas grande coisa seria que a natureza criasse homens apenas para serem vencidos destes [cavaleiros] gregos; porém isto [a vitória] não verão eles em mim, se é verdade que o não fica [isto é: que não fica vencido] quem fazendo tudo o que pode paga com a vida o que se deve a sua honra".

${ }^{5} \mathrm{O}$ termo estorvar foi corrigido pelo copista.

${ }^{6} \mathrm{C}$ : "ainda que iunta mente estivera".

${ }^{7}$ A frase está confusa. O sentido da passagem é que D. Duardos está preocupado com o filho, mas não interromperia a batalha ainda que fosse Palmeirim quem estivesse passando pelas mesmas dificuldades que Floriano contra aquele misterioso cavaleiro.
} 
ti|nhão voltado as costas à batalha, e meas desma|iadas não se falavão palavra. [espaço]

60 Os cavalleiros | tinhão vindo abraços ${ }^{8}$, no que Floriano pudera ar|riscar muito, porque o outro afora muito forçozo, era | grande mestre da quella arte, o que sentindo | Floriano, não querendo que lhe acontecesse algũ | dezastre em homem, pellas culpas de Menino ${ }^{9}$ | soltandoce delle detreminou de acabar de to|do abriga com hũ so golpe. E arrojando o | pedasso do Escudo, que lhe ficara, thomando a Es|pada com ambas as Mãos foice para

65 seu con|trario, que como se se falarão da mesma ma|neira vinha ja para elle, e assim se assentarão | tais golpes nas cabeças, que Floriano que foi colhi|do de prancha (porque a o tempo de ferir se | torceu a espada na mão a o Outro) pos hũ || [24r] giolho no chão, e com a força da pancada lhe | saltou o elmo fora da cabeça quebrandoce | lhe de todo as enlaçaduras delle, e juntamente | com o que elle fes (que não foi de menor effeito) se |

70 lhe quebrou a espada por junto da empunha|dura, deixando o cavalleiro estranho com hũa | ferida na cabeça muito maior que as que dantes | tinha, de que ficou tão atormentado, e com | tanto sague pellos olhos, e rostro, que dando | algũns paços atras de todo esteve para cahir, mas | emfim passandolhe aquelle accidente, e tornã|do a remedearce com a viveza de seu cora|ção, que na quelles trances não dezemparava ${ }^{10}$. |

75 Endireitando o Elmo na cabeça como melhor | poude, socegando a pessoa, e compondo os pas|sos, com a espada na mão se foi para Floriano, | que sem elmo, e sem escudo o estava esperando | com o pouco que da Espada lhe ficara, tão quie|to como seu animo invencivel o ensinava | a ser, ainda na quella fortuna, que foi a maior | em que se elle nunca vio, mas se todos os que en|tão o virão o julgavão por perdido, não he para |

80 preguntar. [espaço] $\mathrm{O}$ cavalleiro pois que ja o tinha | visto da quella maneira, entendendo que se | fazia prestes para tornar a cerrar com elle, primeiro | que o fizesse lhe disse: [espaço] Senhor cavalleiro ainda | que eu pudera uzar justamente desta ventagẽ | que a fortuna me deu tirandovos as armas, | nem eu me sei contentar de tais victorias, | nem segundo o que do vosso valor tenho expri|mentado, em nenhũ estado 85 ellas estão certas | devós, pello que ou thomai outra espada, e | outro elmo, ou tirarei eu o meu, e deixarei $\|[24 \mathrm{v}]$ a minha, e com as adagas acabaremos nos|sa batalha, que

\footnotetext{
${ }^{8}$ A expressão "vir a braços" significa que os cavaleiros estavam abraçados, medindo suas forças e tentando derrubar o oponente.

${ }^{9}$ Não fica claro a que possíveis erros da mocidade de Floriano o autor faz referência nesta passagem, visto que não se percebe como o único defeito notório do personagem durante sua juventude - sua inconstância amorosa - poderia influenciar no resultado desta batalha.

${ }^{10} \mathrm{C}$ : "trances $o$ não desemparava".
} 
segundo ambos estamos ja não | pode durar muito [espaço] Passarão estas palavras | tão junto dos assentos onde a quelles Princepes | e Princezas estavão, que todos as ouvirão, e tão | namorados do comedimento do cavalleiro, | como de sua valentia se desserão 90 abaixo, | porque tambem ouvirão como Floriano lan|çando a guarnição, e pouco mais que da espada | lhe ficara no campo lhe respondeu: [espaço] Outra | espada, e outro elmo thomarei eu senhor ca|valleiro se saràr destas feridas para vos servir | sempre com ella a vida, que agora me dais, que | eu terei por vossa, e por vencido vosso me a|pregoarei sempre.

95 A este tempo estavão ja todos com el|les, e aquellas senhoras reduzidas a o gosto, que a | braveza da batalha lhes tinha tirado, fazendoce | tamanhas festas hũas ás outras, como se ouvera $\mid$ mil annos que se não virão. E rogando o Em|perador a o cavalleiro estranho que tirasse o Elmo | e lhe dicesse quem era, elle com muita cortezia lhe | pedio que o não obrigaçe Sua Magestade à quillo, por |que hũ voto, que tinha feito

100 lho deffendia, antes | the desse licença para se ir curar, e que lhe prome|tia que brevemente o viria a servir nas fes|tas, que havia de fazer. [espaço] Não sou eu tão bõ | de contentar (disse Primaleão) nem vos esta|is em parte que vos hajais de ir assi tão levemente | E porque aquellas senhoras estavão ja todas embai|xo para se hirem com Floriano, voltando o Em|perador para Valeriza, que achou mais perto de $\mid$ si, disselhe:

105 [espaço] Ajudaime senhora a fazer força \| [25r] a este Cavalleiro, que se nos que ir sem nos di|zer quem he, nem receber o gazalhado desta | caza. [espaço] Ella lhe respondeu: [espaço] Mal posso | eu crer que a quem Deus fes tão estremado nas | armas como aqui temos visto, não desse entendi|mento para cahir em tamanho erro, como seria não | fazer o gosto a Vossa Magestade [espaço] E vos cavalleiro fa|zei o que vos roga o 110 Senhor Emperador, senão creremos | que não he em vos tudo igual ${ }^{11}$. [espaço] Elle então sentan|doce em giolhos como melhor poude, lhe disse a ella: | tendo todos os olhos nelle: ${ }^{12}$ [espaço] Vossa Alteza Senhora pode / em mim mais do que cuida, e eu com aobriga|ção, que tenho de lhe obedecer satisfasso a o compri|mento do voto, que tinha feito de me não dar a $\mid$ conhecer nesta caza, sem primeiro merecer com ser|viços as

115 honrras, que sei, que nella me ande fazer. |E deixando com estas palavras suspensos, e al|voroçados os animos de toda aquella compa|nhia tirou o Elmo, e inda que tinha o

${ }^{11}$ Valeriza diz que, se não atendesse ao rogo do Imperador, o cavaleiro daria mostras de que seu entendimento (inteligência, boas maneiras) não se iguala a sua coragem e valentia.

${ }^{12} \mathrm{~A}$ repetição dos dois pontos na mesma frase não se verifica em B e C. 
rosto algũa | couza inchado, e manchado do sangue da | derradeira ferida, toda via Valeriza, que algũ | tempo se criara com elle o conheceu logo, e pon|dolhe a mão em hũ ombro alvoraçada em ex|tremo de o ver lhe disse: Ora seja Deus louvado | que ja estais

120 em parte onde pagareis o cuidado que | aqui dais ha tanto tempo, e voltando para Gri|donia, e Miraguarda lhe disse: [espaço] Que me dareis | senhoras se vos disser quem he este cavalleiro? | Ja então Dramusiando gritando de donde | estava dizia: [espaço] Amim a mim, senhor D. | Floris, se devem primeiro esses abraços, pois fui aqui o | primeiro a quem a força delles custou caro. [espaço] O | Emperador, e todos aquelles 125 Princepes || [25v] sabendo quem era o abraçarão mui estreita|mente, tão espantados de sua pouca idade | e parecer, como de suas obras. [espaço] Miraguar|da, e Gridonia sua filha se chegarão a elle | e abraçandoo Miraguarda disselhe: [espaço] Bem | soubestes o que fizestes em vos chegar à senhora | Princeza Valeriza, que sem tão bom padri|nho, mal o passareis com nosco.

130 E porque elle, e Floriano estavão per|dendo muito sangue, e com aquellas detenças | se hião esfriando, e fazendo termos de desma|ios grandes, antes que o damno fosse maior, os | levarão logo onde fossem curados, Floriano |à sua pouzada, e D. Floris à de Florendos, on|de esteve athe que foi são de suas feridas, assistin|dolhe sempre sua irmã tão affeiçoada a elle, | como suas obras o merecião. E sendo am|bos curados 135 deligentemente deixaramnos | repouzar, e aquelles Princepes acabarão de gas|tar o que ficara do dia em louvores de D. Flo|ris, com grande gosto de ElRey Beroldo, que | mais parte que todos tinha nelle. E assi os | deixaremos hũns, e outros, por dizer como alli vierão ter elle, e Dramuziando a tal tem|po, e o que fazia o sabio Daliarte ordenan|doce para vir aquella corte. 


\section{Capitulo 10}

\section{Em que se da conta como aquelles dous | cavalleiros chegarão juntos à corte | de Constantinopla, e do que fazia || [26r] O sabio Daliarte para ir a ella.}

Nas Choronicas dos Reys de Inglaterra | se le, que tanto que Dramuziando se apartou | de D. Floris, começou a caminhar contra o mar | parecendolhe que estava ja tão perto o prazo, em que | se havia de achar em Constantinopla que | por terra não poderia vencer o caminho a $\mid$ tempo, particularmente achando algũa a|ventura das que de Ordinario nella se offrecẽ. |E assentando neste pensamento, demandou | a cidade de

10 Alta Rocha ${ }^{1}$, onde se achou acabo de | duas jornadas, E alli fretando hũ Navio, partio | com bom tempo para Levante, e tal o teve sempre | athe se achar em terra de Ungria, que reconhecen|doa o Piloto, parecendolhe que ja em poucos $\mid$ dias seria em Constantinopla, desembarcou, | e começou de fazer seu caminho para aquella | corte achando algũas Aventuras, que (sem serẽ $\mid$ da calidade que mereção fazerce rellação

15 dellas) bas|tarão com tudo para o embaraçar de maneira | que não poude chegar senão a o tempo que no capitulo | passado se conta.

De D. Floris se dis tambem, que mor|to Lisanio seu Tio, e deixando suas couzas a bom | recado, se partio na volta de Grecia, armado da | Maneira q ue a tras fica ditto de negro, com lagri|mas de prata, e no escudo em campo de ouro | sinco estrellas

20 sanguinhas, de sinco pontas cada | hũa, e por cima hũ leão dourado rompente, cõ | hũa capella de flores varias nas mãos, que era \| [26v] a diviza, e Armas de sua antiga familia, que | elle não quis então mudar, porque pois não hia | armado como novel a respeito de sua tristeza, | não lhe pareceu deixar aquellas insignias de | seus progenitores, para que na quella nova vida, | que thomava, lhe servicem de lembrança

25 da | obrigação que tinhão os que se honrravão com | ellas. [espaço] E porque tambem dezejava muito achar|ce desconhecido nas festas de Constantinopla | com os intentos que atraz dissemos, e lhe parecia | o tempo pouco, e o caminho largo tratou de I se embarcar, e passando o Tejo junto do seu | castello, foi demandar pella outra parte hũa | pequena habitação de Pescadores, que estava na | costa do mar, onde concorrião navios

\footnotetext{
1 Trata-se de Lisboa; também no Palmeirim de Inglaterra a cidade aparece com este nome: "E, reconhecendo os marinheiros e piloto a terra, determinaram sair na cidade de Altarocha, que depois chamaram Lisboa, cujo nome dizem, que se derivou dos fundadores dela" (cap. 53).
} 
30 Estran|geiros a carregar de sal, de que se alli lavrava | grande cantidade ${ }^{2}$, e embarcandoce em hũ | sem querer ir á cidade de Alta Rocha pello não | conhecerem, Mandou navegar para o Estreito, | o qual passando, e entrando no Mar Adriatico | foi seguindo seu caminho para Grecia levan|do em sua companhia por seu Escudeiro hũ | homem de sua obrigação antiga, e que ja o | ajudara a criar ${ }^{3}$, honrrado, e bem entendido,

35 | com quem se elle muito entretinha, chamado | Gravanào, do qual muitas vezes se falarà nesta | historia, em que se conta que indo assim D. | Floris navegando com bom tempo, haven|do ja dias que andava embarcado, hũ, a o por | do sol divizou a menos que hũa vista hũa | Nao grande, que parecia levar a sua mesma | derrota, e mandando meter manotas, e issar | mais as vellas de gavea, fora seguindo toda || [27r] a noite, entrandoa 40 sempre de maneira, | que quando veio o dia, a manheceu com ella, e a o | levantar do sol se achou tão perto, que poude | fallar a os que vinhão dentro, que erão so tres ca|valleiros armados, os que se mostravão, e algua | gente de serviço, os quais vendo como aquelle | navio os seguia estavão prestes para se deffender | se pudessem, sendo de inimigos. [espaço] A estes des|pois das Ordinarias Salvas, que no mar costumão | os 45 que não buscão brigas, preguntou D. Floris | que gente vinha na Nao, e para onde fazião seu | caminho? [espaço] E foilhe respondido que a Duqueza | de Monte Alto veuva, que hia á corte do Empera|dor Primaleão buscar hũ cavalleiro que se com|batesse por ella na de ElRey de Napoles, onde lhe | cumpria prezentar e com elle aprazo certo, | ou perder sua vida, honrra, e estado, sobre cer|ta accuzação, que lhe era feita. [espaço] D. Floris, 50 que | para aquellas couzas recebera a Ordem de cavalla|ria, mandando pedir licença á Duqueza | para a ver, sabendo della a cauza de sua perigri|nação mais meùdamente,

\footnotetext{
${ }^{2}$ Os grandes centros produtores de sal na costa portuguesa durante o séc. XVI estão nas proximidades de Aveiro, Lisboa, Setúbal e no Algarve. A "pequena habitação de pescadores" a que se refere a passagem não deve ser ao norte do Tejo, onde está Almourol (em cujas redondezas ficaria o suposto castelo de D. Floris), pois, como observa o narrador, a tal vila de pescadores estava "pella outra parte" daquele rio. Assim, pode-se conjeturar que a localidade em questão estivesse ao sul, à volta de Lisboa ou Setúbal. Joaquim Romero de Magalhães observa que por volta de meados do séc. XVI a saída de sal de Setúbal rumo ao norte "começa a sério (...), vindo flamengos instalar-se em Setúbal e aí servindo de corretores"; mais tarde, holandeses instalam-se em Lisboa, intermediando o comércio do Sal com os Países Baixos. Dessa forma, os "navios estrangeiros" que, segundo o narrador, vinham carregar o sal, poderiam ser de holandeses ou flamengos. Tais informações permitem arriscar a suposição, certamente de difícil comprovação, que o texto tenha sido redigido antes dos decretos proibindo o comércio de sal com holandeses e franceses promulgados em 1585 e 1587 por Filipe II (cf. Magalhães, J. Romero de (coord.). História de Portugal (dir. J. Mattoso). Vol. III: No alvorecer da Modernidade (1480-1620). Lisboa: Estampa, 1997, p. 258-259). Trata-se de mais um indício, embora frágil, a atestar a precedência desta cotinuação manuscrita do Palmeirim de Inglaterra frente ao D. Duardos Segundo de Diogo Fernandes (cuja primeira edição é de 1587).

${ }^{3}$ A palavra ja é omitida em C; está presente em B.
} 
offereceulhe sua | pessoa, e serviço, para aquella empreza, a qual | ella aceitou depois de largas praticas, mais per|suadida das boas razões, que lhe elle soube dar, | que das apparencias de seu esforço, que em tão tenr|ra idade, e parecer tão delicado, como tinha,

55 | so as obras opodem acreditar. Mas como digo | persuadida a Duqueza das razões daquelle | cavalleiro, do gosto, e confiança, comque se queria | arriscar por ella, e de hũ certo vaticinio do cora|ção, mandou voltar aproa contra Napoles | que ja lhe ficava atras, onde chegãndo brevemente $\|[27 \mathrm{v}]$ houve D. Floris batalha com hũ cunhado da | Duqueza, que a accuzava de adultera, e de $\mid$ matar seu marido. [espaço] E vencendoo

60 facil | mente, deixandoa restetuhida na honrra, | e na fazenda, se tornou a embarcar para | Grecia, levando, entre outras couzas, que lhe | prezentou a Duqueza, aquellas armas de Ou|ro, e leonado, com que entrou em Constantino|pla como temos contado, onde chegou a o | tempo que fica ditto, acontecendo o mais, que | no capitulo passado se escreveu.

O Sabio Daliarte pois, que como | dissemos, estava ja de treminado de restetuir | 65 aquelles Princepes a seus Pays, aquelle thesou|ro a o mundo, sabendo como em Constanti|nopla estavão todos os Reys, a quem elle tinha| mandado recado, e prestes tudo, o que às festas | convinha, estando tão chegado o dia assinado | para ellas, que so hua semana se metia em meio, | hũa tarde estando todos aquelles moços juntos | na caza da livraria de Urganda, onde se | deleitavão muito por amor dos Retratos antigos, | que

70 nella havia, e de outros, que de novo alli apare|cerão assim como seus donos forão crecendo, | que erão os de Carmelia, Valeriza, Gridonia, | e Flerida, e outro cujas letras dizião Fidelia | Princeza de Bohemia ${ }^{4}$. As Sombras dos | quais tinhão feito os milagres nos corações de | algũns, que adiante veremos, levando concigo | ElRey Floramão, (que alli ficara com elle, assi para que | dezembaraçado de outros cuidados lograsse | o 75 retrato de sua Altea $^{5}$, que o Saber de Urganda | na quella caza prefeitissima mente retratara || [28r] como para servir seus amigos na criação de | seus filhos, em companhia de Daliarte, no que | com seu entendimento eboas partes tinha | aproveitado muito) se

\footnotetext{
${ }^{4}$ Urganda é uma sábia mágica que figura entre os personagens do Amadis de Gaula. No Palmeirim de Inglaterra, diz-se que Urganda guardava na Iha Perigosa sua livraria, motivo pelo qual Palmeirim cedera a posse da ilha a Daliarte. Quando a livraria daquela sábia maga foi encontrada, havia nela o retrato de todas as principais personagens femininas de várias novelas de cavalaria, entre as quais o próprio Palmeirim de Inglaterra (cf. cap. 120); agora, diz-se que foram acrescentados os das princesas que serão objeto da devoção dos príncipes que se criavam naquela ilha. Fidélia, unica das princesas que ainda não é conhecida pelo leitor, será a esposa de Primaleão (II).

${ }^{5}$ Altea era a amada de Floramão. O rei da Sardenha (pai de Floramão) mandou matá-la para evitar que o filho se casasse com ela, o que não impediu que o príncipe passasse o resto da vida no serviço da amiga já morta (cf. Palmeirim de Inglaterra, cap. 19).
} 
foi para elles, e achandoos | que fallavão na jornada, que esperavão fazer, des|contentes de que tardasse tanto, sentandoce entre | D. Duardos, e Primaleão, lhes fes afalla 80 seguinte.

Se me não tivereis pago, senhores, to|do o serviço, que vos posso fazer com o gosto que | tenho de vos ver tão compridos em todas as boas | partes, que em tão excellentes Princepes se podẽ | dezejar, pediravos agora alviçaras de ser chega|do o tempo, em que saiamos daqui, que sei que vos | dezejais tanto, e que eu athe este dilatei 85 para que melhor | cumprisse com a obrigação em que me pos a confi|ança que vossos Pays demim fizerão. [espaço] Demim | como de hũ Philosopho tendes ouvido quantos | e quais sejão os dotes do animo, que constituem | hũ varão perfeito segundo seu ser, e o modo de | que se hade uzar delles, emque conciste a sua perfeição. | Do senhor Floramão como tão esforçado, e ex|primentado as obrigações da Ordem de caval|laria,

90 em que entrareis cedo. Os exercicios, ou | ensaios della, aqui os tivestes conforme ao esta|do de Donzeis, esgrimindo, justando, tronean|do, exercitando as pessoas com as feras às vezes / com maior perigo do que eu quizera, mas porque | entre entender, e obrar, e entre tornear com a|migos, e parentes, a fazer batalhas, e derramar | sangue ha grande differença, lembrovos | so duas couzas, hũa que no que entenderdes muito bẽ |

95 cuidais sempre que pode haver quem melhor, o en|tenda, para que não deixeis nunca de vos a con|celhar, e a outra que não tenhais por pequeno pe $\|[28 \mathrm{v}]$ rigo algũ antes de vos veres nelle nem mos|treis que vos parece grande qualquer que a fortu|na, ou o cazo vos ponhão. [espaço] A prudencia | he a moderadora das acções humanas, e athe | as virtudes obradas sem prudencia, perdem | o nome, e o ser proprio, mas posto que nas 100 imper|feições dos homẽns podem agazalharce mal vir|tudes puras, toda via, fio tanto do que de vos co|nheço, que nem me tenho arrependido de obri|gar vossos Pays a vos deixarem nesta Ilha, | nem elles (como vos tratarẽ) o ficarão de o ter | feito. [espaço] Nos trabalhos em que vos virdes, não per|cais a memoria de mim, porque em quanto eu viver | nos em que me ouverdes mister, não vos faltarei | nunca. [espaço] Agora não fica 105 mais que fazer, que | provardes as armas que vos tenho feitas para ser|des armados cavalleiros, com as quais espero ẽ | Deus que mostrareis quão bem enpregadas ellas são | em vos. [espaço] E fazendo aqui pauza, D. Duar|dos pedindolho os mais, levantouce, e tornan|doce a sentar disse: 
Não podemos negar o dezejo grã|de, que temos de sahir da qui, e de sermos

110 arma|dos cavalleiros, e se elle he reprehensivel em | nos, e não o desculpa a natureza, e a idade ef|ficàs, disculpa he a criação que nos tendes dado, | a qual quando della não sahira este primeiro fruto, mal em|pregada fora certo, os outros mostrarà o tempo, | e demim so sei dizer que estimo tanto aultima | promessa que nos agora fizestes de vos achardes $\mid$ comnosco em nossos trabalhos, como todos os | outros beneficios, que de vós

115 tenho recebidos, porque | nos meus ja comesso a exprimentar que so || [29r] vos me podeis valer. [espaço] E com isto rindoce | Daliarte porque o entendeu ${ }^{6}$, se levantarão to|dos, e querendo sahir pella porta onde es|tavão os Gigantes de pedra, cahirão elles, e Flo|ramão em terra, Ordenando assim Daliarte | para escuzar comprimentos com o Musteiro $^{7}$ [espaço] E tendo dis|postas as couzas a seu modo, partio para Constantino|pla

120 com toda a companhia, que lhe pareceu necessa|ria do modo, que se dirà.

\footnotetext{
${ }^{6}$ D. Duardos está se referindo à paixão que nutre por Carmélia; mesmo sem conhecê-la, o príncipe começara a amá-la pelo retrato dela que havia na livraria de Urganda.

${ }^{7} \mathrm{Na}$ entrada da livraria de Urganda, onde se passa a cena, havia dois gigantes de pedra (cf. Palmeirim de Inglaterra, cap. 120). Não compreendemos, entretanto, o significado da queda dos gigantes e de Floramão "para escuzar comprimentos com o Musteiro". Sobre a existência de um mosteiro na Ilha Perigoza, cf. a nota 02 do cap. 03 .
} 


\section{Capitulo $1^{\circ}$}

De como aquelles Princepes chegarão | a Constantinopla, e do que mais em | sua entrada succedeu.

125

Quatro dias antes da festa do Spirito Sancto, | que era a em que se havia de celebrar aquelle tor|neio, a cuja fama se abalara o mundo. Tinhão | concorrido ja tantas gentes Estrangeiras, que se | agazalhavão em tendas no campo, e com pavelholes, que parecia outro novo cerco a Constanti|nopla. E não deixou de dar cuidado ao Em|perador

130 tamanho ajuntamento, e particular|mente depois que soube que entre elle havia algũns | Gigantes, que se virão dezembarcar, e depois | não aparecerão, e assi se vigiava a cidade | de noite, e se tinha conta com as portas | de dia, como se se temerão de grandes ma|les. [espaço] Neste estado, e a este tempo, estando \| [29v] ja Floriano, D. Floris, e Dramuziando, bem sãos de suas feridas, e perna ${ }^{8}$. En|trou ao Emperador (hũ dia que 135 estava com | todos aquelles Princepes praticando na tar|dança de Daliarte) o capitão da barra de | Constantinopla apressado dizendo: Vem | senhor entrando pello rio em furia amaior | maravilha, que meus olhos nunca virão, e he | hũa Montanha de fogo tão terrivel, e gran|de, que parece que converte todo o mar em si. | Ja a este tempo os grittos da gente no cam|po, e na cidade erão tamanhos que atroavão | o mundo, e o medo tão 140 geral em todos, os que | vião vir chegando cada ves mais aquelle | fogo, que nimguem sabia o que havia de fazer. | Aquelles cavalleiros, em quem elle não tinha | parte, temendoce de algũa treição, se forão | depreça armar, e logo com amaior ${ }^{9}$ que pude|rão concorrerão a o mar, onde se ajuntarão | com os mais que havia dos muros adentro, | cujas portas o Emperador mandara fechar | com o primeiro reboliço, porque não

145 houvesse na ter|ra de que se temesse, quando aquillo por ventura | fosse ordenado para seu danno. A Emperatris, | com as Raynhas, e Princezas, se sobirão a o | alto de hũa torre, donde se descobria tudo, e | dalli meas esmorecidas estavão vendo vir a|quella Maravilha tão nova, e tão dezacostu|mada, a qual era hũ globo estranhamente | grande, assendido todo em chamas ardentes | que despedia de si rayos como fuguetes, que ||

150 [30r] cahindo no mar parecia que o assendião nas | proprias chamas; Mas comessou

\footnotetext{
${ }^{8}$ Lembre-se que Floriano e D. Floris tinham ficado gravemente feridos da batalha narrada no cap. 8 e que Dramusiando machucara a perna ao ser derrubado por D. Floris. Nesta passagem, a lição mais clara é a de G: "estando ja Floriano e D. Floris sãos de suas feridas e Dramuziando da sua perna".

${ }^{9}$ Isto é: a maior pressa.
} 
logo a per|derce o medo, vendo que entrando aquelle | tão extraordinario incendio entre os navios, | que sem se poderem dezembaraçar estavão espe|rando serem abrazados, nem pegava, nem | fazia outro algũ danno nelles, nem em outra | couza algũa, o que conciderando o Emperador | disse para ElRey D. Duardos: Se por ventura| senhor serão

155 isto obras de Daliarte? [espaço] Eu (lhe | respondeu elle) depois que vejo que o fogo não fas | danno nos navios, e que parece que vai perdendo | a cor, algua imaginação tenho disso, mas se for | elle, em verdade que nos pagará o sobresalto ẽ | que nos meteu.

Ja neste tempo o Globo tinha | parado bem defronte dos Paços, onde de novo | começou a despedir de si tamanha multidão | de fuguetes, e outros arteficios de fogo, 160 que se cobrio | a cidade de hũ fumo tão cerrado, e espesso que se | não vião hũns a os Outros, acabado o qual se vio | que a Materia da quelle Globo era hũa Maça | cristalina tão transparente, que se divizava | dentro delle hũa caza grande armada de bor|cados cramezins, que se parecião ou se fazião | parecer de fogo ${ }^{10}$. E sentados nella em cadei|ras do mesmo borcado Daliarte, e Floramão | com todos aquelles Princepes 165 armados de ar|mas branças ${ }^{11}$, sem elmos, espadas, nem esporas, | mas não se vião mui distintamente estas miu|dezas, nem elles puderão ser conhecidos, se ja | todos não sospeitarão que o erão. [espaço] \|[30v] Nisto o Globo se foy reduzindo a hũa forma | comprida como ponte, a qual se sostinha | sobre as cabeças de muitos delfĩns, que sotopondoce | a ella vestidos de varias conchas do mar, lhe | servião de firmes, e 170 immobiles columnas. | E estando ja tão estendida que chegava a terra | querendo aquelles Princepes, e Reys entrar | por ella a ir abraçar seus filhos, tornouce a as|sender de maneira, que não foi possivel poder | tocalla com os pes, porque as chamas crescerão | de sorte, que impedirão a vista de tudo o que não | erão ellas. [espaço] E tornando brevemente a soce|garce o fogo, o que antes parecia caza, e ponte, fi|cou hũa cerpe tão 175 espantoza, e grande, que | assombrou ainda os corações, que não conhecião | o medo, e porque estava tão chegada a terra, que | tinha todo o pescosso, e as mãos nella, e pare|cia que trabalhava de fazer danno na multidão | de gente, que alli se achava, aquelles cavalleiros | esquecidos do que antes lhe tinha parecido, arrã|cando das espadas quizerão ferilla, e D. Floris | que se achou mais perto levantando a sua para | lhe dar na cabeça, 180 abrio a cerpe hũa boca | tão grande, e tão horrível, que pudera bem hũ | navio entrar por

\footnotetext{
${ }^{10} \mathrm{C}, \mathrm{D}, \mathrm{E}, \mathrm{F}$ : "que o fazião parecer de fogo".

${ }^{11}$ Era hábito que os cavaleiros novéis usassem armas brancas, em sinal de ainda não terem realizado proezas que os identificassem.
} 
ella, e lançandolhe a lingoa, | puchou por elle de maneira, que sem se poder | valer o tragou nũ Momento, e recolhendo | juntamente o pescosso em si, lançando grã|de cantidade de fumo pellas ventas, pareceu | a todos os que a vião que com hũa larga roda, que | fes se escondia nas entranhas do mar, || [31r] E sem ser acabado o espanto desta 185 novida|de, começou a aparecer outra, que o dobrou em | tudo. [espaço] E era que daquelle lugar onde a cer|pe se sumergira, se foi levantando pouco a $\mid$ pouco hũa como pyramide oitavada, compos|ta de varias cores, em materia não conhecida, | semelhantes entre si às do Arco de Iris, (a que | vulgarmente chamamos arco da velha) a qual | foi crescendo tanto que igualou a Torre, em que | aquellas Princezas estavão vendo o que 190 passava, | e chegando a emparelhalla, se lançou hũa pon|te della às genellas da Torre. [espaço] A este tempo começarão a correr para la todos aquelles | Princepes, julgandoas por perdidas, a ver se | lhe podião valer de algua maneira, mas ja | quando chegarão áquellas Princezas, (que de todo se | tinhão contado por acabadas quando virão lançar | a Ponte, e desmaiadas todas estavão esperan|do o que a fortuna queria dispor

195 dellas) acharão | que tornadas em seu acordo, e perdido todo o | sobresalto, estavão abraçadas hũas com seus | filhos, e outras em comprimentos com Dali|arte, e os mais que alli não tinhão quẽ com elles | fizesse as outras demonstrações. [espaço] E entrando em | hũa varanda por onde se hia á quella Torre, que to|do o comprimento della, que era grande, estava a|partada do corpo das cazas sahio Daliarte ar|mado de hũas armas azuis 200 semeadas de estrellas | de prata a receber seu Pay, e o Emperador e | os mais que hião entrando, e posto de giolhos dian|te delle tendo tirado o elmo ja quando entrara | na torre e dicelhes o que no outro capitulo se segue. 


\section{|| [31v] Capitulo 12}

\section{Do que Daliarte disse a o Emperador | e do que elle, e os mais passarão com | o Sabio, e os Princepes.}

Posto de giolhos Daliarte, como no capitulo | passado diziamos, diante de seu Pay, e daquel|les Princepes, que pella varanda vinhão, dicelhes: | Bem sei que eide ser perdoado de todos meus | erros, pois venho com tais valias, como aqui den|tro tenho. [espaço] Não sei como isso será (lhe res|pondeu o Emperador) porque juntastes à tardança | de tantos tempos o sobresalto deste dia, que ainda | agora não estou quieto

10 parecendome que me | levaveis outra ves estas Senhoras, sem quem | ja não puderamos viver. E porque ainda não | estou seguro disto, entremos para dentro, que | tambem segundo agente que trazeis necessario | serà que vigiemos todos a que aqui achareis ${ }^{1}$ de | novo. [espaço] Então levantandoo, e tendo elle | bejado a mão a ElRey Seu Pay, entrarão na | caza onde aquellas senhores ${ }^{2}$ estavão, que com | o maior alvorosso do

15 mundo se levantarão | a recebellos, tão sofregas com seus filhos, que os | não deixavão fazer com o Emperador, e aquel|les Princepes os comprimentos, e serimonias, | que divião. [espaço] Miraguarda tinha abraçado Pri|maleão, Polinarda a D Duardos, Leonarda | a Vesperaldo as Raynhas de Hespanha, e França | a Recindos, e Arnedos ${ }^{3}$, Sidella a Palmeirim | de Lacedemonia, Dramaciano ${ }^{4}$ a Belcar, e || [32r] a Emperatris

20 Gridonia, e a Raynha Flerida | depois de terem feito o mesmo com todos | elles, tinhão muitos comprimentos com Trineo | com Ardimão de França, com Pavorante | e Almourol, que estes sós erão os que ali não ti|nhão mãis, e os com que se serrava o numero | dos que na Ilha se criarão ${ }^{5}$. [espaço] $O$ Emperador | entrando na caza acompanhado dos Reys | que temos ditto levando Daliarte pella mão dis|se para ellas:

25 [espaço] Rezão será senhoras que nos dei|xeis lograr tambẽ estes Donzeis, pois no so|bresalto deste [[deste]] dia vos temos sido compa|nheiros, e no trabalho de vir aqui buscallos nos | não fas nimguem companhia. E vos senhor | Daliarte mostrainos a hũ, e

\footnotetext{
${ }^{1}$ Isto é: "vigiemos todos a gente que aqui achareis".

${ }^{2} \mathrm{~B}, \mathrm{C}, \mathrm{D}, \mathrm{E}, \mathrm{F}$ : senhoras.

${ }^{3}$ Recindos é filho de Beroldo e da rainha de Espanha; Arnedos é filho de Graciano e da rainha de França. Os dois possuem os mesmos nomes de seus avôs. Note-se que as rainhas, cujos nomes não são mencionados neste livro, chamavam-se Melisa e Clarísia, de acordo com o que se lê no Primaleón.

${ }^{4}$ C, D, E, F: Dramaciana. Ela era esposa de D. Rosuel e mãe de Belcar (que não deve ser confundido com seu avô, que possuía o mesmo nome).

5 Trineu é filho de Vernau (antigo Imperador da Alemanha) e Vasília, filha de Palmeirim de Oliva. Ardimão era filho de Germão de Orléans (companheiro de Graciano, morto na batalha contra Albaizar) e Floriana (irmã de Graciano). Pavorante e Almourol são filhos de Dramusiando e Almourol, respectivamente.
} 
hũ estes Princepes | que não cuido que sem isso os conheceremos, segun|do estão differentes de quando os deixamos. [espaço] En|tão abraçou os nettos, e todos os mais com igual | gazalhado, e querendolhe hũns, e outros bejar a | mão, não a deu senão a os nettos $^{6}$, e a Pavoran|te, e Almourol, tendoce grandes comprimen|tos com Trineo, que ainda que tinha herdado não | se queria chamar Emperador, a o qual querẽ|do Polynardo seu Tio beijarlha logo, e entre|garlhe o Imperio, que em seu nome governava, | elle o não quis concentir, antes abraçandoo | e confirmandoo nas Merces que Vernào seu | Pay

35 lhe tinha feito, rogoulhe que quizesse admi|nistrallo como fazia, porque elle detreminava | seguir primeiro as Aventuras, e ser cavalleiro An\|[32v]dante, que carregarce com o ceptro, e com a co|roa, crendo que assim viria a por melhor em | pratica a doutrina em que se criara.

Hora depois que o Emperador este|ve vendo, e notando as dispozições, e talhos | 40 daquelles moços, em extremo contente do mo|do, e socego de cada hũ, ficou o ${ }^{7}$ muito mais de | D. Duardos, que no parecer do rosto, na dispo|zição do corpo, na compostura, e quietação | das acções, a todos fazia conhecida ventagem, | e tornou a dizer para Daliarte: Que não sei $^{8}$ cõ | que vos havemos de pagar a obrigação, em que | nos tendes posto dandonos tais successores | a nossos estados, quais se pode crer que estes |

45 Princepes serão criados, e doutrinados por vos. | Mas são vos todos tanto, que tambẽ podemos | dizer, que trabalhastes no vosso ${ }^{9}$. Daliarte lhe | respondeu: Bastava senhor o gosto de vos | servir a vos, e a todos estes senhores para premio | de trabalhos grandes, quanto mais que o contenta|mento, e honrra, que a converçação destes | Princepes me tem dado, he de calidade, que | por isso fico ainda em não pequena dìvida | a seus pais 50 fiandoos de mim tanto tempo. | Florendos atravessou então variando a | pratica, e disse: [espaço] Não ouzo a perguntar | por Floramão, que aqui não vejo, porque ei me|do de algũa nova, que me tire parte do gosto $\mid$ de nos vermos juntos. [espaço] Bem vos merece | (lhe tornou elle ${ }^{10}$ ) o amor de Floramão não || [33r] vos esquecer no meio desse alvorosso que dizeis. | Elle está bom, e são, mas não de suas paixões | antigas, antes tão

55 entregue a ellas, que me ro|gou que o deixasse no navio em que viemos, por|que receava que sua prezença fizesse menos | contente os extremos destas vistas, e assim | ficou la

\footnotetext{
${ }^{6}$ Ou seja, Primaleão e D. Duardos.

${ }^{7}$ Este $o$ exerce a função de pronome; o trecho deve ser lido como "ficou-o".

${ }^{8}$ C, D, E, F: para Daliarte: Por certo Daliarte, que não sei.

${ }^{9}$ Esta frase só faz sentido se considerarmos que ocorre a elipse do termo obrigados depois de tanto, devido à associação com obrigação, que aparece logo acima. Trabalhastes no vosso pode significar "trabalhastes em algo que também vos diz respeito". Dessa forma, a frase deve ser lida assim: "Mas são vos tão obrigados, que também podemos dizer que trabalhastes no que também vos diz respeito".

${ }^{10}$ Embora o texto não esclareça, pode-se deduzir que a resposta é de Daliarte.
} 
com hũ hospede, que nos quizera ma|tar a todos, e que eu quis que estes Donzeis vissẽ | e conhecessem primeiro que animguẽ desta terra, | para que pois ${ }^{11}$ com hua mesma idade ande cor|rer todos quazi hũa mesma fortuna, não | lhes faltasse este conhecimento 60 pois não pode | deixar de ser a criação. Este he D. Floris, por | quem aqui nimguem me pergunta havendo | tantas razões para elle não esquecer. [espaço] Miraguar|da então lhe disse: Eu fio de vos Senhor Daliar|te que sabeis o cuidado com que agora estava | para vos pedir que no lo restetuisseis, e por vida vos|sa que o façais vir, e Floramão juntamente, por|que ha gente aqui que dezeja conhecello. E assi era|verdade, porque as

65 Princezas moças erão tão | affeiçoadas às couzas que de Floramão tinhão | ouvido, que não estavão menos alvoroçadas para $\mid$ o ver que a seus parentes ${ }^{12}$. [espaço] Quem quereis vos | senhora, disse Daliarte, que não obedeça a quem | tão bem se saberá vingar? D. Floris, e Flo|ramão vem entrando, e tão amigos, que ei me|do que nos deixem a todos com ciumes. E | assim passava, porque como D. Floris entrou na / camera do 70 Navio, em que o saber de Daliarte \|| [33v] obrou as maravilhas, que temos ditto por entre|ter aquellas senhoras, tornando em seu acordo, | que a o Entrar lhe roubara a força da arte, que | o recolheu, abraçarãono todos aquelles Prince|pes, que ja por relação de Daliarte sabião quẽ | elle era, e tudo o que lhe tinha acontecido, de que | depois que o virão não ficarão pouco invejozos, | porque sendo mais moço, que todos, tinha ja

75 passa|do pellos trabalhos, que elles tanto dezejavão ex|primentar. [espaço] Seu sobrinho Primaleão foy $\mid$ o primeiro, e logo todos os mais, com quem se tra|tou a seu modo grandes amisades. [espaço] Flora|mão pois detreminado não se achar naquel|las vistas por fugir de contentamentos alheios | deixouce ficar no Navio, e D. Floris com elle, | que não era necessario no recebimento. Eam|bos se contentarão tanto hũ do outro, sem | 80 embargo da differença de suas idades, que se co|meçarão a amar tão estreitamente, que sohia | Floramão depois a fazer escrupulo do gosta ${ }^{13}$ da|quella amizade, como de couza, que lhe entreti|nha o cuidado de sua Altea com mais con|çolação do que sofria o rigor, com que se elle trata|va. [espaço] Emfim, entrando pella porta, obede|cendo à força superior, e interior ${ }^{14}$, com que Dali|arte os obrigara, foi Floramão recebido da|quella companhia com estremado alvoroço, | passando com aquellas senhoras moças, e com | as mais, mil comprimentos conforme a seu | humor, e D. Floris tambem, a quem

${ }^{11}$ C, D, E, F: "para que depois". A frase é um tanto confusa e apresenta grandes variações nas diferentes cópias, conforme esclarecemos na tabela 4.8 do item "Colação dos Códices" (exemplo 3).

${ }^{12}$ Já no Palmeirim de Inglaterra se alude ao fato de Floramão gozar de muito apreço entre as damas, "que viam nele maior fé e amor, que em outros homens" (cap. 153).

${ }^{13} \mathrm{~B}, \mathrm{C}$ : gosto.

${ }^{14}$ A glosa $e$ superior falta a C, D, E, F: "força interior com que". 
julga||[34r]vão por homem ressucitado. E porque a noi|te vinha entrando, ordenouce, que pois aquel|les Princepes havião de ser cavalleiros, e es|tavão armados que logo velassem as armas | para que a o outro dia o fossẽ, e ficasse tempo para | o serem 90 muitos outros Donzeis aquẽ como te|mos ditto o Emperador queria dar a Ordẽ $\mid$ de cavalaria, pello que se forão todos assi como | vinhão á capella, que nos Paços estava a velar | as armas, onde as mais da quellas senhoras | cazadas os acompanharão athe o outro dia, | no qual forão armados cavalleiros, como no | cap itulo seguinte Mostraremos. 


\section{Capitulo 13}

\section{Como aquelles Princepes forão ar|mados cavalleiros, e das estranhas | couzas, que na quelle acto acontecerão.}

Por melhor natureza que aquelles Princepes | tinhão, por mais doutrina que Daliarte lhes | tinha dado, não deixarão de se atalhar em ex|tremo á vista de extremos tamanhos, como | erão as fermozuras da quellas senhoras, e da | multidão de tantas juntas, que eu não sei o que | tem aquelles ajuntamentos, que porforça se fa|zem respeitar com medo, ainda aquem muitas | vezes se vio nelles. [espaço] Os em quem

10 aquellas || [34v] vistas fizerão mais aballo forão D. Duardos, | Vasperaldo, e Trineo, que como ja vinhão mais | que meios rendidos às sombras, e retratos, que na | Ilha de Daliarte tinhão vistos, vendo os Ori|ginaes delles com aquella viveza, com aquel|la graça, a que a pintura não chega, demanei|ra se confirmarão no Amor, que ja lhes tinhão, | que nem os desprezos de Carmellia para D. Du|ardos, nem os rigores de Flerida

15 com Vesperal|do, nem os descuidos de Gridonia nas couzas | de Trineo forão parte para que nenhũ destes Prin|cepes deixassem de se assender cada ves mais | no amor daquellas senhoras, servindolhes suas | asperezas de mores incentivos para as amarẽ, prin|cipalmente D. Duardos, que em amar, e em ser | aborrecido fes ventagẽ a todos, como no discur|so desta historia havemos de mostrar ${ }^{1}$.

20 Feridos da quellas primeiras Mostras se fo|rão á capella avelar as armas estes Donzeis, | onde, como dissemos a maior parte daquellas | Senhoras cazadas os acompanharão, e as mo|ças se recolherão deixando os corações dos tres, | que nomeamos tão cheios de imaginações, e | fantezias, que esquecidos do que pouco havia que de|zejavão tanto ${ }^{2}$, nem sabião onde os levavão | nem inda se estavão alli. [espaço]

25 Em D. Duardos | cresceu tanto a torvação, que deu manifestos in|dicios das novidades, que em seu animo se a|gazalhavão, e tão patente foi isto a todos, que |Floriano lhe disse rindo: Pareceme senhor || [35r] sobrinho que antes de ser cavalleiro achastes | perigos de que as armas não deffendem. Hi|vos devagar se puderdes, que segundo vos ve|jo ei

\footnotetext{
${ }^{1}$ No cap. 172 do Palmeirim de Inglaterra, entre as numerosas notícias dadas pelo narrador acerca dos filhos do herói, há duas referências sobre as penas de amor do jovem D. Duardos: "Do grã Palmeirim nasceu o segundo Dom Duardos que depois reinou em Inglaterra, tão esforçado como seu pai, e tão namorado como ele, e menos venturoso que ele em seus amores, segundo se mostra na crônica de seus feitos". Mais à frente, falando da beleza de Carmélia, o narrador acrescenta que na "crônica do segundo Dom Duardos" se diz que ele "foi seu servidor e pouco favorecido dela".

${ }^{2}$ Ou seja: esquecidos do desejo de se tornarem cavaleiros.
} 
medo que haveis mister mais os meus | concelhos, que os de vosso Pay ${ }^{3}$. [espaço] D.

30 Duardos | corrido lhe respondeu: [espaço] Não sei porque me | Vossa Alteza dis isso, mas mal posso negar que vou me|nos meu do que aqui chegei, mas não menos | contente em verdade. [espaço] Polinarda sua | may disse para Daliarte com quem hia fal|lando: [espaço] Acudi senhor a D. Duardos, que ei | medo que destrua o senhor Floriano todo o | nosso trabalho, e então puchando pello filho | lhe disse rindo: [espaço] Vos filho

35 aprendei de vosso | Tio tudo o que não for a materia em que vos | falla, porque nella he muito sospeitoza a sua dou|trina. [espaço] Ora senhora (respondeu a Raynha|de Tracia) não infameis tanto a vosso primo, | lembrevos quantas palavras me ja dicestes para me | obrigar a não crer o que agora apregoais por | tão certo ${ }^{4}$. [espaço] Nestas zombarias, e verdades | se hião entretendo aquellas senhoras, athe que | chegarão à capella, onde

40 estando prestes todas | as couzas, que erão para aquelle acto necessarias | se passou a noite em encomendar a Deus os | Noveis, os quais se confessarão todos nella, | e comungarão a o outro dia tanto que a ma|nheceu, e depois disto acabado se forão assi | juntos a hũa porta da cidade, com quem | os Paços se comunicavão, onde o Empe ||[35v]rador tinha Mandado fazer hũ sumptuo|zo cadafalço, para se celebrar o acto

45 de os ar|mar cavalleiros. [espaço] Assentado elle, vestido cõ | insignias Imperiaes, e ElRey D. Duardos | tambem, estando todos os mais Princepes | em pe, aquellas senhoras em hũ estrado amão | direita do Emperador, e entre ellas aquelles | quatro Rayos de fermosura, que o Emperador | quis que se achassem prezentes, assi para maior or|namento da quelle dia, como para cingirẽ | as espadas a algũns daquelles Noveis.

50 [espaço] E | continuandoce o som de muitas charamellas | trombetas, e ataballes, e outros instromentos | de guerra, à vista de infinito numero de gẽ|te que alli tinha concorrido, armou ElRey | D Duardos cavalleiro, primeiro que todos, a o Princepe | Primaleão, calçandolhe as esporas Palmeirim | de Inglaterra, e ElRey Floriano seus filhos. | Cingiolhe a espada a Princeza Gridonia | sua irmã: [espaço] E logo o Emperador 55 armou a | D. Duardos seu netto, assestindolhe Dramu|siando, e o Princepe Florendos, e perguntan|dolhe de quem queria receber a espada, elle as|si de giolhos como estava lhe disse que de quem | Sua Magestade ordenasce a tomaria, mas que para | maior obrigação de suas couzas folgaria que | lha desse a Emperatris, o que ella logo fes como | aquillo soube, deixando com cuidado a os | circunstantes, parecendolhes que D.

\footnotetext{
${ }^{3}$ Com efeito, na obra anterior do ciclo, Floriano demonstra possuir muito mais desenvoltura em questões amorosas do que seu irmão Palmeirim.

${ }^{4}$ Há apenas uma cena no Palmeirim de Inglaterra em que Polinarda tenta convencer Leonarda da fidelidade de Floriano (cf. o cap. 122).
} 
60 Duardos | quizera encobrir com as toucas de sua Avó || [36r] algum, que tivesse de novo ${ }^{5}$. Espos elle armou | o Emperador a todos os mais, recebendo as | espadas das mãos de algũas da quellas senhoras | cazadas, porque as moças so a Pavorante, e a Al|mourol as derão, a Almourol Gridonia, e a | Pavorante Carmellia, obrigando tanto a | Dramusiando com aquella honrra, que para | servir a seu pay de novo, thomara entrar |

65 outra ves de novo no mundo ${ }^{6}$. Frenellio | filho de Pompides, tambẽ foi armado caval|leiro, e acabandoce com o ultimo queren|do o Emperador recolherce, para depois de comer | fazer aquella honrra a algũns vassallos seus, | levantandoce em pe para se ir, e todas aquel|las senhoras, começou a soar no ar hũa tẽ|pestade de trovões tão grande, que a poucos co|rações deixou izentos do medo, e entre elles | desceu hũ rayo, que

70 dando no alto dos muros | velhos, que inda por aquella parte tinhão deixa|do inteiros as ruinas antigas ${ }^{7}$, deu com to|do hũ lanço delles no chão, com tal estron|do, que moderou, ou quietou de todo o dos trovo|ẽs, que athe então não cessavão. [espaço] Cahido elle | appareceu entre as ruinas em lugar alto a fi|gura de hũ homẽ velho vestido ao modo | antigo de Grecia, com hũa coroa de Empera|dor na cabeça, e hũ ceptro em hũa mão, e | 75 hum pequeno livro na outra, a seus pes hũ | Drago estranhamente grande; e espantoso | cuberto todo de hũas escamas verdes, e amarellas || [36v] com tres ordens de dentes, que lhe sahião da bo|ca, pouco minores que de Elefante, per entre | os quais meneava a lingoa com tanta velo|cidade, que fazia parecer, que tambem tinha tres | lingoas. Parecião os olhos dous fornos arden|tes, e com o rabo, que era grandissimo, açoutava $\mid \mathrm{o}$ 80 ar, e as pedras do muro de maneira, que dali | a muy longe se deixava ouvir o ruido dos | golpes. [espaço] Estava prezo por hũa muito fraca cadea | ao scetro da quelle personage, e tinha atraves|sada pellos peitos hũa espada que lhe não pare|cia mais que a empunhadura, que não era pou|co para ver, mas não havia alli nimguẽ tão | senhor de si, que pudesse conciderar as perfei|ções, e riquezas della, particularmente vendo | que o

85 Drago trabalhava tanto, e fazia tanta | força por soltarce, e a prizão era tão fraca | que não parecia possivel que tardasse muito em o | fazer, e assim aconteceu, que a poucos arrã|cos quebrando a cadea o Drago, se achou | solto, e remetendo pello campo começou

\footnotetext{
${ }^{5}$ A frase, que tem inegável sabor popular, fica mais clara se resolvermos a elipse do termo cuidado. Assim, deve-se entender que a escolha de D. Duardos deu algum cuidado aos presentes, pois pareceu-lhes que ele queria encobrir algum novo cuidado seu.

${ }^{6}$ Isto é: a honra feita por Carmélia a Pavorante, filho de Dramusiando, fez com que o gigante renovasse seu desejo de servir a Floriano, pai de Carmélia.

${ }^{7}$ Lembre-se que durante a guerra com as tropas turcas, os muros de Constantinopla haviam sido derrubados (cap. 169 do Palmeirim de Inglaterra). Esta passagem pressupõe que, além dos muros reconstruídos por Primaleão (cf. cap. 1 deste livro), houvesse ainda partes aproveitadas das muralhas antigas.
} 
a | espedaçar a o parecer de quẽ o via, homẽns, | e cavallos com tanta facilidade, que nimguẽ | se lhe deffendia mais tempo, que o que elle tar|dava em lhe chegar, e o que 90 mais passou iremos | vendo a fio nesta historia. 


\section{Capitulo 14.}

\section{|| [37r] Da grande perturbação que na quel|le cazo ouve, e de como D Du|ardos acabou a Aventura.}

Aquelles Princepes que dantes cuidarão que erão | aquillo obras de Daliarte como as passadas I para festejar aquelle acto, vendoo agora que se I mostrava mais confuzo, e mais embaraça|do, que todos, não bastando seu saber a penetrar | aquelles segredos, começarão a temer algum | desastre grande, mas não porẽ demaneira | que deixassem de prover no que lhes pareceu ma|is necessario, que era no temor, e perigo da

10 | quellas senhoras, que estavão (para terẽ mais que sen|tir) tão inteiras no juizo á vista da quel|las couzas, que conhecião mui bẽ o risco em | que todos se achavão. [espaço] $\mathrm{E}$ querendo o Empe|rador com conselho dos mais fazellas reco|lher, porq ue o Drago tendo espalhado toda a $\mid$ gente do campo punha o rosto na quella | parte onde o cadafalso estivera (que tambẽ | cahira quando o rayo, posto que sem desastre de seus | povoadores,

15 nem descompostura) acharãoce | todos tão impedidos das pessoas, que nẽ elles, nẽ | ellas, puderão bolirce do lugar em que estavão | por mais que nisso porfiarão. [espaço] O Drago es|tava tão perto que parecendo aquelles cavallei|ros, que o poderião ferir com as espadas, que|rendo lançar mão a ellas para o fazerẽ, nim|guem a poude arrancar, senão so D Duar||[37v]dos, para quem parece que se guardara tantos an|nos o fim da

20 quella Aventura, e assim só elle | se adiantou a buscar o perigo, que todos lhe | julgavão por certo, e pondo os olhos em Car|mellia, que estava descoráda com a trovação | e espanto da quelle cazo, disse para ella entre si. | Não tem senhora este perigo de grande, | mais que parecerme que estais vos tambẽ nelle, | ainda que se esta féra chegar a vervos, bem | cuido que lhe não farà tanto mal a natu|reza que negace a sua brutualidade o

25 co|nhecimento espanto ${ }^{1}$, com que todas as creatu|ras he rezão que vos sirvão. [espaço] Não lhe deu | o Drago lugar para mais contemplações | porque remettendo a elle com hũ salto gran|de, de todo o desfizera entre os braços, se | com outro se não desviara ferindoo em | hum dos dentes, que trazia fora da boca de tão | pezado golpe, que se lhe quebrou a espada | em muitos pedaços, ficando o Drago com $\mid$ mostras de grande

30 sentimento da pan|cada. E voltando sobre elle foy com tan|ta ligeireza que não se poude D. Duardos | desviar. E vendoce entre os braços daquelle | animal tão apertado, que lhe parecia lhe aljuntava as costas com os peitos, com a vive|za da quelle coração que a

\footnotetext{
${ }^{1} \mathrm{C}$ : "conhecimento $e$ espanto".
} 
natureza lhe tinha | dado maior que o de todos seus passados, lan|çou mão na guarnição da espada que o Drago | trazia, e puchando com toda a força que poude || [38r] para se valler della, arrancoulha de todo. E | como nisto so concestia a forsa da quelle | Encantamento, subita mente o Drago ficou | estirado no chão tão morto, como quem havia | tantos annos que não tinha vida. [espaço] E logo | o velho Emperador levantado no ar arrojou | o livro que tinha na mão a Daliarte, dizen|dolhe: Le Daliarte por esse livro, declara a | profecia que nelle está a esses Reys, e faze o que | mais a hi acharás 40 que he nessessario para restetuir|D. Duardos a seu acordo, e os mais que forão to|cados do Drago, tendo por certo que D. Duar|dos sahirà tambẽ de todos os perigos destes ${ }^{2} \mid$ como mal do em que tu nem eu lhe pode|remos valer ${ }^{3}$. [espaço] E dizendo isto desapareceu | ficando o Drago morto estirado no campo, | e D. Duardos pouco menos, e todos os mais | que o Drago tinha toccado. [espaço] Então Daliarte | thomando o livro na mão tão novo naquel|las couzas como cada hũ dos outros, come|çando a ler por elle, entendeu que era do grande | Sabio Appollidon Emperador que fora de Cons|tantinopla, aquelle, de cujo saber, sahirão as | Maravilhas da Insula Firme, de que na Cho|ronica de Amadiz de Gaula se fas menção ${ }^{4}$, | o qual alcançando todas as couzas dos seccu|los futuros pello amor que teve a os Princepes | Gregos seus descendentes ordenou por sua | 50 arte aquelle Encantamento, concervando | nelle aquella sua tão famoza Espada cõ || [38v] as virtudes, que em si incluhia, para que ganhan|doa D. Duardos pello modo, que ouvimos, fi|casse claro a todos ser elle o melhor cavalleiro | da sua geração, que tinha havido no mundo. | E o proprio mundo deffendido com o va|lor de seu coração, e virtude da espada do | perigo, em que brevemente o havia de meter | a furia de hũa mulher, e a sciencia de outra ${ }^{5}$. | Aprofecia dezia assim

No tempo, em que os novos Leões | sahirem da cova encantada para que com | a benção dos Leões velhos seus progeni|tores comecem a exercitar variamente $\mid$ os dentes, e unhas, tornarà o Sol a ver $\mid$ minha figura

\footnotetext{
${ }^{2}$ No manuscrito, há mancha de tinta sobre esta palavra; a lição apresentada aqui é a de B e C.

${ }^{3} \mathrm{O}$ final desta frase é um tanto confuso; em B e C a lição é a mesma. O sentido da passagem parece ser que D. Duardos sairá de todos os perigos como este (a aventura do dragão) e também de outro mal (perigo) em que ele não poderá contar com o socorro de Appolidon e Daliarte.

4 Appolidon (ou Apoledón) é personagem do Amadis de Gaula, antigo príncipe grego e grande conhecedor das artes mágicas. Ao assumir a coroa de Constantinopla, ele deixou uma série de aventuras e encantamentos na ilha onde morava, chamada Ínsula Firme. Os encantamentos foram desfeitos por Amadis.

${ }^{5}$ Esta frase, que não difere da lição de B e C, também é um tanto confusa. Leia-se: o valor de D. Duardos e a virtude da espada que recebera defenderiam o mundo dos novos perigos causados por duas mulheres. É uma alusão às aventuras que se seguirão, motivadas pelo ódio de Targiana e pelas artes da sábia Drúsia Velona.
} 
sobre a porta da antiga | morada dos pastores Gregos, e serà pel|lo que entre

60 elles for mais extremado de|sembainhada a minha rica, e encan|tada espada das entranhas onde | a deixo escondida em beneficio u|niverçal de todos, os que então viverem | de sua familia, e amisade, porque sem | o valor delle, e sem a virtude della, na|da poderà prevalecer contra a malda|de que sedo serà executada nas ca|beças dos melhores que me virem; enão | se

65 sobresalte, nem duvide nimguem | porque por força se hade passar o que està | ordenado.

|| [39r] E acabada de ler a Prophecia | com estranho espanto seu, e de todos, dis|se Daliarte: [espaço] Hũa parte senhores desta | Prophecia está cumprida, e tão clara que não | tem necessidade de interpretação entenden|doce pella cova Encantada a minha

70 Ilha, | pellos leões novos estes cavalleiros, que nella se | criarão, e pellos velhos vós que os fazeis cava|lleiros, para que com desiguais fortunas sigão o | trabalho das armas, que isso (quanto amim) quer al|li dizer aquella particula variamente. | $\mathrm{O}$ mais que està por vir sendo tão escuro que mal | se pode penetrar, fora muito bom ser ainda ma|is escuro, porque porforça o Entendimento de | cada hũ de nos, que prudente mente discorrer |

75 pello peor, não poderá deixar de topar com | trabalhos grandes, de que não sei quem dos que alqui estamos poderà ficar izento. Mas pois a | providencia do grande Apollidon, cuja figu|ra agora tornou a ver o Sol na porta desta | cidade, que elle entende pella Morada dos Em|peradores Gregos, justamente chamados Pastores | porque esta obrigação tem os aquẽ Deus pos em | Estado de governarem homẽns. [espaço] Achou o

80 re|medio tanto de antemão alegremonos mais | com elle, do que nos entristeçamos com os danos | para que serà necessario ${ }^{6}$. E de meu concelho, nim|guem cuide mais nisto, porque aquellas couzas | que a industria humana não pode prevenir | cuidar sempre nellas he dobrar o trabalho a o $\|[39 \mathrm{v}]$ dia. E basta a o varão prudente a obri|gação geral que tem para o não thomarẽ nun|ca os cazos da fortuna de sobresalto.

Não vades mais por diante (disse | ElRey D. Duardos a seu filho) que muito maior | medo nos fazeis com essas circunspecções, | do que nos fes Apollidon com as suas profe|cias. Isto està feito, estas senhoras serà ra|zão que se recolhão, e que se

\footnotetext{
${ }^{6}$ Este é mais um caso em que a pontuação dificulta o entendimento do texto. É preciso considerar que o sujeito de achou é a providencia do grande Appollidon. Além disso, o final da frase (os danos para que serà necessario) refere-se a remedio. Entenda-se: "posto que a providência de Appolidon achou o remédio antecipadamente, alegremo-nos mais com elle do que nos entristeçamos com os danos para os quais o remédio será necessário".
} 
comece a dar Ordẽ | a o Torneio de amanhã, e no mais aqui es|tamos para o que a fortuna quizer dispor de nós. | A todos pareceu bem a dispozição de D. | Duardos, e com

90 isto lendo Daliarte mais pel|lo livro aparecerão hũas varas de fogo, que elle | thomou, e indo dando com ellas (sem deixar | de ler) em todos, os que forão tocados do Drago | assendeuce logo hũ tão grande incendio | por todo o campo, que parecia convertia tu|do em cinza. [espaço] Não tardou muito conti|nuandoce a lição que veio hũa pomba voan|do com tanta força, que com o vento das azas | apagou de todo aquellas chamas, 95 apos o que | derramou em todo aquelle ajuntamento hũa | agoa de cheiro suavissimo, e não acostumado, | e despois desapareceu ficando todos os offendidos $\mid$ da quella cerpe ${ }^{7}$ livres, e em seu acordo, com | grande gosto, e espanto de cada hũ. E assim | se forão aquelles Reys, e Raynhas para caza on|de acharão as mezas postas, que quanto era mais tar|de melhor assombradas lhe parecerão, e aca||[40r]bando de satisfazer a natureza, se 100 tratou | do Torneio, que havia de ser ao outro dia. | No qual acontecerão couzas que no seguin|te capitulo veremos.

\footnotetext{
${ }^{7} \mathrm{O}$ que antes era um dragão, agora é descrito como serpente. O mesmo acontece em B e C.
} 


\section{Capitulo 15.}

\section{Do Torneio, que aquelles Princepes | fizerão, e do que nelle succedeu.}

O concelho de Daliarte, o alvoroço do Torneio | tão esperado de tantos, varrerão

5 da memoria a | todos as couzas passadas, de meneira ${ }^{1}$, que muito pouco | espaço foy, o em que viverão nella, dando porem | grandes louvores a D. Duardos Damas, e ca|valleiros, e muitos parabẽns a Palmeirim seu | Pay, e a Princeza Polynarda sua May. $\mathrm{E}$ | passado algum espaço, que se gastou nisto, e na ad|miração da riqueza, e perfeições da Espada | que discorreu por todas as mãos da quelle ajun|tamento, logo se entendeu

10 em preparar para | o outro dia, o que ainda não estava feito. [espaço] En|tretanto chegou a noite, na qual pello trabalho | do dia, não quis o Emperador que ouvesse Sarào | estando detreminado ${ }^{2}$ de antes o contrario, | a respeito de parecer que poderião impedillo de|pois algũns dezastres do Torneio, e feridas dos $\mid$ cavalleiros, mas propondo aquelles Princepes | cazados de não deixarem (se pudessẽ) chegar || [40v] as couzas a

15 estado de desgostos. ${ }^{3}$ Assentouce | que ficasse para depois do Torneio. A algũns pezou | de isto ser assim, outros o estimarão cuidan|do de fazer obras nelle, por onde fossem melhor | agazalhados das Damas. E assim se recolherão | todos a suas pouzadas aguardando a menhã $\tilde{a}^{4}$ que não tardou muito chea de extraordinarios mo|tivos de contentamento, com o que se compuzes|se ella tambem com mais cuidado para ajudar |

20 a celebrar aquella festa.

O Emperador, ElRey D Duar|dos, e os mais, forão a o apozento da Empera|tris buscalla, a ella, eaquellas senhoras para ouvi|rem missa, e dahi irem aos cadafalsos, donde $\mid$ se havia de ver <o torneyo $>^{5}$, que estavão feitos com grande $\mid$ magnificencia, e commodidade, e assi ou|tros muitos palanques para a gente do povo. Fora|isto Mandou

25 o Emperador formar hũ Es|quadrão de cinco mil cavalleiros armados, | guarnecido com muitos piques, e alabardas para | o que pudesse acontecer, porque como temos ditto | tinha concorrido tanta gente estrangeira | que justamente se podião os naturaes temer | de algum trabalho grande. [espaço] Os Noveis seri|ão por todos quinhentos, e de ${ }^{6}$ outra parte have|ria mais de dous mil, e hũns, e outros acaba|das as missas (que se disserão

\footnotetext{
${ }^{1} \mathrm{~B}$ e C: maneira

${ }^{2}$ Palavra corrigida pelo copista: ele havia escrito detremindo (sem o a).

${ }^{3}$ A compreensão da frase exige desconsiderar este ponto final.

${ }_{5}^{4}$ A forma menhã convive com manhã (cf. outra ocorrência no cap. 22, linha 41).

${ }^{5}$ A inserção foi acrescentada por outro punho nas entrelinhas do texto. B e C não apresentam o acréscimo.

${ }^{6} \mathrm{~B}$ e $\mathrm{C}: d a$.
} 
30 cedo para haver ma|is lugar) forão occupar os postos, que ja a cada | hũa das partes se tinhão assinado. [espaço] Hião os | Noveis armados de armas brancas, lustrozas, || [41r] e louçans, mas sem divizas, nem pinturas | algũas, porque aquelle era o dia, em que cada | hum as havia de merecer. [espaço] A D Duardos | se deu a capitania de todos, assi porque o Em|perador o quis por amor de ElRey seu Avo ${ }^{7}$, co|mo pella oppinião que a

35 Profecia de Appollidon | lhe granjeara no animo delles. Da outra par|te havia cores alegres, pinturas, e divizas diffe|rentes, com о que, e com agrande dezigualdade | do numero, fazião parecer muito arriscada | a victoria por parte dos Noveis, e tanto que | todos estiverão em seu lugar apos hũ profun|do silencio, tocandoce de novo grande can|tidade de charamellas, trombetas, e attambores | que tinhão callado hũ pouco, 40 arremeterão hũns | a outros com tamanho estrondo, que a terra pa|rece que se abria. D. Duardos, Primaleão, | Vasperaldo, Trineo, Palmeirim de Lacede|monia, Frenellio, Polendos $^{8}$, Belcar, Recin|dos, Arnedos, Ardimão de França, Pavoran|te, Almourol, e D Floris, que tambem como No|vel hia entre elles, se encontrarão com ou|tros catorze cavalleiros da outra parte, que dian|te de todos os sahirão a receber, e foi tal o encon|tro,

45 que da dos Noveis não ficou algũ acavallo, | porque os outros que para aquillo vinhão ja prestes | com hua industria torpe, e cautelloza, tirarão | lanças tanto mais compridas, que as ordina|rias, quanto bastou para os encontrarẽ pellos peitos | dos cavallos, no em que ja vinhão todos de a $\|[41 \mathrm{v}]$ cordo, e darem com elles mortos no chão primeiro | que os Noveis the pudesse chegar com as suas, | pelos quais elles passarão sem receber reves 50 algũ, | deixandoos a todos no campo como dissemos, | com seus cavallos Mortos. [espaço] Grande cuidado | deu este encontro a os Reys, Pays, e Avós daquel|les cavalleiros, não porque entendessem que per|derão elles na queda oppinião algũa, porque | logo foi conhecida a industria, mas porque | lhe pareceu que quem tanto contra sua honrra | uzara della teria traçadas outras com que os | poderia por em grão perigo.

55 [espaço] Os mais cavallei|ros se encontrarão variamente cahindo de | hũns, e de outros ${ }^{9}$ como lhe tocou a sorte, e assim | começarão hũ fermozo, e intrincado torneio, | porque

\footnotetext{
${ }^{7}$ Ou seja, o rei D. Duardos, companheiro de aventuras do Imperador na juventude, conforme se lê no Primaleón. Note-se que o Imperador Primaleão também é avô do príncipe D. Duardos.

${ }^{8}$ Embora Polendos seja nomeado juntamente com os demais príncipes criados na Ilha Perigoza, ele não havia sido mencionado até agora. $\mathrm{O}$ fato de ele justar ao lado dos novéis impede a identificação com o filho de Palmeirim de Oliva chamado Polendos (pai de Francião, conforme observamos na nota 14 do cap. 03). No cap. 172 do Palmeirim de Inglaterra, contudo, diz-se que Francião teve um filho chamado Polendos, como o avô: deve ser este o personagem em questão e por lapso do autor só foi lembrado agora. Tal fato confirma a observação, feita na nota supracitada, acerca da insegurança do autor desta continuação quanto aos personagens da família real de Tessália.

${ }^{9}$ Leia-se: de uma parte e de outra.
} 
os Princepes que se acharão no chão sahin|do dos cavallos sem perigo algũ com as espadas | na mão, e os escudos embraçados, esperarão os | que lhos matarão, que assi a cavallo fazião volta | sobre elles para os atropelarẽ tendo entendido, | que tirados, ou 60 embaraçados aquelles, aos mais $\mid$ seria coufa ${ }^{10}$ facil de arrancar do campo, mas | não era assim certo, porque os Noveis erão ex|cellentes cavalleiros, e sostinhãoce contra seus | contrarios tão vivamente, que não perdião | nada a the então. [espaço] Hora os Princepes | que os virão vir serrandoce entre si detremina|rão de esperallos, porque elles tambẽ com o em|baraço de seus companheiros, que ja todos an|davão misturados, não podião

65 correr nos || [42r] cavallos tanto à sua vontade, que os pudes|sem a tropelar, e toda via não deixarão de | tornar a cahir Recindos, Arnedos, Frenellio, | Palmeirim, Belcar, e Polendos. Os con|trarios vierão todos a o chão achandoce hũns | com os cavallos descepados, e outrou ${ }^{11}$ com tais | feridas em si, que se não puderão ter nelles. | Alli foi a pressa de maneira que quazi nimguẽ | ficou a cavallo, porque como os contrarios | erão

70 dos principaes, e tinhão muitos que lhe acodissẽ, | quizerão todos fazello, mas aproveitou pouco, | porque o valor dos Princepes estimulado com | o sentimento da cautella, não poude ter re|zistencia, e assim em pouco espaço não fi|cou nenhũ da quelles com vida. [espaço] Recindos, | e os mais que cahirão da segunda ves, correrão | grande risco de perderem tambẽ as suas, | atropellados dos cavallos, que andavão soltos,

75 e | dos cavalleiros que concorrião a quella pressa. | E foi ella de maneira que Primaleão rece|bendo hũ encontro de lança dado por de tras | foi com tanta força, que cahio com ella atra|vessada por todo o corpo, sahindolhe hũa grão | parte fora, mas tão venturozamente que quazi | lhe não tocou a carne. [espaço] D. Floris que estava | perto delle dando, e recebendo muitos golpes | trabalhando por por ${ }^{12}$ a cavallo a si, e a seus 80 ami|gos, travou pellas redeas ao que o ferio, e deulhe | com a maçã da espada pellos peitos com | tanta força, que Morto o fes cahir a seus pes. || [42v] E thomando o cavallo antes de acordir a Pri|maleão voltou para Recindos diante de quem se elle | puzera pello não acabarem de matar, e a pezar | de todos os que lho deffendião o pos a cavallo, e | Então se foy a Primaleão, a quẽ muitos jul|gavão por morto, senão elle que via como tra|balhava por se dezembaraçar da quella lança | com que estava como espetado, e ajudandoo o pos | em pe quebrandolhe primeiro aquella parte da as|tea que o impedia. [espaço] Foi isto tudo tão perto dos | cadafalços, que todos os que nelles estavão virão |

\footnotetext{
${ }^{10} \mathrm{~B}$ e C: cousa. O erro do copista pode ser explicado pela proximidade com a palavra facil.

${ }^{11} \mathrm{~B}$ e C: outros.

${ }^{12}$ Leia-se "trabalhando por pôr".
} 
quanto alli passara, e os mais da quelles Reys, lou|varão por extremo a D Floris acodir primeiro a | Recindos, que a o sobrinho. So Miraguarda| se não mostrou muito contente 90 da quella sua | fineza mais pello que arguhia de humildade no | irmão, que de perigo no filho, como que o carac|ter de vassalo se possa nunca tirar senão cõ | servir, e mais servir $^{13}$. [espaço] D Duardos, e os $\mid$ mais a este tempo tinhão thomado cavallos. | e hião discorrendo pella batalha fazendo | extremos na quella gente, de que seu pay, e | os outros estavão assas contentes. [espaço] Dramu|siando não tirava os olhos de seu filho,

95 e assi | erão todos, [espaço] E estando a batalha em pezo sus|tentada contra tamanho numero de Estran|geiros so com o valor dos Princepes, entrarão | nella da parte dos contrarios quatro Gigantes | e dous cavalleiros armados todos de negro | com perfis de ouro. Nos escudos em campo || [43r] pardo a morte com hũa caveira nas mã|os, e vinhão fazendo tal estrago nos pobres | Noveis, que não havia entre elles quem lhe pa|rasse 100 diante, não se assinalando menos os | cavalleiros que os Gigantes. [espaço] $\mathrm{O}$ espanto começou | a ser grande em todos, e nos Reys maior, que | logo derão tudo por perdido. [espaço] Palmeirim | de Inglaterra, Floriano, Florendos, Dramu|ziando e os mais cazados quizerão entrar no | Torneio, mas não o consentio o Empera|dor parecendolhe que hia contra o que tinha | mandado apregoar, que so Noveis entrarião | nelle. Pois

105 Mande Vossa Magestade disse Flori|ano que toquem a recolher, porque isto com o que | vimos a o principio na Morte dos caval|los mais parece treição que tornear. [espaço] Não | me parece amim o contrario respondeu o | Emperador, mas nem por isso se fará o si|nal antes da hora que tinhamos assentado. [espaço] | A este tempo soou hũa grande grita que levou | os olhos a todos ${ }^{14}$, e era a cauza que os Gigantes, e | seus dous 110 companheiros tinhão derribado Ar|nedos, Ardimão de França, Palmeirim de | Lacedemonia, e a Trineo, que na quelle dia ti|nha feito maravilhas, e tratavão de os matar | sem que nimguẽ lhe pudesse valer. E de todo o | fizerão se por alli não vierão acodindo aquel|le estrago D. Duardos, Vasperaldo, Prima|leão, Pavorante, Almourol, e D. Floris, que | tinha tomado hũ cavallo, e hia fazendo tais || [43v] progressos nos 115 inimigos, que por aquelle lu|gar onde elle andava, não despejava me|nos o campo do que os Gigantes por cà ofazi|ão, [espaço] E ouvindo aquella gritta grande que | dissemos virando o rosto não poude divizar | mais que a multidão de gente junta, e corre|rem todos seus companheiros para la, e | informandoce de algũns que hião fugindo | dos

${ }^{13}$ Ou seja, Miraguarda desaprovou o fato de seu irmão socorrer antes a Recindos que a seu filho Primaleão não tanto pelo perigo em que este se encontrava, mas sobretudo porque o gesto lhe pareceu motivado pela circunstância de D. Floris ser vassalo de Recindos, príncipe de Espanha.

${ }^{14}$ Isto é: atraiu os olhares de todos. 
Gigantes da razão porque tudo se perdia | thomando hũa lança com a maior pressa, | que 120 poude se foi a socorrer seus companhei|ros, e ajuntandoce com os cinco, que nome|amos, que com o mesmo intento alli tinhão | acodido, todos seis juntos bradarão aos Gi|gantes que querião decerce (para acabarẽ de ma|tar aquelles cavalleiros ${ }^{15}$ sahindoce hũ pou|co do tropel da gente os forão a receber cõ | as espadas nas mãos, porque todos tinhão | as lanças ja perdidas, e da parte dos No|veis so D. Floris a trazia, o

125 qual tanto | que vio que nenhũ dos outros a tinha largã|doa logo meteu tambẽ mão à espada. | O que vendo os Gigantes hũ delles com vox | grossa e pezada disse para elle: [espaço] Ora vos digo | cavalleiro que deveis ser galante homẽ pois | deixais as armas quando as mais ouvereis mis|ter, mas deve de ser para que mais desembaraça|da mente nos deixeis o campo. [espaço] Logo | veremos isso (respondeu D. Floris) porque a $\mid$ mim

130 me parece que desta ves não levareis vos || [44r] outros a diante a tenção com que aqui deveis | ter vindo. [espaço] E remetendo a elle, D. Duar|dos, Pavorante, e Almourol remeterão aos | outros tres, e Primaleão e Vasperaldo aos | dous cavalleiros, e o sucesso nos conta | Henrique Frusto logo abaixo.

\footnotetext{
${ }^{15}$ Em princípio, aqui o parêntese deveria ser fechado. Em B ocorre o mesmo: o parêntese é aberto e não se fecha; em C, cópia na qual os sinais de pontuação são muito escassos, não há parênteses.
} 


\section{Capitulo 16}

\section{Do sucesso que teve aquella | Batalha.}

Notavel, e temeroza couza foi esta batalha | que logo em seus principios 5 demaneira suspen|deu os animos de todos, que nem o Emperador | e Princepes se fallavão, nem os cavalleiros | que tinhão entrado no Torneio se occuparão | mais em o levar a diante como athe então | com tanta despeza de seu sangue, com tan|to perigo de suas vidas, hũns e outros tinhão | feito, antes como se so para verem o fim del|la alli vierão assi se apartarão, e se puzerão | a olhar como aquelles cavalleiros se combatião, |

10 os quais sentindo, ou vendo o silencio comque | todos os olhavão, apartandoce hũ dos da Mor|te disse para os Noveis: Pois que so em nòs pa|rece que está o fim do Torneio, cheguemonos | mais a os cadafalsos onde estão aquellas Prin|cezas ${ }^{1}$, nem lhe daremos trabalho de nos verẽ || [44v] de tão longe, nem ficaremos tanto entre | a gente, que nos possão embaraçar. [espaço] Vamos | (lhe respondeu D Duardos) onde mandar|des ainda

15 que me parece que nos procurais ven|tagem. [espaço] $\mathrm{E}$ assim se chegarão bem perto don|de aquellas senhoras estavão em extremo es|pantadas do sucesso, que aquellas couzas hião | tendo. E alli se tornarão a ajuntar ${ }^{2}$ cada | hũ com o que ja tinha encetado, e se anda|rão ferindo por tantas partes, e tão apressa|damente, que começarão a enfraquecerce os | cavallos de todos de maneira, que não se podião | chegar como

20 querião, pello que appeandoce | delles se a batalha athe então tinha parecido | espantoza, e horrenda, dalli por diante o pa|receu tanto mais, que os Reys, e a outra gente $\mid$ que os via olhavãoce como pasmados sem se | fallarem palavra. [espaço] Os Gigantes andavão | cubertos de seu sangue, e mais cubertos do | fumo que a paixão lhes fazia lansar pellas vi|zeiras dos elmos. E seus companheiros não | melhor tratados, mas não tinhão os

25 Noveis | muito de que se gabar, posto que com mais vive|za, e acordo commetião. [espaço] D. Duardos em | fim, que com a sua nova ou antiga espa|da ${ }^{3}$ tinha feito hũ grande estrago na quel|la torre de carne com que se combatia, não | tardou muito que deu com ella no chão de todo | acabada, e pondoce a olhar para seus compa|nheiros mais devagar do que athe então o $\|$ [45r] pudera fazer, vio que so Almourol não ti|nha

30 tão conhecida ventagẽ como os malis, e pezandolhe de o ver tão mal tratado | bem

\footnotetext{
${ }^{1}$ Esta frase parece refletir a construção mais informal típica da fala; a rigor, neste ponto deveria haver uma conjunção, como "para que". A lição não difere de B e C.

${ }^{2}$ Sobre esta palavra há borrão de tinta no manuscrito.

${ }^{3}$ Nova pois D. Duardos a recebera havia pouco tempo; antiga porque estava reservada para ele há muitos anos pelo sábio Appolidon.
} 
quisera ajudallo, mas lembrandoce | do que ouvira dizer que em outra Occazião | semelhante acontecera a Dramusiando | com Palmeirim seu Pay, antes quis deixar $\mid$ de imitallo no socorro, que dar occazião a Al|mourol de fazer gentilezas com elle | ou roins contas concigo ${ }^{4}$. E assim deixan|doce estar vendo como todos trabalhavão | vio que

35 Primaleão foi o primeiro que se dezembara|çou do cavalleiro com quẽ se combatia | ficando porem tão maltratado de sũas ${ }^{5}$ mã $\mid o s$, e dos mais que ja tinha exprimentado, que | fora forçado tiraremno do campo se dura|ra muito mais a contenda dos outros, mas | os da Morte a pouco, e pouco se hião entregã|do a ella, porque Pavorante estirara ja o | seu, e por se assegurar mais delle lhe corta|ra a cabeça, de que não pesou nada a seu | pay

40 que era inimigo mortal da soberba | de que aquelles homẽns sempre acompanha|vão suas obras ${ }^{6}$. [espaço] Vasperaldo haviáo ${ }^{7}$ com for|te inimigo, e a sua batalha entre todas era | das mais notaveis, e afastandoce hũ do ou|tro para descançarẽ, vendo o cavalleiro da | Morte dous dos seus Gigantes mortos, e | os outros pouco menos, o cavalleiro vencido, | e assim na quelle estado comessou a arrepen||[45v]derce do appetite que o alli

45 trouchera, e disse | concigo: [espaço] Para que he dar couces no aguilhão? | nem cospir para o ceo? [espaço] Estes homens não nas|cerão para os vencer nimguem, eide fazer pa|zes com os dezejos, e deixarme levar do cur|so de sua fortuna ${ }^{8}$. [espaço] A o menos se agora pe|lejão de sua parte os Anjos que aqui vejo, fica|rà mais desculpada nossa fraqueza, e | menos glorioza sua victoria, porque com | tais ajudadores ainda lhe 50 duramos muito. [espaço] |D. Floris a este tempo tinha vindo a braços | com o Gigante, o qual despois que vio que elle | com a ligeireza, e industria lhe fazia per|der os mais dos golpes andava procuran|do aquillo como sua salvação, e tendo o | bem apertado concigo julgandoce por segu|ro, e victoriozo disselhe com grande conten|tamento: Agora vereis cavalleiro quanto melhor | vos fora não sahir nunca dos braços de vossa | May, que 55 virdes ter a estes a onde tão depressa | sereis desfeito em cinza sem vos valerem | os

\footnotetext{
${ }^{4}$ Trata-se de episódio narrado no cap. 94 do Palmeirim de Inglaterra, quando Palmeirim, Floriano e Dramusiando enfrentam três gigantes. Depois de vencer seu oponente, Palmeirim tenta ajudar Dramusiando e é repelido pelo amigo com um duro golpe. Aqui, D. Duardos pensa que não deve ajudar Almourol para que ele não reaja da mesma forma, fazendo roins contas com ele.

${ }^{5} \mathrm{~B}, \mathrm{C}$ : suas. O acento em A deve ser um lapso do copista.

${ }^{6}$ A passagem dá a entender que Dramusiando já conhecia os gigantes e os dois Cavaleiros da Morte, o que não se justifica. A lição é idêntica em B e C.

${ }^{7} \mathrm{~B}$ : haviao; C: aviao. O acento do ms. A não se justifica; além disso, o pronome $o$ não se refere a nenhum antecedente identificável. Acreditamos que a passagem deve significar "Vasperaldo havia-se com forte inimigo".

8 "Fazer pazes com os dezejos" parece significar "desistir de porfiar nos intentos".
} 
vossos saltinhos de Pega ${ }^{9}$. [espaço] Não aca|bava o pobre homẽ de dizer isto quando se achou | tão estirado no chão, que thomava hũa grão par|te daquelle campo, e D. Floris pondolhe hũ | pe nos peitos disselhe: [espaço] Monstro bestial | desta maneira se costumão castigar sempre | os soberbos, emetendolhe a espada pella vi|zeira fes ir a quella alma a carregar a | barca de Aqueronte, que tão material || [46r] era o Gigante, que a the a ella devia ser | pezada. [espaço] Almourol, e seu contrario ja | quando isto foi tinhão vindo ao chão ambos a | hũ tempo, elle mal vivo, e o Gigante de to|do morto. [espaço] $\mathrm{O}$ cavalleiro da Morte que fica|va que athe então estivera vendo o que os ou|tros fazião tendoo pedido a Vasperaldo, que | contra sua vontade estava Occiozo ${ }^{10}$,

65 tanto | que os vio todos acabados foice para elle dizendo: | Pedivos cavalleiro que occiozamente me dei|xasseis ver o fim de meus companheiros | por dous respeitos, hũ por lhes não acrecentar | a penna com elles verem a minha, e outro | porque me servisse a dezesperação de meu re|medio da quillo de que vos a vòs deve ter ser|vido a esperança de vosso gosto, que quẽ passa | a vida na converçação destas senhoras, im|possivel he 70 que possa ser vencido de nimguem. | Agora acabemos nossa batalha, e procurai | de vos deffender, que hũ homem dezesperado | muitas vezes he mais que hũ homẽ. [espaço] Vaspe|raldo estava raivozo de so elle ser quem | não tivesse dado conta de sua empreza, | e tambẽ com sentimento de suas feridas | que erão muitas, e as primeiras, e assim lhe res|podeu mais agastado do que o termo do | Outro Merecia, dizendolhe: [espaço] Não

75 sei na|da desses respeitos, sei que estais vivo, e vossos | companheiros Mortos, e eu Morto tam|bem com tantas detenças. As ventagẽns \|| [46v] que me imaginais se as eu tivera, muito ha que | fora acabada esta porfia. E como isto dis|se indosse a elle com a espada levantada | comessarão a se ferir de novo tão apressada | e rija Mente como se em todo odia | não tiverão feito nada. [espaço] Excellente | cavalleiro era Vasperaldo, e 80 tal que nẽ seu | Pay entre os da outra idade, nem D Du|ardos na sua lhe podião fazer em certa | Maneira Ventagem. Mas o com quem | se combatia o era tanto que não lhe que|ria ficar devendo couza algũa. [espaço] A | tarde chegavasse, a crueza da batalha não | cessava, as feridas de Vasperaldo tinhão ar|rancado rios de lagrimas dos olhos de todas | a quellas senhoras, e a lastima do cavallei|ro da Morte, não era tamb ẽ pequena no 85 | coração de todos. [espaço] A este tempo o compa|nheiro com quem Primaleão se combatera | que athe então tinha estado fora de seu a|cordo tornando em si ainda que

\footnotetext{
${ }^{9}$ A frase de sabor irônico provavelmente se referia a algum dito popular que não conseguimos identificar. Pega é uma ave pequena comum na Europa.

${ }^{10}$ Entenda-se: o segundo Cavaleiro da Morte estava observando o combate de seus companheiros, pois havia pedido uma pausa a Vasperaldo, que a concedera de má vontade.
} 
com gran|de fraqueza, tirou o Elmo da cabeça | e sentandoce no campo encostado no pro|prio Primaleão, que tambem estava nos | braços de D. Floris, que em se desembaraçando | do Gigante se chegara logo a elle porque não | consentira que o levassem como ja tinhão feito | a Almourol, Recindos, Polendos, Franellio, | Ardimão, Belcar, Arnedos, e Palmeirim | todos tão atasalhados, como quẽ ja encetados || [47r] exprimentarão em si a furia fresca da $\mid$ quelles Gigantes $)^{11}$ e vendo o que passava, com | vox fraca disse para Primaleão conhecen|o que elle fora quem o vencera. Dizei | senhor a o Emperador que mande cessar a | batalha da quelles cavalleiros, pois o Torne|io está 95 vencido por vossa parte, e ella se não | fas por outra cauza, porque se morrece meu | companheiro, eu sei que lhe pezarà disso pel|la nobreza grande de seu coração, em que | poderá mais o serviço que de algum paren|te seu tem recebido, que os desprazeres que outros | lhe terão feito ${ }^{12}$. E como isto disse tornou a | cahir tal como Morto, e como tinha o elmo | fora, a todos fes lastima grande, porque era | gentilhomem, e tão moço, que

100 nenhũ sinal | tinha de barba. [espaço] D. Duardos lhe soccor|reu logo naquelle segundo accidente, in|da que não estava tão inteiro, que deixasse de os | padecer bem grandes, mas elle os dissimula|va mais por não perder a vista de Car|mellia, que por pouca necessidade que tivesse de $\mid$ ser acodido. [espaço] Logo o Emperador foi avi|zado do que passava, e julgando que o cavallei|ro tinha razão fes sinal de se acabar o Torne|io, com o que Vasperaldo que andava envolto | na furia de sua batalha não poude ter passien|cia, e o outro que não cuidava que era o que malis ganhava lhe disse vendoo tão colerico: [espaço] | Ora cavalleiro não mostreis tanta paixão || [47v] que se eu viver tempo teremos para que sẽ estes | inconvenientes nos vejamos. [espaço] Daime | ca essa mão (disse Vasperaldo) de ser assim, | que só com essa promessa poderei não morrer | 110 de corrido, quando mais razões não tivera para me acabar a vida este desastre de agora. | Vedela aqui (respondeu o Estranho) e então | dandoce as mãos contratarão a maior ini|mizade, que naquelles tempos houve.

O Emperador quis que aquelles do|us cavalleiros fossem curados em sua ca|za tendoos por pessoas de grão presso, e elles | o consentirão, ou elle (porque o outro 115 estava | mais morto que vivo) [espaço] Recebendo primeiro pa|lavra de que se lhes não faria força algũa, nẽ | para os conhecerem, nem para lhe impedirem | irem se quando o

${ }^{11} \mathrm{O}$ parêntese aqui aparece isolado; o mesmo acontece em $\mathrm{B}$.

${ }^{12} \mathrm{~A}$ informação ainda não pode ser compreendida pelo leitor, que não sabe quem é o cavaleiro em questão. Como será revelado no próximo capítulo, trata-se de Albaizar (filho do primeiro Albaizar e Targiana); assim, percebe-se que os parentes aqui mencionados são seus pais: Albaizar, que causou desprazeres com a guerra contra Constantinopla, e Targiana, cuja amizade com o Imperador já foi objeto de nota anterior (cf. a nota 9, cap. 07). 
quizessem fazer. [espaço] E com isto | apartandoce o cavalleiro da Morte com al|gũns dos estranhos que se lhes chegarão, man|doulhes (porque erão da sua companhia) que se fos|sem a sua terra com os corpos dos Gigantes, | e que lhes deixassem alli, o que lhe a 120 elle pareceu que | haveria mister para seu serviço. E despois de | lhes dar esta Ordem tornouce àquelles Prin|cepes Noveis, que o aguardavão, e todos jun|tos se forão a suas pouzadas, onde em hũa | particular dentro nos paços, elle, e seu com|panheiro forão curados com igual deligen|cia que os mais, havendoo todos mister tan|to que não poude ter lugar o serão que se espe\|[48r]rava, ficando solemnizada a quella fes|ta com sangue

125 de tanto homẽ, como se | fora hũa grande batalha, e com tão altos prin|cipios de cavalleria de todos aquelles noveis | que não so satisfizerão a oppinião de filhos $\mid \mathrm{de}$ seus Pays, mas encherãonos a elles de | hua gostoza inveja, particularmente quando | Daliarte affirmou a saude ${ }^{13}$. [espaço] A o qual dis|se o Emperador ja depois de estarem em ca|za: [espaço] Não vos pergunto quem são estes | cavalleiros Estranhos por não

130 quebrar a pa|lavra, que lhes tenho dado; porem se isto não | he ir contra ella, folgaria que me dicesseis se | são pessoas, em quem caiba por mais razões, | que as que vimos, a honrra que lhe fazemos. [espaço] Ao | que Daliarte respondeu: [espaço] São senhor os caval|leiros Andantes mais, e menos de estimar, | quanto mais, e menos differenção dos outros | em seus procedimentos e valentias. [espaço] Estes, | que agazalhais, pello preço 135 de suas pessoas me|recem toda a merce, que lhe fizerdes, como | elles com o valor, e constancia dellas vos tem $\mid$ mostrado $^{14}$. Por seus Estados, ainda muito me|lhor, porque hũ delles he Princepe muito podero|zo, e outro não ha nenhũ no mundo que o se|ja mais. [espaço] Por agora bem basta isto, e não | tardarà muito que saibais a verade do que vos di|go com maior gosto desta caza, do que agora ha $\mid$ nella, sendo tanto, e mais despeza 140 de seu san|gue em vosso servisso, do que hoje derramarão \| [48v] pello contrario. [espaço] O Emperador contente | do que ouvio, como o mais erão couzas do | futuro, sem curar por então dellas, tratou | so de levar a diante a cortezia, que manda|ra uzar com aquelles cavalleiros de quem | daremos razão no capitulo que se segue:

\footnotetext{
${ }^{13}$ Ou seja, quando Daliarte lhes assegurou que os filhos não estavam gravemente feridos.

${ }^{14}$ Leia-se: "como eles com o valor e a constância de suas pessoas vos têm mostrado".
} 


\section{Capitulo 17}

\section{De quem erão os Cavalleiros da | Morte, e do que aconteceu às qua|tro Princezas na Horta.}

$\mathrm{Na}$ Chronica de Palmeirim de | Inglaterra se conta que por morte de Albai|zar Soldão de Babilonia, e do Soldão de | Persia, que acabarão aos muros de Constan|tinopla ficou a cada hũ hũ filho herdeiros | de seus estados, chamados Albaizar, e Belia|zem ${ }^{1}$. [espaço] Criou Targiana este filho seu, e | a Beliazem juntamente, doutrinando | os nos perceitos de sua ley, e das mais artes | e disciplinas, que a tão altos

10 Princepes con|vinhão, com tanto cuidado, e deligencia, que | lhe não deverão a ella menos pella criação | que a seus Pays pellos grossos Estados, de que os | deixarão herdeiros. [espaço] E sahirão tão extrema|dos nas armas particular mente Albaizar, |que lhe não foi ventagẽ seu Pay, nem no mũdo || [49r] havia muitos que lha fizessem, mas como quẽ | professava hũa ceita tão torpe, não deixou | de ter algũns vicios em seus

15 principios muito | repreensiveis em toda a sorte de pessoa, quanto | mais em Princepe tão poderozo, em quem | não pode haver algũ que seja pequeno. [espaço] Cres|ceu Albaisar, e creceu com elle o natural odio, | que tinha a os christãos, e em particular a ca|za de Grecia, se bem neste o não mitigava | pouco Targinana sua May, movida assim | da brandura de sua condição, como do te|mor que tinha à fortuna da quella caza; fa|tal

20 ruina (inda que não custoza) da de seu Pay, | e Marido ${ }^{2}$, e assi se bem não poude tanto a | criação que total mente arrancasse do animo | de Albaizar o Odio, e dezejo de vingança | dos Princepes Gregos, toda via lho mitigava | de Maneira, que nesta parte era muito differen|te de seus passados.

Chegado pois Albaizar a idade de | ser cavalleiro, chegarão juntamente a sua | noticia às ${ }^{3}$ festas que o Emperador Primaleão | mandara apregoar, e como nos mossos | não tem mais lugar a razão, que o que o appeti|te lhe consente, não ouve discurso, nẽ incon|veniente que lhe o entendimento reprezen|tasse, nem hũ Ayo seu com quẽ comuni|car a jornada, que fosse poderozo para lhe atalhar, | Antes fazendoce armar cavalleiro privada|mente, elle, e Beliazem, que como irmãos se || [49v] criarão sempre, e

\footnotetext{
${ }^{1}$ Os capítulos finais do Palmeirim de Inglaterra mencionam estes dois personagens. Por ocasião da morte de Albaizar, Targiana já esperava um filho seu, a quem daria o mesmo nome do pai; seu companheiro, Beliazem, é filho de Armênia, irmã do Sultão da Pérsia (que também morreu na guerra contra Constantinopla). No cap. 170, o narrador observa que Beliazem "foi grande amigo do segundo Albaizar". ${ }^{2}$ Não compreendemos qual o motivo de dizer-se que a ruína dos turcos não havia sido custosa (note-se que Bluteau dá como significados dessa palavra "cousa feita com grande gasto" e "que custa trabalho, moléstia". A lição de C é igual.

${ }^{3} \mathrm{O}$ acento sobre esta palavra não se justifica e não é reproduzido em B e C.
} 
30 assim se amavão, tho|mando concigo quatro Gigantes Mance|bos, que com elles tambem se tinhão criado | hũ tempo, de grande oppinião entre os Turcos, | posto que não havia muito que erão cavalleiros, filhos | de Barrocante, Albuzario, Albarroco, e Fra|mustante, que em differentes tempos acabarão | em Constantinopla, como no livro de $\mid$ Palmeirim se conta ${ }^{4}$, e algũns outros ca|valleiros. [espaço] E embarcandoce em hũa

35 Nào to|dos sem que sua May o sentisse, vierão ter | a Constantinopla antes algũns dias que os | Princepes da Ilha Perigoza alli chegassẽ. | E dezembarcando em terra mandarão ar|mar tendas de que vinhão providos, e por que | sentirão que a vista dos Gigantes começara | a fazer sospeitoza sua chegada, temendo | serem por elles descubertos, tornarão a em|barcallos de noite, e nunca mais sahirão do | Navio athe a hora do 40 Torneio. [espaço] Albaizar, | e Beliazem se deixarão ficar em terra | e entrarão na cidade, e no Paço muitas vezes / e forão prezentes a tudo o que aconteceu quando | D. Duardos foy armado cavalleiro, e tinhão | visto aquellas Princezas em forte hora, | porque tão rendido estava Albaizar à fermo|zura de Carmellia, que aquelles amores lhe | custarão a elle a vida, e a ella tantos dezas|tres, lagrimas, eperigos, como no discurso

45 des|ta historia havemos de ver. E esta foi a razão \|| [50r] porque elle quis combater perto dos cadafal|sos, perdida ja outra esperança, que a princi|pio concebera de poder darlhe a sorte roubar | aquellas senhoras, quando vio a prevenção que o | Emperador tinha feito no Esquadrão que mã|dara formar, e depois da quella ${ }^{5}$ ter o $\mid$ successo que vimos, não se atrevendo a partir | donde Carmellia ficava, aceitou ogaza|lhado, que lhe o Emperador 50 offereceu, e despe|dio a sua gente ficando so mente com | dous Escudeiros encarregandolhes que onão des|cobrissem, e desta maneira se deixou ficar | na quella caza, a que mor mal quizera, tão | trocado, que ja era a em que mais dezejava de | viver. [espaço] Tal he o poder que a Natureza quis que | tivesse nos corações humanos hũ parecer di|vino.

55 O Emperador, ElRey D. Duar|dos, Palmeirim, Florendos, e os mais estavão | tão contentes da alta cavallaria de seus fi|lhos, e nettos, que não lhes lembrava a dor de | suas feridas. [espaço] O mesmo passava naquellas | senhoras se bem com tudo as não deixava de | lastimar as curas a que assestião, Mas com | o regallo destas vizitas, e com os mais que aos | feridos se fazião, particularmente cõ a boa | deligencia de Daliarte,

\footnotetext{
${ }^{4}$ Os três primeiros gigantes (Barrocante, Albuzário e Albarroco) acompanham uma donzela enviada pelo Sultão de Pérsia solicitando a mão de Polinarda em casamento e ameaçando o Imperador Palmeirim de Oliva caso ele não atenda a seu rogo. Os gigantes são mortos por Palmeirim, Floriano e Dramusiando (caps. 93-94 do Palmeirim de Inglaterra). Já Framustante acompanha as tropas de Albaizar na guerra contra Constantinopla e é morto por Dramusiando (cap. 169).

${ }^{5}$ Entenda-se: daquela batalha.
} 
60 depressa estiverão | em disposição para poderẽ receber outras, ti|rando porem Almourol, e Beliazem, que | muitas vezes chegarão a total desconfiança || [50v] de sua vida ${ }^{6}$, e Almourol mais. [espaço] Os outros | que hião sarando gastavão o tempo em pra|ticas alegres os livres ${ }^{7}$, E em outras, que o não | erão tanto os que tinhão as vontades penhora|das. [espaço] As Princezas, e Raynhas de Ordi|nario acodião a o quarto da

65 Raynha de | Inglaterra, que era o que cahia sobre a Orta, | E alli tinhão seus Entretenimentos, e con|versações conformes a suas idades, e esta|dos. [espaço] Aconteceu pois que hũa tarde se sa|hirão sós as quatro Princezas descuidada | Mente à Orta sem algũa de suas Damas $\mid \mathrm{E}$ dividindoce por huas ruas de jasmins, que | se hião a juntar a hũa fonte, que no meio de $\mid$ certa praça redonda se fazia, forão pas|seando duas, 70 e duas, e por differentes partes | entretendose no que mais gosto lhes dava. |Carmellia, e Valeriza que hião juntas, a poucos | passos que tinhão caminhado, ouvirão (com não | pequeno sobresalto seu) hũns sospiros muito | baixos, e tristes, como de pessoa, que com cada | hũ delles lhe sahia a alma. E depois de estarẽ | quedas hũ espasso, não vendo nẽ Ouvindo | Mais que aquillo, assegurando os animos, | tornarão a proceguir o passeio,

75 o qual as le|vou a dar com os olhos em Albaizar, que lan|çado com o rosto no chão no pe de hũ dos | ciprestes de que se compunha outra rua, que | atravessava a por onde ellas vinhão, sem fa|zer Movimento algũ arrancava aquelles || [51r] sospiros do mais intimo do coração, en|tre os quais estava dizendo a o tempo que ellas | chegavão, tão passo, que so dali pudera ser ou|vido, o que temos aqui logo neste proxi|mo capitulo.

\footnotetext{
${ }^{6}$ B e C: "suas vidas"; em B, o plural de suas parece ter sido fruto de uma correção posterior, visto que não havia espaço para a letra. Em A, o reclame do fólio anterior diz suas, mas em 50v a expressão está no singular, o que parece errado.

${ }^{7} \mathrm{O}$ ms. B não apresenta os livres.
} 


\section{Capitulo 18}

\section{Das pallavras, que aquelle cavalleiro | disse, e do que as Princezas depois | entre si passarão.}

Inda que não mui distintamente, toda via | bem ouvirão as Princezas, que aquelle homem | entre os sospiros, que dissemos pronunciava | estas palavras: Que he isto homẽ desatinado? | Como deixar arrastar tantos respeitos de hũ | so respeito? ${ }^{1}$ Como? E que mais força hade ter | comtigo o parecer de hũa mulher, com quẽ | nem desconhecido podes ganhar nada, nem | conhecido deixar de perder tudo? Que a religi|ão, que o 10 sangue de teu Pay, e o que he mais para | doer que a fama, e boa oppinião de tua May, | Se cada hũa destas couzas puchão por ti para | precurar a ruina de toda esta gente, co|mo sem nenhũa lembrança de quem es, | e do que te deves, te deixas tiranisar de hum | pensamento posto em quẽ nẽ para o fazer | se lembrar que nacestes no mundo? ${ }^{2} \mathrm{Ai}$ Senhora || [51v] Carmellia, e que fora estais vos agora de | cuidar o que por vos padeço?

15 Não digo para o a|gradecer, porque a quem tudo he devido, não | se pode obrigar com couza algua, mas so | para que soubesseis como nesta parte vos pago eu | o que todos vos devem o tomàra ${ }^{3}$. Emfim se|nhora seja assi. Perdoaime esta repugnan|cia que hũa suprestição vã com razões appa|rentes fas a minha vontade, que tão declara|da mente vos cegue $^{4}$, e no mais se a fortu|na me desse Morrer às mãos de vossos ri|gores, não so

20 não teria de que me queixar, | mas darmehia por pago dos danos, que de vossos | parentes tenho recebido, pagandome assim | com minha propria Morte, as mortes de | tantos homens.

As Princezas perdida a tor|vação, que a vista da quelle homẽ, e as primeiras pala|vras lhe causarão, vendo que as não via, estive|rão ouvindo socegadamente, athe que enten|dendo que parava, receozas de que se levantas|se, derão algũns passos atras com o rosto $\mid$ nelle, e voltando forãoce andando hũ pou|co sem se falar palavra hũa á outra. E | depois que lhe a Valeriza pareceu que não podi|ão ser sentidas disse rindo para Carmellia: | Pareceme senhora que não são os homens de | todo dezarrezoados. Eu vos confesso que an|dava queixoza de não ver extremos gran|des feitos por tão grande

\footnotetext{
${ }^{1} \mathrm{O}$ jogo de palavras do personagem significa: “como deixar arrastar tantas outras considerações [que serão explicitadas logo abaixo: a religião, o sangue do pai etc] por um único motivo?"

${ }^{2}$ B: "posto quem" (falta $\mathrm{em}$ ). Entenda-se: “(...) tiranizar por um pensamento posto em uma pessoa a quem ele [o próprio pensamento] nem consegue fazê-la lembrar de ti?"

${ }^{3} \mathrm{O}$ final da frase (o tomàra) não faz sentido; dado que a lição coincide com a de $\mathrm{B}$ e $\mathrm{C}$, isto deve ter sido um erro cometido pelo próprio autor ou por um dos primeiros copistas.

${ }^{4}$ Leia-se: "Perdoai-me o escrúpulo que uma superstição vã, baseada em falsas razões, faz à minha vontade, que tão claramente vos segue".
} 
30 extremo, como a || [52r] natureza em vos fes. [espaço] Agora estou de | outra opinião, e folgo com esta romaria que | fizemos. Não estimara pouco conhecer de | todo este cavalleiro, se bem vou com sospei|tas que me parecem mui conformes à ver|dade. [espaço] Carmellia lhe respondeu: | Não sei eu maior sem razão, que a onde | vos estais, haver quem se lembre de outrem. | Mas deixando isto, digovos verdadeiramen|te, que somos mofinas as mulheres, pois sẽ $\mid$ culpas proprias padecemos atrevimentos allheios. [espaço] Aconcelhaime assi Deus vos grande ${ }^{5}$ o que farei neste, porque quanto amim a dissimu|lação nestes cazos he a primeira quebra da oppini|ão de seus donos ${ }^{6}$. [espaço] Tinha Carmellia | hũa certa vaidade natural, que a não fazia $\mid$ ser mui amada daquellas senhoras, porque ain|da que tudo o que ella de si cuidava era divido | a os extremos de sua fermozura, estava o | danno em cuidar menos dellas, do que tãbẽ | se lhes devia. [espaço] Valeriza era mui sizu|da, e mui discreta, entendialhe ${ }^{7}$ o humor, e | fomentavalho sempre entretendoce muito de | aver caminhar de continuo por pontas de | diamantes $^{8}$, porem ouvindolhe aquillo jul|gandoa por perdida com muito sentimento | lhe replicou o seguinte:

Pezame muito, senhora Carmellia, | de vos ouvir isso, porque se vos obrigardes a | castigar pensamentos, não so levareis a mais || [52v] mà vida do mundo, mas por força haveis|de chegar a estado de julgardes pello menos | por mais culpaveis hũns que outros. Dei|xai por vida vossa sonhar os homẽns em|bora, e contentaivos com não dar azo, a | que nem ninguẽ vos diga suas imagina|ções, nem cuide que as entendeis vos. Que se | 50 fechardes esta porta com o respeito de vossa | pessoa, e com hũa certa industria descuida|da, não so mente ficareis cumprindo com | vossa estimação, mas izenta tambẽ dos $\mid$ perigos aque se arrisca quem sempre cuida $\mid$ que sempre cuidão nella. [espaço] Eu pello menos | desta maneira me detremino governar, e | se não cuidais que são muito desiguais nossos res|peitos, não me desagradecereis aconcelhar|vos o que sigo ${ }^{9}$. [espaço]

\footnotetext{
${ }^{5} \mathrm{C}$ : guarde; o erro de A aparece também em B.

${ }^{6}$ Leia-se: "o que farei neste [caso], porque quanto a mim nestes casos a dissimulação é a primeira causa de quebra de reputação".

${ }^{7}$ Há mancha sobre esta palavra no manuscrito, o que impede sua leitura; a lição apresentada aqui é a de B e C.

${ }^{8}$ Nos dicionários consultados não há referência à expressão "caminhar por pontas de diamantes”. Bluteau traz apenas "pôr-se nas pontas" ou "pôr-se nas pontas da lua", que significam "encher-se de orgulho; presumir ser mais que todos", significado adequado ao contexto em questão. Talvez a expressão aqui usada seja uma variante das registradas por Bluteau.

${ }^{9}$ Valeriza repreende Carmélia que, ao desaprovar os sentimentos de Albaizar, mostra-se alheia e até hostil a qualquer pensamento amoroso. Em sua opinião, Carmélia não deveria ficar descontente de ser amada e, caso não desse oportunidade para que o pretendente declarasse suas intenções, não haveria motivo para se sentir ofendida. Dessa forma, conclui, ela não seria desonrada (cumpriria com sua estimação) e também ficaria isenta dos perigos da vaidade excessiva (cuidar que sempre cuidam nela).
} 
55 Bom estava isso senhora (res|pondeu Carmellia) se nos não conhecera|mos que era aquelle o cavalleiro da Morte, que | se combateu com meu irmão, e se ambas | lhe não ouviramos o que elle tão claramente | disse. [espaço] Ainda quando elle via que o ouviamos | (replicou Valeriza) tinha lugar a compos|tura, e socego da pessoa para lhe fazer crer | que eramos surdas, quanto mais que nos não sentio, | e assim fazei conta que

60 ouvistes o tronco de | hũa Arvore, ou chiar hua gralha, enão ponhais | o mal no que esse homẽ disse, se não em elle | saber que vos o ouvistes. E vamonos mais de|preça, que me parece que vejo vir Flerida, e || [53r] Gridonia a este mesmo posto, enem ellas | saibão o que nos tornou a trazer a elle tam | cedo. [espaço] E assim era verdade que as outras | tambem vinhão arribadas com medo de | outra Aventura muito semelhante àquella. | E era que em chegando à fonte que todas hião | demandar, virão estar D. Duardos lançado | de peitos sobre ella, tão enlevado que as não sen|tio, e reconhecendoo ellas rindo hũa para a ou|tra disse Gridonia: [espaço] Que me matem se este | vosso irmão, e não acabou de ir por diante, | porque àquelle ponto rompendo elle o Silencio | disse a pos hũ profundo suspiro: [espaço] Não | sei porque me aflijo, e porque me inquieto tanto? |

70 Duvide quem não se conhece, e tema em|bora o que espera, mas eu que sei que vos amo cõ | todos os affectos de minha alma, e que não | espero de vos nem ainda desprezos deste sa|creficio, que tenho que recear, nem em que me po|de empecer? ja a fortuna apos me abrir | os olhos no conhecimento do que se vos deve, | com o qual vejo que não vos adorar he culpa, | e que fazello não he merecimento. Mas he | tanto, pobre de mim, o 75 gosto de cumprir com | esta obrigação, que me mete em obrigações | novas cada dia, a que parece, que hũ coração so, | e que só hũa alma o descontentamento não em | vos não adorar, e não em vos não servir, | senão em não ter muitas almas, com que vos a||[53v]dore, emuitas vidas, com que vos sirva ${ }^{10}$.

Forão estas ultimas palavras em|voltas em tantas lagrimas, que se puderão | mal 80 entender se aquellas Princezas não es|tiverão tão promptas, e porque lhe pareceu | que lhe pezaria a elle de ser sentido, $\operatorname{tornarão}^{11}$ | a voltar dizendo Gridonia: Não me enga|nava eu no que vos dizia. D. Duardos an|da perdido por Carmellia, e agora serei ma|is sua amiga, que o conheço por homẽ de tão | boa eleyção, porque verdadeira mente não se | pode negar a Carmellia ser merecedora | de todas as finezas que se por ella

85 fizerẽ. E esta | ufania, que algũns lhe tachão, não me parece | certo que he couza para

${ }^{10}$ A estrutura da frase é confusa. D. Duardos diz que se sente tão obrigado a servir Carmélia que seu único descontentamento não é adorá-la sem ser correspondido, mas sim não ter mais almas e vidas para adorá-la e servi-la ainda mais.

${ }^{11}$ A palavra está corrigida pelo copista, que antes havia escrito tomarão. 
repreender, porque para tu|do he bom cuidar qualquer mulher muito de si, | quanto mais esta, que tem tantas razões para o fazer. | Nos merecimentos de Carmellia, nos não | metamos agora (disse Flerida) e no mais | vos digo, que tambẽ me parece, que ella sospei|ta isso mesmo de D. Duardos, porque lhe não | acho outra rezão para se mostrar

90 tão desconten|te de sua arte, como hũ dia destes me deu | a entender que estava, e com bem pouco pre|pozito, e na verdade ${ }^{12}$ [espaço] Nisto chegarão | hũas ás outras, e disse Valeriza: Pareceunos | tarde para nos empenharmos mais pella rua | adiante, e voltavamos para vos acenar que | nos recolhecemos. [espaço] E nos (respondeu Fleri|da) quizeramos deixarvos ca, e vinhamos $\|$ [54r] rindo das brigas, que sobre vos não 95 aguar|dar teriamos. [espaço] Para ficar, melhor fareis | vos, replicou Carmellia, e por ventura que | não faltara Julião. [espaço] Pello menos senhora | quando faltara Julião (lhe tornou ela) não fal|tara Camilote, que tambẽ as feas temos $\mid$ nossa consolação ${ }^{13}$. [espaço] Nesta conversa|ção hião aquellas quatro Princezas, quando | lhes aconteceu antes de chegarem a caza $\mid$ o que adiante contaremos.

\footnotetext{
${ }^{12}$ A lição de C parece a mais correta: "preposito em verdade". B apresenta o mesmo erro de A.

13 Julião é o nome usado pelo rei D. Duardos quando, disfarçado de jardineiro, conquistou o amor de Flérida no Primaleón. Em tom de gracejo, Carmélia disse à princesa Flérida que ela fazia bem em ficar na horta, pois poderia ter a mesma sorte da avó. A resposta de Flérida também foi jocosa: se não encontrasse Julião, poderia encontrar Camilote, referindo-se a outro personagem do mesmo livro. Camilote era um cavaleiro de aspecto selvagem que servia a uma dama igualmente feia, chamada Maimonda. Ele desafiou os cavaleiros de Constantinopla em defesa de uma guirlanda de flores encantadas que dera a Maimonda e foi derrotado por D. Duardos (cf. caps. 101 e ss. do Primaleón). A associação entre os dois personagens (Julião e Camilote) também ocorre no D. Duardos, de Gil Vicente, que pode ser a fonte desta passagem.
} 


\section{Capitulo 19}

\section{Do que mais succedeu aquelle dia | na Orta.}

Notaveis forão os acontecimentos | que este dia Ouve na Orta, porque inda 5 aquel|las Princezas na converçação, que diziamos | ja perto de entrarem em caza, ouvirão | golpes de espadas, e soar vozes de homẽns a | pos o que sobresaltandoce todas virão vir | [[vir]] hũns villões do serviço da Orta gritan|do Acudão, acudão, sem dizerẽ outra pa|lavra, e inda que lhes dezejarão preguntar o | que era, receozas de que á grita acodisse gente $\mid$ que as achasse alli sós, entrarão de pressa, e so|bindo a hũ apozento

10 particular, que Flerida | tinha na quelle quarto de sua Avó, onde || [54v] ellas quazi sempre de dia rezidião. Pu|zerãoce a huas janellas, que sahião á Orta | donde não Ouvirão continuar os golpes, | não cessando com tudo os grittos, os quais | athe então não tinhão chegado a os Reys, | que dali longe vivião, mas aos cavalleiros | que se combatião si $^{1}$, e como elles em nenhũa | Maneira quizerão ser sentidos deixando | a

15 briga por concelho de hũ, como logo vere|mos, vierãoce a aquietar. [espaço] Aquelles villo|es $\mathrm{e}^{2}$ as Princezas, que os virão vir por entre | as arvores mettendoce para dentro das janellas | que erão de vidraças, ficarão sem ser vistas | podendo ouvir, e ver o que passava, conhecen|do Floramão virão que lhe dizia) ${ }^{3}$ Amigos por|que gritaes? e porque quereis inquietar a gente? | O que vistes era hũa esgrima entre amigos | como cada hora 20 acontece. Se cuidastes | outra couza, não tendes porque vos alterar. | Os villões socegadandoce lhe responderão: | Como vimos senhor espadas nuas, e porfiar|des tanto hũns com os outros, cuidamos que | vos mataveis, e sendo neste quarto onde | nos tem mandado que não deixemos en|trar alguem, ouvemos medo, que nos tornas|sem a culpa. E pois assim he, rogamos|vos que vos queirais ir, antes que vos vejão, | porque por

25 descuido nos ficou a porta aberta. | Floramão sorrindoce dicelhes que assim o faria, | E apartandoce delles, foice a os outros, que o $\|$ [55r] estavão aguardando com grande quie|tação nas pessoas, sendo nos animos muito | a o contrario.

Pasmadas estavão aquellas se|nhoras vendo o que passava porque conhecião | os cavalleiros, e bẽ virão logo que a deligen|cia de Floramão fora mais para callar os 30 ho|mẽns, que por verdade que lhes dicesse. A fora | que tambem lhes parecia que vião

\footnotetext{
${ }^{1}$ Este $s i$, que está grafado da mesma forma em B e C, significa "sim".

${ }^{2}$ Aqui, há um forte traço (talvez acidental) sobre a palavra $e$.

${ }^{3} \mathrm{O}$ parêntese não se justifica: aqui deveria haver dois pontos. O mesmo erro foi reproduzido em $\mathrm{B}$. A lição de $\mathrm{C}$ é um pouco diferente: "Floramão que hera oque vinha diante ouvirãolhe dizer aquelles homẽs meus amigos porque gritais $e$ porque quereis inquietar a gente".
} 
sangue | entre os outros, que erão Vesperaldo, e Albaizar, | D. Duardos, e D Floris. [espaço] E estando assim | nesta confuzão e dezejo, virão vir deman|dar hũa parede, que se continuava com as | cazas a Gravanào Escudeiro de D Floris | homem muito conhecido de Gridonia, e de | Valeriza, porque Miraguarda lhe fazia hon|ra, e merce por ser filho de sua Ama, e de | obrigação antiga de seu pay, e porque elle | era sizudo, e entendido, gostava Gridonia | de lhe fallar algũas vezes, e Valeriza lhe fa|lava tambẽ quando se lhe oferecia ${ }^{4}$, conhecendoo | do tempo que D Floris se criara em caza de | ElRey seu Pay, porque este homẽ tivera sem|pre cuidado delle sem o desacompanhar | nunca; E a the na quella occazião (inda que | a cazo) se achou prezente. [espaço] Vendo

40 pois | as Princezas, que elle vinha demandar a pa|rede, que por alli era mais baixa para sahir | à Orta de fora, porque os cavalleiros se tinhão | ja recolhido, e os villões fechadas as portas de $\|[55 v]$ treminarão chamallo, e saber delle o que fo|ra: E abrindo Gridonia hum postigo da | janella de que o Espreitava, chamou por elle | que estava trabalhando de sobir a parede, di|zendolhe: [espaço] Que he isso Gravanào, quem vos | ca meteu não vos abrirà? ou foi a Entrada | a furto dos Hortelões? [espaço] Gravanào inda | que se atalhou á vista da Princeza, não | deixou de lhe responder: [espaço] Não são senhora | senão desventuras minhas, que me parece que es|tà D Floris ferido, e eu não o pude seguir, | porque me mandou que recolhesse hũ livro, que | elle, e Floramão estavão lendo, e que me não | fosse sem o levar, e quando cheguei à porta ache|ia fechada, e 50 agora não sei o que eide fazer. | Ella se mostrou sobresaltada, e disse: Ferido | a qui? e de quem? Que he isso? Contaime mais | devagar, que neste quarto não costuma haver | Aventuras, porque como sabeis não entra | a qui nimguem senão quando o Emperador es|ta na Orta. [espaço] Não me detenha Vossa Alteza | por vida sua, respondeu elle, que D Floris | vai entre seus inimigos, e eu não sei o co|mo. Deixeme ir, e saberei tambẽ 55 mais para | poder contar quando me quizer ouvir. [espaço] Com | essa condição sou contente, disse a Prin|ceza, Vinde logo pella portaria, e dai reca|do que me quereis fallar, porque fico aguardan|do por vos. [espaço] E com isto metendo elle hũa | adaga no muro, pondoce de pes nella || [56r] poude alcançar a ponta de hũ leadouro ${ }^{5}$, que | sahia hũ pouco da parede, e por alli, ain|da que com trabalho se lançou da outra | parte ficando as Princezas muito mais de|zejozas, que de antes de saberem aquella A|ventura.

\footnotetext{
${ }_{5}^{4}$ Entenda-se: quando se lhe oferecia oportunidade.

5 Pondoce de pes nella: apoiando os pés sobre a adaga. Leadouro: "os pedreiros chamam liadouros a umas pedras compridas, com que se liam [ligam] as paredes" (Bluteau). Consultando A, B e C não pudemos identificar com certeza se se tratava de leadouro ou loadouro; a forma liadouro, que é a que também consta do Vocabulario de Bluteau, foi encontrada em D.
} 
Queira Deus, disse Carmellia, | não seja isto algũa couza, que nos enfade a | todas. [espaço] Não serà (respondeu Valeriza) que | Foramão he sizudo, e aonde elle estiver não | haverà descompostura que possa dar cuidado. | Praticando no que poderia ser se passou hũ es|passo, no qual Valeriza trabalhou por soce|gar os animos da quella companhia, dis|simulando com grande discrição os sobre|saltos, que dentro do seu hião ${ }^{6}$, porque ella por ave|riguado tinha, que não podia aquillo deixar | de ser historia, e o que a consolava era a con|fiança que fazia da prudencia de Flora|mão, e da compostura de D. Floris, que dos | outros, como os tratara menos, não fiava | tanto. [espaço] Nisto derão recado a Gridonia que | estava alli Gravanào, e mandandoo en|trar, a elle lhe pezou de as 70 achar juntas, pare|cendolhe que o não estavão quando ella lhe falara, | e disselhe então: [espaço] Vinha falar a Vossa Alteza em hũns | negocios sobre que me escreverão de Hespa|nha certos parentes meus, e pedirlhe hũa | valia para elles, mas bem vejo que he fora de tem|po, procurarei acertar melhor hora. [espaço] || [56v] Negocios de Hespanha, atravessou Valeri|za, enão tratados comigo, como pode ser sem | culpa vossa Gravanào?

75 pois que sabeis a boa|vontade que sempre tive para vossa couzas. | A $^{7}$ Senhora Priceza Gridonia (respondeu $\mid$ elle $^{8}$ vinha agora pedir que entrecedesse por $\mid$ mim, porque ainda que Vossa Alteza me fes muita mer|ce sempre, não queria eu agora arriscar | a que pertendo a o pouco que por mim so me|reço. [espaço] Valeriza que entendeu sua dissi|mulação se levantou dizendo: Estas senho|ras me darão licença querovos ouvir 80 es|se negocio aqui de parte, porque tambẽ folga|rei de saber novas da nossa terra. [espaço] E com | isto apartandoce com elle para o vão de hũa | janella lhe disse: [espaço] Todas ouvimos Gra|vanào cutiladas na Orta, todas como dices|tes a Gridonia que hia D. Floris ferido, a | primeira couza que façais seja negar a Occazião | qualquer que for se não estiver publica a | todos, porque a parte onde o cazo aconteceu | he mui 85 sospeitoza. E não sei como se al|li ajuntarão aquelles cavalleiros. [espaço] Amim | podeis dizer o que passa, porque trabalharei de | por as couzas no estado que convier. [espaço] Elle | que a tudo fora prezente lhe contou então | que passara. [espaço] E para que melhor se entenda | se ande presupor alguas couzas atrazadas, | que apontaremos em o primeiro capitulo, |que começa.

\footnotetext{
${ }^{6}$ Leia-se: dentro do seu ânimo.

${ }^{7}$ Este acento em Á parece indicar que se trata de uma interjeição (“Ah”). Em B a palavra também está acentuada. Na linha 16 do cap. 32, há outra ocorrência da interjeição, e o copista grafa $A h$.

${ }^{8}$ Em princípio, aqui deveria ser fechado o parêntese. O mesmo erro ocorre em B.
} 


\section{|| [57r] Capitulo 20.}

\section{Em que se torna a dar conta de $\mid$ D. Floris, e Floramão, e do que | Gravanào disse a Valeriza.}

Erão como temos dito muito amigos | D. Floris, e Floramão, dos quais hũ por | costume de muitos annos, e aborrecimẽ|to da vida, de Ordinario se apartava | dos lugares, em que pello menos ho|mens contentes ${ }^{1}$, e o Outro, ou por Natu|reza, ou por arte, tambem fugia da quel|les cavalleiros de sua idade, e folgava | com tanto excesso de andar sò, que lho co|nhecião e estranhavão ja todos, julgandoo | por descontentadisso, e

10 sobre si, demazia|da mente pontoso, e em algũa Maneira | desconfiado, com aqual arte, ja muito conhe|cida nelle, trazia descontentes a seu cu|nhado Florendos, e a o Emperador seu Pay | que pello preço de sua pessoa, e pella razão | que com sua Nora tinha dezejava que ficasse | no conto dos Cavaleiros de sua caza, e | temia que não viesse elle na quillo, ou que quando | viesse senão deixasse lograr como elle qui|zera,

15 porque verdadeiramente D. Floris | tinhas muitas partes para se estimar sua conver|sação quando se deixava tratar, e vendose que | so com Floramão se domesticava ma|is que com outrem, tinhãolhe aquelles Prin |[57v]cepes Pay, e Filho, encarregado que tra|balhasse de o reduzir a hũ termo mais | brando, mitigandolhe aquella altives pu|eril, que o desviava da converçação, e co|mercio dos outros homẽns. [espaço] E Floramão |

20 para satisfazer nisto a o Emperador, e Floren|dos trabalhava o mais industriozamẽte | que podia com D Floris indoo dispondo | a pouco, e pouco para o que elles pertendião, | buscando o muitas vezes, e indoce com elle on|de sós pudessem praticar á sua vontade.

A conteceu pois que aquella tar|de se forão passeando à horta comũ, co|mo muitas outras fazião, porque alli se deleitava | Floramão muito, e achando aberta a porta

25 do | jardim onde as Princezas andavão, en|trarão por ella bem descuidados do que a conte|ceu. E despois de se assentarem no sitio | que escolherão, e lerem hũ pouco por hũ car|tapacio de Obras de Floramão, nas quais | tinha eternizada a Memoria da sua Al|thea ${ }^{2}$, a que D Floris era muito affeiçoado, e que o | Outro so delle fiava, ficarão praticando no | com que Floramão acabava sempre, a o que | D Floris lhe respondeu:

\footnotetext{
${ }^{1}$ A frase (que em C está reproduzida de forma idêntica) é ambígüa. O sentido parece ser "apartava-se para os lugares em que havia menos homens contentes".

${ }^{2}$ No Palmeirim de Inglaterra também há referências acerca dos dotes poéticos (e musicais) de Floramão (cf. caps. 72 e 73).
} 
30 [espaço] Ja vos disse se|nhor Floramão que quando relevar a o Empera|dor que eu o sirva, que como não for contra | meu Rey não deixarei de o fazer, impor|tunallo não detremino a elle nem a ou|trem, assim porque hũ cavalleiro Andante || [58r] não ha mister nada $^{3}$, como porque eu não | quero ser mais do que sou, nem cuido (e per|doaime) que ha mais que ser, porque seetros, e | coroas farão mais ricos os homẽns,

35 mas | não fazem mais nobres os animos, e a | quem a natureza da, o que a fortuna não po|de, bastalhe, ter hũa certa calidade, com que | nem se corra de si, nem de seus passados, | para não ter que invejar nos outros homens os | titulos, e os Imperios, que os fizerão mais il|lustres no mundo, porque não ter estes não | he culpa, e faltar no outro fora vergonha, | e quanto a tratar muito familiarmente com estes | vossos affilhados, 40 muita merce recebo no gaza|lhado que me elles fazẽ, mas confessovos que assi | por andar entre elles Recindos, a quẽ eu he | razão que respeite de maneira que lhe não | consinta a igualdade com que por amor del|les quer tratarme ${ }^{4}$, como por lhes ver a muitos | hũ certo termo, que me ami não contenta, | não o faço de boa vontade, e he que como se | criarão juntos, e são tão parentes, tratamce | com mais familiaridade do que a

45 meu ver lhe | convem. E mais deixadas estas rezões, quando | vos eu tenho a vos que me fazeis merce de | falar comigo, como quereis que falle eu com | outrem? Deixaime lograrvos ja que a sorte | me concedeu este bem, que eu vos affirmo em | verdade que hũa so hora vossa, não trocarei | eu por todo o senhorio delles. [espaço] Floramão que || [58v] hia a responderlhe vio vir andando pella | rua em que estavão a D Duardos, que 50 acordan|do do extacis em que as Princezas o deixarão | vinha a demandar as genellas, a ver se via | quem por alli o trouxera, e em vendo Flo|ramão, e D. Floris com a boca cheia de ri|zo lhe disse: [espaço] Que D Floris, senhor Floramão, | nos deixe a todos por vos, muita rezão lhe acho | certo, mas que a tenhais vos de nos deixar a todos | por elle, quando eu de mim o confesse, não sei se | o fara Ardimão facilmente (era Ardimão | o 55 que entre elles peor tinha espigado, porque a fo|ra ser torto dos olhos, e feo do rosto, como no | livro de Palmeirim se conta, nos dotes do | animo tirado ser bom cavalleiro, erão pou|co melhores ${ }^{5}$, e porque todos conhecião isto, disse |D. Duardos aquillo) e indo

\footnotetext{
${ }^{3}$ A lição é idêntica em B e C. Aqui, o verbo haver parece possuir sentido pessoal.

${ }^{4}$ D. Floris diz que Recindos quer tratá-lo com familiaridade em consideração aos outros príncipes, o que D. Floris julga impróprio, visto que era seu súdito: lembre-se que Recindos era príncipe da Espanha e que D. Floris era natural da Lusitânia.

${ }^{5}$ Ou seja, os dotes do ânimo de Ardimão eram pouco melhores que sua aparência deplorável, embora ele fosse bom cavaleiro. A menção ao Palmeirim de Inglaterra é um equívoco do autor, pois a única
} 
continuando | com aquella engraçada queixa, ouvirão para | a outra parte do jardim soar golpes de espa|das muito apressados, e correndo todos la dei|xou D. Floris o livro que 60 tinha na mão, que | despois mandou buscar, e chegando primeiro que os | outros onde os golpes soavão porque atalhou | por cima de hũns canteiros, vio Vasperaldo | e o cavalleiro da Morte, que com elle se com|batera com as capas feitas ${ }^{6}$, e as espadas nas mã|os andarem em hũa perigoza, e porfiada | contenda. [espaço] E era a historia, que como Ves|peraldo andasse abrazado pellos amores de | Flerida sua prima, buscava todos

65 os meios || [59r] de a poder ver em parte que lhe pudesse | dar a entender o que por ella padecia, e este $\mid$ dezejo o trouxe aquella ${ }^{7}$, onde o mesmo de|zejo com differentes objectos tinha tão | bem trazido a D. Duardos, e a Albaizar | sem saberem hũns dos outros, e cuidando | Vasperaldo que nimguẽ o podia ver vindo | praticando so concigo suas fantezias, e | chimeras, devisou de longe Albaisar, e pas|mando de o ver na quelle

70 sitio foice chegan|do a elle pouco, e pouco, espreitando se lhe | ouvia algũa couza de que conjecturasse se|us intentos, e pondoselhe mui perto vio que ti|rava do ceio hũ papel dobrado como car|ta, e que sem movimento algũ estava cõ | os olhos nelle. [espaço] Isto lhe fes dezejar mais | saber o que era, e parecendolhe impossivel | podelo alcansar de outra maneira, ajun|toucelhe tanto sem que fosse sentido (porque | o Mouro estava tal 75 que o não despertara hũ | rumor bem grande) que poude lançar hũa | mão no papel, levando hũa parte nella ${ }^{8}$, por|que se rompeu logo com a forsa que ambos fi|zerão, que como Albaizar sintio tirar do | papel levantandoce depressa teve rijo, e as|sim ficou cada hũ com a sua ${ }^{9}$ e conhecen|do a Vasperaldo disselhe: [espaço] Não he couza de | cavalleiro, nem de Princepe espreitar os | homẽns descuidados, que do ${ }^{10}$ mais licença | 80 tem para furtar por detras, quem senão atre\|[59v]ve a thomar por diante, mas hũa, e ou|tra couza me pagareis inteiramente | se vos quizerdes vir por aqui comigo | onde nos não acuda nimguẽ. [espaço] | Deveis de cuidar que indonos daqui (res|pondeu

referência a Ardimão naquela obra é a seguinte: "de Germão de Orléans nasceu Ardimã de França, que foi estimado cavaleiro" (cap. 172).

${ }^{6}$ Não encontramos referências à expressão "com as capas feitas"; ela parece aludir ao perigo da batalha, pois (como estavam vestidos apenas com capas, isto é, sem armadura ou escudo) os cavaleiros não tinham com que se defender dos golpes de espada de seus oponentes.

${ }^{7}$ Leia-se: "àquela parte".

${ }^{8}$ Leia-se: "levando uma parte da carta nela [na mão]".

${ }^{9}$ Elipse do termo parte.

${ }^{10}$ Há mancha sobre esta palavra no manuscrito. B traz de; $\mathrm{C}$ traz do. De qualquer forma, a expressão que do [ou de] mais significa "que de resto". 
Vasperaldo) achareis alguem ${ }^{11}$, que vos | tire outra ves de minhas Mãos, e porque | eu tambem o cuido não detremino dilla|tar mais o castigo assim dessa soberba, | como do 85 atrevimento de entrardes neste | lugar donde vos acho não sei com que in|tentos, por isso arrancai dessa espada | que quando vos tirar o coração verei nelle | o que dezejo saber. Bem dizeis (repli|cou o outro) que no coração tenho eu esse | segredo, mas nem vos podereis tanto, | nem quando o fizesseis o acharieis em mim, | que dias ha que não vive comigo. Folgara |que nos foramos desta parte porque qual|quer couza que acontessa

90 nella poderá da|nar a terceiros que não tem culpa, mas | pois quereis que ella seja vossa em tudo, fa|çasse como o Ordenardes, e o que mais a | conteceu no proximo capitulo o veremos.

${ }^{11}$ Como está, a frase fica sem sentido; o correto parece ser "deveis cuidar que indo-nos daqui não achareis alguém que vos tire de minhas mãos”. Ainda assim, a lição de A coincide com a de B e C. 


\section{Capitulo 21}

\section{Do que aconteceu entre aquelles | Cavalleiros.}

|| [60r] Tinha Albaizar a pos as palavras que disse | a Vasperaldo deixado cahir a capa, e meti|do mão à espada, e elle fazendo o mesmo | comessarão hũa assas terribel batalha a res|peito de estarem desarmados, com o que qual|quer golpe que se acertarão fora o derradeiro | que seu dono recebesse, mas elles erão tão des|tros, e tão ligeiros, e cobriãoce com as espa|das de maneira ${ }^{1}$, que não se tinhão feito danno | algũ. [espaço]

10 Neste estado os acharão aquelles ca|valleiros que os ouvirão, e metendoce D Flo|ris entre elles, Albaizar que o vio, e vio vir os | outros deuce por perdido, e disse para Vesperal|do hũ pouco desasocegado: [espaço] Que he isto Vaspe|raldo? Rodeado de vossos amigos, e paren|tes me vindes vos buscar desta maneira? | Couza he esta para hũ homẽ como vos? [espaço] Vas|peraldo que ficara impacientissimo de os | ver, sem lhe

15 responder nada deu com a | espada no chão com a mor colera do mun|do, mas D Floris, que como dissemos com a | sua na mão tinha entrado entre elles, lhe | respondeu: [espaço] Do Senhor Vasperaldo não po|de nimguem cuidar isso, e vos menos, que | tendes exprimentado que sem fazer tudo o $\mid$ que pode, fareis vos tudo o que elle quizer ${ }^{2}$. [espaço] A|pos isso cuidardes tambem que os que aqui vi|mos he para offensa vossa,

20 não tem outra des|culpa comigo senão o estado em que vos de|veis achar, que vos não deixarà fazer tão pe $\|[60 v] q u e n o$ discurso, por isso quietaivos, que desta | ves mais nos podeis chamar padrinhos, | que inimigos. [espaço] Albaisar lhe disse então | ja essas palavras D Floris para homem tão fi|no como vos quereis parecer, vem fora de | tempo, porque para eu responder com outras tendo | a espada na mão, seria couza de mulheres

25 fa|zello, e para vos dar com ella o castigo que vossas pa|lavras merecem bem sabeis vos que nos não dei|xarão estes senhores. Mas eu não me espanto do | que vos errardes, espantarmeei mais depressa se | o não fizerdes, porque a Ordem de cavalleria inda |que vos de andardes entre estes Princepes, não | vos pode dar outras couzas que vos faltão para sa|berdes como se ande tratar os homẽns como | eu. [espaço] D Floris lhe respondeurindo: Co|mo sois sizudo meu fermozo, pois vos quereis $\mid$ melhorar com

\footnotetext{
${ }^{1}$ Isto é: na falta de escudos, eles se amparavam com as próprias espadas.

${ }^{2}$ Ou seja, D. Floris diz que Vasperaldo, mesmo sem fazer tudo o que poderia (isto é, sem usar de toda sua força), seria capaz de vencer Albaizar.
} 
palavras quando vedes que me tem | a todas as mãos o respeito desta companhia | mas se ella me deixar eu vos mostrarei bẽ | depressa que inda que não mereço as merces que | me elles fazẽ, que me sobeja merecimento e | cabedal para mas pedirdes a mim, e de tanto | mor estimação quanto mais os homẽns como vos | costumão folgar com a vida,

35 que cõ a honrra ${ }^{3}$. Albaizar ouvindo aquillo perdida de todo / paciencia remeteu a elle dizendo: [espaço] Vos | e todos os que a qui estais me não poderão | amim nunca fazer padescer indignidades | nem sofrellas, e assim volo mostrarei a hũ e || [61r] hũ, ou a todos juntos, se todos juntos quizer|des acometerme. E como isto disse tendo a | Espada levantada deu em D Floris por ci|ma do hombro esquerdo tão grão golpe, que a | não lho 40 tomar na sua, que logo atravessou, | facilmente lhe derribara todo aquelle quar|to, e inda assim ficou algũ tanto ferido no | proprio hombro. [espaço] Mas elle como hũa vibo|ra se lhe abalançou com hũa estocada tão | de supito que não teve Albaizar tempo para | mais, que fazer hũ pe a tras, e trocer hũ pouco o | corpo, com o que não o cõlheu em cheio, e toman|doo a soslaio, passou o da outra parte, com | pouco mais danno que 45 cortarlhe o couro. E por|que com o passo que fes a tras topando com hũa | rais que estava fora da terra cahio, julgarão | no todos por morto vendoo atravessado na | espada, pello que Vasperaldo com estranha | paixão de lho tirarem das mãos para aquel|le fim, puchou por hũ braço a D. Floris tão | rijo, que quazi ouvera de dar com elle no chão | dizendolhe: [espaço] Vos me pagareis a mim a vi|da que tirastes a esse porque por hua 50 parte não | quero que cuidem que me acodistes, e por outra | que fiqueis sem castigo de vos atreverdes a | tirarme das mãos o que eu tinha nellas. [espaço] D. | Floris lhe respondeu: [espaço] Se para vossa satisfa|ção não basta verdes com vossos proprios o|lhos a occazião que me este homẽ deu, a | mim me da bem pouco disso, porque nem || [61v] a elle, nem a vos, nem animguem costu|mo a sofrer sem razões. [espaço] E com

55 isto sem | que D Duardos, e Floramão os pudessem a | quietar se começarão a ferir ascendidos na $\mid$ maior colera do Mundo. [espaço] D. Duardos | toda via entrou entre elles, e teve rijo a Vas|peraldo, e disse a Floramão que fizesse o mes|mo com o outro, mas pouco aproveitara | isto se Albaizar que ja se levantara da | queda posto em pe

\footnotetext{
${ }^{3}$ Albaizar disse não estar espantado pelos modos de D. Floris, pois um simples cavaleiro como ele não saberia como tratar com um grande senhor como Albaizar, que era herdeiro do Grão Turco. D. Floris responde-lhe ironicamente, dizendo que homens como Albaizar costumam preferir a vida à honra - que é o mesmo de chamá-lo de covarde, pois o cavaleiro deveria estar sempre pronto a sacrificar a vida pela honra. "Vedes que me tem a todas as mãos o respeito desta companhia" (linha 30): "vede que estou impedido de castigar-vos pelo respeito que devo a esta companhia"; em "para mas pedirdes a mim" (linha 32) há elipse do termo "mercês": "para perdirdes merces a mim".
} 
vendo o que passava gui|ado ou da paixão do que lhe tinha a conteci|do, ou da natureza

60 que de todo não perdera | se não viera chegando a D Floris, de quẽ | mais sentido estava para o matar em quanto | Floramão o ditinha, e de todo o fizera | Se o proprio Vasperaldo que andava traba|lhando de se soltar de D. Duardos, e cõ os | olhos nos outros vendo o vir o não avizara $\mid$ com hũ grito. [espaço] Então soltandoce todos para $\mid$ a talhar a quelles perigos disse D. Duardos cõ | algũa paixão: [espaço] Ja nem isto he

65 lugar para | estas couzas, nem eu me quero tão pouco | respeitado. [espaço] Se vos não compuzerdes logo | ficaremos todos cada hũ para si, e então não | sei eu quem será melhor livrado. Flora|mão que tinha Ouvido os grittos dos villões | (que a o ruido dos golpes ali vierão) e vio que | encaminhavão para as janellas, temendo que | alterassem com elles aquellas senhoras que | por alli vivião, lhes disse: O Senhor D Duardos || [62r]

70 tem muita razão, e eu me vou quietar aquel|les homẽns que gritão, e pello menos por res|peito deste lugar. Não haja nimguem que | mais bulla concigo, porque ja outra couza | será mais teima de Moços, que resolução de | cavalleiros. [espaço] Ha tempo para tudo, e este so $\mid$ o he de engolir cada hũ o sentimento, e $\mid$ negar oque tem passado a the a os mesmos que | forão prezentes. E com isto deixandoos pa|cificados exteriormente se

75 foi a buscar os ho|mẽns, com os quais passou o que temos contado.

Gravanáo pois que a tudo foi prezente | o referio a Valeriza assim como aqui fica es|critto, e disselhe mais que as feridas de D Floris | e do cavalleiro da Morte, erão de tão pouco | Momento, que nenhũ delles se quizera deixar | curar e que de comum concentimento esta|vão todos de acordo de não fallar mais na | Materia por não 80 disgostarem o Empera|dor, eque assim lho encarregara a elle seu A|mo, que lhe tivesse ella tambẽ segredo. [espaço] Vale|riza lho preguntou se havia algũa noticia | do que era o papel que Vasperaldo rompera a o | da Morte. [espaço] Eu o tenho aqui (respondeu | Gravanào) que a ambos cahio a sua parte quando | meterão mão ás espadas, e levanteas despois $^{4}$. | E thomandoa Valeriza ambas, e juntando|as ambas, vio que era hũa pasta de 85 papelão me|nor que hũa mão e nella hũ retrato de Celin|da camareira de Carmellia com hua ci||[62v]fra, que assim por estar rotta a pasta, como | por ser muito intrincada em si, não se deixa|va entender. [espaço] E o cazo era que o Mouro como | discretto por não dar indicios de suas calida|des nos pensamentos, que não se atrevia a en|cobrir

\footnotetext{
${ }^{4}$ Levantar significa aqui "apanhar do chão".
} 
detreminado a fingir amores com | Celina ${ }^{5}$, tinha mandado fazer aquelle re|trato seu, e 90 cuidava declararce com ella no | primeiro serão, e pedirlhe lugar para isso, porque | tambem entendia que por aquelle caminho | poderião suas couzas chegar a Carmellia | da cor que lhe a elle relevava ${ }^{6}$, sem sospeitas que | o descobrissem a elle, nem offendecem a | ella. [espaço] Bem folgou Valeriza de ser aquil|lo o papel, que pello que tinha ouvido a Albaisar | receava ser outra couza, e ficandolhe a el|la claros pella mesma 95 razão os intentos de | seu dono, quis ver se os podia escurecer no | animo daquelles cavalleiros, e tornou a dar $\mid$ o retrato a Gravanáo dizendolhe que o desse | a Vasperaldo pois lhe cahira. [espaço] E despedin|doo foise à quellas Princezas que a aguarda|vão com recado da Emperatris, e de Mira|guarda para haver serão a o outro dia, e do que | tinha passado com Gravanáo lhes deu aquella | conta que bastava para terem inteira 100 noticia | de toda a Materia, e não sospeita que decla|rasse o que lhe a ella, e a Carmellia tinha acon|tecido. [espaço] E dali se forão todas a ensaiar as danças | do outro dia, e depois a suas pouzadas compor $\|[63 r]$ as gallas, que detreminavão tirar, onde as | deixaremos por dizer de hũa Aventura |que á corte veio, e do que sobre ella se fes

\footnotetext{
${ }^{5}$ A frase é de difícil compreensão; na verdade, Albaizar seria atrevido se descobrisse (revelasse) seus pensamentos, e não o contrário. $\mathrm{B}$ : detreminando; em $\mathrm{C}$ a frase está transmitida do mesmo modo que $\mathrm{A}$.

${ }^{6}$ Entre os sinônimos para a palavra cor, Bluteau anota: "desculpa, ou razão, para que uma coisa não pareça tão feia ou tão agra, como se julga". O trecho em questão poderia ser lido da seguinte forma: "chegar a Carmélia do modo como lhe interessava".
} 


\section{Capitulo $23^{1}$}

\section{De hua lastimoza Aventura | que à Corte veio.}

Terriveis inquietações se agazalharão a|quella noute no animo de Carmellia, e |

5 tais, que alterando o socego da propria noite | fes levantar com grande preça a Celin|da para lhe acodir nos desmaios, que ellas lhe cau|zavão. Fazialhe força à pobre senhora as | palavras que ouvira a Albaisar, o termo comque | as dissera, o máo tratamento que lhe fizera seu | irmão imaginando o sofrido a sua $\operatorname{conta}^{2}, \mid$ a idade, e o parecer da quelle homẽ, as partes | da pessoa, os dottes do animo, o estar acredi|tado por Daliarte por

10 senhor tão grande, e so|bretudo a estrella felicissima nesta parte de | seu nacimento delle, e a della na quella mes|ma parte pouco ditoza ${ }^{3}$. Revolvia todas es|tas couzas na fantezia, e cotejandoas com as | calidades de sua pessoa, com os respeitos de | seu sangue, e estado, bem via que criava den|tro de si mesma tirannos de sua honrra, | e torcedores de seu Entendimento. julgando \| [63v] então por tais as memorias que lhe

15 reprezen|tavão as couzas de Albaizar como dignas | de Estimação. [espaço] A honrra encontrava o | Amor, O Amor pelejava contra ahonrra, | e por theatro, e campo da contenda de tão | poderozos contrarios, Estava a triste Carme|lia sentada na cama, vestida hua armilha | de tafetà azul claro, acolchoada de ambar | e polvilhos, bordada de hũns torçaes de Ouro | e prata muito delgados, que fazião hũ lavor fer|mozo, e não de

20 pejo, recolhidos os cabellos | em hua rede de thelegacia lavrada de ouro | e negro, e tirados hũns poucos delles fora, com | hũa certa Ordem desordenada, que lhe não | dava pouco ar, Encostado o rosto sobre a | mão esquerda, e a outra posta ondelhe dohia ${ }^{4}, \mid$ Estilava pellos olhos as magoas do coração | com tão pouco movimento, que so naquellas | lagrimas, e em hũa cor viva, que a tinha in|flamada, e belissima, mostrava

25 que vivia. | Chegou Celinda a ella com hũa vella na | mão, que assendera em hũa cassoula que lhe | servia de alampada, e achandoa daquella | Maneira, despois de a despertar hũ pouco | perguntandolhe o que tinha, conheceu no des|concerto das palavras,

\footnotetext{
${ }^{1}$ A numeração está errada: este capítulo é o 22.

${ }^{2}$ Ou seja, imaginando que ela tinha sido a causa da briga entre Vasperaldo e Albaizar.

${ }^{3}$ Carmélia deixa-se impressionar por Albaizar e sente certa inclinação por ele. Entre as causas apontadas, a última é a menos clara. É verdade que Carmélia e Albaizar haviam nascido na mesma época pouco ditoza, ou seja, no período imediatamente posterior à terrível guerra entre turcos e gregos narrada no Palmeirim; não se percebe, contudo, qual o motivo disso ser qualificado de estrella felicissima. Além do mais, Carmélia ainda não teria condições de saber com exatidão quando nascera aquele cavaleiro, pois não sabia que se tratava de Albaizar.

${ }^{4}$ Isto é, o coração.
} 
que começou a soltar, na | frequencia dos sospiros com que rebentou, nas | lagrimas que não cessavão, no descorarce, e assen|derce de subito, e em hũ tremor frio que de | 30 quando em quando a thomava toda, que havia alli mal, || [64r] que não tinha o remedio nas boticas, e dis|celhe: Se eu senhora não cuidara que me co|nhecieis vos melhor amim, do que me eu co|nheço, tivera de que me queixar, pois me escon|deis o que sentis, mas vos que o fazeis bem deveis | entender que não mereço eu fiarce tanto | de mim, e assi me fico so com a dor de vos | não poder servir pois de todo ignoro o em | que o devo

35 fazer. [espaço] Carmellia tornando | então sobre si lhe respondeu hũ pouco agas|tada, $\mathrm{de}^{5}$ : Como vindes doce, e tolla senhora | Celinda, parece que estaveis sonhando, ora i|devos deitar, e não entreis ca ainda que vos cha|me. [espaço] $\mathrm{E}$ fazendolhe deixar a vella em hũ | pequeno bufete de prata, que tinha á cabecei|ra a fes ir sem lhe querer ouvir mais pala|vra algũa, ficando ella emvolta em suas | preplexidades, e ja com maior 40 medo dellas | do que dantes tinha, parecendolhe pello que ou|vira a Celinda, que contra sua vontade | davão indicio do que erão, E assim athomou | a Menhã com pouco gosto seu, porque lhe | era necessario entrar em fingimentos, | e dissimulações, que não custão barato ao a|nimo singello, e novo na quellas industri|as. [espaço] As outras Princezas tambẽ tiverão | seus discursos sobre as couzas daquelle dia, | e Valeriza por remate de todos os que fes se re|zolveu em pedir a seu Pay (que ja tratava de / se ir) que anão deixasse alli $^{6}$, como queria $\|[64 \mathrm{v}]$ fazer, porque o animo lhe dava que não para|rião bem as couzas da quella caza. [espaço] E | Flerida que ja conhecia os intentos de Vaspe|raldo ajuntando a hũa sequidão natural | que tinha de condição á raiva de Carmellia | tratar mal a D. Duardos como ella cuida|va, detreminada estava de se vingar 50 no | coitado do Irmão ${ }^{7}$. [espaço] A Gridonia que her|dara de sua May hũ descuidado socego $^{8} \mid$ não lhe lembrava por então mais que aga|zalhar bem suas hospedas, e comporce de | Maneira que se não deixasse vencer dellas, | com o que fazia, sem atentar

\footnotetext{
${ }^{5}$ Este $d e$, que não faz sentido na frase, também consta de B e C. Trata-se de um provável erro em um antecedente comum a estas (e talvez às demais) cópias.

${ }^{6}$ Frase confusa, que se repete em $\mathrm{B}$ e C. Conforme será esclarecido mais à frente, quem pede para partir com o pai é Carmélia e não Valeriza, como este trecho dá a entender. A decisão foi tomada depois dos comentários (discursos) das outras princesas (entre as quais Valeriza, que falara por último) sobre os acontecimentos do dia anterior.

${ }^{7}$ Entenda-se: "E Flérida, que já conhecia os intentos de Vasperaldo, acrescentando à aspereza (sequidão) natural de seu temperamento (condição) a raiva por Carmélia tratar mal a D. Duardos, estava decidida a vingar-se no coitado do irmão [isto é, no irmão de Carmélia, Vasperaldo]”. Lembre-se que Flérida era irmã de D. Duardos, o que explica o desagrado pela atitude de Carmélia.

${ }^{8}$ Esta observação não parece condizer com o caráter de Miraguarda tal como pintado no Palmeirim de Inglaterra; cf. nota 12, cap. 7.
} 
nisso, crueis es|tragos na vida, e alma do triste Trineo. | Emfim levantandoce todas gastarão a me|nhã em seus Ordinarios exercicios, a the que | chegou a hora de comer. E como aquella | noite havia de haver serão, puzerãoce as me|zas na maior, e mais publica salla que nos | Paços havia, dedicada ja para aquelles actos, | E alli com a Ordem que entre aquelles Reys | se guardava, se solenizou o jentar ${ }^{9}$, mais | com o decóro, e magnificencia que tantas | grandezas pedião, que como era necessario à | natureza para se poder concervar ${ }^{10}$. Eaca|bado elle, estando o Emperador pratican|do com aquelles

60 Reis, e cavalleiros, convidan|doos para irem à cassa à sua Floresta das tres | fontes, que não era mais que hũa legoa da ci|dade, entrou pella porta hũa Dónna || [65r] vestida de negro, grave na pessoa, e não | mal assombrada no rosto, acompanhada | de outra Donna mais velha, e da mesma | libré, e de tres cavalleiros velhos desarma|dos, e fazendo hũa grande inclinação a o Emperador, chegouce ao Estrado da Em|peratris levando tras si 65 os olhos de toda | a salla, e posta alli de giolhos, comessou a | despedir alguas lagrimas, que antes de fallar | lhe grangearão hũa certa compaixão no | animo de todos, com que depois lhe doerão $\mid$ mais suas couzas. $\mathrm{e}^{11}$ limpandoas ella, emfim, | começou a dizer.

Os acontecimentos, e desastres | da fortuna, de que nenhũ dos nascidos em | quanto vive em nenhũ estado seguro ${ }^{12}$ (muito alta, | e muito poderoza Emperatris) me 70 trazẽ a vos|sa caza neste ${ }^{13}$ em que me agora vedes. [espaço] Ja | outra ves sahi da minha para buscar o reme|dio nella, que a qui todos os mizeraveis tive|rão sempre certo, e quis a ventura que antes | que ca chegasse encontrei com elle, Mas co|mo não era dado por vos, e pello Empera|dor em cuja vontade parece que se assegura | tudo, não so o logrei pouco tempo, mas ser|viome de maior mal. [espaço] Eu sou senhor, ou fuy |Duqueza de

75 Montalto no Reyno de Na|poles, vivi cazada algũns annos com o Du|que meu senhor, que era muito parente de ElRey | Evaristo, por quẽ agora com menos culpa || [65v] sua que de minha fortuna ando desterrada. | Tinhamos hũa so filha de treze annos her|deira de nosso Estado, e merecedora por su|as boas partes (se me não engana o amor $\mid$ de May) de outros muito maiores. Meu ma|rido tinha hũ irmão, com quem tratava $\mid$ de cazar sua filha, para assegurar no meu es|tado a concervação de sua famillia. Não |

\footnotetext{
${ }^{9} \mathrm{Na}$ época em que o texto foi redigido, as formas jantar e jentar conviviam.

${ }^{10} \mathrm{Ou}$ seja, o jantar estava arranjado para atender à grandeza dos convivas e não apenas ao essencial, que seria a "conservação da natureza".

${ }^{11}$ Letra minúscula no $\mathrm{ms}$.

${ }^{12}$ C: "estado está seguro".

13 Isto é, "neste estado".
} 
vinha eu de vontade no cazamento | assi por que as partes de Pamphilio (que este no|me tem o destruidor de minha honrra e | sangue) me parecião pouco merecedoras $\mid$ das de minha filha. [espaço] Como pella sua idade | della, e pella minha, que me não desespera|va de ter ainda filhos, com que meu Mari|do conceguisse o que pertendia em sua pos|teridade, o que quando acontecesse não me pare|cia razão que ficasse minha filha cazada com | hũ homem sem partes, sem estado, e com i|dade muito differente. [espaço] Com este intento | hia industriozamente detendo o caza|mento, que Pamphilio a pressava por meios | tão injustos como mostrou no cabo, porque | sentindo que de mim lhe vinha o danno, e que | a sobrinha por meu respeito lhe não mostra|va a 90 correspondencia e vontade, que elle | pertendia, sem tratar de me grangear a $\mid$ mim como Entendido, nem de incli|nar a sobrinha como affeiçoado, e cavallei|ro, fundouce so em me omisiar com meu || [66r] marido fazendolhe sospeitoza minha fee | com tão pouca verdade, e tanta ignorancia | que antes de se apartar do lugar onde quis per|suadir isto a seu irmão, ficou o Duque conhe|cendo claro minha innocencia, e a cobiça | e Maldade

95 de Pamphilio, E despedindo o | de si com mostras de grande indignação. | Não o quis concentir mais em sua caza | com o que vendoce elle perdido em suas perten|çoes, tomou a mais estranha rezolução que se | nunca achou em peito de hũ homem nobre | e que se publicava por namorado, e foi corrom|per hũ camameiro do Duque para o meter hũa | noite na camera onde elle e eu dormiamos | dizendolhe que so era para nos pedir 100 perdão a | seu irmão, e amim. E persuadindoo com | isto, deu execução à maior maldade, que por I ventura vos nunca ouvistes nomear, porque | escondendoo o camareiro em hũ retrete que | tinha hũa porta na camara, e outra em ou|tro apozento do seu uzo, a primeira couza que fes foi | Matar apunhaladas o triste que o alli metera, |E depois sentindo o Duque socegado en|trando dentro na camera o matou tambem | 105 tendome amim a mão na boca para que não | gritasse. [espaço] A pobre de minha filha que em ou|tra caza que se servia pella camara ${ }^{14}$, dormia | ouvindo assim o ruido, e palpitações do cor|po Morto, como o que eu fazia trabalhando | por me queixar, veio abuscar por seus pro||[66v]prios pes a morte que tinha certa nas mãos da|quelle Algos de sua fermozura, e idade. E | Entrando na caza em que estavamos vendo | o que passava 110 começou a romper o ceu com | os gritos, que a dor do que via lhe causavão. E | como Pamphilio tinha fechadas as entra|nhas a todos os respeitos de christão, e | de homem,

${ }^{14}$ Isto é, a filha estava em outro quarto, que se comunicava com aquele onde havia ocorrido o crime. 
com a mesma adaga, com que ma|tara a o pay, tirou tambẽ a vida à filha, i|gualando com hũa mesma morte, hũa | mesma innocencia em tão deziguais i|dades. [espaço] $\mathrm{E}$ como acabou de fazer isto en|trou no retrete adonde estava Morto o / camareiro do

115 Duque, e meteu o corpo na | camera, e thomandome então pellos ca|bellos, que estava com grittos culpando minha | vida por que durava à vista da quellas mor|tes tão proprias minhas, comessou elle tã|bem a gritar pella gente de caza, que não | tardou muito porque tudo andava ja revolto | nella, e mostrando aquelle espetaculo a | todos os que entravão, trabalhava de lhe per|suadir que o criado com meu consentimẽ|to, e Ordem matara o 120 amo e a filha para se | cazar commigo (cujo o Estado era) ${ }^{15}$, e que el|le sendo avizado desta treição, não pude|ra acodir se não a tempo, que com o peque|no gosto da Morte do adultero detivesse | em si a vida para que me visse Morrer quei|mada como meus delitos merecião, e que || [67r] então siguiria sua alma a de seu irmão | e sobrinha com mais consolação sua. | E porque elle sabia que seus procedimentos, e os | meus havião de

125 fazer sospeitoza sua ver|dade, tinhasse valido de hũas provas, que por | promissão de Deus antes servirão deapurar | minha inocencia, que de escurecer sua | maldade. [espaço] E bastando estas para que ElRey | examinando o cazo conhecesse a verda|de, não bastarão com tudo contra a carne | e sangue, para executar o castigo de hũ tão | abominavel excesso, antes detendome em | hũa prizão muito aspera, condenoume a 130 per|dimento de vida, e de estado, se dentro de | certo termo não desse hũ cavalleiro que em | prova de minha innocencia se comba|tesse com Pamphilio, que se offerecia a provar | de pessoa, a pessoa a qualquer que fosse, que eu | fizera o delicto, porque justamente era con|demnada ${ }^{16}$.

Ser Pamphilio tão claramente | convencido na quelle crime, e ser tão pa|rente de 135 ElRey mostrarão a todos os Na|turais da quelle Reyno, que não folgava elle que | nimguẽ deffendesse minha cauza, pois para $\mid$ me restetuhirẽ a mim, e condemnarem | a elle bastavão menos provas das que havia. | Por isto não achei em todo hũ Reyno hum | homem em quem pudesse mais o zello da | justiça para emparar hũa viuva, que a adu||[67v]lação de hũ Rey para castigar hũ Máo. E ven|do que se me gastava o tempo 140 esperando vam | mente o favor de meus naturaes, e parentes, | pedi e alcancei que se me

\footnotetext{
${ }^{15}$ A observação significa que o ducado de Monte Alto originalmente pertencia à família da duquesa e não à do marido morto.

${ }^{16}$ É claro que a duqueza era vítima de injustiça; o termo justamente (confirmado em B e C) neste contexto é fruto do discurso indireto livre, que emprega o vocábulo utilizado por Pamphilio.
} 
prorrogasse o termo, | e me dessem licença para ir pello mundo bus|car quem me valesse. [espaço] Não foi virtude nẽ | commiseração isto, porque como todo o inten|to era despojaremme do meu estado, persua|dirãoce que solta hũa ves me contentaria com | a vida sem querer mais tornar a Napoles. | E certo que se então eu não aventurara mais | 145 que ella, que tão aborrecida estava da terra on|de tamanhos malles recebera, que em qual|quer outra fora de melhor vontade escrava | que alli senhora, Mas o amor da honrra of|fendida, a dor, e o dezejo de vingança da | Morte de meu Marido, e filha, me fizerão | não so peregrinar, mas dezejar de viver | a the que visse o com que se me a alma quietasse. | Com este fundamento sahi aquelles dias de | Napoles, e com esta mesma 150 companhia | que agora trago, e vindo direita a esta corte, | onde nimguem recorreu nunca, que lhe fal|tasse remedio nem refugio de seus malles | quis a sorte que topei no Mar hũ cavalleiro | Mancebo chamado D. Floris de Lusitania | o qual compadecendoce de meus desestra|dos ${ }^{17}$ infortunios, se foi comigo a Napoles | onde prezentandome a ElRey, e prezen|tandoce a si para executar da justiça de Deus || [68r] a que elle faltava, 155 entrou em campo com | Pamphilio, que pello ver mui moço cuidou que | tinha seu negocio feito, Mas assim porque | D. Floris (segundo Mostrou) deve ser extre|mado cavalleiro, como porque nunca Deus de|zempara de todo a verdade, inda que por al|gum tempo a deixe estar opressa, em pou|cos golpes ficou Pamphilio vencido, e con|vencido por su ${ }^{18}$ publica confição dos cri|mes que cometera, e eu restetuhida com | as lingoas a o 160 que os corações tinhão confes|sado ${ }^{19}$. [espaço] Não morreu Pamphilio das feridas $\mid \mathrm{q} u e$ recebeu na batalha, porque elle teve cuidado | de não esperar muitas rendendoce logo, nẽ | ficou obrigado a o rigor das leis, por dizer | que o cavalleiro que se combatera com elle, | e o vencera ficara senhor da sua vida, | e que dandolha não tinha obrigação a outro | tribunal por aquelle cazo, e assim solto | como de antes começou a urdir outras 165 trei|ções com que de novo me tras em busca de | D. Floris, ou de Outrem, que livre, e desapresse | O Mundo de tão pernicioza peste. E | fazendo a qui hũa pequena pauza, fallae|mos não ${ }^{20}$ tambem.

\footnotetext{
${ }^{17} \mathrm{Em}$ B e C a grafia da palavra é a mesma.

${ }^{18} \mathrm{~B}, \mathrm{C}$ : sua.

${ }^{19} \mathrm{C}$ : “com as lingoas a que os corações". O sentido da passagem parece ser que a duquesa foi declarada publicamente inocente (com as lingoas), o que antes o povo só podia fazer nos corações, por medo de Pamphilio.

${ }^{20} \mathrm{~B}$ : nào; C: nós.
} 


\section{Capitulo 23}

\section{Do mais que referio a Duqueza || $[68 \mathrm{v}]$ e do assento que se thomou | em suas couzas.}

Acabando a Duqueza de descançar hũ pou|co, tornou com novo allento, e novas cores a | proceguir a pintura de suas disgraças pella | Maneira seguinte.

Tem senhora ElRey Evaristo (dizia | ella) hũa filha chamada Lisandra tão mossa | que não chega a vinte annos, e tão fermoza | que a the hoje, que cheguei a esta caza, não cui|dei que ouvesse Outra no mundo, que o fosse tan|to, he esta senhora todo o

10 regallo do Pay, e a uni|ca consolação que tem seus vassallos, porque por | seu respeito della, he ElRey mais toleravel | do que por sua natureza o fora se a filha de | contino lhe não mitigara suas paixoes | intercedendo indeferentemente por todos | os que abuscão, assi que com esta filha vivia o | Pay consolado das molestes que o Governo | dos vassallos muitas vezes cauzão nos Prin|cepes, e os vassallos alliviados tambẽ dos |

15 rigores, que da condição de seu Pay sohião | a exprimentar antes que a filha crecesse, mas | ordenou a fortuna para que tudo se alterasse, e | descompuzesse, que a huas justas que em Napo|les se fizerão viesse Filismarte filho de ElRey | de Cicilia nosso vizinho, mancebo, egentil|homem, o qual vencendoas, e mostrandoce | excellente cavalleiro, como o he, ficou tão || [69r] vencido da fermosura de Lisandra, que | se deixou ficar na

20 corte de ElRey seu Pay | servindoo a elle com grande satisfação | sua, e continuando no serviço della | com fe, com segredo, e deligencia, veio a al|cançar hũa aceitação expressa de seus ser|viços, e hũa correspondencia ${ }^{1}$ tacita da | sua vontade, com a qual Lisandra estava | disposta a cazarce com elle quando seu Pay o | houvesse assim por bem. [espaço] Einda com a | continuação passou adiante a boa ditta de | Filismarte,

25 porque obrigou a Princeza a $\mid$ que o quizesse Ouvir de hũa genella alta, que | do seu aposento cahia sobre o mar, ao pe | da qual the elle vinha fallar algũas vezes | em hua pequena barca. [espaço] Pamphilio | pois que nascera para Emulo da quietação | e ventura alhea, cego de sua cobiça es|tava persuadido que cazaria ElRey sua fi|lha com elle pello parentesco, que tinhão, | e cheirando os intentos de Filismarte | não so espreitava os progressos de sua vi|da, mas tambem como melhor podia os | passos de sua pessoa. E tantas vezes fes is|to, que em fim veio a ver com os olhos, o que | athe

\footnotetext{
${ }^{1}$ Há mancha sobre parte desta palavra no manuscrito; a lição foi confirmada em B e C.
} 
então de todos se escondia, E não | se atrevendo per si so ao que logo imaginou | fazer, falouce com hũ Gigante senhor da | Ilha Deiscla ${ }^{2}$, que por ser tão perto de Napoles | alli vinha muitas vezes, o mais fero, e abo||[69v]minavel Mostruo de cruel, e forte | que nunca se vio entre aquella casta de $\mid$ homẽns, e persuadindoo por seu modo, fa|cilmente o troche a o que queria. [espaço] Con|cervavace no Reyno de Napoles hũa ley | antiga, mas não praticada nunca em $\mid$ meu tempo a o menos $^{3}$ que condemna à $\mid$ Morte de fogo indifferentemente a toda $\mid$ a mulher que sem ser cazada agasalha da | porta adentro qualquer vehemente sospeita | de sua honestidade. [espaço] Pello rigor desta | ley pois

40 acuzou Cadramonio (que assim se / chama o Gigante) Lisandra a seu Pay, di|zendo que elle vira Filismarte sobir á | Torre, onde ella vivia, e vir ella recebello a genella por onde entrava. [espaço] Nenhũa | couza mais parecida com a verdade po|dia haver, que esta, se se conciderasse hũa | Princeza moça, hũ Princepe Mancebo | iguaes em sangue, iguaes, e vizinhos em | estado; Mas conciderados Melhor os pro|cedimentos de 45 Lysandra, a virtude, e re|colhimento, e compostura em todas su|as acções, a natureza de todos os Gigan|tes, os costumes da quelle, a pouca pro|va, com que affirmava o que dizia, clara | mente conhecião todos, que não havia | mais verdade na quella Accuzação que | a força do Gigante tam justamente | timida. [espaço] Hora ElRey que do meu || [70r] cazo ficara desconfiado, e arrependido | do pouco zello de justiça, que mostrara,

50 de|terminou sacrificar sua propria alma | (que disso lhe servia a filha) à observação | de hũa ley tão cheia de inconvenientes, | e assim fazendo logo prender a FilisMar|te, e a Lysandra, condenou os a dentro | em certo tempo darem hũ cavalleiro | por si, que em igual batalha vencesse a | Cadramonio, que era quem os accuzava. |Bem pareceu que so o termo que se lhe dera | seria o que tivessem de vida, porque o Gigan|te era tal, que 55 nem vinte cavalleiros juntos | lhe ouzarião a esperar em campo, e assi | não havia que tratar deste meio, nem nim|guem cuidar nisto. [espaço] Pamphilio que vio | as couzas reduzidas a os termos que elle | desenhara, teve intelligencia, com que mã|dou dizer a Lisandra à prizão donde es|tava, que se lhe prometia de cazarce com | elle, que faria com que o Gigante se decesse | da accuzação, e ella ficasse restetuhida a | sua honrra.

60 [espaço] Não festejou ela pouco | este recado no meio de suas mizerias | porque como Pamphilio era tão conhecido | por suas manhas, ficaria manifesta sua | inocencia à hora que se soubesse que elle se | Entendia com o Gigante, e assim guiou | O negocio por

\footnotetext{
${ }^{2} \mathrm{O}$ nome da ilha é de difícil leitura. B: Ilha de Deiscla; $\mathrm{C}$ : Ilha de isella.

${ }^{3}$ Há mancha sobre esta palavra no manuscrito; a lição foi confirmada em B e C.
} 
termos que houve à mão | papeis do que constasse do comettimento ${ }^{4}||[70 \mathrm{v}]$ que lhe elle fazia, e tanto que os teve man|dou mostrar a seu Pay os intentos da|quelle seu parente, 65 o que sabendo o pobre | Rey movido do conhecimento de sua an|tiga culpa, quis que Pamphilio the ajudas|se tambem a sentir a penna, fazendoo | prender, com o que começou logo a gente | a ter grandes esperanças que acodiria Deus | á quelles innocentes, pois tão manifesta $\mid$ mente erão acuzados com tanta falcida|de, porque a the então como disiamos a for|ça do Gigante, e a incerteza da verdade | não deixavão cuidar

70 em nenhũ remedio. | Eu pois que mais que nimguem vivia obri|gada a Lysandra do tempo de minhas | perseguições, e mais escandelizada de | Pamphilio, vendoo obrigado à mesma | penna, que elle procurava a Filismarte | se o Gigante não vencesse, confiada em | sua maldade, e mais confiada na bon|dade de Deus, que ajudou hũ pastor para que | com hũa funda matasse Outro mais | forte inimigo, e deu forças a hũa mulher | para

75 cortar a cabeça de Olofernes no meio | de seu exercito ${ }^{5}$, detremineime em vir $\mid$ dar conta deste cazo a Vossa Magestade, e a o | Emperador, esperando achar tambem | D Floris, porque para esta corte me disse elle | que vinha, em quem eu cuido que está o | remedio de Lysandra certo, tendo assenta||[71r]do quando tudo falte não tornar a Napoles | porque melhor me parecerà a vida, ou me|nos penoza pello menos, passada em qual|quer 80 dezerto na converçação das feras, que | ver com meus olhos o cruel sacrificio de | Lysandra.

Estas palavras acompanhou | a Duqueza com tantas lagrimas, e so|luços, que nem entre aquellas senhoras fi|cou algũa que lhe não fizesse companhia | nellas, nem entre os cavalleiros quem de $\mid$ muito boa vontade não aceitasse a Empre|za, por mais que 85 ella a tinha difficultado, | Espantandoce, e escandelizandoce todos | da maldade, e invenção de Pamphilio.

A Emperatris então fazendoa | sentar junto ao Estrado, consolandoa, e | animandoa em seus trabalhos postos | primeiro os olhos no Emperador, dicelhe que alli | Estavão muitos cavalleyros, que folgarião de se | empregar em tão justificada demanda, | 90 mas pois que ella conhecia D Floris, e elle | estava prezente, não seria razão encomẽ|darce a outrem, que ella esperava em Deus, na | justiça da cauza, ena bondade

\footnotetext{
${ }^{4}$ Comettimento significa culpa ou delito (Bluteau). A frase, que se apresenta idêntica em B e C, deve significar "papéis em que constasse $o$ cometimento", ou seja, que comprovassem a culpa.

${ }^{5}$ Sâo referências a dois episódios bíblicos em que os mais fracos vencem grandes e poderosos guerreiros: a luta entre Davi e Golias e o assassinato de Holofernes por Judite. Note-se que Judite, além de mulher, era viúva, como a duquesa que a menciona.
} 
daquelle | cavalleiro, que lhe daria neste cazo a con|solação, que no outro ja lhe tinha dado. [espaço] E | chamandoo logo, quando a Duqueza o vio, | não se pode crer o alvoroço, com que o recebeu | e depois de passados alguns comprimentos || [71v] 95 dizendo a Duqueza que o termo era breve | e que assim convinha que a partida o fosse. | D. Floris se foy a sua pouzada, e vol|tando armado disse à Duqueza que quando | quizesse podião partir. [espaço] E porque ella não da|va vagar; elle se despedio de todos aquelles | Reys, e cavalleiros dando palavra ao Em|perador, que o tornaria a servir como lhe $\mid$ as couzas dessem lugar. E chegandoce ao | Estrado beijou a mão à Emperatris por |

100 seu criado, com consentimento, e gosto de | ElRey Beroldo. [espaço] E falando a todas a|quellas Princezas Gridonia lhe deu (não | sem mostras de grande sentimento de o | ver ir a tão duvidoza empreza) hũas reli|quias suas, porque Trineo dera de boa von|tade grão parte de seu estado ${ }^{6}$. [espaço] Todas | tiverão muitos comprimentos com elle | por amor de sua irmã, e sobrinha, e por el|le tambem, que era em extremo bem quis|to dellas, mais 105 que dos cavalleiros, os quais com | tudo, tirando Albaizar, o acompanharão | a the a porta do Paço, e alli abraçandoce, dei|xandoos com não pequena inveja, se foi | a embarcar, indo com elle athe a Náo Flora|mão, e Dramusiando seus grandes ami|gos, e vendoo fazer á vela tornarãoce ao | Paço, onde acharão entre as preparaçoes do | serão saudades de D. Floris, e abominações | de Pamphilio. [espaço] Dramusiando se chegou ||

110 [72r] a Floriano e disselhe à orelha: Bem pode | ser compadre, que tenha o rapagão por la tra|balho, mas entre tanto bem accomodado | vai porque o gasalhado da Náo he bom e os | capellos parecerãome hũ pouco acasoadiços. | Floriano lhe respondeu: Se posso eide dar | pessonha a todos estes, porque nunca me pare|ceu que não era homem senão despois que os $\mid$ vejo $^{7}$. [espaço] Nesta, e em outras praticas, que to|dos entre si tinhão se 115 chegarão as horas do se|rão, no qual aconteceu, o que no seguinte | capitulo veremos.

\footnotetext{
${ }^{6}$ Gridônia dá a D. Floris alguma prenda valiosa (reliquia) em sinal de amizade. Pelo que diz o texto, é provável que Gridônia tivesse recebido este mesmo presente de Trineo.

${ }^{7}$ O diálogo entre Dramusiando e Floriano, que reproduz a espontaneidade da linguagem coloquial, é de difícil compreensão. Dramusiando diz que, embora D. Floris esteja indo a uma empresa arriscada, vai bem acompanhado, em possível alusão à beleza da duquesa. Capello era um tipo de touca de uso comum entre as viúvas (como a duquesa); entretanto, não pudemos descobrir o significado de acasoadiços, pois nenhum dos dicionários compulsados traz o termo ou outro semelhante. Imaginamos (mas sem qualquer embasamento além da sugestão do contexto) que acasoadiços possa significar algo como casadoiros. Também a resposta de Floriano é bastante enigmática. A quem ele quer dar peçonha: aos outros príncipes? O pronome os (em depois que os vejo) refere-se a capellos? As cópias B e C não trazem nenhuma variante que possa ajudar a esclarecer essas dúvidas.
} 


\section{Capitulo 24}

\section{Do Serão, que ouve no Paço, e do | que nelle succedeu}

Não se tinha descuidado Albaisar em | procurar lugar com Celinda, e assi o

5 ti|verão com ella na quelle serão elle, e Ardimão | de França, que lhe não foi depejo, porque os Fran|cezes, não são homẽns de puridades ${ }^{1}$. [espaço] Vas|peraldo o teve com Flerida em hũa das pon|tas do Estrado, e Floramão tambẽ, aquẽ ella | mandou chamar, para que tivesse o Primo me|nos tempo de falarlhe. [espaço] Valeriza, que ja tinha | sabido de Gridonia os intentos de D Duar|dos, chamou o para junto de si estando

10 a||[72v]companhada de Carmellia, porque dezeja|va que ella se fosse antes por alli (quando se fosse) $)^{2}$ | porque pello que ouvira a Albaisar na Orta | e por algũas Outras conjecturas sem nenhũa | duvida $\mathrm{O}$ conhecia e de que nem elle, nẽ Be|liazem erão christãos havia ja sospeitas | em muitos, porque tendo Beliazem chegado a | o derradeiro fio da vida, não dera sinal al|gũ do que os que uzão na quelle estado professão, | e sentia

15 muito que Carmellia malpersuadi|da desse entrada a algũ pensamento, de | que despois se arrependesse, e por isso fes aquella | deligencia em favor de D Duardos. [espaço] Trineo, | tambem teve hora para Gridonia saber quam | boas lhe a elle parecião todas as da vida gasta|das na contemplação de suas perfeições.

Começouce o serão emfim, e | começarão estes cavalleiros que nomeamos | a 20 acreditar suas dores com as palavras, que | mais efficaces lhes parecerão para persuadir o | rigor dellas, sem offensa do respeito de quem | lhas cauzava, nem profanarem o termo de | que na quelles actos as Damas fião os ouvidos ${ }^{3}$. | Trineo se contentou de por na lingoa do | silencio todas suas magoas, ajudandoa cõ | a torvação da pessoa, com a cor do rosto | perdida, e com hũ certo movimento nos | olhos que dizião mais temor que

25 atrevimento. | Gritou isto de maneira nos ouvidos de Gri|donia que poude despertalla, e fazer que dalli || [73r] por diante fosse o seu descuidado socego | hũa muito cuidadoza dissimulação, que em|fim veio a fruticar ${ }^{4}$ pello tempo adiante | em seu Entendimento, o

\footnotetext{
${ }^{1}$ Comentários depreciativos acerca do comportamento dos franceses são abundantes no Palmeirim de Inglaterra, especialmente ao longo do famoso parêntese com a aventura das quatro damas francesas. Veja-se, por exemplo, no cap. 138: "não repartiu o amor com eles [os franceses] tanto de suas dores, que saibam que coisa é o ciúme, nem em nenhum deles é a afeição tão viva, que ela mesmo lhos ensine".

${ }^{2}$ Valeriza desejava que Carmélia cedesse antes os rogos de D. Duardos (fosse antes por alli), do que os de Albaizar, se é que ela se cederia a algum deles (quando se fosse).

${ }^{3}$ Ou seja, sem profanar o modo com que as damas se dispõem a ouvir seus pretendentes.

${ }^{4} \mathrm{C}$ : frutificar; B apresenta o mesmo erro de A.
} 
que Trineo dezejjava, e o que a ambos estava bem pellos me|ios que acada hũ convinha, servindo elle, | folgando, e dissimulando ella ${ }^{5}$. [espaço] D. | Duardos teve a sorte muito 30 dizigual então, | porque querendoce valer do mesmo que Tri|neo não ouzando, nem podendo deza|pegar as palavras do coração, absorto na | contemplação, e gloria do que via, fazia seus | colloquios dentro de sua alma, para o que so a|chava alingoa livre; mas a mesma Car|mellia, ou que quizesse armarlhe a elle ${ }^{6}$, ou de|zenganar Valeriza authora daquella | vezinhança, disse para ella: Pareceme senhora | que fizemos má obra a meu

35 Primo trazen|doo para aqui, porque segundo o vejo pertur|bado, ou veio de ma vontade, ou achou | couzas que lhe não contentão. [espaço] Valerisa pe|sandolhe de a Ouvir, virou para D Duardos | dizendolhe: [espaço] Esta vossa Prima senhor D. | Duardos pareceme que quer brigar comigo, | e eu temome muito que vos tenha ella a vos da $\mid$ sua parte, e assim me parece que a eide so|frer a the que ambas nos vejamos sós ${ }^{7}$. [espaço]

40 Elle | então compondo hũ pouco os affectos in|teriores, que padecia the respondeu: [espaço] Se | eu prestasse para se servir de mim a senhora || [73v] Carmellia em algũa couza, em verdade $\mid$ que athe de ser groceiro me não escuzara, e o | bem he que não valerà esta minha confição | para a obrigar a ella a que o fassa, e por ventura $\mid$ que valha para me vos negardes amim as in|tervenções que ha mister hũa fe posto que fir|me, nua porem de todos os outros mere|cimentos, que a podem acreditar, mas inda | quando assim acontessa, ou a senhora Carmellia | hade confessar que não val Vossa Alteza muito com el|la (o que me não parece possivel) ou que ja me | deve aventurar eu esta valia com a decla|ração que tenho feito ${ }^{8}$. [espaço] Mas melhor he (disse | Valeriza) que vos queirais vós aproveitar do | que eu posso com Carmellia, declarandovos | contra 50 mim, e se isso assim hade ser, pare|ceme que o bom será obrigarvos eu a vos para | outro cazo offerecendovos de boa vontade | aquillo, de que assim ou assi detreminais de vos | valer ${ }^{9}$. [espaço] Tende mão senhora Valeriza | (replicou elle) que se fallamos de

\footnotetext{
${ }^{5}$ Ou seja: Gridônia notou os sentimentos de Trineo e passou a tratá-lo de modo que cada um fazia o que lhe convinha: ele a servia e ela fingia não compreendê-lo, embora estivesse satisfeita com seu serviço.

6 "Armar a alguém" significa "usar de sutileza, para o induzir a fazer alguma coisa" (Bluteau).

${ }^{7}$ Valeriza finge não perceber que a provocação era dirigida a D. Duardos, dizendo que Carmélia queria discutir e que, como D. Duardos tomaria partido da prima, preferia deixar a conversa para depois.

${ }^{8}$ Todo este diálogo é de difícil compreensão. D. Duardos afirma que, se Carmélia solicitasse algum serviço seu, ele o cumpriria mesmo à custa de parecer grosseiro a Valeriza. Esta confissão não moveria o ânimo de Carmélia para acolhê-lo melhor e talvez fizesse Valeriza desistir de interceder por ele; mas ele não acredita que isso possa acontecer, pois indicaria que Valeriza não teria crédito com Carmélia, ou que o socorro de Valeriza iria colocá-lo em risco. A lição do trecho foi confirmada em C.

${ }^{9}$ Valeriza, querendo evitar atritos com Carmélia, finge acreditar que D. Duardos está apaixonado por outra pessoa e se oferece para interceder junto a ela, com ajuda de Carmélia.
} 
sizo, não | vos mereceria eu bem essa vontade que | me mostrais se vos obrigasse a empregar | em tão ruim sogeito tão poderozo reme|dio com tão provavel risco de seu 55 descre|dito. [espaço] Eu não mereço as merces que me of|fereceis, nem tão pouco as hei mister, por|que como não pertendo mais que o gosto da $\mid$ minha entrega, o cabedal, que tenho so me | basta, e todo o outro, que metèra ${ }^{10}$ em adiantar || [74r] hum passo, inda que fora a vossa muita valia | não me servira de mais que de infamar os | remedios, como por aqui se canta ${ }^{11}$. [espaço] | Carmellia, que estava ouvindo D Duar|dos, e com

60 os olhos em Celinda rezoluta | no que havia de fazer, inda porem quis justifi|car mais sua indignação, e cobrindoa cõ | hũ certo sorrizo, disse para elle: Pezame muito | Primo de vos ver com agoas de dezesperaço|es ${ }^{12}$, e pois engeitais as valias de Valeriza, o|lhai se as minhas juntas com as suas vos po|dem ser de proveito, porque a o menos por | não apartar nunca a minha tenção da | sua, vos ajudarei eu, quanto mais que o parentesco, |

65 que comvosco tenho me não obriga pouco a / dezejar de vos ver contente; por isso pesso|vos por tudo aquillo, em que vos vai muito | que nos digais claramente onde quereis | que apliquemos nossos poderes, senão fica|remos cuidando que desconfiais de que pos|samos nos fazer milagres. [espaço] Atra|vessou Valeriza depressa entendendo a Car|mellia, e cuidando poder deter o impe|to da fortuna de D Duardos dicelhe rindo: |

70 Não façais tal senhor por vida vossa, a o $\mid$ menos diante de mim. [espaço] Carmellia $\mid$ se esta occioza, ouçavos o que ella quizer quando | estiver só, porque eu não estou tão metida | na baralha que queira ouvir triũfos alheios $\mid$ com dezenganos proprios ${ }^{13}$. Mas não foi || [74v] possivel, inda que aplicou meio tão podero|zo, porque a Outra que queria dezembaraçar|ce do parente tornou o ajudar ${ }^{14}$ dizendo: | Acabai de fazer o que vos 75 pesso, que ao me|nos por ser a primeira petição minha, não serà | razão que seja apior despachada, e mais | quando pode acontecer ficar tudo em beneficio | vosso. [espaço] D Duardos então tremendolhe | os membros, enfiado todo, com mal pro|nunciadas palavras lhe respondeu o que o | seguinte capitulo nos mostra.

\footnotetext{
${ }^{10} \mathrm{C}$ : metera. Não conseguimos compreender o que isto significa.

${ }^{11}$ D. Duardos recusa a oferta de Valeriza por dois motivos: em primeiro lugar, porque sua satisfação está toda no servir, ainda que sem recompensa; além disso, como seu caso lhe parece sem esperança, ele declara que os esforços de Valeriza seriam inúteis (infamando os remedios, ou seja: fazendo crer que a causa do fracasso teria sido a própria Valeriza).

${ }^{12}$ Esta expressão, de sabor popular, não está registrada no Vocabulario de Bluteau.

13 "Andar metido na baralha", de acordo com Bluteau, significa "desistir de suas pretenções".

${ }^{14}$ Isto é, tornou a solicitá-lo, instá-lo.
} 


\section{Capitulo 25}

\section{Do que D Duardos passou com | Carmellia, e como se foy da | Corte.}

Attenta estava Carmellia para lançar mão do |que D Duardos lhe dicesse, e levar

5 ao cabo o | que dentro de si detreminado tinha, quando elle | como no fim do capitulo passado vimos, arreba|tado de sua fortuna, e das terribilidades de | sua Prima lhe disse: [espaço] Se vos offenderdes | senhora do que me mandais que vos diga, offe|reçovos a obbediencia com que o fasso para re|paro da vossa ira, quanto mais que quem so se | contenta com vos adorar, não sei se quando | não merecer piedades, pode merecer

10 rigores. || [75r] Não vos pesso que me perdoeis, porque não | confessarei nunca erro, nem que me agrade|çais, porque nem eu, nem nimguẽ pode ter $\mid$ merecimentos diante de vos, digovos so ob|bedecendo ao que me mandastes. [espaço] Basta | isso que tendes ditto (disse Carmellia) para que eu | toda aminha vida escandelizada de mim / e de vos viva sempre, e assim vos digo, que | ou não amanheçais nesta terra, nem nun|ca em

15 algua que eu esteja, ou que eu com minhas | proprias mãos thomarei a vingança de | mim, que de vos dezejo. E minha inconci|deração merece, e vos senhora Valeriza não | podeis ficar livre desta culpa, que pois cha|mastes para aqui a D Duardos, sinal he que | foy concerto contra o que vos eu mereço. | Qual elle ficou, não sei animo livre que o | possa dizer, julgueo quem algũa hora ex|primentou sem razões dos Idolos, a quẽ | adora.

20 [espaço] Sei que o maior acto de valor que | nunca fes foi soster a vida, e o respeito para | que todos não sentissem o que o triste padecia, | para o que não ajudou pouco a occupação em | que os mais estavão. [espaço] Valeriza porem | com hũa collera nobre respondeu a Car|mellia: Porcerto senhora que não cuidei eu | nunca que fizeceis vos de mim este proce|dimento, porque inda que vos mereço muito foi | muito mais isto, do que

25 nimguẽ vos pode me|recer. Pello que vos tocca avos callarei eu os \|| [75v] concertos que da qui me ficão ${ }^{1}$, e pello que tocca $\mid$ a minha pessoa, e idade, não aconselharei $\mid$ a $\mathrm{D}$ Duardos (pois, como dizeis, sou quẽ o alqui fes vir) o que eu entendo que lhe a elle está | melhor, mas praza a Deus, que lho não mostre | o tempo ${ }^{2}$, e a vos tambem o que agora não | vedes. [espaço] D. Duardos nada disto ouvia | tal o tinha aquelle a contecimento.

30 Car|mellia não estava ainda arrependida, | nem Valeriza em estado que acabadas as |

\footnotetext{
${ }^{1}$ A expressão parece significar "calarei as considerações que disto me ficam".

2 Acreditamos que a frase deveria ser "praza a Deus que lho mostre o tempo" (sem o não). A lição de A coincide com a de B e C.
} 
razões, que dicemos the desse azo para lhe | responder outras, porque dittas ellas puchou lo|go por Miraguarda, que perto de si tinha, | e ficou conversando com ella em quanto du|rou o serão. [espaço] Flerida foy so quem dos $\mid$ de fora entendeu o que alli tinha passado por|que como trazia os olhos naquillo, quando o res|peito de Floramão lho concentia, não | os tirava de la, e posto que não ouvio as | palavras, dos movimentos, e cores das pes|soas, claramente conheceu o estado em que o | irmão se achava, e ajudou isto tão pouco | a Vasperaldo, que não ficou grangeando | mais daquelle lugar, e se vingava nelle $\mid$ das culpas que lhe outrem tinha. E ainda | que para o credito de seu amor não fosse a|quillo pouco, com tudo em hũ filho de Flo|riano arriscada couza parecia 40 fazer muitas | experiencias daquellas ${ }^{3}$. [espaço] Mas verdadeira || [76r] mente Vasperaldo amava muito a Flerida, | e inda que nisto não chegou a D Duardos, | nem a Palmeirim seu tio, mais pareceu | toda via filho seu, que de seu Pay. E assi pa|deceu muito tempo constantemente os rigo|res de Flerida, e os de Carmellia juntamente | como no discurso desta historia mostrare|mos.

Albaisar pois que fallava com Ce|linda detreminado a se aproveitar da li|berdade da terceira dicelhe. [espaço] O fingimento | senhora sirva para enlear outrem, avos dezen|ganevos a verdade, Se a senhora Carmellia | soubesse que me matava, nenhũ outro bem | eu pudera querer da vida, porem contento|me que o saibais vos, e não para que ella conheça | o que pode em mim, senão para que vos enten|dais o que eu posso 50 por amor della, que he ven|cer a natureza, não respeitar a religião, e | domesticarme com meus inimigos. Con|ciderai estas couzas, como obras suas, e a|chareis que são pequenas mostras de seus mila|gres; porem se as virdes como minhas, pel|lo menos quando não abonẽ a pessoa, não | podem deixar de acreditar o Entendi|mento. [espaço] Não vos sobresalteis, eu sou | Albaisar Soldão de Babilonia, Senhor $\mid$ de togo ${ }^{4}$ o estado do Gram

55 Turco. [espaço] Sou quẽ | por razão deve querer o maior mal a esta | caza, mas sou quem por amor lhe quererá $\|[76 \mathrm{v}]$ o maior bem, e precurarei sempre a sua con|cervação em quanto a Senhora Carmellia tiver o | mesmo dezejo. [espaço] Se este sacrificio que lhe $\mid$ fasso de meus agravos, junto com as calida|des de minha pessoa, puderão ter algua | valia, eu a renunciara de mui boa von|tade, e me não ajudara se não do gos|to com que

\footnotetext{
${ }^{3}$ Flérida, que havia percebido a rispidez de Carmélia para com D. Duardos, faz o mesmo com Vasperaldo (irmão de Carmélia, que a cortejava), afastando-o de si (por isso Vasperaldo "não ficou granjeando mais daquele lugar"). O narrador observa que tal procedimento de Flérida era arriscado, pois Vasperaldo, sendo filho de Floriano, poderia ser inconstante nos amores como o pai.

${ }^{4} \mathrm{~B}$ : todo (com $d$ corrigido); C: todo.
} 
60 lhe offereço tudo o que sou e posso ${ }^{5}$, | e do pezar com que vivo denão ser o que ella qui|zera para que fora demim melhor servida. | Mas bem sei senhora Celinda, que com ne|nhũa couza que a fortuna de, se pode obri|gar Carmellia, porem sabei vos tambẽ |que tudo o que o mundo possue não val o me|nor quilate de meu Amor. Tenhovos dit|to quem sou, tenhovos ditto o que me aqui | tem, se vos escandelizo com hua couza, | rezão

65 serà que vos mitigueis com outra, | porque amar a Carmellia, não so não | he culpa, mas deixar de o fazer fora o maior erro do mundo, e se o he declaral|lo, primeiro que me condeneis averiguai bem | qual he a força do amor, e qual foi a que eu | fis para rezistirlhe, se achardes que vim na | entrega com gosto, e na manifestação | forçado, pareceme certo que antes me da|reis ajuda que castigo.

70 Celinda amais atalhada mu|lher que se nunca vira, olhando primeiro para Ar|dimão vendo que não dava fe senão dos que || [77r] dançavão, querendo despois de cuidar hũ pou|co responderlhe, posselhe diante Belcar, que vi|nha a tiralla para hũa dança, que lhe tinha pedi|do. Com o que deixando Albaizar sem re|posta, e muito mais mouro do que era, se levan|tou, e foi acompanhada delle, e de Ardimão | athe o posto 75 onde se começavão as Danças, | e para a disgraça de Albaizar ser ainda Ma|ior, com aquella se acabou o serão, levan|tandoce, o Emperador, e a quelles Reys, e Se|nhoras para se recolherem cada hũ a sua pou|zada.

D. Duardos, que aquillo so espe|rava aborrecido da vida, e toda via per|dido por Carmellia, sem lhe fallar pala|vra a ella, nem a Valeriza as foi acompa|nhando a the o 80 apozento da Emperatris, on|de ellas depois se dividião, e deixandoas al|li, com mais sinais de morto, que de vivo se foi | a sua pouzada, e escolhendo entre os que o ser|vião hũ escudeiro de quem mais se fiava | filho de Selvião chamago ${ }^{6}$ Trogonio $^{7}$, lhe man|dou (depois que o ajudou a Armar das armas | que adiante diremos) que o Esperace com dous ca|vallos, e hua lança fora da cidade em certa | parte, onde elle da hi a pouco foi 85 ter, e | pondosse a cavallo sem falar palavra, ca|minhou por onde a fortuna o quis guiar | tudo o que da noite ficava, a the que amanhecẽ|do se achou dentro de hũa Floresta, não || [77v] mui desviada de Constantinopla, porque | elle com as voltas que O cavallo fazia,

\footnotetext{
${ }^{5}$ Leia-se: “...qualidades de minha pessoa pudessem ter alguma valia, eu renunciaria dela [de minha pessoa, de mim mesmo] de mui boa vontade, e o faria apenas [me ajudara se não] pelo gosto com que lhe ofereço tudo o que sou e posso".

${ }^{6} \mathrm{~B}$ : chamado; C: trecho ilegível.

7 Trogônio (ou Trigônio) será o escudeiro que acompanhará D. Duardos em suas aventuras. Seu pai, Selvião, era irmão colaço de Palmeirim de Inglaterra e também o servira como escudeiro.
} 
não | poude adiantar muito caminho, e parecen|dolhe que se o buscassem caminhando de dia | não poderia deixar de ser achado, detremi|nou de passar alli aquelle para que 90 denoite se | apartasse tanto que não ouvesse lugar de en|contrarem com elle. [espaço] E com este pensa|mento se apeou no mais espesso do Mat|to, onde o deixaremos por dizer o que em | Constantinopla aconteceu aquelle mes|mo dia. 


\section{Capitulo 26.}

\section{Das novas que vierão a Dramu|siando, e como aquelles cavallei|ros mancebos se forão todos | com elle a sua Ilha.}

Amanheceu em Constantinopla o dia $\mid$ que D. Duardos não amanheceu nella, hum | cavalleiro da Ilha de Dramuziando ${ }^{1}$ com | as peores novas para elle, que lhe podião vir, e | forão que os Gigantes seus cunhados filhos de | Calfarneo, e Camboldão, que lhe tinhão in|quietado a terra, como a principio temos | ditto, tanto que o virão auzente com hũa armada | que ajuntarão de algũns valedores, que a os fora|gidos poucas

10 vezes faltão, tinhão dezembarca||[78r]do na Ilha, e desbaratada toda a resistencia | que lhe Arlança, ajudada de seus vassallos, nel|la fizera e emfim apoderados de toda a terra com grandes extorções, e cercado Ar|lança em hũa praça forte a que se retirara, | na qual se deffendia mais com esperanças | de que o Marido a Socorrece cedo, que com a for|ça que dentro della tinha, e para o avizar do esta|do em que se achava mandou aquelle

15 cavallei|ro em hũa barca escondidamente, porque | na quillo tinhão os Gigantes grande vigi|lancia. [espaço] Chegou pois elle a Constan|tinopla, e informandoce da pouzada de | Dramusiando, que era no Paço, indo la achou|o, que se tinha levantado, e andava passean|do com Graciano Rey de França, e Be|roldo de Hespanha, tratando de aplicarem | suas partidas, em que ja todos estavão resolutos, | e Entrado, como Dramusiando o vio,

20 tris|te no rosto, e carregado na pessoa, adevinhan|dolhe o coração que não podia ser trazerlhe no|va de gosto, antes que lhe elle falasse lhe pergun|tou se Arlança era viva? [espaço] Viva a deixei | eu senhor (respondeu Timandro, que assim se | chamava o Cavaleiro) mas não sei se o esta|rà agora. E então dandolhe hũa carta sua | que trazia, lhe contou despois o mais que nella | não vinha. [espaço] Grande animo, grande

25 en|tendimento era o de Dramusiando, mas o | perigo da pessoa, vida, e honrra de Arlança, || [78v] o amor, que lhe elle tinha, e o receio de lhe tar|dar, o descompuzerão de maneira que logo sẽ | mais detença se quizera ir meter na barca | em que Timandro viera, para lhe acodir, ou pas|sar com ella a mesma fortuna, mas não | lho concentirão aquelles Reys, a quem pare|ceu, que a empreza pedia mais concideração. | E indoce todos juntos a o Quarto de ElRey | D. Duardos, que tambem ja andava levanta|do, derãolhe conta do negocio, que começou a | se publicar logo. [espaço] Não tardou o

\footnotetext{
${ }^{1}$ Isto é: quando amanheceu, estava em Constantinopla um cavaleiro da Ilha de Dramusiando (e D. Duardos já havia partido da cidade).
} 
Empera|dor, e todos os mais Reys, e Princepes que na | corte estavão, porque as couzas de Dramuzi|ando a todos erão proprias. [espaço] Inda então | senão tinha achado menos D. Duardos | mas depressa se entendeu que não estava no | passo, nem na cidade, porque 35 buscandoo seus | amigos para lhe darem conta do que passava | em quanto o Emperador, ElRey D. Duardos, | Palmeirim, e Floriano, Florendos, e Platir | Graciano, e Beroldo, Pompides, e Blandin|don, Francião, e Polynardo, Dragonalte | e D. Rosuel, Floramão, e Daliarte, estavão | em Concelho, resolvendo o modo de que se | havia socorrer Arlança, e não o achando | em sua pouzada, indo tirando das novas que |

40 confuzamente acharão delle, vierão a enten|der como era hido, e as horas a que se fora, e alte|rados não pouco com isto, tendoo primeiro bem | averiguado entrarão à quelles Reys dandolhes || [79r] estoutra ${ }^{2}$ nova, que não os deixara de inquietar muito | se Darliarte lhe não dicera que D. Duardos | se fora a hũ negocio precizo, e que por hora | não havia que tratar de o buscarem, como | aquelles mancebos querião fazer, senão | de socorrer Dramusiando, para o que bastari|ão elles sós, sem as mais preparações que se a|pontavão, porque a pessoa de Arlança podia| correr perigo se se dilatasse o Socorro, e que | apressandoce, bastava o de Dramusian|do, e daquelles cavalleiros que o acompanha|cem.

Assentado isto, começouce a sen|tir no Paço hũ grande reboliço, e inquie|tação,

50 porque os cavalleiros alvoraçavãoce para| se partirem, e os Reys que bem quizerão tam|bem fazerlhes companhia particularmente | Palmeirim, e Floriano, mas entenden|do de Daliarte, que não convinha, assegu|rarãoce. [espaço] As Raynhas, e Princezas a|quem ja tinha chegado a nova de tudo, co|meçarão a sentir novas saudades de seus | filhos, e irmãos. Todas sabião que D Duar|dos era desaparecido, e as mais que não entendi|ão a 55 cauza que o levara, cuidavão que Daliar|te lhe diria que se fosse para se achar primeiro no Soccor|ro de Dramusiando que os outros, enesta con|ta entrava seu proprio Pay; porem Carmel|lia, Valeriza, e Flerida, bem entendião o que | aquillo fora, e anenhũa dellas pesava; com || [79v] differentes respeitos, porque Carmellia viasse | obedecida, e desapressada, e as Outras esperavão | do tempo, e da auzencia heregias contra a fe de | D. Duardos ${ }^{3}$. [espaço] A pressa pois ${ }^{4}$ de Timandro, | a impaciencia de Dramusiando, e

\footnotetext{
${ }^{2}$ Esta palavra falta no início do f. 79r, mas consta do reclame do f. 78v; B e C registram-na normalmente.

${ }^{3} \mathrm{O}$ sentido da passagem parece ser o seguinte: Carmélia havia sido obedecida e sentia-se mais livre; as outras princesas esperavam que o passar do tempo e a ausência de D. Duardos demonstrassem a injustiça (heregia) que fôra cometida contra sua fidelidade (sua $f e$ ).

${ }^{4}$ A palavra está corrigida; parece que inicialmente havia sido escrito foi. B e C: pois.
} 
appro|vação de Daliarte, obrarão tão poderozamente | e com tanto fervor que quando veio a o meio dia | Estavão embarcados Dramusiando, seu filho | Pavorante, Franellio Polendos, Palmeirim | de Lacedemonia, e Primaleão, em hũa | Náo. [espaço] E em outra (porque se querião divi|dir para que a fortuna de hũns não impedisse | a dos outros)

65 Vasperaldo, Recindos, Arne|dos, Trineo, Belcar, Ardimão, e Almourol, | que ja para aquella empreza se achou em des|pozição de acompanhar seus amigos ${ }^{5}$. [espaço] Al|baizar fes hũ fingido offerecimento a Dra|muziando, o qual assim porque Beliazem | não acabava de sarar de todo, como por ser | mui sabido do Odio, que entre elle, e Vasperal|do havia, temendo que lhe não pudesse la va|ler, como athe então tinha feito, que precizamente | Mandou a Vasperaldo que não tivesse brigas | com elle em quanto estivesse em sua caza, | não asseitou, e assim ficou Albaisar só na | Corte, onde não era malvisto, porque elle se | sabia fingir de maneira, que sendo muito ma|is soberbo, e mais altivo, do que seu Pay o fora, | para poder lograr o serviço de Carmellia || [80r] se mostrava tão outro, que por brando, e por | tratavel, não havia nimguẽ nella, aquem | suas couzas não parecessem bem.

Hora partidos os Cavalleiros, | que logo se fizerão à vella, ficou em toda | a cidade hũ tão profundo silencio, com | tantas mostras de descontetamento, as $\mid$ si nos Reys e Raynhas, como na gente do | povo, que parecia Constantinopla outra | ves despovoada, no que se prova quanto a Na|tureza inclina indifferentemente os | homẽns á converçação, e amizade dos | Mancebos, porque estando alli Palmeirim | de Inglaterra, Floriano do Dezerto, Floren|dos, Platir, Floramão, Pompides, Beroldo, | Graciano, Blandindon, Dragonalte, e | Daliarte, que havia poucos annos que erão a | flor do mundo, e que poucos delles juntos o | fazião parecer cheio e fermozo, os eccos | de cujas obras inda não cessavão nelle, | não havendo das de seus filhos athe então | mais que as 85 esperanças $^{6}$. [espaço] Não sei que força | tem aquella idade, ou que segredos são da | natureza que leva tras si os olhos do proprio | Mundo de Maneira que não ponho cul|pa a os Moradores de Constantinopla | terem a sua cidade por $^{7}$ só sem aquelles | Princepes, ficando cheia dos que nomea|mos, porque emfim a verdade he que muita malis gente adora o Sol quando nasce, que quando $\|[80 \mathrm{v}]$ se poem, quanto mais que Daliarte que

\footnotetext{
${ }^{5}$ Lembre-se que no torneio dos novéis, os dois cavaleiros que ficaram mais feridos foram Almourol e Beliazem (conforme o cap. 17).

${ }^{6}$ A estrutura da frase é confusa, apesar de seu sentido ser claro. A lição de A coincide com a de B e C.

${ }^{7}$ Há mancha sobre esta palavra no manuscrito; a lição foi confirmada em B e C.
} 
90 podia so | alegrar tudo antes de accabados os primeiros | accidentes da quellas saudades, despedioce | tambem de seu Pay, e parentes no mesmo | dia, dizendo que lhe não davão mais lugar $\mid a^{8}$ que tinha dos seus livros, e que a todos con|vinha não fazer tão, larga auzencia delles. [espaço] | E indo fallar à Emperatris, e mais Prin|cezas, não so lha ${ }^{9}$ derão facilmente, mas an|tes se alegrarão muito de que se elle fosse, por|que como

95 cuidavão que na sua sciencia se as | seguravão muitas vezes as vidas de seus fi|lhos, e maridos, tendo por arriscadas as dos | Princepes na Empreza a que hião bem fol|garão que elle em algũa maneira lhes fizesse | companhia, e assim encarregandolhe ca|da hũa com muitas lagrimas o que mais lhe | dohia o despedirão, e apressarão, com o que | elle, que ja (como dissemos) se tinha despedi|do dos Reys, não dilatou mais sua parti|da, 100 daqual não dizemos por hora o sucesso | por contar o que tiverão os Princepes que em | Constantinopla ficarão.

${ }^{8}$ Ou seja, as saudades.

${ }^{9} \mathrm{O}$ pronome não se refere a nenhum antecedente expresso: deve-se supor o termo licença. 


\section{Capitulo 27}

\section{Do que passou na Corte de | Constantinopla depois de | partidos os Princepes.}

|| [81r] Dias havia, como fica ditto, | que aquelles Reis tratavão de sua partida, |

5 porem vendo a saudade, que o Emperador | mostrava dos que se forão, não quizerão por | aquelle dia falar nella, antes lhes disse $\mathrm{O}$ | de Inglaterra, que seria bem, que a o Outro fos|sem à cassa, para aliviar a penna das sau|dades. [espaço] E assentandoce assim Mandou o | Emperador, que logo aquella noite levassem | tendas àFloresta das Tres fontes, que estava per|to da cidade, e pegada com o mar, com | infinitas relees ${ }^{1}$ para

10 todo o dezenfado, e quis | que fossem todas aquellas senhoras a jantar la | e para tudo mandou fazer prestes. [espaço] Não | forão ellas de mui boa vontade, porque lhes | parecia que não dizia bem com as lagrimas | das saudades de seus filhos, as alegrias da cas|sa, e Montaria. [espaço] E mais porque sempre $\mathrm{O}$ | coração em algũa Maneira costuma a $\mid$ ser presago dos trabalhos de seus donos. | Mas por fazerem a vontade a o

15 Empe|rador, que dezejava aquillo, se aparelharão | para o outro dia como estava assentado, e | vindo elle, partio logo mui de menhã o | Emperador, e os Reys, e cavalleiros, que os ac|companhavão, mas em pouca cantidade | estes, porque para se lograr melhor a Floresta | não quis o Emperador Occupalla com | muita gente. [espaço] A Emperatris, as Raynhas, | e Princezas, mais tarde partirão tãbem || [81v] E as

20 Princezas, e Damas sahirão do Paço | em Coches, mas em passando os Muros tho|marão logo Palafrẽns. [espaço] Hião as quatro ves|tidas de campo de hũa mesma libré, tão | fermozas, que honrravão a Natureza, alegravão | os olhos, e abrazavão os corações, principal | mente de Albaizar, que industriozamente se | deixou ficar a tras para as acompanhar, com | algũns outros cavalleiros da corte, que tambẽ | por alli tinhão seus

25 cuidados. Levavão saias | de tella azul, e ouro, abertas por diante, e a|botoadas com alamares, e botões de dia|mantes, com duas bordaduras em roda, | e pella dianteira de hũns aljofres grossos | com que se formavão muitas divercidades de | passarinhos, cervos, e outros animaes, os | olhos, e pescossos dos quais, e outros lugares que | o pedião erão de rubins, e Esmeraldas muito | finas. Cintas e colares de diamantes, e |

\footnotetext{
${ }^{1}$ Não pudemos descobrir o que significa esta palavra, grafada do mesmo modo em A, B e C; D: reles. O Vocabulario de Bluteau dá relé como "companhia, laia" (com aparente sentido pejorativo, como o moderno ralé). Talvez relees aqui indique os acompanhantes dos príncipes, embora neste caso não se justifique a acepção negativa da palavra.
} 
30 adagas do mesmo com boemios de sitim | de ouro da propria cor, e guarnição das saias, | forrados em lobos, e nos cabeções, e encon|tros outra maneira de botões de diaman|tes mais grossos. Sombreiros de veludo ne|gro chão, com trancelins, e medalhas de pe|draria, com plumas brancas, e risos azuis. | Hião em palafrẽns remendados de diffe|rentes cores, com silhões de prata, e esculpi|dos nelles de relevo muitas maneiras

35 de cassa. | As gualdrapas, e mais guarnições da mes||[82r]ma tella das saias, senão que erão todas co|alhadas da quelles aljofres das bordaduras del|las em hua tão justa, e proporcionada obra $\mid \mathrm{q} u e$ as fazia igualmente ricas, que fermozas.

Desta maneira pois começa|rão a caminhar estas Princezas para a Flo|resta, tão olhadas de si mesmas, como Car|mellia de Albaizar, que tambem em habito | de Monte 40 airozo, e gentilhomẽ a hia a|companhando, e fallando com ella, e com | Flerida, que aquelle dia lhe quis ser compa|nheira, mais com travessura, que com ami|zade; Mas Carmellia ou que a tivesse enten|dido, ou que quizesse darcelhe a entender, co|meçou a fallar com Albaisar com tão boa | sombra, e de tão boa maneira, que Flerida | era aque hia Moura, e elle não sei o que hia. | Assim chegarão à entrada da Floresta, | onde 45 Floriano, Palmeirim, Florendos, Pla|tir, e Floramão as vierão esperar, fazendo | todos officio de tão galantes, e discretos, co|mo elles erão. [espaço] Floramão se foi a Va|leriza, que era a com que mais folgava de fal|lar, porque demaneira lhe perguntava por | suas contemplações, que sem o Magoar de | novo o levantava, e ajudava a ellas ${ }^{2}$. [espaço] Al|baisar disse para Floriano vendoo ir entre | sua filha, e Flerida tão sofrego

50 como se | the forão menos ${ }^{3}$ : Pareceme senhor que ainda | agora vos dera pouco trabalho levar estas || [82v] Senhoras a o Castello de Almourol e deffen|dellas a o Mundo todo ${ }^{4}$. [espaço] Assim quizerão | ellas ir, respondeu elle, como as eu levara a | partes de Mor perigo sem temer nenhum | mais que o que com ellas em todo o lugar está | certo. [espaço] Vede bem o que dizeis, replicou | Flerida, porque nos todas quatro temos 55 pro|metido hũa romaria larga, e so a falta | de hum bom guardador he que nos detem. | Não o dizia eu por tanto senhora (tornou a | dizer Floriano) mas com tudo, se me asse|gurardes de Leonarda, vamos onde Man|dardes, que não serà possivel fazerce máo |

\footnotetext{
${ }^{2}$ Ou seja, Valeriza encorajava com delicadeza as contemplações amorosas de Floramão.

${ }^{3}$ Isto é: tão sôfrego como se elas lhe faltassem, ou tivessem desaparecido.

${ }^{4}$ Albaizar refere-se ao período em que, acompanhado por 9 mulheres, Floriano perambulou por terras de Espanha e França fazendo proezas e sendo apelidado de Cavaleiro das Damas. Entre outras aventuras, ele as levou até o castelo de Almourol, onde justou com Florendos (caps. 126 e 127 do Palmeirim).
} 
gazalhado a quem levar tão boa mercado|ria. E querendo a sobrinha responderlhe | succedeu hũ cazo, que não deu lugar aisso como $\mid$ logo veremos. 


\section{Capitulo 28}

\section{Da Prizão da quelles Reys.}

Pouco durão os gostos desta vida. Tudo | a fortuna altera como lhe parece. Quem

5 | vira estas Princezas no trajo que temos ditto, | quem contemplara bem suas perfeições, Es|tados, e calidades, que cuidara que se havião de | ver dentro de breve espaço no mais mize|ravel, e perigozo estado, que para elles ${ }^{1}$ podia haver || [83r] no mundo? Quem dissera que quando Floriano | do Deserto, aquelle tão esforçado e valente | cavalleiro do Salvage $^{2}$, hia mais fanfarrão | desafiando o mundo todo á vista, e acom|panhado do 10 grande, e nunca vencido Pal|meirim de Inglaterra seu irmão, de | Florendos, de Floramão, de Platir, e tan|tos ouros com tanto risco de suas vidas, | com tanta quebra de suas honrras, com tão | pouca rezistencia de suas pessoas, se havião | de ver com as mãos atadas, entregues elles, | suas mulheres, e filhas nas mãos de seus i|nimigos, sem lhes poderem valer, nem $\mid$ deixar de vellas, e conciderallas? ${ }^{3}$ [espaço] Assi he | que não

15 ha mais certa espia do maior tra|balho, que o descuido, que o maior bẽ tras sem|pre concigo. [espaço] Naquellas, e em outras | praticas hião aquellas senhoras caminhando | como temos ditto pella Floresta dentro, a $\mid$ demandar as tendas, ondo ${ }^{4}$ o Emperador, $\mid$ os outros Reys, e suas mulheres estavão, quando | daquella mesma parte das tendas virão sa|hir dous Gigantes armados, e emvoltos | em sangue de maneira, que mal se divi|zava

20 a cor das armas, que erão de hũ asso | azulado sem nenhũa pintura, e junto a | elles hũ tropel de cavalleiros todos corren|do, e comessou a soar hũa gritta, que se fun|dia, a Floresta toda ${ }^{5}$. Com o que sobresaltan|doce não pouco aquella companhia, Pal||[83v]meirim, Floriano, Florendos, e Floramão, | Platir, e Albaizar, e os outros Cavalleiros que | vinhão com as Princezas postos diante dellas a pe (porque com o 25 sobresalto da gritta se | tinhão todas deixado cahir de pes ${ }^{6}$ dos palafrens | abaixo) com as espadas nas mãos, e os capo|tes nos braços, esperarão aquelles Gigantes e | Cavalleiros, que vinhão dizendo: [espaço] Chegada | he a hora lobos carniceiros do sangue de |

\footnotetext{
${ }^{1} \mathrm{~B}, \mathrm{C}$ : ellas.

${ }^{2}$ Cf. nota 4 do cap. 03.

${ }^{3}$ A passagem é atestada também pelas cópias $\mathrm{B}$ e $\mathrm{C}$.

${ }^{4} \mathrm{~B}, \mathrm{C}$ : onde.

${ }^{5} \mathrm{Ou}$ seja, os gritos ecoavam por toda a floresta.

${ }^{6}$ A concordância entre pés e princesas também é registrada em B e C.
} 
Colambrar $^{7}$, que pagueis com o vosso os dan|nos que tendes feito, sem vos valerem as | feitiçarias do vosso Daliartinho. [espaço] E chegan|doce bem a elles vendoos da quelle 30 modo, te|mendo com tudo que lhe custasse a victoria | tão cara, como ja nas tendas, de donde vi|nhão começarão a exprimentar, porque o Em|perador, ElRey D. Duardos, Pompides, e | Blandindon, Graciano, Beroldo, Drago|nalte, Francião, e Polinardo, que nellas dei|xavão prezos, e assás feridos, não se tinhão | vendido tão barato, que não tivessem Mor|tos sos com as capas, e espadas mais de | quinze cavalleiros, pello que

35 temendo como | diziamos, estoutros, lhes discerão; E se com | tudo vos quereis dar à prizão, assegurarvos | emos das vidas atroco de outras couzas, que vos | custem menos. [espaço] Palmeirim the respon|deu: [espaço] Se nas palavras dos homẽns como | vos estivesse algũa couza segura, partido | era esse, em que se pudera fallar no estado, || [84r] em que nos thomais, mas porque entendo que te|meis que nem nelle podereis fazer

40 a vosso | salvo o que intentastes, melhor será morrer | fazendo o que devemos, que entregarnos nas | mãos de quem não saberà fazer o que pro|mette. [espaço] Nisto chegarão mais quinze | ou vinte cavalleiros a os Gigantes, que an|davão pella Floresta á cassa dos que fogião | mattando a todos porque não pudessẽ dar | avizo na cidade, que seria dalli pouco | mais de hũa legoa, com o que ficando a | the trinta em numero, 45 remeterão com | as lanças baixas, os que ainda as tinhão, à | quelles Princepes, que desarmados, e a pee, | com os animos de que a Natureza os do|tara, os esperarão, tratando so de vende|rem as vidas o melhor que pudessẽ. [espaço] | Não lhe fizerão os Gigantes, nẽ os de sua | companhia danno com os Encontros | porque elles se tinhão retirado a hũas Ar|vores, levando as Princezas entre si | mais mortas que vivas, e alli se

50 deffendião | e offendião tão bravamente, que depressa | estirarão mais de oito, e tomandolhes os | Escudos, creceulhes cubertos delles tanto | animo, que sahindose imprudentemente | do reparo das Arvores, que os não tinha aju|dado pouco, derão entre os cavalleiros ma|tando e ferindo nelles, como lobos entre | Carneiros. Mas que prestava, que os inimigos || [84v] erão mais de trinta, e entre elles dous | Gigantes 55 notavelmente grandes, e esforça|dos, e os outros so seis, desarmados de to|do, e feridos ja em tantas partes, que melhor | se pode dizer que cada hũ de seus corpos, e|ra hũa so

${ }^{7}$ Colambar era a mãe de Arlança e dos gigantes Calfarneo e Comboldão, já lembrados (cf. nota 1, cap. 04). Depois de ver seus filhos mortos e Arlança reconciliada com Floriano, ela se atira de uma janela do palácio do Imperador em Constantinopla (Palmeirim de Inglaterra, cap. 121).Com efeito, conforme será dito adiante (cap. 31), os gigantes que armaram esta emboscada são os filhos de Calfarneo e Comboldão que estavam tentando retomar o senhorio da Ilha de Dramusiando. 
ferida, E inda o danno não es|teve nisto, que bem puderão durar mais tem|po, e fazello melhor em seus contos, mas | como se apartarão das Arvores, que lhe def|fendião as costas, derão lugar a que as Prin|cezas fossem thomadas de algũa gente | de serviço, que

60 os Gigantes tambẽ trazião | e mettendoas em hũ dos coches, que na | companhia vierão, comessavão a cami|nhar com ellas para o Mar, para onde ja em | Outros ${ }^{8}$ levavão o Emperador, e os mais / prezioneiros. [espaço] Albaisar, que primeiro cahio | nisto deixando os com que peleijava, foi | correndo a de ter o coche, ou apressar | a vida para que á vista de Carmellia lhe | sahisse a alma ${ }^{9}$. [espaço] O mesmo fizerão | todos depois

65 que o Entenderão, com o que | os Gigantes, que de industria se tinhão | poupado, assi por não exprimentarem | golpes de homẽns dezesperados, como para | ficarem inteiros para o que pudesse acon|tecer, atropellando com os cavallos a | hũ e hũ, prenderão a todos, tão cuber|tos de sangue, como quem sem armas | tinha peleijado com mais de trinta ca||[85r]valleiros armados, e morto mais de des|oito, e feridos aos mais, e 70 valeolhes a Pal|meirim, e aos companheiros para os Gi|gantes os não acabarem de mattar, esta|rem em estado que se não podião temer $\mid$ delles. E assim fazendolhes atar as Mãos | atras, como se tinha feito a os outros Reys | com notavel exemplo da ${ }^{10}$ instabilidade | do Mundo, os meterão em hũ coche, E | recolhendo depois tudo o que lhes pareceu de | Estimação forão caminhando para o mar | apressadamente com amaior

75 preza, que se | nunca imaginou. E contando sua cõ|panhia de sincoenta cavalleiros que dezẽ|barcarão com elles, não se acharão com | mais de quinze, que pudessem thomar | armas. Tal estrago fizerão nelles estes | Princepes so de virtude, e de valor arma|dos. [espaço] Mas Deus que ainda que castiga os | seus sempre he como Pay, não permittio, | que aquelles Barbaros triumfassẽ mais | tempo de tanto Rey, de tanto Monarca, | que o

80 que bastou para lhe mostrar que so elle he o|Rey dos Reys, Senhor dos senhores, e que so na | protecção, e guarda sua se concervavão | os Imperios, e as Authoridades ${ }^{11}$, pello que a|codindo tambẽ a o perigo da quellas Prin|cezas, e Raynhas, que como outras Porcias | hião detreminadas, não a se livrarẽ das $\mid$ dores com as brazas ${ }^{12}$, mas das brazas

\footnotetext{
${ }^{8}$ Isto é, em outros coches.

${ }^{9}$ Apressar a vida significa "arriscar a vida".

${ }^{10}$ Há mancha sobre esta palavra no manuscrito; a lição apresentada é de B e C.

${ }^{11}$ Leia-se: "Mas Deus, que é como pai ainda que castigue os seus, permitiu que aqueles bárbaros triunfassem sobre tantos reis e monarcas apenas o tempo necessário para demonstrar que só Ele é o Rei dos reis, Senhor dos senhores, e que só na sua proteção e guarda se mantêm os Impérios e as autoridades".

${ }^{12} \mathrm{O} b$ inicial foi corrigido sobre um $p$.
} 
com $\|[85 \mathrm{v}]$ recolherem os allentos dentro de si, quando tu|do lhes faltasse $\mathrm{e}^{13}$, tinhalhe 85 prevenido o re|medio pello meio que no seguinte capi|tulo veremos.

\footnotetext{
${ }^{13}$ Pórcia foi esposa de Bruto, o assassino de Júlio César. Conta-se que, quando soube da morte do marido, ela se suicidou engolindo carvões acesos em brasa, episódio que foi tema de um soneto de Camões (“Como fizeste, Pórcia, tal ferida?”). O sentido da passagem parece ser que, diferentemente de Pórcia, as rainhas e princesas não fugiriam da dor engolindo brasas, mas fugiriam das brasas (o cativeiro?) através da morte (recolhendo os allentos dentro de si).
} 


\section{Capitulo 29}

\section{Do modo porque estes Princepes | forão livres da quella pri|zão, em que hião.}

Caminhando hião os Gigantes para o | Mar com a maior pressa, que podião, a

5 re|colherce em hũa Náo, em que alli vierão | temidos da vizinhança da cidade, por|que ainda que fizerão grandes deligencias | por lhes não escapar quem la levasse a no|va de tamanha desventura, bem lhes | parecia, que entre tanta gente como de | la viera, não seria possivel deixarem | de se acolher ${ }^{1}$ muitos, e com este cuidado | não parando, ja que hião chegando à pra|ya virão os dianteiros que guiavão os co|ches sahir de hũa parte da

10 Floresta | hũ cavalleiro correndo à redea solta | em hũ cavallo castanho escuro, grande | e forçozo, segundo o rumor que vinha fa|zendo, Armado de hũas Armas de Es|camas muito meùdas verdes, e negras, com || [86r] hũas pintas amarellas, muito mais meùdas | ainda, e no Escudo em campo das mes|mas cores hũns troncos de cipreste [espaço] | quebrados com hũ rayo, que dava nelles (no|tarãoce depois que elle chegou todas esta

15 me|udezas) e parecendolhes a o principio que | era dos seus, que por la ficaria ${ }^{2}$ recolhendo | algum despojo, não fizerão cazo delle, | nem deixarão de caminhar. O qual che|gandoce aos coches, que erão quatro os que | levavão os prezioneiros, a primeira couza que | fes, foi alancear sem que nimguẽ lhe | deffendesse os cavallos de todos, com que | se não puderão mais bolir, E então | concertandoce na sella, porque vio que os |

20 Gigantes a o maior correr de seus caval|los o vinhão demandar, e todos seus ca|valleiros, partio para elles dizendo primeiro en|tre si com os olhos em hũ daquelles co|ches, em que hião as Princezas: [espaço] Bem | sei senhora que não he este operigo que me | amim hade mattar, não me atormen|ta senão o que vos correis de desagrade|cida, que sejà o he castigo da dezestimação | da Minha fe, este em que agora vos vejo, | que não

25 poderà temer quem sempre vos | servirá sendo vos só por isso aborresi|vel sempre? [espaço] Eu da minha parte bem | vos quitto certo o agradecimento, porque em | me saber perder achei a satisfação, mas \|| [86v] que faremos à fortuna pezado, e grocei|ro Juis segundo vejo ${ }^{3}$. [espaço] Não lhe de|rão tempo para mais aquelles perturbadores $\mid$ de

\footnotetext{
${ }^{1}$ Ou seja, não seria possível que alguns não voltassem à cidade para avisar do ocorrido.

${ }^{2}$ Em princípio, o verbo deveria ser ficara, mas a lição coincide com a de B e C.

${ }^{3}$ Leia-se: "Bem sei, senhora, que não é este o perigo que me há de matar; outro maior é o que vós correis sendo tão mal agradecida (a meus serviços). Se este perigo em que estais é castigo pela desconsideração com que tratais minha lealdade, que outros perigos poderá temer quem vos servirá sempre, parecendo-vos
} 
suas fantezias, porque como elles não | querião ganhar honrra, nem arriscar a | empreza, todos juntos o Encontrarão | mão ${ }^{4}$ tão venturozamente para elle, que ne|nhũ danno recebeu, não aconteceu assim | a hũ dos Gigantes, a quem elle encontrou | porque como aquelle era o primeiro encontro, que da|va em serviço de seus pensamentos, foi | de maneira, que atravessado na lança deu | com elle Morto no chão, emetendo mão | á espada começou a fazer tais mara|vilhas entre aquelles Cavalleiros, que | mais parecião

35 obras da justiça de Deus, que | da força de hũ homem Mortal. [espaço] O | Gigante, que ficava, (vendo a jornada em | condição, porque dos cavalleiros tinhão, ja | cahido seis, e os outros não se ouzavão a | chegar, nem o deixavão chegar à sua von|tade à quelle cavalleiro,) com hũa vos gros|sa, e pezada lhes disse: [espaço] Afastaivos mi|zeravel, e cativa gente, deixaime so | com este destruhidor de meus intentos | que não se me poderá deffender apartando | de mim toda a fraqueza, que a compa|nhia de vos outros me comunica, e entre | tanto, ou levai esses prezos ao Mar, ou | degollai toda a couza viva que nos coches || [87r] estiver. [espaço] O Cavalleiro dos cyprestes, | que trazia o tento na quillo mais que ẽ tudo, | gritou aos cavalleiros dizendo: [espaço] Olhay | vos outros o que fazeis, que se este Gigante | se não tivera por perdido, não quizera | perder

45 a preza que tem certa, pois eu so | sou aqui quem lha deffende, e se he as|sim que lha posso deffender, tambẽ vos po|derei queimar a vos se intentardes ta|manho sacrilegio. [espaço] E com isto che|gandoce bẽ a os coches vio aquelle vene|ravel Emperador Primaleão com as | Mãos atadas, e com hũa pequena feri|da na cabeça, e a ElRey D. Duardos | da mesma maneira ferido em hũ bra|ço, e assim a os Outros, que todos em seu

50 a|cordo o estavão olhando, tendoce hũa ves | por salvos, e outra temendo os novos desas|tres da fortuna. [espaço] O Gigante fazendo | a fastar como diziamos aquelles seus caval|leiros, que o obedecerão de mui boa von|tade, começou com o do Cyprestes hũa | Monstruoza batalha, por que elle andava | fresco, e são, e era hũ dos mais valentes ca|valleiros, que em toda a casta dos Gigan|tes se podia achar. Pelleijava pella vida, | 55 pella honrra, e pella fazenda, que a callida|de daquelles prezos the assegurava. [espaço] | O Outro andava com o escudo desfeito | com as Armas rotas, ferido em muitas || [87v] partes, mas lembrandolhe que ainda que | vencesse ao Gigante lhe ficavão nove | ou des Cavalleiros diante, e vendo prezos | aquelles Reys, que conhecia, e que aquellas |

apenas por isso tão enfadonho? Eu por certo vos isento do agradecimento (por meus serviços), mas que faremos para que a fortuna, juiz severo e rude, (também o faça?)"

${ }^{4} \mathrm{~B}, \mathrm{C}:$ ñ̃o. 
Princezas postas de giolhos com lagrimas | infinitas regavão a Deus por sua liberda|de, 60 combatiasse tão desacostumada mente | dos Outros homẽns, que tinha assombrados | todos os que de fora o vião, e a o Gigante | tão apertado, que tornou a chamar pellos ca|valleiros, que o socorressem. O que elles fize|rão com maior animo, que de antes, | porque ou na quelle espaço, que descançarão | cobrassem novo alento, ou que entendes|sem que a grandeza de sua culpa ven|ceria toda a Mizericoria que pudessem |

65 esperar, remeterão como leões ao cava|lleiro, que andava bem pouco para aquellas | ajudas $^{5}$, Mas detreminando vender | bem a vida quando não pudesse mais. [espaço] | Não deichou descansar o Gigante, como | elle quizera, antes o apertou no meio | dos seus demaneira, que ja não entendia | se não sò em se lhe deffender. E Estando | a couza neste Estado lembrandoce Va|leriza da adaga que tinha na cinta ven|do todos Occupados 70 no Espanto de tão | desigual batalha, sahiose do coche com | hũa rezolução Generoza, e chegando ao ${ }^{6}$ | em que aquelles Reys estavão prezos, sem || [88r] ser vista de quem lho impedisse fes o que | a o diante veremos.

\footnotetext{
${ }^{5}$ Ou seja, o cavaleiro talvez já não tivesse forças suficientes para resistir àqueles novos combatentes.

${ }^{6}$ Isto é: chegando ao coche.
} 


\section{Capitulo 30}

\section{Em que se procigue a liberda|de dos Reys, e se declara | quem era o que os livrou.}

Com estranho valor, como no capitulo | passado dissemos, se chegou Valeriza a

5 o $\mid$ coche, em que seu Pay estava, e lhe cortou | as prizões com notavel admiração sua, | e dos outros, e elle soltando os Mais, tho|mando os que menos feridos estavão algũas | espadas, e escudos, que pello campo jazião se | forão a socorrer aquelle cavalleiro, a tẽ|po que ja o Gigante estava estirado no | chão de todo morto, e dos cavalleiros ma|is quatro. [espaço] Os que ficavão, e agente de | serviço vendo os Gigantes Mortos, e os |

10 prezos soltos, postos di ${ }^{1}$ giolhos pedirão | merce das vidas. [espaço] Ja então começa|va a aparecer hũa grande multidão de | gente de guerra, que desordenadamente | vinha acodindo da cidade, que toda via | forão muitos os que fugirão, e forão la dar | as novas que os Gigantes temião, e chegan|do todos a seus Princepes, achandoos na || [88v] quelle estado, com lagrimas de conten|tamento solemnizavão hũ cazo tão | dezastrado, e

15 tão venturozo juntamente. | E tanto se embaraçarão os Reys com os | subditos, que quando quizerão procurar pel|lo Cavalleiro que os livrara, virãono | ir mui desviado quanto o cavallo o podia | levar, e não querendo em nenhũa Ma|neira deixar de conhecello, parecendolhe | que pella fraqueza do cavallo o alcansa|rião depressa, mandarão espos elle, e a|vizallo, que se não bolirião da quelle lu|gar em quanto não

20 viesse, e ficando envol|tos nestas esperanças recebião agente da / cidade que em grande numero vinha | chegando, a the Mulheres, e Meninos, | que o Amor que tinhão a seus Princepes | lhe dava animo para julgarem por mor | perigo a quietação de suas cazas sem | elles que o risco que em sua companhia | se correce.

Tratouce logo de apertarem | as feridas a Palmeirim, e a seus compa|nheiros, que 25 estes erão os peor livrados, e foi | necessario que os lenços da quellas senhoras | suprissem a falta de outras ataduras. [espaço] | Certo he que não tocou em Albaizar o de | Carmellia pois não sarou subitamente | mas tambem he certo que lhe não esqueci|ão a ella as feridas que elle tinha, posto que \| [89r] com as de seu Pay so se occupava. | Nisto chegarão os que tinhão hido expos | o Cavalleiro dos Cyprestes com novas | que em

30 dobrando hũa ponta que a Flores|ta fazia a o Mar, para aquella parte o vi|rão embarcar em hũa setia que alli pa|rece que o aguardava, com que os Reys per|derão hũa grão parte

\footnotetext{
${ }^{1} \mathrm{~B}$ : di; em C, não foi possível distinguir com precisão.
} 
do gosto de sua | liberdade, porque de nenhũ Modo podi|ão cahir em quem fosse que assi se quizes|se encobrir. [espaço] E como a fortuna em ne|hũa couza sabe ter meio, assi como os | livrou do trabalho em que os tinha posto | não quis que ficassem com aquella pena | porque os regedores de Constantinopla | tanto que lhes chegou recado do que na Flo|resta acontecia, entendendo que aquel|la gente não podia deixar de vir por | mar, temendo que embarcarião os Reis | antes de poderem ser socorridos por ter|ra, Mandarão logo sahir seis Galés | que mais a ponto se acharão com toda a gente que puderão levar. [espaço] Estas pois | com o mesmo fervor da liberdade de | seus

40 Princepes forão contra aquella par|te costeando a terra, e em dobrando a | ponta que na Floresta havia virão logo | a cetia do cavalleiro dos Ciprestes, | E mais adiante hũa Nào $\operatorname{surta}^{2}$, e in|doce quatro ${ }^{3}$ á Náo, e duas à setia, entra||[89v]rãona com facilidade porque elle sem receio | da quelle assalto se estava curando de suas | feridas, que erão muitas e não pouco perigozas. | E conhecendo que era o Princepe D. Duar|dos de Bretanha, que

45 havia dous dias que fal|tava de Constantinopla, pasmados de o | verem na quelle estado, souberão delle (com | grande desgosto seu de se ver conhecido) | o em que ficava o Emperador, com aquelles | Reys, e rogandolhe que o desculpassem com | todos de se lhe não dar a conhecer, pediolhes | juntamente que o agradecessem de sua par|te a Valeriza o socorro que lhe dera, E | despedindoce delles Engolfouce logo por|que o não 50 tornassem a buscar. [espaço] As | quatro Gallés thomarão tambẽ a Nào, que | era a que trouchera os Gigantes, dos quais | quem erão ${ }^{4}$, e do que aquelles Reys fizerão | depois de saberem a quem devião sua | liberdade, e de como D Duardos se | alli achou à quelle tempo daremos ra|zão no capitulo seguinte.

\footnotetext{
${ }^{2}$ Ou seja, uma nau parada no porto.

${ }^{3}$ Aparentemente, o copista iria abreviar a palavra quatro, pois há o $t$ suspenso sobre ela.

"Isto é: "acerca dos quais [diremos] quem erão".
} 


\section{Capitulo 31}

\section{Em que se da conta quem erão | os Gigantes, que prenderão o Em|perador, e decomo D Duardos $\mid$ se achou alli à quelle tempo.}

|| [90r] Contado temos no principio desta | Historia como Dramusiando deixara

60 sua | mulher na sua Ilha quando partio para Cons|tantinopla a respeito de quietar com sua | prezença os tumultos, que dous Gigantes | filhos de Calfurneo, e Camboldão seus cu|nhados na propria Ilha tinhão movido | no tempo que elle estivera na Perigoza | curandoce de suas feridas. [espaço] Estes pois | vendoo de novo auzente fervendo nelles | o natural Odio, que pella amizade de Floria|no lhe tinhão, e vendoce juntamente |

65 desherdados da quelle rico patrimonio | que Dramusiando lhe occupava, cer|rando os olhos a os discursos que puderão | fazer, e fizerão depois de que não seria | possivel tirarem a quella Ilha de seu Se|nhorio, tendo o melhor do Mundo para o | ajudar ${ }^{5}$. Movidos do primeiro accidente ajun|tando hũa grossa Armada, ajudados | de algũns parentes, e amigos seus, de|zembarcarão em terra, e comessarão | a devastalla toda.

70 [espaço] Acodio Arlança | a deffenção com valor, e prudencia [espaço] | grande, e deu hũa notavel batalha a os | sobrinhos, em que ella se achou prezente, | Mas perdeu a com grande danno de $\mid$ seus vassallos, e não lhe ficando força para| tornar outra ves a tentar a fortuna | emcampo aberto, doendosse da terra, || [90v] de que era natural senhora, que indifferentemente | padecia os dannos da guerra, Ordenou | a todos os lugares, que inda

75 fazião rezisten|cia que se entregassem, e ella com o me|lhor de sua fazenda, e muitos de seus vas|sallos se retirou a hũa praça forte, que ti|nha a olongo do Mar, aonde logo foy | cercada pellos sobrinhos, dos quais ella | como melhor podia se hia deffendendo | com esperanças que o Marido a socorre|ria depressa, para o que tratava de o mandar | avizar, Mas os Gigantes, que ja tinhão a cor|dado, parecendolhes que não serião mais tẽ|po

\footnotetext{
${ }^{5}$ A compreensão da frase exige que se desconsidere este ponto final. Os gigantes não apenas acreditavam ter direito à posse da ilha, como se agastavam pelo fato de Dramusiando ser amigo de Floriano: lembre-se que foi Floriano quem venceu Calfarneo e, mais tarde, dois outros irmãos seus, Bracolão e Baleato, não lembrados neste livro (cf. Palmeirim de Inglaterra, caps. 27, 106 e 107). Por isso, cheios de ódio, os dois sobrinhos de Arlança fecharam os olhos a todos os argumentos (discursos) que comprovavam ser impossível tomar de Dramusiando o senhorio da ilha, tendo o melhor (senhorio) do mundo em seu socorro (isto é: contando com o auxílio de Constantinopla). Dessa forma, estimulados pelos fatos passados (movidos do primeiro accidente, como se dirá logo a seguir: a morte de seus pais) eles reuniram grande armada e desembarcaram na ilha.
} 
80 senhores da terra, que o em que Dramu|siando não soubesse o Estado della ${ }^{6}$, pu|nhão todo seu cuidado assim em forta|lecer os portos mais fracos, como em vi|giar o mar, de maneira que não sahisse | nimguem da Ilha, que o pudesse avizar | pello Menos antes que se elles fizessẽ senho|res da pessoa da Tia, a cujo troco espera|vão alcançar pas, e Estado. E erão tão | extraordinarias as deligencias que para isto | fazião, que não poude

85 em muito tempo Dra|muziando ter recado, porem como sejja verdade o que dis o proverbio que a arte $\mid$ se engana com a arte, Timandro que | era hũ Cavalleiro natural da Ilha, e paren|te de Arlança, e a fora isto grandemente | affeiçoado a Dramusiando, assi pellas || [91r] virtudes que tinha, como pello modo que | com elle uzava dellas, arriscandoce na $\mid$ quelle cazo de tanto servisso seu, pou|de passar hũa noite pella armada 90 dos | Gigantes sem ser sentido, senão a o ou|tro dia. [espaço] $\mathrm{E}$ inda que elles trabalharão de o | thomar, mandando expos elle, vendo que | era em vão, receozos do que podia vir so|bre elles não tendo athe então ganhado a | prassa, que constante mente se lhe deffen|dia, detreminarãoce em deixar estar o | cerco como estava, e embarcaremce | com algũa companhia, e ir na volta de | Constantinopla, com tenção de verẽ | por espias

95 que lançarião em terra o que a no|va fazia em Dramusiando, porque se / desestimando o perigo se arrojasse ao so|corro mal accompanhado, assaltando o no | mar thomallohião com facilidade, e que quando | toda via se aprestasse poder, a que não pudes|sem rezistir, tornarião à Ilha, e tirarião | della tudo o que lhe fosse possivel, cedendo de|pois a o impeto de tão poderozo inimigo. | E assentando nesta resolução não mal | ponderada 100 para o Estado, em que se elles acha|vão derão conta della a hũ parente seu | que alli tinhão, encomendandolhe que a per|tasse o cerco o mais que pudesse, entre | tanto que elles não vinhão, e embarcandoce | de noite em hũa Náo com sesenta caval||[91v]leiros comsigo, e algũa gente de serviço, | fizerãoce à vella escondidamente, e tive|rão tão bom tempo que chegarão a Cons|tantinopla poucas horas depois de Timan|dro. E entrando no

105 porto Onde por mui | frequentado de Nàos, e Navios de vari|as partes do Mundo se não podia conhe|cer hũ que denovo chegasse, deixarãoce es|tar quietamente nelle Mandando suas | espias a terra, das quais forão avizados | logo do socorro que se aprestava, e virão | embarcar, e partir aquelles cavalleiros | em duas Nàos com grande gosto seu | parecendolhes que as tinhão nas Mãos, e | querendoce fazer à vella espos ellas, 110 sou|berão como o Emperador hia a o Outro | dia à cassa à quella Floresta que se

\footnotetext{
${ }^{6}$ Ou seja: os gigantes já suspeitavam que permaneceriam em posse da ilha apenas enquanto Dramusiando
} não soubesse do ocorrido. 
acaba|va nas prayas do Mar, e Enchendoce | de esperanças de fazerem hũa grão couza | (não tamanha porem como depois a | sorte lhe meteu nas mãos) levarãoce a|quella Noite, e forão surgir detras da|quelle promontorio que dissemos, onde | dezembarcando com grande quietação $\mid$ elles $^{7}$, e cincoenta Cavalleiros, deixando | os des na Náo, forãoce 115 lançar no matto | esperando o que o outro dia trazia a seu poder | que foy, o que no capitulo atras temos contado.

Hora Mortos os Gigantes e | seus companheiros, não tardarão em che||[92r]gar a o Emperador as Gallés, com a Náo, ẽ | que thomarão a mais companhia que elles | trazião, da qual, e dos que em terra se tinhão | rendido todos souberão quem elles erão | 120 e os intentos, com que alli tinhão vindo, e | juntamente entenderão aquelles Reys, a | quem devião sua liberdade, que lhes ficou | de tanto maior gosto, quanto era grande o A|mor que todos tinhão a D Duardos, dequẽ | dis a Historia que esteve na Floresta aquel|la noite, ou o que ficava della quando alli chegou, | lançado a o pe de hũ pinheiro com o rosto | no chão, e o Elmo na cabeça (que nẽ para o | tirar teve acordo) revolvendo 125 na fantezia | as palavras de Carmellia, a ira com que lhas | dicera, a rezão que tivera para dizerlhas, da | qual julgava as mais das vezes como par|cial da propria Carmellia, tornandoce | a si aculpa da Occazião que lhe dera, ou|tras acodia a natureza a seu ser, e parecia|lhe que não fora grande a de obedecerlhe, | porem quando se sentia inclinado a o Amor | proprio, e apertado da rezão la guardava | sempre seu lugar a o respeito de 130 Carmel|lia de maneira, que quando se não via asi cõ | culpas, por fe prosupunha que não faltari|ão nella cauzas secrettas para ademonstra|ção que com elle fizera ser arrezoada, | e justa $^{8}$. [espaço] Nesta imaginações o tho|mou amenhã, que elle julgou pella mais $\|$ [92v] pezada, e triste, que a the então tinha vis|to. [espaço] E assentado concigo de obedecer de | modo que não so satisfizesse a o que se lhe ti|nha Mandado, mas à 135 vehemencia do af|fecto interior, com que se lhe mandara | mudando parecer em sua jornada de|treminou embarcarce, e buscar algua | ilha despovoada onde acabasse a vida,

\footnotetext{
${ }^{7}$ Palavra corrigida pelo copista: o primeiro $l$ foi escrito sobre um $e$.

${ }^{8}$ Leia-se: "cuidando na fantasia nas palavras de Carmélia, na ira com que lhas dissera e na razão que tivera para lhas dizer, julgava-a [a razão] as mais das vezes favorável a Carmélia, assumindo a culpa por ter lhe dado motivo para tanto; outra vezes, acodia-lhe a consciência de si e parecia-lhe que não fôra grande [a culpa] de obedecer-lhe. Porém, quando se sentia inclinado ao amor próprio e constrangido pela razão [isto é: quando estava inclinado a julgar-se isento de culpa], lá [nesta ocasião] continha-se por respeito de Carmélia, de modo que quando não se via culpado, pressupunha por sua lealdade [fé] que haveria causas secretas que justificassem a razão e justiça do comportamento dela". A versão de B apresenta diversas lacunas neste trecho, o que o deixa sem sentido: "Revolvendo na fantezia as palavras de Carmellia, [lacuna] tornandoce a si a culpa da occazião que lhe dera outras a codia anatureza eparecialhe [lacuna] porem quando se sentia inclinado..."
} 
| que a seu parecer, qualquer espaço que lhe du|rasse seria grandissimo a respeito da dor | com que ella mesma o atormentava, E | chamando Trogonio (que sem se ouzar che|gar a elle, o estava vigiando de longe pare|cendolhe ${ }^{9}$ que algũ mal grando ${ }^{10}$ o tinha 140 oppprimido) dicelhe que se fosse à cidade em|buçado, e que lhe fretasse algua embarcação | pequena, porque elle se queria embarcar, | e que de noite o viesse thomar à quella pon|ta da Floresta, advirtindo que em nenhũa | Maneira fosse conhecido. [espaço] Fes a|quillo Trogonio com grande deligen|cia, e segredo, e achando hũa setia de | Levante mui a prepozito para o que seu senhor | queria, pagando a o Mestre, feslhe 145 meter | provizão do que lhe pareceu necessario, e a $\mid$ mesma tarde se veio nella surgir ao ros|tro da ponta, e dezembarcando foise a | buscar D. Duardos, o qual achou não | mui desviado do lugar em que o deixara | passeando entre hũas giestas altas, com o || [93r] elmo ja fora, e todo banhado em lagrimas, tão descorado, e transido, como | se ouvera muito Mais tempo que padescera | a dor de que se queixava, mas tal era ella, | que em

150 tão pequeno espasso tinha feito estes | estragos na quelle pobre mancebo. [espaço] Eo | $\mathrm{q} u e$ mais $\mathrm{O}$ atormentava era parecerlhe $\mid \mathrm{q} u e$ tantos erros $\mathrm{q}^{11}$ cometia contra Carmellia, | quantas erão as horas que vivia no mundo ${ }^{12}$. Me|neava a cabeça, cruzava os brassos, para|vace de quando em quando, Olhava hũas vezes para| o chão, outras para o ceo, fallava entre dentes, | sospirava, cantava, e tudo nũ momẽnto. | Trigonio que o vio de 155 longe andar daquel|la maneira, ficou como pasmado cui|dando que de todo tinha perdido ojuizo, e | não sabendo julgar a cauza, não ouzava | tambem chegarce a elle. E estando assim | confuzo cuidando no que faria, vio que de | cançado se sentou a o pe de hũa da quel|las giestas, e que expos hũ profundo sospi|ro dizia o que em outro capitulo contaremos.

160

\footnotetext{
${ }^{9} \mathrm{O} p$ inicial está corrigido, pelo que poderia ser um $t$ ou $d$.

${ }^{10} \mathrm{~B}, \mathrm{C}:$ grande.

${ }^{11}$ A letra $q$ não está acompanhada do traço superior com que normalmente se indica a abreviação. B: que; C: que.

${ }^{12}$ Entenda-se: "E o que mais o atormentava era parecer-lhe que cada hora que continuasse a viver significava uma nova desobediência a Carmélia".
} 


\section{Capitulo 32}

\section{Em que se da conta de qual Tro|gonio achou seu Amo, do que | elle dizia, e de como ouve | vista dos Gigantes, e como || [93v] os Reis chegarão a Cidade.}

Encostado aquella giesta de todo entregue a $\mid$ suas dezesperações dizia D. Duardos entre os sus|piros que no passado Capitulo contamos.

Que culpa pode ter quem he forçado? se | não a de haver rezistido? Amovos sobre todas as | criaturas, busquei sempre remedios, não para a|froxar neste Amor, mas para poder com elle den|tro de mim mesmo, e isto que vossos respeitos | me pedião, me

10 difficultavão vossas perfeiço|es, e eu padecia a bocca fechada a força $\mid$ destes extremos contente de vos servir athe | com o discredito que de tamanho silencio vi|nha a minha fe, E assi em quanto me eu gover|nei a mim serviavos, e calavame, quando me | vos governastes faleivos, e offendivos. Onde | esteve logo esta tamanha culpa minha? | Em vos amar, ou em vos obedecer? Se o cal|lar foy meu, e se o falar foy vosso, virei a |

15 cuidar que vos devo terdesme por couza tão | propria, que vingais em mim aira que de | vos tivestes ${ }^{1}$. [espaço] Ah triste, por onde se despenha |o pensamento, que impossiveis ajunta a fante|zia! abre os olhos homẽ coitado, e verás | que se o amor desacredita, e se escandeliza | a obediencia, que não te fica que fazer mais que | acabar a vida. Não digo obedecendo por não | incorrer de novo em novas offensas, mas fu|gindo de ti mesmo, em cujas imperfeições $\|$ [94r] se deve fundar a justificação de teu castigo.

E como isto disse, ficou em hũ | tão grande Accidente, que não bastou a de|ligencia de Trigonio (que logo lhe acodio) | para o despertar, e foi necessario ir por agoa $\mid$ a hua das fontes de que aquella Floresta thoma|va o nome, com a qual, e com o tempo fa|zer seu officio tornou a si este miseravel | Principe, tão descontente de se ver

25 vivo, co|mo alegre da couza porque morria.

Trogonio lhe disse o que tinha feito | que lhe elle agradeceu com lhe não falar pala|vra, e erguendoce para se ir embarcar assi a | pe como estava, foi tal a fraqueza que o des|maio lhe deixara, que o não poude fazer, e | pondece a cavallo querendo começar a | caminhar vio atravessar hũ pião que desa|tinada mente não sendo ja o dia mui cla|ro se

30 foi a elle dizendolhe: Onde estão os | Gigantes? E como dezembarcarão tão ce|do? que anda ja por aqui gente do Emperador | e se nos sentem não se fará nada. E | reconhecendo D Duardos querendo fogirlhe | a o mais cerrado do bosque onde tinha a |

\footnotetext{
${ }^{1}$ A frase, transmitida da mesma forma em B e C, é de difícil compreensão. Seu sentido parece ser: "virei a cuidar que deveis ter-me por coisa tão vossa, que vingais em mim a ira que de vós mesma tivestes".
} 
guarida certa, estava ja tão perto, que o não | poude fazer, e a tromentado do respeito, | de quem o prendia, que com a espada na | mão lhe fazia perguntas, confessou que | era 35 hũa das espias dos Gigantes, os quais ha|vião de desembarcar logo, mas que não sabia \| [94v] para que effeito. [espaço] E callandolhe a certeza da | vinda do Emperador á Floresta, so lhe disse | que os Gigantes erão dous, e que o mandarão bus|car, e segurar algũa parte escondida na|quelle Matto para se elles meterem em cila|da nella, e dalli fazerem o danno que pudes|sem na cidade. [espaço] Com o que alvoroçando|ce D.

40 Duardos, cuidando que ou acharia nas | mãos da quelles homẽns o fim que dezejava | a sua vida, ou poderia fazer algũ serviço | a o Emperador seu Avó antes que se apartas|se de sua terra, onde não cuidava que tornaria | nunca, determinou deixarce ficar alli a|quella noite esperando o que o outro dia trazia | concigo. [espaço] E Mandando a Trogonio que atas|se as Mãos à quelle homẽ ordenoulhe que com | elle se fosse 45 embarcar, e o esperasse athe o ou|tro dia, porque elle seria la athe então. [espaço] | Obedeceu Trogonio inda que contra sua vonta|de, porque lhe parecia que para algũa detreminação | perigoza queria D. Duardos ficarse so no | campo, mas não podendo fazer mais foi|ce, deixandoo nas imaginações em que $\mid$ de antes estava. [espaço] E assim passou hũa par|te da Noite sem outro algũ cuidado mais | que o que o occupava todo,

50 mas não tardou muito | que o despertou da quelles pensamentos hũ $\mid$ rumor que sentio não mui longe donde elle | estava. E levantando a cabeça vio os | Gigantes, e seus cavalleiros, que o mais qui||[95r]etamente que podião se hião lansar na sua | cilada, mas como erão tantos, e o silencio | da noite grande, não era possivel deixa|rem de o alterar.

Bem lhe pareceu a D Duar|dos (que do lugar em que estava os esteve con|tando

55 devagar) que seria dura couza | desbaratar tamanha companhia, mas as|si por que em seu animo não entrava temor | como pello estado em que então se via, resolveu|ce de os acometer a o Outro dia encomen|dando depois o successo à fortuna. E com | este pensamento esteve a the quazi ama|nhecer, com tão confuzos cuidados, como o | cazo prezente, e o passado o pedião. [espaço] E | tanto que amenhã rompeu querendo por|ce a 60 cavallo como elle fora o que o prendera | soubeo tão mal fazer, que o não achou onde | o deixara, e vendoo andar mui desviado | dalli passeando no campo, tomando o freo | na mão, e armado de todas as peças com a | lança ás costas, que o não embaraçava pou|co se foi a elle cuidando thomallo com faci|lidade. [espaço] $\mathrm{O}$ cavallo esperou, athe que quando o | ja hia aprender dando couces, emettendo a | cabeça entre as mãos se lhe 65 tornou aapartar | outro grande espaço de caminho, parece que | assi o queria a boa sorte do Emperador | e dos mais, porque verdadeira mente mal | se pode duvidar se D. 
Duardos que deixara $\|[95 \mathrm{v}]$ de se perder primeiro que vallesse o que valeu despois ${ }^{2}$. | E finalmente elle gastou tanta parte do | dia na quelle trabalho, e tão desviado de | donde as tendas e os Gigantes ficavão, que | não poude chegar se não a o tempo que fica | dito.

70 E vendo as couzas acabadas, tornou|ce (como tambem dicemos) à sua setia, | que ja tinha visto quando andava expos o cava|lo, eachando o batel que o esperava embar|couce logo, e nella lhe aconteceu o que ja | vimos, e assi o deixaremos entregue a sua | fortuna a the seu tempo, em que havemos | de Mostrar outro Mor serviço que inda fes | a Carmellia deffendendoa de Albaizar, | e deffendendoo a elle de Vasperaldo, e D

75 Flo|ris por amor della com outras couzas mais | dignas de se saberem pello que tem de fine|zas, e acontecimentos grandes, que pello mo|do de que forão agradecidas ${ }^{3}$.

Tornando aos Reys, que despois de in|formados de quem erão os Gigantes, e que | era D. Duardos quem os livrara delles tan|to à custa do seu sangue, dando graças a Deus | e benções a elle, aballarão para a cidade não | cabendo nos caminhos a gente que 80 della sa|hia a recebellos. [espaço] Praticas alegres tiverão to|dos com Valeriza, a quem Albaizar man|dou dizer do coche em que hia ferido, que a D. | Duardos esperava servir a parte que da|quelle seu socorro lhe cabia, mas que a ella \| [96r] não sabia em que o pudesse fazer. [espaço] Ella lhe | respondeu que se dava por bem paga com | entender que toda aquella companhia devia | tudo a D. Duardos, dequem era muito gran|de 85 amiga. Carmellia que ouvio os rec|cados porque todas hião juntas, disse para Vale|riza: [espaço] Se assim he que todas devemos tudo | a D Duardos não deve elle logo pouco a | meu Pay, e a meu Tio, e a os mais que desar|mados á custa de tanto sangue seu lhe | grangearão essa obrigação, em que quereis que | lhe estejamos. [espaço] Jesus Maria lhe replicou Fle|rida, e que mal vos parecem as couzas de D. | Duardos, e eu não sei com 90 que razão certo, porque | elle por ventura que será bom para maltratado, | mas para o peor tratado, não mo parece em ver|dade ${ }^{4}$. [espaço] Carmellia discretamente lhe res|pondeu emtão rindo: [espaço] Mui de sizo thomais | vos isto senhora Flerida, e folgo

\footnotetext{
${ }^{2}$ Não fica claro por que a dificuldade em prender o cavalo teria depois ajudado D. Duardos a socorrer o Imperador. A expressão "e [o cavalo] mettendo a cabeça entre as mãos" (linha 64) também é difícil de compreender: pode ser que o autor esteja querendo dizer que o cavalo passou a cabeça por entre as mãos de D. Duardos, soltando-se do laço ou dos arreios que este tentava colocar sobre seu pescoço.

${ }^{3} \mathrm{O}$ narrador está aludindo a aventuras futuras, em particular as narradas entre os caps. 45-48, dizendo serem coisas dignas de se saber por serem finezas e grandes acontecimentos; mesmo assim, essas proezas não foram agradecidas, ou seja: não foram suficientes para abrandar o ânimo de Carmélia.

${ }^{4}$ Carmélia, com sua habitual frieza, não aceita que o mérito do salvamento de todos seja creditado unicamente ao esforço de D. Duardos, como pretende Valeriza. Flérida responde dizendo não ver problema em Carmélia mostrar-se indiferente a seu irmão D. Duardos (pois o contrário seria infamante para uma donzela), mas acredita que ela está passando dos limites do razoável.
} 
que me ensi|nais a ser mais irmã de meus irmãos, que | prima de minhas primas ${ }^{5}$. [espaço] Gridonia | Ouvindo aquillo disse para Valeriza: Que | vos parece destas

95 Mulheres, que assim vão con|verçando como senão tiverão passado | ha tão pouco pello trabalho em que todas nos | vimos, que me amim leva de maneira | que inda agora cuido que estou em poder da | quelles Gigantes, e não me parece que aquel|le foy D Duardos, senão todos os Santos | do ceo juntos que nos vierão livrar. De mim || [96v] vos digo, disse Valeriza, que foi elle bem mal | aconcelhado em se ir, por que lhe ouvera eu | de 100 agradecer mui bem as ancias de que me | tirou.

Nestas, e em outras semelhantes pra|ticas chegarão aquellas senhoras a caza, on|de os feridos forão curados com grande res|guardo, e os corpos dos Gigantes, e dos mais | cavalleiros seus, que morrerão com elles, que todos $\mid$ o povo trouxe, forão queimados, uzandoce | nelles grandes generos de cruezas mais a respei|to de Mortos, 105 que de faltarem razões para se faze|rem se forão vivos ${ }^{6}$, e inda assim não parecia | que se mitigava na gente comũ a sede da | vingança que dezejava thomar. E assi os | deixaremos por dizer o que aconteceu a D. | Floris na demanda da Duqueza de Mon|talto, com quem foy.

\footnotetext{
${ }^{5}$ Carmélia diz que Flérida não deveria levar tão a sério o que ela havia dito e insinua que, defendendo o irmão daquela maneira, Flérida poderia aborrecer a ela e às demais primas.

${ }^{6} \mathrm{O}$ narrador qualifica de cruel o tratamento dado pelo povo aos gigantes pois era desnecessário, visto que eles já estavam mortos (embora acrescente que não faltassem razões para proceder daquele modo se eles estivessem vivos).
} 


\section{Capitulo 33}

\section{Do que aconteceu a D. Floris | no Reyno de Napoles com | Cadramonio.}

De D. Floris conta a Historia que nave|gou com bom tempo depois que partio de 5 Cons|tantinopla a the chegar ao porto da quella | famoza cidade de Napoles a tempo que || [97r] não faltavão oito dias para comprimento | prazo, que se tinha assinado a Lysandra, e | Filismarte, sem athe então haver quem | fiasse mais da inocencia dos prezos para os def|fender, do que temesse as forças do Gigante que | os accusava. So o proprio Filismarte se | tinha offerecido varias vezes á quelle risco | como Cavalleiro ao

10 menos de Lysandra | dizendo, que se vencesse a o Gigante ficasse | ella livre, e elle obrigado à penna que lhe | ElRey quizesse dar; mas como era o Reo | de que se havia fazer justiça, nunca o quize|rão ouvir. [espaço] ElRey de Cicilia seu Pay | não era tão poderozo que bastasse ao livrar | por força, inda que não deixava de ameaçar | hũa guerra muito perigoza para aquelle esta|do aprestando para ella todas as forças de seu |

15 Reyno, e de seus amigos, e parentes, mas não | ouzava a rompella pello perigo do filho ${ }^{1}$. | E estando as couzas neste termo, chegou | como dissemos D. Floris, e sahindo a Du|queza em terra accompanhada de seus | Cavalleiros, foi recebida do povo com grã|de alvoroço, porque como era muito conhecida | e sabião todos ademanda, a que fora, e $\mid$ a determinação que levava de não tornar | se não com pessoa, de que pudesse fiar o reme|dio da quelles Princepes. Vendoa vir, e | com hũa certa alegria no rosto, que mostrava | o que trazia no coração, bem lhes pareceu que || [97v] não viria sem o que todos dezejavão. Eassim | seguida de hũa grande turba chegou ao Pa|ço a horas que ElRey acabava de gentar, o qual | sendo avizado de sua vinda, dissimulando | como melhor poude o gosto que della tambẽ | teve, mandou que entrasse, e pondoce a

25 Duque|za de giolhos diante delle dicelhe: [espaço] Se da| minha perigrinação resultar senhor o que eu | espero da bondade de Deus, e da innocencia | de vossa filha, não quero mais galardão |que a vingança do traidor de Pamphilio, de | cuja maldade sahio o estado em que este Rey|no se acha. [espaço] Eu trago hũ Cavalleiro, | que se obriga a provar a Cadramonio de I pessoa a pessoa, que os prezos são innocen|tes da accuzação, que lhe 30 elle fas, mal per|suadido de Pamphilio, por isso mandailhe | assegurar o campo, e dar salvo condut|to para dezembarcar, porque não espera ou|tra couza. [espaço] O Gigante que estava prezen|te respondeu à Duqueza sem esperar, que | ElRey o fizesse: [espaço]

\footnotetext{
${ }^{1}$ Ou seja, o rei de Sicília não ousava declarar guerra a Nápoles por medo de pôr a vida de seu filho em risco.
} 
Quanto melhor vos fora quie|tardevos em vossa caza, que andar espan|cando os Mares, e as terras, enganando | os pobres cavalleiros com lagrimas fingi|das, e desestimação do 35 perigo, a que elles se | não aventurarão se o conhecerão. [espaço] Atra|vessou ElRey logo, e disselhe: [espaço] Palavras | Cadramonio, emais com mulheres, indig|na couza he dos homẽns comovos. [espaço] O || [98r] Cavalleiro venha seguro diante de nòs, a|qui lhe daremos conta do cazo, e se com|tudo presistir em sua porfia, então vinga|reis nelle a paixão, que agora mostrais con|tra a Duqueza, com mais honrra vos|sa, e maior

40 confuzão della. [espaço] E com isto | Mandou a o seu capitão da Guarda, que | fosse por D Floris, e o trouxesse seguro a $\mid$ sua prezença. [espaço] E sendo obbedecido, | sahio aquelle valente, e ditozo Cavallei|ro em terra encima de hũ cavallo baio | grande, e fermozo canipreto, e de cabos | negros, e elle armado de hũas armas dou|radas todas, e semeadas de estrellas encar|nadas sem outra algũa pintura, no es|cudo em campo 45 dourado hũa tarja com | cinco da quellas estrellas, e hũ Leão doura|do por cima com hũa capella de flores va|rias nas mãos. [espaço] Trazialhe seu Escudei|ro a lança, e o Elmo, e elle na cabeça hũ | sombreiro negro com hũa pluma tãbem | negra. [espaço] E como era tão moço, e tão gen|tilhomem, a todos pareceu hũ Anjo que | vinha a resgatar aquelle povo. [espaço] Logo o co|nhecerão algũns do tempo que outra ves cõ | a Duqueza alli 50 viera, e hiãolhe lançando | benções pellas ruas, porque em extremo era | Lysandra bem quista, e abborrecidos | Pamphilio, e o Gigante. [espaço] Chegou des|ta maneira ao Paço mais olhado e ac||[98v]companhado do povo, do que o a li nunca | fora Cavalleiro Estranho, e prezentandoce | a ElRey, elle o recebeu com toda a cortezia | que se podia dezejar, e conhecendoo tambẽ, | algũa couza se alvoroçou, pella boa op|pinião que de seu valor alli tinha deixado. | Mas com tudo bem cria que se Deus não obra|va, que em balde seria tudo com Cadramo|nio, que ainda tinha mais de fero, e Mons|truozo, que D. Floris do contrario. [espaço] | Elle lhe disse despois de passados os primeiros compri|mentos. [espaço] Ja Vossa Alteza deve ter sabido a cau|za porque aqui venho, será necessario saber | se os prezos se comprometem em mim. | E tambem folgara eu de

60 fallar com elles | porque ainda que nunca lhe faltarei com o | pouco que posso, quizera que me assegurarão | da innocencia de suas pessoas. [espaço] | Cadramonio ouvindo aquillo comessou | a rir tão dezentoada mente, como elle | costumava, e disse para a Duqueza, que era | prezente. [espaço] Que dizeis agora senhora? Ve|des aqui como este cavalleiro so de me | ver busca ja razões para se escuzar da ba|talha. De meu concelho 
65 ouvereisvos $^{2}$ de | tornar com elle, que he mancebo, e gentil|homem, e poupallo para outras Aventuras | Menos perigozas para elle, e de mais gosto | para vos ${ }^{3}$. [espaço] D. Floris voltando então | para o Gigante, respondeulhe ja quazi ven||[99r]cido da ira: [espaço] Agora vos digo que não que|ro mais justificação da innocencia | de Filismarte, que accuzardelo vós, por | isso hivos armar, que antes que anoite venha | Eu vos

70 ensinarei o respeito que haveis de | ter a ElRey que aqui està, à senhora Duque|za, e a mim muito acusta da vossa sober|ba. [espaço] O que ouvindo Cadramonio | lançando fumo pellos narizes, comessou | a maltratar o sofrimento de seus falços $\mid$ Deuzes $^{4}$ (ordinaria couza na quella sor|te de homẽns) e com hũ gritto, que pare|ceu que derribava as cazas lhe disse pondose / em pe: [espaço] Minino desventurado, quem | te engana?

75 Cuidas que sou eu Pamphilio, | que a qui vencestes à treição? Ou que influxo | máo dessas estrellas te mette essa nescia | prezumpção na cabeça? [espaço] D. Floris | ouvindo fallar em treição, sahindolhe tã|bem fogo pellos olhos hia ameter mão | à espada para lhe responder com ella; porẽ | lembrandolhe com toda apaixão, o lu|gar em que estava, e que o Gigante não ti|nha armas, respondeulhe so mente: [espaço] | Vos 80 mentis em dizer que venci Pamphi|lio à treição. [espaço] E virando para ElRey | disse: [espaço] Vossa Alteza me perdoe se tenho excedi|do em algua couza, e bem pode escuzar | de mandar vir os prezos como lhe ti|nha pedido, porque ainda que por amor delles $\|[99 \mathrm{v}]$ vim aqui, ja agora pello que tocca a minha | honrra quero fazer esta batalha. [espaço] $\mathrm{Eu} \mid$ me vou ao campo, mandai aesse Mons|tro que não tarde, porque 85 espero em Deus que | hoje serà o dia em que o Ceo alivie a terra | do pezo que lhe elle fas, thomandome amim | por instromento do justo castigo seu.

Ja a este tempo o Gigante se ti|nha hido armar nas maiores blasfemias | do mundo, e a ElRey não lhe pezou do que |D Floris dissera a cerca dos prezos, porque | como não lhe esperava a victoria, e arrisca|va na batalha a vida da filha, bẽ folgou | que

90 ella se fizesse sem a quele concerto, es|perando do tempo Maior beneficio. | E despedindoce D. Floris, elle se pos com | os grandes de sua corte a ver o Terreiro | da quella duvidoza contenda, das genellas | do Paço, que sobre elle cahião. [espaço] $\mathrm{O}$ caval|leiro que ja la tinha chegado armado do | Elmo, e lança, que lhe so faltava, estava | esperando o Gigante encomendandoce | toda via a Deus, porque elle lhe parecia o mais |

\footnotetext{
${ }^{2}$ Leia-se: "houvéreis vós".

${ }^{3}$ Cadramônio insinua que a Duquesa deveria poupar D. Floris para outras aventuras, as amorosas, o que justifica a indignação de D. Floris.

${ }^{4}$ Sofrimento, neste caso, significa "paciência ou tolerância"; o sentido da passagem é que Cadramônio começou a blasfemar, injuriando seus deuses.
} 
95 Mostruozo que nunca tinha visto, e assi | era verdade, porque se não podia então | achar no mundo outro que o fosse tanto. | e o successo da batalha veremos em o | capitulo seguinte. 


\section{|| [100r] Capitulo 34.}

\section{Da batalha, que D. Floris, e $\mid$ Cadramonio tiverão, e $\mid$ do successo della.}

Não tardou muito Cadramonio emci|ma de hũ cavallo Napollitano castanho | 5 claro, tamanho, e tão forçozo, como para so|frer tão grande pezo era necessario. [espaço] Vi|nha armado de hũas armas branças de | asso lizas sem pintura algũa, tão grossas, | e fortes, que não parecia possivel podellas pe|netrar outro algũ ferro. No escudo, que em | tudo era conforme com as armas, trazia | pintado o Monte Ethna lançando os | seus fogos. [espaço] Vinha com a vizeira levan|tada, e hũa entena na mão

10 por lança $^{1} \mid$ brandindo tão facilmente, como se | fora hũa leve cana. [espaço] Mal podia pa|recer a nimguem que hũ exercito inteiro | pararia diante de tão desacostumado ho|mem, quanto mais hũ so Cavalleiro, e assim | Gravanáo, a Duqueza, e os que dezejavão | por seus respeitos a victoria a D. Floris, | começarão a derramar tantas lagrimas, | como se o ja virão no derradeiro ex|tremo. [espaço] O Gigante entrando no

15 cam|po sem fallar palavra occupado ainda | da ira que o tinha senhoreado, callando | a vizeira $^{2}$, remeteu com aquella sua $\|[100 v]$ lança baixa a D. Floris na maior | furia que o cavallo poude levallo, sahindo el|le da mesma maneira a recebello. Co|mo se fora de papel, assi falsou, o Gigante, | que não erro o encontro, o escudo de D. Floris ${ }^{3}$, | passandolhe por entre o braço, e o corpo, mais | de ametade da lança sem lhe fazer

20 ou|tro danno, permittindoo assim Deus, que | queria castigar a Maldade de Cadramo|nio. [espaço] D. Floris o encontrou a elle tam|bem com aquella força que a Natureza lhe | dera, na quelle seu impenetravel escudo, | e resvalando a lansa por elle foi a topar | em hũ cordão, que o cercava em roda, e | fazendo ali preza puxou de maneira que | o Gigante se dobrou tanto para tras, que fes | impinar o cavallo, mas foi tão ditozo que |

25 antes de cahir sobre elle (com que a batallha se a cabara) lhe quebrarão as redeas, | e assim o cavallo desafogado poude tor|nar a por as mãos em terra, porem sen|tindoce livre começou a correr pello | campo fazendo tantos saltos, e corve|tas, que emfim arrojou de si com hũa grão | queda o pezo que o opprimia. [espaço] Dom | Floris que sem receber reves algũ tinha / parado o seu, e estava vendo como $\mathrm{Ca}$ |dramonio se 30 livrava da quelle, tanto | que o vio no chão, não querendo acometel|lo a cavallo, a

\footnotetext{
${ }^{1}$ Entena, segundo Bluteau, é o mesmo que antena, que na época significava "o pau que atravessa o mastro do navio e onde se ata a vela". Aqui, deve significar uma vara de pau muito longa.

${ }^{2}$ Isto é, abaixando ou fechando a viseira.

${ }^{3}$ A ordem direta da frase seria: "O gigante, que não errou o encontro, amassou o escudo de D. Floris como se fosse de papel".
} 
peouce, e mettendo mão \| [101r] á espada, e embraçando bem o escudo | foice a demandallo detreminando valer|ce de suas industrias mais que de tudo, es|tando avizado da experiencia do encon|tro que não lhe convinha esperar muitos gol|pes do Gigante. [espaço] E elle que tambem | (ainda que com trabalho se tinha levanta|do) arrancando de 35 hũ cutello grande que | na cinta trazia, tão pezado, que terião bẽ | que fazer dous homẽns em levantallo do | chão, esgrimindoo facilmente, se foi | tambem para elle a o passo que o pezo do cor|po, e o quebrantamento da queda lhe con|centião. [espaço] E juntandoce no meio daquel|le grande Terreiro, comessarão hũa assás | notavel batalha, porque o Gigante por mais | que trabalhava não podia acertar golpe | em seu contrario, e elle por

40 muitos que lhe | dava assi lhe saltava a espada para cima | como se tocara em hũa viva pedra. | Desta maneira andarão tanto que aba|fando o Gigante dentro do Elmo quizera | descançar tirandoce a fora. [espaço] E D Floris | parecendolhe que na quillo estava ter ou não | ter victoria não o deixava, e chegou a | couza a estado, que o Gigante se lhe livra|va sem poder firillo, vendoce perdido | de puro cançado, e vendo que nem podia | menear os braços, nem thomar folego fi|ado na fortaleza das armas deixouce es\|[101v]tar quedo encostado sobre o cutello, que | como hũa firmissima columna o sostinha. | E assim esperou sem se menear toda a tem|pestade de golpes, com que D. Floris o accome|tia, o qual vendo a Estranha Maneira | de que o Gigante se lhe livrara sem poder | ferillo nem impedirlhe o descanço, thomou | tambem outro novo caminho 50 de deffen|dello, e foi dar com a Espada de prancha | com toda sua força no cutello em que o | Gigante se sostinha, e foi tal a pancada | e o sucesso della que lhe deu a victoria, | que por outro modo tão difficultoza se Mos|trava, porque torcendoce aquelle esteio | da direitura em que estava, veio todo | o edifficio a terra com tal estrondo, co|mo se se arruhinara hũa grão Torre. | E toda via querendo levantarce, não | o deixarão, porque 55 nem elle o podia fazer | facilmente, nem seu contrario se des|cuidava, opprimindoo sempre hora | com a Espada, hora com as mãos, cõ | as quais em elle thomando sitio para se | erguer o tornava logo a estirar no cam|po. [espaço] Monstruoza couza foi certo | ver esta batalha, e que aquelle Gigante que | desprezava o Mundo, em cuja prezen|ça não ouzava alguem falar palavra | com que o desgostasse, sem dar nẽ receber | ferida 60 algũa estendido no chão com || [102r] hũa grande Machina a puros acciden|tes de ira ${ }^{4}$, e falta de folego sem se poder | valer, nem para desenlaçar o elmo, aca|bou de espirar de

${ }^{4} \mathrm{C}$ : como hua grande machina; B apresenta o mesmo erro de A: com no lugar de como. Machina, de acordo com Bluteau, pode significar "grande massa", como parece ser o caso aqui. Jáaccidentes de ira é expressão menos clara: pode tanto indicar "casos da ira" ou então "achaques ou desmaios causados pela ira”. 
todo. [espaço] E vendo D. | Floris que não bolia pe, nem mão, pareceu|lhe ao principio que seria nova indus|tria de descançar, mas toda via não | tardou muito em conhecer do cahir dos | braços, e do estirar das pernas, que estava | aquillo acabado. [espaço] $\mathrm{E}$ 65 dezenlaçandolhe $\mid$ o Elmo inda a catadura que no rosto $\mid$ mostrava pudera fazer medo a qualquer | animo, menos quieto que o seu, que com tu|do lhe cortou a cabeça, com que a gente da | cidade, e ElRey que os estava vendo com | toda a corte se acabarão de certificar | do que athe então não podião crer. [espaço] $\mathrm{E}$ | levantandoce hũ grande alvoroço no | povo, não parou athe que quebrarão as | portas onde Pamphilio estava, e 70 elle | foi trazido à praça, onde ja ElRey | tinha vindo para honrrar a D. Floris co|mo a restaurador de sua honrra, e gos|to, ealli diante de toda agente confes|sou assim a primeira Maldade da Morte do | Irmão e sobrinha, como a $\operatorname{com}^{5}$ que fize|ra acuzar Lisandra entendendo que | por aquelle caminho se cazaria com | ella. ${ }^{6}$ porque elle de acordo nisto com o Gi|gante (com quem não cuidava que nim $\mid[102 \mathrm{v}]$ guem quereria

75 entrar em campo) ti|nhão assentado que quando tudo faltasse, acaba|do o termo, se desceria da acuzação que|rendo ${ }^{7}$ ElRey, e ella vir no cazamento. | Ja o mesmo Povo, que o alli trouchera ti|nha ascendido hũ grande fogo, no qual | acabada a confição que fes, como dicemos, | publicamente sem esper ${ }^{8}$ o mais, o arroja|rão logo juntamente com o corpo do | Gigante, com tanta pressa, e alvorosso, | como se se temerão que outra ves 80 tornasse $\mid$ a reçussitar $-{ }^{9}$ hũ, e outro.

D. Floris disse a ElRey (esti|mulado tambem do Povo que gritava por | aquillo) que não se desarmaria athe que | Lysandra, e Filismarte fossem soltos. [espaço] Não | se dilatou isto muito porque dezejandoo ElRey | a motinandoce o Povo, e instando D. | Floris, logo alli vierão, que não se conten|tou aquella gente com menos, hũ e ou|tro 85 informados do que passava (que athe en|tão não tinhão ouvido mais que aquelle | rumor grande, que andava entre agente | sem saberem a cauza.) [espaço] Veneravão | a D. Floris como couza vinda do ceo, | e passando elle com aquella Princeza | (que em

\footnotetext{
${ }^{5}$ Há mancha sobre esta palavra no manuscrito, o que dificulta a leitura. Em B, a palavra foi rasurada, de modo que não é possível ler; C: com. Leia-se: "confessou tanto a primeira maldade [ao causar] a morte do irmão e $[d a]$ sobrinha, como a [maldade] com que fizera acusar Lisandra".

${ }^{6}$ Aqui, o copista inseriu um ponto final que ele mesmo desconsidera, visto a frase continuar com letra minúscula.

${ }^{7}$ A parte final da palavra (-rendo) está manchada no manuscrito. A lição apresentada aqui é a de B e C.

${ }^{8} \mathrm{~B}, \mathrm{C}$ : esperar.

${ }^{9}$ São raras as ocasiões em que o copista utiliza o traço, a modo de hífen ou travessão, e nem sempre justificadamente. $\mathrm{O}$ ms. B, que via de regra reproduz os sinais de pontuação de A com bastante fidelidade, não o apresenta. Outros exemplos ocorrem nos caps. 39 (linha 51), 52 (linha 27) e 55 (linha 51).
} 
extremo lhe pareceu fermoza) $\mid \operatorname{com}^{10}$ grandes comprimentos a foi ac|companhando a the o Paço, onde se re|colheu depois de ter contentado a gente $\|$ [103r] com sua 90 prezença, e remunerandolhes | com o modo de que agazalhava a todos | com os olhos, e palavras o gosto que mostra|vão de sua liberdade. [espaço] E deixandoa $\mid$ no seu apozento com ElRey seu Pay, | agasalhando ainda outras pessoas de mais | Authoridade, que os vinhão visitar, acom|panhado dos Ministros de ElRey, foy le|vado a hũa pouzada, que nos mesmos $\mathrm{Pa}$ |ços lhe tinhão concertado, porque afora ser | a noite ja muito

95 Entrada, elle posto que não | estava ferido, sentiasse tão quebranta|do, que tinha assas necessidade de repouzo. | A Duqueza (a mais contente mulher | que se nunca vira) ficouce toda a noite | com Lysandra, dandolhe particular | conta de suas jornadas, e de quem D. | Floris era. [espaço] E assi os deixaremos athe | seu tempo, por Dizer como ElRey D. | Duardos, e os mais que em Constantino|pla estavão se partirão para suas 100 cazas, e $\mid$ do que lhes aconteceu.

\footnotetext{
${ }^{10}$ A palavra com é fruto de um erro do copista, pois é desnecessária. Ela é reproduzida também em B, mas não em $\mathrm{C}$.
} 


\section{Capitulo 35}

\section{Da partida da quelles Reys, | e do que lhes conteceu.}

ElRey D Duardos, e os mais que em $\|[103 \mathrm{v}]$ caza do Emperador estavão senda ${ }^{1}$ 5 ja sãos | das feridas que na Floresta receberão trata|rão de se partir para suas terras donde havia | tanto tempo que tinhão sahido, e Onde era | necessario que assistissem, se não para gosto de | cada hũ (porque este satisfeito estava na con|verçação de todos ${ }^{2}$ ) para o remedio, e conçola|ção dos vassallos, que nunca està mais certo | que à vista de seus Reys, nem os proprios Re|ys melhor servidos delles que quando prezentes. | Dura

10 couza era esta de sofrer a Prima|leão, mas por força havia de ser, E assim | assinandoce o dia puzerãoce em Ordem | as couzas necessarias à partida.

A Princeza Carmellia in|da que seu Pay tinha dito a o Emperador | que a deixaria alli com as mais, a seu re|querimento della ordenou com a Rai|nha sua May que não consentisse na quillo | porque ella se tinha detreminado em não | ficar em nenhũ Modo,

15 e a rezão que para isso | lhes deu foy dizerlhes que tinha entendido | com grandes demonstrações que todas a|quellas Princezas lhe querião grande | mal, e se cançavão muito com ella, e que | a occazião que lhe para isso dava não podia | tirarce pello menos dahi a muito tempo, | querendo inferir que era inveja de seu | parecer. ${ }^{3}$ quem lhe fazia guerra [espaço] E | como aquillo não era couza contra o || [104r] gosto da May, creu

20 facilmente, e fol|gando tambem muito de levar a filha | que contra sua vontade deixava, córã $\mid \mathrm{do}^{4}$ o negocio com hũa indispozição que | Carmellia soube fingir publicouce a | sua hida, de que as outras espantadas se quei|xarão com ella grande Mente, E o Em|perador mais, que o sentio sobre modo. | Porem como elle não tinha perdido de to|do o antigo brio de sua condição, En|tendendo que Floriano com leve cauza | lhe negava a palavra,

25 não lhe quis mos|trar maior sentimento que o que fora groce|ria não se lhe enxergar.

Varias oppiniões ouve en|tre as Princezas da resolução de Carmel|lia, e não faltou quem cuidasse que se | queria ella ir a parte onde sem o emba|raço de sua companhia pudesse occup|parce nos pensamentos que lhe imagi|nava a dona deste discurso; mas eu que | não achey escritto em Henrique | Frusto a verdadeira cauza,

\footnotetext{
${ }^{1} \mathrm{~B}, \mathrm{C}:$ sendo.

${ }^{2}$ Há mancha sobre esta palavrano manuscrito; a lição apresentada é a de B e C.

3 Aqui, o copista inseriu um ponto final que ele mesmo desconsidera, visto a frase continuar com letra minúscula.

${ }^{4}$ B: corado; C: corando. O copista de B (que, segundo cremos, se baseou em A) deve ter se confundido com a acentuação incomum da palavra e desconsiderou o til sobre o $a$. É evidente que a lição de A e C são as corretas: "corando o negócio" significa "disfarçando; alegando um pretexto".
} 
30 fundando|me nas rezistencias que ella fazia à|quelles pensamentos, e nas calidades $\mid$ de sua pessoa conhecidas, eobservadas | della, mais cuido que foi quererce apartar $\mid$ da Occazião que lhe faria algũa força | em que a Natureza podia so ser a culpa|da ficando a vontade sem culpa, || [104v] porque ainda que cuidasse que não deixarião | de a seguir todos os tropheos de seus tri|umphos, tambem podia entender que sendo | Albaizar 35 quem era (prosupomos que Ce|linda lho tinha ditto) não ouzaria buscallla em caza de seu Pay, onde quando toda via | o fizesse tinha o perigo, e amorte mais | certa, que em nenhũa Outra, não deixan|do ella então de o descobrir, o que na com|panhia da quellas Princezas não podia | fazer, por poder elle no publico atribuir| seu obzequio a qualquer dellas tirava a | cada hũa a razão de thomarẽ a vingan|ça á sua conta, o que em Tracia não po|dia haver ${ }^{5}$. [espaço] A esta cauza que eu te|nho pella formal e certa, se ajuntaria | o termo de Flerida, que não deixava de | ser demaziada mente rigurozo para o res|peito de tão callificada Princeza, e as | discrições de Valeriza, que quando se encami|nhão a lastimar doem tanto mais que as | necedades, quanto melhor sabẽ dizer o que que|rem, porque em fim os ditos dos necios | sendo lançadas que attravessão tem toda | via remedio; Mas os dos discretos co|mo lancetas picando sem sentirẽ as | arterias, a tudo deixão perdido ${ }^{6}$. [espaço] Afora | isto, entender tambẽ que a auzencia de D. | Duardos seria larga, e arriscada a po|dia fazer não se querer aventurar a q ue $\|$ [105r] a thomasse a nova de algũ dezastre seu | entre tantas amigas, e parentas suas, que | sabião a cauza de sua hida, e em caza | de seu Avó. [espaço] Com estas razões, ou | outras mais forçozas se devia mover Car|mellia a deixar Constantinopla ${ }^{7}$, e se|guir seu Pay como fes,

\footnotetext{
${ }^{5}$ Esta longa e curiosa análise dos motivos da decisão de Carmélia é justificada porque o narrador, colocando-se no papel de mero tradutor, diz que Henrique Frusto, o suposto autor do texto original, não explica satisfatoriamente por que Carmélia decidiu partir de Constantinopla com seus pais. Entre as possíveis causas apontadas, não se conta o desejo de poder ocupar-se em pensamentos amorosos sem o estorvo da companhia das demais princesas, como uma delas supunha. O mais plausível, segundo o narrador, seria o oposto: as rezistencias que ella fazia àquelles pensamentos e as calidades de sua pessoa levariam Carmélia a querer evitar qualquer risco de envolvimento amoroso (occazião que lhe faria alguma força a natureza). Ainda que Carmélia soubesse que os apaixonados por ela (os tropheos de seus triumphos) poderiam buscá-la à casa de seu pai, ela não acreditava que Albaizar o fizesse (supondo que Celinda a tivesse advertido da real identidade daquele cavaleiro), dada a particular inimizade entre os pais dos dois (Floriano e Albaizar) e sobretudo porque em Trácia ela poderia revelar a todos quem ele era. Se ela o fizesse em Constantinopla, Albaizar poderia fingir estar apaixonado por qualquer uma daquelas princesas (atribuir seu obzequio a qualquer dellas), o que as impedirira de pessoalmente thomarẽ a vingança [dele] à sua conta.

${ }^{6}$ Ao motivo apontado acima, que o narrador (empregando um termo filosófico) diz ser a causa formal da decisão de Carmélia, acrescentam-se outros dois: o primeiro são os modos (termo) de Flérida, que não aceitava o tratamento que ela dispensava a D. Duardos. O outro motivo diz respeito às discrições ("agudezas", observações perspicazes) de Flérida, pois se as tolices dos néscios são como lançadas (golpes de lança), os comentários dos discretos, embora mais sutis, picam como lancetas (agulhas) e fazem mais estrago.

${ }^{7}$ O verbo mover aqui tem sentido de "motivar".
} 
partindoce todos | no dia que para aquillo estava deputado. | E assim como não dicemos as ceri|monias e contentamentos do recebi|mento, não diremos as lagrimas, e sau|dades da despedida, deixando nisto li|vres os juizos, e imaginações dos leito|res, e so diremos os lacrimozos progres|sos da quella navegação, e as couzas que | della rezultarão, que 55 forão o inteiro com|primento daquella temeroza profecia | do grande Sabio Apollidon, que no prin|cipio desta historia referimos. ${ }^{8}$ tanto de $\mid$ ante mão vio aquelle homẽ os sucessos | prezentes que Henrrique Frusto conta | desta maneira.

Havendo seis dias que par|tirão de Constantinopla em hũa gran|de, e comoda Galeáça El Rey D Duar|dos, sua mulher, seus filhos, e suas noras, | e a Princeza

60 Carmellia, os Reys de | França, de Hespanha, de Lacedemonia, | de Thessalia, de Niquea, de Navarra, | Polinardo, e D. Rosuel, seguidos das || [105v] Armadas em que alli tinhão vindo, que|rendo elles ir juntos athe as paragẽns em | que cada hum se dividia, indo navegã|do com vento prospero contentes de lhes | parecer que cedo serião em suas cazas, hũa | tarde se levantou de subito hũa tama|nha trovoada do Sul, que quazi sosobrou | a Armada toda, e crescendo a tempes|tade cada ves mais com tanta sarra|ção que dentro da Galleaça se não vias ${ }^{9}$ as | pessoas, senão à lus dos continuos fuzis | que não cessavão, cevandoce elles na quelle | vento, ou o vento nelles. Correrão to|da a quella noite, e o outro dia so com | hũa Moneta cengida no castello da $\mid$ proa $^{10}$, sem terem nunca mais vista | de outro algũ navio da sua concerva, | recebendo tanta agoa pellas arromba|das que anão podião vencer com nenhũa | dilligencia. [espaço] Omedo era geral, inda que | se não mostrava geralmente em todos | porque aquelles Princepes, e cavalleiros | Encobrião o que cada hũ tinha, assi por | não mostrarem na quellas horas, que el|les julgavão pellas derradeiras suas, o que | em todas as mais de sua vida tinhão | Mostrado $^{11}$, como por darem com seu ex|emplo animo à quellas senhoras, e à gen|te do mar, a ellas porque depuro temor | não espirassem, e a os Marinheiros || [106r] paraque de todo não dezemparacẽ o gover|no do Navio como fazião, e inda assi | approveitavão pouco, por que as mulheres | hião ja tão mortas, que so na respiração se | lhes conhecia a vida, e a gente do mar | como quem melhor conhecia operigo, | vencida a Esperança da grandeza delle, | e a força do trabalho, sem se occuparem | em mais que olharem para

\footnotetext{
${ }^{8}$ Aqui, novamente, o copista inseriu um ponto final que ele mesmo desconsidera, pois a frase continua com letra minúscula. $\mathrm{O}$ ponto é reproduzido em $\mathrm{B}$.

${ }^{9} \mathrm{~B}, \mathrm{C}$ : vião.

${ }^{10} \mathrm{Ou}$ seja, a tempestade havia partido todas as velas da embarcação, exceto a moneta, certo tipo de vela pequena utilizada para manobrar o navio.

${ }^{11}$ C: não tinhão mostrado. A lição de A e B, em que falta o não, parece afirmar que os cavaleiros sempre mostraram medo, o que obviamente seria inadmissível.
} 
80 qual da quellas on|das os tragaria, se deixarão ir tão en|tregues, como quem ja sem remedio | se contava por Morto.

Desta maneira correrão | tres dias sem governo por onde a furia $\mid$ do vento os Encaminhava, no cabo | dos quais começou a abonançar o tẽpo | de algua maneira, e a dar aos Marinhei|ros algũa pequena esperança, com aqual | comessarão a acodir a seus

85 officios, e a refffazer como podião os dannos que tinhão | recebido da tormenta, assi no leme, vel|las, e enxarxia, como em algũns outros | lugares do Navio. [espaço] Hia o tempo acla|rando cada hora Mais, e elles occupa|dos neste exercicio, tiverão com grande | alvorosso vista de hũa terra alta, mas | tão cuberta de nuvẽns que a fazia pare|cer mui distante; e não a conhecendo | pella carta, nem podendo á quella hora | thomar a altura,

90 demarcarãona com a || [106v] agulha determinando thomalla ${ }^{12}$, por que | qualquer que fosse lhe seria menos perigo|za, que o Mar, e Navio espedaçado, em que | vinhão. E resoltos $^{13}$ nisto derão hũ bolso | de vella, e forão navegando para la, mas | porque se lhe anoite hia cerrando temendo | de dar à costa se correcem, tornarão atho|mar a vella detreminando pairar toda | a noite, porque o Mar estava ja menos | grosso, e como 95 amanhecessem irẽ deman|dar a terra, e não foi este por ventura|O Menor perigo, posto que parecia o melhor | concelho, porque ainda que o mar não andasse | ja tão inquieto toda via lhes derão tan|to trabalho os balanços, e pancadas da | Galleaça, que pareceu forçado darem outra | ves algua vella fazer na volta do $\operatorname{Mar}^{14} \mid$ que algũns acconselhavão, a fora que elles jul|gavão o Navio por de todo aberto. [espaço] $\mathrm{O}$ | vento 100 era alli travessia, tão rijo, que por | força os levava a terra, e assim escolhẽ|do o menor de tantos malles, forãoce a | demandalla com quazi nada de vella | prestes para Encalhar. Eo que mais aconte|ceu veremos no capitulo que se segue.

12 Dado que a ilha avistada não constava do mapa, os marinheiros marcaram a posição da bússola (agulha) a fim de poder mais tarde verificar exatamente em que posição (altura) estavam.

${ }_{13} \mathrm{~B}, \mathrm{C}$ : resolutos.

${ }^{14} \mathrm{Ou}$ seja, como o mar ainda estava um tanto agitado e a nau estava próxima à costa, temendo topar com alguma pedra ou outro tipo de obstáculo, eles decidiram afastar-se para o mar novamente. No entanto, eles não conseguiriam realizar seu intento, pois, como se dirá a seguir, o vento era de travessia, ou seja, soprava em direção à costa. 


\section{Capitulo 36}

\section{De como os Reys derão $\|$ [107r] em terra, e forão encan|tados, e do que fes o Em|perador com a fama $\mid$ de sua perdição.}

Bem claro ficarà o perigo em que | aquelles Reys se imaginavão, pois esco|lhião por remedio hir de noite com vento | rijo demandar hũa costa não conhecida | prestes para darem nella. Deste modo os | deixamos no capitulo passado, e indo assi | não andarão muito espaço, que sentirão toccar | o Navio como em vaza, ou Area, e a|codindo logo com o prumo $^{1}$, foi couza | Maravilhoza que não acharão agoa, e

10 cor|rendo como dezatinados pellos bancos, | e coxia hũns ca, outros lá, parecialhes | (e assi era) que corrião por terra firme, e se|gura, e porque o fogo dos lampioes se lhes | apagou logo não se vendo hũns a os | outros, nem se entendendo com a grit|ta das mulheres, forçados ${ }^{2}$, e marinheiros, | determinarão com hũa nova, e intrince|ca dor que todos sentião, esperar amenhã | para verem o que não entendião, e como hũns | e outros

15 assentarão nisto, ficarão logo | todos em hũ profundo silencio sem | ouvirem mais que huns gritos de infini|tas Aves nocturnas que por alli andavão | tão tristes emal entoados, que se lhe dobra\|[107v]va a penna interior que sentião. [espaço] Não | tardou amenhã com novos Motivos de / descontentamento para elles, porque ainda $\mid$ que não era mui clara, toda via se acha|rão em hũa terra a seu parecer despo|voada de gente, de arvores,

20 de Ervas, e | de Animaes. ${ }^{3}$ rodeada toda do Mar como | Ilha de figura longa, e Estreita. Teria | de comprimento legoa, e meia, e me|nos de meia de largura, com tres castellos | grandes velhos, e mal obrados, assentados | como em compasso, nas pontas, e no meio ${ }^{4}$, | Nos quais parece que se recolhião, e criavão | a quellas multidões de Aves, que de noite | Ouvirão. Eo que os mais estantava que tudo, | era ver, que do navio, em que

25 vierão, não ap|parecião fragmentos algũns, nem elles se | achavão com nenhũa couza menos do | que nelle embarcarão quanto as recameras, que | tudo vião diante de si, e não se lembra|vão como dezembarcarão, nem enten|dião o modo de que se perderão, e para que tudo | fossem novidades, todos sem que cahissem | nisso, estavão divididos hũns dos outros, | de maneira, que em hũa das pontas se a|charão ElRey D Duardos, seu filho

30 Pal|meirim, Pompides, Platir, Blandin|don, E ElRey de Navarra. E da outra | Floriano,

\footnotetext{
${ }^{1}$ O prumo, também chamado sonda, era um pedaço de chumbo que, amarrado a uma corda, se utilizava para verificar a profundidade da água.

${ }^{2} \mathrm{Na}$ época, era comum que as galés levassemforçados, isto é, prisioneiros.

${ }^{3}$ Aqui, o copista inseriu um ponto final que ele mesmo desconsidera, visto a frase continuar com letra minúscula.

${ }^{4}$ Ou seja, dispostos exatamente nas pontas e no meio, a distâncias regulares.
} 
Polinardo, Beroldo, Gracia|no, Francião, D Rosuel, [espaço] No meio as \| [108r] Raynhas, e a Princeza, e as outras mulhe|res de seu serviço. [espaço] Os forçados da Gale|aça e mais gente do Mar não aparecião. | Os cavalleiros estavão armados, porque tan|to que o dia de antes tiverão vista de terra | e se detreminarão em demandalla, logo |

35 thomarão as armas para o que pudesse succe|der. [espaço] E estando hũns, e outros nesta con|fuzão assentado cada qual dos bandos que | todos os que faltavão se afogarão a o tocar | do Navio, e que verdadeiramente tocara, | e se perdera sem o elles sentirẽ mais que | no primeiro Movimento ${ }^{5}$, dobrandocelhe com is|to a dor que os atormentava, que em nenhũ | espasso os deixara depois que alli chegarão, | determinarão em ir ver se

40 na quelles | Castellos havia algua gente, ou couza | por onde pudessem conjecturar onde es|tavão, E caminhando cada hũa destas | companhias para o que lhe ficava mais perto | entrando nelles não a charão mais que ruhi|nas antigas, limos do Mar, Niños ${ }^{6}$ velhos | e novos da quellas Aves, e immundici|as dellas. E vindo cada hũa por sua par|te a demandar o do meio, como aquil|lo verdadeiramente era hũ Encantamẽ|to em que elles

45 sem o entender estavão | e elle obrava ja conforme á tenção | de quem o fizera, não so mente se | desconhecerão hũns a os ouros, mas || [108v] a cada qual delles se lhes afigurou que os que | vião levavão aquellas Prẽncezas pellos ca|bellos á rasto, trabalhando de as meterem | na quelle castello, de que ellas com grittos que | rompião o ar se queixavão, e deffendião, | como lhes era possivel. [espaço] Não se pode | crer a

50 colera que logo conceberão hũns | contra os outros, e cegos della, e mais ce|gos da forsa do Encantamento remete|rão Irmãos a Irmãos, Pay a Filho, pa|rentes a parentes, amigos a amigos cõ | as espadas nas Mãos, e os Escudos em|braçados, e começarão entre si a mais las|timoza, e cruel batalha que nunca se vio | no Mundo, Mattandoce todos pella | honrra, e servisso dos que os Matavão, | na qual D. Duardos, e Francião, Po|lynardo, e

55 Platir, Beroldo, e Pompides, | Blandindon, e Graciano. ${ }^{7}$ D Rosuel, | e Dragonalte, Palmeirim, e Floriano, | se tratarão de maneira, que em pouco es|passo estava aquelle fingido sitio semeado | de pedaços dos escudos, de Malhas, de lorigas, | e de seu proprio sangue a o parecer. [espaço] | Não lhes deixava a Ordem da quelle | cruel Encantamento fazer discurso | nem tambẽ acabar as vidas, que muitas | vezes se perderão de todo no rigor da | quella contenda, mas como Deus não | da licença a o Demonio, cujas aquellas

\footnotetext{
${ }^{5}$ Cada um dos grupos acreditava que o outro havia caído ao mar quando a galeaça foi movimentada pelo primeiro contato com os limos e a areia da praia.

${ }^{6}$ Esta é, salvo engano, a única ocasião em que o copista adota a grafia $\tilde{n}$ ao invés de $n h$.

${ }^{7}$ Este ponto final deve ser desconsiderado.
} 
|| [109r] obras erão para as tirar a algue é ${ }^{8}$, contentou|ce a pessoa cujos ministros elles naquillo | forão com lhes escolher a penna que mais | os atormentasse, e de que menos pudessẽ | nunca ser livres, e Assim em quanto onão | forão gastavão o dia $\operatorname{todo}^{9}$ na quella | batalha, e de noite se apartavão, e curavão | hũns companheiros aos outros, 65 tornando | todas as menhãs à quelle mortal exerci|cio, sem entenderem como se lhes passa|va o tempo.

As Princezas tambẽ a o seu | Modo padecião o mesmo trabalho, porque | todas se achavão juntas na quelle castel|lo, tirando Carmellia, e Celinda sua | Aya, que em hũ apozento separado as | tinha quem as alli trouxera para o fim que a $\mid$ o diante veremos

70 demaneira occupadas | de somno, que nada do que passavão sentião. | E as outras cuidavão que tudo o que não vião | se perdera no Mar, salvandoce ellas sós, | e que aquelles cavalleiros se combatião | em competencia de quais ficarião melhor | entregues no rico despojo de suas pessoas $\mid$ dellas, E assim não dezejando a victoria $\mid$ a nenhũns, pezavalhes das feridas de to|dos em quanto os dispunhão para serẽ vencidos | dos 75 outros.

Os Marinheiros, a Chusma, | a gente de cerviço da Galleaça e dos Reis || [109v] se acharão a o Outro dia todos em terra | sem saberem o como na Costa de Un|gria, allembrandoce da tormenta que | passarão, e de que o Navio toccara em terra, | firmemente crerão que anado se tinhão | salvado, achandoce particular mente mo|lhados,

80 e que todos os outros se afogarão; | E assim o comessarão a publicar con|firmando a nova que a Armada que par|tira de Constantinopla com os Reys | em differentes esquadras cada hũa em | sua parte tinha dado delles, porque como a | tormenta com que se apartarão foi mais | arteficial, e nascida de hũ Odio Entra|nhavel, que por curso algũ do tempo, ou | influxo dos planetas, na primeira trovoada | perderão os Navios a

85 Galleaça de vis|ta sem que elles padecessem outro algũ | danno ${ }^{10}$. E não havendo passado a cerra|ção, que a seus olhos durou poucas horas, | buscandoa ${ }^{11}$ depois algũns dias por todas $\mid$ aquellas alturas, por onde conforme ao | vento entenderão que poderia correr, não | achando nenhũa nova della, crendo que | a comera o Mar, se tornarão algũns | a suas terras cheos da tristeza que aquel|le sucesso pedia, e outros arribarão a |

\footnotetext{
${ }^{8}$ Ou seja, era da vontade de Deus que alguém os salvasse daquele encantamento.

${ }^{9}$ A palavra foi corrigida, pois antes havia sido escrito toda.

${ }^{10}$ A única nau encantada por Drúsia Velona havia sido a galeaça em que os reis e príncipes iam todos juntos; as restantes naus da esquadra que os acompanhava perderam a galeaça de vista e seu tripulantes foram levados à costa da Hungria, de onde começaram a espalhar a notícia do desaparecimento dos reis.

${ }^{11}$ Buscando a galeaça. O não do início da frase aparentemente a deixa sem sentido, embora B e C também o registrem.
} 
90 Constantinopla a dar conta delle a o Em|perador, que ainda que mostrava consolarce | com as fracas esperanças que no cazo se po\|[110r]dião ter, cuidando que poderia a Gallea|ça thomar algũa terra na força daquel|la fortuna, não deixava de sentir ta|manho mal no grào em que o obrigava | a amisade e parentesco da quelles Prin|cepes, [espaço] E assim hia passando mandan|do fazer delligencias por todas as Ilhas, e | portos de Mar

95 de que se tinha noticia.| Mas tanto que os Marinheiros, e mais | gente da Galleaça, que sahirão em Ungria | se começarão a espalhar confirman|do a nova da perdição, e morte dos Reys | em toda aparte chegando brevemente | a o Emperador algũns delles, não pare|ce que se elle pudera deffender de tão ri|gurozo golpe, se juntamente lhe não | chegara avizo de Daliarte, em que lhe | certeficava que os Reys não erão mortos | se

100 bem não estavão em sua liberdade. | Com o que socegandoce o Emperador | algua couza, mandou logo recado a os | Reynos de todos assi para se aquietarem | algũns Movimentos que podião nascer | no governo delles, como para que por todas | as gentes interessadas na quella univer|sal perda se fizessem deligencias pellos | acharem. [espaço] Com o que se começou | a encher o Mundo de novas Aventuras | e 105 acontecimentos grandes como no | discurso desta historia veremos, e desta || [110v] maneira se cumprio nas Pessoas da $\mid$ quelles Princepes a prophecia referida $\mid$ com mais certeza, do que elles por ventura | então cuidarão, ou com mais brãdura $\mid$ pello menos ${ }^{12}$. Os quais deixaremos na | penna que temos visto por dizer quem | lha ordenou, e outras couzas que dela suc|cederão.

110

\footnotetext{
${ }^{12}$ Não fica claro por que o narrador diz que a profecia se cumpriu com mais brandura que o esperado. O texto da profecia da Appolidón (cf. cap. 14) diz apenas que sem o valor de D. Duardos e a virtude da espada encantada que ele retirou do dragão, nada poderia prevelecer contra a maldade que sedo serà executada nas cabeças dos melhores que me virem, isto é, dos reis.
} 


\section{Capitulo 37}

\section{Em que se da conta quem en|cantou estes Reys, e de como | Albaizar, Florendos, e Flo|ramão se partirão da $\mid$ Corte.}

Escritto foi atras como Albaisar, e Be|liazem com a companhia que dicemos | partirão para Constantinopla sem que | sua May o soubesse, a qual quando os achou | menos ainda que se desconsolou muito não | sabendo a jornada que tinhão feito, pare|cendolhe que não seria muito apartada, e peri|goza, não o sentio tanto, mas como che|gou a maior parte de sua gente com a | nova da Morte dos Gigantes, e do risco, | em

10 que Beliazem, e elle ficavão, então | se dobrou a dor, renovando a da morte || [111r] de seus Pays ${ }^{1}$, e a da perda de tantas gen|tes, e depois de passados os primeiros impetos $\mid$ de tão justo sentimento querendo tra|tar do remedio daquelles Princepes | fes vir Drusia Velonna, aquella grã|de Sabia sua amiga, de quem na Cho|ronica de Palmeirim se conta, que en|cantou a Raynha de Tracia a seu re|querimento, em respeito do amor que

15 Flo|riano lhe tinha ${ }^{2}$. [espaço] Esta pois, a que não se | escondião as mais secretas couzas dos $\mid$ seculos futuros, claramente disse a Tar|giana que ainda que seu filho, e Beliazẽ | estavão sãos, e a seu gosto, que toda via | lhe parecia que não tornarião a Turquia | porque as estrellas lhe ameaçavão a mor|te naquellas partes Occidentaes. [espaço] A | pobre Princeza que cria na Sabia co|mo na propria verdade, derramando | muitas

20 lagrimas, torcendo as Mãos se | lhe desmaiou muitas vezes no collo, rogan|dolhe que se na quillo não podia haver re|medio, que a matasse primeiro que ella visse a mor|te do filho, como tinha visto a do Marido. | Com o que, e com o natural apetite que todos tẽ | de mostrar mor poder na maior diffi|culdade, inda que Drusia tinha visto | nos aspectos dos planetas a morte de Al|baisar, tanto por satisfazer, e consolar | sua May, como por se encontrar com || [111v] a detreminação dos Ceos prometeu a | Targiana que faria o ultimo de potencia $\mid$ pello trazer salvo a sua prezença. [espaço] $\mathrm{E} \mid$ dandolhe conta dos amores que o detinhão | e do que detreminava fazer tornouce a o $\mid$ uzo de seus instromentos esperando a oc|cazião da partida da quelles Reys para vin|gar nelles as magoas antigas, assim por | serem os proprios cauzadores dellas, como | porque por mais apartados ja do mundo | erão menos vigiados de Daliarte que seus | filhos, de cuja

\footnotetext{
${ }^{1}$ Ou seja, a morte do Sultão da Babilônia (Albaizar, pai do personagem de mesmo nome) e do Sultão da Pérsia, pai de Beliazem.

${ }^{2}$ Drúsia Velona é uma maga da Pérsia cujas artes já haviam sido requeridas por Targiana no Palmeirim de Inglaterra, quando a princesa turca concebe o plano de raptar Leonarda a fim de vingar-se de Floriano (cf. caps. 154-155).
} 
sciencia se ella mais temi|a que das armas do proprio mundo ${ }^{3}$. E or|denou a este fim a tormenta que no capitulo | passado dissemos com o mais novo modo | de Encantamento que nunca a industria | humana imaginara, fazendo conver|terce a Galleaça em que os Reys hião em | ilha, que bem conciderada tinha ames|ma forma contandoce o Mastro 35 gran|de pello castello do Meio. Eisto a respeito | de não poder ser nunca achada de nim|guem por nova, e não sabida ${ }^{4}$. [espaço] Outros | dizem que a fazia andar movibel pello | Mar, mudandoa com amesma ten|ção de hũa paragem a outra, Mas Henrri|que Frustão $^{5}$ aquem seguimos, destoutra | maneira o conta, traçando a continua bri|ga em que aquelles Cavalleiros andavão para que | occupados nella quando senão matassẽ de

40 todo || [112r] não ${ }^{6}$ cuidassem nunca no remedio de suas vi|das, ordenando mais que todos juntamen|te se unissem em danno de qualquer pes|soa que a ventura por ali trouxesse acazo, | ou de prepozito, servindoce com nunca ou|vida crueldade e sotileza do valor da | quelles Princepes para morte, ou perpetuo ca|tiveiro dos mesmos Princepes. [espaço] E porque | entendeu ${ }^{7}$ tambem do amor, que Albaizar ti|nha a 45 Carmellia, que nenhũa couza o apar|taria da quella gente se não apropria Carmel|lia, separou-a ${ }^{8}$ das outras Princezas com | aquella criada sua para lha entregar com fes $\mid$ da maneira que em seu lugar se dirà. [espaço] $\mathrm{E}$ | tendo obrado estas maravilhas, $\mathrm{e}$ encanta|do a Ilha para que se não pudesse achar sem | trabalho grande, trouche alli Targiana | como ja outra ves fizera a ver outra obra | sua, para que tambem agora visse

50 aquella, | a qual vendo a crueza da batalha inda | que nella andassem Floriano, que era o homem | a quem maior mal queria ${ }^{9}$, não lhe sofrendo | o coração ver couza tão horrenda passou|ce a o castello onde as Princezas estavão | desfeitas em lagrimas com a dor das mortes | de seus maridos que tinhão por certas, e com o | receio em que as metião aquelles aquem | estimavão enimigos de suas honrras, e sen|tindo tambem muito ver 55 entre ellas Polynar|da sua amiga bem quizera livralla se $\|$ [112v] Drusia lho

\footnotetext{
${ }^{3}$ A frase está ambígua (pois o pronome cuja parece referir-se a filhos e não a Daliarte, como deve ser), mas o sentido é claro: Drúsia temia mais a ciência de Daliarte que todas as armas do mundo.

${ }^{4}$ Os adjetivos nova e não sabida ("desconhecida") referem-se a ilha.

${ }^{5}$ B: Frustão; C: frusto.

${ }^{6}$ Esta palavra aparece unicamente no reclame do f. $111 \mathrm{v}$, mas o copista deixou de transcrevê-la no início de 112 r. Em B e C ela é transcrita normalmente.

${ }^{7} \mathrm{O} d$ está corrigido sobre letra que parece $t$.

${ }^{8}$ A separação entre o pronome oblíquo e o verbo por hífen é muito rara neste manuscrito. Outro exemplo pode ser encontrado no cap. 43, linha 12.

${ }^{9} \mathrm{O}$ ódio de Targiana por Floriano é um dos elementos centrais da trama do Palmeirim de Inglaterra, e foi motivado porque Floriano, com de hábito, seduziu a princesa e depois aborreceu-se dela. Sobre a referência ao fato de, também por ocasião do rapto de Leonarda narrado no Palmeirim, a sábia ter levado Targiana para conferir pessoalmente os efeitos de seus encantamentos, cf. o cap. 155.
} 
concentira $^{10}$. E passando a $\mid$ ver Carmellia onde a ella tinha tão occup|pada em hũ profundo somno, que nenhũa | couza sentia, pasmada de couza tão fer|moza disse para quem a guiava: Ja perdoo | a Albaizar tudo o que por esta Princeza | fizer, porque melhor se lhe pode chamar cer|to, desculpa de dezatinos, que cauza delles, e | bem serà 60 levarmola com nosco para a dispor | pouco a pouco a o gosto de meu filho, e à ${ }^{11}$ ob|servação de nossa ley para que o Matrimonio | de ambos não seja forçado, pois nos em que ha | muito menor desigualdade que a da religião [espaço] | não he possivel que possa haver vida, nem con|tentamento della. [espaço] Drusia lhe disse | que não convinha, porque antes seria meio effficacissimo para danar oaque $e^{12}$ se pretendia

65 reme|dio, porque a Carmellia quando algũa couza a o|brigasse á quillo não seria se não os extre|mos, que Albaizar por ella fizesse ${ }^{13}$. [espaço] $\mathrm{E} \mid$ com isto partindoce ficarão os da quella I|lha no estado que temos visto, e Albaizar | que por senão declarar de todo não tinha ac|companhado aquelles Reys, sebem não dei|xou de selhe offerecer para isso com mui boa | vontade. [espaço] Andando tratando de se | despedir do Emperador para

70 se ir por outro | caminho onde o animo o levava, chegarão | as primeiras novas da perdição de todos, que de ma|neira abalarão tudo, que a tardar mais o Soc $\|[113 r]$ corro de Daliarte, nem Albaizar pudera | conservar o respeito, nem o Emperador | e Florendos castigarlhe o atrevimento ${ }^{14} \mid$ porque todos andavão tais como perda tão nota|vel que não foi pequeno milagre concervarẽ | as vidas a despeito de tamanha dor. [espaço] $\mathrm{E}$ 75 pro|vasse bem qual ella ${ }^{15}$ era, porque com Daliar|te lhes mandar dizer que estavão postos em | tão grave prizão, que mais se devião contar por | mortos, que por vivos, se aliviarão grandemente | com tudo sabendo que vivião esperanda ${ }^{16}$ da $\mid$ Mizericordia de Deus, que não faltaria com li|berdade a quem tinha acodido com vida. | Estes erão o Emperador, Florendos, E Flora|mão, que alli ficara com elles, que quanto a Albai|zar, so 80 saber que Carmelia era viva o resu|citou, e alegrouce juntamente daquelle | acontecimento esperando obrigalla com $\mid$ o serviço da sua liberdade a que pello me|nos a

\footnotetext{
${ }^{10}$ Acerca da especial amizade entre Targiana e Polinarda, ver referências nos caps. 90 e 95 do Palmeirim de Inglaterra.

${ }^{11} \mathrm{O}$ acento desta palavra talvez tenha sido acrescentado posteriormente e por outra mão, visto que o traçado e a tonalidade da tinta diferem. Em B a palavra não está acentuada.

${ }^{12} \mathrm{O}$ a foi aparentemente inserido pelo copista posteriormente. B: ao que; C: o a que.

${ }^{13}$ Drúsia diz que, se Carmélia ceder seu amor a Albaizar, será pelas proezas que ele fizer em seu nome.

${ }^{14}$ Entenda-se: se Daliarte não os tivesse tranqüilizado, assegurando que os príncipes e princesas estavam vivos, Albaizar não teria conseguido conter-se e, ainda assim, o Imperador e Florendos não teriam conseguido castigá-lo, tão abalados estavam todos com o desaparecimento dos amigos.

${ }^{15}$ Ela foi escrito sobre era, a próxima palavra. "E prova-se bem qual ela [a dor] era..."

${ }^{16} \mathrm{~B}, \mathrm{C}$ : esperando.
} 
conhecesse de sua mão ${ }^{17}$. [espaço] E tão cego $\mid$ he o dezejo dos homẽns, que sem Albaisar sa|ber em que parte do mundo Carmellia Es|tivesse, nem se fosse facil, ou difficil leber|talla, ja se fazia rico dos merecimentos $\mid$ da liberdade, que cuidava darlhe a 85 pezar do $\mid$ mundo todo, e so sentia que D Duardos se | lhe estivesse adiantado no socorro dos Gi|gantes, e a esta conta nada mais dezejava que | ser maior o perigo, de que ella alivrasse. [espaço] | Com esta imaginação elle, e Beliazẽ || [113v] Se partirão a o outro dia de madrugada | deixando escrita hũa carta a o Empera|dor, em que se despedia delle dizendolhe que | não tornaria a sua corte a the revolver | o mundo na demanda da quelles

90 prezos, | com que o Emperador se mostrou contente | pello menos da gratidão da quelles Caval|leiros. [espaço] Florendos, e Floramão não tar|darão expos elles, e o proprio Emperador | de boa vontade fizera o mesmo inda | que ja sua idade não era para aquelles cami|nhos, se o governo de seu Estado, e a assisten|cia que de Constantinopla fazia a todos | os da quelles Reys auzentes lhe não ata|lharão. E assim o deixaremos a the dar 95 con|ta do que fazia o Sabio Daliarte.

${ }^{17}$ Ou seja: caso conseguisse libertá-la, Albaizar esperava que Carmélia ao menos reconhecesse que ele havia sido o autor da façanha. 


\section{Capitulo 38}

\section{Em que se da conta de alguas | deligencias de Daliarte | e do que succedeu a | Dramuziando e | a seus compa|nheiros.}

Do Sabio Daliarte (que como disse|mos se tinha partido para a sua Ilha quando a|quelles Princepes Mancebos se forão || [114r] com Dramusiando) dis agora a Histo|ria que gastava o tempo em estudar por a|quelle livro de Appolidon tão descontente | de si por o não entender de todo, que nenhũa | outra couza lhe lembrava. E thoman|doo na mão hũa tarde despois de aconteci|do o desastre, ficoulhe tão claro, como se | fora

10 qualquer dos Outros ${ }^{1}$, e acodindo logo $\mid$ a o perigo do Emperador fes a deligen|cia, que contámos $^{2}$ com outras que adiante | se dirão. ${ }^{3}$ porque agora torna a Historia | a dar conta do que acconteceu a Dramu|ziando, e seus companheiros na deman|da do socorro de Arlança, a que partirão. | E dis que navegarão com bom tempo e | sempre juntos, athe que hũa madrugada | virão terra da ilha, e chegandoce bem a | ella ja despois de

15 levantado o Sol veio | hũ batel a reconhecellos fiado na boa es/quipação que trazia. [espaço] Não era elle de ini|migos, porque o tempo tinha alterado tudo | como costuma, e assim não se esconden|do a Arlança a auzencia dos Gigantes por | aviso de algũns vassallos seus tornando a | ajuntarce hum bom numero delles, mais $\mid$ confirmados ainda na fee pellas cruezas | que começarão a exprimentar de suas mã|os, na quelles poucos

20 dias que governarão | a terra, que pella obrigação em que os punha | a obediencia, que divião a Dramusiando || [114v] seu natural senhor por tantos titulos. [espaço] | Forão a descercar Arlança, e em poucos | dias lhe tornarão a restetuir todo o | Senhorio inteiramente, porque como os so|brinhos erão os que sustentavão a força da | rebellião, idos elles não ouve mais pessoa | que resistice, e como toda via Arlança | não sabia se

25 tornarião, e esperava tam|bem algũ fruto da deligencia de Timan|dro, tinha em todos os portos grande vi|gilancia para rezistir a hũns, e para agaza|lhar a outros, e como aquelle, a que Dramu|ziando chegou era o que mais perto estava | do lugar, em que ella rezidia, alli era aguar|da muito maior.

Hora não podendo Dramusi|ando alcançar do batel (que apos reconhecer | as 30 Naos voltara logo remandoce a grande | pressa) nada do que dezejava, foice chegando | a o porto, tendo por certo que tudo estava pellos | Gigantes, e não tardarão em sahir

\footnotetext{
${ }^{1}$ Qualquer dos outros livros.

${ }^{2} \mathrm{O}$ acento indica que o verbo está no pretérito. Embora seja raro neste texto, o uso está de acordo com prática em vigor no português europeu.

${ }^{3}$ Este ponto final está fora de lugar e o próprio copista o desconsidera.
} 
delle | muitos navios cheios de gente armada que os | vinha a receber como a roins hospedes, | porque a gente do batel vendo Gigantes ${ }^{4}$ nas | náos, tornarão a voltar com apressa, que | dissemos, avizando os da terra, que erão os | de que se temião, com o que 35 inda que todos os mo|radores se encherão de novos alvoroços, e | temores, podendo mais com elles a obrigação | que o medo, e vendo tambẽ que no Mar podião || [115r] ajudarce melhor dos inimigos sendo muito | menos em numero, encherão algũns | navios que tinhão de gente, e de arteficios | de fogo, e sahirão a recebellos com gran|des esperanças de que desbaratarião as duas | Náos, em que os Gigantes não poderião co|mo 40 em terra uzar suas forças contra | elles. E chegando hũns a os outros, antes $\mid$ de haver rompimento algũ perguntan|do Dramusiando por quem se tinha a terra, e que vox seguia aquella armada? | Foilhe respondido que tudo alli era de Dra|muziando, e de Arlança sua mulher. [espaço] | E elle espantado, e alegre se tornou a affir|mar dizendo que tambem vinha em soccor|ro de Arlança, e não sendo crido facil | mente foi 45 necessario reconhecerẽ os da | Armada a Timandro, e a o proprio Dra|musiando, que toda via cuidavão que podia | ser cautella dos tirannos, porem despois | de averiguada a verdade, convertendo | em instromentos de alegria os arteficios | de fogo que trazião para o serem da morte | de seus inimigos, tudo foi demonstração | de prazer, e contentamento, o com que os | vassallos de Dramusiando o receberão. | E sahindo em

50 terra, antes que se pudesse de|sembaraçar dos aplauzos da gente de guer|ra que nella estava, para levar a agasalhar | aquelles Princepes, que o accompanhavão || [115v] a sua caza, e a ver Arlança, não tardou | ella, que sendo avizada do que passava, inda | que estava hũa boa legoa pella terra dentro | não se podendo conter nos termos da gra|vidade ${ }^{5}$, arrebatada do alvorosso de tão | alegre couza, como para ella era ver seu

55 ma|rido, e filho, acabo de tantos trabalhos, e pe|rigos de sua propria pessoa, posse ao ca|minho ${ }^{6}$, e veio ter a onde elles estavão, e $\mid$ chegando alli depois de fazer as cirimonias | costumadas, e muitos comprimentos a todos | a quelles Princepes, thomando Pavorante | entre os braços com lagrimas de Conten|tamento, mostrava, o que tinha na alma | de o ver na quelle estado. E antes de se bo|lirem dali chegou Daliarte da sua Ilha, | o qual 60 sabendo como aquelles Cavalleiros | estarião na de Dramuziando á quella | hora juntos, não quis dilatarlhes a nova da | prizão de seus Pays, inda que fosse com | offensa do repouzo de Arlança, e elles que | o conhecerão, entendendo que vinha ao pro|prio

\footnotetext{
${ }^{4}$ Trata-se de Pavorante e Almourol, que acompanhavam Dramusiando, conforme dito no cap. 26.

${ }^{5}$ Entenda-se: ao receber a notícia da chegada de Dramusiando, Arlança não pôde manter a gravidade que de uma senhora se esperava.

${ }^{6}$ Leia-se: pôs-se em caminho.
} 
socorro $^{7}$, com os braços abertos se fo|rão para elle com mostras de mais conten|tamento do que o outro trazia, e conhecen|dolho Dramusiando no rosto, que diante de | todos hia, 65 disselhe com algũ sobresalto: [espaço] | Que he isto senhor Daliante? que não me pare|ce pequeno misterio vervos em minha | caza, e neste dia com sinais de menos || [116r] contente do que vos mereço? [espaço] E informan|doos elle de tudo o que passava, converten|doce a alegria, em que estavão em dor do que | ouvião, sem outra concideração nem tar|dança cada hũ daquelles Princepes, e | Dramusiando primeiro, se

70 forão embarcar | em differentes Navios, aconcelhando Da|liarte a divizão, e com tanta pressa, que | nenhũ dos outros, nem delle se despedirão. | So Daliarte ficou, que tendolhes dito primeiro a $\mid$ morte dos Gigantes, quis tornar a dizello $\mid$ a os Moradores da quella Ilha para que per|dessem o temor delles, que com Arlança não | poude falar, porque vendo ella apreça, com que | o Marido, e filho, e toda aquella companhia | a 75 deixarão, o pouco espaço que poude lograllos, | parecendolhe que sonhara o que vira, sem ter | comprimento algũ com Daliarte se fes | levar a sua caza mais morta que viva | do que passara por ella. [espaço] Mas Daliarte que | era filho de D Duardos, e sabia a estima|ção em que todos tinhão Dramuziando, e | suas couzas, chamando os principaes de $\mid$ seus vassallos, que alli estavão juntos, assegu|rouos de todos os temores dandolhes

80 conta | da Morte dos Gigantes, e do que elles primeiro fi|zerão, e consolandoos na auzencia de seu se|nhor, confirmandoos na fidelidade que de|vião a Arlança, e a elles, e encomendando | a Timandro, que o desculpasse com ella, foice || [116v] a sua Ilha continuar em seus estudos | para remedio de todos aquelles Princepes. | E assim a elle, e $\operatorname{aos}^{8}$ outros, que logo derão á vel|la deixaremos a the seu tempo, por dizer | como D.

85 Floris com não pequena dif|ficuldade poude sahir de Napoles á mes|ma empreza thomandoo la anova da | quella perdição.

\footnotetext{
${ }_{8}^{7}$ Os príncipes imaginaram que Daliarte estava ali para ajudá-los no socorro a Arlança.

${ }^{8}$ Aqui há correção do copista: inicialmente ele havia escrito apenas $a$, inserindo posteriormente -os nas entrelinhas. Em B e C lê-se aos.
} 


\section{Capitulo 39}

\section{Do que aconteceu a D Floris | antes de sahir de Napoles.}

Ao Outro dia que se fes a batalha do Gigante | tendo a Duqueza de Montalto 5 gastado | toda aquella noite em louvores de D. Flo|ris, ajuntando às obras que elles virão a gran|de estimação em que o tinha o Emperador de | Constantinopla, e todos os mais Reys do | Mundo, sabendo o parentesco, que entre elle | e Miraguarda havia, e as calidades de sua | pessoa, tal aballo fizerão na quelle Rey estas | couzas, que sem mais concideração nẽ dis|curso, esquecido do perigo, e Merecimentos | de Filismarte,

10 detreminouce de entre|gar a filha, e o Reyno a D Floris. [espaço] E assen|tando neste pensamento, encarregou à | Duqueza que com grande segredo tratasse || [117r] logo a o outro dia com elle da quella Ma|teria, a qual Duqueza pello amor, e obrigação que lhe tinha, alvoraçada em ex|tremo, parecendolhe que lhe estava aquelle | cazamento mais a prepozito, que quantos elle | podia pertender no Mundo ${ }^{1}$. Tanto que a|manheceu teve

15 cuidado de saber quando | se levantava D Floris, e mandandolhe | recado que o aguardava na antecamara | da Raynha para hũ negocio, que importava, | elle deixando Filismarte, com quẽ estava | falando, o qual bem descuidado do novo | trabalho que se lhe ordenava, entendia só | em assegurallo de sua gratidão, e obrigallo | para outros beneficios, que delle queria. [espaço] Foise | la por hũns corredores, que sahião áquelle |

20 quarto em que pouzava, e a chando a Duque|za accompanhada de hũa Donna somente | fazendo ella apartar, sentarãoce ambos | em hũ banco que alli havia, edespois dos | primeiros, e ordinarios comprimentos | lhe declarou emfim a Duqueza a tenção | da quelles Reys, e o gosto com que aguardavão | sua reposta, crendo que com so sua pes|soa davão o maior, e melhor marido a sua | filha, e o melhor successor a seus 25 vassallos, | que podião dezejar.

Não foi pequena tentação es|ta para ${ }^{2}$ hũ cavalleiro Andante sem esta|do, vassallo de hũ Rey em nada maior que $\|$ [117v] aquelle que lhe offerecia seu Reyno, que ja | então era dos melhores de Europa, e com | a pessoa de Lysandra, que por so seu parecer | e calidades pessoaes a pudera dezejar des|herdada o maior Principe do Mundo. | E sobre tudo sendo elle tão livre, e tão se|nhor de si athe então, que não conhecia amor | se não por especulação. [espaço] $\mathrm{E}$ assim não dei|xou D. Floris de ponderar na quelle bre|ve espaço a calidade de tão importante | negocio. Mas lembrandolhe com outras |

\footnotetext{
${ }^{1}$ Este ponto deve ser desconsiderado.

${ }^{2}$ Há mancha sobre $p$ no manuscrito; parece que houve correção.
} 
couzas, que inda aquella propria menhã | prometera a Filismarte de falar a ElRey | na quelle casamento seu, disse à Duque|za, (que com os olhos nelle estava espantada $\mid \mathrm{de}$ seu silencio) [espaço] Por certo senhora, que | não sei eu como possa servir a ElRey E|varisto amerce que me quer fazer tanto ma|ior que o que lhe a elle convem, quanto o he que | aquillo que eu mereço. Mas assim porque ain|da agora não sei quão bem contado me $\mid$ seria o descanso ${ }^{3}$, não tenho feito couza com $\mid$ que me aquiete com elle, como por não per|der o Merecimento do trabalho que a qui pas|sei por Filismarte, e

40 principalmente por | lhe ter prometido bem pouco ha que o aju|daria com ElRey nesta tão justa perten|ção sua. [espaço] Haverei por força de perder o | nome de filho que quer darme, ficandome | o de criado que sempre serei seu. [espaço] E vos || [118r] senhora fazeime merce de lhe persuadirdes | que com este titullo trabalharei de lhe servir |o outro que me offerece.

45 Notavel he a força que tem nos | homẽns os appetites de que elles deixão ven|cerce. [espaço] Este Rey Evaristo era tão | desigual em suas acções como temos visto | no discurso desta historia, e tanto se tinha | entrado da pessoa, e estimação de D. Flo|ris, que não via a hora, em que lhe entregasse | a filha, e a fazenda. E assim estava detras | de hũ canzel ${ }^{4}$ ouvindo o que a Duqueza pas|sava com elle, mas tanto que 50 entendeu | a rezolução que thomava, indignandoce | como da maior injuria, logo alli o quize|ra fazer Matar $-{ }^{5}$ pella sua guarda, mas | parecendolhe que sempre haveria tempo | para aquillo, dissimulou com a paixão, e | sahio do canzel com amelhor sombra | que soube fingir, dizendo: [espaço] Por certo D. | Floris que mal vos merece o gosto com que | vos quero por filho entregandovos a cou|za deste mundo que mais amo, a sequidão

55 | com que nos desprezais. [espaço] Cuidai bẽ nisto, | e vede se vos convem o que vos offereço, | porque eu só serdes muito namorado noutra | parte será a escuza, com que me deixareis $\mid$ sem queixa ${ }^{6}$. [espaço] D. Floris, que logo se $\mid$ pos em pe em elle aparecendo lhe respon|deu: [espaço] Bem maior senhor a pudereis \|[118v] vos ter demim, se asseitara a merce que | me quereis fazer, por que eu amereço tão mal | que fora grande sem razão pagarvos essa | vontade com vos deixar enganar com|migo. [espaço] Vossa filha por vossa filha ${ }^{7}$, e | por qual Deus a fes, não ha couza grande | no Mundo que o

\footnotetext{
${ }^{3}$ Entenda-se: "não sei se teria o descanso [a vida de casado, abandonando as aventuras de cavaleiro andante] em boa conta", ou seja, se isto o agradaria.

${ }^{4}$ B: canzel; C: cansel. Não conseguimos encontrar o significado desta palavra: seria cancela ou portão?

${ }^{5} \mathrm{O}$ hífen, talvez acidental, não se justifica no contexto. Em B e C ele não é reproduzido.

${ }^{6}$ Leia-se: "porque a única justificativa que podeis dar para me deixar sem queixa é serdes muito enamorado por outra pessoa".

${ }^{7}$ A repetição, que reproduz possível hábito da linguagem falada e coloquial, significa "vossa filha em si".
} 
possa ser para ella. [espaço] Eu | sou hũ pobre Cavalleiro Andante, posto que | tão honrrado, que assim por vos servir, como | por não faltar com a palavra que dei a | Filismarte não so não farei o que me man|dais, mas me deixarei antes attar, e lançar |a 65 leões. [espaço] Filismarte he hũ grão Prince|pe, e por sua pessoa tão bem dotado da na|tureza como tem mostrado em vosso ser|visso. [espaço] Seu estado tão vizinho do vosso co|mo sabeis, e sobre tudo Lysandra tão jus|tamente affeisoada a elle, que seria tirarlho | muito grande injustiça, pella qual Deus | vos castigarà mui rigurozamente. | Lembrevos senhor quão pouco ha, que atives|tes offerecida a o rigor de hũa Ley, em que 70 | vos posto que senhor supremo não podieis | dispensar, ou não quizestes por vos não | encontrar com a obrigação que os tais tem |á observancia dellas ${ }^{8}$. [espaço] Lembrevos o que | dereis por ver salva a honrra, a vida, e o | gosto. [espaço] E pois Deus a tudo vos acodio, e a | pessoa de Filismarte he tão callificada | e o gosto de vossa filha tão declarado, não || [119r] queirais com tão perniciozo exemplo | desconçolalla a ella,

75 pagar mal a Filis|marte, offender a Deus, e escandelizar o | Mundo, a quem os maiores tem maior | obrigação de dar satisfação de si. [espaço] E | se meu serviço val com Vossa Alteza algũa cou|za eu vos pesso que esta Merce que me | amim quereir fazer, façais a Filismar|te, onde verdadeiramente entendo que | só será bem empregada.

Espantado estava ElRey [espaço] | das razões de D. Floris, mas como o 80 de|zejallo se fundara antes na virtude alhea | que na propria, mais tinha aquillo de appe|tite que de outra couza, o qual estando ja | accompanhado da soberba, julgando a | repulsa por desprezo, entrandolhe de novo | a inveja de ver a magnanimidade cõ | que hũ Cavalleiro Andante engeitava | couza tamanha so por não faltar a hum | leve comprimento que a Filismarte fizera. | Demaneira opprimirão ao pobre Rey es|tes dous 85 effeitos que detreminando que morto | pois não queria vivo lhe ficasse em caza | traçou logo alli concigo hũa Estranha trei|ção, e guardando a execução della ${ }^{9}$ para $\mid$ melhor tempo, respondeu ao Cavalleiro | o que abaixo diremos.

\footnotetext{
${ }^{8}$ Encontrar parece significar aqui "chocar-se" ou "ir contra" (em sentido semelhante ao de cavaleiros que se encontram numa justa). Leia-se: "ao rigor de uma lei da qual vós, posto que senhor supremo, não $a$ [Lisandra] podíeis dispensar, ou não quisestes fazê-lo para não descumprir a obrigação que os tais [os senhores supremos] têm de observá-las [as leis]".

${ }^{9} \mathrm{O}$ primeiro $l$ foi corrigido sobre um $f$.
} 


\section{|| [119v] Capitulo 40 \\ Do que ElRey disse a D. Floris | e do em que se elle resolveu}

Toda via vos pesso, que cuideis mais nisso | disse ElRey a D. Floris, e eu 5 cuidarei tã|bem no que me aconcelhais, porque se não | pode negar, que concorrem em Filismarte | todas as couzas que dizeis. [espaço] E falarei junta | mente com Lysandra, que algũa imagi|nação tenho que ha neste negocio segredos | que vos sabeis melhor que eu; porem em tudo | o que aqui passamos vos pesso que o tenhais | vos às proprias partes, e a Duqueza farà $\mid \mathrm{O}$ mesmo ${ }^{1}$, athe que as couzas thomem melhor $\mid$ assento.

10 [espaço] E com isto se apartarão | D. Floris tão desasombrado como quem | não cuidava se não em irse; porem El|Rey em quem fervia o sentimento da | repulsa, a dor da perda, a Enveja do valor, | Estimulado destas tres furias ${ }^{2}$, rezolveose | na mais abominavel maldade que se | pode imaginar, e foy, chamar sua filha | e dizerlhe, que a troco de lhe fazer a vonta|de assim em o cazamento de Filis|marte, como em tudo o mais que delle

15 qui|zesse, lhe pedia que trabalhasse de persuadir | D Floris a que quizesse ficar em seu serviço | offerecendolhe de seu Estado tudo o que sou|besse dezejar, porque elle estimaria mais ser || [120r] senhor so de sua pessoa, que de todos os Rey|nos do Mundo. [espaço] E ella que não entendia | a tenção que o Pay naquillo tinha, e que es|tava lembrada do que divia a D. Floris, en|ganandoce com o dezejo em the parecer | possivel,

20 cega tambem das esperanças | de seu gosto, prometeu a o Pay mil | castellos de vento. [espaço] $\mathrm{O}$ qual depois de ter | isto feito, chamou a Filismarte, e com | grande segredo, e mostras de muito amor, e | sentimento lhe disse, que estando detremi|nado alhe entregar a filha pello presso de | sua pessoa, e pellas mais partes que nelle | concorrião tinha entendido com grande | dor sua, que D. Floris, com ajuda da Du|queza de Montalto, não

25 so lhe tinha | ganhado a vontade para se cazar com elle, | mas persuadindoa, cevada em seu pare|cer esquecida das obrigações que lhe a elle | Filismarte tinha ${ }^{3}$, que aquella ou outra | noite quando melhor pudesse ser se fosse cõ | ella, pello que não via melhor remedio, que | Matar a D. Floris, antes que effeituasse | Maldade tão grande, mas que como a cou|za não era mui clara, e elle o tinha tão | obrigado na batalha que vencera, e

\footnotetext{
${ }^{1} \mathrm{O}$ rei pede que todos guardem segredo do que foi conversado.

${ }^{2} \mathrm{O}$ autor faz referência às três filhas de Aqueronte, as fúrias do inferno. Neste caso, o termo pode ser interpretado também como "ardor ou paixão violenta", como o define Bluteau.

${ }^{3}$ Leia-se: "cevada [satisfeita] em seu [de D. Floris] parecer, [Lisandra] esquecida das obrigações que tinha a Filismarte".
} 
30 era tão | aparentado com os maiores Princepes | do Mundo, que receava que lhe pedissẽ con|ta da vida alhea, $\mathrm{e}^{4}$ da honrra propria, e que | de outra parte a discimulação e tardança || [120v] no estado em que elles tinhão o negocio, era | a propria perdição, e ruina de sua ca|za, e que assim entendia que o que mais con|vinha para segurança da honrra, e esta|do de Ambos, era que elle com algũns ca|valleiros de quem se fiasse,

35 armados o | esperassem aquella noite debaixo das | jenellas de Lysandra, onde tinha por cer|to que elle acudiria conforme a o que com | a Duqueza tinha tratado, e que matandoo | tão facilmente como se podia fazer a | hũ homem descuidado, lançalohião no | Mar, e que a gente se persuadiria com qual|quer arteficio, que D Floris se partira escon|dida mente, com o que tudo ficava quieto | e elle cazado, que visse o que na quillo lhe 40 pare|cia, porque quando se não concertassem nas | oppiniões, estava determinado amatar an|tes sua filha com peçonha, que a darlhe tem|po para lhe fazer tal affronta.

Bem pudera Filismarte discur|çar concigo hũ pouco sobre o que ouvio, | ponderando a Natureza da quelle Rey, | o procedimento de Lysandra, o amor que | the a elle tinha, a singeleza de D Floris, | o pouco tempo que havia estava naquella | caza para

45 começar aquelle negocio, quanto ma|is para o ter tanto no cabo; Mas esta ne|gra paixão dos ciumes tiraniza de | Maneira O Entendimento de seu dono, || [121r] que não deixa cuidar nunca omelhor, e | acrescentandoce a Filismarte o temor de | perder a Lysandra, ou por alhea, ou por mor|ta, à esperança de que por aquelle meio po|deria ser depressa sua, sem mais concide|ração algũa se offereceu ao que lhe aquelle | Rey comettera, 50 louvandolhe a tenção, e | queixandoce de D Floris, que lho merecia | da maneira que temos visto ${ }^{5}$. [espaço] E vendoo El|Rey atravessar por outros corredores a o ap|pozento da Princeza chamado della para 1 he ${ }^{6}$ | dizer o que o Pay lhe tinha Encomendado, | como ainda lhe faltavão algũns fios que aljuntar à quella tea que hia urdindo, foise lo|go la com Filismarte, assi por lhe não dar | tempo a falarem a the fazer o que mais ti|nha 55 imaginado, como porque vendo o proprio Filismarte o modo de que Lysandra tra|tava com D Floris, ficasse mais confir|mado do que lhe elle dicera. [espaço] E tudo the suc|cedeu assas bem na quelle prepozito, por|que como Lysandra aventurava na per|suação de D Floris o gosto do Pay, o seu, | e o de Filismarte, que ella sobre tudo

\footnotetext{
${ }^{4} \mathrm{O}$ e parece ter sido incluído depois, corrigido sobre algo que havia sido escrito antes.

${ }^{5}$ Ou seja, D. Floris não merecia as queixas e suspeitas de Filismarte. O verbo cometter, logo acima, é empregado com o sentido de "delegar uma tarefa ou função".

${ }^{6} \mathrm{O} l$ inicial foi corrigido sobre um $f$.
} 
estima|va, com a mais humana demonstração | que podia lhe estava fazendo hũ largo | 60 preambulo para lhe vir a dizer o de que se ti|nha encarregado. [espaço] E parando nelle | com a vinda de ElRey, começarão ou|tras praticas, nas quais ella misturava \| [121v] sempre couzas, comque melhor dispuzes|se D. Floris para lhe não negar o que lhe de|treminava pedir, e forão ellas de manei|ra para Filismarte que as via com tão diffe|rentes olhos, que não podendo aguardar | mais, pedindo licença se foi a sua caza |

65 ardendo por ver ja executada a quella | grande façanha que cuidava fazer. [espaço] | ElRey sentindo o humor que levava, con|tente de ver como se encaminhavão aquel|las couzas, disse a D. Floris, que pois alli | estavão, que lhe queria mostrar hũ jardim | que havia na quelle quarto da Princeza | porque tambem tinha certo negocio, que tra|tar com elle. [espaço] E apartandoce primeiro com a | filha soube como com sua vinda não |

70 tivera ella tempo para lhe fallar no para que o | chamara. [espaço] Pois he necessario (lhe dice | elle) que trabalheis de o fazer inda que seja | denoite pella janella do jardim, porque te|nho Entendido que amenhã detremina | despedirce, e não façais outra couza. | Em acabando aquillo entrou com D. | Floris para o jardim, que era dos bõns que podia | ser, com toda a perfeição de lavores, embre|chados, nichos, e figuras, e columnas, que |

75 a curiozidade, e industria Italiana sa|be inventar. [espaço] E depois que o andarão ven|do apartandoo da gente que os acompa|nhava, dicelhe, que tinhão tamanho lugar || [122r] suas couzas com elle, que despois que se dezen|ganara que não queria ficar em Napoles | se detreminara logo pello que lhe tinha | aconcelhado de cazar sua filha com Fi|lismarte, e que querendo que fosse em sua | prezença, não dilatara nada o tratallo |

80 com ella, mas que como não nascera se|não para desconsolações, que a achara tão re|zoluta no Contrario, que lhe dissera que | antes se faria freira, que cazarce alli, por|que não ouvesse nunca quem pudesse di|zer vendoa cazar com Filismarte, que | não era de todo Mentira o que Cadrimonio | affirmava. [espaço] Com o que lhe não ficava | algũa Outra esperança para a persuadir, | senão conhecer a despozição que nella havia | para o 85 satisfazer a elle D Floris em tudo o | que lhe pedisse, pello que lhe rogava que quizes|se verce com ella, e persuadirlhe aquelle | cazamento, porque quando o elle não acabasse, | que não ficava mais remedio, que o da força, | da qual antes de estoutra deligencia não lhe | parecia razão que se uzasse, E com isto | acabou aquelle honrrado Rey de clauzu|lar ${ }^{7}$ a maior Enormidade, que nunca en|trou em coração humano. [espaço] $\mathrm{E}$

${ }^{7}$ B: clauzalar (leitura possível também para A); C: clauzular. Embora o termo esteja registrado no 
90 parecen|dolhe a D. Floris que seria couza facil de / tirar aquella apparente vaidade do a|nimo de Lysandra, consolou o Pay | com as melhores palavras que poude, pro\|[122v]metendolhe que faria na quillo quanto lhe man|dava. [espaço] Eindoce com isto ElRey a | sua caza gloriandoce entre si do que lhe | parecia que tinha bem ordenado, D. | Floris o accompanhou athe o deixar nel|la, e dahi se foy a sua pouzada para | 95 mandar recado à Duqueza que lhe ouvesse | hũa Audiencia de Lysandra, da qual re|sultou o que adiante diremos.

Vocabulario de Bluteau, a acepção dada não se adequa ao contexto (seria o moderno "enclausurar"). É provável que a palavra esteja empregada em sentido figurado, com significado de "decidir", "ajustar" ou "legislar". 


\section{Capitulo 41}

\section{Do Estranho perigo em que D. | Floris esteve, e de como delle | se livrou.}

100 Como D Floris não descançava | fora dos trabalhos, morria por tornar a | elles. Com esta tenção querendo dezem|baraçarce depressa da quellas couzas, orde|nava mandar à Duqueza o recado, que no | capitulo passado contàmos, mas Lysandra | que tratava negocio proprio, ouvindo dizer a | ElRey que elle se queriadespedir, parecendo|lhe que na sua assistencia se assegurava | o seu cazamento, porque não fiava

105 do | Pay que ido elle lhe deixaria de achar algũns | [[algũns]] inconvenientes, com o pouco | gosto que delle se lhe enxergava, pello menos || [123r] se detreminou em lhe pedir que se não | fosse sem deixar concluhido o que tanto | perigo, e trabalho lhe custara. [espaço] E com | esta tenção, tendo não so licença do | Pay, mas perceito, antecipouce a lhe | mandar recado que aquella noite lhe vies|se fallar a hũa janella, que

110 por mui bai|xa estava toda ferrada, aqual daquel|le jardim, em que andara sahia a hũa pra|ceta escuza, que elle tambem vira, por|que lhe queria dizer, o que aquelle dia não | pudera. [espaço] Com o que o triste cuidan|do que Deus guiava aquellas couzas, ficou | o mais contente do Mundo. ${ }^{8}$ [espaço] Tão ce|gos são os Entendimentos dos homẽns, | e tão impenetraveis as Machinas de | hũ coração humano. Passando a | tarde em alvorosso 115 grande occupado | em vizitas dos cortezãos, chegarãoce | as horas de cear, para o que chamandoo da $\mid$ parte de ElRey, (que toda via não estava | mui quieto esperando o successo, que suas $\mid$ traças terião. ${ }^{9}$ ) foy, e em acabando com a|quillo recolhendoce todos, como lhe a | D Floris pareceu hora, com hũa espada | e hũa rodella só, sem outra algũa ar|ma, nem companhia, sahio de sua | pouzada (sem que o entendesse) ao ma|ior perigo, 120 em que se nunca vira.

Não se tinha descuidado \| [123v] Filismarte, antes armando ce secretta | mente, elle, e cinco cavalleiros vassal|los, e parentes seus, de quem muito se fia|va, dizendolhes que fizessem o que lhe vis|sem fazer, foice meter com elles em hu|as cazas cahidas, que estavão à entrada da | quella praça por onde se hia ao jardim, | lugar, per que necessaria

125 mente havia de | passar quem fosse demandar a jenella, | determinado em fazer a vontade á quel|le Rey, que era o maior inimigo que tinha, | o qual não aguardava mais para se livrar | tambem delle, que o fim da quella treição, | tendo assentado de o

\footnotetext{
${ }^{8}$ Este ponto deve ser desconsiderado.

${ }^{9}$ Este ponto, também reproduzido por B, deve ser desconsiderado para a compreensão da próxima frase.
} 
despachar logo com | titulo de homecida do proprio D Floris. | Com o que lhe parecia que de todo ficava livre | de seus parentes, e vingado de ambos. | De hũ por lhe engeitar 130 a filha, e do outro | por lha querer por força. [espaço] Mas Deus que para | maiores couzas tinha guardado D. Flo|ris não permittio que tanta innocencia | fosse opressa de tanta maldade, e assim | obrou com Filismarte de Maneira, al|lumiandolhe na quelle espaço interior | mente $\mathrm{O}$ Entendimento, que o fes vir em | o conhecimento de quem era, e do que a $\mid$ D. Floris devia.

135 Tinha Filismarte muitas e mui | boas partes naturaes, porque era honrrado, | era entendido, emuito bom cavalleiro, e || [124r] tanto que a razão começou a ter algũ lugar | nelle, logo vio qual o tinha parado o im|peto da quella paixão, que o suppiditara | tanto $^{10}$, e correndoce de si mesmo no rigor $\mid$ que aquelle erro merecia, quizera conver|ter em seu danno as armas que alli trou|xera para offença de D Floris, e sem en|tender nada

140 da quella invenção, que ElRey | tinha tramado, antes crendo que tudo era | verdade, movido so da obrigação que | lhe tinha, detreminouce, não somente | em o não offender, mas em lhe ajudar a | cobrar Lysandra athe se perder a si, e a o | Estado de seu Pay na quella demanda, | juntamente, que tambem na quillo a ser|via a ella, pois não podia deixar de ter | gosto da elleyção, que tinha feito. [espaço] E | com esta generoza 145 rezolução, mandou | logo a companhia, que concigo trouxera | porque não vissem D Floris, e acertassem | de o conhecer, dizendolhes, que era passada | a hora para que vierão, e que elle seria logo cõ | elles em caza. [espaço] E deixouce ficar aguar|dandoo, que não tardou muito que o vio vir tão | descuidado, e so, como o fazia ser a ver|dade que professava. [espaço] E sahindoce de cer|to cuberto que o escondia foice andando 150 para | elle, o qual vendo aquelle homem, e que | se lhe vinha chegando foi ${ }^{11}$ o a demandar | prestes para o que lhe fosse necessario. Filis ||[124v]marte como esteve perto dicelhe rindo: | Commenos descuido Senhor D. Floris cũ|pre andar por estes paços. E elle que o conhe|ceu abraçou o com tão boa vontade, co|mo quem por seu serviço os dava. [espaço] |E assi praticando lhe fes Filismarte suas | queixas de não fiar delle os 155 intentos que lhe | imaginava, pois nimguem o havia de a|judar melhor na Occazião delles, e que ser tan|to à custa do seu gosto, estimava, por gran|de beneficio da ventura,

${ }^{10} \mathrm{O}$ verbo supeditar significa "fornecer, ministrar, administrar", acepções que não se adequam ao contexto desta frase. O autor deve tê-lo empregado com o sentido de "estimular" ou "conduzir".

${ }^{11}$ Há mancha sobre a palavra no manuscrito; a lição apresentada é a de B e C. 
porque so com a|quelle tão custozo sacreficio lhe podia sa|tisfazer a obrigação em que lhe estava pella | vida e honrra de Lysandra.

D. Floris novo na quellas cou|zas, pos a perigo com as negar a fidalguia $\mid$ de 160 Filismarte $^{12}$, e Emfim de pouco em $\mid$ mais, vierão a tirarce, ou a a clararce as | nevoas, e a descobriremce as machinas | e estartagemas de Evaristo, das quais ${ }^{13} \mid$ pasmados ambos benzendoce muitas vezes | assentarão que não havia melhor remedio | que levarem Lysandra para Cicilia, pois | em quanto estivesse em caza de seu Pay | não podião estar seguros de sua vida, e | rezolvendoce nisto forão demandar a | janella para the darem 165 conta da quelle con|certo, e da cauza delle, e chegados alli | fazendo D. Floris o sinal, que lhe tinha da|do, ella que não se descuidara abrio logo $\|$ [125r] hum postigo, pello qual despois de largas | praticas, que com ambos teve, entenden|do a Ordem da treição, que o Pay tinha | feito, pello que tambẽ passara com ella, | não se foi dalli sem que interpondoce D. | Floris não se recebesse com Filismarte ${ }^{14}$, | com que elle acabou de 170 conhecer quam | enganado vivera, e tratando logo da | disculpa, que cada hũ delles havia de dar | a o Outro dia a ElRey de não fazerem | o de que se tinhão encarregado para que nella | tivessem tempo de ordenar a partida na | seguinte noite, Antes de se rezolverẽ ou|virão hũa grande gritta no Passo, e acco|dindo depressa cada hũ a sua pouzada | para os achar nellas o que quer que aquillo fosse, | entenderão brevemente que Deus o tinha | 175 traçado melhor, porque elle que athe então dis|simulara e sofrera a quelle Rey ${ }^{15}$, ou para que se | emmendasse, ou para castigo de seus vas|sallos, vendo emfim que não lhe servia a | vida mais que de merecer maiores pennas | uzando athe em lha tirar de Mizericor|dia com elle, estando o triste na cama | envolto na aflicção que a conciencia lesa, | e a incerteza do successo de suas Ma|chinas lhe cauzavão, deulhe hũ accidente | 180 que logo lhe tirou a falla, e brevemente | a vida. [espaço] Esta era a cauza da gritta | que se tinha Ouvido, mas como elle geral $\|[125 v]$ mente era tão malquisto como suas obras | merecião, certeficandoce a gente que era | morto tudo se converteu em alvoroços. | E tanto que amanheceu enterrarãono com | tanta pressa, como se se temerão que tor|nasce a resuscitar. [espaço] E a pos isto jurando | a Lysandra por sua natural senhora,

${ }^{12}$ D. Floris, que não fazia idéia das tramas de Evaristo, negou que estivesse planejando casar-se com Lisandra. É natural imaginar que, num primeiro momento, Filismarte tenha imaginado que D. Floris estivesse mentindo, o que pôs a perigo sua fidalguia, nas palavras do autor.

${ }^{13}$ A concordância de gênero deve considerar apenas o termo machinas, visto que estratagema sempre foi considerado masculino, como atestam os exemplos aduzidos no Vocabulario de Bluteau.

${ }^{14}$ Entenda-se: D. Floris esforçou-se para que Filismarte e Lisandra se reconciliassem.

${ }^{15}$ Neste contexto, dissimular significa "relevar os pecados" de Evaristo. 
185 jun|tamente lhe rogarão todos os Magistrados, | e grandes, que intervierão ${ }^{16}$ aquelle acto, que logo | quizesse cazarce com Filismarte, porque para | o bem, augmento, e conservação de sua co|roa, nenhũ outro cazamento lhe estava | tão bem, não so pellas calidades de sua pes|soa tão justamente Estimadas, e conheci|das della, senão tambem pella grandeza de | seu senhorio, e pella vizinhança que com a|quelle Reyno tinha.

190 [espaço] E querendo ella | industriozamente alargar a resolução cõ | palavras geraes, e graves, D Floris que a tu|do era prezente lhe não concentio Oran|do de novo, em a provocação de tão acertado | Matrimonio ${ }^{17}$. [espaço] E com isto sorrindoce | Lysandra para elle da fingida authoridade, ve|io (inda que com mostras de difficuldade pel|lo pouco que havia que seu pai era morto) no | que D. Floris, e seus vassallos lhe rogavão, |

195 recebendoce com mais solemnidade ou|tra ves com Filismarte, thomando porem | a palavra a D. Floris que estaria alli com | elles athe ce celebrarem as festas que logo || [126r] se começarão a ordenar, a qual lhe elle | não poude cumprir, porque ao outro dia | chegou à quella corte a nova daperdição | de D. Duardos, e seus companheiros, | com a qual D Floris cheio do sentimen|to que divia a cazo tão desastrado deixou | aquelles

200 Princepes tão saudozos, como | obrigados aelle, o que lhe depois mostrarão | em hũ grande aperto em que o tempo $\mathrm{O} \mid$ Metteu, no que não teve pouca necessida|de de sua ajuda, que Filismarte lhe fes | com todo seu Estado, como veremos no | discurso desta historia $^{18}$, ficando bem pro|vado que nunca as obras virtuozas deixão | de ter seu justo gallardão.

${ }^{16}$ A palavra foi corrigida, pois o copista havia grafado interrierão. Intervir pode significar "achar-se presente" ou "interpor sua agência ou sua autoridade para compor um negócio" (Bluteau): ambos os significados se adequam ao contexto.

${ }^{17}$ D. Floris fez uma oração ou exortação pública em favor (provocação) do casamento entre Lisandra e Filismarte.

${ }^{18} \mathrm{O}$ episódio a que o autor faz referência aqui não se encerra nos limites desta primeira continuação manuscrita do Palmeirim de Inglaterra. 


\section{Capitulo 42}

\section{Do que succedeu a Albaizar | E Beliazem despois | que partirão de Cons|tantinopla.}

Que muito que Albaisar achasse primeiro a | Carmellia, se era elle so quem a

5 bus|cava guiado da lus da propria Carmellia | que dentro delle ardia ${ }^{1}$ ? [espaço] Assi foi, que tendo | caminhado duas jornadas despois que de || [126v] Constantinopla sahira accompanhado | de Belliazem, e tão enfadado com elle, | como quẽ lhe estorvava o gosto de suas | contemplações, porque nunca Albaizar lhe | descobrio com clareza os intentos que o tra|zião por aquellas partes, se bem como te|mos dito era aquelle o

10 homem, a quem | mais amava, e ainda que de muitas conjec|turas não deixava Belliazem de sos|peitallo, da sua boca porem não poude | nunca sabello. Tão ciozo era elle de seus | pensamentos, e tão fino, e tão contem|plativo, que não lhe parecia razão commu|nicallos, ou por não arriscar o respeito de | quem amava, ou a grandeza do exces|so com que o fazia. [espaço] E tendo, como fica | ditto, caminhado duas jornadas,

15 tão mu|do, e descontente, como o fazia ser o pe|jo da companhia, a perda de Carmel|lia, a incerteza do lugar onde estava, | o receio de poder outrem adiantarcelhe $\mid$ no serviço de sua liberdade, levãdo | detreminado de revolver o mundo athe | poder achar, ou a vida alhea, ou a morte | propria, que na quella falta seria o bem | que elle so estimasse, hũa tarde caminhã|do pella falda de hũa Floresta, vio sa|hir della hũa Donzella encima de hũ

20 | palafrem ruço, correndo elle apodia le|var em cabello ${ }^{2}$, e com o trajo mal com $\|[127 r]$ posto, rompendo o ar com grittos, e an|tes de lhe poder fallar, e detela, vio junta $\mid$ mente hũ Leão grande emedonho, que $\mid$ com hurros terriveis a vinha seguindo $\mid$ de tão perto, que ao emparelhar com elles | poude lançar as mãos nas ancas do | palafrem, com que o espedaçou tão fa|cilmente, como costumão fazer a tu|do, o que com ellas

25 tratão. [espaço] Os cavallos de | Albaizar, e Belliazem com aquelle na|tural medo, que todas as feras tem à quel|las feras, sem obedecerem aos freios, nẽ | à vontade de seus donos, começarão a | correr pello campo para se apartarẽ do pe|rigo, que a natureza lhe ensinava a ter | alli por certo; porem vendo Albaizar o | em que ficava a Donzella ${ }^{3}$, e que

\footnotetext{
${ }^{1}$ Que muito que Albaizar achasse primeiro: "O que há de surpreendente que Albaizar tenha achado primeiro".

${ }^{2}$ C: correndo quanto elle apodia levar em cabello; a B também falta quanto. A expressão levar em cabello pode indicar o fato de a vestimenta da donzela estar descomposta, como se dirá a seguir, ou que o palafrém que a conduzia estava sem sela.

${ }^{3}$ Leia-se: "vendo o perigo em que ficava a donzela".
} 
não era | tempo de domar o cavallo, lançouce | delle como hũ rayo, e foi correndo para on|de o Leão se estava cevando no palafrẽ | da triste, que sem pes para fugir, e com juizo | para conhecer seu estado, estava assentada | junto delle esperando quando lhe chegaria | a hora, mas chegou Albaizar primeiro que as|segurou tudo, porque tanto que o leão o vio | tão perto, assim banhado em sangue co|mo estava remeteu a elle para olevar nos | braços, mas apertou os fios da espada, que | se lhe pos diante, nos quais achando o

35 que | não cuidava trabalhou por se valer dos || [127v] dentes; porem Albaizar que não dormia | entregandoo no escudo que lhe offereceu | poude colhello com hũ golpe em ambas | as mãos $\operatorname{tal}^{4}$, que lhas cortou de todo, com | que o leão ficou mais bravo, mas menos | perigozo, e porque a este tempo chegara | Belliazem, que athe então não pudera | socegar o cavallo para se lançar delle | e Albaizar vio que a Donzella vendo o | leão embaraçado com elle, dezenvol|vendo os pes que o medo da morte lhe tinha $\mid \operatorname{atados}^{5}$ se hia metendo no matto, não | querendo perdella deixou o Leão dece|pado em poder de Belliazẽ, e foice | tras ella, e alcançandoa depressa porque | toda via lhe não deixava o temor ca|minhar com muita tornou a acodir a | Belliazem trazendoa concigo, o qual | tinha assas que fazer na batalha em que fica|ra, porque dezestimando o leão por Man|co

45 chegoucelhe mais do que lhe cũpria, e | elle vendoo tão vizinho erguendoce nos | pes deixoucelhe cahir de subito encima | colhendoo com os dentes pello alto do El|mo, e valeulhe ser por aquelle lugar on|de não chegou à carne para o não matar | de todo, mas a inda assim puchou tão riljo que ambos vierão a o chão. [espaço] Bellia|zem vendoce na quelle perigo não se | podendo aproveitar da Espada metteu || [128r] mão a hũ punhal 50 que trazia, e com elle | deu tantas feridas no Leão que o acabou | de matar ao tempo que Albaizar chega|va, que ainda lhe não foy de pequena | ajuda, porque com a força que o Leão fizera | no elmo não se quebrando as enlaça|duras delle, torceucelhe de maneira | na cabeça, que quazi lhe ficou a vista para | tras, e não acertando a indireitallo | hiacelhe estreitando a respiração de mo|do, que a tardar mais o socorro pudera|lhe a contecer bem grande dezastre, | mas dezenlaçandolho Albaizar depres|sa ficou tudo em passa tempo, porque ne|nhũ delles estava ferido. [espaço] E depois que lhe | encomendou que não provasse mais | forças com aquelles lutadores, quis sa|ber da Donzella quem a puzera na quel|le risco. [espaço] Senhores, respondeu ella, Eu | sou Estrangeira desta terra ando

${ }^{4}$ Tal refere-se a golpe. Leia-se: "colhê-lo com um tal golpe em ambas as patas que as cortou por completo".

${ }^{5}$ Dezenvolvendo aqui significa "soltando, desatando": o mesmo verbo é empregado em B e C. 
bus|cando algũ cavalleiro que queira fazer | hũ socorro a hũa Donna minha Tia | que certo Gigante tem preza por hũa | tamanha sem razão, como elles todos | costumão, e inda que tenho corrido boa | parte deste imperio, onde cuidei achar | o que nas outras terras não pude, não so | o não fis athe agora, antes vindo por | esta Floresta com tenção de chegar a | Constantinopla a ver se negociaria || [128v] alli o remedio a pos que ando, sahiome | alli esse leão tão de subito, que não me | deixou lugar de eleger por onde

65 fugiria mas quis minha ventura que fosse por este | onde em vosso valor me tinha assegu|rado a vida que como couza vossa farei | ja pouco offerecendoa a o vosso servi|ço. [espaço] A Donzella não era mal pa|recida, e com o gosto da vida em que a | seu parecer entrava, ainda estava me|lhor assombrada, mas porque as ramas das | Arvores por onde correra lhe tinhão | levado as toucas da cabeça, e descom|posto hũ 70 pouco o trajo, sentindoa Albai|zar com algũ pejo, e tendo o elle tam|bem de a ver da quelle modo disselhe: |Em quanto Senhora Donzella himos a | recolher nossos cavallos, e escudeiros, fi|caivos vòs aqui remediando as descorte|zias do matto mais commodamente | do que à nossa vista o podeis fazer, e | como viermos nos dareis mais larga | conta da sem rezão do gigante, e por | ventura que vos escuzaremos de thomar |

75 mais trabalho em buscar quem vos satis|fassa della. [espaço] E com isto voltandolhe as | costas levou Beliazem concigo, que de / melhor vontade a ficara acompanhan|do. [espaço] Aqual vendoos apartados acodio a o | lugar Onde o Palafrem cahira, e tirando || [129r] de hum lio $^{6}$ que nelle trazia o que lhe pareceu | depois de se compor á sua vontade foy | a receber os Cavalleiros, que ja voltavão tendo | recolhido os Cavallos, e

80 Escudeiros. E porque nis|to se não gastou muito tempo, he de crer que as | Donzellas daquelle não tinhão açafates muito | curiozos nem com muitos vidros, pois com a | queda, e trabalho do palafrem não se perdeu | o cabedal, se por ventura não vinha em pa|peis, que tambem as que caminhão se costumão | aporveitar de certas letras de cambio $^{7}$. [espaço] $\mid$ E chegando hũns aos outros, querendo os $\mid$ cavalleiros saber

85 inteiramente da Don|zella a cauza de seu desterro, ella lhe con|tou como hũ Gigante senhor de hua Ilha | que entre Grecia e a Marca estava roubara | aquella Dona sua Tia de hũ castello em que | vivia defronte de sua Ilha cituado nas der|radeiras prayas da Costa

\footnotetext{
${ }^{6}$ Não conseguimos descobrir o que significa esta palavra, transcrita com a mesma grafia em B e C.

7 A observação irônica acerca da conduta feminina é obscura. Se de início o autor parece criticar a quantidade excessiva de cosméticos e adereços utilizados pelas mulheres de então (o que contrastaria com a relativa simplicidade dos usos do tempo em que se passa a história), por outro lado a referência às letras de câmbio diz respeito a hábitos ou circunstâncias que nos escapam de todo.
} 
de Grecia pora|quella parte, e porque nella não achara hũa Don|zella sua filha, aquem o Gigante queria | haver as mão para aqueimar viva (segundo | elle dizia) porque por seu 90 respeito matarão | hũ sobrinho do Gigante, tinha jurado de | a não soltar, nem restetuirlhe o castello, a the que lha entregasse para fazer aquelle Sa|creficio á alma do sobrinho, e que na mes|ma prizão tinha ja postos algũns cavallei|ros, que ella, e a prima filha da Dona tinhão | la levado para emmendarem tão desarrezoada || [129v] força, e que por alguns delles serem extremados | em armas, e por outras certas conjecturas, se |

95 entendia que o Gigante fazia treição a os que o | hião buscar depois de lhes assegurar o campo. ${ }^{8}$ | e que disto os avizava ella a elles pello socorro que | lhe tinhão feito, que pois por elle lhes devia a vi|da propria, não seria razão quererlhes arris|car a sua para salvar outras alheas. [espaço] No a|nimo de Albaizar, e de Beliazem mais | cervirão a quellas dificuldades de incentivos | para dezejarem verce com o Gigante, que de | temores para

100 se apartarem do perigo de suas | cautellas. [espaço] E acomodando os seus Escudei|ros em hũ palafrem, derão o Outro à Don|zella, e forão caminhando athe hũ porto de | Mar que perto da li estava, onde embar|candoce em hũ navio que fretarão, man|darão navegar para a Ilha do Gigante | não lhe pezando a Albaizar daquella | Aventura, porque segundo affirmavão os | Marinheiros que se salvarão 9 da perdição | de ElRey D.

105 Duardos, na quella para|gem acontecera ella, e o animo lhe re|velava que por alli havia de achar algũa | nova do que dezejava tanto. [espaço] Tambem | Belliazem o deixava mais livre para cui|dar nisto, porque hia occupado em grange|ar a vontade da Donzella que concigo | levavão, a furto porem de Albaizar que | vivia, e tratava com tanta compostura || [130r] na quellas materias, que mais parecia hũ | relligiozo modesto, e 110 grave, que hũ caval|leiro Mancebo, e Mouro; com o que se | prova que não ha melhor Escolla de bõns | costumes, nem mais excellente Mestre | delles que o Amor e trato das Damas, que me|recem este nome. [espaço] Ora indo Albai|zar entregue a seus pensamentos, e Be|liazem divertido com os outros, tendo | velejado com bom tempo dous dias, e | duas noites, aconteceulhes o que logo diremos ${ }^{10}$.

\footnotetext{
${ }^{8}$ Ocorrência de mais um ponto final injustificado, que o próprio copista parece desconsiderar. O ponto não é reproduzido por $\mathrm{B}$ e $\mathrm{C}$.

${ }^{9}$ A palavra foi corrigida; antes o copista havia grafada salvavão.

${ }^{10} \mathrm{O}$ próximo capítulo narra o encontro de Albaizar com os reis que haviam sido encantados, e a donzela que os levava para a ilha onde a tia estava presa não é mais mencionada. A aventura será resolvida mais tarde, por D. Duardos (cf. cap. 51).
} 


\section{Capitulo 43}

\section{De como Albaizar, e Belia|zem forão ter a Ilha on|de os Reys estavão encã|tados, e do que | nella lhe suc|cedeu}

Navegando hião estes dous Princepes na | forma que temos ditto, quando acabo de dous dias, | e duas noutes amanhecerão abarbados com | aquella encantada e terrivel Ilha estranha | sepultura de tantos corpos vivos, guiandoos | a ella, ou alus que no principio do passado ca|pitulo dicemos ${ }^{1}$, ou o favor de Drusia Velona $\|$ [130v] sua amiga, que queria cumprir a Targi|ana a palavra que lhe dera a pezar de to|da a

10 dispozição de Estrellas. [espaço] E como | ella sabia que sem Carmellia nenhũa | força tiraria a Albaizar do trabalho de | buscalla, trazendo sempre os olhos nelle | tanto que o vio embarcado guiou-o para aquel|la parte onde a ilha Estava, para lha en|tregar, e fazello ir com ella ao repouzo de | sua caza. [espaço] Mas os Marinheiros que não | conhecerão a terra pasmados da novi|dade e sitio della, como quem caminhã|do muitas

15 vezes por aquella altura nunca $\mid$ a tinha $^{2}$ visto, quizerão arribar temendoce $\mid$ do que não sabião, e como fundarão a cau|za na Novidade, Albaizar que aquillo | era o que buscava lhes fes contra sua von|tade lançar ferro em hua pequena en|seada que se fazia na quella parte por on|de elles chegarão, a qual estava senhore|ada de hum da quelles castellos que temos | ditto de maneira, que parecia que para deffen|der aquelle porto fora feito, mas como | tudo era despovoado não sentirão cou|za de que se temessem, e querendo ver | toda a terra, armarãoce toda via, e fi|zerão lançar os cavallos fora e comes|sarão a caminhar por ella sos sem ou|tra algũa companhia e quanto mais entravão | menos sem razão lhe parecia que fosse $\|$ [131r] deshabitada por ser toda calva, esteril, e | pedregoza. [espaço] E indo assim caminhan|do contra o castello do Meio, que não lhes | parecia 25 mui distante, ouvirão o ruido | da quella medonha e nunca vista ba|talha, que incessavelmente se continu|ava todos os dias, e correndo para onde a|quelle som os chamava, depressa derão | com os olhos na quelle miseravel expecta|culo fruto do odio de hũa Mulher, e do Di|abolico engenho de outra ${ }^{3}$. [espaço] Os cavallei|ros andavão tão

\footnotetext{
${ }^{1}$ Veja-se o início do cap. 42: Albaizar andava "guiado da lus da propria Carmellia que dentro delle ardia".

${ }^{2} \mathrm{~B}, \mathrm{C}$ : tinhão.

${ }^{3}$ Isto é: o ódio de Targiana e o engenho de Drúsia. Observação semelhante havia sido feita no cap. 14 (cf. nota 5).
} 
vivos, e accometedores, | como se aquella hora comecarão ${ }^{4}$ o jogo. | Albaizar, e

30 Beliazem, que como fora de | si os estavão vendo, não podião cahir | como, ou porque razão tantos, e tão valen|tes cavalleiros como aquelles lhes pareci|ão se ajuntarão em parte tão dezerta. | E despois de os Estarem vendo algũ es|paço espantados, como digo, do valor de | todos, principalmente de Palmeirim | e de Floriano, que facilmente se differen|cavão entre os outros, disse Albaizar: | Esta he a mais notavel couza que nunca |

35 cuidei de ver, e ou estou fora de mim | ou vi ja as armas que estes cavalleiros tra|zem vestidas, mas não me pode lem|brar aonde. [espaço] Eu (disse Beliazem, cõ | o mesmo pensamento estava agora. ${ }^{5}$ | se vos parece vamolos apartar, e por || [131v] ventura que folgarão com isso, e quando não | algũ meio se offerecerà para os compor|mos de algũa maneira, porque isto mais $\mid$ me parece dezafio aprazado para este lu|gar, que batalha

40 feita a cazo. [espaço] E como | Albaizar estava da mesma oppinião | sem lhe responder se foi andando segui|do delle para onde os cavalleiros se com|batião tão occupados em fazello, que a|the então não tinhão dado fe dos que os | vião. E como chegarão a elles Albaisar | lhes disse: [espaço] Se a cauza, Senhores cavallei|ros, que vos trouxe a parte tão remotta | fazer esta batalha he tal que não sofra algũa | suspenção, pedimosvos que

45 nos queirais | dar conta della para que em beneficio de | todos empreguemos tambẽ nossas pes|soas, e armas, ou conpondevos hũns | com os outros, ou ajudando aos que mais | razão tiverem ${ }^{6}$. [espaço] Por certo que pala|vras, e offerecimentos erão estes para terẽ | outra reposta differente do que lhe aquel|les cavalleiros derão, e mais sendo el|les os Mestres de toda a cortezia, e bom | termo que se podia dezejar. [espaço] Mas de |

50 maneira tinha aquella velha honrra|da envolvido os Entendimentos da|quelles Princepes, que em vendo os cava|leiros unindoce todos entre si, como se | delles so receberão as feridas de que tanto $\|[132 \mathrm{r}]$ se sentião ${ }^{7}$. Esquecidos tambẽ dos respeitos | de suas honrras para não cometerẽ tantos $\mid$ a dous. [espaço] Como leões bravos remetterão | a elles reputandoos autores das lagrimas | e prizões de suas mulheres eparentes, | e comessarão a tratallos de sorte, que se | Drusia (que não tinha prevenido aquillo) |

\footnotetext{
${ }^{4} \mathrm{O}$ copista não acrescenta o traço ao que deveria ser um ç. O mesmo ocorre algumas linhas adiante, na palavra differençavam (linha 34).

${ }^{5}$ Este ponto também deve ser desconsiderado e não é reproduzido em B. A ambos os mss. (A e B) falta o fechamento do parêntese, que deveria encerrar-se depois de disse Beliazem.

${ }^{6}$ A ordem da frase está invertida. Leia-se: "pedimos que nos deis conta da causa da batalha para que em benefício de todos possamos interferir a fim de que chegueis a um acordo (comporvos uns com os outros); caso contrário lutaremos em auxílio dos que mais razão tiverem".

${ }^{7} \mathrm{O}$ sentido da frase exige que sejam desconsiderados este e o próximo ponto final.
} 
tardara com o remedio à quelles cavallei|ros, que erão couza tanto sua ${ }^{8}$, pagarão por | ventura sem culpa propria a industria |E maldade alhea. [espaço] Mas ella (que como di|cemos) alli os tinha levado, quando vio que lhe | cahia na cabeça o que ordenara para ruina | de Outrem, recorrendo depressa a oque | convinha fes cahir subitamente a to|dos 60 em hũ profundo somno, com que li|vrou os dous companheiros do trabalho | que se lhes aparelhava, e a os outros por hũ | breve espasso daquelle, em que os ella puze|ra. [espaço] E porque lhe não sofria o coração | ver repouzar estes, e acordallos não era | couza segura em quanto Albaizar alli esti|vesse, tomou outro novo concelho, e foy | levar Carmellia, e Celinda, e a elle, e | Beliazem juntamente a o Navio, que os | alli trouxera, e depois que os la teve fazen|do tornar aquelles mizeraveis Princepes | a o exercicio, em que os tinha occupados, | foice ella embarcar tambẽ para persuadir | a Albaizar a o que tinha detreminado.

|| [132v] Parece que se governara melhor es|ta mulher que tão empenhada estava, em | o levar a sua May, pois o tinha em seu po|der e a Carmellia juntamente occupa|dos 70 do somno, em que os fizera cahir, e os | Ministros de suas Maravilhas tão promp|tos para lhe obedecerem, que fazião ley da | sua vontade della, em os por com hũ leve | voo no mais intimo das cazas de Targia|na, e alli tornallos a seu acordo, cũprir | a palavra, e celebrar as bodas que tanto se | esperavão, e procuravão. [espaço] Assi parecia quanto | a os olhos da carne, mas ou que ella não al|cançasse isto cegandoa o ceo, contra culjas

75 detreminações nimguem se reziste | nem prevalesce, ou que o mesmo ceo, que to|ma a os máos, e a os tiranos muitas vezes | por instromento de Castigo, não lhe pre|mitisse alargar tanto amão no da quella | innocente Princeza, que mais por pecca|dos de seu Pay, que por erros seus, tinha che|gado àquelle estado ${ }^{9}$. [espaço] E assi Drusia, e | toda sua negociação se perderão pello me|io por onde cuidou que tinha acabado tu|do, por que 80 tendo embarcado Albaizar, e | Beliazem invizivelmente, ella thoman|do a forma de hũ delles, e constrangendo | hũ Espirito que thomasse a do Outro, fes | com os Marinheiros que despregassem as | vellas, dizendolhes que não tinhão achado || [133r] na Ilha couza

\footnotetext{
${ }^{8}$ Erão couza tão sua: Albaizar e Beliazem eram caros a Drúsia Velona.

${ }^{9}$ A providência divina ( $c e o$ ), que às vezes se vale dos maus para castigo dos seus, não permitiria que Drúsia levasse adiante (alargasse mão) o castigo de Carmélia, visto que ela havia chegado àquela situação mais por pecados de seu pai que por erros próprios. O pecado do pai de Carmélia foi ter seduzido Targinana e a levado sem o consentimento do pai para Constantinopla, como se lê no Palmeirim de Inglaterra. $\mathrm{O}$ fato de ter sido seduzida por Floriano foi o motivo da ira de Targiana contra ele; a viagem a Constantinopla foi o pretexto que justificou a inimizade entre o Império Turco e o de Constantinopla. Dessa forma, compreende-se a observação do narrador: Carmélia estava de fato pagando os erros cometidos pelo pai.
} 
que os obrigasse a deterẽ|ce. [espaço] Elles o fizerão de tão boa vontade, | como o pararem fora contra ella. [espaço] E | despois de começarem a navegar restetu|indo 85 aquelles dous Princepes a seus jui|zos, não os quis deixar vascilar muito tẽ|po no espanto do que lhes tinha aconteci|do, antes se lhes deu logo a conhecer cõ | a melhor sombra do mundo tornando | a sua propria figura, que bastava para aquil|lo, porque como tão de Ordinario vizitava | a Targiana, e era tão estimada della, | não havia pessoa em todo o senhorio de | Albaizar, a quem elle melhor conhecesse. | E alvoraçado em 90 extremo de aver, cui|dando, que tinha achado o fim de suas pe|regrinações, e trabalhos, quis logo tratar | com ella daquillo de que so cuidava ${ }^{10}$. [espaço] $\mathrm{E}$ | apartandoa de Belizaem para que mais | à sua vontade o pudesse fazer, tanto que se | ella vio so com elle interrompendolhe $\mid$ o que queria dizer, começou com hũa $\mathrm{O} \mid$ ração grave, e pungente a preparallo | desta maneira que logo vos diremos.

\footnotetext{
${ }^{10}$ Ou seja, no amor que sentia por Carmélia.
} 


\section{Capitulo 44}

\section{Do que disse Drusia a Albaizar | e do em que se elle rezolveu.}

|| [133v] Não sei se pode amor se|nhor Albaizar (dizia Drusia Velona) des|culpar

5 hũ Princepe tão grande como vos $\mid$ sois dos erros que obrigado delle comette | contra o que se deve assi ${ }^{1}$, e a seus Estados, | porque os homẽns que fundão suas desculpas | nesta paixão, he necessario que para terem al|gua sombra dellas, sejão particulares, cujos | máos procedimentos so a elles danem, por|que se o amor he vosso, e o mal que delle nasce | alheio, claro està que não se remedea a dor | daquelle curandoce estoutro, e

10 assim os | Princepes, cujos dilirios pagão, e sentem | os vassallos, não se podem desculpar com | razões particulares dos damnos, que são | tão publicos ${ }^{2}$. [espaço] Para vos bem vejo eu que | não são pequenas ${ }^{3}$ vossa idade, vossa in|clinação, e a fermozura de Carmellia, | mas nenhũa dellas o he para se consolarem | os subditos, que dezemparais, e vossa May | de quem tendes perdido a Memoria, nẽ | o sangue de vosso

15 pay, acujos brados cer|rastes os ouvidos, e muito menos para deixa|res de cumprir com o que deveis aos Deuses, | a quem tão mal sabeis agradecer o muito que | lhe deveis, esquecendovos ha tanto tempo | de seu culto, não frequentando seus tem|plos, nem offerecendo sacreficios em Sulas Aras. [espaço] E porque saibais senhor quã | differentes memorias das que tendes deveis || [134r] a mim, a vossa May, e a os mesmos

20 Deu|zes, sabei que com trabalho meu, com la|grimas della, e com primissão ${ }^{4}$ delles, estão | em vosso poder assim todos os Matado|res de vosso Pay, e Parentes, para vos vin|gardes de todos à vossa vontade, como | a senhora Carmellia, com quem vos ca|zareis, descançado dos trabalhos, que seu A|mor vos tem dado, e dos perigos, a que por | ella andaveis offerecido, bem maiores cer|to, do que vos podeis cuidar. [espaço] $\mathrm{E}$

25 então lhe | contou por Ordem o que tinha obrado no | encantamento da quelles Reys, e lhe des|cobrio como em hũa camara da quelle | proprio navio estava Carmellia, tão | preza de somno, que sem difficuldade a | podia por em estado, que quando acordasse tives|se por bem de se cazar com elle. [espaço] E tho|mandoo pella mão, quis levallo onde a|quella pobre senhora estava tão roubada | dos sentidos, como arriscada à maior |

\footnotetext{
${ }^{1}$ Leia-se: "que se deve $a$ si".

${ }^{2}$ Note-se que, de acordo com Bluteau, o termo particular na época significava também "homem que não tem ofício público", o que ajuda a compreender a fala de Drúsia Velona.

${ }^{3}$ Elipse do termo desculpas.

${ }^{4} \mathrm{C}$ : permição; B apresenta a mesma grafia de A.
} 
30 desventura, que hua mulher honrrada pode / padescer. [espaço] Mas a verdade he, que se o amor | he grande, e os sogeitos são nobres, que pocas ${ }^{5}$ | vezes se inclinão a vilezas. [espaço] Albaizar | amava Carmellia sobre todas as couzas | da vida, e inda que Mouro era nobre, e | de animo muito mais nobre, e posto que ter $\mid$ novas della era a couza que sobre tudo de|zejava, quanto mais tela em seu poder, ser $\|[134 \mathrm{v}]$ por aquelle modo, era

35 tanto contra seu hu|mor, que lhe veio a ser Materia do maior | Sentimento, aquillo que por outro caminho | comprara a troco de todo o seu Estado, de | todo o seu sangue, e da propria vida. [espaço] | E não menos inflamado em ira contra | Druzia Velona, do que o pudera ser o pro|prio D Duardos se ali se achara, ten|doa bem segura pella mão que lhe ella dera | respondeulhe deste Modo: [espaço] Se o Diabo | cujo instromento vos sois, e 40 cujas são vos|sas obras, não estivera ja aborrecido, e en|fadado de vos, bem vos pudera dizer as | alviçaras, que por estas novas haveisde achar | em mim, porque nem eu sou homẽ, que para | me vingar de meus inimigos haja de | me valer antes de vossos enrredos, que de $\mid$ minhas forças, nem que com algũa mais | que as do amor queira obrigar a Carmellia. | E se as do que lhe tinha não bastarem para | a inclinarem a mim, 45 contentome com | que bastarào ${ }^{6}$ para a não offenderem a ella. | E porque me não sofre o animo saber o que | por minha cauza padece, posto que não por | minha culpa, o mais seguro meio para es|capardes com vida destas mãos em que vos | tenho, he obrardes de maneira com que Car|mellia seja logo levada á companhia das ou|tras senhoras, e sem que a eu veja, porque nẽ | com os olhos he razão que offenda o respeito, || [135r] que lhe

50 devo. [espaço] E tanto que la estiver juntamente | haveisde desfazer O Encantamento de todos | que livremente fação seu caminho. E in|da assim me ficareis devendo o disgosto | de seu trabalho, e o corrimento em que sem|pre vivirei de se poder cuidar que com con|centimento meu estiverão nelle. [espaço] E para | que eu fique seguro da singileza com que que|ro que procedais na conformidade do que vos | tenho ditto, haveisde jurallo

55 pellas agoas da|Lagoa Estigia, que eu sei que he o que so vos fa|rá não torcer de minha vontade $^{7}$.

Estas ultimas palavras sentio | muito mais Drusia, que tudo o outro, como | quem sabia que feito aquelle juramento | ficava attada á infalivel observação delle. | Mas por

\footnotetext{
${ }_{6}^{5} \mathrm{C}$ : poucas; B apresenta a mesma grafia de A.

${ }^{6}$ A acentuação serve para reforçar a percepção de que se trata de um verbo no futuro do indicativo. O mesmo recurso será utilizado logo abaixo, na linha 64 .

${ }^{7}$ Albaizar sabe que o único juramento capaz de impedir que Drúsia o desobedeça (torcer de sua vontade, desviando-se dela ou distorcendo-a) é o juramento em nome do Estige, ou seja: do inferno.
} 
se livrar das mãos, que tão apertada | a tinhão fazendo o juramento, confuza, | e

60 Medroza lhe disse: [espaço] Bem fazeis Al|baizar de pagardes desta Maneira a mi, | que vos sirvo, e a os homẽns que mores mal|les vos tem feito. Mas isto são obras dos | Deuzes, que a ambos nos querẽ castigar, a | mim porque contra o que elles tem ordena|do trabalhava por vos izentar de seus | poderes, permittem que a vossas mãos ve|nha a padecer tal infamia, e a vós por | tratardes com seus inimigos vos trarào | a 65 morrer ás proprias da quelles que agora | quereis livrar da morte. Carmellia || [135v] tornará como Mandais, mas o Encanta|mento não posso eu desfazer, porem se na | quelles Navios que aparecem vem quẽ eu | sospeito, brevemente se acabarà. [espaço] Mas | se vos quizeceis thomar melhor concelho | e levantarme o juramento, a que me ten|des attada, ainda tudo podia ter bom | remedio, e quando não daime esse livro que |a

70 hi cahio, e queirão os Deuzes que vos não | arrependais a tempo, que nem eu vos possa | valer, nem Carmellia gratificar esses ex|tremos de vossas nescias finezas. [espaço] Eque|rendo Albaizar tornar a apertalla, estava | ja hũ dos Navios (que erão dous, e havia gran|de espasso que se lhe vinhão chegando) tão | perto, que não teve tempo para mais que fa|zerlhe rateficar o juramento, entregar|lhe o livro, e ir a responder á gente do 75 Na|vio. [espaço] Com que lhe aconteceu o que no capitulo se|guinte contaremos. 


\section{Capitulo 45}

\section{Do que aconteceu a Albaizar | com agente, que na quelle primeiro | navio vinha.}

Verdadeiramente que bem concidera|das as couzas, que escrevemos, a variedade

$5 \quad||[136 r]$ dos cazos, a grandeza dos dezastres, a no|vidade dos sucessos, que mais parecerà que | fazemos rellação curioza de fabulas so|nhadas, que Choronica grave de Historias | verdadeiras. [espaço] Eu pello menos não quero | obrigar a maior credito aquem ler esta | nesta lingoa, do que me ficou della quando | a li na em que Henrrique Frusto a com|pos, porque não cei certo como partindo | havia tanto tempo D. Duardos da

10 Flo|resta das tres Fontes, e Albaizar algũ des|pois de Constantinopla, Vasperaldo | da Ilha de Dramusiando, D. Floris de | Napoles, se vierão a ajuntar por varios | caminhos em occazião tão forçoza, em | hũ mesmo dia, em hũa mesma paragẽ | e em hũ Mesmo Navio ${ }^{1}$. [espaço] De outra parte | quando isto fora ficção alegorica para persua|dir debaixo deste enrredo o conhecimen|to da inconstancia, e mutabilidade | das couzas do

15 mundo, e o pouco, que se pode | fiar do bom rosto da fortuna pintan|donos Albaizar em hũ pequeno Espasso | senhor da pessoa de Carmellia, e não so $\mid$ no mesmo² despojado della, mas do San|gue, e da vida, entregue nas mãos de | seus inimigos por jogo, e ludibrio de se|us tão altos pensamentos, não parece que | se Ouvera de fazer o Exemplo em pesso|a de Albaizar, porque se elle com o mais \| [136v] heroico acto que nunca se

20 achou em animo | algũ deu tão patente testemunho da gran|de fidalguia do seu, a que prepozito no lo | pintão não so mal logrando o fruto de | tamanha generozidade, mas idade tão | tenrra, e senhorio tão grande, vindo assim | a ficar o exemplo de sem razões tamanhas | so em materia ${ }^{3}$ de lastimas muito justas sẽ | se conceguir outra algũa philosophia de | tantas como parece que se incluẽ nesta His|toria ${ }^{4}$; porque se as couzas

25 que logo recitaremos | são Mentirozas, e apocriphas, toda via po|dece ver ainda assim nellas, que a fortuna | envejoza ordinaria mente de suas pro|prias obras, tanto mais

\footnotetext{
${ }^{1}$ Embora o narrador declare não saber como D. Duardos, Vasperaldo e D. Floris chegaram ali ao mesmo tempo, ele o explicará mais à frente, no cap. 50.

${ }^{2}$ Elipse do termo espaço.

${ }^{3} \mathrm{O}$ copista havia escrito materias, mas riscou o $s$ final.

${ }^{4}$ A frase é confusa e, devido a sua extensão, a paráfrase apresentada a seguir é resumida. Leia-se: "Por outra parte, se isto fosse ficção para demonstrar a instabilidade das coisas do mundo, Albaizar (que em um momento estava em posse de Carmélia e em seguida estava entregue às mãos de seus inimigos para desengano de seus altos pensamentos), não parece ser bom exemplo. Se ele deu patente testemunho da grande fidalguia de seu ânimo, com qual intenção ele seria retratado não podendo lograr o fruto de tamanha generosidade, tornando-se apenas exemplo de injustiças e motivo de lástima? Com isso, não se proporia nenhuma idéia elevada como as outras que esta história parece conter".
} 
depressa semostra | arrependida dellas, quanto maior he o cabedal | que num homem mete donde vem con|cervaremce tão rara mente os que ella tho|ma ás costas para os fazer grandes ${ }^{5}$. [espaço] E se por | ventura forão verdadeiras só em parte, | que he o que 30 mais verisimel me parece, per|suadido estou, que o que tocca a o dezastre de | Albaizar foi invenção sonhada por Hẽ|rrique Frusto, com raiva, e inveja de lhe | ver merecer com ageneroza, enão ac|costumada magnanimidade, que uzou | com Carmellia, aquella maneira de | benevolencia que lhe amesma Carmel|lia tinha, porque vós crede ${ }^{6}$ que ha gente | para quem he muito maior materia de inveja || [137r] merecer hũ homẽ muito

35 inda que possua | pouco, que possuir tudo não merecen|do nada, E essa he a differença que ha | entre ambição, e cubiça, porque a os co|biçozos, escandelizaos a ditta, e a os am|biçiozos o merecimento, e nesta con|formidade mal podia escapar o triste | de Albaizar, pois para a emulação de | hũns era tão honrrado, e para a inveja | dos outros tão ditozo ${ }^{7}$. E assim ou seja / philosophia nascida da inveja, e arre|pendimento da

40 fortuna, ou fabula cõ|posta pella dor, e raiva do Choronista, | elle escreveu o cazo desta maneira.

Grande espaço havia, dis | a Historia, que aquelles dous navios vinhão | navegando na volta do de Albaizar, | hũ muito diante do outro, mas davão pou|co cuidado com sua vista, assi porque os | seus Marinheiros tinhão a paragẽ por | segura, e cada dia por alli encontravão | navios de diversas partes, que fazião seu | caminho a differentes rumos, como por|que Albaizar que por prudencia, e coriozi|dade pudera ter algũ ${ }^{8}$, estava tão em|baraçado com Drucia Velona despois | que tornou a si, que não acodio, senão quando | ja Beliazem armado de todas as ar|mas, como o thomara o extacis, em que || [137v] os ella metera a ambos, respondia aos do | Navio dianteiro, que 50 chegara, que lhe não | queria dizer o que lhe perguntavão. E | era o cazo, que tanto que aquelle Navio che|gou (que desde que rompera amenhã o seguia) | se puzerão no castello da proa dous caval|leiros armados, hũ delles com hũas ar|mas columbinas gravadas de ouro e | prata, e no Escudo em campo azul hũ | dádo grande, cujos pontos

\footnotetext{
${ }^{5} \mathrm{O}$ pronome os (em os fazer grandes) refere-se a homem. O sentido da frase é que quanto mais a fortuna favorece um homem, mais depressa ela costuma arrepender-se de suas obras; daí se segue (donde vem) raramente conservarem-se afortunados aqueles que ela (a fortuna) toma às costas para os engrandecer.

${ }^{6}$ O porque aqui tem o sentido de "para que".

${ }^{7} \mathrm{O}$ sentido da passagem é o seguinte: a diferença entre a ambição e a cobiça é que os cobiçosos invejam a boa sorte (ou os bens) e os ambiciosos invejam o merecimento (ou o valor); por isso, nos dois casos Albaizar era invejado: aos ambiciosos, incomodava-lhes o fato de ele ser tão honrado, e aos cobiçosos, o fato de ele ser tão ditoso (afortunado, poderoso).

${ }^{8}$ Ou seja, algum merecimento.
} 
erão huas | letras que dizião: [espaço] Sempre direito. | E o outro trazia as suas cor de

55 viollas muito | escuras, e no escudo em campo de prata | hũns mares a o parecer muito tempestuo|zos, e hua Náo entre elles sem vellas, | nem governo, e dali começarão a | preguntar para onde hia o Navio, e que | gente vinha nelle? [espaço] Belliazem, que | estava desocupado vendo como aquelle | se lhe vinha chegando, posse em parte | assim armado de donde podia Ouvir | o que lhe dicessem, e impedir tambẽ o | que lhe 60 quizessem fazer. E ouvindo os | Cavalleiros respondeulhes, que o Navio | era de pàs, e fazia seu caminho para on|de lhe importava, e que nem tinha outra | couza que dizerlhe, nem elles que querer sa|ber. [espaço] Pois anos (respondeu hum | dos companheiros) mais nos importa | entender que isso, e pois não quereis satis||[138r]fazernos, forçado será que vamos la a | procurallo. [espaço] Ca não entrareis vos | (lhe tornou Beliazem) 65 senão por vosso | danno, por isso se muito dezejozos vindes | delle, podeisvos chegar, que mais depressa | vos arrependereis do que cuidais. [espaço] Não | sei como isso serà (replicou hũ dos ou|tros) mas ja desta ves havemos de ver se | conformão as obras com as palavras. [espaço] | E fazendo chegar bem o Navio, quize|rão saltar dentro, mas oppuzerãocelhes | a quelles dous Princepes com as espadas | nas mãos, e os escudos 70 embraçados, ar|mados de não menos ricas, e lustrozas ar|mas, que as suas, e ambas de hũa mesma cor | e diviza, que erão de hũ verde muito aperta|do cubertas de alcachofras de ouro, esmal|tado de suas cores, enos escudos em cam|po negro hũas lenternas apagadas | como quem sem lux hia á pos o que de|zejava, as quais Albaizar mandara | fazer para entrar na empreza de buscar | Carmellia. [espaço] E porque lhe a elle pareceu

75 | que aquelles cavalleiros os accometião cõ | pouca occazião, e que as armas, e manei|ra das pessoas não erão de cossarios | para que melhor se justificasse lhe disse: | Porque como vedes senhores cavalleiros | inda agora aqui chego, e não tenho ou|vido o que com meu companheiro passas $\|[138 v]$ tes, folgaria de saber a cauza por que | nos accometeis, que por ventura poderà | ser tão leve, que folgue antes de vos sa|tisfazer, que de 80 exprimentar o rigor de | vossas mãos. [espaço] E como elle isto dizia | com a confiança de que era cheio fes hũ | certo geito com o corpo encolhendo os | hombros, que costumava quando falava com | ironia, tão conhecido nelle, como quẽ | o tinha por natureza. [espaço] Eporque os cõ|panheiros estavão tambẽ pouco coleri|cos, e meios ${ }^{9}$ arrependidos parecendo|lhes que se tinhão demaziado muito, parti|cularmente despois

\footnotetext{
${ }^{9}$ A concordância de meios com companheiros também é atestada em B e C.
} 
85 que de mais perto vi|rão na riqueza das armas, e no modo | das pessoas, que não podião deixar de ser | de preço, estavão attentissimos olhando. | Em ouvindo falar a Albaizar, e ven|dolhe fazer a quelle Movimento que di|cemos, o que trazia a Náo por diviza, que | mais impressas tinha nalma suas cou|zas, o conheceu subita mente, e alle|grandoce pouco menos que se achara o q que todos buscavão respondeulhe: [espaço] Bem | vejo

90 que zombais senhor Cavalleiro, mas | eu vos affirmo em verdade que tudo vos | fora melhor como logo vereis, que encon|trarmonos aqui. [espaço] E em dizendo is|to saltou no Navio de Albaizar tão | inconciderada mente, que esteve perto || [139r] de perderse, porque com a força que fes nos | pes para dar o salto, afastou o seu navio, | que ainda não estava afferrado, e cahio de $\mid$ rosto entre aquelles dous cavalleiros, que | facilmente 95 o puderão opprimir, mas co|mo aquelle era o dia em que Albaisar ha|via de mostrar todas suas finezas, espe|rando que se levantasse lhe disse: [espaço] Por | certo que com menos perigo vosso vos a|gazalhara eu ca dentro se vos soubera| essa vontade. [espaço] Não tenhais compri|mentos comigo (lhe respondeu o da Nao) | que eu nenhũ eide ter com vosco, nẽ ei|de deixar de vos cortar essa cabeça como | dezejo ha muitos dias.

100 [espaço] Não sei (lhe disse | Albaisar) a quem devo esses dezejos, porque | ainda agora vos affirmo, que nẽ os tenho | iguais para vós, nem cuido que me conhe|ceis, [espaço] Mas estais tão bravo que me parece | que me não querereis Ouvir nenhũa sa|tisfação que vos de de palavras $^{10}$, por isso se|rà forçado que nos remetamos às Obras. $\mid \mathrm{E}$ então dizendo a Beliazem que não | bollisse comcigo em quanto não chegava | o Cavalleiro,

105 que como hũ cão raivozo | se vinha Mordendo a si mesmo, pa|recendolhe que tardava em tornar a ar|rimar o Navio, começou a ferir o | da Náo de Maneira, que a não ter ja ex|periencia de seus golpes, bem se pu\|[139v]dera arrepender da pressa com que fora | buscar a quelle gazalhado. [espaço] E o compa|nheiro em se os navios tornando a | ajuntar como hũ passaro se lançou $\mid$ dentro, e sende ${ }^{11}$ recebido de Beliazẽ | começarão 110 todos quatro amais perigo|za, e cruel batalha, em que se elles nun|ca virão, E mais digna, em verdade, | da quelle ${ }^{12}$ grande terreiro de Constan|tinopla, e do juizo das Damas daquella | caza, que da rusticidade dos Marinhei|ros, e do silencio da quelles Mares, a $\mid$ quem os ventos ${ }^{13}$ parece que deixarão so|cegar todo a quelle dia, como que

\footnotetext{
${ }^{10}$ Leia-se: "vos dê de palavras".

${ }^{11} \mathrm{~B}, \mathrm{C}$ : sendo.

${ }^{12}$ Palavra corrigida: inicialmente o copista havia grafado da guelle.

${ }^{13}$ Paravra corrigida: inicialmente o copista havia grafado vendos.
} 
estives|sem attentos ás couzas que nelle alli passa|rão, as quais acabaremos de ver 115 depois | de descançar aqui hũ pouco. 


\section{Capitulo 46}

\section{Da cruel batalha que aquelles | cavalleiros fizerão, e de | como chegou a elles | Outro Navio.}

Porque presso hũ Poeta deixara de $\mid$ fazer neste passo hũa grande ladainha $\mid$ dos Glaucos, Milicertas, dos Tritoes, e das || [140r] Nereidas ${ }^{1}$ ? Mas Henrrique Frusto, que com | estillo mais singello conta suas poezias | dis somente, que os Cavalleiros se anda|rão ferindo tanto espaço, que ja as armas | tinhão perdido o mais de sua fermozu|ra, e fortaleza, e elles começavão a sen|tir nas carnes a pouca rezistencia que seus | golpes

10 tinhão nellas, particularmente Be|liazem, que andava o peor tratado de todos. | Albaisar como se na quella hora come cara $^{2}$ a batalha assim respondia a seu con|trario, que mal se podia julgar qual delles fi|cava devendo. Passavace o tempo, o ou|tro navio vinhace chegando, e cuidan|do Albaisar, que poderião ser ambos de hũa | conserva appressavace por acabar o que | tinha diante, antes que o outro chegasse. | Mas que importava? que

15 elle haviao com Ves|peraldo tão valente, que não sofria venta|gem, e tão raivozo que se lhe dobrava a força. | Beliazem hia enfraquecendo tão conhe|cida mente que se quis tirar a fora, mas o | outro que tambem se $\operatorname{siava}^{3}$ do Navio, que | via vir, não lhe deu lugar para isso, an|tes o começou a apertar de maneira que | ja o pobre Mancebo não entendia em | mais que guardarce dos golpes, o qual ${ }^{4}$ por|fiou tanto, que o fes chegar a o bordo, e ven|doo alli cerrou com elle abraços, e junta | mente o levantou no ar, e o arrojou do || [140v] bordo abaixo, onde com o pezo das ar|mas nunca mais apareceu. [espaço] Bem | quizera Albaizar valerlhe, que não deixava | de ver o que passava, mas Vasperaldo $\mathrm{e}^{5}$ en|treteve tão de cizo, que não poude fazer ma|is que sentir que se lhe chegava a hora, mas | não que deixasse de o apertar de modo, que | nem hũ tinha de que segabar, nem outro | de que haver inveja. [espaço] E porque a necessida|de de descançar era igual,

\footnotetext{
${ }^{1} \mathrm{O}$ autor refere-se, um tanto despropositadamente, a divindades marinhas da mitologia clássica. Glauco era um pescador que, arrojando-se ao mar, foi recebido por Oceano e Tétis e transformado em Tritão. Milicerta (ou Melicertes: dependendo da versão, pode ser uma figura masculina ou feminina) também foi lançado ao mar juntamente com a mãe (Ino); os deuses compadeceram-se de sua desgraça, transformando-o no deus Palêmon, que era invocado pelos marinheiros e tinha o poder de salvá-los de naufrágios. Os tritões eram monstros marinhos com aspecto humano da cintura para cima e cauda de peixe; portavam cornos que emitiam sons estridentes e irresistíveis aos seres humanos, além de terem capacidade de prever o futuro. As nereidas são as ninfas do mar.

${ }^{2}$ Falta o traço do $c$, fato já verificado anteriormente (cf. cap. 43, nota 4).

${ }^{3} \mathrm{O}$ verbo ciar aqui parece ter o sentido de "preocupar-se".

${ }^{4} \mathrm{O}$ qual refere-se ao outro cavaleiro, com quem Beliazem combatia.

${ }^{5} \mathrm{~B}, \mathrm{C}: o$ entreteve.
} 
ambos se ti|rarão a fora. [espaço] Vasperaldo chegan|dose a D. Floris (que era o companheiro, | com quem se tinha ajuntado pello modo | que adiante diremos) disselhe: [espaço] Senhor | D. Floris, como vedes, neste Navio não | ha mais gente, que este cavalleiro, que comigo | se combate, e o outro, de que vos vos dezẽ|baraçastes, por amor

30 de mim que vos | queirais tornar a o Nosso, porque ainda | que eu sei que me não fareis tamanha in|juria como serà quererme favorecer, | por ventura, que o não imaginarà assim | Este cavalleiro, e que o cuidado disso o | ajudará a quebrantar. Curarvoseis en|tre tanto, que estais ferido, e depois se minha | fortuna me não deixar levar adiante | esta obra como dezejo, tão bom navio | tendes como este, e tão perto estais, | que podereis

35 saber quem me matou, que | para me vingar pouco vos ficarà em que o || [141r] [[o]] fazer; E tambem podereis ${ }^{6}$ estorvar | o outro, que tanto se nos chega, se | por ventura vier em nosso danno. | D Floris lhe respondeu: [espaço] Pareceme | senhor, que he isso Escuzado, porque para satis|fazer a o cavalleiro, bem basta que me | veja elle estar Occiozo, e para rezistir | a o Navio estou melhor ca, e as feri|das não são tais, que hajão $40 \quad$ mister curadas $^{7} \mid$ com essa pressa.

Albaisar que neste espaço este|ve conciderando o que Drusia Velona | havia tão pouco the tinha ditto, e que se | vinha a perder tendo a Carmellia na quelle Navio, despois que de novo tor|nou a assentar concigo que com melhor | vontade Morreria, que arrependerse do |que tinha feito, creceulhe tanta força, e | tanto allento, de lhe parecer

45 que não po|dia ja a fortuna fazerlhe mal tama|nho, que igualasse o bem, que della recebera | em lhe dar Occazião para Mostrar O A/nimo que tinha nas couzas de Carmel|lia, ficou tão outro, como digo, favore|cido deste pensamento, que gritou a D. | Floris, e Vesperaldo, que estavão nos compri|mentos que contámos, dizendolhe, que se | esperavão socorro no outro Navio, que | vinha chegando, que ainda que fosse gran|de, 50 não poderia prevalescer contra o $\|[141 \mathrm{v}]$ que the a elle na quelle espaço dera a | suavidade de hũ pensamento seu. | Mui bem ditto esta isso (lhe respondeu | D. Floris) mas eu sou tão groceiro que | vos thomara antes hũ bom par de com|panheiros á ilharga. [espaço] E para que vejais co|mo os pensamentos enganão, Esta | dettença, que cuidaveis era esperar socorro | foi pedirme meu companheiro que me | fosse a o Nosso 55 Navio para vos desasom|brar. [espaço] Albaisar conheceu D. Flo|ris na quella Maneira

\footnotetext{
${ }^{6}$ Palavra corrigida: o $o$ foi escrito inicialmente como $d$.

${ }^{7}$ Embora a lição de A coincida com a de B e C, aparentemente foi omitido o verbo ser (mister ser curadas).
} 
de fallar, porque | a experiencia de quão levemente ven|cera Beliazem, e tello por engraçado, e | livre de amores, lhe fes que se affirmasse | nisso, e correndo pella memoria as pallavras de Vasperaldo, e seus golpes, tambẽ | lhe ficou claro cujos erão, porque nem | havia outrem, com quem vivesse tão | inimistado, nem de quem cuidasse |

60 que o apertaria tanto. E assentando nisto | bem lhe pareceu que so vencer, ou Morrer | poderia apartar aquella contenda, e | duvidando do vencimento, não quis | toda via deixar de fazer tudo, o que se di|via a si, e a seu animo, e nesta con|formidade respondeu a D Floris: [espaço] | Se me eu não engano cavalleiro, de ser|des muito livre vos vem dizeres heregi|as contra opoder dos pensamentos, $\|$ [142r] E por aqui me parece que vos conheço, e | sei de vos que mais depressa cuidareis o que |me dicestes, do que ajudareis a vosso com|panheiro por mais apertado que o vejais, | pello que vós a vós mesmo deveis. Eassi | vos pesso não so que vos não queirais ir, | Antes que mui devagar estejais vendo es|ta batalha, e se o sucesso della for qual lhe | eu espero, que mudeis de oppinião no cre|dito dos pensamentos, porque se sois o que | eu imagino, so isto vos falta para 70 seres $^{8}$ per|feito.

Não erão bem acabadas es|tas palavras, quando Vasperaldo impaciente | de tantas detenças, sem curar de porfi|ar mais com D Floris, tornou a remet|ter a Albaizar, que o recebeu com tama|nhos golpes, como se em todo o dia | não tivera feito nada. [espaço] E assim se anda|rão outra ves ferindo, hora travandoce | a braços, Ora 75 tornandoce a soltar e $\mid$ dandoce com os pomos das espadas de $\mid$ maneira, que abolados ${ }^{9}$ os elmos por huas par|tes, e por outra abertos dos golpes, que tinhão | recebidos, não havia deffensa algũa nel|les. [espaço] As forças enfraquecião, o san|gue esgotavace, so os espiritos não can|savão. [espaço] Valialhes, que com o Movimento | do Mar não se chegavão tanto á sua | vontade, mais assim se tinhão posto || [142v] em estado, que nenhũ delles esperava sal|varce das mãos de seu contrario.

No Navio tudo era pranto, as|sim de Drusia, que como vio cahir Be|liazem a o Mar, nunca mais deichou | de chorar, arran<can $>\operatorname{dosse}^{10}$, e arrancando a $\mid$ quelles seus cabellos tão envelhecidos em | maldades, como dos Escudeiros do pro|prio Beliazem, e

\footnotetext{
${ }^{8}$ Aqui ocorre uma mudança na forma de tratamento: em princípio o verbo deveria estar grafado serdes. Em B ocorre o mesmo erro. C: ser.

${ }^{9} \mathrm{~B}$ : abalados; C: ilegível.

${ }^{10}$ A sílaba can foi inserida entre linhas pelo próprio copista, o que resulta numa repetição evitada pelo copista de B: "chorar arrancandosse aquelles cabellos". A lição de C parece ser a correta: "chorar aRanhandosse eaRancando aquelles seus cabellos".
} 
Albaizar, com o que D. | Floris não estava izento de hũa muito gra|ve dor, porque ainda 85 que lhe parecesse, que |Vasperaldo trazia as Armas mais | sans, e andava mais solto, era tanto | o sangue, que selhe hia, e por tantas par|tes, que não esperava, que se pudesse reme|diar, ainda que lhe durasse mais oalento, | que a o Outro, que era a victoria, que so po|deria ter delle, quando a tivesse ${ }^{11}$, O qual tam|bem sentia muito ver acabar, julgandoo | por hũ dos excellentes cavalleiros do | Mundo, e não podia cahir em quẽ 90 fosse.

Nisto se tornarão a apartar | os Cavalleiros, e tais que as espadas se lhe | torcião nas Mãos. [espaço] Bem via Vaspe|raldo que seu contrario andava de todo per|dido, mas elle se sentia tanto no cabo, que | não lhe parecia que lograria a victoria | se a alcançasse, e assi tratava ja mais | de se poupar para que o outro cahisse primeiro, que |

95 de o ajudar a cahir com novos dannos.

|| [143r] Neste estado estava a couza, quando | chegou a abordaraaquelle ${ }^{12}$ navio o outro, ẽ | que tantas vezes temos falado, o qual fa|zia sua viagem direita mente para aquella | parte, mas havia muito tendolhe acalmado | o vento, que fazião grande deligencia os Ma|rinheiros delle, remandoo para chegar, por|que vendo hũ cavalleiro 100 que nelle vinha a | quelles dous Navios embaraçados hũ | co outro, e que se não bolião nem go|vernavão tendo ambos dado por da|vante, bem lhe pareceu que algua nuvi|dade o cauzaria ${ }^{13}$. [espaço] E fazendo dar a pres|sa que dicemos tanto que chegou a Espaço | donde poude ouvir o som, e ruido dos gol|pes, dobrandocelhe mais o dezejo de che|gar, fesse $^{14}$ a deligencia dobrada, mas como | o vento estava de todo calmo como temos | 105 visto, e os remos, e remeiros não erão | muitos, nem o Navio mui sotil, não pou|de chegar se não a o tempo que fica ditto. | E de quem elle era, e do que em sua chega|da aconteceu, daremos conta no capitulo| seguinte.

\footnotetext{
${ }^{11}$ Ou seja: embora as armas de Vasperaldo estivessem menos estragadas e ele um pouco menos ferido, ele perdia tanto sangue que sua única esperança de vitória seria se seu alento durasse um pouco mais que o de Albaizar.

${ }^{12}$ A letra $a$ entre abordar e aquelle parece ter sido acrescentada depois pelo copista.

${ }_{13}^{13}$ B: novidade. Dado por davante significa "encontrado frente a frente".

${ }^{14}$ Leia-se: fez-se.
} 


\section{Capitulo 47}

\section{De quem era o cavalleiro, que | no Navio vinha, e do que em | sua chegada acconteceu.}

|| [143v] Tanto que aquelle Navio chegou | ao em que os Cavalleiros fazião sua ba|talha porque era mais pequeno que o outro | hũ Cavalleiro, que nelle vinha, que era o va|lente, e esforçado Princepe D. Duar|dos de Bretanha armado de outras ar|mas como as com que entrara na batalha | dos Gigantes na Floresta das Tres fontes, | com a propria diviza dos troncos de | cypreste queimados, de que se tinha con|tentado muito começou

10 a sobir pella | Xarcea do Navio tão solta, edesemba|raçada mente, como se o fizera por hũa $\mid$ muito firme, e bem lançada escada. [espaço] | Mas D Floris se lhe pos diante antes que | acabace de chegar acima, e disselhe: [espaço] | Em verdade cavalleiro que deveis ser cu|riozo, pois com tanta pressa vos vin|des Metter onde não sabeis o gazalhado |que vos farão. [espaço] D Duardos lhe respon|deu: [espaço] Deixaime entrar la, e depois |

15 vos darei conta da cauza que me tras. | Nem isso, nem essoutro (replicou D. Flo|ris) pode ser agora, tornaivos com Deus | e se vos quizerdes deixar estar hũ pou|co, pode ser que cedo haja lugar para o que di|zeis, que por entre tanto estamos ca oc/cupados, e crede que se isto não fora, que | tudo estava a vosso serviço.

Os cavalleiros tinhão tornado $\|[144 \mathrm{r}$ ] a sua contenda. [espaço] D. Duardos

20 esta|va sem paciencia, e D. Floris pouco a|gastado, com o que D Duardos the tor|nou a dizer: [espaço] Cavalleiro, eu ei la de | entrar, ou queirais, ou não queirais, me|lhor vos serà que seja por vossa vontade $\mid \mathrm{a} o$ menos não dirá esta gente que vos $\mid$ temeis tanto de hũ so homem, que vos | valeis da ventagem da Mor altura do | vosso Navio para me impedir a entrada, | e como isto disse, metendo o braço esquer|do e o escudo por entre a

25 Xarcea $^{1}$, e | firmando os pes como melhor poude | nas faxas do Navio, começou com a es|pada a querer fazer a fastar a quelle tão | pezado cavalleiro. [espaço] D. Floris, que co|mo discemos não estava colerico, ven|do a deligencia que o outro fazia, e a con|fiança com que quazi suspendido no ar | detreminava entrar por força dicelhe: | Contra tão valente cavalleiro não ha | nenhũ remedio senão este. Edando hũ | golpe nas

30 cordas, em que se sostinha | cortandoas com facilidade, fello cahir | de subito pella Náo abaixo, de tão peri|goza queda, que a não topar no seu pro|prio Navio, facilmente levara

\footnotetext{
${ }^{1}$ Palavra corrigida pelo copista, que antes havia escrito xarxea.
} 
o ca|minho de Belliazem, mas tendoce | alli, e vendoce dezesperado, quis toda | via tornar a sobir. Então lhe disse || [144v] D. Floris, que não se apartava do bordo: | Ja vedes senhor Cavalleiro, que contra a | vontade dos porteiros não se entra por | estas

35 portas, agora se mo rogardes muito | eu vos darei a mão, e vireis ver o que mos|trais dezejar tanto. [espaço] D Duardos lhe | respondeu: [espaço] Nenhũa Cortezia quero | de vós por não ficar obrigado a uzalla | com vosco, porque de maneira me ten|des enfadado, que a não estar tão perto o cas|tigo, não sei o que fizera. [espaço] Em ver|dade que sois Mào de servir, lhe tornou a | replicar D Floris, pois vos enfadais de | vos não

40 querermos deixar entrar em | nossa caza sem no lo agradecerdes, | mas pois sois tão porfiozo, acabareis quanto | quizerdes. [espaço] E como isto disse, afastan|doce, Entrou D. Duardos, que toda via | hia subindo ardendo em colera, de | ver a pouca, que D Floris mostrava. | E como se vio dentro sem curar de | mais nada remeteu a elle dizendo: A|gora vereis cavalleiro desprezador a Es|timação, que se hade fazer dos hospedes | 45 como eu. [espaço] E começou a ferillo com | outra maneira de golpes tão dezacostu|mados, que D. Floris não tinha exprimẽ|tado outros da quella sorte, de que nas $^{2}$ se es|pantava pouco, mas como quem não e|ra novo naquelles trances inda que da \| [145r] batalha de Beliazem não tinha ficado | muito inteiro demaneira lhas tinha tezas ${ }^{3}$, | que tambem D Duardos gostava fruta que | nunca provara, mas comtudo se a cou|za

50 durara muito mal pudera escapar D. | Floris de tão grande trabalho, inda que o ou|tro não ficaria em lançoes de Olanda $\mid$ como dizem.

Druzia vendo perdido | Albaizar, que ja a este tempo, de pura fraque|za, estava sentado em huas amarras, | que no convés estavão enrroladas, e Vaspe|raldo encostado defronte delle na amu|rada com pouco mais alento, vendoce | atalhada com o juramento

55 que tinha fei|to para uzar de sua sciencia na forma q qe ella quizera, thomou outro novo con|celho, e foi levar Carmellia em hũ Mo|mento ao lugar aonde de antes a tinha | para cumprir com a vontade de Albai|zar, e promessa, que lhe fizera, e no Mes|mo Momento tornarce a o navio onde | thomando a figura da propria Carmellia | tão ao vivo como o ella sabia fazer, ten|do entendido o que aquella vista obraria | em D Duardos, e na 60 quelles cavalleiros, | sahindo da camara do navio se lhes a|prezentou toda banhada em

\footnotetext{
${ }^{2}$ B: não. O trecho em C está diferente: "começou aferilo com outra maneira de golpes tão desacostumada dos que Dom Floris ate então tinha experimentado que elle senão espantava pouco".

${ }^{3}$ Não se compreende exatamente a qual antecedente o pronome lhas se refere; em B e C a lição é a mesma.
} 
lagrimas | e thomando a D. Duardos pello braço | fazendoo divertir da praveza ${ }^{4}$, em que || [145v] andava, disselhe: [espaço] Senhor Cavalleiro | se as lagrimas de hũa Donzella desterra|da podem com vosco algua couza, pesso|vos pello que deveis à Ordem da cavalaria $\mid$ que recebestes, e pella couza do mundo que | mais amais, se amais algũa, que me livreis | destes cavalleiros, que sem mais occazião | que a de roubar minha honrra tem aquel|le cavalleiro que alli está sentado, e em cuja | companhia vinha segura, porque he meu | irmão, no estado que vedes, e morto outro | companheiro seu, que lançarão impiamente | a o mar sem the valer querer renderce.

D. Duardos que tinha os olhos | nella, affirmandoce bem sem se poder | ter nos

70 pés, tal como morto deu concigo | no chão, e Vasperaldo, e D Floris, que | tambem conhecerão a Carmellia, ou|vindolhe dizer que Albaizar era seu Ir|mão, espantados de hũa, e de outra cou|za, ficarão tais, que por hũ bom espaço | não se souberão detreminar. [espaço] Com | tudo D. Floris, que se achava mais livre | e mais perto parecendolhe que aquillo de|via ser algũ engano do cavaleiro que se fa|zia ter por Vasperaldo, chegouce a

75 Car|mellia que tambẽ se mostrava espantada | do successo da quellas couzas, e dicelhe: | Chegaivos senhora á quelle cavalleiro, | de quem mostrais tanto temor, que não || [146r] sei nenhũ no mundo aquem mais va | em vosso serviço, e por ventura que com o | conhecerdes deis remedio a essas lagrimas | e a suas feridas. [espaço] Vasperaldo se vinha | ja chegando com bem grande fraqueza, | e Albaizar, que denenhũa Maneira 80 podia | bolirce vendo a Carmellia cuidan|do que fora mal obedecido de Druzia | encostou a cabeça, e dando hũ profun|do suspiro disse: [espaço] Bem bastava oh | fortuna, que triumfacẽ estes cavalleiros | da minha vida, mas hũa feiticeira da mi|nha honrra, quando to mereci eu? Edizen|do isto, de todo ficou fora de si. [espaço] Neste | tempo acordou D. Duardos, e vendo | aquelles cavalleiros pegados com Carmel|lia 85 cuidando que lhe querião fazer a força | que ella fingia, remeteu a elles pouco menos | furiozo, que o mais violento rayo, dizendo: | Esperai, esperai, treidores, que não vos ireis | assim tão leve mente com o maior the|zouro, que o mundo nunca teve. [espaço] Não | tinha elle acabado estas ultimas pala|vras, quando se escureceu o ar de subito | como se fora de noite, e começarão a so|ar nelle trovões, e a fuzilar relampagos ${ }^{5}$ ẽ $\mid$ tanta 90 quantidade, que parecia que o mesmo | ceo cahia de seus exos, com o que não | se vendo hũns a os outros, trabalhou | cada hũ de se soster nos pes o melhor que $\|$ [146v] poude,

\footnotetext{
${ }^{4} \mathrm{~B}, \mathrm{C}$ : braveza. O termo divertir, neste contexto, significa "desviar, diminuir".

${ }^{5}$ Palavra corrigida pelo copista: o $p$ havia sido grafado $g$.
} 
pegandoce no que mais perto de si | acharão. [espaço] Eo que sobre isso aconteceu ire|mos vendo no lugar que lhe Henrrique | Frusto assinou nesta sua Historia. 


\section{Capitulo 48}

\section{Do fim da quellas batalhas, e | de como os Reys forão de|zencantados, e Dom | Duardos se foi, sẽ | ser conhecido | delles.}

Sem se verem hũns a os outros em|voltos em a Escuridão das trevas que disse|mos, e na confuzão de que aquellas couzas lhe | erão cauza, estavão aquelles cavalleiros, | quando a pouco, e pouco se foi dissolvendo a $\mid$ nevoa, e elles se tornarão a ver como de|antes assi, e a Carmellia em poder de | hum homem velho vestido de pelles de a|nimais, com hũa barba muito crecida, e | branca, e hũ grande cutello na cinta, e | hũ

10 livro nas mãos, o qual a tinha pellos | cabellos, e ella derribada a seus pes, e | querendo todos valerlhe, nenhũ se pou|de mover do lugar em que estava, e logo | conhecerão que o velho era o Sabio Dali||[147r]te, e que aquella que deantes lhe parecia |Carmellia, era hũa velha tão torpe, e | tão disforme, como dantes semostrava | o Contrario. [espaço] E correndo todos a abra|çallo, so foi com os animos, porque com $\mid$ os pes ainda então se

15 não puderão bolir. | E elle lhes disse rindo tornado ja a sua | natural figura: [espaço] Convem senhores que não | chegueis ca a estorvarme a obra que quero a|cabar, que he livrarvos a todos desto ${ }^{1}$ Donna | honrrada, que tantos sobresaltos nos tem | dado, e porque podelo fazer se deve a esse | cavalleiro que a hi jas tal como morto ${ }^{2}$, será $\mid$ bem que para sua honrra delle, ella por sua | propria bocca vos conte o que tem passado. | E

20 então dizendo Druzia que pois Albai|zar era morto, não tinha para que esconder | nada do que delle sabia. [espaço] Contoulhe quẽ | era, como partira de sua caza a acharce | no Torneio dos Noveis em Constanti|nopla, os intentos com que se deixara | ficar na quella corte, o que ella tinha feito | no Encantamento dos Reys, e o que com | o proprio Albaizar alli lhe tinha aconte|cido, e como depois thomara a figura | de Carmellia para

25 os fazer matar hũns | com os outros pella livrarẽ a ella, e tu|do o mais que acerca desta Materia te|mos contado. [espaço] Acabado o que tornou o | Ar a Escurecer como de antes e tor||[147v]nou tambẽ brevemente a sua antiga | lus, achandoce todos em terra na quel|la Ilha onde nimguẽ athe então ti|nha aportado sem concentimento de | Drucia. [espaço] E logo abraçandoce hũns $\mid$ aos outros ${ }^{3}$, perdida a paixão que entre si $\mid$ tinhão, a 30 primeira couza em que Daliarte enten|deu foy nas feridas de Vesperaldo, que nas | de

\footnotetext{
${ }^{1} \mathrm{~B}, \mathrm{C}:$ desta.

2 Trata-se de Albaizar.

${ }^{3}$ Palavra corrigida pelo copista: o $t$ parece ter sido escrito sobre um $v$.
} 
Albaisar tinha ja provido fazendo o | levar a sua Ilha, donde depois de largo | tempo foy são, e Mandado a Targiana | sua May em recompença da boa vonta|de, que nella sempre ouvera para a caza de | Grecia, mas o amor de Carmellio ${ }^{4}$ o tor|nou outra ves a arrancar de la para no|vos dezastres, como em seu lugar dire $\mid \operatorname{mos}^{5}$, e Druzia foi tambem levada |

35 A Mesma Ilha, e dali a Constanti|nopla preza em hũa gaiolla de ferro | onde teve o fim que sua vida merecia, | e acabandoce com aquillo sabendo aquel|les cavalleiros que na Ilha em que estavão | se encerrava o descanço de todos, quize|rão logo D. Duardos, e D. Floris ainda ${ }^{6} \mid$ não estavão mui sãos, entrar no perigo, | que a solidão do lugar, e o Misterio daquel|las couzas Merecião, e estavão prometẽ|do. [espaço] Mas dizendolhe

40 Daliarte que para o | fim da quella Aventura igualmente | era necessaria a virtude da espada de || [148r] D Duardos, que o valor de seu dono, e que | sem ella não tinha nimguem que ir alli | buscar, D Floris, se ficou com Vaspe|raldo no Navio ${ }^{7}$ em que alli vierão, a o qual | Daliarte se quis recolher, porque como ti|nha ante visto o que havia de ser alli, lhe pa|receu que estava mais prompto para qual|quer socorro. [espaço] E foi

45 assim, que tendo D. | Duardos caminhado pouco espaço ou|vindo o som da quella tão porfiada ba|talha, atinando a elle, depressa se achou $\mid$ entre el ${ }^{8}$ aquelles cavalleiros, que lhe quize|rão fazer hũ gazalhado, que lhe a elle esti|vera bem mal se o aceitara, mas como | hia industriado do que havia de fazer, cu|brindoce bem do escudo, e guardandoce | dos golpes o melhor que podia, começou a | tocallos hũ, e hũ, com aquella espada | em cuja tempera Appolidon tantos se|culos antes concervara o remedio de | tamanha maldade, como Drucia al|li obrara, e era couza Maravilhoza | que aquelles cavalleiros tão bravos, e tão es|forçados, em tocando D Duardos a qual|quer delles assi cahião no chão fora de | seu acordo, como se verdadeiramente | forão mortos. [espaço] $\mathrm{E}$ finalmente desta ma|neira era necessario que fezesse, porque no | pouco espaço que se 55 elle deteve em os tocar | a todos, forão tantas as feridas que lhe || [148v] derão, e tanto o

\footnotetext{
${ }_{5}^{4} \mathrm{~B}, \mathrm{C}$ : Carmellia.

${ }^{5} \mathrm{O}$ narrador refere-se a episódios futuros que não se encerram nos limites desta primeira continuação manuscrita do Palmeirim de Inglaterra.

${ }^{6} \mathrm{~B}, \mathrm{C}$ : ainda que. A falta do pronome torna a lição de A incompreensível.

${ }^{7}$ A espada a que Daliarte se refere é a que o sábio Apolidón outorgou a D. Duardos depois que ele a retirou do peito do Dragão (cf. cap. 14). Este trecho contém duas incongruências: em primeiro lugar, note-se que Albaizar havia exigido de Drúsia Velona que desfizesse o encanto em que todos aqueles reis e rainhas estavam presos, mas ela agora se esclarece que libertou apenas Carmélia; além disso, ao dizer que Vasperaldo ficou com D. Floris no navio, o autor parece ter esquecido que pouco acima dissera terem eles desembarcado na ilha (cf. linha 27).

${ }^{8}$ Erro riscado pelo copista.
} 
trabalho em que se vio, que | a não se rolver ${ }^{9}$ de pressa o negocio, menos | facil ficara a Empreza do que Daliarte a | pintara, mas tanto que acabou de cahir o | derradeiro, subitamente soltandoce os | liames com que a quella Ilha estava ata|da, tornou a seu antigo ser, que era hũa $\mid$ muito comprida, e fermoza Galleaça co|mo temos ditto, e como

60 tal começou a | nadar logo tão levemente, como quem | estava no mais profundo da quelles Ma|res, e não tendo chusma, nem Marinhei|ros, nem deixando de estar quebranta|da naturalmente, assim da tormen|ta que correra, como do tempo que havia | que estava como surta, facilmente pu|dera meter os povoadores della em peri|gos menos prodigiozos, mas mais | verdadeiros. [espaço] Mas Daliarte, que es|tava á mira acodio logo afferrandoa $\mid$ e segurandoa com o seu navio.

Os Reys, e Raynhas, e Prince|zas, que tornarão em seu Acordo, em se | a Galleaça começando a Mover, lem|brandoce da tormenta que tinhão passa|do, como derão em terra, da perdição | de suas mulheres, e parentes, vendoce | todos juntos, e vendoas, a ellas, sentindo|ce com grandes dores pello corpo, e não | tendo memoria da

70 batalha que fazião || [149r] não sabião que dicessem, nem ouzavão | a falarce, crendo que tudo o que vião erão | fantasmas.

Daliarte que logo como dicemos | atracou o seu Navio à Galleaça, sobin|do a ella, sentouce de giolhos diante de | seu Pay eirmãos, e dicelhes: [espaço] Não ten|des pouca rezão de vos enleardes senho|res no estado em que vos achais, porque de

75 callidade forão vossas couzas, que ainda aos que de | fora as vimos não deixão o Entendimento | livre de hũ muito justo, e dividido espanto, mas | graças a Deus, que como senhor de tudo que he | vos livrou por meios tão estranhos de tra|balhos mais estranhos ainda. Vos estais | livres do maior perigo em que vos nunca | vistes, e a Profecia de Appolydon cum|prida em todas suas partes, com o que pa|rece que não fica 80 mais que fazer, que agra|decer tantos beneficios a Nosso Senhor e queixar | da fermozura da Senhora Carmellia | que de tudo tem sido a cauza, Mas porque | se ella não veja em outros trabalhos co|mo os porque passou, vos senhora (voltando|ce para sua May ${ }^{10}$ ) lhe dai este anel, que em quanto | o tiver concigo, não poderà pervalescer | contra ella, nem os conjuros de Drusia | Vellona, nem de Outrem, e assim se acha|ramos

\footnotetext{
${ }^{9} \mathrm{~B}$ : rezolver; $\mathrm{C}$ : resolver.

${ }^{10}$ Isto é: voltando para Leonarda, mãe de Carmélia.
} 
85 outro para assegurar a todos dos ris|cos, que com ella se correm, puderamos lo||[149v]grar com mais quietação o gosto de vossa | liberdade ${ }^{11}$.

Isto dizia Daliarte, porque D. | Duardos tanto que vio nadar a Galleaça | sabendo que na quillo concestia o fim do | Encantamento, vendo do lugar em que es|tava a sua cetia pegada a ella, e que nim|guem com o sobresalto, e maravilha do | cazo attentava

90 nelle, contente do que tinha | feito se recolheu a ella, e alargouce hũ | grande espaço, invejozo porem dos pri|mores de Albaizar, e não pouco affeicoa|do, assi pellos fazer ${ }^{12}$, como pellos in|tentos que tinha. [espaço] E não julgue nimguẽ | isto por remissão de seu animo, nẽ de | seu Amor, porque hũ, e outro, eu os tenho | pellos maiores, ena materia do amor pella | maior fineza delle, assim porque nunca | ciumes deixão de ser offensa da

95 couza | amada, como porque D Duardos não se | affeiçoou a Albaizar porque elle amava a | Carmellia, senão por couza sua della, | adorando nelle effeitos que ella fazia ${ }^{13}$. E a | resposta da pratica de Daliarte, e rezolução | que os Reys thomarão veremos adiante.

\footnotetext{
${ }^{11}$ Daliarte está se referindo a D. Duardos: se ele tivesse outro anel que permitisse proteger-se dos efeitos da beleza de Carmélia, o príncipe não precisaria afastar-se do convívio dos demais reis e rainhas, o que lhes permitiria lograr com mais quietação o gosto da liberdade.

${ }^{12}$ Leia-se: por fazê-los. Em affeicoados, como em outras ocasiões, o copista não acrescenta o cedilha.

${ }^{13} \mathrm{D}$. Duardos não se afeiçoava a Albaizar porque ele também amava Carmélia, mas porque contemplava nele os efeitos que Carmélia era capaz de gerar.
} 


\section{Capitulo 49}

\section{De como aquelles Reis souberão || [150r] quem os livrou do Encan|tamento, e como parti|rão para Constanti|nopa, e de como | la chegarão}

Tendo o Sabio Daliarte acabado de | clauzular as rezões que no capitulo passado vi|mos, e dado no fim dellas aquelle anel á | Raynha de Tracia, ElRey seu Pay a cujos | pes elle estava de giolhos depois de o abra|çar, e todos os mais tão contentes como | se resucitarão de novo então no mundo, | forão com grande particularidade infor|mados de todas as couzas que tinhão passado | nelle depois de seu Encantamento. E | querendo

10 Carmellia (que atudo era prezente $f^{1} \mid$ não pouco espantada emedroza do que ou|via que tinha passado por ella) queixarce com | Daliarte de lhe não ter dado aquelle anel | mais cedo, seu Pay thomandoa pella mão | lhe disse: [espaço] Não creais filha tudo o que vosso | Tio vos dis, porque se crerdes o que deveis a Al|baizar, ou vos haveisde offender a vós mos|trandovos ingrata, ou amim sendo lhe | agradecida. [espaço] Deixai tudo isto

15 a minha | conta, que verdadeira mente entendo que he | ou foy Ordem particular de Deus, para con|fuzão e vergonha minha entregandovos | a hum filho de Targiana. E eu estou tão || [150v] conhecido disto, que se Albaizar he vivo, e | se quizer fazer christão, não sei couza | no mundo porque deixasse de vos cazar cõ | elle. [espaço] Carmellia thomando hũa cor | qual aquellas couzas a pedião sem lhe respon|der ficou cuidando no

20 que ouvia a o Pay | de que nasceu não dar por então entrada a hũ | pensamento que lhe hia acreditando os ser|viços de D Duardos concervandoce li|vre para o que seu Pay quizesse Ordenar della. | E querendo toda a quella companhia velo | a elle cuidando a the então que estava com | os outros no Navio, disserão á Daliarte que | o Mandace vir para lhe agradecerẽ a li|berdade que tantas vezes lhe dera. [espaço] Elle | lhes mostrou a

25 cetia, que ainda aparecia | dizendolhes que se fora nella, e que lhe não pu|zecem culpa, porque seguia por então Or|dem, e vontade alhea posto que não forçado. | Valhanos Deus, disse Palmeirim seu Pay, | ja este homem nos fugio outra ves, e em | verdade que sendo vos quem o criou, que es|tou mui perto de cuidar que senão soube | aproveitar da doutrina, pois falta com | comprimentos tão dividos. [espaço] Daliarte | lhe replicou

30 rindo: [espaço] Se o cavalleiro do Sal|vage ${ }^{2}$ (senhor Palmeirim) dissera isso, por | ventura que lhe acharamos mais razão, | mas vós que sempre soubestes obedecer, como |

\footnotetext{
${ }^{1} \mathrm{O}$ copista havia inserido um parêntese aqui por engano e risca-o.

${ }^{2}$ Pseudônimo utilizado por Floriano no Palmeirim de Inglaterra.
} 
quereis que senão pareça vosso filho com $\|$ [151r] vosco? D Duardos he vosso filho mas | (perdoeme a Senhora Polynarda) não na | fortuna. Deixaio seguir a sua, que o tem|po vos mostrará que não he elle quẽ tem a | culpa neste a partamento. [espaço] Polinarda | 35 se corou hũ pouco, e toda via respondeu | Apello para a experiencia da coppa de Sar|damante. [espaço] Leonarda acodio logo di|zendo: Toda via senhora maior foi o fogo $\mid$ de Flo<re>ndes, Miraguarda tem hũa filha | tão fermoza como ella que sabemos $\operatorname{nos}^{3}$. | ElRey D Duardos atalhou aquella con|verçação vendo que hia ja chegando a particu|laridades, couza que em todas se deve jul|gar por pezada, e perigoza. [espaço] $\mathrm{E}$

40 querendo | ver Vasperaldo, e D Floris, pois D. Duar|dos era hido, disse a Daliarte que os fizesse | vir. [espaço] Antes me parece (lhe respondeu | elle) que será necessario segundo estais mal | providos de Marinheiros que se passem para | ca todos os de seu Navio, e juntamente que | assenteis para onde se hade fazer o caminho | porque o vento vem Entrando, e será bõ | não o perder. [espaço] Nisso não ha que fallar | lhe disse o

45 Pay, porque a todos estes senhores | lhe parecerá bem, que vamos primeiro que tudo | alegrar com nossas prezenças ao Empe|rador Primaleão, que não deve ser muy| longe Constantinopla, porque se me | mal não lembra pouco tempo havia || [151v] que tinhamos partido de la quando a tormen|ta deu, e dahi tornaremos a nossas ter|ras divedidos, porque nos não colha jun|tos outra redada, se ainda Ouver quẽ | nos queira 50 tomar nella. [espaço] E assentan|do todos naquillo, passouce á Galleaça | tudo o que no Navio de Vasperaldo vinha | deixando a elle so, em que se perdeu pouco. | Todos aquelles Reys, e senhores fizerão grã|des demonstrações de alegria com Vaspe|raldo, inda que suas feridas não deixavão | de lhe dar grande sobresalto, porque erão | muitas e perigozas. [espaço] Com D. Floris se | tiverão tambem muitos comprimentos, e | 55 navegando com bom tempo brevemente | chegarão a Constantinopa, e porque | o subito alvoroço he muitas vezes tão peri|gozo, como a maior tristeza, pareceu|lhes bem áquelles senhores, que Daliarte | fosse prevenir primeiro o Emperador de sua | vinda,

\footnotetext{
${ }^{3}$ Daliarte diz que D. Duardos é um amante devotado como o pai havia sido, mas não é favorecido pela amada como Palmeirim o fôra, o que deixa Polinarda encabulada. Por isso, ela lembra da aventura da copa mágica do rei Sardamante, que ardia mais quando em mãos de amantes desfavorecidos: com Palmeirim, a copa havia ficado roxa e fervente, demonstrando que, àquela altura, Polinarda ainda não havia aceitado seus serviços. Leonarda (neta de Sardamante) replica que naquela aventura provou-se que o amante mais desfavorecido era Florendos, pois quando ele apanhou a copa todo seu corpo começou a arder: de fato, ele servia a Miraguarda, que se caracterizava por sua altivez e pela indiferença com que tratava seus servidores. A observação final de Leonarda, concernente à beleza de Gridônia, filha de Florendos e Miraguarda, parece um tanto despropositada. Sobre a aventura da copa encantada, cf. os caps. 90-92 do Palmeirim de Inglaterra.
} 
que chegarlhe com elles mesmos | a nova della. [espaço] Assi se fes, e foi bem | necessaria a quella deligencia, porque elle | com a idade, e com o disgosto da quel|la perdição, e auzencia de seu filho Florendos | que nunca o desacompanhara ${ }^{4}$, andava | tão cortado, que não ouve mister menos | que a prudencia de Daliarte para lhe tem|perar as paixões naquelle accidente. | Mas em fim, como obem he toda via || [152r] mais amigo da natureza que o mal, o | Emperador poude melhor com aquella | nova, que com apassada, e informado de | Daliarte de tudo o que tinha a contecido | louvando por 65 extremo a Albaizar, e | preguntando se era vivo. ${ }^{5}$ [espaço] Levou o a $\mid$ Emperatris, e a Miraguarda, as quais | com grande alvoroço mas temperado | com a falta de Florendos, o receberão. | Nisto começou a Galleaça com os | tiros que disparava, e bandeiras de que se | encheu a acreditar a Embaixada de | Daliarte, a qual logo se começou a es|palhar pella cidade, e concorrendo o | povo todo à ribeira, o Emperador foy | tambem, e a

70 Emperatris, e Miraguarda, | e as Princezas por hũ passadiço por den|tro se forão a o Cais, onde a Galleaça | tinha posta a proa, a receber suas hos|pedas com o mor gosto do mundo, e | chegando hũns a os outros, abraçandoce | como pedia a restetuição de dezastre | tão grande, não se podia apartar o Em|perador quando chegou a Carmellia. Abra|çandoa lhe disse: [espaço] Não me espanto se|nhora dos trabalhos, que vosso Pay 75 passou | pois com tão pouca rezão vos levou desta | caza, tão propria mente vossa, como sem|pre o foy sua. Mas ja agora por mais | que elle queira, se vos eu não tiver contra || [152v] mim, nimguem vos tirarà della em | quanto não ouver quem vos seja mais ${ }^{6}$. [espaço] | Isso pesso eu a Vossa Magestade (respondeu Car|mellia) e basteme por penna de enten|der algũa hora que me convinha o contra|rio, os malles que tenho padecido 80 auzente | destas Princezas. [espaço] E abraçandoas en|tão a ellas com melhor coração do que leva|ra, ficarão todos na quella Corte com | grande contentamento, o qual se dobrou | dalli a poucos dias com hũa Aventura | que veio a ella, como veremos depois de dar | conta do Modo por que aquelles Cavallei|ros se juntarão.

\footnotetext{
${ }^{4}$ Lembre-se que, de acordo com o cap. 37, Florendos havia partido juntamente com Floramão, depois de chegar a Constantinopla a notícia do desaparecimento dos reis.

${ }^{5}$ Este ponto final deve ser desconsiderado.

${ }^{6} \mathrm{O}$ final da frase está confuso. Cremos que houve uma elipse do termo contra. O sentido da frase parece ser o seguinte: "se eu vos não tiver contra mim, ninguém vos tirará dela (desta casa) enquanto não houver quem esteja mais contra vossa vontade".
} 


\section{Capitulo 50.}

\section{De como D. Floris, e Vasperal|do se juntarão na quella | paragem, e do modo | porque $\mathrm{D}$. Duardos | vio ter a ella.}

Dous dias havia somente que Vaspe|raldo, e D. Floris se tinhão encontrado | quando aconteceu o que a tras fica ditto, e por|que foi denoite dando com hũa cerração | grande hũ Navio pello outro sem se ve|rem, Ouverace de perder Vasperaldo \| [153r] por ser o seu mais fraco, e pequeno, que | era o que primeiro poude haver á mão no por|to de Dramusiando, onde cada hum | de seus companheiros thomarão o que | havia, sem que a

10 pressa, e dor, com que par|tirão lhes desse lugar para fazer eleyção, | O que não tinha acontecido a D. Floris | que como sahira com mais vagar, e de | caza de hum Rey tão seu amigo, e obri|gado, vinha em melhor embarcação, e | melhor provida, e assim recebeu pouco | danno na pancada que os navios de|rão, sendo tanto o de Vasperaldo, que se | abrio de todo, e foi necessario que se recolhes|se ao Outro, em que elle não sabia quem |

15 vinha, nem que gazalhado lhe farião, | porem posto que àquelle tempo se não a|chou com mais armas, que a espada, e o | Escudo, não deixava de levar no pen|samento de se fazer senhor delle, e | castigar nos que alli vinhão o descuido | que hũns, e outros tiverão. E não valeu | pouco o ir elle desarmado para que o perigo | de ambos não fosse maior, porque segun|do Vasperaldo hia colerico, e D. Floris | sofria mal demazias, por ventura que não | o conhecendo se chegarão a bem mi|zeravel estado; Mas D. Floris que tanto que | sentio que o Navio que dera por elle se per|dia, pezarozo do dezastre, acodio || [153v] logo armado com lampiões a recolher | a gente delle, não querendo porem | concentir que entrassem senão a hũ, e hũ, | e sem armas, por the não a contecer cou|za de que fosse culpado de zello impru|dente. [espaço] Topando primeiro que tudo com

25 Ves|peraldo reconhecendoo logo, dando hũa | grão vox se abraçou com elle dizendo: | Valhame Deus senhor Vasperaldo he possi|vel isto? Deucelhe tambem a conhecer. | Vasperaldo então perdida a paixão | com que vinha o apertou comcigo, e dis|selhe: Differente abraço he este de outro | que ja algũa hora nos demos ${ }^{1}$, mas louvado | seja Deus que vos acho, quando cuidei que de todo ti|nha perdido tudo com a vida. [espaço]

30 Então | recolhendo toda a gente do navio, alar|gandoce delle foice logo ao fundo, e | elles ficarão dando conta hũ a o Outro | da demanda em que andavão, e do pou|co que

\footnotetext{
${ }^{1}$ Vasperaldo refere-se ao desentendimento havido com D. Floris narrado no cap. 21.
} 
nella tinhão feito, e assim se forão | a the lhe acontecer com Albaizar o que | no capitulo passado temos visto.

E de D. Duardos dis a His|toria que tanto que se apartou da costa de | 35 Constantinopla, onde fizera aquelle | notavel Socorro a Carmellia, e aos outros | Princepes, e Princezas, sendo recebido | de Trigonio, desarmado, e curado de | suas feridas, que erão grandes, e perigozas, $\|$ [154r] mandou guiar por onde o vento o le|vasse, sem por a proa em algua parte | certa, dezejando achar algua Ilha des|povoada onde pudesse acabar a vi|da ás mãos de sua saudade, e da dor, | que lhe cauzava o rigor

40 de Carmellia, | E como esta sua tristeza era tão gran|de, $\mathrm{e}^{2}$ suas feridas (como dicemos) tão | perigozas $^{3}$, passou muito tempo primeiro que de to|do sarasse dellas, no qual tendo discorri|do com varias $\operatorname{proas}^{4}$, por muitos e varios | Mares, Ouve vista hũa menhã do $\mathrm{Na|vio} \mathrm{em} \mathrm{que} \mathrm{Vasperaldo,} \mathrm{e} \mathrm{D.} \mathrm{Floris} \mathrm{hião,} \mathrm{e} \mathrm{|} \mathrm{querendo} \mathrm{desviarce} \mathrm{delle} \mathrm{como} \mathrm{de}$ cou|za, em que podia ir gente, que era ode que | então mais se aborrecia, não poude cõ |

45 o vento, que cursava, fazer outra nenhũa | derrota, pello que mandando mesurar | hũ pouco as vellas, deixouce ir devagar na $\mid$ sua Esteira ${ }^{5}$. [espaço] Não tardou muito que se | vio tambem o Navio de Albaizar, que | ainda então não fes nenhũ Movimento | em seu Animo; porem quando entrando | mais odia vio os Navios embaraçados, | sospeitando o que podia ser, tornou a fa|zer issar Vellas, mas a tempo que o ven|to hia acalmando de 50 todo. [espaço] E porque Or|dinaria mente a difficuldade fas crecer $\mid$ o appetite, comessando a soar confu|zamente os golpes das batalhas, que nos $\|[154 \mathrm{v}]$ navios se fazião, á vella, e a remos fes | D. Duardos correr a sua settia, e com|tudo não poude chegar, senão a o tempo |que fica ditto, e a contecendo o mais que vi|mos. [espaço] Elle com algum alvoroço | de ver Carmellia livre tornou a con|tinuar a peregrinação em que 55 o ella trazia, | e a mesma deligencia que fizera para che|gar a os Navios, fes tambẽ para se apartar | delles, parecendolhe que não calaria Da|liarte, e seus companheiros à quelles | Princepes quem elle era, nem elles dei|xarião de o mandar de ter se lhe ficasse | a tiro ${ }^{6}$. [espaço] E com este cuidado despois que | anoiteceu, mandou Marear em outra | volta, e

\footnotetext{
${ }^{2} \mathrm{O} e$ foi escrito sobre o parênteses, que deveria ser logo adiante.

${ }^{3} \mathrm{O} s$ final foi acrescentado depois da palavra ter sido escrita.

${ }^{4}$ Ou seja: tendo percorrido várias direções.

5 D. Duardos não pôde afastar-se da outra nau porque o vento soprava (cursava) naquela direção. Por isso, mandou recolher (mesurar) as velas e deixou-se ir devagar.

${ }^{6} \mathrm{D}$. Duardos afastou-se depressa porque imaginava que o deteriam se sua setia ainda estivesse próxima ( $a$ tiro: cremos significar "à distância de um tiro", ou seja, não muito distante) quando Daliarte revelasse sua identidade.
} 
então se tornou a seus antigos | pensamentos, entregandoce á contẽ|plação das couzas da 60 quelle dia, e apar|tandoce para hũ lugar, que elle por mais só | tinha escolhido lembrandoce de Albai|zar, e do que passara com Druzia a cerca | de Carmellia rompeu apos hũ pro|fundo sospiro nestas palavras.

Ditozo, e bem aventurado | Albaizar, não so por que a fortuna te deu | Occazião de igualares a os pensamentos $\mid$ os serviços, senão porque $\mathrm{ti}^{7}$ vieste a per|der a tempo, 65 que não visses, ou o desprezo | delles para o Sentir, ou a aceitação para os | dezacreditar $^{8}$. [espaço] Não te envejo eu a sorte $\|$ [155r] inda que a conheço por tão boa, porque a ca|lidade que a minha tem deserdada por | Carmellia, me fará não a trocar por ne|nhũa Outra, que me amesma Carmellia | a mim não desse; porem não deixo | de notar neste teu tão extraordinario | procedimento hũa circunstancia muito | para invejar certo, 70 ponderada como a eu | entendo, e foi o não quereres tu ver a | Carmellia, mas isto não porque nẽ cõ | os olhos profanasses aquella divindade, | senão para poder dizer que fizeste algũa | couza, porque à sua vista não digo eu | quem tão bem como tu soube enten|der onde estava o maior merecimento, | mas amais bruta, e fera criatura, que a | natureza tenha produzido, não ficaria | com mais liberdade, nem com mais | alvedrio,

75 que aquelle, que ella lhe desse ${ }^{9}$, e assim | não foi respeito o deixar de vela, foy, | ó discreto Albaizar, quererte conservar | livre, senhor de teus effeitos, para os sacrifi|car todos à tua tão divida adoração. | Entenderes tu que na sua vista estava | a sua segurança te pudera invejar | quem não possuhira dores com gosto | de Carmellia, e bem puderão as mi|nhas perder por esta razão o nome, e os | effeitos, se eu não entendera senhora que 80 | dardesmas vós, não era so por mas dar, || [155v] senão para que eu as tivesse ${ }^{10}$.

Parece que se juntarão ellas en|tão todas para suffocarem o coração deste | pobre mancebo, porque pronunciadas es|tas ultimas palavras, cerroucelhe arespira|ção de maneira que sem poder dizer ma|is algũa cahio juntamente do assento, | e dos sentidos, e

\footnotetext{
${ }^{7} \mathrm{C}$ : $t e$; em $\mathrm{B}$, a palavra foi rasurada e está ilegível.

${ }^{8}$ De acordo com esta peculiar linha de raciocínio, até mesmo o reconhecimento dos sacrifícios feitos pelo amante faria com que eles perdessem seu valor (os desacreditaria), pois o serviço amoroso deveria ser desinteressado e isento de qualquer expectativa de recompensa. Tal observação reforça a figura de D. Duardos como a do amante perfeito.

${ }^{9}$ Leia-se: "porque à vista de Carmélia - não digo quem tão bem como tu soube entender o merecimento de Carmélia - mas mesmo a mais bruta criatura que a natureza produziu não ficaria com juízo mais livre que o que ela [Carmélia] lhe desse".

${ }^{10}$ O período final do solilóquio de D. Duardos é de difícil interpretação, embora não haja indícios de que tenham ocorrido erros do copista, pois as lições de B e C são idênticas. O sentido geral da frase parece ser que D. Duardos diz não poder invejar a Albaizar, pois sofria as penas de amor com gosto, entendendo que Carmélia o achava digno delas.
} 
assim ficou tiraniza|do de suas imaginações, a the que o Sol | a o Outro dia o tornou a seu acordo. E | não foi so esta ves a que lhe aquillo acon|teceu, que poucas erão as horas que o não oc|cupacem semelhantes desmaios, porque | não havia algũa em que se apartassem delle | as Memorias, que os produzião. E fluc|tuando assim entre estas contrarieda|des, folgando com a vida em quanto era $\mid$ concervação $^{11}$ do cuidado, e aborrecen|doce della pello não deixar so com elle, | hũa Menhã a o levantar do Sol se |

90 achou a o pe de hũ penendo em extre|mo alto, e tamanho em roda, que oc|cupava pouco menos de tres legoas, e | sendo por aquella parte onde elle apor|tou tudo discuberto, e talhado, era pel|las mais povoado de muito arvoredo cõ | ladeiras verdes e apraziveis á vista. | Descião do mais alto ribeiras ao Mar | que quebrando as agoas nas pedras que en|contravão fazião hũ ruido saudozo e || [156r] contemplativo. [espaço] Dias havia que

95 D. | Duardos buscava hũ sitio como aquel|le, e assim com a vista deste se co|messou, a alvoraçar cuidando que tinha | achado o que sua tristeza lhe pedia, e | como por alli não havia porto, Abra, | calheta, nem comodidade outra al|gua de sahir em terra por ser a pedra | cortada, e altissima, foi a rodeando, | a ver se achava algũa Maneira de | dezembarcadoiro, e não andou muito que | pella parte do Norte não visse hũ tão |

100 pequeno, que não era bem capàs de tres | Navios e esses de pouco porte, em ci|ma do qual estava situada hũa caza | comprida como terecena, depouco ar|teficio a o parecer defora. Emuito mais | adiante, se enchergava hũ castello che|io de tantas torres, guaritas, e curucheos, | que o fazião parecer couza muito fermoza, | do qual vinhão correndo como des, ou | doze homẽns para aquella Terecena. E | no porto, que fora feito com 105 industria | de homẽns cortando na propria ro|cha a despeito da Natureza, que não pa|rece que quizera dar a comunicação | daquella terra se não ás Aves, se via | hũ Navio, em que se trabalhava a grão | pressa por sahir ao largo. Pello que D. | Duardos conciderando todas estas || [156v] couzas, perdido o primeiro pensamento, com | que hia rodeando a Ilha, começou a en|trar em outro, de que poderia ser mais po|voada do que lhe a elle 110 cumprisse. E | querendo com tudo ver o fim dellas ${ }^{12}$, en|trou dentro no porto fechando com o seu | Navio aboca delle de maneira que não | podia sahir, o que, como dicemos, se da|va pressa por o fazer. Com o que contan|doce por perdida agente que nelle Estava | hũa Donzella que alli era a principal pes|soa sahindoce da camara delle se quis ar|rojar nas ondas. Mas D. Duardos, que | ja tinha saltado no Navio para ver que gente | trazia, a

\footnotetext{
${ }^{11}$ Palavra corrigida pelo copista.

${ }^{12}$ Ou seja: o fim das coisas (cf. estas couzas, linha 108).
} 
115 deteve, e ella lhe disse: [espaço] Ai senhor | Cavalleiro, se isto he socorro que cuidais fa|zerme, sabei que a maior crueldade es|tá em estorvarme a morte, que nestas | Ondas não pode deixar de ser mais brã|da que nas mãos do senhor desta Ilha. E | se por ventura vos sois seu, e me vin|des buscar como aquelles que la vem cor|rendo, pessovos pella Ordem de cavalla|ria que recebestes, não que me $\left\langle\right.$ não $>^{13}$ deixeis ir, se $|$ não que me não 120 entregueis viva à quelle | Monstruo que não se sabe contentar com | A morte de hua innocente. E Em di|zendo isto cahio desmaiada nos braços | que a sostinhão. Os progressos dos quais $^{14}$ | na materia de seu socorro temos $\|$ [157r] no capitullo que abaixo se segue.

\footnotetext{
${ }^{13}$ A inserção nas entrelinhas, feita pelo próprio copista, deixa a frase sem sentido e foi reproduzida em B. $\mathrm{O}$ ms. C apresenta lição diferente, embora também não muito clara: recebestes não que me deixeis hir senão que não emtregueis.

${ }^{14}$ Dos quais refere-se a braços.
} 


\section{Capitulo 51}

125 De como D. Duardos | dezembarcou, e do que lhe | succedeu, a the en|trar no Castello.

Sostinha por hũa parte D. Duardos a | Donzella, que se lhe desmaiara nos braços | porque não cahisse, e por outra vendo que os | homẽns que vinhão correndo do 130 castello, ti|nhão ja entrado na quella caza comprida | e estavão salameando com grande | gritta como agente do Mar costuma | para alivio do trabalho do cabrestante, ou | de outros, não cahindo no que podia ser, | não tendo achado no Navio da Donzel|la mais que Marinheiros, e poucos, Entre|gandoa a ella a Trogonio fella passar a $\mid$ sua setia, e mandoulhe que se sahisse da | Abra a o Mar por lhe não acontecer alli | algũa couza,

135 porem que se não apartasse | muito porque elle queria ir ver os Misteri|os, que na terra havia. E fazendoo assi | comessou a caminhar para a caza, | da qual ja hião sahindo a quelles homẽns || [157v] tirando por huas cordas huns jorrões co|mo emvasaduras, em que vinha hũa galleo|ta tão aponto que não havia mister mais | para navegar que lançalla a o Mar, e casar | as escotas ${ }^{15}$, a qual se concervava na quel|la terecena para os bons

140 usos, que alli se | costumavão. [espaço] Mas o cavalleiro dos | cyprestes não querendo deixar atras a|quelle escrupulo, tendo ja toda aquella gen|te por mà, e facinoroza, Escandelizou os | com a espada de maneira que querendo | elles offendelle com as armas que na Galle|ota levavão, ouverão por melhor concelho | deixallo entregue della, e forãoce corren|do dar rebate no castello, onde pella Oc|cupação, que nelle então havia 145 (como con|taremos) ${ }^{16}$ não se sentia nada do que pas|sava, Se bem era tudo debaixo de muitos | Eirados, e genellas, que para a quella parte ca|hião. [espaço] $\mathrm{O}$ cavalleiro vendoce so, en|trou primeiro que tudo na quella caza, onde não | achou mais que algũns barcos pequenos, | que so servião de pescarẽ, Monições da | Galleota, e outra que se estava lavrando. | E entendendo por aquillo que tirando a a os Moradores da ilha lhes 150 ficava pon|do hũ apertado cerco, sahindo fora fes | sinal a os seus Marinheiros, que ainda se | não tinhão apartado. E vindo Trogonio | ter com elle, mandoulhe que junta a ||

${ }^{15}$ Jorrão é um tipo de carreta sem rodas; o termo emvasadura, que não consta do Vocabulario de Bluteau e modernamente tem outro significado, deve indicar o espaço reservado ao transporte de cargas do jorrão; galleota é uma galé pequena; casar (ou caçar) a escota significa puxar a corda que prende a vela (escota) para ajustar a vela. O sentido da passagem é, portanto, o seguinte: os homens que saíam da terecena (depósito onde se guardavam naus pequenas e apetrechos náuticos) estavam puxando com cordas uns jorrões em cima dos quais vinha uma galeota pronta para navegar.

${ }^{16}$ A palavra foi corrigida pelo copista, que no lugar do $a$ havia escrito outra letra. 
[158r] sua gente, com a que estava no Navio | da Donzella, por aquelles mesmos enge|nhos lançassem a Galleota a o Mar, | pois concestia nisso sua total seguran|ça, porque pello que vira na caza, e na | despozição da Ilha, julgava que não ha|via nella 155 outra algũa embarcação, e que | feito aquillo puzessem fogo a terecena, | para se queimarem todas as materias que | nella havia, de que se os moradores pu|dessem aproveitar para acabarem a que | tinhão começado ${ }^{17}$. [espaço] $\mathrm{E}$ deixandoos en|carregados daquillo (que com grande | pressa, e alvorosso foi executado) porque | com a boa deligencia de Trogonio, e com | o medo que a gente do Mar tinha, ven|do que 160 assim se asseguravão, nũ pensa|mento foi tudo feito. E começou a ar|der a caza, que foi o remedio para D Duar|dos sahir com victoria da quella Em|preza, porque hũ Gigante que era o Senhor | da Ilha, e do castello, e aquelle Mesmo | de quem se queixara a Albaizar, e | Belliazem a quella Donzella, que elles li|vrarão do Leão junto a Constantinopla | por cuja occazião se embarcarão como $\mid$ temos contado ${ }^{18}$, que com hũa

165 estranha trei|ção prendia a todos os cavalleiros, que | alli hião ter, demaneira estava asse|gurado nella, que não era possivel poder $\|$ [158v] ser desbaratado, como logo veremos, | Este pois que o tempo que D Duardos che|gou estava embaraçado com dous cava|lleiros, que alli aquella menhã tinha tra|zido a Donzella que se quizera afogar|que era prima da Outra, e filha da Dona | preza (que foi o respeito porque senão soc|correrão 170 os homẽns da galleota) ${ }^{19}$ tendo $\mid$ ja dado fim a sua maldade, com a|quelles mizeraveis, derãolhe recado que | a terecena ardia, e sabendo elle que se | se queimassem as Monições que nella ti|nha, inda que lhe ficavão outras no castel|lo não poderia por muito tempo socor|rerce de couzas que na Ilha faltavão. ${ }^{20} \mid$ Cuidando tambem que no porto não ha|via mais cavalleiros (que isto fazia elle | espiar primeiro que se recolhessẽ os com 175 que se com/batia) [espaço] Sahio desatinada mente a alpagar o fogo, que por desastre entendeu que | se tinha pegado. [espaço] E como Deus o tra|zia para lhe dar o castigo de suas obras | deixou fechadas hũas roldanas por on|de cahia a ponte do castello de Maneira | que poude D. Duardos depois que o Matou | entrallo a seu salvo ${ }^{21}$. [espaço]

\footnotetext{
${ }^{17}$ Isto é: a outra galeota que estava em construção.

${ }^{18}$ Cf. cap. 42, em especial a nota 10.

${ }^{19}$ Não conseguimos entender a pertinência da observação, que se repete adiante (cf. cap. 52, nota 9). Qual a relação entre o fato de os homens da galeota não se socorrerem da galeota e a chegada de dois outros cavaleiros naquela manhã ou ?

20 Este ponto final deve ser desconsiderado. Note-se que a pontuação de todo este trecho é particularmente confusa, embora não dificulte a compreensão do sentido da passagem.

${ }^{21}$ Leia-se: "entrar nele (o castelo) a salvo".
} 
Vindo elle pois | com apressa que dicemos acodir a o fogo | não andou muito pella 180 ladeira abaixo (que | por aquella parte não era mui agra) que não | Encontrasse com o cavalleiro dos Cyprestes || [159r] que hia sobindo. Einda que lhe pezou de | o ver por estar tão longe da sua guarida | toda via, mandou a quinze, ou vinte pe|aẽs que o accompanhavão que fossẽ apagar o | fogo, e elle remeteu a o cavalleiro com hũa | simitarra grande que trazia cuidando par|tillo pello meio com o primeiro golpe. Mas o |

185 dos Cyprestes, que era ja costumado áquelles | assaltos desviandoce foi para oferir na cabe|ça, e vendoo sem elmo (que para poder cami|nhar a pe tinha dado a hũ da quelles seus ho|mens) deteve a espada, e dicelhe que tomasse | o elmo, por que elle se não contentava de | cortar cabeças desarmadas. [espaço] O Gigan|te, a quem as treições de que uzava tinhão | feito fraco, vendo aquelle valor e cortezia, | julgandoo a grande ${ }^{22}$ 190 confiança de seu | dono, ficou tanto mais cobarde, que se se a|chara mais perto do castello, ou menos | pezado da pessoa, sem duvida voltara | aacolherce a elle. Mas dissimulando o |que sentia respondeulhe: [espaço] Ora cavalleiro | ja que tanto vos fiais em vos que fazeis | hũa tão desnecessaria gentileza vamo|nos a o castello, e la thomarei o Elmo que |me falta, e despejaloei de toda agente para |que a portas fechadas façamos 195 nossa bata|lha, a respeito que se me vencerdes não | tenhais mais que fazer para o ganhar despois, | que sem isto não vos seria facil de acabar || [159v] inda que como digo vo lo eu não pudesse / deffender. [espaço] O Cavalleiro dos Ci|prestes assi porque não tinha noticias das | treições do Gigante, como por lhe pa|recer que dizia bem para se conceguir aquel|le fim, estando para aceitar o concerto | vio vir correndo o homem a 200 quem | o Gigante dera o Elmo que lhe vinha | socorrer com elle, que para seu amo foy bẽ | roim deligencia, porque dever o cavallei|ro inclinado a o partido cuidava que | sem nenhũ risco o tinha ja na algi|beira, e como depois de o ter na cabe|ça tornou a apertar pello que dantes ${ }^{23}$, co|mesou a ser sospeitoza a D Duardos | tanta cortezia, não sendo particular | mente ordinaria na quella sorte de homẽs | pello que remetendo a elle 205 dicelhe: [espaço] Pois | estais armado aqui acabaremos nossa | batalha, depois o tempo Mostrarà | o que convem que fassa. [espaço] Não durou el|le muito porque o Gigante estava cortado | do Medo que a conciencia lesa sempre | tras concigo, e D Duardos era

${ }^{22} \mathrm{C}$ : julgando $a$ agrande; a lição de B coincide com a de A. Em todas, como se vê, a inserção do pronome ( $o$ ou $a$ ) é desnecessária.

${ }^{23} \mathrm{C}$ : antes. Ou seja: depois de pôr o elmo na cabeça, o gigante continuou a insistir no que havia dito antes (que D. Duardos aceitasse lutar no interior do castelo). 
costu|mado a desbaratar facilmente aquellas | apparencias, assim em poucos golpes | lhe tirou a vida, que tão perjudicial hia | sendo no mũdo. [espaço] E vendo que os peães | 210 que forão a dar rebate a o castello quando lhes | elle thomou a Galleota, juntandoce cõ || [160r] os outros, que tinhão vindo com o Gi|gante sem poderem apagar o fogo o | vinhão a socorrer armados das ala|bardas, e capacetes, meteuce entre elles | como lobo entre carneiros, e deixan|do hũns abertos, outros sem pernas, e | braços, foi correndo espos hũns poucos | que se hião acolhendo a o castello, masmais | porque lhe não

215 fechassem as portas delle, que | por vontade de os tratar peor, por que | não entrava no seu animo amenor | paixão do mundo contra gente ren|dida, e chegando a tempo que os achou | embaraçados em derribar a ponte, | porque se passava hũa profunda, e larga | cava, que rodeava o castello, elles lha lar|garão logo, e as portas tambẽ, indoce | a esconder no lugar que o seu medo lhe $\mid$ mostrou por mais seguro. [espaço] E D.

220 Du|ardos livre mente poude entrar onde | o aguardava o maior perigo de que $\mathrm{O} \mid$ avizou quem nenhũ bem lhe queria, | e foi que hũ dos vilões que hia fugindo, ou | que o levasse o dezatento do medo, ou | que o quizesse guiar a hũ precipicio Mor|tal que no primeiro pateo havia, deixouce | ficar nelle (se foi mais maldade que me|do) e em o vendo entrar fes que lhe fu|gia por hũa escada grande e fermoza | que daquelle pateo sobia ahuas 225 varandas, || [160v] que o rodeava todo, e soube o tão mal | fazer, que pos os pes no engano em que | queria que o outro os puzesse, e assim | á vista de D Duardos que o seguia para se | informar delle se foi abaixo subita | mente com hũ grão roido, pello que pa|rando, e não vendo pessoa algũa na | quellas varandas nem no pateo, tor|nouce á porta do castello que sahia à ca|va, e fechandoa por dentro com hũas | grandes aldabras

230 que tinha, assentouce | a descansar hũ pouco do trabalho, que lhe | dera assim a batalha do Gigante, como | a pressa com que sobira a costa a im|pedir a deligencia dos villões, e o mesmo | faremos nos antes que demos conta | do mais que lhe ali a conteceu. 


\section{Capitulo 52}

\section{Do mais que D Duardos | passou naquelle castello | e da gente que nelle | estava preza.}

Depois que D Duardos se sentio | descançado para qualquer trabalho que lhe | sobreviesse, tornou a entrar no pa|teo a ver se lhe aparecia alguem. || [161r] Então vio ir correndo pellas varan|das algũas mulheres, e outra gente de | serviço, e perguntandolhe por onde se | hia la, não lhe responderão palavra | nem pararão nos corredores, com o que el|le ficou o mais confuzo do mundo, pare|cendolhe ja que tudo era treição quanto

10 alli | havia. [espaço] Foi andando á roda do pa|teo sem ouzar meter os pes na quella es|cada onde vira somir o outro, e por | hum canto, que estava cuberto com hũa | das columnas, em que os corredores decima | se sostinhão achou hũa porta pequena | com hũa escada de caracol, pella qual | entrando sahio a elles por aquella parte | onde tinha visto as mulheres, que em hũa | das cazas que para alli tinhão as portas, esta|vão

15 fazendo hũ grande pranto, Mas | vendo os inimigos dentro deixarão | as lagrimas, ou as engolirão, e sahirão | todas fora apedir Mizericordia, inda | que alli senão costumava athe então o uzo | della, e pondoce de giolhos começarão | a carregar a culpa a os Mortos, e a of|fereceremce os vivos á penitencia que | lhe quizessem dar. [espaço] Mas o cavalleiro | que tinha outros intentos assegurando | a quella gente coitada do medo que mos|travão quisce informar de quem era o | Gigante, e da razão porque aquelle homẽ || [161v] se somira no pateo. A que hũa daquellas | mulheres, que entre ellas parecia a prin|cipal, sem embargo de estarẽ alli tãbẽ | todos os piães que se tinhão salvado do | furor de D. Duardos, thomando a | mão respondeu desta maneira.

Sabei senhor cavalleiro, que o | Gigante por quem nos perguntaes se | chamava

25 Brusdolfo. [espaço] Foy seu Pay natural | do Reyno de Ungria, e por disgostos, que | ouve entre elle, e os Reys da quelle Reyno | teve Maneira como matou ao Prin|cepe Ditreo filho de Frisol - salteandoo | em hũa Floresta, em que estava folgando, | e sendo despois por aquelle crime mor|to ${ }^{1}$, deixou este filho menino aqui nes|te castello encomendada $^{2}$ a hua Dòna | sua May, com quem por força se tinha | cazado, onde o ella

\footnotetext{
${ }^{1} \mathrm{O}$ assassino de Ditreu foi o gigante Bracandor, que em seguida foi morto por Palmeirim de Inglaterra (que, tendo sido atacado também por outros cavaleiros e pelo sobrinho do gigante, foi socorrido por Albaizar, pai do personagem homônimo desta obra). O episódio é narrado no cap. 79 do Palmeirim.

${ }^{2} \mathrm{~B}, \mathrm{C}$ : encomendado.
} 
30 criou com mais te|mor de Deus, do que nos Gigantes costu|ma haver; Mas morrendo, se mostrou | brevemente que a natureza delle estava | violentada, porque a primeira couza que fes | foi irse a Armar cavalleiro a outra | Ilha, que não mui apartada desta Senho|reão outros Gigantes seus parentes, | e trazendo dali hum sobrinho seu con|cigo, e algũns Piães, e Marinheiros, | porque nem a terra pode sofrer outra | gente, nem elle aqueria

35 nella, começa||[162r] rão cada hũ em hũa barca a fazerem | os maiores insultos que se podẽ imagi|nar. ${ }^{3}$ Saqueando Navios, Matando ca|valleiros, e roubando Donzellas. [espaço] Epor|que o Sobrinho por fazer hũa preza des|tas sahio hũa ves em terra, e se quis | achar em hũas justas que por cerviço de | certa Donzella se fazião em o Reyno | de Ungria, e foi morto nellas, premi|tindoo assim Deus, ficou o Tio quando o $\mid$ soube, com 40 a dor que o sangue, e a con|formidade de suas naturezas lhe cau|zarão. [espaço] E em lugar de se emendar | com aquelle avizo do Ceo, fesse tanto | peor, que não volo sei encarecer. Enão | descançou a the que salteando o castello | da quella Donzella por cujo respeito o | sobrinho fora Morto, não a achando | nelle, trouxe a pobre de sua May, que | aqui tem preza, cuidando que serà | negaça para haver tambẽ a filha, co|mo cada dia 45 esperava, porque ella, e ou|tra prima sua segundo nos dizem / tem vindo muitas vezes ao porto desta | Ilha com algũns cavalleiros, que tra|zem para vingar a força que lhe foi feita, | e resgatar amay, mas Brusdolfo, pa|rece que temendo isto, proveo de ma|neira que pudesse viver seguro fazen|do hũ Engenho a o pe da Escada que $\|[162 \mathrm{v}]$ do pateo sobe para cima, com que em sen|do tocada hũa lagea que fas quazi todo | o primeiro tabuleiro della, jugando hũ | as moles em que se sustenta, da com os | que incauta mente se fião em hũa $\operatorname{cova}^{4}, \mid$ onde ou da queda, ou do máo tratamen|to que se lhe depois fas, não escapa nim|guem muitos dias com vida. [espaço] Se Sa|bermos nós isto sem o poder remediar | padescendo tambem em nossas pesso|as as forças, e violencias do Gigante he | ser cumplices em suas proprias cul|pas, a qui nos tendes a todos para nos dar |o castigo, que Deus quis que ja tenhais dado|a quem elle sabe que so o merecia.

Bem sospeitou D. Duar|dos que não era aquella coitadinha tão | inocente, e escrupuloza como queria | mostrarcelhe, mas por que as culpas das $\mid$ mulheres so outras mulheres as casti|gão, assegurando aquellas, e thoman|do o juramento a os homẽns, pediolhes | as chaves das prizões, que logo lhe fo|rão trazidas, e Mandando abrir hũa |

\footnotetext{
${ }^{3}$ Este ponto final deve ser desconsiderado.

${ }^{4}$ Entenda-se: no primeiro degrau (tabuleiro) da escada, havia uma pedra (lagea) sustentada por molas (moles). Oscilando (jugando), o mecanismo lançava numa cova quem pisasse ali.
} 
60 porta onde estava a May da Donzel|la, feslhe tirar os ferros de que estava | carregada, e tão mal tratada delles, | e de outras penitencias, que a não co|nheceu a filha facilmente quando depois | veio a o castello. [espaço] Dali se foy a hũ || [163r] pateo pequeno (deixandoa solta em | poder das outras) onde havia hũa ge|nella ferrada toda, e não grande, | pella qual aberta entrava lus na co|va onde os enganados paravão que lhe |

65 ficava abaixo perto de quarenta pal|mos, cavada toda a o picão sem nenhũa | outra entrada mais que a por onde ca|hião, porque como o Gigante não detre|minava tirallos dalli, mais fes aquil|lo para sepultura de muitos mortos, que pera | prizão de algũns vivos. E porque para con|versar com elles (deleitandoce com no|tavel crueldade nas mizerias alheas | como se doutra especie fora formado) | os não queria Mattar de todo,

70 por a|quella genella lhes mandava lançar | algũas vezes algũ pouco Mantimen|to. [espaço] Alli levarão os homẽns o ca|valleiro dos Ciprestes dizendolhe que / não havia outra parte de que pudesse ver | os prezos, e que tirallos não seria possi|vel se se não desfizesse a propria ge|nella, e ouvesse engenhos para os alarẽ | acima, couza que não tinha remedio, nẽ | elles cuidavão que havia para que lho pro|curar, porque não 75 entendião que pode|rião estar vivos, se não fossẽ sos dous | cavaleiros, que inda aquella menhã | alli cahirão, se aqueda os não tinha || [163v] acabado, porque haveria bem outo di|as que se aquella genella não abrira para | darem a os prezos o pouco Mantimen|to que sohião. [espaço] D Duardos cada | ves mais espantado de tão desacostu|madas cruezas começou a sentir, e a $\mid$ doerce de cuidar que socorria tarde, | mas não era assim,

80 porque guardando | Deus os Cavalleiros que alli estavão sepul|tados para serviço seu não havento muito | que tinhão cahido, guiou $\mathrm{D}$ Duardos, a | quem thomou por instromento de sua | liberdade, a tempo, que pudesse estorvar a | Maldade de Brusdolfo, E fazendo elle | com o pezar que dicemos abrir a genella | os dous cavalleiros que tinhão cahido aquella | Menhã com pouco danno deffendendoos as | armas da pancada como a

85 os mais tinha ac|contecido começarão com ador da injuria | fresca a provocar os que estavão decima cui|dando que era o Gigante com palavras ma|is dignas da treição delle, que do animo e | costume de quem as dizia imaginando | que com a indignação dellas quereria o Gigã|te vingarce com as Mãos tornandoos a | Mandar ir Onde o pudesse fazer. E a is|to respondeu outra vos mais fraca de | algũ dos que dentro havia: Senhores 90 cavallei|ros encomendaivos a Deus em quanto tendes | vida para opoder fazer E não cuideis que quẽ || [164r] vos aqui lançou he para vos tirar. Outras | tais palavras como 
essas temos todos $\mid$ ditto, de nada nos tem aproveitado malis que do dezengano com que nos achamos | E com que vos tambẽ depreça vos acha|reis. [espaço] Era aquella vox tão fraca | soavão as abobedas tão tristemente cõ | os ais e sospiros da outra companhia |que

95 ali estava, que cobiçou D Duardos a|quelle apozento para suas obediencias se | estivera menos povoado, mas não julgã|do os outros por tão inimigos de si, não | deixou de se compadecer grandemente | de tamanha Mizeria. [espaço] Eaffastandoce | da genella assi por não ver aquella seme|lhança do Inferno, como pello roim chei|ro que por ella vinha, Mandou aos homẽns | que a abrissem de todo, e que dicessẽ aos prezos | que estivessem 100 de bom animo, que preste | se verião livres. E levou os concigo | para ver com elles a Ordem que sepodia dar | na quillo. [espaço] Eos prezos ainda que não de|rão muito credito á promessa de sua liber|dade com tudo se alegrarão de ver ficar | a genella aberta por onde virão a lus | do Sol couza que athe então não tinhão | visto depois que ali cahirão, porque quando lhe | lançavão de comer era por hũ tão pe|queno postigo que 105 quazi se não via na|da. [espaço] Tambẽ aquelle vilão que cahira \| [164v] e morrera logo antes que acabasse de espi|rar lhe disse como hũ cavalleiro aquella | Menhã Matara a o Gigante, e o aperta|ra a elle tanto, que sem saber guardarce dera| no laço que sabia que alli estava armado, e | conferindo isto com o outro forão dando | mais algum lugar á esperança de seu | remedio. [espaço] E como a claridade que entrava | pella genella era

110 muita por ser opateo des|cuberto, e cheyo de Sol os dous cavalleiros | que ainda estavão armados como cahirão | vendo aos outros prezos posto que estavão | tão descorádos e fracos que quazi se não po|dião soster nos pes conhecerãonos logo cõ | estranha dor sua de os verem na quelle | Estado, e tirando os elmos forão tambẽ | conhecidos delles, que erão estes dous o Prince|pe Florendos, e ElRey Floramão, que par|tindo de 115 Constantinopla na demã|da que temos ditto a cabo de terem revol|vido tudo o que lhes foi possivel sem acha|rem novas do que buscavão toparão aquel|la Donzella filha da Donna preza, que |com lhes dar conta da força que o Gigante | lhe tinha feito os trouche á quella Ilha no | navio em que D. Duardos a achara, onde | enganados do Gigante hũ primeiro que outro en|trarão na quelle lasso de que nimguẽ esca|pava. [espaço] E o 120 modo $^{5}$ que elle para isto tinha | era meter os cavalleiros, a hũ e hũ no || [165r] pateo com salvo conducto, que lhes logo | dava, e alli dizendolhe que a batalha | havia de ser nas

\footnotetext{
${ }^{5}$ Há mancha sobre esta palavra no manuscrito; a lição foi confirmada em B e C.
} 
barandas $^{6}$ á vista da | Preza, que mandava tirar sobia por hũ | canto da Escada ${ }^{7}$ que estava firme, e põ|do as mãos no cavalleiro que hia junto | com elle não ficava remedio, porque | logo jugavão as molles, e davão com o | Outro no calabouço. E porque 125 Floramão | que fora o derradeiro que passara a ponte | da pouca detença que o Gigante fizera com | Florendos, e de quão são o via, ajuntan|do algua noticia que a Donzella dava | de elle não proceder singellamente ar|gumentando que havia alli treição, despois | que entrou no pateo não quis sobir acima | onde o Gigante se lhe Mostrou chamã|doo e tendo a Donna pellos cabellos | antes lhe disse que decesse, porque elle cuida|va que não

130 podia deixar de haver algũa | treição, que não era seu companheiro | pessoa que sem ella tão a seu salvo, e tão | depressa prendesse. [espaço] O qual vendoce en|tendido da quelle cavalleiro não queren|do de nenhũa Maneira haver brigas cõ | elle, nem podendo persuadillo que sobis|se acima detreminou de o prender com | a força da gente que tinha, para o que mandan|dolhe thomar as armas posse todo o cas|tello em revolta, e sentindoo

135 Floramão || [165v] cuidando que aquella era a treição de que | se temia, vendo que não se podia esca|par della detreminou havello antes cõ | elles nos corredores que lhe parecerão es|treitos, que no pateo, que era mui grande e | largo. [espaço] E indo a sobir com esta tenção | achouce com Florendos que o esperava ja | ficando ambos certificados assim do que | elle so temera, e esta foi a cauza porque | o não socorrerão os villões ${ }^{8}$, 140 que hião lan|çar a Galleota na agoa, para thomarem | a Donzella que Florendos quando dezafiou | o Gigante lhe disse que alli tinha conci|go. [espaço] Os outros prezos que em differentes tẽ|pos alli vierão guiados hũns da Donzella | que trazia a Albaizar, outros da Sorte, erão | Palmeirim de Lacedemonia, Almourol, | Franellio, Polendos, Belcar, e Pavoran|te, os quais todos pello mesmo engano, al|li forão sepultados. Eo como hũns, e | 145 outros forão livres veremos no capitulo se|guinte.

\footnotetext{
${ }^{6} \mathrm{C}$ : varandas; B: barandas. É oportuno notar que, em C, o copista havia redigido inicialmente barandas, como nas demais cópias examinadas, o que pode indicar que num antecedente comum a palavra já estava grafada desta forma. Não encontramos qualquer referência à variante baranda nos dicionários consultados.

${ }^{7}$ Nesta passagem parece faltar uma palavra. B e C apresentam a mesma lição.

${ }^{8} \mathrm{O}$ autor repete a observação feita anteriormente (cf. cap. 51, nota 5).
} 


\section{Capitulo 53}

Como D Duardos soltou os | prezos, e foi conhecido delles | e de como cada hũ depois se|guio sua fortuna, e Florendos \| [166r] e Floramão chegarão a | Constantinopla.

Dis a Historia que D Duardos | que se tinha hido a buscar remedio para | tirar a quelles cavalleiros não se fian|do de nada em parte de tanta sospei|ta quis ver primeiro com os olhos todas As | Officinas que no castello havia, e depois | de assegurado que não tinha de que se temer | abrio as portas que a o entrar fechara, e | Mandou hũ

10 daquelles homens ao Mar | chamar Trogonio com sinais deque não | duvidasse. [espaço] Veio logo o escudeiro | com tanto alvoroço como se pode crer | e thomando a Ordẽ que lhe seu Amo deu | voltou a os Navios e fes que agente delles | levasse os aparelhos da Galleota, enbra|ços ${ }^{1}$, e bolinas dos mais Navios, dos quais | D. Duardos quis compor hũa escada | para lançarem aos prezos, porque não havia | na terra commodidade de se fazer

15 ou|tra mais firme. [espaço] E tornando todos | com a Donzella, deixando os extre|mos do contentamẽto que ella fes com | a may depois que a conheceu. ${ }^{2}$ [espaço] Tratouce $\mid$ logo do modo que na quillo se teria, e | juntandoce as cordas, e atravessandoas cõ | outras, e com algũns páos das hasteas | das lanças, e alabardas que ali não fal||[166v]tavão fesse hũa escada pella qual cõ | pouco trabalho puderão sobir ainda os $\mid$ mais fracos. [espaço]

20 D Duardos os estava es|perando em hũa fermoza quadra cujas | genellas descobrião a porta e ladeira por | onde se vinha delle não tão descuidado que | tivesse o Elmo fora, nem tão prevenido | que mandasse esconder Trogonio, nem | mudandoce assi as Armas, pello qual que | com todos tinha tratado, e por ellas de que |Florendos, e Floramão bem se lembra|vão, o conhecerão logo em entrando na | caza, e elle a elles, com tamanha dor

25 de os | ver tais, e tal sobre salto de se lhes não po|der esconder, que não sei qual dos extre|mos foi nelle maior. Florendos com os | braços abertos lhe disse: [espaço] Ora senhor D | Duardos não vem fora de prepozito aqui | o que ja outro cavalleiro disse a vosso Pay | livrandoo duas vezes de prizões semelhã|tes, e foi que lhe não dava nada de

\footnotetext{
${ }^{1} \mathrm{~B}, \mathrm{C}$ : e os braços. O braços de um navio são cabos utilizados para manobrar as vergas de mastros de navios. As bolinas, citadas logo a seguir, são cordas ou cabos com que se esticam as velas de embarcações.

${ }^{2}$ Este ponto final deve ser desconsiderado.
} 
o pren|derem cada dia pois la ficava elle para o | soltar sempre ${ }^{3}$. [espaço] E se vos

30 affirmar que folgo | igualmente de me ver solto, e de serdes | vos a quem o devo, bem mo podeis crer, | porque espero saber novas de vosso Pay, e dos | outros Princepes que com elle se perderão. | Nada dezajava tanto como darvos este albraço ${ }^{4}$. [espaço] D Duardos dissimulando a | paixão de se ver conhecido tirandoo elmo $\|$ [167r] o recobeu ${ }^{5}$ a elle, a Floramão e aos outros | com tão verdadeiro amor como entre | todos havia, e

35 porque os mais delles estavão | tais que tinhão necessidade de serem reme|diados depressa tratouce logo de seu gaza|lhado, e da comodidade que no castello havia | posto que não era muito o regallo se proveu tu|do como melhor poude ser. Eassim estive|rão aquelle dia, e o outro dandoce conta do | que lhes tinha acontecido, a the que anoite se|guinte D Duardos que julgava por offensa | de sua fee conversar com agente, cuidã|do 40 que quebrava nisso os perceitos de sua | senhora, deixando hũa carta escrita a | Florendos em que se desculpava, e lhe dava | conta de como aquelles Reys erão livres | o que athe então lhe não tinha declarado | por não fallar em couza de que o pudessem | louvar, pedindolhe que mandasse desfazer | o engenho da escada, e entulhar aquella | prizão ou cova de maneira que não pudes|se nimguẽ servirce mais della e que a Ilha | se 45 lhe parecece, podia dar á Donzella, | ou a Dona sua May.

Foice na sua setia com ten|ção de thomar a primeira terra que achasse, e despo|jarce da companhia de Togronio, e de to|da a outra, e ainda de deixar as armas |e o uzo dellas para se não ver por aquelle res|peito em outra affronta como para elle era \| [167v] teremno conhecido. Tal impressão tinha | feito neste Princepe a inconcideração |

50 ou collera de hũa mulher, a quem quando não | tivesse pezado do que tão sem cauza lhe ti|nha ditto, seria por lhe não lembrar mais | o que fizera ${ }^{6}$. [espaço] Mas estes são os Milagres | do Amor, e os seus poderes de que he tão pro|digo, que a troco de mostrallo assi como ja | lhe não deu nada devermos a Hercules | em outra idade dobando, e fiando,

\footnotetext{
${ }^{3}$ A frase foi dita por Germão d’Orléans no cap. 58 do Palmeirim de Inglaterra: "Já agora me não dá nada, que me prendam cada dia, pois enfim lá ficais vós, que tendes por ofício soltar todos".

${ }^{4}$ A estrutura e a pontuação desta passagem são confusas.

${ }^{5}$ No reclame do f. 166v o copista registrou recebeu. Em B, o verbo recebeu foi omitido: tirando o elmo [...] aelle, a Floramão.

${ }^{6}$ Leia-se: "de uma mulher a quem, quando não pesasse mais do que tão sem razão lhe tinha dito, seria por não lembrar mais o que fizera".
} 
não | lhe darà de precepitar agora nesta a D. | Duardos em algũ ludibrio destes ${ }^{7}$, como |a seu tempo por ventura que veremos.

Tornando a Florendos, tanto que | a o Outro dia lhe derão acarta do sobrinho | sentindo muito que tivesse Occazião que o a|partasse assim de seus amigos, e paren|tes, tornouce a conçolar entendendo, que | o desencantamento da quelles Princepes | de que lhe dava novas, em que tanto hia a o Mundo, e a sua soltura delle, e dos outros | que 60 estavão na quella caza, erão tudo fru|tos do mesmo apartamento. ${ }^{8}$ [espaço] Crendo tã|bem que Deus que tão estremado fizera a | quelle cavalleiro sobre os outros homẽns | o guiaria sempre com particular pro|videncia pellos passos que lhe melhor es|tivessem. [espaço] Despois dando conta a | Floramão e a os mais que cada hora me|lhoravão, de tudo quanto a carta continha $\|$ [168r] fazendo quanto lhe o cavalleiro dos Cipres|tes encomendara, esperou alli athe que | todos os prizioneiros estiverão em | despozição de poderem caminhar, en|tão deixando a Dóna, e sua filha no | Senhorio da Ilha, que não constava de | mais habitações que aquelle castello, e | algũas cabanas de pastores, que por ella | havia, thomando juramento a os ho|mẽns, que escaparão das mãos de D. | Duardos, que bem, e lealmente serviri|ão sempre, deixoulhes o Navio em que | vierão, e

70 elle e os companheiros se par|tirão todos na Galleota, e atravessã|do hũ pequeno golfo que havia dali a ter|ra firme de Ungria, todos os mais | tirado Florendos, e Floramão, se deixa|rão ficar em terra, para cada hũ per si | seguir suas Aventuras, dezejozos de | adquirirem algũa gloria pessoal em que | estribasse melhor a que as obras de seus | Pays lhe davão. E de todos dará razão | a seu tempo a Historia, a qual conti|nuando com os 75 dous Princepes que fi|carão na Galleota com tenção de hirẽ | a Constantinopla, onde tinhão por | certo que acharião mais meudas novas | dos desencantados, do que $\mathrm{D}$ Duardos | lhes dera quando os não achassẽ alli ${ }^{9}$, dis que che|garão poucos dias despois

\footnotetext{
${ }^{7} \mathrm{C}$ : "que atroco de mostrallos assy como lhe ia não deu nada de vermos a Herculles em outra idade debando efiando não lhe dará deprecipitar agora nesta aDom Duardos em algú ludibrio destes”. A lição de $\mathrm{B}$ é semelhante à de $\mathrm{A}$, com a diferença de, assim como em $\mathrm{C}$, apresentar debando no lugar de dobando. Não conseguimos entender exatamente o sentido da referência ao herói grego. Hércules foi vítima do ciúme de sua esposa, que lhe deu um manto envenenado pensando que ele garantiria sua fidelidade amorosa. Os verbos dobar e debar (das lições de A e B/C) são sinônimos e podem significar "enovelar ou fazer novelos" e "cair dando voltas ou rodopiar". Dessa forma, ficamos em dúvida também quanto ao sentido que se deve atribuir ao verbo fiar, que vem logo a seguir: seria uma referência ao manto (fiar com sentido de costurar) ou à confiança na esposa que lhe entregou o manto? De qualquer modo, a intenção do autor foi demonstrar como o poder do Amor pode gerar desastres, comparando o fim trágico de Hércules com o sofrimento injusto de D. Duardos.

${ }^{8}$ Este ponto final deve ser desconsiderado.

${ }^{9}$ Floramão e Floriano decidem voltar para Constantinopla crendo que lá teriam mais notícias dos reis desencantados, mesmo que não estivessem naquela cidade.
} 
delles a o por||[168v]to da quella cidade sem lhes acontecer | couza de que se deva fazer Memoria, | e sahindo em terra armados de todas | as peças, entrarão pello Passo a tempo 80 | que os Reys, e o Emperador acabavão | de gentar, e contentes de os verem ou|tra ves alli juntos todos, sentandoce | de giolhos diante do Emperador tirando | os Elmos das cabeças, acabarão de fazer | a quella corte contente, porq ue em sendo | conhecidos, foi o alvorosso tão geral nos | Princepes, e nas Senhoras, que não ouve | nimguẽ a que não coubesse hũa grão par|te, e depois de socegados os primeiros Mo|vimentos contando

85 Florendos o peri|go, em que cahira, e quem o livrara delle | começou a voar a fama de D. Duar|dos demaneira, que nenhũa couza de se|us passados parecia grande junto das | suas, E dandoce novos parabens huns | a os outros, tambẽ se consolarão da sua | auzencia parecendolhes, que o Ordenaria as|sim Deus para remedio de muitos. [espaço] Medo | hei eu (respondeu Daliarte diante quẽ | tudo isto passava) que brevemente haja |

90 D. Duardos mister socorrido ${ }^{10}$, e que lhe | não valha para o ser a pouca culpa que elle | tem em seu desterro, porque receio que a | muita tristeza o ponha em estado que não pos|sa valer a outrem, nẽ outrem a elle.

|| [169r] Não se pode negar que tocarão | estas palavras no coração a Carmellia | que as ouvio, e notou, fazendo nella ta|manha impressão na quelle primeiro acci|dente, 95 que a durar, não fora muito obri|garemna a algũ extremo, Mas como | era tão altiva, lembrandolhe que o arre|pendimento do que tinha feito condena|va toda a obra passada, antes quis pa|decer aquella dor, que a começava a ator|mentar, que dar o seu braço a torcer co|mo dizẽ por se livrar della, quanto mais que | como a quella piedade entrou de subito $\mid \mathrm{e}^{11}$ pellos ouvidos, não se continuando | a bataria, tornou D Duardos a ficar $\mid \mathrm{em}$ 100 sua memoria no esquecimento | em que dantes vivia.

\footnotetext{
${ }^{10} \mathrm{~B}, \mathrm{C}$ : mister ser socorrido.

${ }^{11}$ No manuscrito, há uma mancha sobre $e$, o que o torna ilegível; a lição apresentada aqui é a de B e C.
} 


\section{Capitulo 54}

\section{Do que aconteceu a o Prin|cepe Primaleão no Reyno de Bohemia, depois | que partio da Ilha de Dramuzi|ando.}

Do valente, e esforçado Princepe | Primaleão, de quẽ ha muito que não falamos, || [169v] dis a historia que tanto que partio da Ilha | de Dramuziando no primeiro Navio que | poude haver à mão, guiado da quella | dor que a perda de tantos Reis no cora|ção de todos tinha impressa, começou | de navegar por onde a fortuna o enca|minhava com tão pouca certeza do que | queria, como todos então na quella ẽ|preza levavão. E

10 discorrendo por va|rias partes sem achar couza que lhe miti|gasse a paixão enfadado do Mar, e dos | Marinheiros mandou thomar terra no | Reyno de Bohemia, donde se acharão | mais perto, na qual então reinava Vin|ceslao segundo do nome. [espaço] Era este | Princepe ja de idade, mas são na pes|soa, e muito mais são no juizo, que com | a boa natureza, e experiencia larga | era grande, e claro. [espaço] Vivia cazado com |

15 Madama Rodeginia irmã do Archi|duque de Austria, senhora dotada de tan|tas, e tão grandes excellencias, como ti|nha o sangue, e o Estado. [espaço] Estavão em | conformidade contentes de seu senhorio, | mas muito mais contentes da ditoza sorte | que os ajuntara no Santo vinculo da | quelle Matrimonio, com a qual ja qua|zi desperados de terem filhos, ouverão hũa | filha tão extremada, e fermoza que pu|dera mui bem ser tida entre as Prince||[170r]zas de Grecia por quinta maravilha | em numero, enão segunda em per|feição a nenhũa dellas. [espaço] Acompanha|va a esta Princeza com tantas ou|tras calidades esta calidade, que ainda | que lhe ella faltara, qualquer das mais | que ella possuhia a puderão fazer muito no|tavel no mundo, porque a sutileza do | Entendimento, a prudencia do proceder, | a compostura da pessoa, a gravidade | dos

25 termos, e a suavidade do trato, dei|xando a Muzica, e algũas outras artes | de mãos, em ${ }^{1}$ que era insigne, a tinhão | constituhida hũ exemplar pouco imi|tavel de todas as perfeições, que a industria | humana podia alcançar. [espaço] Era de de|saceis para desacete annos, e tão namora|da dos muitos de seu Pay pello que delles a|prendia, que com difficuldade se lhe des|pegava, com o que o velho a amava tão | tenrra, e intença mente, que bẽ se deixava | ver que no menor gosto della andava | pendurada toda a sua vida delle. De|zejava ás vezes cazalla para não ter em | hũ só folego a successão de seu

\footnotetext{
${ }^{1}$ Há mancha sobre esta palavra no manuscrito; a lição foi confirmada em B e C.
} 
Reyno $^{2}$, | outras parecendolhe que a perdia, e que não | havia no mundo hũ, de quẽ se pudesse fi|ar thezouro tão grande, de nenhũa ma|neira admitia semelhante tentação. |E passava a couza de modo, que não so por $\|[170 \mathrm{v}]$ indicios dava elle conta destes 35 pensa|mentos á propria filha, mas conhecen|do bem a confiança que podia fazer del|la, claramente lhos comonicava, e | lhe pedia seu parecer apontandolhe os | inconvenientes que achava nas escolhas | que se lhe offerecião, com oque veio a criar | no animo da quella senhora hũ tão gran|de aborrecimento da quelle estàdo ${ }^{3}$, que lhe | não foi despois pouco penozo querella | persuadir a que o thomasse. [espaço] Materia | era esta que nos

40 dava licença para discorrer | hũ pouco com doutrinas geraes pella | criação que se deve dar ás filhas, mas porque | não venhamos a topar com particulares, | que poucas vezes pode deixar de fazerce, e | nenhũa a meu juizo de recitar sem escan|dalo, digo só que se o Pay he honrrado, e | Entendido, e a filha entendida, e honrra|da, que nada pode correr perigo se não | so o gosto, porque na gente honrrada, e se|zuda a honrra, e o

45 Entendimento sẽ|pre levão a vontade tras si ao que comvẽ, | ou com vontade, ou sem ella, e sendo is|to desta maneira, maior groceria serà | não converçar hũ homẽ com quẽ o ama | como Pay, respeita como senhor, respon|de como discreta, e calla como obrigada, | que prudencia deixar de lograr o bẽ que des|ta tal converçação se rezulta por hua || [171r] moucarrarice carregada, que não conhe|ce, ou não quer admitir nunca as

50 ex|cepções que todas as regras padessem ${ }^{4}$. [espaço] | Neste estado pois estava Bohemia quando | Primaleão chegou a ella tão enfadado | do Mar, e do pouco que nelle tinha achado | a respeito das novas que pertendia, que se | pos a caminhar por terra armado das | armas com que sahira de Constantino|pla ao socorro de Dramuziando, as | quais tinha mandado fazer para comecar ${ }^{5}$ | a entrar no mundo buscando as Aven|turas para 55 que todos os Princepes Noveis se | fazião prestes quando chegou à corte o reca|do que os levou della. Epor isso erão ma|is louçãns, e galantes, do que elle então le|vava a

\footnotetext{
${ }^{2}$ O Vocabulario de Bluteau registra a expressão "de um fôlego", à qual atribui o significado "sem tomar respiração". O sentido da passagem parece ser o seguinte: se sua filha ainda não estivesse casada quando o rei morresse, a sucessão do reino seria mais abrupta; se ela se casasse com o pai ainda vivo, poder-se-ia tratar com mais calma do processo de transição de governo.

${ }^{3}$ Estado refere-se à vida matrimonial.

${ }^{4}$ As reflexões do narrador estão redigidas de modo um tanto confuso. O sentido da passagem parece ser um elogio à franqueza com que rei Venceslau conversava com a filha sobre seu casamento. A atitude é tida como louvável por dois motivos: sua filha era entendida e honrada e, além disso, seria moucarrice não conversar com uma filha que respeita e ama seu pai. A palavra moucarrice não está registrada nos dicionários consultados, mas deve ser derivada de "mouco"; por isso, acreditamos que ela deve significar "surdez ou teimosia".

${ }^{5}$ Falta o cedilha.
} 
vontade, porque sendo o corpo de | todas ellas de hũa cor roxa muito fina, e|rão coalhadas de hũns como pespontos | verdes, brancos, eamarellos, que formavão | huas Ondas no modo de que hião lança|dos, com que ficava hũ novo, e engraça|do trajo.

60 [espaço] No escudo emcampo ce|leste Phaetonte morto, e o seu carro | quebrado, com hua letra que dizia: Nem | por isso. pella qual diviza, de que se veio | a contentar muito lhe chamavão por aquel|la terra o cavalleiro do $\mathrm{Sol}^{6}$, e com este | nome se começou a fazer respeitar | por toda ella pello melhor do mundo, por||[171v]que discorrendo por aquellas partes seten|trionais, em todas as Aventuras que se | lhe 65 offerecião mostrou sempre vallor no | accometer, ditta no acabar, sofrimen|to nos perigos, temperança nas victo|rias, odio a os vicios, clemencia com $\mid$ os viciozos, comque athe os seus propri|os vencidos o respeitavão, e amavão. | previlegios, e prerogativas que so alcan|ça quem de tal maneira administra | justiça, que mais parece que pertende a $\mid$ Emmenda, que o castigo.

70 Andando assim pois este Prin|cepe soccorrendo Donzellas, desagra|vando veuvas, com que sua fama tinha | cheios de hũa louvavel inveja os ani|mos dos bõns, e de não menor temor | os corações dos Máos, contente de como | gastava o tempo, enfadado do pouco que | no seu principal intento arrecada|va, indo hũa Menhã ja tão tarde, que | começava a obrigar o Sol a buscar al|gua parte onde se passacem as horas da

75 | césta, que por ser na força do verão erão | pezadas, e grandes, vendo não mui desvi|ado do caminho que fazia hũ valle povo|ado de muitas arvores verdes, e altas, foice | a demandallo cuidando achar alli cõ|modidade para o que queria, e quanto mais se | lhe avezinhava, mais certa, e melhor $\|$ [172r] lhe hia parecendo, porque ouvia correr | agoa, companhia assás alegre para a|quelles tempos, e entrando emfim | no valle pella parte de 80 baixo vio hũ | ribeiro, não de muita agoa, mas muito cla|ra, cujas margẽns se cobrião de hũa | Erva muito meúda, e verde, e hũas ave|leiras, que por baixo de frexos, olmos, | chopos, e outras arvores mais crecidas, | que ellas, fazião hũ cuberto á propria a|goa, tecidas entre si com Eras, e Erva | cidreira tão em Ordem, que parecia ma|is obra da arte que da natureza. Ter|minavace aquelle valle em hũ prado | redondo sem arvore algũa no 85 qual | se recolhia parte da agoa do Ribeiro | e se tornava a sahir por hũ conducto |

\footnotetext{
${ }^{6}$ Faetonte é o famoso personagem mitológico que, tendo tomado as rédeas do carro que conduzia o Sol, aproximou-o demasiadamente da terra. Por isso, Zeus o castigou e Faetonte, desgovernado, caiu sobre o rio Pó. Graças à representação de Faetonte no escudo, Primaleão ficou conhecido como Cavaleiro do Sol.
} 
descuberto deixando ${ }^{7}$ rico de ervas, e | flores, aprazivel á vista, e não intra|tavel aos pes, porque não se detinha a | agoa mais espaço nelle, que o que bastava | para fazer a terra grossa, e não molha|da. [espaço] $\mathrm{O}$ cavalleiro do Sol vendo lu|gar tão aparelhado, sem fazer mais deli|gencia se apeou logo, e entregando o | cavallo a seu Escudeiro (que

90 tirandolhe $\mid$ o freio o deixou lograr, com o em que elle vinha do que aquelle prado tão liberal $\mid$ mente lhe offerecia) ${ }^{8}$ entrou debaixo | do cuberto das Avelleiras, e alli tirando || [172v] o elmo, e o escudo, lavando as mãos e | o rosto se deixou andar passeando hũ | pouco em quanto o escudeiro lhe trazia dos | alforges o com que o costumava agazalhar, | fesse $^{9}$ aquillo assim, e como Primaleão | so trazia o cuidado nas novas dos | Reys, que

95 não achava, inda que lhe este da|va penna, não era demaneira, que lhe | violentasse a natureza para que não fizes|se as opperações nelle, que em hũ homẽ | livre costuma a fazer. Eassi entreten|doce hũ pouco com Ardenio (que este nome | tinha aquelle Escudeiro seu, que era filho | de Armello, que o ja fora do Princepe | Florendos $)^{10}$ dizendolhe quanto melhor compa|nhia fizera áquellas Arvores o espiri|to de Floramão 100 que o seu, eoutros re|moques a os sospiros do Pay bem longe | de cuidar que alli se começarião os seus, $\mid$ o despedio, e se encostou a dormir, com $\mid$ o escudo junto de si, e o elmo á cabiceira. | E nós quando não dormirmos, rezão se|rà que pello menos descancemos, para que | com novo alento tornemos a dizer | o mais que depois de acordado lhe acon|teceu.

\footnotetext{
${ }^{7}$ Aqui possivelmente haja erro comum às cópias $\mathrm{A}, \mathrm{B}$ e $\mathrm{C}$; em princípio, cremos que deveria haver um pronome (deixando-o).

${ }^{8}$ Entenda-se: "tirando-lhe o freio, o deixou lograr, juntamente com o [cavalo] em que ele [o escudeiro] vinha, do que aquele prado tão liberalmente oferecia".

${ }^{9}$ Leia-se: "fez-se".

${ }^{10}$ Assim como D. Duardos, que escolheu o filho do escudeiro de seu pai para acompanhá-lo (lembre-se que Trigonio é filho de Selvião, que servira Palmeirim de Inglaterra; cf. cap. 25, nota 7), Primaleão também escolhe o filho do escudeiro de seu pai para servi-lo. Armelo desempenhou um papel de certo relevo no Palmeirim de Inglaterra no episódio em que Florendos foi proibido por Miraguarda de portar armas durante um ano (cf. em especial o cap. 72).
} 


\section{Capitulo 55 \\ || [173r] Do que succedeu a Prima|leão em aquelle lugar | em que estava.}

Não mui longe da parte em que Pri|maleão dormia tão descuidada men|te como 5 convem que esteja hũ homẽ | em quem o amor quer fazer hũa fac|ção grande ${ }^{1}$, estava a fonte donde se de|rivava a agoa, que fazia aquelle ribeiro | tão rica, e bem obrada no arteficio, co|mo a Natureza a fizera fermoza, e | fresca no Nacimento, rodeada de ou|tras Arvores $^{2}$, de outras Ervas tanto mais | para ver, e para lograr, quanta he a ventagem | que a natureza ajudada da arte se fas | a si mesma, onde ella algũas vezes | como por

10 ludibrio da propria arte | se fas a si mesma imitadora de quẽ | a imita com muito maior ventagem. | Senhoreava aquelle lugar hũ padastro | não mui apartado, no qual estavão si|tuados hũ castello ou caza de Prazer, | e hũ Mosteiro dos Religiossissimos fra|des Hieronymos $^{3}$, que os Reys de Bohe|mia alli fizerão com tanta perfeição | e sumptuozidade que não deixavão | com menos admiração o juizo de | quem via hũ, que

15 devação nalma dequẽ | contemplava outro. [espaço] Neste sitio que era || [173v] são por ares, comodo pella vizinhança $\mid \mathrm{da}^{4}$ cidade onde a corte rezidia, de|leitozo pella cantidade de todas as | cassas, de que era rodeado, sumptuozo | pella Magnificencia, e celebridade | do Edifficio, em que ElRey Vincislao | por descurso de muitos annos tinha ẽ|pregado fazenda, e coriozidade, se | entretinha muito de verão a Prince|za Fidelia (que assim se chamava | a quella senhora) e quazi sempre passa|va alli a maior parte delle, indo mui|de ${ }^{5}$ Ordinario visitar seu Pay, quando elle | por algũa occupação do governo a não | vizitava a ella, o que com pouca mo|lestia se podia fazer, porque não passa|va de legoa a distancia que entre o cas|tello, e a cidade havia. [espaço] Aconteceu | pois que poucas horas antes que Primale|ão entrasse no valle, que por sua frescu|ra se chamava

\footnotetext{
${ }^{1}$ Facção significa "ação ou empresa militar" (Bluteau).

${ }^{2}$ Provavelmente a concordância dos adjetivos no feminino se justifica pela elipse do termo fonte. Leia-se: "estava a fonte donde se derivava a água que tornava aquele ribeiro [uma fonte] tão rica e bem obrada no artifício, como a Natureza a fizera formosa e fresca no nascimento, rodeada de outras árvores".

${ }^{3}$ A ordem dos Jerônimos foi fundada na Espanha no séc. XIV e gozou de grande prestígio durante o Renascimento por toda a Península Ibérica; não foi por outro motivo que D. Manuel I entregou o monumental mosteiro construído na praia do Restelo em Lisboa a esta ordem, que já possuía casas em outras regiões do país. Diz o autor que o vale onde se encontrava Primaleão estava sob um monte (padastro ou padrasto) em que havia o referido mosteiro e uma caza de prazer, ou seja, um castelo construído para o repouso do rei e sua família.

${ }^{4}$ Há mancha sobre a palavra no manuscrito; a lição apresentada é de B e C.

${ }^{5} \mathrm{Na}$ mudança de linha o copista inseriu um hífen, pelo que transcrevemos as palavras mui e de juntas. Em B e C elas estão separadas.
} 
25 de Flores dando o pro|prio nome á quelle Castello, e Mosteiro | tinha chegado a Princeza à outra en|trada delle pella parte da fonte, recolhẽ|doce da cidade, onde o dia antes | fora ver ElRey seu Pay, e detreminã|do vir jantar a ella como muitas vezes fa|zia, mandou que lhe tivessem alli pres|tes em tendas que mandava armar. I E porque quando Primaleão chegou a ella ti||[174r]nha ja comido, e estava agasalhada, e | os Ministros, e

30 gente de serviço se | tinhão sobido a o castello, ficando só | des cavalleiros, que fazião guarda com | grande silencio por não inquietarem | o repouzo da Princeza, não sentio | elle o rumor da vezinhança, que inda | que estava hũ bom tiro de besta pello | ribeiro acima, se viera mais cedo | não pudera deixar de sentir o estre|pito dos cozinheiros, e de lhe cheirar | o fumo das iguarias, mas por este res|peito se agazalhou tambẽ com o 35 descui|do, e socego que temos contado, no qual | esteve a the que o acordou hũa novidade | com que o pobre Princepe deixou de ser | dali por diante tão senhor de si, como | dantes era. [espaço] E foy que a Princeza ha|vendo grande espaço que repouzava, vẽ|do o Silencio em que estava o Mundo | chamou hũa Aya sua que muito amava | por nome Enaclia filha de hũ dos | móres senhores daquelle Reyno, e hũ |

40 Enano, com que tambem folgava, e man|doulhe que thomassẽ duas canas delgadas | comque sohia pescar ás tencas, de que o | ribeiro era assás provido, e pondolhe | Mais ás costas duas béstas de pelouro | para tirar aos passarinhos que pellas ar|vores se agazalhavão, sahindo por hũa $\|[174 \mathrm{v}]$ porta da tenda que vinha para o rio, se | forão andando por elle abaixo a de|mandar o posto, em que Primaleão es|tava, que tirado o da 45 fonte era o me|lhor que em todo o curso do Ribeiro | havia. [espaço] Hião vestidas a respeito | do tempo, e das horas, mais discreta, | que rica mente, sem verdugadas, cõ | vasquinhas, e saios de catalufas leves ${ }^{6}$ | em mangas de camiza crespas emuito | largas, voltas no pescoço de trancinhas | com pontas de pita negras, os cabel|los lançados para tras, e postas sobe el|les hũas capellas de flores da quelle va|le com cadeas de goivos 50 amarellos | e encarnados atravessadas como ban|das. [espaço] Fermoza, engraçada, e Mo|ça era Enaclia, mas os extremos | de Fidelia só em Constantinopla | se podião igualar. Eassim inda que o | trage era conforme, havia tanta de|zigualdade em tudo o mais, que facil | mente julgara quem as vira onde es|tivera mais prompto o cuidado da | Natureza. [espaço] O Enano era pe|queno, e feio á Maravilha, mas vivo | e galante

\footnotetext{
${ }^{6}$ Não conseguimos descobrir o significado de catalufas, embora o contexto permita deduzir que seria um tipo de tecido.
} 
55 homẽ, e por tal estimado ẽ | extremo da Princeza. E indoas | elle Enterdendo ${ }^{7}$ offerecendoce a deffen|dellas com aquellas canas a o cavalleiro \| [175r] do Sol, cuja fama então tinha aquel|la terra cheia, dando de subito com | a vista por entre as Avelleiras que dice|mos, em Primaleão que quieta e des|cuidada mente repouzava. Tal | como Morto voltou para ellas dizẽdo | Senhoras minhas falemos agora de si|zo, alli està

60 hũ cavalleiro deitado | ainda que não deve de ser o do Sol, | com tudo se for menos comedido | do que dizem que elle he, necessario | vos serà melhor guarda do que eu. | Ellas, que inda o não tinhão visto cui|dando que erão travessuras suas quize|rão ir por diante, mas porque todavia | elle Mostrava no rosto a verdade | das palavras, affirmandoce mais vi|rão o Cavalleiro, e sobresaltandoce | algũ tanto inda que não muito 65 porque a | calidade das pessoas, a segurança dos | Animos, a vizinhança das tendas, | não deixavão grande lugar ao te|mor, parárão, e o primeiro Movimento| foy olharẽ para si, e para o modo de que hião | compostas, e tras isto tornarão a por | os olhos no Cavalleiro, e vendo que | não se Movia disse a Princeza para | Pleonido, que assim se chamava o Ena|no, [espaço] Que máo fora Pleonido ador|mentares ${ }^{8}$ com hũ pelouro desses aquelle 70 || [175v] Cavalleiro de maneira que pudessemos | lograr o sitio que nos thomou, sem nos | temermos delle. - Senhora, lhe respon|deu o Enano, não zombemos agora | por vida vossa, vamonos embora an|tes que este homẽ acorde, que despois nẽ | vos haveisde ter pes para fugir, nem | eu lingoa para gritar, e se eu tivera | juizo não acompanhara com gen|te que tentando concigo, tambẽ con|cigo desculpa ${ }^{9}$. [espaço] E porque toda via $\mid$ a

75 Princeza não queria que aquelle | cavalleiro acordasse à sua vista, tor|nou a voltar por onde viera dizen|do para o Enano. [espaço] Ora bem senhor, | saberei da qui por diante que guardador | tenho em vos, pois carregado de ar|mas vos não a treveis a deffenderme | de hũ cavalleiro desarmado, e dormin|do. [espaço] E depois que estiverão tão apartados que | o Enano se contou por seguro disse para | ellas: [espaço] Em verdade que vou 80 arrependi|do de não chegarmos à quelle cavalleiro | porque segundo parece encalmado | Ouveralhe de Aconcelhar que fora ca|valleiro de Inverno, e jardineiro de | verão. Aqui no nosso castello passá|ra assim a vida com acomodida|de de que deve ser devoto.

${ }_{8}^{7} \mathrm{C}$ : entretendo; B apresenta a mesma lição de A.

${ }^{8}$ Apesar de não fazer sentido no contexto, a lição confere com a de B e C. Cremos que melhor seria atormentares, embora mesmo esta opção não se adequar perfeitamente à frase.

${ }^{9}$ Não está clara a observação final de Pleonido. Seu sentido parece ser o seguinte: "Se eu tivesse juízo não acompanhara gente que me usa como instrumento de tentação e desculpa”. A lição do trecho coincide com a de B e C (embora em B haja uma repetição indevida: "não acompanhara não acompanhara gente que tentando") 
[espaço] Ta, tá ${ }^{10}$ Pleoni|do respondeu Enaclia, haver medo diante \| [176r] e mormurar de tras, não he couza de | homem, nem sei se de mulher. [espaço] | Ainda assim poderá 85 ser minha (res|pondeu elle) que não sou hũa couza | nem outra. Mas vós quereisme | mal, e tanto que athe isto que eu dizia | por vos adular a respeito de como | as mulheres se soem a cançar com | homẽns descuidados e livres, me | agradeceis dessa maneira. [espaço] Mui | enganado estais (replicou ella) por|que quando essa regra fosse geral, e certa, | nenhũa das quais couzas tem, a | inda vos responderiamos, que não | são os

90 livres, e descuidados, os de quẽ | as mulheres se aborrecẽ, senão daquel|les que a pos as verem ficão descui|dados, e livres, e sendo isto assim | mais me parece injuria, que adulação | esse vosso conceito; Mas eu não | me espanto de não atinardes com | o que dizeis, porque o medo grande para | se agazalhar em couza tão pequena | por força hade lançar o juizo fora. |E mais senhora (lhe disse elle) quando eu le|vo o meu, e juntamente

95 o que fora | razão que vos mostraceis ${ }^{11}$. Mas pois | sois tão valente daime essa cadea | levalahei por gáie ${ }^{12}$ áquelle cavalleiro | dezafialohei de vossa parte para se || [176v] combater com vosco. E se por ventura | vos tornar com a aceitação do dezafio | quiçá vos parecerei melhor do que me | agora julgais. [espaço] Como Pleonido, | (disse então a Princeza rindo de ver | Enaclia a talhada, com a sua resposta) | Estamos aqui no Reyno 100 das Ama|zonas, ou que dezafios são estes? ${ }^{13}$ [espaço] Ena|clia senhora (lhe respondeu elle) he discre|ta pagame as obrigações com inju|rias e eu que o não sou tanto, respon|dolhe ás sospeitas com verdades. [espaço] |E com isto entrando nas tendas a que es|tavão ja pegadas, não ouve lugar por | então para mais perguntas e respostas.

\footnotetext{
${ }^{10}$ Esta expressão, que certamente reflete hábitos da linguagem coloquial da época, será empregada novamente mais adiante (cap. 64).

${ }^{11}$ Enáclia diz não se surpreender com o que ela julga tolices de Pleonido, pois, sendo ele tão pequeno, não conseguiria abrigar em si ao mesmo tempo o juízo e o sentimento de temor pelo cavaleiro desconhecido. A esta observação sarcástica, ele retruca que manteve seu juízo são, o que Enáclia também deveria fazer.

12 O termo, não registrado no Vocabulario de Bluteau e também no Dicionário Aurélio, é tomado do francês gage, e indica o objeto usado como penhor num desafio.

${ }^{13}$ As amazonas eram guerreiras lendárias da Antigüidade.
} 


\section{Capitulo 56}

\section{De como Primaleão foy de|mandar as tendas da Prin|ceza, e das justas que | teve com seus ca|valleiros.}

Poucas couzas das que Fidelia, Enaclia, | e Pleonido passarão deixou de ouvir Pri|maleão, porque toda via não fallarão ellas | tão manço o espaço que se detiverão no || [177r] lugar de que o virão, nem elle estava tão | occupado do somno, que as não sentisse | Mas não fes rumor por não espantar a | cassa, cuidando que não deixarião de | chegar; porem como vio que voltavão | enlaçando o Elmo, e tomando o Escudo | se foi

10 quieta mente espos ellas, mas a | verdade he que contra Amor não val el|mo nẽ escudo, e assi o Exprimentou | este Princepe, porque sem lhe bastar | aquella pervenção ficou para mor gloria | do mesmo Amor armado de todas | as pessas, vencido de hũa Moça de quin|ze annos em mangas de camiza ${ }^{1}$. | E tornando a o fio da historia, elle as $\mid$ hia espreitando tanto mais enlevado | na quella converçação, quantas mais erão | as palavras

15 que algũas vezes perdia, por | que por as não atalhar não se ouzava | a chegar muito, e assim andando as | vio meter nas tendas, antes das quais | ellas nunca pararão. [espaço] E parecendolhe | que alli ficavão seguras, tornouce depres|sa aonde deixara Ardellio, porque tam|bem do lugar a que chegara vira lanças | Encostadas ás arvores, e Escudos pen|durados nellas, E não querendo deixar | de ver o fim da quella Aventura

20 a|cordandoo feslhe que enfreasse o caval|lo, e lho trouxesse logo, e pondoce $\|$ [177v] nelle, advertindo a o Escudeiro que por | nenhũa couza que lhe succedesse des|cobrice quem elle era, thomou o ca|minho para a fonte andando por fora $\mid$ das armas, quero dizer das arvores $^{2}$. [espaço] $\mid \mathrm{E}$ chegando brevemente à vista das $\mid$ tendas vendo occupada a estrada | de Cavalleiros armados, concertandoce | na sella, e thomando a

25 lança, chegou | a onde elles estavão, os quais havia es|paço que o vião vir, e depois de se salva|rem cortés mente, o do Sol lhes disse | que se a passagẽ se havia de franquear | por força, que lhe pezava muito de o não | saber a tempo que sem se correr de si | pudesse thomar outro caminho, mas que | elle não cria de tão honrrada companhia | como the parecia a quella, que quizessẽ | impedir os que por direitos das gentes e|rão comuns a

\footnotetext{
${ }^{1}$ Em mangas de camisa indica que a princesa não estava usando um casaco ou jaqueta sobre a camisa; no contexto, implica o fato de Fidélia estar vestida de modo simples. Note-se que, se nesta passagem o narrador diz que ela é moça de quinze annos, antes (cap. 54, linhas 27-28) o texto informara que ela era de desaceis para desacete annos.

${ }^{2}$ Aqui há evidente erro e emenda do copista. Em B e C lê-se: andando por fora das arvores.
} 
30 todos. [espaço] Os caval|leiros, que como dicemos o tinhão vis|to de longe, e conhecido na diviza | e Armas, de que todos tinhão novas, | alvoraçandoce para se provarem com | elle, estavão prestes para o fazer, e co|mo o virão falar com tanta mo|destia, e bom termo, crerão que tudo | seria verdade o que delle se dizia. | E hũ que entre todos era o mais prin|cipal, primo de Enaclia, e não || [178r] pouco a martelado seu lhe disse: |

35 Senhor Cavalleiro, livre he este ca|minho, e todos oserão para os tais como | vos. [espaço] Os que nos aqui vedes accom|panhamos a Princeza Fidelia | que na quellas tendas está, mas se pel|la entreter a ella, e fazerme mer|ce amim quizeceis que corressemos | hũ par de lanças, não ouvera couza | com que mais folgasse, porque segundo | a diviza de vosso Escudo publica | nem ser vencido vosso pode ser fal|ta, nem

40 provar com vosco deixar de $\mid$ ser honrra. [espaço] Primaleão contente da | Cortezia do cavalleiro, e muito mais de | saber que estava alli aquella Princeza | de quem tinha ouvido grandes ma|ravilhas disse: [espaço] Não sei senhor o que me | acontecerà nas justas, mas athe agora $\mid$ mal me posso negar que me acho ven|cido vosso. [espaço] $\mathrm{E}$ pois dizeis que a Senhora | Princeza se entreterà de nos ver jus|tar, podeislhe mandar

45 recado, porque | em quanto me dura esta lança obedece|rei de tudo o que demim quizerdes. | Ja a este tempo o Enano vinha | com grande pressa dizer aos Cavallei|ros que se aquillo havia de passar em | justas que esperassem a the que a Prince|za se puzesse em lugar que as pudesse $\|[178 \mathrm{v}]$ ver. E chegandoce a o do Sol, que elle | reconheceu nas Armas dicelhes ${ }^{3}$ : [espaço] Se|nhor Cavalleiro se afrontardes com o | 50 trabalho aqui para baixo esta hũ sitio | no qual em tirando o Elmo, e o Escu|do logo vos refocilareis ${ }^{4}$. [espaço] E sem espe|rar reposta se tornou à tenda da $\mid$ Princeza, a qual não tardou muito que | se sentou á porta della rodeada das | Damas que então alli tinha concigo, | que erão somente as que aquella semana | servião, não fallando em Enaclia | que sempre a acompanhava.

55 Tinha parece o Amor esco|lhido esta hora para meter Primaleão de | baixo da quelle jugo, que a the então não | reconhecera, e assi da quella primeira vista | encontrandoce os rayos visuais de | ambos passarão os da Princeza a pe|netrarlhe o coração de maneira, que | nunca em nenhũa Materia se es|culpio forma, que assim

\footnotetext{
${ }^{3} \mathrm{~B}$ : lhes; $\mathrm{C}$ : lhe.

${ }^{4} \mathrm{O}$ termo afronta, além de significar "injúria", podia indicar também o "muito calor que acende o rosto", tornando-o vermelho (Bluteau). Cremos que neste contexto, o verbo afrontar deve significar "sentir calor, abafar-se".
} 
permanecesse $\mid$ nella ${ }^{5}$. [espaço] Logo apos o ver, canonizou | o Entendimento aquelle objecto, e tras | isto o adorou a vontade ficando tão | outro do que dantes era que entre todas as | dores de que aquella hora lhe foy Occazi|ão a que elle mais sentia era que não | chegace mais cedo. [espaço] Ali lhe veio à | Memoria como tinha visto o retrato, || [179r] e nome de Fidelia na Ilha de Dali|arte, e quantas porfias houvera entre os que | nella se criarão sobre qual dos sinco $\mid$ mais modernos era mais fermozo ${ }^{6}$, | e deixandoce

65 levar desta concidera|ção, detevece tanto nella, que tornou | Pleonido a ter com elle em hũ rocim | em que andava fazendoce grão Mes|tre do campo na quellas justas ${ }^{7}$, e dis|selhe: se não detreminais ainda de | dormir hũ pouco, he tempo de come|çar, e se toda via vos arrependeis daime | as armas e o cavallo, e eu farei as justas | por vos em nome de hũa da quellas | senhoras, e em virtude dessa diviza, que | me parece he a

70 Authora dos milagres | que della se publicão. [espaço] Façamos ou|tra couza (disse Primaleão acordado | ja daquelle amoroso extacis) dizeime | em nome de qualquereis que a fassa, e | fique o trabalho comigo, e a honrra se a | ganhar com a elleição que fizerdes. E | tendes geito (lhe respondeu o Enano) de | alegardes desculpa se vos eu negar es|se partido, mas para que fiqueis sem ella, | digovos que a fassais em nome de

75 Ena|clia que he hũa Aya da Princeza, | e tão fermoza, que nem na victoria | havera honrra; nẽ na queda pode dei|xar de haver infamia e vergonha. || [179v] E não me mandeis que va buscar consẽ|timento, porque eu tenho procuração sua | para todos os contratos. [espaço] Pois eu, lhe | replicou o do Sol, assi por vos não pedir | a procuração, como por poder ganhar | nos ganhos, enão perder tanto nas | perdas, eime de aventurar a 80 fazellas | Em vosso nome. [espaço] Jesus nome de | Jhs, respondeu o Enano, homen con|vertate Deus ${ }^{8}$, e voltou fugindo para as ten|das, deixando Primaleão, eaquellles | cavalleiros com o maior rizo do mun|do. [espaço] E porque a Princeza havia espaço |

\footnotetext{
${ }^{5} \mathrm{O}$ fim da frase (permanecesse nella) talvez seja um erro. Aparentemente, a frase deveria terminar com nelle, isto é, o coração; como está, nella parece referir-se à vista de Primaleão. A lição coincide com a de $\mathrm{B}$ e $\mathrm{C}$.

${ }^{6}$ Lembre-se que no cap. 10, quando Daliarte convocou os donzéis que se criavam na Ilha Perigosa para partir rumo a Constantinopla, o narrador informa que na livraria de Urganda (onde estavam retratadas as damas mais belas do mundo) haviam surgido cinco retratos novos (ou modernos), entre os quais constava o de Fidélia (cf. cap. 10, nota 4).

${ }^{7} \mathrm{O}$ grão mestre do campo aqui aludido deve ser o que tradicionalmente se chamava "rei de armas". Sua função era a de juiz da justa, resolvendo eventuais conflitos, estabelecendo regras e proclamando o vencedor. Cf. Flori, 1998, p. 196.

${ }^{8}$ Pleonido expressa seu espanto com a decisão inédita de Primaleão proferindo esta expressão em latim macarrônico, que significa "homem, converte-te a Deus". O copista de B apresenta a fórmula aportuguesada: "Jesus nome de Jesus, respondeu o enano, homem convertete Deus". A lição de C é quase idêntica à de $\mathrm{A}$.
} 
que esperava, apartandoce cada hum | para sua parte por thomarẽ do campo | o necessario, com as lanças baixas | bem cubertos dos Escudos, partirão hũ | para o Outro na maior furia que os caval|los os podião trazer, e encontrandoce | o cavalleiro do valle, e o do Sol, não | lhe fes mais danno que quebrar alança, | e passar por diante sem receber re|ves algũ, porque elle torcendoce o caval|lo hũ pouco a o tempo que se hião a jun|tar, feslhe errar o Encontro. E tho|mando o cavalleiro outra lança das | de seus companheiros, tornarão ou|tra ves a encontrarce com differente | fortuna, porque

90 Ludimio (que assim se | chamava aquelle cavalleiro) tornou a || [180r] quebrar a lança no escudo de seu con|trario, sem o mover pouco nem muito | da sella, e elle foi encontrado tão du|ramente, que com a sua entre as per|nas veio a o chão com grande disgos|to seu, assim porque era mui bom ca|valleiro, como por ser diante de Enaclia | aquem servia. E querendo satisfa|zerce da quella quebra arrancando | da Espada

95 dezafiou Primaleão para | a segunda prova, do que se elle quizera | escuzar com hũa brandura e modestia | em que era tão estremado, como na pai|xão quando entrava nella. [espaço] E porque toda | via Ludimio porfiava, a Princeza | lhe mandou dizer por Pleonido (que | ja hia tendo melhor oppinião do cavalleiro) | que em quanto ouvesse lanças deixasse justar | seus companheiros, o que se fes assim, vin|do do castello muitas, 100 e muito mais gente a | ver as justas, porque a inda que das genellas | delle se via a fonte, e o prado, com tu|do não se podião lograr bem as mi|udezas, porque o padrasto era alto, e o | campo estendido. [espaço] E por nos não de $\mid$ termos em encontros, o cavalleiro $\mid$ do Sol derribou a todos os nove cada | hũ do seu, sem elle receber danno ou | reves algũ. [espaço] E querendo então Lu|dimio tornar a sua porfia, a Princeza || [180v] o atalhou de

105 todo temendo que lhe aconte|cesse pior, porque o estimava muito [espaço] Se / bem lhe disse que por o cavalleiro do | Sol andar: ${ }^{9}$ cançado de tantas justas, não | lhe convinha a elle accometello então.

O Enano andava assombra|do, e toda via por entreter a Prince|za se fazia Author de tamanha vic|toria havendo que assi a dessacreditava. I E vendo o cavalleiro que 110 aquillo estava | accabado mandando pedir licença | á Princeza para lhe fallar, appeandoce $\mid$ foice com elle á tenda ${ }^{10}$. [espaço] Onde tirã $\mid$ do o elmo, e as manoplas, e assentan|doce em giolhos diante della com ta|manha trovação que se lhe costavão as | palavras na boca, com tudo lhe disse | o que para outro capitulo diffirimos.

\footnotetext{
${ }^{9} \mathrm{O}$ uso dos dois pontos não se justifica no contexto e eles não são reproduzidos em $\mathrm{B}$.

${ }^{10}$ Isto é: foi com Pleonido até as tendas.
} 


\section{Capitulo 57}

\section{Do que Primaleão disse à Prin|ceza, e como se ficou | no valle continuan|do as justas oito | dias.}

Na postura e com a trovação que $\|$ [181r] temos ditto, disse Primaleão á Prince|za: [espaço] Se obedecer a Vossa Alteza não he | desculpa de afazer deter este espaço a | troco do que me ficar que sentir, me ficarà | tambem ter mais que alegar a este fer|mozo Donzel (apontando para Pleonido) | por cujo serviço se fizerão as justas. ${ }^{1}$ [espaço] | Forte homem he este (respondeu o Enano) | Senhor cavalleiro, nem Donzel,

10 nem Don|zella, la vos avinde com Enaclia | por quem vos eu disse que entrasseis nellas | e comigo não vos metais, porque vos affir|mo que vos tenho ja tanto medo acorda|do, como dormindo $^{2}$. [espaço] A Princeza | rindo fes levantar o Cavalleiro não | querendo concentir que lhe elle bejasse a | mão, como quizera fazer, edepois lhe | respondeu: [espaço] Não era necessaria a ex|periencia desta justa para acreditar | com nosco com

15 valor de vossa pessoa. ${ }^{3}$ | porque a fama della o tem feito de ma|neira que não sei em toda esta terra | quem não dezeja vervos ha muitos di|as. [espaço] E porque entendo o gosto que ElRey | meu senhor terà de vos ter tão per|to, não detremino dilatarlhe tão boa | nova. E entre tanto vos rogo que senão | cuidardes que vos agazalharáõ estes ca|valeiros mal no castello, que queirais | esperar nelle o seu recado, que eu || [181v] sei

20 que não tardarà muito, nem vós dei|xareis de receber delle toda a honrra | e mercé, q ue a os que tão bem merecem he | rezão que todos os Reys lhe fação. [espaço] | Primaleão que cada ves mais se ascendia | na quelle amorozo fogo, que de todo se ti|nha apoderado de sua Alma, ouvindo | que a Princeza lhe offerecia aquillo que | elle mais que tudo dezejava, tendo a gran|de mimo da ventura tão ditozos prin|cipios, esforsandoce quanto

25 poude lhe disse: | Se eu não entendera que tamanha| Merce como aque Vossa Alteza me fas nas pala|vras que me disse, se não pode merecer | com obras algũas, não ficara pouco | corrido do que $e^{4}$ as minhas conheço, | mas se hũa vontade prompta, edis|posta

\footnotetext{
${ }^{1}$ Segundo Bluteau, a troco significa "contanto que"; neste contexto, talvez signifique "além de" ou "em contrapartida". De qualquer modo, temos dificuldade em compreender o sentido preciso da fala de Primaleão.

${ }^{2}$ Ao remoque de Primaleão, Pleonido responde dizendo ser homem e não simples donzel. Além disso, o anão recusa o fato de o cavaleiro ter combatido em seu nome, aconselhando-o a entender-se $(l a$ vos avinde) com Enáclia, em nome de quem ele havia sugerido que Primaleão justasse.

${ }^{3} \mathrm{O}$ ponto final foi desconsiderado pelo próprio copista, que continua a frase com letra minúscula.

${ }^{4}$ Esta palavra foi corrigida pelo copista, que inicialmente havia escrito a letra $d$.
} 
acredita a falta dellas, a minha $\mid$ o está tanto a vosso serviço, que me da|rá confiança para entrar nelle no nu|mero destes cavalleiros, mas porque a $\mid$ voltas disto ${ }^{5}$ dezejo 30 tambẽ acreditar|me com Pleonido, pesso a Vossa Alteza que me | de licença para que oito $^{6}$ dias guarde este / valle em seu Nome a todas as pes|soas que aqui vierem, e não quizerẽ | confessar as excellencias que eu nelle | contemplo. [espaço] A Princeza então | dissimulando mal o rizo respondeu|lhe: Pello que toca ami não so vos dou $\|$ [182r] a licença que me pedis, mas obrigome que | elle venha ver as batalhas, ejustas que se |

35 fizerem, porem folgara eu que para o peri|go dellas não tivereis tão duvidozo o fa|vor de quem vos mete nelle, porque segũ|do me parece Pleonido está de má | condição em vossas couzas. [espaço] E elle que | athe então com extremada graça se | estava fazendo cruzes $^{7}$, respondeulhe | com mostras de grande indignação: | Dizeime por vida vossa senhor caval|leiro que parentesco temos vos, e eu? | Emque barca entramos? de que estalagẽ | nos conhecemos para me saberdes o no|me, e para vos entenderdes comigo? fa|zei vossas batalhas, ajudevos Deus, e bas|tevos serdes valente, não queirais tã|bem ser tão cortezão que nos metais em | cabeça que tem misterios estas vossas zõ|barias. [espaço] Ora bem, disse o cavalleiro, | a senhora Princeza temme dado licẽ|ça, eu de pois de a accompanhar ao | Castello me tornarei aqui, e vos quando me | não queirais

45 favorecer, não me pode|reis tirar o gosto, com que dezejo servir|vos, que não será pequena satisfação $\mid \mathrm{de}^{8}$ trabalho que se tiver em fazello. [espaço] | A Princeza se levantou então não | podendo soster o riso, a que a provoca|va a paixão que mostrava o Enano || [182v] da quellas couzas, o qual ou por adulação | (como muitos costumão) ou por natureza, | não fallava palavra nem fazia demõs|tração, em que se lhe enxergace quã

50 | senhoreado estava della. [espaço] E costumã|do a Princeza a ir dalli sempre em | coche a o castello, então fes que lhe trou|xessem palafrẽns para honrrar mais a|quelle cavalleiro, que lhe tinha parecido | mui bem assim nas obras, como no | termo emaneira da pessoa, e despozi|ção della, que tudo era nelle extrema|do. [espaço] E estando tudo prestes comessou | a caminhar para o castello chamando | para perto de si Primaleão, 55 que a hia | accompanhando tão contente, como | entregue, e praticando com elle em |

\footnotetext{
${ }^{5}$ Bluteau atesta que a expressão "de volta" era utilizada com o sentido de "juntamente". Nesta passagem, a voltas disto deve significar "juntamente com isto" ou "além disto".

${ }^{6}$ Palavra corrigida pelo copista; inicialmente, ele havia escrito a letra $d$ no lugar do $t$.

${ }^{7}$ Não conseguimos descobrir o que significa fazer cruzes: o anão estava fazendo um tipo de piruetas (como parece indicar a extremada graça) ou persignando-se?

${ }^{8} \mathrm{~B}, \mathrm{C}:$ do.
} 
couzas geraes, mui satisfeita do modo | de que lhe dava razão de tudo. [espaço] Che|gou a caza onde a Princeza se re|colheu, e a o despedir lhe disse, que pois | havia de pouzar no campo aquelles | oito dias, que ella teria cuidade ${ }^{9}$ de in|terceder com Pleonido para que fosse | o Mordomo de seu gazalhado.

60 Mandou logo a Princeza | que se levantassem a quellas tendas, e | que no mesmo lugar se armassẽ outras, | em que o Cavalleiro se agazalhasse, e que | nellas o provessẽ de tudo o que parecesse || [183r] necessario, não só á comodidade, mas | a o regallo, o que a Princeza fazia | assim pella nobreza de sua condição | como porque tinha entendido de El|Rey seu Pay, que dezejava em extremo | ver aquelle Cavalleiro na sua 65 Corte | com algũa inveja das em que rezidião | os que as fazia ${ }^{10}$ famozas, e assim o Avi|zou logo do que tinha acontecido pello | proprio Enano, para que melhor tho sou|besse dizer, escrevendolhe particularmente | as suas raivas, e queixas ${ }^{11}$, com o que ElRey | alvoraçado grande mente veio ao ou|tro dia ao castello, no qual o deixare|mos, e a Primaleão no valle, athe $\mid$ dar conta do Emperador Trineo, de quẽ | parece, que nos 70 temos descuidado.

\footnotetext{
${ }^{9}$ B, C: cuidado.

${ }^{10} \mathrm{~B}, \mathrm{C}$ : fazião.

${ }^{11}$ Raivas e queixas de Pleonido contra o Cavaleiro do Sol.
} 


\section{Capitulo 58}

\section{Do que Aconteceu ao Empe|rador Trineo despois | que partio da Ilha de Dramu|ziando.}

Partio o Emperador Trineo com | os Mais da ilha de Dramuziando || [183v] estimulado da dor da perda da quelles Reis | e cobiçozo da gloria que grangearia quẽ | fosse Author de sua liberdade, mas como | a Embarcação foy thomada com o primeiro | impeto, a poucos dias de navegar se a|chou com faltas que o obrigarão a demã|dar a primeira terra que achasse, eassim tho|mou a de França na Provincia de | Linguadoc

10 junto a Marcelha. E dalli cõ|tinuando seu intento não tendo cami|nho certo atravessou aquelle grande | Reyno, e parte do de Hespanha fa|zendo nas Aventuras que se lhe offereci|ão tudo o que devia á obrigação de seu | officio, e sangue, não degenerando do | valor de seus passados. [espaço] E se aqui não | fazemos particular memoria de se|us trabalhos, e dos fins gloriozos que nel|les teve, he porque a Historia propria | mente trata

15 de D Duardos, e se Ou|vessemos de particularizar as proe|zas de cada hũ dos cavalleiros que em | seu tempo concorrião, fora necessa|ria nova formação no gosto dos ho|mens para senão cançarẽ com volu|mes tão grandes. [espaço] Tambẽ como Tri|neo era tal pessoa, os choronistas de | seus estados não se descuidaráõ na re|lação de suas couzas, e assim nos An|naes de Alemanha se devem achar || [184r] mui extençamente, e esta he a

20 razão | segundo eu cuido porque Henrrique | Frusto callou os mais dos aconteci|mentos dos Princepes senhores, e her|deiros de Reynos, que com D Duardos | se criarão, porque lhes não faltou em | suas terras quem lhos escrevesse, não | deixando toda via de dizer algũns | como veremos assim de Trineo, como | dos mais. E entre o numero dos que des|te Emperador conta foy hũa Aven|tura que lhe Aconteceu em hũa Pro|vincia de

25 Hespanha sem dizer qual | fosse, pella Maneira seguinte.

Tempo havia, dis elle, que | o Emperador Trineo andava por a|quellas partes fazendo obras tão fa|mozas como delle se esperavão. E | indo hũ dia caminhando ja sobre | a tarde por hua charneca despovoa|da thomou o anoite a o sahir della | em hũ grande, e dilatado campo, | no qual se não vião mais que de espaço | a espaço hũns

30 palheiros altos rodea|dos de cebes, e curraes de gado, e porque | a noite era de chuva, e fria, e em | nenhũa parte em quanto alcancava ${ }^{1}$ a $\mid$ vista havia povoado, pareceulhe a |

\footnotetext{
${ }^{1}$ Falta o cedilha.
} 
Trineo ir demandar hũ daquelles | palheiros, e passar alli a the que ama||[184v]nhecece, porque a fora perder no campo | o caminho que trazia, era elle cortado | por muitas partes de tantas alvercas, e val|las cheas de agoa, que não so ficava arris|cado, e 35 perigozo de noite mas ainda sem | guia com Sol claro senão podia an|dar por elle. E indo indireitando para $\mid$ o que lhe pareceu mais perto conveolhe $\mid$ dar tantas voltas a o longo de hũa | da quellas vallas para achar passagẽ, que não | poude chegar a elle se não em muito tem|po a respeito do pouco caminho que lhe | pareceu tinha para fazer, e Em fim che|gando à quelle lugar que buscava, abrin|do hua cancella por onde se entrava $\mid$ no

40 rodeo da cebe, que abraçava dous | ou tres daquelles palheiros, vio com | a claridade da lua, que toda via esta|va limpa, e sem nuvens, hũa rotura | do tamanho de hũ postigo grande ẽ | hũ delles, que lhe deu esperança de poder | passar a noite melhor do que cuidava | E apeandoce metendo a mão á espada | por se acazo alli ouvesse de que se temer | entrou pella rotura dentro, e achou | hũ concavo feito no corpo daquelle | 45 palheiro tão grande que podia agaza|lhar com comodidade mais compa|nheiros do que elles alli vinhão ${ }^{2}$. E des|pois que o tentou todo á roda entẽ $\mid[185 \mathrm{r}]$ dendo que estava despejado. Saindoce fora | festejou a rusticidade da quelle apozento | dizendo ao seu Escudeiro que lhe parecia que | a li passarião tão bem anoite que nenhũa | saudade lhe fizesse a sumptuozidade de | Constantinopla. E dezenfreando os ca|vallos querendoos 50 accomodar onde lhe pa|receu melhor, acharão entre os palheiros | dous rocins sellados com os freios pendu|rados dos Arções prezos por hũns cabres|tilhos comendo quietamente. E enten|dendo por aquillo que não podião estar lon|ge os donos delles fizerão mais deligencia | alli dentro sem que della rezultasse outra no|ticia algũa. [espaço] E sahindo fora Trineo da $\mid$ cebe deu em hũ carreiro estreito que entre o $\mid$ pão ${ }^{3}$, 55 que estava semeado se fazia, e indo por | elle hũ espaço, foi ter a hua praya, que antes | de chegar a ella lhes pareceu agoa, assim | por sua alvura, como porque hũ grande rio | que por alli corria inda que não tinha pedras | em que se quebrasse, não deixava com a gro|çura das agoas de fazer algũ rumor, que | alterava aquelle silencio da noite. E | vendoce a talhado para não poder ir adian|te da quellas agoas, e areas, determinou |

60 tornarce á pouzada, e esperar nella o que | pudesse acontecer. [espaço] E querendo voltar sẽ|tio no rio hũ ruido maior que o que athe | então tinha ouvido, e parandoce mais || [185v] promptamente a escutar, cada ves lhe | parecia que o ruhido era maior, assim

\footnotetext{
${ }^{2} \mathrm{O}$ narrador refere-se a Trineo e seu escudeiro.

${ }^{3}$ Ou seja: Trineo passou por um caminho estreito (carreiro) no meio da plantação de trigo (pão).
} 
nas | agoas, a que elle ja estava pegado, como de | palavras, não mui destintas, que se lhe afi|gurava ouvir. E estando assi todo suspẽ|dido do dezejo de entender bem aquellas | couzas, e indoce cada ves chegando mais a | elle o que o suspendia, ouvio claramente | hũa vos baixa que dizia: Deixemonos | ir mais abaixo á vontade dagoa, que me|lhor será caminhar depois pella praya | assima, que cançarmonos muito em cortar $\mid$ a corrente. [espaço] Ao que respondeu outra vox: | Nos temos ja passado a maior força da a|goa, vamonos assim tendo, que se cahimos | podernos ha a corrente metter outra ves | mais

70 dentro, e serà pior. [espaço] Estava aquillo | ja tão perto, e a lua dava tanta claridade | que poude Trineo divizar dous vultos que vi|nhão nadando para terra, e conversando en|tre si na forma que temos ditto, e espantan|doce não pouco, porque o tempo era inverno|zo, e a noite estava fria, de haver quẽ por | sua vontade cometesse aquelle caminho | a fora o perigo de a travessar o rio (que a | Trineo lhe parecia inda maior,

75 porque jul|gava por agoa todas as prayas que via) pa|recendolhe que não podia deixar de ser cõ | grão cauza, apartouce para certas quebra|das que se fazião num Maranchão ${ }^{4}$ gran ||[186r]de, em que se começava a praya, que aly pa|rece que se fizera para reparar de algũa ma|neira os campos, que não fossem innunda|dos tão facilmente das crecentes do Rio, | donde escondido se pos a esperar em que pa|raria a quella Aventura com maior 80 de|zejo, e gosto de ver o successo della, que o de | quantas athe então tinha encontrado. [espaço] | Não aguardou muito que não visse sahir dous | homẽns daagoa com hũns lios, ou trochas | nas cabeças, que erão aquelles vultos que antes | tinha visto, e ouvido, os quais tanto que pu|zerão os pes em terra sentandoce na A|rea bem perto donde elle estava tirarão | das cabeças o que alli trazião que erão seus ves|tidos entrochados em

85 hũns gabões gran|des com que se cobrião, e começandoce a | vestir, começarão tambẽ entre si hũ gra|ciozo coloquio, que a pouco, e pouco se foi $\mid$ continuando com palavras mais gra|ves que daquelles trajes se podião esperar, | como poderá ver quem senão cansar, no | capitulo seguinte.

\footnotetext{
4 A palavra, que volta a aparecer adiante, é grafada de várias maneiras nos diversos manuscritos: maranchão ou marachão (A, B, C, E e G), marchao (F) e camarcham (D). Acreditamos tratar-se da palavra "caramanchão".
} 


\section{Capitulo 59}

Do que aquelles homẽns passa|rão entre si, e do que Trineo | passou depois cõ hũ delles.

|| [186v] Sobre o que nos tem acontecido (disse hũ da | quelles homẽns para o outro) não faltava a|gora mais que acharmos os rocins furtados, | e cahirmos em algũa das vallas, que ha por | esse campo. [espaço] Bem empregado serà tudo | (respondeu o companheiro) pois vos por tei|ma não quizestes esperar o que quando fora men|tira vos dera a vos menos culpa, e à parte | mais vergonha ${ }^{1}$. [espaço] Ás avessas entendo eu | isso (tornou o outro) porque se esperara mais | mentiras tivera mais que sentir, e ella menos | de que se correr, mas vos não quereis entender | isto, nem he rezão que o entendais, porque neste | negocio nunca vistes senão com os olhos. | Eu (lhe respondeu elle) pouco especulativo | sou, mas com isso que alcanço me parece que | quando hũa mulher da quella calidade, e estado | chega a me descobrir amim o que vos sabeis que |

15 me ella tem descuberto acerca de vossas cou|zas, que nenhũa que prometta deixarà de | cumprir podendo, porque amais da gente | antes se corre de lhe saberem os peccados | do que de fazellos, e a razão he que como com | hũa couza se offende o respeito, e com | outra a Deus, para elle cuidão que basta a descul|pa que está na fraqueza, e para o mais que não | bastará nada, pella differença que ha entre | o sofrimento de Deus, e o dos 20 homẽns, e assi | quando esta mulher me chegou a descobrir por | sua vontade o que queria fazer por vos $\|$ [187r] fechada deixou a porta a todo o arrepen|dimento honrrado, ao christão não, | mas quem tem este não finge de novo, | nem trata mais das couzas de que se arre|penda, porem forte couza he não quere|res vos crer que hũa moça cativa de seu es|tado, cativa do Pay, da May, dos Irmãos, | dos criados, das criadas, de tantos outros | inconvenientes, como cada hora succe|dem aquem vive entre estes, não possa muitas $\mid \operatorname{ver}^{2}$ o que quer por mais que o pertenda, e dezelje. [espaço] Mas a verdade he senhor que vos não | deveis vir tão despicado como me quereis | persuadir, pois vos quizestes antes arriscar | a lhe parecerdes groceiro vindovos, que espe|rando achalla de

\footnotetext{
${ }^{1}$ Neste contexto, parte refere-se a outra personagem, ainda desconhecida dos leitores. Leia-se: "pois vós por teimosia não quisestes esperar o que, caso fosse mentira, vos daria menos culpa e a ela mais vergonha". O longo e curioso diálogo travado entre os dois nadadores, que ocupa grande parte deste capítulo, transmite de modo bastante eficaz a impressão de ser parte de uma conversa iniciada antes. As diversas informações por ora incompreensíveis serão esclarecidas mais à frente e servem para aguçar a curiosidade de Trineo, conseqüentemente, a do leitor também.

${ }^{2}$ Todas as cópias, à exceção de $\mathrm{A}$ e $\mathrm{B}$, apresentam vezes no lugar de ver.
} 
todo sem desculpa ${ }^{3}$. [espaço] | Ora sois o mais galante homẽ (replicou o cõ|panheiro)

30 que em minha vida vi, pois que sa|bendo muito bem tudo o que tenho passado, e | sendo testemunha de todas as mentiras | desta mulher, athe dessas mesmas que dizeis |que vos descobrio então, e das mais que despois | disso acontecerão, e vindo agora sobre tu|do isto de esperar toda hũa noite, e hũ dia, | hũa hora prometida em tantos dias, em | tantos mezes, em tantos annos, e em qua|zi todas as horas desta mesma noite e dia | não vos 35 basta para entenderdes o que se mais | podia esperar, ver que chegou o inconveni|ente a o mesmo ponto em que se havia de $\|[187 \mathrm{v}]$ cumprir ou quebrar a palavra que nos | a qui trouxe, como? E experiencia he a | que vos de mim tendes para me julgardes tão | mal que deixara eu de esperar hũ largo | tempo ${ }^{4}$, quanto mais o de hũ so dia, e o de esta | noite agora de que he ja passada tanta parte | se me parecera não so que seria verdade $\mid \mathrm{o}$ que se dizia no ultimo escritto que vistes | se não que o deixarme eu enganar tantas | vezes não seria julgado da propria par|te mais a falta de juizo cego de interesse | proprio, que a algũ da quelles respeitos, comque | quem engana costuma a haver lastima | de quem he enganado. [espaço] Pellas couzas $\mid$ das telhas a baixo ${ }^{5}$ meu amigo, não se ha|de fazer mais que o que basta, e por algũas | Menos. [espaço] Oque tenho visto, e o que 45 tenho En|tendido, e o que tenho exprimentado, bas|tou efficasmente para me livrar, a este res|peito, não tenho que esperar mais. [espaço] Se fi|zera o que me aconcelhaveis, nem pude|ra acontecer melhorar a sorte na per|tenção primeira, nem grangeara melhores | dezenganos com hũa mentira mais, ou | menos. [espaço] Essoutro que dizeis sim por ven|tura, pudera ficar Daraja menos des|culpada, e mais confuza em suas pro|messas ${ }^{6}$,

\footnotetext{
${ }^{3}$ Um dos nadadores tenta convencer o outro de que a mulher sobre a qual falavam não havia mentido. Seus argumentos são basicamente dois: em primeiro lugar, ela teria revelado a ele suas intenções (e $a$ mais da gente antes se corre de lhe saberem os peccados do que defazellos); o motivo é que ela talvez não pudesse desembaraçar-se dos inconvenientes causados pela presença dos familiares e criados para encontrar-se com eles. Por fim, ele conclui que seu amigo não devia sentir-se tão satisfeito ou vingado dela (despicado) quanto queria parecer, pois preferira arriscar a parecer grosseiro não esperando-a por mais tempo ao invés de continuar aguardando, para deixá-la sem possibilidade de justificar-se depois.

${ }^{4}$ Este trecho é particularmente confuso e apresenta diversas variações entre as várias cópias. O sentido da passagem deve ser o seguinte: "[tão longa espera] não vos basta para entenderdes o que era previsível $(o$ que se mais podia esperar): ver que o inconveniente chegou ao ponto em que se havia de cumprir ou não a promessa que nos trouxe aqui? Como? Que conhecimento (experiencia) é o que de mim tendes para me julgardes tão mal, [pensando] que eu deixaria de esperar um longo tempo?"

5 A expressão "das telhas abaixo" é registrada por Bluteau, que a dá como tradução das expressões latinas sub coelo, subter coelum; o Vocabulario registra ainda a expressão "falar das telhas abaixo", que significa "não meter-se em teologias, quem não o entende". Neste contexto, significa "para as coisas mundanas" ou "para as coisas que não envolvem obrigações religiosas".

${ }^{6}$ Após responder aos argumentos utilizados pelo companheiro, o primeiro nadador diz que o outro poderia ter razão apenas quanto ao fato de deixá-la sem possibilidade de justificativa (menos desculpada), se tivesse continuado a aguardá-la.
} 
50 mas a isso vos respondo, que em quanto | me eu deixei cevar dos Enganos, de que | vivia, sempre em todos meus progressos $\|$ [188r] a respeitei a ella muito mais que amim, | mas agora que ja vivirei com os dezen|ganos, não vos parecerá sem razão | que seja isto a o contrario. [espaço] E pois não | se pode negar, que ainda pella liberali|dade das mentiras lhe tenho obrigação | satisfaçamos com o que hũ homẽ honrra|do se deve a 55 si proprio, com a não a|purar a ella tanto ${ }^{7}$. E finalmente livre $\mid$ mequero, vingado não me dezejo. | Deus lhe fassa a ella muitos bẽns, e amim | me concerve neste estado, que eu $\operatorname{vos} \mid$ prometto que nem nelle me arrepen|da nunca de não ter esperado, nẽ | me queixe do que esperei, porque ainda | que viva com dores (o que não serà) | com queixas não heide viver. [espaço] | Nunca tão perdido me parecestes co|mo agora (lhe tornou o 60 outro) mas va|mos buscar os rocĩns, que depois de $\mid$ sairmos do campo teremos mais lu|gar de tratar desta materia, e mais eu | não sei que tenho, que ei mais frio agora |que quando estava na agoa. [espaço] E com isto le|vantandoce forão indireitando para| onde estava Trineo, porque perto da|quelle lugar era mais facil a sobida | do Marachão, e elle que attentamente | os estava ouvindo ponderando as ra|zões de cada hũ, bem lhe pareceu

65 que || [188v] lhe não seria proprio o trage em que | os via, senão que lhe servia de disfarce | para a quella Empreza de que tratavão. | E dezejando saber o mais que não enten|dia, não lhe occorria caminho que fosse | a prepozito, porque thomallos às mãos, | e tirarlho por força, a fóra que a primeira vista | lhe parecia acto muito indigno de quem | elle era, fazendo mais concideração | não o tinha por couza facil, porque se | os homẽns

70 erão honrrados como lhe | a elle parecião, quando não tivessẽ força | para se deffender, terião animo para não | confessar, e se o não fossem em re|mettendo a elles lhe fogirião, e como | estavão desarmados, e divião ser pra|ticos na terra, não poderia havellos ${ }^{8}$. | Ora ir tras elles dissimulada mente es|preitando, a fora que mal poderia deixar | de ser sentido, não lhe ficava esperan|ça de recolher couza algũa ainda quando | o não fosse a 75 the a pouzada onde esta|vão os rocĩns de todos pello que o outro | tinha ditto que depois de sahirem do cã|po fallarião. [espaço] E assim nesta preplexida|de antes de se rezolver vio que passavão | o vallado, e que hião seguindo apressadamente | seu caminho para o palheiro, e saindoce | das quebradas para os seguir tãbẽ, não | querendo por fim, ou por

\footnotetext{
${ }^{7}$ Leia-se: "E, dado que não posso negar que devo ser-lhe grato (tenho obrigação) pelas esperanças que me deu (pella liberalidade das mentiras), cumpramos o que um homem honrado deve fazer não a pressionando (apurando) tanto".

${ }^{8}$ Leia-se: “como estavam desarmados e deviam conhecer bem a terra, não conseguiria alcançá-los”.
} 
não que o deixas ||$[189 \mathrm{r}] \mathrm{sem}$ a pé, não ouve vista delles, porque | erão tão vistos 80 naquellas veredas, que che|garão primeiro tanto espaço, quanto bastou para | não sentirem quem os seguia, e para | se enlearem brava mente com os novos $\mid$ hospedes, que acharão aos seus rocins, e | cuidando que serião de algũa gente, que | estivesse no concavo do palheiro dor|mindo, quizerão ir sem roido, porque | a hũ dos nadadores não lhe importava | pouco não ser conhecido na quelle ha|bito por aquella terra, e estando ja 85 para | se sahirem pella cancella fora, chegou | Trineo a ella, ao qual hũ delles arran|cando de hũa espada que trazia, e enrro|lando o gabão no braço, perguntou | quem era com tanta segurança, co|mo se elle estivera melhor armado, ou | peor o com que falava. Trineo pondo | tambem mão à sua lhe disse: [espaço] Com | menos ira se costumão receber os hos|pedes que vem de pax. [espaço] Não sei que mais | vos diga de

90 mim, senão so que dezejo sa|ber muito de vos. [espaço] O Outro então com / grande comedimento lhe respondeu: | As horas, e o lugar, senhor cavalleiro, des|culpão qualquer desconfiança em quẽ | se teme. [espaço] Eu sou hũ homẽ que ha dias | que me aparto de povoados por respeitos, | que ditos a vós, não vos serviràõ de nada, || [189v] e a mim poderião danar muito [espaço] Vim a | fazer noite aqui, e não me fiando de | quão

95 so achei este lugar quis fazer de|ligencia por fora para passar com mais qui|etação, quando voltei acheime com sinais | de terem vindo mais hospedes como | vos dizeis, que são dous cavallos que a qui es|tão dentro. [espaço] Detremino deixar a | pouzada a seu dono, porque a fora que ella | he estreita para tantos, amim menão | cumpre occupalla mais tempo. [espaço] | Bem vio Trineo que a quelle homẽ se | queria encobrir,

100 e tendoo em melhor | oppinião do que o habito lhe grangeava | folgava toda via de o ver armado para | lhe fazer por força que se confeçasse com | elle; Mas vendo que na quelle estado | sem grande quebra de sua honrra não | se podia tentar aquelle caminho, não | querendo dizistir do outro, tornoulhe | a replicar dizendo: Os cavallos que di|zeis, são meus, e porque quando aqui cheguei | achei outros, que devem ser vossos, e nenhũa | 105 gente com elles, quis ver se havia por a|qui algũa de quem me pudesse temer | pois nem este muro, nem as portas as|segurão aquem se fiar delles, e vindo | cançado de buscar o campo la por fora $\mid$ achovos agora ca dentro. [espaço] Das ra|zões porque fogis do povoado, não quero || [190r] saber mais que o que tendes dito, porem se | vós soubesseis algũ por aqui perto não | me farieis má obra em me guiar | la, porque eu me temo por 110 hora mais | da incomodidade deste sitio, que dos | perigos, que poderà haver no outro, | 
porque vos pregunto. [espaço] De mui boa | vontade farei eu isso, respondeu aquelle | homem, e com melhor vos levàra a | hũ que vos farão toda a cortezia senão | fora tão longe, que hei medo que vos de | trabalho. [espaço] Como seja ir com vos|co, respondeu Trineo, não pode haver | algũ que mo pareça, porque vos estou ja | mais affeiçoado do 115 que podeis cuidar. | Então metendo as Espadas nas bai|nhas, fazendo Trineo enfrear os seus ca|vallos, ao seu Escudeiro, que athe o sentir | a elle Estivera Escondido, pondose nel|les começou a caminhar por aquelle | campo seguindo o dos Gabões, e | sahindo seguramente delle entra|rão na charneca por onde aquella tar|de caminhara. [espaço] E porque ja alli não | havia risco na jornada, forão prati|cando em tantas couzas, que veio

120 Trineo | a confirmarce na oppinião que daquel|la companhia levava, porque achava no | homem noticias grandes de todas as ${ }^{9}$ do | Mundo, tanto das que se lem nas Historias, || [190v] como das que se alcanção com a experi|encia, especulação, e coriozidade. | E não querendo aguardar mais des|cobriolhe o furto com que o thomara, | E ajuntando a isto dizerlhe exponta|nea Mente quẽ era, e offerecercelhe | por amigo, obrigou-o a que lhe 125 desse | tambẽ conta de si, satisfazendo o | na quella parte que Trineo dezejava. | O que começou desta Maneira.

\footnotetext{
${ }^{9}$ Elipse do termo coisas.
} 


\section{Capitulo 60}

\section{Da conta que aquelle homem | deu de si a Trineo, e de | como chegarão a o | seu castello.}

Ainda que em vossa idade senhor | Trineo (disse o do gabão) e no officio e ex|ercicio de cavalleiro Andante, tenho se|guro não so perdão, mas piedade das | liviandades, de que me mandais que vos $\mid$ de conta, toda via o respeito de vossa | pessoa, a grandeza de vosso estado, não | me fazem tão pequeno medo, que deixe | de vos offerecer a obediencia, com que faço | о que me ordenais, em disculpa do que jul|gardes

10 em mim por repreensivel. [espaço] || [191r] Eu senhor sou cavalleiro, ja andei pello | Mundo, e andarei ainda quando vos cũ|prisse a vos. Passei seguramente as | Aventuras que se me offerecerão. ${ }^{1}$ nas | terras estranhas, porem nesta de que sou | natural não pude escapar ao que a fortu|na tinha de mim disposto, porque vin|do de andar por diversos lugares deste, | e de outros reinos, agazalheime em hũ | castello que perto da qui está, de

15 que he se|nhor hũ cavalleiro meu conhecido ca|zado, e com filhos, entre os quais entra | hua filha de pouca idade, fermoza muito | e muito bem entendida. [espaço] $\mathrm{O}$ conhecimẽ|to que eu tinha com seu Pay, e com sua | May era fundado em razões, que me | facilitavão as entradas da quella ca|za, mas muito mais o fazia a facilida|de, e o termo, que os senhores della tem cõ | todos seus conhecidos. [espaço] Com isto e cõ | eu

20 ser vindo de partes mui remotas | que nos vizinhos he cauza ainda de me|lhor recebimento, se me fizerão alli muitos | gazalhados em verdade. [espaço] Vi Daraja, | que assim se chama esta tirana de minha, | não sei se diga honrra, se liberdade. | Faleilhe, perguntoume pello mundo, dis|selhe que não vira nunca nelle couza que fos|se como ella. Riose o Pay, creuo a May | não o desagradeceu a filha. Continuei dous ||

$25[191 \mathrm{v}]$ dias que alli estive com estas lizonjas | mais com intento de lhe não parecer | groceiro, que com o que Daraja logo cui|dou, porque ainda que verdadeiramente | ella tem todas as partes com que poder | obrigar, havia tanta differença em | nossas idades, e estados, que não poude o | Amor por então presuadirme ás sem | rezões, de que depois ajudado das indus|rias alheas me encheu o peito. [espaço] Parti|me emfim, e com

30 cuidado ja, de ver o | que Daraja mostrava de minha auzencia | Obrigado delle, e obrigado do gazalhado | que de seus Pays tinha recebido, De|pois que estive em outro

\footnotetext{
${ }^{1} \mathrm{O}$ ponto final foi desconsiderado pelo próprio copista, que continua a frase com letra minúscula.
} 
castello meu a $\mid$ ondo $^{2}$ agora vamos, mandei vizitar | aquelle Meus vizinhos com ordina|rios comprimentos de hũa amiza|de Antiga. Rezultou disto que me | responderão o Pay, e a May de Daralja (a quem eu tinha Mandado per|guntar pella saude e 35 Entertimentos $^{3}$ | da filha) que ella estava bem, mas quei|xoza de o eu querer saber por terceiros. | Thomeime eu então com esta repos|ta conta a mim mesmo de quão aca|bado me devia ter o tempo, pois com | tanta liberalidade me dava aquella | gente tão largas licenças. $^{4}$ [espaço] Apro|veiteime dellas, escrevendolhe debaixo \| [192r] da cuberta da de seu Pay, a quẽ tã|bẽ escrevi, e nesta conformidade ti|ve reposta algũas vezes, que o

40 fis. [espaço] $\mathrm{E} \mid$ como as cartas se escrevẽ com me|nos pressa do que se falla, ainda que não | levem aquella viveza com que as pa|lavras persuadem, levão toda via | outra calidade, com que são mais pe|rigozas, que he poderẽ ser lidas, e conci|deradas de vagar. Por este caminho | pois com pouca advertencia minha | vim a beber hũa pessonha, que quando foi co|nhecida, não havia ja força na na|tureza para poder com o remedio. | Com tudo, entendendo o danno, es|forçadome ajudado da razão su|perior, que de todo não estava supedita $\mid \mathrm{da}^{5}$, ainda quis valerme amim, e va|ler tambẽ a Daraja, que mal persua|dida de minhas palavras, pouco aju|dada de sua idade, e peor dos exemplos | de quem lhes devia dar bons, se hia | a mais andar despenhando de hũ | bem grande percepicio. [espaço] O meio que to|mei para isso foi o melhor que o meu En|tendimento 50 soube eleger, mas teve $\mid$ o peor sucesso, que eu como honrrado pu|dera dezejar, ainda que assas bom para | hum apetitozo do seu gosto. [espaço] Escrevi | pois a Daraja em resposta de hua car||[192v]ta sua mais favorecida do que lhe aella | cumpria, que eu não podia merecer | nunca merce tamanha, se não pri|vandome do bem que della me rezulta|va, para o que lhe lembrava a desigualda|de de nossas idades, sendo ella muito | 55 moça, e muito fermoza, e eu muito mais | velho, e mais acabado do que era razão que | confeçasse, a differença de nossos Esta|dos sobre tudo, que da quelle trabalho ${ }^{6}$ lhe | não

\footnotetext{
${ }^{2} \mathrm{~B}, \mathrm{C}:$ onde.

${ }^{3} \mathrm{C}$ : entretimentos.

${ }^{4}$ Ou seja: a falta de preocupação dos pais de Daraja fizeram-no perceber como ele estava velho, significava que eles nem sequer poderiam suspeitar que ele fosse capaz de novos envolvimentos amorosos.

${ }^{5}$ Segundo Aristóteles e a filosofia Escolástica, a razão é atributo da alma intelectiva, que permite ao homem a distinção do bem e do mal, em oposição à alma vegetativa, responsável pelas sensações e apetites. É por isso que o personagem faz referência à razão superior, que o ajudaria a resistir às insinuações de Daraja. No entanto, o significado de supeditada (assim como na outra passagem em que foi empregado: cf. cap. 41, linha 41) não é claro. No contexto, o termo parece indicar que a razão superior não estaria de todo derrotada ou submetida aos apetites.

${ }^{6}$ Todos os manuscritos, à exceção de A e B, trazem trato ao invés de trabalho.
} 
podia a ella vir senão danno, e a $\mid$ mim muito ao contrario, mas que não era $\mid$ tão pouco o que lhe eu divia que quizesse | com tão provavel risco seu antepor | minhas Utilidades a suas convenien|cias ${ }^{7}$. E que se o Escreverme era entreter $\mid$ a solidão em que vivia, polir o 60 engenho, | e exercitar o Entendimento, que fosse / com presuposto de me consultar co|mo vizinho curiozo, e que tinha anda|do pello Mundo, porque então sem me | correr de mim com repostas abertas a|codiria demaneira, que quando não satisfizes|se a suas duvidas, satisfaria pello me|nos ás dividas em que à primeira confiança | de seus Pays estava [espaço] Quem cuida|ra senhor que não seria isto cauterio bas|tante para mal 65 muito conhecido, quanto ma|is persevativo para hũ, que tanto no prin|cipio ainda estava? [espaço] E não foi assim || [193r] certo, antes o contrario que nos matou ${ }^{8}$ | a ambos, porque ella cuidou que devia | satisfação a este serviço, como a sa|creficio dalma, e eu fiquei com a re|posta sem lingoa para replicar, e cõ | sentimento de me parecer, que fican|dome bastante desculpa em meus | erros, não me ficava couza algũa |

70 que lhe offerecer no proceguimento del|les, que fora só a obrigação que me ella | pudera ter, porque amor justificado, | mais parece rezão que Amor. [espaço] Respon|deume emfim Daraja hũas palavras | que concervei hũ tempo nalma para | freio das culpas do pensamento, e a|gora as tenho nella por remedio con|tra o credito que se da a todas as das mu|lheres, e vede se tenho ${ }^{9}$ rezão porque volas | quero referir, e dizião assim.

Se foreis tão moço como eu | e vivereis livre, cazarãome meus Pa|is com vosco, mas comvosco cazado, | e com vosco de tanta mais idade me | caza Amor, E eu me entrego de tão | boa vontade, que thomara ter mais que | sacreficar ás partes que em vos conheço. | Se vos isto parecer obrigação, pagai|ma na continuação do amor que | me tendes, e em não querer com | estas vossas advertencias, e lembranças, || [193v] que seja 80 eu so a que erre, pois não ha|veis querer confessar que so sou a que $\mid A_{m o}{ }^{10}$.

Que dizeis agora a isto Senhor | Trineo? parecevos que ficava retirada | algũa a hũ homem que não he de pe|dra, nem dellas nasceu? parecevos | que podia eu deixar de seguir a | Daraja os passos por onde me ella | encaminhava? parecevos que podia | eu

\footnotetext{
${ }^{7}$ Neste contexto, utilidades deve significar "favores" ou "serviços". Entenda-se: "com tão provável risco seu antepor meus serviços àquilo que lhe seria conveniente".

${ }^{8}$ Palavra corrigida pelo copista.

${ }^{9}$ Palavra corrigida pelo copista.

${ }^{10}$ Leia-se: "Se fôsseis tão moço como eu e se vivêsseis livre, casariam-me meus pais convosco; mas dado que sois casado e de mais idade que eu, casa-me o Amor, e eu me entrego com tanta boa vontade que gostaria de ter mais que sacrificar às qualidade que vejo em vós. Se vos parecer que isto merece agradecimento, pagai-me continuando a cultivar o amor que tendes por mim e deixando de insinuar com advertências que sou a única que erro, pois não haveis de confessar que sou a única que ama”.
} 
deixar de crer hũa Mulher não | obrigada a the então mais que com | geralidades, 85 independente de mim | em tudo por todas as razoes conci|deraveis, e cativas ${ }^{11}$ pellas mesmas ra|zões do respeito de seu estado, de | seus annos, e de sua calidade? As|si foy que dalli por diante a comecei | a apressar àquillo de que antes a dissu|adia. E como este caminho nos le|vava ao que a nenhũ de nos convinha | poucas vezes se offerecerão nelle diffi|culdades, a the me entrar pella porta $\mid$ com muito bons fundamentos a cre|dulidade

90 dos Maiores impossiveis. | Alli parava Daraja, e fazia pe a tras | para tornar outra ves de novo a conti|nuar com enganos novos. ${ }^{12}$ [espaço] Thoma|va eu as mãos á fe rota na palavra | empenhada, e com hua frivola des||[194r]culpa tornava as passadas experi|encia ${ }^{13}$. Foi isto por tantas vezes | que entendi que me convinha, a the | para não ser mal julgado de Daraja | mostrar hũ pouco de mais senti|mento de suas extratagemas,

95 | e parei no curso que levava retirã|dome da communicação. [espaço] Não | vos digo a quanto custo da minha | vida, mas hia passando ferrado na | honrra, que valeroza mente rezestia. | Aproveitou pouco com tudo, porque | Daraja vendome assim retirado | escreveume hũa carta, e outra carta $\mid$ e tantas outras, a the que lhe respondi | espos hũ largo silencio hũa mui|to breve, que tambẽ vos relatarei | porque vou vendo que vos não 100 cança | escutarme. Dizia assi.

Extraordinaria habelida|de me era amim necessaria para | começar, e acabar esta carta, porque gui|alla pellos passos antigos perdesse á | vista dos olhos conciderando os barrã|cos, com que sem rezões grandes tem a|talhado aquelle caminho. Queixarme | dellas, que he o que parece que so ficava, a fóra | ser tempo perdido, não quizera 105 mos|trando tanta fraqueza, fazer o triumfo | da minha paciencia menor, pois quanto || [194v] mais muda sofrer ${ }^{14}$, mais acrecentarà $\mid$ o gosto de seu danno ou de seu dono ${ }^{15}$, | e a confuzão de quem me exercita | nella, vendo que o Espanto comum | me hade vir a ser consolação particu|lar ${ }^{16}$.

${ }^{11}$ C: cativa; B apresenta o mesmo erro de A.

${ }^{12} \mathrm{O}$ relacionamento entre os dois enfrentou poucas dificuldades e, por isso, ele começou a crer nos maiores impossíveis, isto é, que seus desejos seriam acolhidos por Daraja; no entanto, ela hesitava em entregar-se de todo, alegando pretextos falsos.

${ }^{13}$ B: experiencias; C: experiencias passadas.

${ }^{14}$ Palavra corrigida pelo copista: o $r$ final parece ter sido escrito sobre um $v$.

${ }^{15}$ Trata-se de um erro comum a A e B. Todas as outras cópias apresentam a seguinte lição: o gosto de seu dono.

${ }^{16}$ Entenda-se: "Extraordinária habilidade era necessária para começar e terminar esta carta, porque conduzi-la pelos passos das cartas anteriores seria ineficaz, considerando os barrancos com que sem razões plausíveis aquele caminho tem sido vedado. Queixar-me delas [das razões], que é a única alternativa que parecia restar, além de ser perda de tempo, faria com que a recompensa de minha 
A reposta disto foi hũ escri|to de promessas ainda muito mais cla|ras, que as 110 mentiras, de muito boa letra, as|sinado, e com sobreescrito, e hua re|gra por baixo que dizia: Assinei este | para que o ponhais no mais publico pe|lourinho quando vos faltar com o que nelle | vos prometto, e se não estais de todo | entregue a não crer nada, vede que tras | fazer estas promessas, e assinallas, não | fica que negar a quem se estima. [espaço] | Finalmente tornoume a mentir | a esperança, e eu por me vingar | torneilhe 115 amandar o seu Esrito di|zendolhe que lhe não queria dever | fiallo de mim offendido. ${ }^{17}$ [espaço] Inda | despois disto (olhai que vergonha minha) | teve esta mulher habelidade para me fa|zer agora passar anado aquelle rio | que vistes, e irme meter em hũ lugar | que me assinou, onde estive hũa noite | e hũ dia inteiro, e parte desta aguar|dando para lhe falar de hua genella | hũa hora prometida em tanto an||[195r]nos. [espaço] Passouce 120 como vos digo a | noite, passouce o dia, e quando ouvera de | vir a hora de ver a Daraja, chegou|me hũ escrito com mais desculpas | que letras, pedindome que esperasse mais | esta noite, porque amenhã poderia | ser que faltasse o inconveniente, com | que hontem não pudera verme. E | Este meu companheiro porque o eu | não quis fazer, diziame que o fizera | por lhe deixar desculpa para outros | fingimentos.

125 Estavão ja tão perto do | castello aque caminhavão que não teve | Trineo tempo para mais que dizerlhe | que se poupava para ao outro dia falla|rem naquella materia. Eapean|dose foi agazalhado daquelle cavallei|ro melhor do que prometia o habito ẽ | que elle vinha. E despois que se recolhe|rão passou oque ficava da noite nas i|maginações que veremos no capitulo | seguinte.

paciência fosse menor, pois quanto mais muda sofrer [a paciência], mais aumentará meu gosto e vossa confusão, vendo que o espanto comum a nós dois me servirá de consolação".

${ }^{17}$ Leia-se: "Assinei este papel para que o ponhais no mais público pelourinho se eu vos faltar com o que nele prometo. E se não estais de todo cético, vede que depois de fazer estas promessas e assinar esta carta, não vos resta alternativa se não negar a quem estimais. Por fim, ela tornou a enganar minha esperança e, para me vingar, devolvi a carta dizendo-lhe que não lhe queria ver confiá-lo a mim, enquanto estou ofendido". 


\section{De como Trineo se despe|dio de seu hospede, e do | que lhe succedeu indo || [195v] ambos com dous cava|lleiros.}

Não dormio Trineo tudo o que da | quella noite ficava, porque por hua parte $\mid$ o

135 cuidado de Gridonia que nunca per|dia, e por outra as historias de seu hospede | não lhe davão lugar para que repouzasse. [espaço] | Ponderava os affectos, com que elle lhas con|tara, as lagrimas que em muitos passos del|las engolia, a nova liberdade com que | queria mostrarcelhe, e tudo isto lhe de|clarava quam entregue o pobre homem | vivia, e que so era senhor de si para entẽ|der a pouca razão que tinha de ser cati|vo, porque

140 assim fosse maior apenitencia | pois era maior a culpa. Ponderava tam/bem em deffensa sua o que ouvira de Da|raja, o parecer, a idade, a calidade, e | o Estado, o entendimento, as traças, e | Em cada couza destas achava hũa grande | descarga a os dilirios da quelle homem | E finalmente em todo o progresso da | quelles amores infinitas couzas que lhe pa|recião encontradas, certo sinal de quão | certos elles erão, porque o compasso 145 achas|se so no Arteficio $^{18}$. [espaço] Via elle de hũa par|te a firmeza da quella fe sustendada | em sua perfeição contra o rigor de tan|tos dezenganos. Via a quella fineza || [196r] grande de lhe tornar amandar o seu | escrito, porque ainda que tambem o fo|ra o concervallo sem offensa de seu | dono, nunca Daraja em quanto o não | tivesse na mão podia estar quieta | com o credito tão aventurado co|mo nelle tinha. [espaço] E querella

150 elle asse|gurar dos temores, que justamente po|dia imaginarlhe ainda à custa de | perder o merecimento da rezisten|cia que se fazia ${ }^{19}$ a si proprio, fazendo | com o papel remoellas a o sentimento | julgava por circunstancia de gran|de calidade na quelle serviço $^{20}$. [espaço] Via $\mid$ o outro prodigio de primor nas adver|tencias que lhe fizera no principio | com tão provavel risco de incorrer | na indignação de hũa mulher decla|rada,

155 e não admitida, e tinhao pello | mais novo sacreficio que nunca na | quelles cazos ouvera. Por outra | parte conciderava aquelle homẽ cheio $\mid$ de tantos, e tão finos

\footnotetext{
${ }^{18}$ O sentido da observação deve ser o seguinte: a desordem dos sentimentos e os excessos cometidos por ambas as partes pareciam confirmar a Trineo quão verdadeiro era o amor que seu amigo votava a Daraja, já que o compasso (ordem, medida, vagar) só existe no arteficio, e não nos sentimentos verdadeiros.

${ }_{19}$ Todos os demais manuscritos, à exceção de A e B, apresentam faria no lugar de fazia.

${ }^{20}$ Remoella significa "pirraça, acinte" (Bluteau). Trineo considerava que o fato de seu amigo ter devolvido a carta a Daraja era uma demonstração de sua lealdade, embora a atitude pudesse ser interpretada também como sinal de fraqueza ou desabafo (perder o merecimento da rezistencia que se fazia), pois de alguma forma a devolução do papel também significava uma provocação ou pirraça (remoella) aos sentimentos da donzela.
} 
extremos, descon|tente de servir, com hũ bem, a que elle | com razão segundo a differença de seu | Estado não podia aspirar nunca, por|que as Mentiras de Daraja que erão a Ma|teria de sua queixa, parece que o ouve|rão de ser da sua consolação, sen|do 160 assim que quando pudessem danar o gosto || [196v] de hũ apetitozo, não podião deixar | de recrear o animo de hũ Entendi $\mid \mathrm{do}^{21}$, e sendoo elle, mais as havia de ter $\mid$ por fruto da honrra da quella mulher, | que por ludibrios de sua vontade, a | fora que tratando com hũa pouca de es|peculação esta Materia, mais tinha | de que se contentar na quebra daquel|las promessas, que no comprimento del|las, como ella perdia mais em fazellas |e 165 cumprillas, do que em observallas, e a | razão era que em dar perderia o que desse | carregando a culpa, aquẽ na quelles | cazos a tem sempre, que são aquellas | violencias grandes, com que o amor cega | O Entendimento ${ }^{22}$, arrasta a razão, | e affeiçoa a $\operatorname{vontade}^{23}$. E hũa Mulher pos|ta neste estado pouco mais Mõtão os | triumfos que della se tiverẽ, que os que se po|dem ter de hũ corpo sem alma. Mas | prometendo perdeu o que 170 prometeu, co|mo se o dera, e perdeu a desculpa que | podia ter dando ${ }^{24}$, porque a concecção | foy acto da liberdade forçada, e a | promessa da vontade livre, e dada es|ta differença não se pode hũ deduzir $\mid$ do outro ${ }^{25}$. [espaço] E esta liberdade da vonta|de, era a que Trineo julgava que seu hos|pede ouvera de estimar muito nascendo | della aquellas promessas com hua força $\|$ [197r] suave que o conhecimento, e concide|ração de suas 175 boas partes fazião a | Daraja, com a qual prometia co|mo rendida á justa estimação | das couzas, e despois nẽ se arrojava | comoopprimida ${ }^{26}$, e forçada, nem | voltava como livre e enganoza, | mas rezestia como sizuda, e honrra|da, e ficavão assim tendo tanta | differença as victorias que della se ti|nhão prometendo, e negando, das ou|tras que

\footnotetext{
${ }^{21}$ Leia-se: "descontente de servir com vistas a um bem que ele, com razão, segundo a diferença de condição, não poderia aspirar; e, posto que as mentiras de Daraja eram a causa de suas queixas, [a Trineo] pareceu o contrário: que elas deveriam ser seu consolo. Sendo assim, se [as mentiras] pudessem contrariar as intenções de um cobiçoso, não podiam deixar de oferecer ocasião para reflexões de uma pessoa inteligente".

${ }^{22}$ Todo o início desta linha está bastante borrado no manuscrito, pois o copista havia feito algum erro.

${ }^{23}$ A frase é confusa. O sentido geral da passagem parece ser o seguinte: especulando sobre o caso, Trineo concluiu que seu anfitrião não deveria se queixar do descumprimento das promessas, pois a realização de seus intentos seria danosa para ambos. Caso Daraja cumprisse o que tinha prometido, ela assumiria para si a culpa, que nesses casos é sempre do Amor, que cega o juízo, arrasta a razão e aprisiona o desejo. ${ }^{24} \mathrm{C}:$ dado.

${ }^{25} \mathrm{O}$ texto prossegue com sentido um tanto obscuro. Entenda-se: a concessão (ou seja, a realização das promessas feitas por Daraja) seria fruto da liberdade forçada, visto que, neste caso, ela poderia sentir-se compelida a conceder o que prometera; a promessa, no entanto, havia sido feita por vontade livre, pois nada a obrigava a empenhar sua palavra. Dessa forma, uma coisa não poderia justificar a outra (não se pode hũ deduzir do outro).

${ }^{26}$ A letra inicial de opprimida foi inserida posteriormente pelo copista.
} 
parecia que seu hospede dezejava, | quanta ha das que se alcanção da quella parte | onde 180 o Entendimento julga, as pai|xoes obedecẽ, a razão governa, à outra | Onde tudo isto acontece ao contrario $^{27}$. | Egraduadas as couzas assim como Tri|neo as Entendia, não sabia que julgasse | das acções da quelle homẽ rezolvendoce | emfim que nas Materias que com circuns|tancias mudão calidade, não podẽ ser | bons juizes os que as vem defora, e devẽ | so nestes cazos sello as partes ${ }^{28}$.

185 Envolto nestas fantezias, | Eimaginações o thomou a Menhã, e | fazendo então hũa breve tregoa com $\mid$ o pensamento repouzou hũ pouco, e | sabendo depois que acordou que o hospede o | aguardava ja levantado, vestiose e | foise para elle, e alli gastou todo aquelle || [197v] dia a the tarde falando nesta, e nou|tras Materias. [espaço] E depois de contratada | muita amizade querendo Trineo par|tirce o hospede lhe quis ir 190 mostrar O | caminho por onde queria ir, e acom|panhallo hũ pouco nelle, e Armando|ce de huas armas cabelhadas, e cheas de | Malmequeres brancos, e no Escudo ẽ | campo azul Protheo com hũa letra, | que dizia em qual quer. ${ }^{29}$ pondoce | num cavallo castanho escuro, grande | e fermozo, e thomando hũa lança na | mão só sem companhia algũa, a foi fazen|do àquelle Princepe, que hia bem mais | contente delle na quelle 195 habito, que no | outro, em que anoite passada o vira. | E depois de terem caminhado mais de | Mea legoa, querendo ja despedirce, e | daremce os Ultimos abraços, virão vir | pella estrada que elles levavão dous caval|leiros mui bem postos, e airozos, ar|mados de ricas, e lustrozas armas, am|bos de hũa Maneira, senão que nas di|vizas diffirião, porque hũ trazia em | campo sanguinho o jugo e Nós de Mi|das com hũa espada entre elle como 200 quẽ | os cortava, e o outro em campo verde | o Laberinto de Cretta espedaçado, e aber|to $^{30}$. E chegando hũns a os outros saudã|doce cortes mente, os que vinão ${ }^{31}$

${ }^{27}$ O simples fato de Daraja ter feito tais promessas já seria um prêmio maior que a recompensa visada pelo anfitrião de Trineo. As promessas dela eram fruto da liberdade da vontade (pois nascidas da força suave proveniente das qualidades que Daraja via em seu amigo); ao passo que a consumação dos desejos significaria a submissão da razão e do entendimento às paixões.

${ }^{28}$ Ao final do longo exame da situação, Trineo não sabe a que conclusão chegar e se isenta de formular um juízo sobre o comportamento de seu anfitrião. De fato, o caso apresentado pelo cavaleiro é complexo e não se enquadra nos modelos tradicionais de relacionamento amoroso retratados em novelas de cavalaria.

${ }^{29}$ O próprio copista desconsidera este ponto final e continua a frase com letra minúscula. Proteu era um deus grego que possuía o dom de conhecer o futuro, embora freqüentemente costumasse recusar-se a revelar o que lhe perguntassem.

${ }^{30} \mathrm{O}$ primeiro escudo faz referência à lenda no "nó górdio": Midas era filho de Górdias, um pastor que se tornou rei da Frígia, e sucedeu-o no trono; porém, dado que Midas não deixou herdeiros, espalhou-se a notícia de que quem conseguisse desfazer o nó do jugo de bois de Górdias tornar-se-ia rei da Frígia. Conta-se que, como ninguém nunca conseguiu desatar aquele nó, Alexandre Magno cortou a corda com 
pregunta||[198r]tarão a Trineo, se lhe saberia dar | razão de hũ cavalleiro, que trazia as | armas de Escamas muito meùdas ver|des, e negras com muitas pintas amarel|las, e no escudo em campo das mes|mas cores hũns troncos de cypres|tes queimados de hũ rayo que dava nel|les? [espaço] Trineo que a the então não | tinha sabido nada, da quellas armas, | nem ouvido fallar na quelle cavallei|ro, porque ainda que Daliarte quando na I|lha de Dramuziando lhe deu novas | da perdição dos Reys lhe contou tãbẽ | o que antes disso tinha acontecido com | os Gigantes que tinhão thomado aquella | Ilha, e como D Duardos os livrara | com morte de ambos com que os Morado|res della ficarão quietos

210 como temos | contado, não lhe particularizou as ar|mas, nẽ a diviza que elle trazia, e | assim não podia Trineo saber nada | daquelles sinais, porque lhe pergunta|vão. E respondendo nesta conformi|dade, queixouce tãbẽ do ${ }^{32}$ pouco que ti|nha aproveitado em outra de Manda | em que andava, se bem tinha corrido | boa parte do mundo a pos ella. Eos | outros que estimarão por injuria haver | nelle quem não tivesse noticia das grã|des 215 couzas do cavalleiro dos cyprestes, || [198v] Responderãolhe: Ora ja que assim he que | nos dais tão ma razão do que vos pergun|tamos, dizeinos que demanda he essa vossa | e por ventura que vos demos melhores no|vas della, porque ainda que não temos anda|do tanto Mundo, ja pode ser que esse que foy | fosse com os olhos mais abertos. [espaço] Ca|valleiros, disse o Hospede de Trineo $)^{33}$ hi|de vosso caminho embora, e ja que tendes | 220 os olhos abertos, abrios bem, e não deis | occaziões para que vo los fechẽ. [espaço] Elles que erão | pouco costumados aquellas palavras sẽ | replicarẽ mais algũa thomarão as lan|ças a seus Escudeiros, e com ellas bai|xas tendoce afastado o que cũmpria re|meterão a Trineo, e a seu companhei|ro, que do mesmo modo os sahirão a rece|ber, e succedeulhes o que adiante diremos.

sua espada a fim de legitimar a conquista da região. No escudo do outro cavaleiro havia a representação do Labirinto de Creta construído por Dédalo para aprisionar o Minotauro. Posteriormente, o rei Minos mandou que o próprio Dédalo, juntamente com seu filho Ícaro, fossem encerrados no labirinto, donde conseguiram escapar após construírem asas de cera. No entanto, como se sabe, Ícaro não sobreviveu ao vôo, pois suas asas derreteram depois que se aproximou imprudentemente do Sol.

${ }^{31} \mathrm{~B}, \mathrm{C}$ : vinhão.

${ }^{32}$ A palavra foi corrigida pelo copista; o $d$ foi corrigido sobre um $p$.

${ }^{33} \mathrm{O}$ parêntese não havia sido aberto; em B ocorre o mesmo. 


\section{Capitulo 62}

\section{Da batalha que aquelles cava|lleiros fizerão do que re|zultou della, e do que fa|zia Primaleão | na guarda | do valle.}

Em cheio se encontrarão aquelles || [199r] Cavalleiros com tanta força que so | o Hospede de Trineo ficou a cavallo | mas deixandoo logo foise juntar com | elles, e mettendo todos quatro mão ás | espadas começarão hũa assas notavel | e perigoza batalha, na qual andarão | tanto espaço dando, e recebendo golpes | que comessarão as armas a perder a fer|mozura das cores, e a fineza da tempe|ra, e elles a sentir nas carnes

10 a for|ça de que aquillo nascia ${ }^{1}$. [espaço] Trineo era $\mid$ mui bom cavaleiro mas não lhe de|via ${ }^{2}$ nada o com que se combatia. O com | que o Hospede estava embaraçado extre|mado era, porẽ elle o era tanto, que com | isso, e com a experiencia de muitos | trances daquelles o terem feito robusto | e alentado, era o que melhor livrava de | todos os companheiros, que a muita pai|xão com que se accometião, e a pressa | que se davão

15 por se vencerẽ, os trazia ma|is afogados do trabalho que impossebili|tados das feridas, se bẽ não lhes falta|vão. [espaço] E vendo o Hospede aquillo | que ainda que andava na sua batalha | não tirava os olhos de Trineo, apar|touce a fora e dicelhes que descãçassẽ. | Os dous estranhos que athe então não | tinhão encontrado com inimigos | tão duros, emquanto repouzavão estavão $\|[199 v]$ ce tomando assi mesmos conta da | confiança com

20 que athe então vive|rão de suas couzas ja a seu parecer | não bem fundada principalmente | o que o havia com o Hospede que cla|ra mente entendia que mais por cor|tezia, que por nececidade lhe dera a quelle lugar ${ }^{3}$. [espaço] Os pensamentos de | Trineo, não erão mais quietos, que | tambem exprimentava agora o que | dantes não conhecia, e seu companhei|ro que o sentio embaraçado com aquel|la concideração

25 chegandoce a elle dis|selhe rindo: [espaço] Inda este senhor Trineo | não he o perigo em que vos eu eide acon|celhar que vos encomendeis á Senhora Gri|donia (paresse que algũa couza lhe tinha | elle palrrado) apresaivos de vagar ${ }^{4}$, e | livrarvoseis facilmente delle, e se | vos parecer não lhe demos mais | tempo. [espaço] Queria Trineo

\footnotetext{
${ }^{1} \mathrm{O}$ final da frase é provavelmente fruto de um erro, compartilhado por todas as cópias (a única lição divergente é a de F, que faz mais sentido: a força daquillo na sua).

${ }^{2}$ A letra $i$ foi acrescentada posteriormente, nas entrelinhas.

${ }^{3}$ Leia-se: "mais por cortesia que por necessidade dera-lhe aquela oportunidade de repousar".

4 A expressão, aparentemente contraditória, deve significar: "deixai logo (apressai) este descanso (vagar)".
} 
responder|lhe bem mais satisfeito que nunca | de suas couzas, quando vio vir correndo |

30 o seu Escudeiro em companhia dos | daquelles cavalleiros dizendo em grã|des gritos: Deixai, deixai senhores | as brigas, que entre tanto parentesco | e amizade não he razão que as haja. | Estes cavalleiros São o Princepe Re|cindos, e Arnedos, vede agora se as || [200r] quereis ter com elles. Trineo ouvin|do aquillo se foy com os braços a|bertos a demandallos, e tirando os El|mos hũns eoutros ouve algũ ${ }^{5}$ que não | festejasse muito

35 aquelle conhecimento | a tal tempo, particularmente Bracili|ano, que assim se chamava o hospede de | Trineo, para o qual não pudera haver mate|ria de maior sentimento, que aconte|cer algũ dezastre a Recindos, em que elle | pudesse ter culpa inda que tão remotta $^{6}$, | E posto que com Arnedos fora a sua ba|talha informandoce de qual era Re/cindos porque nunca o tinha visto, ti|rando o Elmo, e sentandoce em gio|lhos

40 disselhe: [espaço] Bem vejo senhor que he / pequeno castigo de minha ignoran|cia o sangue que me ella custa, | Mas apromptidão com que estou para $\mid$ o dispender todo no a que me obriga | ser vassallo de ElRey vosso Pay, o | gosto que tenho de vos conhecer cõ | tão verdadeiro testemunho por seu | filho, bem pode achar perdão em | hũ Princepe, que como cavalleiro | Andante segue as Aventuras. [espaço] | Recindos o fes levantar, e 45 abraçan|doo mui Estreitamente lhe disse: | Que se no senhorio de seu Pay havia | tais cavalleiros, que entenderia que era || [200v] O mor senhor do Mundo. E tendo [espaço] | Barceliano depois outros muitos compri|mentos com Arnedos, levouos a seu | castello, onde forão curados das peque|nas feridas, que todos tinhão com muita | deligencia e cuidado a sua satisfação del|les. [espaço] E porque deste [espaço] Braceliano fas |

50 Henrrique Frusto memoria em ou|tros lugares desta choronica, deixamos | para então dizer quem era ${ }^{7}$, dizendo ago|ra so mente que os Princepes ẽ ter|mo de oito dias partirão de sua caza | todos tres juntos para Constantinopla | onde os dous Primos avizarão a Tri|neo que ja Estavão outra ves os Reys li|vres do Encantamento, e de quem os | livrara delle, que de tudo tinhão sido in|formados no Reyno de Ungria, onde | forão ter depois

55 que sahirão da Ilha de | Dramuziando. E embarcandoce | ali com aquelle mesmo intento o | tempo os lançou em Hespanha | pella qual caminhando algũns dias | sem se darẽ a

\footnotetext{
${ }^{5}$ Aqui há um erro exclusivo às cópias A e B. Certamente a lição correta é a dos outros testemunhos: "hũns e outros não ouve algũ".

${ }^{6}$ Lembre-se que o caso se passa numa província de Espanha, de onde Braceliano era natural, e que Recindos era o príncipe espanhol. Braceliano era, portanto, seu vassalo.

${ }^{7}$ Braceliano não volta a ser mencionado nesta primeira parte das continuações manuscritas do Palmeirim de Inglaterra.
} 
conhecer preguntando | sempre por D Duardos vierão ter | com Trineo, e Barciliano, com quẽ | lhes aconteceu o que temos contado. | E os Escudeiros de hũns e outros jun|tandoce a recolher os cavallos de que seus | senhores tinhão cahido, como se tinhão || 60 [201r] criado $^{8}$, logo se conhecerão de que se | seguio o effeito que vimos.

Deixando Estes cavallei|ros seguindo seu caminho torna a | historia a dar conta de Primaleão | que deixamos por Bohemia na Guar|da do valle da Princeza Fidelia | a qual depois de recolhida a quelle cas|tello donde mandou recado a ElRey | seu Pay, e elle se foy para as tendas, que | ja lhe tinhão armado acompanhado | da quelles 65 cavalleiros, com quẽ tinha | justado, e despois de estarem conver|cando ${ }^{9}$ hũ espaço despedindoce, dei|xarãono entregue a seus novos | cuidados, e tão contente do empre|go que de si tinha feito, que bem thoma|ra que as partes, e perfeições de Fidelia | não assentarão sobre tamanha ca|lidade e estado, porque lhe não ficasse | $\mathrm{O}$ amor em algũa Maneira sos|peitozo, mas logo tornava a castigar | este pensamento como descortes | a o 70 respeito da quella Princeza ${ }^{10}$.

Era Primaleão novo | nestes accidentes, e como não tinha | reservado para si parte de si algũa, pa|deciaos differentes, mas com intento | indifferente em tudo, que era de amar | a Fidelia com os maiores extremos || [201v] reduzidos a pratica, a que a mais sotil | especulação nunca soube o nome ${ }^{11}$. | Resoluto nisto chamou Ardellio, e dis|selhe:

75 [espaço] Ardellio amigo, mal me ouza|ria eu chamar filho de meu Pay, e neto | de meus Avos, se passasse por esta ter|ra livre dos merecimentos desta | Princeza, que hoje vi. Elles me tem o|brigado a me não sahir nunca del|la. Bem sei o pouco que meus ser|viços poderão Montar para a inclina|rem a asseitallos, que fora a verdadei|ra satisfação sua, mas isso que vale|rem detremino offerecer a o que lhe | quero, sem algũ outro animo 80 malis que o da fe, com que serão offerecidos. | Por isso vos avizo, que por nenhũa cou|za que a conteça descubrais quẽ sou | em quanto eu viver nesta parte, que | serà o tempo que as memorias da se|nhora Fidellia me deixarem de vi|da. [espaço] E porque nesta

\footnotetext{
${ }^{8}$ Ou seja: os escudeiros haviam sido criados juntos, na mesma corte.

${ }^{9}$ Falta o cedilha.

${ }^{10}$ Leia-se: "Deixaram-no entregue a seus novos pensamentos e tão satisfeito do que fizera, que talvez fosse melhor que as prendas e perfeições de Fidélia não se encontrassem em pessoa de tanta qualidade e estado [como ela, que era uma princesa], para que não pudesse haver suspeitas quanto a seu sentimento; mas logo voltava a repreender este pensamento, acusando-o de ser descortês à consideração que se devia àquela princesa".

${ }^{11}$ A frase, de difícil compreensão, significa que Primaleão, inexperiente naqueles casos, padecia seus sofrimentos de amor sem reservas e totalmente entregue, indiferente a tudo que não fosse Fidélia. Seus sentimentos eram tão intensos, que o faziam viver de um modo que até mesmo a mais sutil imaginação não saberia nomear.
} 
Materia nem | quero concelho, nem aprovações, | não vos atrevereis a falarme nella | Em nenhũ estado em que me virdes. | E com isto deixandoo foice passe|ando pello prado 85 contra o castello | athe chegar á raiz do Outeiro, on|de elle, e o Mosteiro estavão ediffi|cados. E lançandoce a o pe de hũa || [202r] daquellas arvores, que por alli havia, | começou a dar de si hũ rico tributo | Ao Amor, a quem por obrigação | e herança parece que o devia. [espaço] Assi | o deixaremos por dizer o que sentia | a Princeza com a sua vizinhança. 


\section{Capitulo 63}

\section{Do que fazia a Prince|za depois que se reco|lheu no seu cas|tello.}

Pouco ou nenhũ cuidado da quel|les ficara com Fidelia, mas dos outros | a que 5 não fora rezão se rezistira, não lhe $\mid$ faltarão algũns ${ }^{1}$, e assim não deixou | de fallar, e rir com Ennaclia nas | graças de Pleonido, e no passeio, que | ellas levavão, no bom termo do ca|valleiro, e em que não podia deixar de | ser pessoa de preço, dezejando que fi|casse em caza de seu Pay, e juntamente | que na guarda do valle acontecesse al|gũa couza, com que se averiguacem $\mid$ melhor as sospeitas de seu valor, e $\mid$ calidade. [espaço]

10 Ennaclia não estava || [202v] contente do Cavalleiro por respeito | do desastre de Ludimio seu parente, | e so se conformava com a Prin|ceza em dezejar que na guarda do | valle ouvesse novidades que a satisfi|zessem, porem por não dar muitos | indicios de seu animo a sua ama, | lançava a demonstração de seu descon|tentamento a os partidos do Enano $^{2}$, | E finalmente nestas singilezas da Prin|ceza, e nas dissimulações de

15 Ennaclia | estiverão ambas conveçando, a the que | forão horas de se recolherẽ. [espaço] Chegou | a Menhã do outro dia, e nas ${ }^{3}$ primei|ras horas della chegou hũ recado de El|Rey a o cavalleiro do Sol, em que lhe mã|dava dizer, que tinha sabido como era | alli chegado, e o exercicio, a que estava | offerecido, e que inda que esperava vello | brevemente, toda via, para o que pudes|se acontecer lhe mandava aquel|las lanças, e

20 aquelles cavallos diante. | Então lhe prezentou quẽ lhe a|quelle recado trazia hũa grande | cantidade de lanças, e seis cavallos | mui em ordem para qualquer traba|lho. [espaço] Ao que o Cavalleiro respondeu | com o comedimento que costumava | e devia a favor tão grande. [espaço] Não | tardou muito que ElRey não viesse ter || [203r] a o Castello com grande alvoroço | pello que Pleonido lhe tinha conta|do, e sendo recebido com o 25 mes|mo de sua filha, estiverão fallando | na quella Aventura, e no dezastre, | de que Pleonido affirmava, que as livra|ra. [espaço] E querendo ElRey que lhe ar|massẽ tendas em baixo para ir a | jantar la, e ver as justas á tarde se | as houvesse, a Princeza lhe disse, que | descançasse, e repouzasse, e que depois | se faria o que elle quizesse, e lhe pareces|se. [espaço] Assi o fes ElRey, e quando foy | hora de comer mandou a Pleonido

\footnotetext{
${ }^{1}$ Fidélia ficou sem aqueles cuidados amorosos que atormentavam Primaleão, mas ficou com outros, aos quais não era necessário resistir,pois seriam cuidados mais inofensivos à sua honra.

${ }^{2}$ Neste contexto, aos partidos do enano significa "para o lado do anão". Ou seja: para não mostrar sua insatisfação com o Cavaleiro do Sol, Enáclia fingia estar aborrecida apenas com Pleonido.

${ }^{3}$ Palavra corrigida pelo copista, que inicialmente havia escrito não.
} 
30 | que fosse gentar com o Cavalleiro do | Sol, e que o avizasse de sua chegada. | Foy o Enano, e achandoo que andava | passeando junto da fonte, comessou|lhe a perguntar de longe, como an|dava tão ociozo tendo o campo che|io de inimigos? Forte couza he (lhe | respondeu odo Sol) julgardesme sempre mal, porque vos affirmo em verda|de, que nunca tanto, nem tão bem | occupado estive como agora. Mas | não sei que fassa a

35 minha fortuna | que não quer a cabar de me mostrar | caminho para vos persuadir a verdade | de minhas couzas. [espaço] Ao que eu estou | persuadido (replicou o Enano) he que || [203v] me quereis vos fazer crer o que por | ventura a nenhũ de nos convem ${ }^{4}$. | Mas deixando agora isto ElRey me | manda que venha ser vosso hospede, | he chegado desta menhã $\tilde{5}^{5}$, e cuido que des|cerà por cà á tarde. [espaço] Não vos posso | deixar de 40 dizer, que lhe deveis juntamente | com esta romaria, que á vossa conta | fes, hũa grande de monstração de al|vorosso, que se lhe enxergou logo que hon|tem soube que estaveis nesta terra. Por | isso sabeilho servir, que nunca vos arre|pendereis de cumprirdes com o que so|is obrigado. [espaço] Ja me isso parece bẽ | (respondeu o cavalleiro) dezejardes de eu | acertar, que he o que vos mereço, e para que en|tendais quanto de vossa parte 45 tendes minha | vontade prometovos que fora de hũa | so couza, em nenhũa outra deixar | de seguir vosso parecer. [espaço] Domes|ticandoce então Pleonido muito mais | com elle, ficarão fallando em materi|as geraes com grande Espanto de Pri|maleão de ver quão bem pagara a na|tureza a Pleonido no Entendimẽto, | as faltas que lhe dera na pessoa, porque ver|dadeira mente era hũa das entendi|das sevandijas que se podião achar. $\mid \mathrm{E}$

50 chamandoo para comer despedio to|dos os Ministros com que ElRey o man||[204r]dava agazalhar. ${ }^{6}$ e ficarão sos Pleo|nido, e Ardellio; servindo, todos os | officiaes sem amolestia de muitas ceri|monias, apos o que, comendo elles tã|bẽ, e tornando depois a suas prati|cas, hia cada hũ espreitando o outro | com o maior cuidado que podião. E | como os livres são verdadeira mente | Mais promptos para o que não he amar, | muito 55 mais descobrio a industria de $\mid$ Pleonido do amor de Primaleão, que a $\mid$ de Primaleão do seu cuidado delle. | E tendo assentado com certeza que aquel|le cavalleiro estava abrazado com | amores, per discurso presuadiasse que | podião ser de Fidelia, Então imagi|nando que não se agazalhavão aquel|les pensamentos em parte de pouco |

\footnotetext{
${ }^{4}$ A observação final de Pleonido é obscura.

${ }^{5}$ Em princípio o mais correto seria "chegado nesta manhã”, mas o termo desta também foi empregado em B e C.

${ }^{6} \mathrm{O}$ próprio copista desconsidera este ponto final e continua a frase com letra minúscula.
} 
Merecimento, comessou a respeitallo | interiormente mais do que a the então | fazia.

60 [espaço] Eparecendolhe a o do Sol que | seria ja hora de ir fallar a ElRey | querendo mandar o Enano a saber | o que fazia, virão vir Ministros se|us armar não longe das suas, outras | tendas, onde logo veio com a Prince|za, e suas Damas. [espaço] Foy o cavalleiro | a recebello, e querendo bejarlhe a mão | ElRey lho não consentio, tratandoo || [204v] com muita cortezia, e gazalhado. E | depois de passar com elle e com a Prin|ceza muitos

65 comprimentos de que ElRey | ficou assas satisfeito, foise por no pos|to thomando primeiro cavallo, porque lhe | disserão que dous cavalleiros o aguarda|vão. E indo a demandallos concer|tandoce na cella remetteu a o primeiro | que o sahio a receber ferindoo de tal | Encontro, que porcima das ancas do | cavallo o arrojou grande espasso pel|lo campo. [espaço] $\mathrm{O}$ mesmo fes a seu com|panheiro, e a mais quatro que chegarão |

70 espos elles, sem que denenhũ dos se|us encontros recebece reves algũ, cõ | o que o Enano se mostrava conten|te como senhor da quellas victorias ${ }^{7}$. | Ennaclia triste, a Princeza socegada | e ElRey contente e alvoraçado. | Os cavalleiros cahidos erão todos da | corte, enamorados os mais delles, com | que tudo estava revolto entre contenta|mento publico, e pezar dissimulado. | Com aquillo se acabou a tarde, | porque

75 não veio mais quem justasse, | e ElRey se recolheu ao castello, a|companhado do cavalleiro do Sol, e | rezoluto em estar alli todos os dias que | as justas durassem. Amais $\mathrm{de}^{8}$ gen||[205r]te, que o accompanhava se tornou | outra ves á cidade, e o Caval|leiro do Sol passou a noite em suas | contemplações, cada ves mais con|firmado no gosto de sua entrega. | A o Outro dia pella Menhã o veio |A ver Pleonido, com o qual passou | o que 80 adiante veremos.

\footnotetext{
${ }^{7} \mathrm{O}$ sentido da próxima frase exige que este ponto final seja desconsiderado.

${ }^{8} \mathrm{~B}, \mathrm{C}: d a$.
} 


\section{Capitulo 64.}

\section{Do que passou o Cavalleiro do | Sol com o Enano, e | despois com alguns | cavalleiros, com | que justou.}

Não era gastado muito da menhã | quando Pleonido veio a vizitar Prima|leão, e fazendoce ambos seus comprimentos, com o recato que cada hum | costumava. $\mathrm{O}$ Cavalleiro depois de | passados se foi com elle ao Mosteiro | deixando recado que o chamassẽ se ou|vesse para que, e tendo ouvido Missa e | visto a fabrica da quelle convento, que | era grande, e Magnifica a respeito do | pouco sitio que occupava na

10 coroa | daquelle Monte e no cume da quelle || [205v] penedo. [espaço] Levouo Pleonido Onde | cahia hũa tribuna interior da Prin|ceza com tenção de ver se podia con|jecturar ${ }^{1}$ das suas demonstrações al|gũa Mais certeza das sospeitas com | que andava ${ }^{2}$. [espaço] Não havia na tribuna | mais que so duas embuçadas que quietamente | estavão rezando. Enão as podendo reco|nhecer o Enano perguntoulhes aquem se | encomendavão? Hũa

15 dellas vendoo so $\mid$ com o cavalleiro dissimulando a falla $\mid$ respondeulhe a São Christovão rezava agora | e por aqui vereis se tem algũa conveni|encia com vosco minhas orações ${ }^{3}$. [espaço] A | São Matheus me parece (lhe replicou elle) | que fora melhor, porque segundo vos da traba|lho o encobrirvos necessario vos he algũa|de suas Maravilhas ${ }^{4}$. [espaço] Vedes ahi qual he $\mathrm{O} \mid$ Mundo lhe tornou ella, que nòs estamos | nessa fadiga que dizeis, e vos não descanças|tes athe não trazer a qui esse Cavalleiro | dandolhe a conhecer vossas habelidades de que | lhe deveis ter metido em conciencia grã|des milagres. [espaço] O Enano confuzo so|bre Maneira porque não acabava de pene|trar aquelle segredo, toda via lhe respõdeu: | Ta ta ta, ja vos conheço, e em verdade que fi|quei tão Mestre do tempo que vos servi, que bẽ | posso prometer todo o bom

\footnotetext{
${ }^{1}$ Palavra corrigida pelo copista, que inicialmente havia redigido conjecturão.

${ }^{2}$ Como dito anteriormente, Pleonido começara a suspeitar que o Cavaleiro do Sol amasse secretamente a princesa Fidélia.

${ }^{3}$ Entenda-se: "veja se minhas orações têm algum interesse para vós", ou "se tendes relação com elas". O episódio do diálogo entre Pleonido e as embuçadas, aqui iniciado, é certamente o mais obscuro desta obra: não há elementos que expliquem ou justifiquem o motivo da troca de ironias e acusações a que eles se entregam. $\mathrm{O}$ tom jocoso com que as embuçadas respondem às perguntas do anão parece-nos ter um efeito humorístico que nos escapa de todo.

${ }^{4}$ Não conseguimos encontrar qualquer referência a devoção particular de S. Mateus que justificasse a observação de Pleonido. Como se sabe, antes de tornar-se um dos apóstolos, Mateus era cobrador de impostos e, depois da morte de Cristo, foi autor de um dos evangelhos. Quanto a S. Cristóvão, sua biografia é menos segura: supõe-se que tenha sido um mártir do séc. III e seu culto foi muito difundido durante toda a Idade Média. Cf. Donald Attwater. Dicionário de santos. 2. ed. Trad. Maristela R. A. Marcondes. São Paulo: Art Editora, 1991.
} 
25 successo de minha | deligencia, quanto mais que vos não ${ }^{5}$ sois tão || [206r] christã que suprireis com charidade os def|feitos de minhas ignorancias. [espaço] Oh que gra|ça tamanha, disse a Embuçada, quereis me me|ter em cabeça que sabeis quem sou, e daisme | sinal que denenhũa maneira conheço. [espaço] | Meu amigo, vendei se puderdes pella amos|tra, que com apessa, não haveis de enganar $\mid$ nimguẽ ${ }^{6}$. [espaço] A

30 fe que sois vos mui letrada, | disse elle, e pareceme amim que não deve / deser esta aprimeira ves que rezais Matina, cõ | os Padres, que vem assender as alampadas. |Agora vos digo, respondeu ella, que vos não es|tou em nenhũa restetuição de quão gro|ceiro, e pezado me parecestes sempre. | E podeisvos ir embora que ja chegastes a o | valhacouto de todos os atalhados ${ }^{7}$. [espaço] Não pro|vou mal o Enano em não ficar de todo cõ | 35 aquella reposta porque com tudo tornou a | dizerlhe: Destesme a vida senhora verda|deira mente porque vos que acodis onde vos $\mid$ doe, he sinal que não estão as paixoes de to|do mortificadas, e assim vos pesso me diga|is se sabeis a devação das Missas de Santo E|rasmo, e das cadeas de São Pedro, porque deze|jo tirar hũa alma para saber com quẽ me | eide cazar ${ }^{8}$. [espaço] A outra companheira que nun|ca falou palavra 40 se levantou, e puxan|do pella das praticas recolherãoçe ambas, re|bentando com rizo sem falarem mais | palavra. [espaço] Então disse o Enano para o || [206v] cavalleiro: Em toda a parte Senhor ha $\mathrm{A} \mid$ venturas, mas porque vos não espanteis desta | será razão que saibais que o uzo desta tribuna he | da camareira Mor da Princeza onde | nunca vem senão gente que anda embuça|da no Paço. Não era aquillo assim como o | Enano dizia, mas a elle lhe pareceu fazel|lo por se acazo o cavalleiro julgasse por grã|de a liberdade da quella embuçada. E elle | lhe respondeu: Melhor quizera eu Pleonido | sahir das minhas Aventuras, do que vos tendes | sahido desta, porque falastes com escandeli|zado,

\footnotetext{
${ }^{5}$ Os manuscritos A e B são os únicos a acrescentar esta palavra, que deixa a frase sem sentido.

${ }^{6}$ Não encontramos qualquer menção a esta expressão no Vocabulario de Bluteau. Ainda assim, seu sentido é claro.

7 Não pudemos determinar com um mínimo de segurança o sentido desta passagem. Os termos valhacouto e atalhados significam, respectivamente, "refúgio" e "confusos, perplexos".

8 As devoções referidas, certamente populares no tempo em que o texto foi escrito, não foram identificadas com segurança. Santo Erasmo foi mártir do séc. IV e uma lenda pia afirma que, durante a tortura que sofreu, seus intestinos tinham sido retirados do corpo com um molinete. A semelhança entre este instrumento e o cabrestante de navios talvez seja a explicação do porquê de as descargas elétricas, que às vezes surgem nos mastros das embarcações, terem sido chamadas de "fogo de Santo Elmo", uma variação do nome de Erasmo. A devoção às cadeias de São Pedro é antiquiíssima e foi muito difundida sobretudo a partir do séc. IV, quando se encontram as correntes que mantiveram o apóstolo preso em Roma e foi construída a igreja de San Pietro in Vincoli, no mesmo local da prisão. Não encontramos referência alguma que explicasse a ligação entre os dois santos e a crença em sua capacidade de prever casamentos.
} 
e ellas como travessas. A tribuna não | sei de que uzo seja, porem as mulheres não me | parecerão dessa classe em nada ${ }^{9}$. E vamo|nos antes que tornem, porque eu medo que o 50 ha|jão comigo, e que me não queirais vos acu|dir no perigo em que me meterẽ. [espaço] Não me | offereço, por não fazer certas aquellas fei|ticeiras (disse Pleonido) Mas se o Espirito | me adivinha a verdade não estou dezes|perado de que tenhais nececidade de mim | ainda algũ dia. Como ainda algũ dia? | (replicou o cavalleiro) [espaço] Da primeira hora que vos | vi estou nesse estado, mas não valho nada $\mid \operatorname{com}_{\text {vosco }}{ }^{10}$. E 55 praticando nestas, e em ou|tras couzas se sahirão, e forão para as tendas | nas quais passarão a the ser hora que ElRey | ea Princeza se vierão ás suas, e alli foy | logo chamado o Cavalleiro porque ElRey \| [207r] Se entretinha muito com elle, e preguntan|dolhe no descurso de muitas praticas de que ter|ra era natural? elle lhe respondeu, que a | todos os homẽns de bem toda a terra era | patria, porem que nem da

60 em que elle nas|cera, nem de quem era, podia por então | dar algũa noticia a sua alteza sem offfensa de sua honrra, mas que brevemente | cuidava podello servir na quillo, e sem|pre em todo o mais que lhe mandasse. | Nisto derão recado que havia Aventurei|ros, e foice o Cavalleiro pòr no posto, on|de o aguardavão ja tres que alli tinhão che|gado, e foralhe ${ }^{11}$ melhor tardarem mais | porque facilmente os derribou a todos. | E não tinha

65 acabado com o derradeiro | quando chegarão à quelle lugar mais seis, e | hũa Dóna embuçada em hũ palafrem | Murzello, e mui bem sellado, com mais | duas Donzellas tambem embuçadas. | E como quem ja sabia o costume da $\mid$ quelle $^{12}$ valle hũ dos seis companheiros | pondoce no posto abaixou a lansa, e re|meteu a o do Sol, e encontrandoo no $\mid$ meio do Escudo foy com tanta força | que quebrando a lança em muitos pedaços |

70 feslhe perder hũ Estribo, e fazer hũ de|zairoso reves na sella, mas o do Sol | O Encontrou de Maneira, que a elle, e a | o cavallo fes ir a o chão com bem grã||[207v]de dezacordo. Emenencorio do que lhe tinha | accontecido demaneira se ouve com os | outros, que em pouco espaço os fes a todos te|rem companhia com o primeiro mas custando|lhe a elle seus revezes, e justar com algũns | mais que hũa ves, porque erão 75 todos escolhi|dos. [espaço] A Dona, que vio no chão sua | companhia appeandoce do

\footnotetext{
${ }^{9}$ Ou seja: não pareceram gente da corte, como Pleonido dissera.

${ }^{10}$ À insinuação do anão, dizendo que talvez pudesse auxiliar ao Cavaleiro do Sol algum dia, referindo-se ao amor de Primaleão por Fidélia, este lhe responde dizendo que estava naquele estado (ou seja: procurando servi-lo para conquistar sua boa vontade) desde o momento em que o conheceu, mas sempre notava que Pleonido não o tinha em muita conta.

${ }^{11} \mathrm{~B}, \mathrm{C}$ : lhes.

${ }^{12}$ Palavra corrigida pelo copista: a letra $q$ foi escrita sobre um $d$.
} 
palafrem com a|juda delles, e das Donzellas, que logo se chega|rão a ella, foice ás tendas de ElRey, que a | porta de hũa dellas estava com a Prince|za vendo as justas, e disselhe: Parece|me senhor que não tem culpa este cavalleiro | em deffender o paso, que sohia ser livre senão | vós, que sendo Rey, e senhor desta terra, e | obrigado por isso a fazer 80 justiça, não so | lho concentis, mas antes o favoreceis cõ | vossa prezença. Então tirando o rebuço | foy conhecida pella Raynha Rodiginia | que sabendo como ElRey detreminava es|tar alli aquelles dias, quis ir a vello na quel|la forma, por lhe acrecentar o gosto de | sua assistencia. E sendo recebida delle, e | da filha conforme a razão e amor que entre | todos havia, fallou tambẽ ao cavalleiro | do Sol, que logo lhe veio a bejar 85 amão, e | teve com elle muitos mais comprimentos | que ElRey seu marido, sabẽdo o gosto que nisso lhe | dava. E a o outro dia succedeu ao cavalleiro | o que veremos no capitulo seguinte. 


\section{|| [208r] Capitulo 65}

\section{Do que passou o Cavalleiro | do Sol a o outro dia na guar|da do valle.}

Thomavace Primaleão denoite es|treita conta asi mesmo da tregua, que | lhe

5 fazião ter com seus cuidados as jus|tas, com que se embaraçava de dia, porque | demaneira vivia entregue a elles (tã|to era o gosto que tinha de suas ${ }^{1}$ imagina|ções) que lhe parecia perdido todo o tẽ|po que se não gastava nellas. [espaço] Amava | a Fidelia, cuidava em Fidelia, chama|va por Fidelia, e Fidelia não amava, | Fidelia não cuidava, Fidelia não respon|dia. [espaço] Regulava o amor pellas perfeiço|es da couza amada, e

10 não achando li|mite nellas, arguhiase asi hũas vezes de | desleal a o conhecimento de couza tão | grande, parecendolhe que faltava com o | que lhe devia, outras de atrevido de querer | com algua sua igualar o que a seu ver | nascera sem igualdade, e vinha a pa|rar em fazer de sua parte hũ holocaus|to de todos seus effeitos ${ }^{2}$ à quelle Idolo, que | dentro de sua alma adorava, sem rezer|var couza que não ficasse abrazada na | quelle

15 sacreficio. [espaço] Não deslustrava | aquella pureza esperança algũa de || [208v] retribuição, nem de agradecimento, por|que fazendo elle do amor razão, vinhão a | ficar em obrigações todas as couzas, que | concorrião em Fidelia para ser amada, | E como elle cuidava que as não podia ha|ver tais em outrem, nunca se imagina|va tão fino, que não lhe parecesse que ainda | ficava devendo muito da quelle foro, com que | a Natureza

20 quizera, que todas as crea|turas reconhececem o merecimento do | seu Maior Milagre. [espaço] Nas conce|quencias que destas premissas nascião | passava este Princepe todos os Espassos | que o desoccupavão, e assim dezejava | igualmente a Noite para poder lograllas, | que o dia para ver a Princeza. [espaço] Passa|da aquella pois em que a Raynha chegara | na qual ella com seu Marido, e filha. ${ }^{3} \mid$ recolhidos no seu castello,

25 estiverão fal|lando nas grandes cavallerias de Pri|maleão, e nas outras boas partes que lhe | vião, dezejando muito conhecello, e tello | em seu serviço, e elle nos exercicios | que temos ditto, Amanheceu hũ dia fer|mozo, ealegre ajudando o valle a pa|recello mais. Passouce a menhã bre|vemente, passarãoce tambẽ as horas de | cesta, e chegarão as em que aquelles Reys | e a Princeza descerão ás tendas, ves|tidos elles em habitos mais

\footnotetext{
${ }^{1}$ Ao final desta palavra há um traço e um ponto, um pouco acima da linha: por parecerem acidentais, não os reproduzimos.

${ }^{2} \mathrm{C}$ : affeitos.

${ }^{3} \mathrm{O}$ próprio copista desconsidera este ponto final e prossegue a frase com letra minúscula.
} 
30 louçãos, do que || [209r] sua idade requeria. E ella senão tão | fermoza como Primaleão a imagina|va, pello menos tanto que dera bem que | fazer entre as quatro de Constantino|pla a hũ juizo claro para lhes graduar os | lugares. [espaço] Acompanhava a Ennaclia | com outras muitas Damas, e hũa grão cor|te, que com a Raynha viera. [espaço] Não pou|de o cavalleiro do valle ir a fazer os $\mid$ comprimentos que costumava, e

35 devia, | porque o Entretinhão dous cavalleiros, que | chegarão a elle hũ pouco primeiro que ElRey en|trasse nas tendas, e porque Primaleão | sabia que partira elle ja do castello, estava|lhes rogando, que aguardassẽ por elle. A | o que hũ dos companheiros lhe respondeu | Estais tão bem acreditado nesta terra | que não podemos deixar de temer que nos | aconteça o que aos Mais, que com vosco se | tem provado, e sendo isto assim, 40 melhor | nos será que nos não veja cahir a gente | porquem nos mandais aguardar. E | tambem se por ventura o Diabo for | sotil, não vos estaria a vos isto mui mal, | porque sempre os auzentes costumão ale|var qualquer disculpa em conta ${ }^{4}$. [espaço] Bẽ | vejo disse Primaleão que de grande con|fiança nascẽ essas palavras, mas por|que eu tenho para mim que quem não fo|ge aos perigos em que tem obrigação de || [209v] entrar, e

45 fas nelles tudo o que pode, e se | deve, não perde muito inda que não ganhe | nada. [espaço] Não me acrecentará, ou di|minuirà o pezar de ser vencido verme | ou não verme quem hade saber que o fui, | por isso se vos parecer, esperemos ElRey | que vedelo vem descendo, e senão fasa|mos o que Mandardes, que em tudo oque não | for deixarvos passar sem confessares as | condições do meu cartel $^{5}$, vos servirei | de boa 50 vontade. E eu, replicou o outro, | nem detremino fazervola ${ }^{6}$ nisso, nem | em esperar mais, porque vejo vir roupas de $\mid$ muitas cores, e ei medo, que ou me embara|cem a mim, ou vos ajudem a vos. [espaço] | Então abaixando as lanças remeterão | hũ a o outro a o maior correr de seus ca|vallos, e encontrandoce em cheio no me|io dos escudos foi com tanta força, que | o cavalleiro do Sol perdeu as estribei|ras, e apegouce a o pescosso

55 do cavallo por | não cahir. [espaço] Eo Estranho veio ao chão | quasi desacordado, mas não demanei|ra que deixasse (ainda que descompostamente) | de arrancar da espada, e desafiar a o do | Sol para aprova dellas. [espaço] ElRey estava ja | prezente porque vendo estar os caval|leiros no posto apressouce em hũa fac|ca em que vinha, e chegou

\footnotetext{
${ }^{4}$ Leia-se "os ausentes costumam aceitar qualquer desculpa".

5 Cartel significa “desafio". C: sẽ confessardes; estas duas palavras foram inseridas nas entrelinhas, posteriormente, pelo próprio copista. O ms. B apresenta confessares, como A, o que implica uma mudança da forma de tratamento (da $2^{a}$ pessoa do plural para o singular) no meio do diálogo.

${ }^{6} \mathrm{O}$ pronome la (feminino) refere-se ao termo vontade, do final da fala de Primaleão.
} 
ao tempo que os | cavalleiros partirão hũ para o outro, e não || [210r] pouco espantado de 60 tamanho encontro | assim a cavallo os esteve vendo. [espaço] O | do Sol corrido do que lhe acontecera, a|cabando de se indireitar, e concertar na $\mid$ cella, respondeu a o que o chamava: | Deixaime justar com vosso compa|nheiro, e se elle vos não vingar a vos, | a qui me tendes para vos vingar em mim, | posto que as condições destas justas, so na | igualdade concedem as batalhas. [espaço] Não | me parece, replicou o Outro, que eu 65 estou | fora das condições, inda que a pe, porque de $\mid$ mim a vos pouca differença ouve, e | os nossos cavallos não contratarão par|tidos ${ }^{7}$ (isto dizia elle porque o seu morrera $\mid$ do Encontro) [espaço] Seu companheiro, que se | não tinha espantado pouco da justa, e do | successo della, disse para elle: Porvida vos|sa senhor que me deixeis provar minha for|tuna com este cavalleiro, que segundo | vejo nelle, tempo vos ficarà de o dezafi|ardes

70 com mais cauza. [espaço] Apartan|doce então o que estava a pe, elles thoma|rão do campo o Necessario, e encontrã|doce a meia carreira, não se fizerão | mais danno, que quebrarem as lanças, | e passarem hũ pello outro sem recebe|rẽ reves algũ. [espaço] $\mathrm{E}$ tornando a thomar | Outras correrão a segunda do mesmo | Modo, com o que o do valle andava tão || [210v] apaixonado, como se os cavalleiros cõ | quem justava forão dos

75 Ordinarios da | quella terra. [espaço] E porque ElRey, a Raynha, | e a Princeza, que ja havia espaço que tinhão | chegado, estavão com algũa incomodida|de a cavallo, e as justas se hião dilatando $\mid$ muito appearãoce, tendo primeiro ditto aos ca|valleiros que o querião fazer, e thomando | nas tendas os seus assentos, que para aquillo lhe | tinhão prestes, tornarão os cavalleiros a | encontrarce terceira ves, de sorte que o do | Sol 80 perdeu os Estribos, e fazendo hũ de|sairozo reves na sella, passou todavia | a cavallo pordiante, e o Estranho veio | a o chão com a sua entre as pernas. [espaço] | Tinhão chegado a este tempo por differen|tes partes quatro cavalleiros á quelle pos|to, hũ delles Gigante, outro que lhe faltava | pouco para o ser, e vendo acabada a justa, | querendo elles tambem justar, atraves|souce, o que primeiro cahira dizendo para o do Sol | o que 85 Henrriq Frusto em outro capitulo | nos conta.

\footnotetext{
${ }^{7}$ Contratar partidos significa "tomar partido", "desafiar-se um ao outro".
} 


\section{Capitulo 66}

\section{Do mais que passou entre a quelles Cavalleiros.}

|| [211r] O Cavalleiro que primeiro tinha justado | vendo chegar os outros, e

5 querendo tam|bem justar, atravessandoce entre elles, dis|se para o do Sol: Vedes aqui cavalleiro o | que eu arreceava porque vos apertava | tanto. [espaço] Que remedio dais agora aisto? | porque estes cavalleiros não ande querer | deixar de justar, e eu em nenhũa Ma|neira deixarei de me provar com vos|co. [espaço] Odo Sol lhe disse: [espaço] Amim me pe|za muito de haver inconvenientes, que me | tirem fazervos esse gosto nisso que 10 que|reis, que o dezejo que mostrais, me não tem | com pouco de vo lo satisfazer. [espaço] $\mathrm{O} \mid$ remedio eu não o vejo, senão se esses ca|valleiros quizerem estar pello que vos Or|denardes. [espaço] E ElRey que vio a porfia $\mid$ e ouvio o que dizião quis compolos, rece|ando muito a força da quelle cavalleiro, e | a apparencia dos Gigantes, Mas o do | Sol, que sentio por onde elle queria levar | o negocio, não o concentindo em

15 ne|nhũa Maneira do Mundo, disse para | o que o dezafiava: [espaço] Cavalleiro, a qui | não ha outro caminho mais que esperar|des que eu derribe essoutros que a hi estão | para vos combaterdes comigo, ou se me | elles derribarem combatervoseis com o que o fizer, e vingarnoseis a ambos jun|ta mente, porque as justas, por força seande || [211v] fazer com todos os que vierẽ em quanto eu | ficar a cavallo nellas. [espaço] Pareceme 20 que ten|des razão, disse o Estranho, e achastes o | melhor modo de escuzar brigas, que nun|ca vi, porque nem eu as quererei com | vosco se os derribardes a elles, nem cõ | quem vos derribar a vos, porque todos so|mos hũns ${ }^{1}$. [espaço] $\mathrm{O}$ do valle então rindoce, | passouce a outro cavallo, que tinha manda|do vir, porque o seu andava ja floxo, e re|mettendo aos dous cavalleiros, que com | o Gigante vinhão, a cada hũ de dous

25 en|contros os fes ter companhia a os primeiros | com não pequeno espanto de todos, par|ticularmente não conhecendo o vence|dor. [espaço] O terceiro dos quatro que ultima | mente tinhão chegado, que sahio a justar foi | o Gigante, o qual brandindo alança | como se fora hua leve cana se foy por | no posto, descontente de lhe parecer que | não ganharia muito na victoria a res|peito de quão cançado thomava aquel|le cavalleiro.

30 [espaço] Não era a Princeza | tão de pedra que lhe não pezasse do certo de|zastre que lhe

\footnotetext{
${ }^{1}$ Não está muito claro o que significa todos somos hũns. Quererá dizer que o cavaleiro que fala é companheiro dos demais (como mais adiante se dirá) ou que ele não quer discutir com todos, pois não considera adequado que um só enfrente tantos?
} 
imaginava, nem tão pou|co livre que lhe parecesse lhe convinha | encobrir este temor ${ }^{2}$, antes mostrandoo | grande, como fruto de animo generozo, || [212r] disse para Pleonido, que perto della estava: | Porcerto Pleonido, que pagais mal a o | cavalleiro do Sol, senão sentis muito o | trabalho, em que o tendes metido. [espaço] Ay | senhora (disse elle) não

35 me falle Vossa Alteza nisso | que tal me tem a vista da quelles Gigan|tes, que não sei que não dera, por não ter | conhecido este cavalleiro. [espaço] Ouvi di|zer que nestes perigos se esforçavão muito | os que se combatião com algũ favor das | pessoas por quem entravão nas batalhas. | Diga Vossa Alteza a Ennaclia que me empreste | hũa fita sua, levarlhaei, e por ventura | que dada em meu nome seja antidoto | contra a peçonha

40 de que aquelle Monstro | parece que vem cheio. [espaço] Ennaclia esta|va junto da Princeza, e ou porque co|mo temos ditto, não tinha boa vonta|de ao cavalleiro, ou porque sospeitasse que | elle a namorava a ella, thomou aquillo | tão de sizo, que disse: [espaço] Não concinta Vossa Alteza | a Pleonido que se despeje tanto, que poderà | (se o ja não tem feito) dizer algũa couza | a este cavalleiro com que me amim con|venha, ou

45 aterme por mal satisfeita de | Vossa Alteza nos serviços que lhe tenho feito, não | o Mandando castigar, ou a desgostalla | dando ordẽ para que se fassa. [espaço] A Prince|za então dissimulando com discrição | grande, hũa paixão não pequena, com que || [212v] ficou da reposta de Ennaclia julgan|doa por desnecessaria, e fora de prepo|zito, disse para o Ennano: [espaço] Ennaclia | Pleonido, tem razão porque mais he de / crer 50 que o cavalleiro quererà antes a fita | por sua, que por vossa, e Mandarlha | ella assim tão levemente, seria hũa | forte couza, porque este fumo que as Da|mas vendem, não se compra amenor | presso que o de hũa fe muito exprimenta|da, na qual tambẽ se assegurão seus millagres, e se por ventura esta faltasse no | cavalleiro, ficaria bem aviado o cre|dito da fermozura de Ennaclia aven|turado sem devação da parte á força |

55 de hũ Gigante, que de ordinario são tão | groceiros que nunca se deixão vencer | das vontades das Damas ${ }^{3}$; mas eu quero | fazer com meu Pay que acuda a o vosso |

\footnotetext{
${ }^{2}$ Ou seja: Fidélia não era tão insensível e indiferente à sorte de Primaleão que não deixasse de se preocupar com ele, mas também não lhe era tão afeiçoada que julgasse conveniente ocultar esta preocupação, temendo comentários alheios.

${ }^{3}$ Fidélia não considera apropriado que Enáclia entregue um dom ao Cavaleiro do Sol dizendo que as mulheres só devem dar demonstrações de afeto aos homens que provarem ser leais (fe muito exprimentada), pois só assim os dons oferecidos poderão ter efeito (fazer seus milagres). Sendo que eles ainda não conheciam bem o Cavaleiro do Sol, se ele não fosse digno desta confiança a fama e a honra (o credito) de Enáclia ficariam prejudicadas.
} 
cavalleiro com hũa reliquia do lenho ${ }^{4}$ q qe sempre tras concigo, e por ventura, | com sua licença de Ennaclia, que lhe a|proveite mais, que a sua fitta. [espaço] E então | pedindoa a ElRey dizendolhe o para que a |queria, deu a a o Enano que a levasse de | sua parte 60 della a o Cavalleiro, e que lhe / dicesse, que contra os Diabos não havia / em Bohemia melhor remedio que a crus. | Chegou Pleonido com ella a tempo que o | Cavalleiro acabava de thomar um || [213r] cavallo, porque a apparencia do inimigo | que tinha diante, a todas as deligencias | obrigava. E fazendo sua Embaixada | o cavalleiro recebeu a reliquia da ma|neira que entendeu que se lhe mandava, | que foi com mais devação, 65 que alvoroço. | E toda via depois de dizer a Pleonido | que beijasse a mão por elle á senhora Prin|ceza, acrecentou, mas vos não tendes | que lhe agradecer nesta merce que me fes, | porque antes me parece, que foi querer vos $\mid$ tirar a honrra deste dia mais, que dezejos | de me ver amim com ella. [espaço] Ora | estais bem aviado, lhe respondeu o Enano, | Nos estamos sem alma á vista destes | homẽns, e vós que o haveisde haver cõ 70 elles | dizeis graças? [espaço] La vos avinde que eu não | tenho mais que fazer, que confessarvos sen|timento grande de vos ver tão arrisca|do. [espaço] E com isto sem aguardar mais | reposta voltou logo.

O Gigante esperava espaço | havia, e o do Sol concertandoce na | sella remeteu a elle. [espaço] Differente foi | este encontro dos passados, como tãbem | era dado com 75 differentes ajudas ${ }^{5}$, porque | o do Sol com a lança de seu contrario | atravessada por entre o braço esquerdo | e o corpo, passou por elle sem receber re|ves algum. Eo Gigante com huma || [213v] tamanha ferida nos peitos, que dalli a | muito não convalleceu della, veio a terra | porcima das ancas do cavallo, com tal | queda que não bollio pé nem mão por muito | espaço. [espaço] Pleonido então que ja estava | com a Princeza, vendo o 80 successo da | quelle Encontro, chegouce a Ennaclia | e disselhe: [espaço] Alegraivos senhora, que eu dei | a crus da vossa parte a o cavalleiro. | Não ouve lugar de reposta, porque os cõ|panheiros acodirão depreça ao Gigan|te cuidando que era morto, pello san|gue que lhe virão sahir, e desacordo, cõ | que estava. E tratandoce da cura, ElRey | o mandou levar a o Mosteiro accompa|nhandoo os dous cavalleiros que com elle | vierão,

85 e o segundo dos dous, que primeiro che|garão, ficando o que toda via queria as | brigas, e oque ainda não tinha justado, | o qual como temos dito era pouco me|nor de corpo, que o Gigante, mas mais | airozo, emais bem posto na sella, que to|dos seus companheiros.

\footnotetext{
${ }^{4}$ Trata-se, certamente, de uma relíquia do lenho da cruz de Cristo.

${ }^{5}$ Diferentes ajudas porque desta vez Primaleão portava a relíquia da cruz de Cristo oferecida por Fidélia.
} 
[espaço] Este pois des|contente do dezastre de tantos, e mais | do Gigante que hia no estado que dissemos | remetteu a o do Sol, que ja o aguardava | contente do successo, 90 que as couzas hião | tendo, com que não sentia o trabalho dos | Encontros, que não era pequeno; porem | não livrou elle deste Modo dos mais, || [214r] porque despois de se toparem dos corpos | e dos cavallos, com tal pancada, que pa|receu que duas grandes torres se ajun|tavão ambos vierão a o chão com as | sellas entre as pernas, com que cahirão as | Esperanças dos que dezejavão que se con|tinuasse a victoria, julgando que 95 não | poderia pervalecer odo Sol contra a for|ça da queloutro, assim pello que sua dispo|zição prometia, como por estar pou|pado. E para esta desculpa comessavão a | apellar ja seus amigos; porem não lha | levara Ennaclia em conta se a cou|za chegara a esse termo, porque não sen|do muito sua comadre pellas razões que | temos ditto, ficou o ainda menos, sen|tindo que a Princeza não folgara do que | lhe ella dissera a cerca de 100 Pleonido. [espaço] | Mas o do Sol levantandoce como ou|tro novo filho da Terra com mais | viveza depois de tocalla, e mais apai|xonado do que em sua vida se vira | arrancou da espada, e remeteu como | hum rayo a o Cavalleiro, que o der|ribara, que com a sua na mão | não menos manencorio | O vinha buscar, mas o | que cahio primeiro se me|teu entre elles dizendo. 


\section{|| [214v] Capitulo 67}

\section{De como aquelle cavalleiro Es|tranho continuava em sua | porfia, e da Aventura cõ | que se quietou, e o do | valle continuou | com os com|panheiros}

Com estranha furia se hião a juntar | aquelles cavalleiros, mas o que primeiro cahira, | que toda via queria levar adiante ser tã|bem o primeiro na batalha, interpondosse co|mo costumava disse que com elle se havia | de acabar primeiro aquelle jogo, porque com es|sa condição dera lugar para as justas. [espaço] | Não folgara eu pouco com isso, lhe respon|deu o cavalleiro Estranho, porque me li|vrareis do perigo,

10 que nas mão deste ca|valleiro tenho certo, mas bem vedes vos | Senhor que o lugar he meu pois ambos fi|camos iguais na justa. [espaço] Tambẽ o eu | fiquei, replicou elle, e nisto não ha ma|is que tratar, nem vos fazeis o que vos me|reço em dar razões contra o que digo. [espaço] | Primalião que ardia em collera lhes gri|tou que não porfiassem na quillo, porque | elle os queria contentar a ambos jun|tos. Bem o creio eu do vosso valor

15 (res|pondeu Pavorante, que este era o com quẽ || [215r] ultima mente justara) mas não vos ha|vemosde dar tanto trabalho, a hũ e hũ | nos haveis de engolir, que se formos ambos, | ei medo que vos engasgueis; [espaço] E voltan|doce para o Outro que era Palmeirim de La|cedemonia com grande comedimento | lhe tornou a dizer: Rogovos senhor, que | queirais ver com menos paixão este | negocio, porque se eu tenho

20 obrigação | de vos servir, não $\operatorname{vos}^{1}$ falta ella a vos | de não querer de mim couza que me po|de estar tão mal. Este cavalleiro he | tão valente que não lhe poderei durar | muito, guardai essa colera, que contra | mim mostrais, para me vingardes des|pois nelle, e será então com mais ra|zão de vossa parte, emenos queixa | da minha. [espaço] Palmeirim bem conhe|cia a Pavorante porque todos dormirão | juntos aquella noite, e elle, e

25 Franellio, | que era o companheiro comquẽ alli | chegara, se levantarão de madrugada | a furto dos outros para se virẽ diante | provar com o cavalleiro do Sol, aquẽ | todos vinhão demandar, receozos de $\mid$ que se chegassem juntos quando elles não fos|sem os primeiros, que não lhes ficaria que fazer. | E vendo agora aquella empreza nas | Mãos de Pavorante a quẽ por muitas | experiencias todos tinhã por tão bõ || [215v] Cavalleiro como seu Pay,

30 bẽ lhe parecia | que não lhe ficaria lugar para saber se a|quelle cavalleiro feria tão bem com a | espada, como encontrava com a lança. | E não querendo em nenhũa manei|ra

\footnotetext{
${ }^{1}$ Palavra corrigida pelo copista: a letra $v$ parece ter sido escrita sobre um $p$.
} 
largar aquella Occazião, obrigou | Pavorante a lhe perder o respeito, e | querer a batalha primeiro com elle, que com | o cavalleiro do valle. [espaço] A ElRey lhe | não pezava da quella desavença, por | que temia muito as apparencias de Pavo|rante, e dezejava a 35 saude do cavallei|ro do Sol, mas elle que estava sem paci|encia de os ver desconcertados, não sa|bia que fizesse para os satisfazer a ambos, | e estando Palmeirim para voltar de to|do a paixão contra Pavorante, chegou | à quelle lugar hũ cavalleiro muito grande | de corpo, e tanto que se alli á quella hora | não tiverão visto dous Gigantes, elle | o parecera em tudo, mas com o costume | dos outros não attentarão tanto

40 na dif|ferença que fazia a os demais homẽns. | Vinha num cavallo Murzello, arma|do de hũas armas negras sem outra al|gũa pintura, e no Escudo em cam|po verde hũ Mocho cercado de muita | variedade de passaros que o persegui|ão. E vendo aquella companhia infor|mandoce de quem era, appeandose || [216r] do cavallo chegouce á tenda de ElRey | e fazendolhe hũa grande reverencia | a elle, á Raynha, e à Princeza, não | pouco

45 espantado de couza tão fermo|za, disselhe: [espaço] Eu sou Senhor hum ca|valleiro estranho, a quem os desastres | da fortuna trazem em busca de outros | Maiores desastres, pois chegou aqui a tal | tempo. Pesso a Vossa Alteza que me mande in|formar da cauza com que se guarda | este valle, e da que aquelles cavalleiros | tem para impedirẽ a batalha hũns dos $\mid$ outros. [espaço] ElRey tratandoo com muita | cortezia 50 contoulhe brevemente tudo | o que passava, e ja a este tempo Pavorã|te perdida a paciencia de todo, reme|tia a Palmeirim, que para o mesmo se | chegara a elle, porem Primaleão atra|vessandoce depressa com a espada na $\mid$ mão lhes disse: [espaço] Esta he a mais nova | couza que eu nunca vi. Se vos digo que | eu so vos satisfarei a Ambos, porque vos | quereis matar pello que ouvereis deagrade|cer hũ a o Outro? [espaço] $\mathrm{O}$ 55 cavalleiro das | armas negras vendo que crecia a revolta | pedindo licença a ElRey acodio la, e | diselhes: [espaço] Eu vi ja Senhores cavalleiros | Outras duvidas como estas em que agora | estais, se vos quizerdes comprometer | em mim dandome conta do que tem || [216v] passado pode ser que vos concerte. [espaço] | Palmeirim era soberbo, e estava escan|delizado, porem vendo a pessoa e come|dimento da quelle Cavalleiro,

60 disselhe a | razão com que queria ser preferido para a primeira | batalha, e acresentou, e não me parece | amim que haverá nimguẽ que julgue ou|tra couza, quanto mais vos, que dizeis ten|des visto materias semelhantes. [espaço] | Pois eu Senhor (disse o das armas negras) | entendo o contrario, epareceme que vos | deveis compor com a falta, em que 
$\operatorname{vos} \mid$ meteu o vosso cavallo, que emfim caistes | e vosso inimigo não, o que não aconte|ceu a essoutro. [espaço] E se este juizo vos não | parecer bom perdoaime, que como he | livre, não pode deixar de dizer o que | sente. [espaço] O Mesmo lhe persuadi|rão os companheiros, que como deixa|rão o outro no Mosteiro curãndoce | logo voltarão com o receo do que podia | ser para o estorvarem, porque como temos | ditto, todos se conhecião, e erão amigos | e parentes; [espaço] com o que affastandoce |

70 Palmeirim não de todo quieto | deixou lugar a Pavorante, e a Pri|maleão que cada hũa ${ }^{2}$ por sua parte | dezejava antes as brigas com elle, que | com o que tinhão diante. [espaço] Emfim | remetendo hũ a outro comessou a || [217r] mais notavel batalha que nunca | senaquella terra vira, e a mais peri|goza em que nenhũ delles tinha entra|do, e sem descançar se chegarão a es|tado, que todos julgavão que não ficari|ão pare ${ }^{3}$ entrarem em outra, emfim | cedendo o dezejo á Natureza, tira|rãoce a fora, e Pavorante que sevio | com as armas rotas, com o escudo |desfeito, e correndolhe sangue $\mid$ de muitas feridas, que tinha, começou a | dizer concigo: [espaço] Que he isto Pavoran|te? hũ so cavalleiro, e cansado vos | tem a vos posto tão perto de ser ven|cido? Este he o esforço, este he o valor, | de que confiaveis tanto? isto he ser fi|lho daquelle Dramusiando, de cujas | obras

80 inda o mundo treme? ja se | este cavalleiro fora D Duardos, in|da parece que tivera algũa desculpa | minha fraqueza, mas hũ homem | nascido em Bohemia, criado com | Martas, e sustentado com Manteigas, | como he possivel que me tenha neste es|tado, se eu presto para o que algũa hora | cuidei? [espaço] Mas acabece a vida em|bora na concervação da honrra, que | isto me não poderà tirar a fortuna, | nem a força deste cavalleiro. [espaço] 85 E | saiba meu Pay quando lhe chegar esta || [217v] nova, que se não venci como ditozo, | que não fui vencido como cobarde. | Primaleão pouco melhor tratado di|zia tambem $e^{2} t^{4}$ si com os olhos ẽ | Fidelia: [espaço] Impossivel he senhora que seja | vencido de outrem, quem o está de | vossa fermozura, morto bem pode|rà ser, porque nem eu mereço que vos | me ajudeis neste perigo, nem quero | vossa ajuda para os desta 90 calidade. [espaço] | Pezarame de vos não ter servido, se | cuidara que vivendo o pudera fazer | algua hora, mas quem tambẽ co|nhece quão longe estava de merecer | nunca bem tamanho, não lhe fica | que sentir na perda da vida, se não o | deixar de vervos. Mas se eu posso, es|te cavalleiro me pagarà esta dor de | Maneira que nem elle tenha de que

\footnotetext{
${ }^{2} \mathrm{~B}, \mathrm{C}: h \tilde{u}$.

${ }^{3} \mathrm{~B}, \mathrm{C}:$ para.

${ }^{4} \mathrm{~B}, \mathrm{C}$ : entre.
} 
sega|bar, nem eu de que me correr. [espaço] E | como isto disse, embraçando o pouco | 95 que do Escudo lhe ficava, tornou a | partir para Pavorante, que do mesmo | modo o sahia a receber. Mas pois | elles descançarão, descansemos nos | tambem. 


\section{Capitulo 68}

\section{|| [218r] Do fim que teve aquella | cruel batalha, e de | quem era o caval|leiro das ar|mas ne|gras}

Tornarãoce a ajuntar aquelles | cavalleiros, acabadas as palavras, que | no fim do passado capitulo refe|rimos, e desta segunda ves se tra|tarão de maneira, que não havia | ja deffensa nas armas, nem san|gue nos corpos. Sostinhãoce nos | espiritos, com que incançavel men|te trabalhavão. Pavorante an|dava de todo perdido, e o outro pouco | menos, porem algũa couza trazia | as armas mais Sãns, e se mostrava | com mais alento,

10 mas não de maneira | que o entendesse se não so aquelle caval|leiro, que ultimamente alli tinha che|gado, $\mathrm{O}$ qual ainda que aquella batalha | lhe parecia muito estranha, bem conhe|cia, que os Cavalleiros não erão mui | versados na quelle exercicio, porque | de sofregos, e apressados cuidava elle | que se tinhão acabado tão depressa. | E com isto dandolhe saltos o cora|ção, não tirava os olhos delles, doen||[218v]dolhe suas feridas

15 como se conhe|cera. Anoite chegavasse, ou era che|gada de todo, e ElRey como homem | que nunca vira aquillo ainda que muito en|tendido, não deixava de dar sinais de | seu Espanto $^{1}$. Na Princeza não se en|xergava mais que hũa piedoza compai|xão da morte da quelles homẽns, e | Ennaclia não folgava do cavalleiro | do Sol se deffender tanto. [espaço] Os cava|lleiros pedião tochas, e não se podia a|cabar com elles que deixassem a

20 conten|da para melhor hora. [espaço] O das armas ne|gras disse a ElRey: Vossa Alteza devia apar|tar estes cavalleiros porque se escapa|rem com vida, de nimguẽ melhor |que delles vos poderà ser servida obra | tão justa. [espaço] Deboa vontade fizera | eu isso muito ha (respondeo elle) se enten|dera que menão perderião o respeito, | mas a troco de salvar tais homẽns, | tudo he razão que se aventure. [espaço] E le|vantandosse foy se

25 meter entre os ca|valleiros, que ja outra ves se tinhão a|partado, e estavão descançando encos|tados nas espadas, tais, que mal se podi|ão ter em pe. E com tudo nenhũ | quis ser o primeiro que respondesse a ElRey | para lhe obedecer no que lhes mandava | Antes rogandolhe, que mandasse vir || [219r] tochas para acabarem o de que estavão tão | perto, moverão nelle mais lastima que | paixão de sua contumacia, vendo|os em estado

30 que nem para se bolirem | parecia que finhão ${ }^{2}$ força, quanto mais para | peleijarem. [espaço] Vierão as tochas que | para tudo erão necessarias, a o lume | das quais os

\footnotetext{
${ }^{1}$ Palavra corrigida pelo copista: a letra $e$ inicial foi escrita sobre um $s$.

${ }^{2} \mathrm{~B}, \mathrm{C}$ : tinhão.
} 
cavalleiros como melhor | puderão moverão outra ves hũ para o ou|tro. [espaço] Mas o das armas negras ven|do ElRey a talhado com odescostume | daquellas couzas, adevinhandolhe o | coração o que lhe hia no sangue que a li | se derramava, tornou a lhe

35 dizer: | Senão quereis senhor ver morrer estes | cavalleiros com vossos olhos, rogai à | senhora Princeza que os aparte, e quando | elles o não fizerem por ella lho man|dar, não sei eu melhor remedio para que | os nòs não sintamos. [espaço] ElRey que na|da mais dezejava que a saude daquel|les homẽns thomando a filha pella mão | que composta, e socegadamente estava | vendo o fim daquella tragedia, levou | a ao lugar onde se ella

40 reprezentava, | E entrando assim entre os cavallei|ros, que fracamente se andavão to|da via ferindo, disse ella para Pavo|rante: Rogovos Cavalleiro que quei|rais deixar esta batalha pois ja della || [219v] se não pode esperar se não a morte de | ambos. E destoutro cavalleiro confio | que fassa tambem o que lhe nisto mandar. | Pavorante era filho de Dramuziando | em tudo, e tinha a criação de Daliar|te, pello que tanto que vio, e ouvio

45 aquella| Princeza pondosse fracamente em gio|lhos diante della, disselhe: Pezame muito | senhora de ser eu o que ganhe tanto em dei|xar a batalha, porque mais he isto mer|ce, que vos me fazeis que serviço que vos eu | fassa. [espaço] Ella està acabada, e não por $\operatorname{vos} \mid$ mo Mandardes, se não porque não estou | eu para alevar mais avante. ${ }^{3}$ para que não | tenhais que me agradecer, nem eu tenha | de que me contentar. [espaço] Estas

50 ultimas | pallavras cauzarão grande lastima em | toda aquella companhia, porque dittas ellas | o pobre Mancebo fazendo termos | mortais cahio nos braços de seus com|panheiros, que logo lhe acodirão com ta|manha dor de todos, como se de todo | ja o virão morto. [espaço] $\mathrm{O}$ cavalleiro das | armas negras era o valente, e esforça|do Dramuziando que pella maneira | que contaremos alli chegou na quella | conjunção, o 55 qual vendo seu filho sẽ | elmo, porque seus companheiros lho ti|rarão logo, não podendo tanto a | compostura que vencesse na quelle acto || [220r] a natureza. ${ }^{4}$ Arrebatado dos affectos | della, dando hũa grão vox, deixouce | cahir sobre elle, porem tornando lo|go sobre si, tirou o Elmo e disse para | ElRey, e para a Princeza, que não esta|vão com menos espanto que Magoa: | Perdoaime senhores esta fraqueza | minha, que não 60 rezistimos bem os $\mid$ velhos a os accidentes, que descompoẽ | a natureza. [espaço] Este

\footnotetext{
${ }^{3} \mathrm{O}$ próprio copista desconsidera este ponto, pois continua a frase com letra minúscula.

${ }^{4} \mathrm{O}$ sentido da frase exige que este ponto seja desconsiderado. Ao ver o filho quase morto, Dramusiando não pode conter-se: o amor paterno (natureza) foi mais forte que o decoro (compostura).
} 
cavalleiro he meu | filho, buscavao vivo, e venhoo a achar | Morto, mas pois que foy fazendo o que | devia não me ficará pequena con|çolação.

Primaleão, que estava en|costado ja aquelle tempo em Ludimio, | que se chegara a elle, ficoulhe tanto a|cordo quando vio cahir a Pavorante | (que foy só a ventagem que

65 lhe teve) que | poude conhecello, como the tirarão o | elmo, e a Dramuziando tambem. | Eantes que ador que aquelle dezastre lhe | cauzava o tirasse tambẽ de seu juizo | juntamente com o sangue que tinha| perdido, não querendo que o conhececẽ | disse a Ludimio que o levasse para as ten|das porque lhe não convinha ser conhe|cido da quelles cavalleiros, e com isto | accabando tambẽ de se perder de to|do com hũ desmayo,

70 que logo lhe sobre\|[220v]veio, foi forçado que ElRey, e a Princeza | que o sintirão temperassem a dor, que Dra|musiando e seu filho lhe cauzavão en|tregandoce a Estoutra, que ja por conver|çação lhes era mais propria. [espaço] En|comendando sua cura a Ludimio or|denoulhe ElRey que o levassem a o Cas|tello, porque nas tendas teria mais arris|cada a saude. [espaço] Elle o fes assim logo | e tão socegadamente que não foi

75 Pri|maleão conhecido por ventura daquel|les Cavalleiros, que todos estavão occupa|dos com Pavorante, que acada passo fa|zia termos Mortais. [espaço] E Sabendo El|Rey quem elles erão $\left({ }^{5}\right.$ porque como Dramu|siando tirou o elmo, tirãoramno ${ }^{6}$ elles $\mid$ tambẽ dandocelhe a conhecer logo com | bem pouco alvoroço pello dezastre que tinhão | entre mãos) fazendolhe muito mais corte|zia, e gazalhado levouos concigo athe o | Mosteiro,

80 onde os apozentou como a suas pessoas convinha, tendo muitos com|primentos com cada qual delles [[delles] $]^{7}$, | que erão Palmeirim de Lacedemonia, | e Frenellio os que primeiro alli tinhão chegado, | e os outros Polendos, Belcar, Almou|rol, e Pavorante, que tendo sahido | da prizão de que D Duardos os livrara | e despedidoce no Reyno de Ungria de | Florendos, e Floramão com o respeito || [221r] que na quelle capitulo 85 contamos, vierão | alli ter aquelle tempo pello modo que | adiante se verà.

Chegado ElRey pois com | esta companhia perto da quelle Mosteiro | achou duas Donzellas muito estranhas | no trajo, e no parecer, que falavão lin|goagem que nimguẽ entendia, E | tirando hũa dellas hũ escritto do | Seio, meteulho na mão. Aberto vio|ce que dizia assim: [espaço] Se as feridas de | Pavorante, e do Cavalleiro do Sol po|dem ter

\footnotetext{
${ }^{5} \mathrm{O}$ erro de pontuação do copista de $\mathrm{A}$ não é reproduzido em $\mathrm{B}$, que neste ponto apresenta apenas a vírgula.

${ }^{6} \mathrm{~B}$ : tiraramno. Em C, a lição parece ser ligeiramente distinta, mas o trecho está quase ilegível.

${ }^{7}$ A palavra delles foi repetida e riscada pelo copista.
} 
90 algũ remedio por mão dessas | mulheres hade ser, por isso não concin|ta Vossa Alteza que outre curem delles. [espaço] | Então se consolou mais Dramusian|do, ouvindo ler o escrito, e ElRey | deixando hũa dellas com elle no Mos|teiro para se lhe entregar Pavoran|te e Almourol, que tambem não esta|va mui quieto com alançada, que nos | peitos tinha, elle se foy com a outra | para o castello por hũa comprida gal|leria, que 95 atava aquelles dous Edifficios. |E Sabendo como o cavalleiro do Sol | não tinha tornado a seu acordo, entre|goulho na quelle estado, com não pequena $\mid$ magoa de toda a gente. ${ }^{8}$ e delle, e do que suc|cedeu nas curas, e de outras couzas, darà | razão o capitulo seguinte.

\footnotetext{
${ }^{8} \mathrm{O}$ próprio copista desconsidera o ponto final e continua a frase com letra minúscula.
} 


\section{|| [221v] Capitulo 69}

\section{Em que seda conta como Dra|muziando, eaquelles caval|leiros alli vierão ter, e do | mais que succedeu na cu|ra dos feridos.}

Partio Dramuziando de sua Ilha | com apreça, que vimos, e com ador que se po|de bem crer da grande nobreza de sua con|dição, e da fidalguia de seus precedimẽ|tos. [espaço] Revolveu do Mundo aquella parte | que na quelle breve tempo lhe foy possivel, | tão enfadado e triste das novas que não | achava, como da conformidade com que | ouvia fallar a toda a gente na morte | da quelles seus amigos. E

10 como todos af|firmavão que acontecera ella na costa do Rey|no de Ungria detreminou ir contra | aquella parte ver o lugar infamado cõ | tão grandes dezastres. [espaço] Tinhasse elle ja | desembarcado havia muito porque como te|mos ditto quando fallamos de Trineo os Na|vios que na quelle porto Estavão, não ti|nhão em si nenhũa daquellas couzas que | para navegar são necessarias, mas como a | dor não deixa fazer discursos, assim

15 a|quelles cavalleiros como Dramusiando | exprimentarão primeiro os dannos, que vies|sem no conhecimento ${ }^{1}$ da pressa que os $\|$ [222r] fizera errar, pello que foi forçado que hũns | e outros thomassem a primeira terra. | Assim o fes Dramuziando, e entran|do em Alemanha, detevesse nella | alguns dias com Aventuras que se | lhe offerecião, entre as quais foi li|vrar hũa Donzella que hia à corte | de Constantinopla com recados $\mid$ de

20 Hespanha para Valeriza, de hũ Gi|gante que a detinha para fins que a ella lhe | não convinhão, com o qual teve | hua porfiada contenda, e toda via | no cabo ficou a victoria com quẽ | sempre a levava. [espaço] Sobre esta Mor|te teve hũ dezafio no Condado de | Flandes na Provincia de Artues $^{2}$ cõ $\mid$ outro Gigante sobrinho da quelle, que | o accuzou de treição. Mostrouce a | verdade, e innocencia de Dramusiã|do, mas á custa de muito

25 sangue seu porque | o Gigante era Moço, e muito bom cavallei|ro, e deffendeuse valerozamente athe a | derradeira baqueada. [espaço] E porque daquel|la, e de outras batalhas ficarão as armas | que levava em estado de não poderẽ ser|vir, Mandou alli fazer as negras que | trazia conformes a sua tristeza | mais, que as que se lhe acabarão, e indo as|sim caminhando para Ungria chegou | a o Reyno de Bohemia, e atravessãdo || $30[222 \mathrm{v}]$ por elle hũa tarde ja quazi Sol posto ou|vio hũns ais muito piedozos, e tristes, que

\footnotetext{
${ }^{1} \mathrm{C}$ : viessem $a$ conhecimento. O sentido desta afirmação deve ser "os danos decorrentes da pressa".

${ }^{2}$ Trata-se provavelmente da província de Artois.
} 
o es|pertarão dos accidentes, em que suas imagi|nações o metião ${ }^{3}$ sempre, e attinando para | onde soavão, porque elle não via nada, não | andou muito que não desse de rosto em hũa | Donzella que estava com as mãos atadas | atras, pendurada pellos cabellos de hũa | Arvore, e hũ Enano muito velho, e feio ẽ|cima de hũ rocim muito magro, e fraco,

35 que | a assoutava cruelmente. [espaço] Chegou | Dramuziando depressa ao Socorro as|sas indignado da quella torpeza, e quando | cuidou que tinha feito tudo não vio nada. | Ficando espantado da quella illuzão, que|rendo tornar a continuar seu caminho | vio outra ves nũ lugar mais desviado | aquelle Enano ir correndo no rocim | como hũ raio, e levar a Donzella atraves|sada no arção, a qual continuando as | queixas obrigava a todo

40 o coração nobre | a o remedio dellas. [espaço] Menos bastava para |Dramuziando, e assi querendo ir espos | aquelle Monstro, Ouvio hũa vox, que | lhe dizia: Não te embaraces Dramuzi|ando nestas couzas, sigue teu caminho | que não sahirás de Bohemia sem veres | aquella que maior pena tedé, e juntamente | a que mais alegre te fassa. E porque tua jor|nada pode ser Occazião da vida de || [223r] algũa gente em que te va muito quem |

45 não te dezeja tanto bem como mere|ces trabalha de te desviar com estas fan|tasmas que te offerece á vista. [espaço] Dramu|ziando Maravilhado do que ouvia inda / com tudo cuidava, que poderia ser aquillo | engano para elle não socorrer a Don|zella, mas não a vendo mais, nem | podendo attinar com o caminho que o | Enano thomara, foi continuando o $\mid \mathrm{seu}^{4}$ aquelle, e o outro dia. E Sabendo | que estava hũa so jornada da

50 Corte, e | que em Valdeflores havia justas novas, | guardando o o cavalleiro do Sol, de | quem elle tinha achado grandes notici|as por aquella terra, detreminouce em | se ir ver com elle, para entender se i|gualavão as obras à fama, que se dellas | publicava. [espaço] Com este desenho | pois chegou este tão valente cavalleiro |á quella parte a tempo que poude dar a | vida a seu filho, e a Primaleão nas ins|tancias que fes a ElRey para que os 55 apartasse. I E cahindo elle despois no que tinha ouvi|do, vendo cumpridas duas daquellas cou|zas, esperava que a outra tambẽ se cum|prisse porque sem a nova da liberdade | de seus amigos, que ainda não tinha, não | podia elle ver nenhũa, que o de todo ale|grasse, posto que Pavorante resucitas ||[223v]se cem vezes. [espaço] O qual, e os mais compa|nheiros que alli estavão apartandoce de | Florendos, e Floramão, como 60 temos ditto, | para cada hũ por sua parte seguir as A|venturas, que sua fortuna lhes offereces|se, agazalharãoce aquella noite em | caza de hũ cavalleiro velho, que os

\footnotetext{
${ }^{3}$ Palavra corrigida pelo copista: a letra $t$ foi corrigida sobre um $f$.

${ }^{4}$ Elipse do termo caminho.
} 
hos|pedou mui bem, com tenção de se a|partarem a o Outro dia cada hũ para | seu caminho, mas o Hospede, que se achou | com tão lustroza companhia em caza, | dandolhes conta como hũ senhor que en|tão era da Provincia de Transcilvania | lhe tinha

65 Occupados por força hũns | Castellos, que alli lhe forão dados em dote | havia muitos annos, com sua mulher | que era natural de lá, sem nunca ter remedio | contra a sua tirania, obrigou os a o / irem ajudar emmendandolhe o agra|vo que se lhe fazia, e embarcandoce | com elle forão ter àquelle Estado, no | qual tiverão hũa porfiada guerra | com o Tirano delle, porque não so foi ne|cessario occuparemce nella todos, mas |

70 valeremce da força de algũns parentes | que o Hospede la tinha, que inda que não e|ra o numero grande a respeito do | com que o Tirano se Mostrava, bastou | com tudo ajudado do valor da quelles | cavalleiros para acabo de algũ tempo o || [224r] desfazerem de todo, matandoo no ul|timo recontro que com elle tiverão, cõ | o que pacificandosse a terra, elles a En|tregarão a o Hospede, e deixandoo o|bedecido, e pacifico senhor de toda

75 ella | se tornarão a embarcar para se dividirẽ | em outra ${ }^{5}$ mais larga. [espaço] E alli se assina|lou Pavorante tanto porcima de to|dos seu companheiros, que não havia en|tre elles quem não cuidasse que não fora | seu Pay tão bom Cavalleiro como | elle, o que nós não dizemos por Modes|tia, e respeito de Dramuziando, mas a | verdade era que Pavorante em tudo se mos|trava hũ vivo retrato seu.

80 Palmeirim de Lacedemonia | provou tambem excellente mente, e sẽ | duvida inda que hũ pouco soberbo, era | melhor cavalleiro que Platir seu Pay, pare|ce que forão previlegios do nome. E assim | todos os outros erão extremados não de|generando do vallor de seus predescessores. | E não querendo como fica dito, tornar | a Constantinopla onde o Amor da / criação, e dos parentes novamente acha|dos, os chamava, sem fazerem

85 algũa | couza, com que la chegasse primeiro que elles a fa|ma que os acreditasse, forão demandar | o Reyno de Bohemia para se espalharẽ | alli, e buscarem a D Duardos, a quem || [224v] todos dezejavão ver, respeitando o pello que | delle virão, e ouvirão por senhor de todo o | Esforço, que então florecia no mundo. [espaço] E | chegando a thomar terra na quelle Rey|no, acertou a ser muito perto donde a cor|te rezidia, e como

90 então em todo elle | senão falava se não nas altas cavalle|rias de Primaleão, dezejarão pois alli | estavão, de se hirem a provar com elle. | E agazalhandoce aquella noite a me|nos de duas legoas do valle, onde as justas | se fazião, sabendo dellas, determinarão |

\footnotetext{
${ }^{5}$ Elipse do termo terra.
} 
de ir ao Outro dia ter a elle, e porque | zombando ouve algũ que disse que seria | bom lançarem sortes, em quẽ havia de ser | o primeiro que justasse, o Hospede que os 95 agazalha|va vendo que toda via porfiavão nellas | lhes disse que sobre quem havia ser o derra|deiro lhes aconcelhava elle que as lançassẽ | porque quem estava mais longe do cava|lleiro do Sol he que melhor livrava, e assen|dendoos mais com isto forãoce toda via | a dormir, mas cada hũ com tenção de | Madrugar e apartarce da companhia | para chegar primeiro a o valle. 


\section{Capitulo 70}

Em que se continua a nar||[225r]ração dos outros meios por | onde se veio ao que atras fica | escrito, e como Dramuzi|ando soube do desencã|tamento dos Reys | e do que sobre isso | fes, e de ou|tras cou|zas.

Dis pois a Historia que Palmeirim | que se recolhera com a tenção que atras temos | ditto madrugou quanto lhe foy possivel, mas não | se podendo dezembaraçar de Frenellio, que tam|bem para o mesmo effeito madrugara, foi for|çado partir e chegar juntos, a pos os quais | não tardarão os outros cada hũ por sua parte | como temos visto,

10 onde lhes aconteceu o que | fica escrito no capitulo passado, e despois de esta|rem recolhidos no Mosteiro dando conta | a Dramuziando de suas Aventuras, e das | Extremadas cavallerias de seu filho, disse|rãolhe tambem como D Duardos os livrara | a todos, e a Florendos, e Floramão da prizão | em que os metera a treição de Brusdolfo, e co|mo se partira escondidamente deixando | escrito a Florendos como os Reys erão

15 livres | e dezencantados, e estavão em Constantino|pla. Aquella era a nova que lhe a Dramuziando | faltava para cumprimento da profecia que || [225v] referimos. E com ella ficou tão contente | que nada lhe lembravão as feridas de seu filho | fazendo tamanhos extremos de alvoroço | que mais parecia moço contente eleve, que homẽ | prudente, e assentado. Claro sinal de quão | bem fundada estava a gratidão, e amizade | de

20 Dramuziando, e assim eu para mim creio | que nenhũ homem da quelles tempos se lhe pou|de preferir no a que se chama ser verdadeira | mente honrrado. [espaço] Etornando a Historia. ${ }^{1}$ | Passados os primeiros accidentes de tão alegre no|va ficarão praticando depois todos em quẽ | poderia ser aquelle cavalleiro do Sol, e lan|çando muitos juizos não atinavão com o certo, | porque ainda que tinhão a Primaleão por muito ex|cellente 25 cavalleiro, assim pello que lhe virão fa|zer no Torneio dos Noveis, como por ser filho | de seu Pay, como athe então não sabião | mais delle não chegavão com a opinião ao | que daquelle sabião ${ }^{2}$. [espaço] Offerecendocelhe D. | Duardos, não crião que andandoce elle enco|brindo com tanto cuidado quereria parar | alli a deterce na quellas couzas. E mais al|gũns indicios havia ja entre elles de que tinha $\mid$ a vontade penhorada, e não

\footnotetext{
${ }^{1} \mathrm{O}$ sentido da próxima frase exige que este ponto final seja desconsiderado.

2 Ou seja: como desde o torneio dos novéis eles não tinham mais notícias de Primaleão, a reputação (oppinião) dele não parecia justificar obras tão grandes quanto as que viam executadas pelo misterioso Cavaleiro do Sol; por isso, seus amigos não desconfiaram que o do Sol na verdade era Primaleão.
} 
30 deixava de se | Mormurar, que indignação, ou brio alheio | o trazião no fadario, em que os livres o ima|ginavão. [espaço] De D. Floris, e de Vasperaldo ti|nhão sabido por hua Donzella, que encontrarão | de Constantinopla que estavão de prezente na || [226r] Corte; $\mathrm{E}^{3}$ não faltava quem cuidasse que era $\mid$ o cavalleiro da Morte que se combatera com | Vasperaldo ${ }^{4}$, porque deste so não tinhão noticia | algũa, mas não se affirmando em

35 nada | ficava sempre em trabalho o pensamento. | Dramusiando perguntou, se por ventura | o conhecia ElRey, $?^{5}$ e elles lhe disserão que na | pouzada, em que inda anoite passada se agasa|lharão, ouvirão dizer que não. [espaço] Ora senhores | lhes disse elle então amanheceremos Deus | querendo, e o novo dia nos darà quiçà | mais certeza em nossos discursos, ou ma|is materia para nossos enganos Eu folgara | saber pello Menos em que estado ficou o | Cavalleiro, porque com o sobresalto em que | me meteu Pavorante perdio de vista $\mid$ E inda que o escrito, que troucherão as Don|zellas mostra quam necessitado elle | tambem està de remedio, toda via se $\mid$ me mal não lembra em pe estava | elle quando Pavorante cahio. [espaço] Darlhes | ha Deus saude a elles, e a nós, e inda que | o mundo he grande, não serà possi|vel que algũa hora nos não conheçamos. |

45 A ElRey temos todos obrigação de ser|vir, e a sua filha mais, não so porque nos | derão as esperanças que hoje temos da | vida destes cavalleiros, senão pello ex|tremo grande da fermozura della, | que certo me pareceu hũ notavel exẽplo || [226v] do muito que Deus pode, e assim será bem | que amenhã em sabendo que estão levanta|dos lhes vamos fallar, porque eu estou de|terminado em me deter por aqui, athe |que os feridos estejão em despozição de po|derem caminhar, e irmos despois a Cons|tantinopla ver estes homẽns que tão caro | me tem custado tantas vezes. [espaço] Mas | entre tanto não deixarei demandar hũ | Escudeiro meu a Avizallos do que aqui|nos aconteceu, porque o amor que lhes tenho | Me assegura, que folgarão tambẽ de saber | de mim. [espaço] E com isto repouzarão aquella | noite hũns, e outros, assás contentes, pos|to que nos

55 cavalleiros não deixava de haver | algũ sentimento do que lhes tinha aconte|cido, mas como erão couzas, aque andavão | offerecidos, consolavãoce com não terem | faltado a o que se devião assi mesmos, por|que nimguem he mais obrigado que fazer | tudo o que pode, e a fortuna dispoem depois $\mid$ como lhe parece.

\footnotetext{
${ }^{3}$ Logo após esta palavra o copista escreveu e riscou a palavra que.

${ }^{4}$ Eles ainda não sabiam que o cavaleiro em questão era Albaizar.

${ }^{5} \mathrm{Na}$ realidade, no ms. a vírgula está situada exatamente embaixo do ponto de interrogação, o que pode demonstrar uma hesitação do copista quanto ao sinal de pontuação por empregar.
} 
ElRey passou tambẽ anoite | com grande contentamento parecendolhe | que não

60 perigarião os cavalleiros com o so|corro que lhes vinha nas Donzellas, e fóra | daquillo alegravasse grandemente dever | em sua caza na quella derradeira ida|de, tantos, e tais Principes, como alli Es|tavão, e a Dramuziando entre elles que era || [227r] o mais conhecido, e estimado homem, que | havia no mundo. [espaço] A Princeza | tambem se mostrava contente do que | seu Pay se contentava. [espaço] So Pleonido | não tinha lugar

65 na quelles prazeres, nẽ | aparecia tão pouco, porque de mistura cõ | Ardellio entrou com a quella Donzella | estranha na caza onde estava fora de seu | acordo o cavalleiro do Sol, e alli vendo | a primeira cura, inda que o Amor que ja lhe tinha | era grande, não poude sofrer, o horror $\mathrm{de}^{6} \mid$ tantas, e tamanhas feridas, e desfalecido | cahio. [espaço] Ardelio toda via o sosteve, e aju|dou àquella Donzella, aqual infundin|dolhe depois de curado hũ 70 somno pezadis|simo; a hũ, e outro, fes lançar fora, mos|trando por seus ascenos que lhe erão alli de | embaraço aquelles Escudeiros, com que a | penna de ambos se dobrou por então. | ElRey chamou Ludimio depois que ceou | para lhe perguntar pello Cavalleiro e entẽ|dendo delle o estado em que estava, não dei|xou de se sobresaltar de novo, particular | mente vendo em Pleonido, que veio com | Ludimio hũa viva imagẽ da morte 75 do ca|valleiro, Mas na Princeza não poude | deixar de mover hũ grande rizo a descom|postura, e fealdade do Enano, de que se el|le não escandelizou pouco, e disselhe que não | era contra o Estado de Princeza, nem || [227v] contra a fermozura, e estimação de Da|ma, mostrar compaixão dos afligidos, a|inda condenados por crimes contra as | proprias Damas, quanto mais dos que em algũa | Maneira o Estavão por sua cauza

80 dellas, | porque não era o cavalleiro do Sol tão fora | do Mundo, que por seu respeito delle entras|se na quelle perigo, senão pello serviço de | sua Alteza alegrando a corte de seu Pay. [espaço] | Não he isso Pleonido (lhe respondeu a Prin|ceza) que aqui muito sentimos as feridas do | Cavalleiro do Sol, mas como vos vejo tão | angustiado querendolhe deantes tão mal, | pareceme que vos disse a Donzella Estranha | que não 85 está elle tão perigozo como antes devos | ver cuidavamos. [espaço] ElRey disse então para | o Enano: Não me quereis crer Pleonido?|Tenho vos ditto mil vezes que não vos fieis da | Amizade de Fidellia, que he amais má, e | a mais falça creatura do mundo, e vós a | ter mão. [espaço] Ora la vos avinde, que eu vos porme|to que ella vos guarde mui

\footnotetext{
${ }^{6}$ Palavra corrigida pelo copista.
} 
bẽ as $\operatorname{costas}^{7}$. [espaço] Bẽ | fas senhor, lhe respondeu o Enano, que assim se | ande tratar 90 os criados antigos, e conheci|dos por affeiçoados, mas praza a Nosso Senhor que não | venha a senhora Princeza a pagar por junto | o que agora vai merecendo por partes. [espaço] | Ludimio, depois de passadas aquellas praticas, | que todos festejarão, disse a ElRey o que o do | Sol the pedira a cerca de se encobrir da quel||[228r]les cavalleiros, com que o meterão em va|rias imaginações, e perguntando a sua | filha o que entendia 95 da quillo, ella lhe res|pondeu o que abarxo ${ }^{8}$ veremos.

\footnotetext{
${ }^{7}$ Bluteau registra a expressão "guardar as costas ou fazer costas", que significa "assistir a alguém para o defender”. Quanto à expressão “ter mão", significa "teimar, obstinar-se”. É evidente que o rei está falando de modo irônico a respeito do caráter de Fidélia.

${ }^{8}$ B: abaixo; C: a baxo.
} 


\section{Capitulo 71}

\section{Do que a Princeza respondeu | a seu Pay, e de como Dramu|ziando se offereceu a continu|ar na guarda do valle | pello cavalleiro | do Sol.}

São senhor tão honrrados homens, disse | a Princeza Fidelia, os de quem o caval|leiro do Sol mostra temerce, e elle tão pon|derádo em suas couzas, que não me pode dei|xar de parecer que ha aqui misterio, e mais $\mid$ me inclino a cuidar que se quer encobrir | delles por os não seguir, que por medo de cul|pas que tenha cometido, porque nẽ dos pro|cedimentos de hũ se podem cuidar estas, | nem das calidades dos outros temer que ma|tarião hũ homẽ ja quazi Morto. Sobretudo | me não parece mal chamarce o seu Escu|deiro, e fazer Vossa Alteza algũa deligencia com | elle, por ventura que della rezulte algũa | mais clareza desta minha sospeita. || [228v] ElRey se teve por bem aconcelhado, e man|dou alli logo chamar Ardellio, que veio com | mais sentimento que Pleonido, mas mais | enxuto, posto que acor dos olhos bem descobria | o que por elles

110 passava. E Sentandoce em giolhos | com muita criação, e comedimento dizendo | que o chamarão de sua parte, ElRey lhe respon|deu: [espaço] Estou com tanto sentimento, ami|go, das feridas de vosso senhor, que vos affirmo, que | comprara com hũa grande parte de meu | Estado sua saude, mas espero em Deus que lhe | não tarde com ella, por isso me consollo, e vos | o deveis fazer assim tambẽ. [espaço] Estimaria muito |que me

115 dicesseis quem he, para que se por ventura | nos descuidamos em seu tratamento, se | emmendarem as faltas, em que o não o conhe|cer nos pode ter metido, pois que elle não es|tà em estado para que no lo diga, nem o tempo | deu lugar para lho perguntar antes. [espaço] Ardel|lio era discreto, einda que não estivera tan|to de ante mão avizado, não deixara de res|ponder attinadamẽte e assim o fes dizẽdo: | Saude quererá Deus dar ao

120 Cavalleiro do | Sol para servir a Vossa Alteza amuita merce que lhe | fas, e o que eu posso dizer delle he, que tendoa | não haverà Vossa Alteza por mal empregada al|gua ${ }^{9}$ que lhe tenha feito, e se Nosso Senhor dispuzesse | outra couza (o que eu não espero de sua mise|ricordia), gente fica no mundo, que dezẽ|penhará esta obrigação mui a satisfação || [229r] desta caza. Eentão direi eu quem elle he, | entretanto pesso a Vossa

125 Alteza que me não man|de outra couza, que seria fazerme errar | ao que devo aquem me criou, e deu o ser que | tenho. [espaço] ElRey então mui satisfeito | do Escudeiro, e mui

\footnotetext{
${ }^{9}$ Elipse do termo mercê.
} 
confirmado tãmbem | nas proprias sospeitas, que sua filha tinha ${ }^{10} \mid$ lhe disse, pois assi era, que se fosse agazalhar, | e que tivesse cuidado de não sahir aonde o | conhecessem os cavalleiros que o dia deantes | justarão com seu senhor, porque elle dissera a |

130 Ludimio que lhe cumpria encobrirce delles, I E que tudo o que lhe fosse necessario pedisse | ao proprio Ludimio, e despedindoos a â|bos foyse a repouzar, e ao outro dia man|dou convidar aquelles Cavalleiros para jan|tarem com elle, e tratandoos com muita | cortezia, esteve fallando com todos nas cou|zas do mundo, particularmente a Dra|muziando, perguntandolhe pello Empe|rador, e por ElRey D. Duardos, e os mais |

135 dequem tambẽ lhe disse que erão dezencanta|dos, que por via de Alemanha o tinha sabi|do, e de quem fora quem os Encantara ${ }^{11}$, | e o mais que acerca disto temos contado | que Dramuziando não sabia, o qual infor|mandoo a elle tambẽ das outras couzas do | tempo passado pellas quais lhe ElRey pergũ|tava assendeu bravamente em dezejo, ea|mor de ver, e tratar aquelles Princepes, || [229v] E lembrandolhe tambem a idade, q ue 140 tinha | e a de sua filha, julgandosse por desterra|do do mundo por não ter conhecimento | daquelles homẽns que erão os melhores delle. ${ }^{12}$ | Tambem entendeu, que so na quella Escolla | e na sua conversação poderia achar senão | quem satisfizesse ${ }^{13}$ o merecimento de Fi|dellia, pello menos omelhor que se podia bus/car para isso. [espaço] $\mathrm{E}$ rezolvendoce em tratar a|quella Materia com Dramuziando, quis | trattalla primeiro com 145 afilha, a quem como te|mos ditto, elle costumava dar conta de | tudo o que se lhe offerecia, assim do governo do | Reyno, como na despozição de sua vida | della, e guardando para melhor hora, ficou | praticando no que dantes ${ }^{14}$ fallavão.

Dramusiando lhe pedio que o | Mandasse levar á Princeza porque lhe | queria pedir hũa merce a ella em que sua | Alteza não ficaria desservido. [espaço] Pareciame | 150 disse ElRey que jantassemos primeiro, e à tarde | podereis fazer vossa vizita porque tudo o |que for de vossa honrra, e gosto, a qui procura|remos como em Constantinopla. [espaço] | Antes folgara eu que fosse, respondeu Dramu|ziando, porque não se cuide do que eide dizer | se não for mui conforme com minha ida|de, que as alegrias da meza mo

\footnotetext{
${ }^{10} \mathrm{Ou}$ seja, os bons modos do escudeiro pareceram confirmar que o Cavaleiro do Sol deveria ser uma pessoa honrada e que o motivo de querer ocultar-se dos demais cavaleiros não seria por algum crime que tivesse cometido.

${ }^{11} \mathrm{Em} \mathrm{B}$, este trecho parece ter confundido o copista: de quem fora qmencantara. A lição de $\mathrm{C}$ é idêntica à de A.

${ }^{12} \mathrm{O}$ sentido da próxima frase exige que este ponto seja desconsiderado.

${ }_{13}$ A palavra foi corrigida pelo copista: a letra $t$ foi escrita sobre um $f$.

${ }^{14}$ Há mancha sobre esta palavra no manuscrito; a lição apresentada é a de B e C.
} 
fizerão fa|zer. [espaço] ElRey então rindo thomou o | concigo, e levou o a o apozento da 155 Prin||[230r]ceza, dizendolhe que queria ser testemu|nha daquelles misterios, e que tambem | o fossem todos aqueles cavalleiros. E | assim entrando hũns e outros despois | das primeiras cerimonias sentandose Dra|muziando em giolhos diante della, dis|selhe: [espaço] Ainda que meu filho senhora està | assás castigado de impedir ao cavallei|ro do Sol continuar com a guarda do | valle, a que por amor deste vosso Donzel | se offereceu 160 segundo tenho sabido (estava | Pleonido prezente) eu por emmendar | esta queixa que Pleonido pode ter de | Pavorante, pesso a Vossa Alteza que me de licen|ça, para assestir nas tendas os dias que fal|tão a o Cavalleiro do Sol, porque ainda | que não preste para tanto como elle, pello | menos o para que prestar empregarei sempre | em vos servir a vos, e a ElRey vosso Pay | com tão boa vontade como nelle tenho | visto para nos 165 honrrar, e favorecer a todos. | A Princeza pondo os olhos em ElRey | vendo nelle que levava gosto daquella Ma|teria, respondeulhe então fazendoo levan|tar primeiro [espaço] Pareceme Dramuziando que | quereis injuriar o Castello de Almourol | occupandovos estes dias em couza que vos te|nha no campo, mas vai tão pouco de | Pleonido à senhora Miraguarda, e do que | vos agora sois, a o que então devieis ser, que || [230v] por outra 170 parte vos desculpo, e folgo cõ | isso que quereis fazer, mas quero ser eu a | porquem o façais, e tervos por meu cava|lleiro inda que peze a Miraguarda, ea | Pleonido juntamente. Grandemente | abalou isto que a Princeza disse a toda a | caza de rizo, e a o Mesmo Dramusian|do tambem. E de pois ${ }^{15}$ de tudo socega|do voltandoce para Pleonido disselhe: | A senhora Princeza amigo assim como | he tão grande mostra do poder de 175 Deus | thoma tambẽ muitos dos seus poderes que|rendo igualar os valles com os oiteiros. | Digo isto porque igoalmente zomba de | hũ Enano moço, que de hũ Gigante velho, | Mas pois (voltando então para ella) Vossa Alteza | me fas esta merce, eu prometo de ser | não seu cavalleiro, mas seu Alcoviteiro | que he officio que me está melhor, ede apregoar | pello mundo onde vive o melhor delle, | e não quero ordenado com este 180 cargo, por|que eu espero que me saberei mui bẽ pagar. | ElRey ficou em extremo contente com o |que Dramuziando respondeu à Princeza | imaginando que guiava Deus a quillo na | conformidade que elle concigo assentara. | Então disse para elle: Vamonos Dramuzi|ando acomer, que esta gente ocioza sem|pre leva boa vida à custa dos maiores | amigos. [espaço] E vos não vos ouvereis de || [231r] cançar no que quereis fazer, porque

\footnotetext{
${ }^{15}$ Palavra corrigida pelo copista.
} 
185 ainda | que vosso valor não possa ter rezistencia | quizeravos eu mais perto para vos lograr $\mid$ os dias que vos aqui detiverdes. [espaço] Senhor, lhe | respondeu Dramuziando, experiencias | de muitos dias me tem amim ja ensina|do a thomar na capa ${ }^{16}$ as zombarias das | Damas. [espaço] Á senhora ${ }^{17}$ Princeza eide ser|vir no que lhe disse, e ao cavalleiro do Sol | na guarda do valle. E vamonos tras | isto onde Vossa Alteza Ordenar, porque

190 quizera | esta tarde despachar hũ Escudeiro meu a | Constantinopla dar novas a o Empera|dor destes cavalleiros, e demim, e pedirlhas | tambem mais meudas dos desencantados | porque a detença por ca com licença de | Vossa Alteza será em quanto as feridas de Pavorante | lhe não derem lugar a porse a caminho. |E com isto deixarão a Princeza com quei|xas de Dramuziando não querer ser seu | cavalleiro, e com 195 conhecimento da diffe|rença que em tudo havia daquelles, aos | com que tinha tratado, e com dezejos jun|tamente de conhecer outra gente comque se | entendesse melhor, do que com seus vassallos | fazia. Os Princepes se descontentarão | de que Dramuziando se antecipasse na | quillo, porque cada hũ delles o detreminava | fazer, mas em fim se ouverão de sofrer | pois mais não podião. [espaço] Acabada ameza, || [231v] recolheuce

200 ElRey, e elles se forão a suas pou|zadas, donde Dramuziando despachou lo|go hũ Escudeiro a Constantinopla | com novas de tudo o que alli tinha passado, | e grandes gabos da quella corte, pedindo | a o Emperador que mandasse ter muitos | comprimentos com aquelle Rey pello ga|zalhado que lhes fazia, e pello amor, que | Mostrava a todas suas couzas. E com | isto aconcelhando aquelles Mancebos |(que tambem se quizerão ir 205 logo) conforme | á obrigação que lhes tinha, despedindose del|les foise a continuar com aguarda do | valle, e elles cada hũ por sua parte se | forão buscar suas Aventuras, tirando Al|mourol, aquem a ferida dos peitos não deu | tão depressa lugar.

\footnotetext{
${ }^{16}$ Não encontramos referências a esta expressão. O sentido dela, no entanto, é claro: thomar na capa as zombarias significa "não se deixar atingir pelas zombarias".

${ }^{17}$ A abreviação aqui foi feita com troca de posição de letras: sñar e não sñra.
} 


\section{Capitulo 72}

\section{Do que passava em Constanti|nopla, e de certo coloquio que | tiverão Carmellia, e | Valeriza.}

Servia a memoria dos trabalhos passá|dos a os Reys que em Constantinopla esta|vão mais degosto de os ter ja detras ${ }^{1}$ das cos|tas, que de penna de terẽ passado por elles. Or||[232r]dinaria couza em nossa natureza, | e providencia grande do Author della | que quis que isto assim fosse não so para re|medio daquelle mal, senão porque senão | alternára deste modo, em hũ homem | cahindo nũ trabalho nunca mais se pu|dera ter por

10 livre delle, e vinha assim | a ser a memoria, tão excellente parte | de nossa alma, omaior inimigo, que ti|vessemos. Não fallo na quelles trabalhos | de que a honrra fica maculada, porque | nestes disso he que a lembrança serve sem|pre a os honrrados ${ }^{2}$. [espaço] Continuavãoce | festas, havia justas entre os cavalleiros da | Corte, A Emperatris tinha Seroes, mas | tudo parecia sombra faltando alli D Du|ardos, e os mais companheiros,

15 que nas passa|das ${ }^{3}$ se acharão, porque inda que da quella ca|mada estavão prezentes Vasperaldo, e | D Floris, como nenhũ delles entrava nas jus|tas, nem thomavão lugar nos serões, | com particularidade D. Floris, porque não ti|nha couza particular, Vasperaldo porque não | querião ter particularidades com ele ${ }^{4}$, fi|cavão aquellas couzas sem os extremos de | seu valor exercitados, e sem os seus sus|piros ouvidos, como joias sem

20 esmalte, | ou como pinturas cubertas. [espaço] Assi o julga|vão os Reys, assi o Entendião as Princezas, | mas nem Flerida dava lugar a que Vaspe||[232v]raldo lhe falaçe, nem Gridonia falava | nunca em Trineo, nem em Carmellia | havia memoria de que nascera D Duardos no $\mid$ mundo. Valeriza so falava em todos, e $\mid$ achava tudo so sem elles. Gabavaos, resu|citava couzas suas, quando mais the parecia $\mid$ que lhes a elles

25 estaria melhor, e como continu|ava nisto muito Carmellia lhe disse hũ dia | Estando ambas sos:

\footnotetext{
${ }^{1}$ A palavra está ilegível. A lição apresentada é a de B e C.

${ }^{2}$ A lição de $\mathrm{C}$ contém um erro: disso de que a lembrança. O sentido da observação do narrador é: se é bom que a memória dos perigos passados não perdure, o mesmo não vale para os casos em que a honra poderia ficar maculada; por isso a memória é sempre benéfica para quem é honrado.

${ }^{3}$ Aqui parece haver erro, comum aos mss. A, B e C: o correto seria passados, pressupondo a elipse de serões.

${ }^{4}$ O jogo de palavras deve significar o seguinte: a D. Floris não apeteciam os serões, pois ele era indiferente a questões amorosas; Vasperaldo também não comparecia aos serões porque Flérida não queria intimidades (particularidades) com ele.
} 
Digovos em verdade, Valeriza, que | me trazeis a mais enleada mulher do mũ|do, com o termo que tendes thomando nas coulzas de D Duardos, e de todos estes Cavalleiros, | dequem vos mostrais tão declarada amiga, | porque por hũa parte vejovos 30 tratar destas ma|terias como velha, e fea, havendo em vos | tão differentes calidades, e por outra descon|fiame amim tamanha confiança; porque | para vos parecer que será ${ }^{5}$ bom para nós o de que vos | não tratardes como parte, não vos confeça|remos facilmente tamanhas ventagẽns, | a o menos pella natural condição de todas as $\mid$ mulheres ${ }^{6}$. [espaço] Ora para que vos diga tudo, que seja es|ta vossa amizade vingança do descuido

35 | que estes homẽns Mostrão com vosco, ainda que | em nimguẽ se empregue ${ }^{7}$ nada melhor que | em vós, não entendo que haveis de cuidar que | ficarà perdido a quelle de quem eu quizesse | deixar servirme ${ }^{8}$. $\mathrm{E}$ assim vos confesso que | vos não entendo, dezejando muito entẽdervos, || [233r] porque sou mais vossa amiga do que cuidais, | enão queria dar tão ma conta demim | como fora tratandovos não o ser $^{9}$. [espaço] |

40 Valeriza, que a estava ouvindo, e espreitando, | vendo que callava, respondeulhe: Porcerto | Carmellia, que só agora cuido que me pagais | o que me deveis, mas pois que como vos mes|ma confessais, he necessario falarvos com a | boca aberta, detremino não vos encobrir | onde essencialmente está amaior obri|gação que me tendes. Mas primeiro para que percais | algũas devossas imaginações, irei assim | fazendo hũ descurso de nossas calidades |E pessoas. [espaço] Vos senhora sois filha de ElRey | de Tracia, e eu de ElRey de Hespanha. | Sois de pouca idade, Eu não tenho muita Ten|des olhos azuis, e sobrancelhas louras, Eu | tenho os olhos, e sobrancelhas negras. Que ga|nhe muito mais quem vos servir a vós, que quẽ | me servir amim, vede vós se vos está | bem confessallo, que eu não o Eide negar | nunca. [espaço] Que me peze muito que D Duardos | fosse tão mal tratado, tão pouco vo lo posso | encobrir, e na razão disto está a divida | que vos eu

\footnotetext{
${ }^{5} \mathrm{C}:$ seja.

${ }^{6}$ Carmélia diz que estranha o fato de Valeriza sempre tratar dos cavaleiros mancebos como se fossevelha e fea, isto é, como se não admitisse a possibilidade de algum deles amá-la. Carmélia ainda observa a contradição: Valeriza icentivava as demais princesas cuidarem de questões amorosas mas se eximia a si mesma de tratar desse assunto. Assim, conclui, as demais princesas não poderiam confiar em seus conselhos.

${ }^{7} \mathrm{C}$ : emprega.

${ }^{8}$ Entenda-se: Carmélia sugere que a boa vontade mostrada por Valeriza com relação aos cavaleiros seria uma forma de vingança, pelo fato de nenhum daqueles príncipes servi-la como namorado, mesmo que ela o merecesse (em ninguem se empregue nada melhor que em vós); ainda assim, Carmélia diz não entender o motivo de Valeriza pensar que deveria ficar sem esperança (perdido) quem Carmélia aceitasse como servidor.

${ }^{9}$ Isto é: "tratando-vos como se não fosse vossa amiga".
} 
dizia que me deveis. [espaço] Praza | a Deus que não sirva o declararvola de $\mid$ me perder o Amor, que agora me confes|sastes. [espaço] Bem vos lembrarà senhora $\mid$ o que nos aconteceu na Orta, quando ouvi|mos, e vimos Albaizar, O que me dicestes, || [233v] o que vos respondi. Pellas palavras que elle en|tão alli soltou, e por alguas conjecturas | 55 outras, bem entendi eu quem era, e rece|oza que vós vos cegaceis onde mais cumpria | ter os olhos abertos, sabendo por outra parte | a boa eleição dos pensamentos de D Duardos | e quão igual couza vos seria cazardesvos | com elle, mais com lastima de vos, que com | outro algũ respeito, procurei que o ouvisseis | na quelle serão em que o despedistes, porque quando | demais não service, ficarvos hia claro que | não era so

60 Albaizar quem dezejava ser|virvos. [espaço] Vos thomastes isto tão mal, que | me escandelizastes amim, matastelo a el|le, e destes grande nota de $\operatorname{vos}^{10}$, ajuntan|do a este tal procedimento deixardes esta | caza com tanta inconcideração, que se as | couzas que por vós passarão não forão tão las|timozas, inda hoje nos tivereis queixozos | a todos os moradores della. [espaço] Não sei se |vos parecerào agora meus officios de velha | e fea,

65 mas sei que o intento que nelles tive | foi mais depressa desafeisoarvos do que vos | não convinha, que inclinarvos a onde vosso | Merecimento parece que ficava satisfeito, | Eassim nem era desprezo do que nunca | se me offereceu, nem podia ser vingan|ça do que me não lembrou nunca ${ }^{11}$. [espaço] Vós, | e vós senhora fostes só o tudo em todas | as minhas demonstraçoes, e se inda || [234r] agora me quizeceis crer alegrarieis esta |

70 corte, consolarieis vossos Pais, e descançar|voshieis a vos. [espaço] Prestes estava Carmel|lia quando começou a fallar com Valeri|za, para ouvir o que lhe ella respondesse; | porem pareceme amim, que não devia | cuidar, que a outra lhe diria tanto, mas dis|simulando o melhor que poude o que daquil|lo sentio, replicoulhe desta maneira. | Igualasteme, senhora, por me fazer merce | tanto comvosco, que me não 75 posso escan|delizar de julgardes D Duardos tão bem, | como tendes feito, Antes vos quero a gra|decer pello parentesco que com elle tenho | haverdelo por couza que tambẽ vos esti|vera $^{12}$. [espaço] Mas pois entrais nesta materia / mais com respeito meu que alheio, parece|me que será escuzado fallar nella, porque Al|baizar, que não seja morto,

\footnotetext{
${ }^{10}$ Segundo Bluteau, nota significa "defeito, falta, ação de que alguém é notado e censurado". A expressão dar nota de si, não registrada no Vocabulario, deve significar "cometer um erro".

${ }^{11}$ Valeriza diz que seu objetivo era apenas evitar que Carmélia se afeiçoasse a Albaizar; sendo assim, ela não agia por desprezo do amor (desprezo do que nunca se me offereceu), nem por vingança de não ter sido cortejada por nenhum dos cavaleiros da corte (vingança do que me não lembrou nunca).

${ }^{12}$ Cremos que seja preciso ler "tão bem vos estivera", embora a grafia tambem esteja registrada nos mss. $\mathrm{A}, \mathrm{B}$ e $\mathrm{C}$.
} 
para mim o foi des|de a hora que eu sube ${ }^{13}$ quem elle era, e não | vos quero dizer que sempre por não porfiar | comvosco. E assim determino tomar|vos o officio ainda que com differentes res|peitos, porque o que vós não quereis que vos $\mid$ deva $\mathrm{D}$ Duardos, quero eu que me deva | a mim hum cavalleiro aquem dezejo | ver empregado em vós ${ }^{14}$. E não vos heide | pedir perdão ${ }^{15}$ porque ainda que vosso Mere|cimento he tão grande, em suas calida|des tudo poderà estar bem. Este he D. || [234v] Floris, a quem vos melhor

85 que nimguem co|nheceis, e de quem não parece que se pode | descontentar hũa filha de ElRey de Espanha. | Não parava Carmellia, mas Valeriza | lhe disse rindo: [espaço] Querovos atalhar porque | athe hi não temos porque haver brigas, | e dahi por diante não sei o que serà. E digo | que não temos athe hi porque haver brigas, por|que conhecida couza he que as filhas dos vas|sallos de meu Pay são cazamentos pro|curados dos 90 Princepes herdeiros de Cons|tantinopla, e como os Reys de Hespa|nha entendem isto, tambẽ não deixão | da mesma maneira de cazar suas fi|lhas com elles, mas para me vos thomar|des officio como dizeis, e pagarme i|goalmente, ouvereisme de me ver in|clinada a outra couza que me estivesse | peor, como digamos Albaisar, ou outro | assim como elle, e então entrava bẽ | isso que me agora dizeis, mas eu folgo muito | com as novas 95 que me dais de vós, e no ma|is o tempo mostrará de todos quão segu|ros estejão em seus presupostos. [espaço] | Assim se apartarão a quella ves estas Prin|cezas, Carmellia escandelizada, e Va|leriza desgostoza, mas nẽ lho enten|dia nimguẽ, nem nimguẽ se enten|dia com ellas. [espaço] E deste modo as deixa|remos por dizer como o Escudeiro de || [235r] Dramusiando chegou à corte, ede ser|ta rezolução que Carmellia thomou com $\mid$ a sua vinda.

\footnotetext{
${ }^{13}$ A grafia sube deve ser fruto de erro do copista, pois pouco adiante a forma verbal será grafada soube (cf. cap. 73 linha 45).

${ }^{14}$ Leia-se: "quero fazer o mesmo que fizestes por mim (tomarvos o officio), ainda que por motivos diferentes (com differentes respeitos), porque o que vós não quereis que vos deva D. Duardos, quero que me deva um cavaleiro a quem desejo ver em vosso serviço (empregado em vós)". Lembre-se que Valeriza havia dito que não fizera D. Duardos aproximar-se de Carmélia para favorecê-lo, mas apenas para afastála de Albaizar; este é o motivo de Carmélia dizer que Valeriza não pretendia deixar D. Duardos em dívida.

${ }^{15}$ A palavra foi corrigida pelo copista: a letra $p$ foi escrita sobre um $d$.
} 


\section{Capitulo 73}

\section{Da trovação que entrou em o | animo de Carmellia com | a chegada do escudeiro de | Dramusiando á cor|te, e do que passou cõ | D. Floris, e de | Outras cou|zas.}

No estado, em que no passado capitulo vi|mos que estava a Corte, se concervava ain|da quando chegou a ella o Escudeiro de Dramu|siando, o qual depois de dar sua Embaixada | ao Emperador, e aos mais Princepes, a | quem a trazia, crescerão os alvorossos de | todos pellas novas que tiverão da quella com|panhia, que em Bohemia ficava, e cres|cerão tambem, ou se começarão hũns te|mores em Carmellia, que athe

10 então não | tinha conhecido. Parece que espreitava | o Amor hũa hora boa, para se vingar | das injurias que desta Princeza tinha || [235v] recebido em pessoa de D Duardos, porque | publicandosse as altas cavallerias do ca|valleiro do Sol, a grande fermozura da | Princeza Fidellia, affirmandoce que elle | não era conhecido, ella foi só quem fir|me mente creu que devia ser D Duardos, | e que servia aquella Princeza, aquem

15 | de novo se devia ter entregue, ou por de|zenganado della, ou por Fidellia the pare|cer mais fermoza. [espaço] Não bastou esta | imaginação com tudo para que D Duardos | lhe parecesse melhor, porem bastou toda | via, para que o ella não perdesse mais do | sentido ${ }^{1}$. E ainda que o não dezejava firme | em seu Amor, de nenhũa maneira so|fria que o elle tivesse a Fidellia, porque tinhão | soádo tanto os Extremos da quella Prin|ceza,

20 que lhe parecia a Carmellia, que po|deria haver quem julgasse por arrezoada | a mudança de seu primo, e isto era o | que ella não queria. E tanto a atromentou | esta terrivel paixão, que seveio a rezolver | num excesso não menos terrivel, se | ponderarmos os inconvenientes que delle nas|cerão, e puderão nascer. [espaço] Como fechou | de pancada contra o respeito, que parece que a|venturava na quillo ${ }^{2}$, e foi que

25 não se poden|do deffender contra o Estimulo accutissi|mo, com que a marterizava ou o amor | proprio, ou o odio de Fidellia, mandou || [236r] hũ dia chamar D Floris a o apozento | da Raynha sua May, e apartandoce | com elle, apos hũa pequena torvação |e descorarce hũ pouco the disse: [espaço] Folgo | D Floris que nesta occazião esteja Vaspe|raldo nesta corte para que entendais quãto | mais fio de vos, que delle. [espaço]

\footnotetext{
${ }^{1}$ Ou seja: se as suspeitas de Carmélia não fizeram com que passasse a se interessar mais por D. Duardos, serviram ao menos para que ela não mais se esquecesse dele.

${ }^{2}$ A expressão de pancada significa "de repente" ou "inconsideradamente". A passagem não é muito clara, mas seu sentido deve ser que Carmélia tomou uma decisão precipitada, sem considerar os riscos.
} 
30 Não vos que|ro obrigar a fazerdes o que vos pedir com | mais rezões, que a que vos conheceis que ha | para satisfazerdes hũa Mulher como eu. | Eassim so vos digo que me importa co|nhecer quem he o cavalleiro do Sol, que | em Bohemia se combateu com $\mathrm{Pa}$ |vorante, e justou com seus companhei|ros. [espaço] Se se isto puder fazer sem risco | de vossa pessoa, inda o estimaria ma|is; porem deixar de sabello não quize|ra em nenhũ

35 modo. [espaço] Abrevidade vos | encomendo, que do segredo vossos procedi|mentos me tem assegurado ${ }^{3}$. [espaço] D. | Floris lhe respondeu, que naquillo, eno malis que lhe mandasse a serviria sempre | conforme a obrigação emque o metia | merce tamanha, como era o quererce $\mid$ servir delle. E que a partida seria aquella | mesma noite se lhe a ella não parecesse | que era tarde. [espaço] A Princeza lho a|gradeceu, e o despedio, não

40 sei se ja ar|rependida do que lhe tinha pedido que | mui de ordinario acontece a quem se || [236v] precepita depressa não durar muito em hũa| detreminação.

Não foi Escondida aquella | vizita a Flerida, que entre todas era quẽ | mais trazia em Carmellia os olhos, e | inquietandoa logo o dezejo de querer sa|ber a cauza, parecendolhe novidade | mandallo ella chamar alli, fallandolhe | muitas vezes no 45 apozento da Emperatris | onde todas as couzas publicas se fazião | não soube melhor caminho que dizer a | Valeriza que lho preguntasse, porque a el|la diffiria D Floris muito mais, que à sobri|nha ${ }^{4}$. [espaço] Valeriza ouvindo aquillo não | poude tanto o seu entendimento, que | a soubesse aconcelhar nos cazos que ti|nha por proprios, e ficou logo como hũa | Leoa contra D. Floris, assentando con|cigo que tratava com Carmellia 50 de a | grangear a ella, pello que a outra lhe tinha | ditto, julgando agora por culpa sua del|le, o que tivera então por mininice de | Carmellia. [espaço] E ainda que aindigna|ção foy grande, não rompeu porem | pellos muros da prudencia, antes re|concentrando a paixão disse a Flerida: | Por vida vossa Senhora que me não man|deis fazer essa deligencia porque Carmellia | he vidrenta, e D. Floris não dirá segre|do de hua Dama 55 inda que o matem, quanto \| [237r] mais que isso não deve ser nada, e a nós | querernolohão vender por muito [espaço] E | estando ellas nisto chegou Gridonia | e perguntoulhes o que fazião. [espaço] A qui es|tava, disse Flerida, rogando a Valeri|za que me soubesse hũa couza de D. | Floris, e ella he tão joia, que não quer fa|zello, mas

\footnotetext{
${ }^{3}$ Leia-se: "Recomendo-vos apenas que sejais breve, pois entendo que vos pedir discrição (segredo) é desnecessário tendo em vista o modo como sempre procedeis".

${ }^{4}$ Flérida pensou que seria melhor Valeriza interrogar D. Floris, pois este a obedecia mais que à sobrinha (Gridônia, filha de Miraguarda, irmã de D. Floris). Lembre-se que Valeriza era filha do rei de Espanha, a quem D. Floris devia obediência.
} 
eu hei hoje de lavrar com $\mid \operatorname{rattos}^{5}$ athe me tirar desta duvida. E | dandolhe conta do que 60 passava, Gridonia | lhe respondeu: [espaço] Bom era isso por certo para | deixarde saber. D Floris no lo dirà ou | o diabo andarà com elle. [espaço] Então | Mandando chamallo, Valeriza se qui|zera ir, mas porque lhe aellas não pa|recesse misterio, forçouce a ficar bra|vamente Escandelizada do coita|do que lhe não tinha mais culpa, que por | ventura não cuidar naquillo. [espaço] Veio | elle logo com aquella boa sombra

65 que a | Natureza lhe dera, e achandoas todas | juntas começoulhes afallar com a corte|zia, e liberdade que costumava, e inda | que não vio no rosto de Valeriza a ale|gria para elle que sohia, não cahio por en|tão nisso, por que o Animo innocente | nunca ante mão se teme do casti|go. [espaço] Gridonia lhe disse: [espaço] Mandà|mosvos chamar ha mil horas para | certa couza, que queriamos de vós, e || [237v] dicerãonos que

70 estaveis com a Raynha | de Tracia chamado tambem. Di|zeinos o que vos la querião e por ven|tura que seja tudo o mesmo. [espaço] Trazia | Vasperaldo pouca saude na quelles di|as, em que era mais culpado o rigor de / Flerida, que alguma outra disconformi|dade de humores, e esteve aquelle dia | em caza de sua May athe tarde lan|çado sobre hũa camilha, e tinha mã|dado tambẽ chamar a D Floris com ten|ção de 75 concertarem ambos certo tor|neio de pe no Passo com espadas, e bo|tas, para poderem entrar em quadrilhas ${ }^{6}$ em que ja tinhão fallado. E quando D Floris | la foy chamado de Carmellia, ja lhe | tinhão dado o recado do irmão, porem | Vasperaldo que em nenhũa parte repouza|va senão nos lugares em que lhe parecia | que podia ver Flerida, antes que D Flo|ris viesse foice a passear ao Terreiro es|perando achallo la, e por isso quando D 80 Floris | falou a Carmellia o não achou aelle; po|rem servindoce da quelle recado, pouco cõ|tente do que lhe asobrinha perguntava | sem lhe mentir lhe respondeu com | elle, acrescentando não haver acha|do a Vasperaldo. Ao que Fle|rida replicou o que no se|guinte capitulo veremos.

\footnotetext{
5 A linguagem utilizada por Flérida é repleta de expressões coloquiais de significado obscuro. Não encontramos no Vocabulario de Bluteau referências às expressões joia e lavrar com rattos.

${ }^{6}$ Não compreendemos exatamente que tipo de torneio seria este: torneio de pe parece indicar que os participantes não estariam montados, o que exigiria o uso de algum calçado especial (as botas a que o texto se refere); quadrilha, entre outros sentidos, pode significar um grupo de quatro cavaleiros ou combatentes. Mais à frente, no próximo cap., Vasperaldo afirma que o torneio aconteceria no interior de uma sala do paço (cf. cap. 74, linha 51).
} 


\section{|| [238r] Capitulo 74. \\ Do que as Princezas passa|rão com D. Floris, e | decomo elle, e Vaspe|raldo partirão | da Corte.}

Não foi má a trocca, disse Flerida | a D. Floris, se por ventura vistes a Car|mellia. ${ }^{1}$ (sabia ella que elle lhe falara, e | esperava que lho negasse para se confirmar | em que tinha que querer saber) ${ }^{2}$ Com | Carmellia fallei senhora (lhe respondeu elle) | mas a Vasperaldo buscava como vos te|nho ditto. [espaço] Cheirame isso a groceria Tio | (acodio Gridonia) olhai la o que fazeis, não | dezacrediteis as

10 finezas dos Portugue|zes, que não sou eu quem menos o hade | sentir ainda que aqui esteja Valeriza. [espaço] | Nimguem senhora (lhe disse então D Flo|ris) pode parecer groceiro onde não po|de nunca ser galante, e se vos a vós | parece que não he sello fazer esta confição | lembrevos que no respeito das Damas to|do o respeito he divido, e a senhora Valerisa | poderá julgar se offende este conhecimento | a pureza dos

15 Portuguezes. [espaço] Valeriza | hia ouvindo, ponderando as razões, e demonstrações que lhe via | fazer. Vendo naquellas então omesmo || [238v] modo que em todas sohia ter, ouvindolhe ul|tima mente aquellas palavras, Se por | hũa parte lhe parecia que era D. Floris dis|creto para saber dissimular,. ${ }^{3}$ tambem por | outra lhe lembrava que como podia elle | sendoo Mostrarce tão humilde em | respeito de Carmellia diante de hũa | 20 mulher como ella se aspirasse a grangear|lhe a vontade ${ }^{4}$ E socegandoce com esta | duvida mais algũ tanto apaixão respon|deulhe: [espaço] Ora D Floris nós nos quie|taremos com que nos confesseis, não o que |Carmellia vos queria, senão se ereis | vós o que tinheis negocio com ella, porque | sendo todas as que aqui estamos tão vos|sas amigas, particularizardesvos mais | com outrem, não poderá deixar de nos $\mid$ dar indicios

25 de que não fiais muito desta ver|dade. [espaço] Elle então pasmado de ver a so|tileza, e coriozidade, com que o hião aper|tando, não entendendo a cauza, respõ|deulhe: [espaço] Eu não valho tanto senhoras | que possa ter negocio algũ com Carmellia | nem tão pouco

\footnotetext{
${ }^{1}$ Este ponto final deve ser desconsiderado.

${ }^{2}$ Ou seja: Flérida esperava que D. Floris negasse ter conversado com Carmélia para confirmar a suspeita de que ele estava querendo ocultar o que ela lhe havia dito.

${ }^{3} \mathrm{O}$ ponto final deve ter sido inserido aqui acidentalmente, visto que o próprio copista continua a frase com letra minúscula.

${ }^{4}$ Valeriza começa a acreditar na inocência de D. Floris, porque, ainda que ele fosse perspicaz para saber dissimular a verdade, não se mostraria tão humilde diante dela se realmente estivesse interessado em conquistá-la (grangearlhe a vontade).
} 
que fiasse alguẽ de mim | o que com ella tivesse, e assim vos affirmo | pella verdade que vos devo, que nem em meu | nem em alheio lhe fallei nunca, Se | não no Navio de 30 Drusia Vellona à sua | sombra ${ }^{5}$. Hora se isto he assim da mi|nha parte, da sua vede vos que negocio || [239r] pode ella ter comigo? Vasperaldo hia | buscar, se quizeres ${ }^{6}$ que vos digo o paraque, | não volocalarei por certo. [espaço] Nada | disso queremos saber, replicou Flerida, | nem de vos mais algũa outra couza. | Mas prometovos que eu me va à Gaiolla | de Druzia Vellona saber se vos devemos | todas tão pouco como sospeito.

35 [espaço] Forte | couza he senhora Flerida, lhe replicou | elle, mostrardes tanto pezar de $\operatorname{vos} \mid$ não mentir hũ criado vosso, e tanto | tambem de que outro vos falle verdade. | Para isso estava eu agora, tornou ella, | Não me quereis dizer o que vos pregunto | e quereis que vos ouça o que nimguẽ se atre|veria adizerme. [espaço] Ora idevos embora, | e viva Daliarte muitos annos que nos mã|dou ca Drusia, a quẽ havemos de vir | a dever todas mais, que a nimguem. | Assim era aquillo que como a tras fica dito | Daliarte tinha mandado aquelle bom | prezente ao Emperador metida em | hua gaiolla de ferro, avizandoo que a não | soltassem, e alli estava ${ }^{7}$, mas não se hi|ão a dezenfadar as Princezas cõ ella | como Flerida dizia, assim pello gran|de medo que lhe tinhão, como por que ella | não falava com nimguẽ, nẽ ainda | com quem lhe dava o necessario. E | tornando á Historia despedio \|| [239v] D. Floris com grande impaciencia, po|rem rindoce, e elle se foy a Vasperaldo que | o aguardava no terreiro de donde o via | estar a hua genella fallando com aquel|las senhoras, e mais envejozo da quelle lu|gar que dos melhores cetros que havia no mũ|do. [espaço] E passando como chegou muitas couzas | com elle acerca disto, despois de gracejarem | hũ pouco, dentro dos limites que a quellas 50 so|frião ${ }^{8}$, disselhe Vasperaldo o que detremina|va acerca da concluzão do Torneio, ro|gandolhe que quizesse thomar à sua con|ta outra quadrilha para entrarem ambos | na salla quando aquellas senhoras estivessẽ | juntas. [espaço] D. Floris lhe disse que de boa | vontade o accompanhara na quillo | se não tivera sua palavra empenhada | em certa parte onde lhe convinha ser | a prazo certo, e que estava ja tão chega|do que se não

\footnotetext{
${ }^{5}$ D. Floris declara ter falado apenas à sombra de Carmélia, isto é: a Drúsia Velona, que tinha assumido a aparência da princesa para confundir os cavaleiros que lutavam com Albaizar. Cf. o cap. 47.

${ }^{6} \mathrm{~B}$ : quizereis; $\mathrm{C}$ : quiserdes.

${ }^{7}$ Cf. cap. 48.

${ }^{8}$ Note-se que, nesta frase, o termo como assume um valor temporal; além disso, o pronome aquellas refere-se a coisas. Leia-se: "E comentando logo que chegou [junto a Vasperaldo] muitas coisas com ele acerca disto, depois de gracejarem um pouco, dentro dos limites que aquelas [coisas] permitiam...”.
} 
55 partisse aquella porpria $^{9} \mid$ noite, como detreminava fazer, não | poderia vencer o caminho, e que se o elle | vira mais livre de achaqués do que então | andava, que tambem lhe ouvera de | lembrar que deixasse o Ocio da corte, | porque os homẽns como elle não se podião | negar ás necessidades do mundo.

A Vasperaldo tinha o alli Fleri|da como muitos ja sospeitavão, mas cui|dando

60 elle que aqueloutro era o caminho || [240r] de agrangear melhor desapresandoa de | sua vista couza que para ella era tão pe|zada, tambem para se empregar no para que|Deus o fizera, rezolveose de se partir | com D Floris aquella propria noite, | e assim o fizerão o que foi vida para quietar $\mid$ Flerida $^{10}$, e as mais na oppinião que ti|nhão da quelle chamamento de D. | Floris. [espaço] E Valeriza ficou Entendendo| tambem que singella

65 mente tratava | com aquelle cavalleiro de sua partida, | e não pouco mal concigo de ter dado en|trada ao outro pensamento, não por | lhe pezar de o achar falso, por se ter per|suadido sim, aque poderia ser verdadeiro. | Edeixando estes cavalleiros a the seu | tempo que na primeira jornada se apartarão | logo, porque nunca as Aguias andão | de boa vontade juntas, tornaremos | a dar conta do que o Emperador, e Reys | de sua 70 jornada sentirão eo que mais or|denarão.

\footnotetext{
${ }^{9}$ Trata-se de um erro do copista. B e C: propria.

${ }^{10} \mathrm{O}$ termo vida aqui tem significado diverso dos apontados no Vocabulario de Bluteau e nos dicionários modernos: o sentido do termo neste contexto é algo como "alento, auxílio". Note-se que no cap. 64 (linha 35) há uma expressão em que o termo pode assumir signficado semelhante: desteme a vida (neste caso o sentido da expressão também pode ser interpretado como ajuda, favor, benefício).
} 


\section{Capitulo 75}

\section{Do que os Reis sentirão da | partida da quelles cavallei|ros, e do que mais aconteceu | entre as Princezas.}

|| [240v] Tanto que o Emperador, e ma|is Reys souberão da partida da quelles | cavalleiros, não so lhes não pezou, antes | lha louvarão muito entendendo que perdião | mais na occiozidade, e regallo de que fogi|ão, que no trabalho, e perigo que hião bus|car $-{ }^{1}$ pello mundo. [espaço] Estavão elles todos | contentes das novas que tiverão de Dramu|ziando, e o Emperador affeiçoado parti|cularmente à quelle Rey de Bohemia, | e

10 dezejava muito pagarlhe o gazalhado que fa|zia a quelles seus cavalleiros. E sendo | informado tambem da fermozura, e bo|as partes de sua filha, tendo para si que lhe | não pezaria a elle com isto, detremino ${ }^{2}$ | com o parecer de todos aquelles Reys de / lhe mandar por Embaixador hũa pessoa $\mid$ grave de seu senhorio ${ }^{3}$ a congratularce $\mid$ com elle da occazião de o poder commu|nicar, e a pedirlhe juntamente que quizesse | mandar

15 criar sua filha à quella ca|za em companhia das outras Princezas, que | nella vivião para que quando fosse tempo alli ca|zassem todas com satisfação, e benepla|cito seu. [espaço] E assentando nisto despachou | logo o Escudeiro de Dramuziando cõ | avizo que senão bolisse da quella corte | athe la ser Outro recado que ficava apres|tando, e partiria logo, o que assi se fes, | porque o Emperador dezejava aquillo tãto || [241r] que não descançou athe que vio posto a ca|minho hũ Duque honrrado, e velho, seu | vassallo, com hũa grande caza, e hum | grande prezente, que por elle Mandava | a ElRey Vincesláo, escrevendolhe na | conformidade que temos dito com todos | os encarecimentos que hũ dezejo grande | costuma descobrir a quẽ se aconcelha | com elle.

Partido pois este Embaixador | comessando a publicarse entre as Prin|cezas a

25 comissão que levava, começou tã|bem a haver novos alvoroços entre ellas, | porque não havia algũa tão confiada a quem as novas daquella hospeda deixas|sẽ izenta de algũ temorzinho (pello me|nos daquelle aplauzo geral, que ordinaria | mente as couzas novas conceguem) | riãoce ellas entre si juntas, e mostravão|ce contentes, mas cada hua concigo | não vivia mui quieta. [espaço] Merendan|do estavão todas hũ dia alegres, e rizo|nhas, quando Carmellia que não perdera nũ|ca a natural vaidade, que sempre teve, |

\footnotetext{
${ }^{1}$ Este traço provavelmente é acidental, pois não se justifica no contexto.

${ }^{2} \mathrm{~B}, \mathrm{C}$ : detreminou.

${ }^{3}$ Palavra corrigida pelo copista.
} 
lhes disse: [espaço] Riámos, e folguemos por | vida vossa em quanto temos tempo, porque ei|medo que como vier Fidellia que nenhũa | das que aqui estamos viva mais hũ dia. | Nos ca todas tres, respondeu Flerida, muito | havemos de viver com a ajuda de Deus, que || [241v] pois vos nos não tendes mortas, não nos | poderá ja nimguem tirar o 35 gosto da vida. | Mas a vós não sei o que vos acontecerà, | porque estais peor costumada. [espaço] Boa graça | he essa, replicou Valeriza, como Carmel|lia não ha nenhũa no mundo, senão so | Carmellia. O dó ei eu daquão ${ }^{4}$ enleada | a coitada de Fidellia se hade achar quando a | vir. [espaço] Sabeis como eu Entendo isso, disse | Gridonia, que pella obrigação que Pavorante | e Almourol lhe tem, determino odia | que ella vier porvos 40 mascàrras a vos outras | todas porque a pobre mulher não morra à | vossa vista subitamente $^{5}$. Dai a o di|abo, tornou adizer Carmellia, que estas no|vas que de la vierão não nos chegarão | por Bohemios mal praticos, se não | por Dramusiando que nos tẽ visto a todas | e que vio nossas mãis em melhor tẽpo, | e assim me parece que temos mais que | temer do que cuidamos. Tornava Vale|riza a querer confialla outra ves, mas |

45 Flerida atravessandose empuxou a cõ | as Mãos dizendo: [espaço] Ora verdadeiramente | Valeriza que sois a mais forte mulher que | nunca vi. Se nos Deus fas mercé de nos | vingar de Carmellia no ter atodas por tão | feas, com se persuadir a si mesma que po|de haver outra mais fermoza quereis | vos forçadamente que perca ella esta || [242r] oppinião? pois nunca Deus tal queira | E voltando então para a prima disselhe: | Mana 50 tendes muita razão porque Deus que vos | a vòs fes, fes tambẽ a Fidellia. Possivel | serà que seja ella mais fea, mas bem pode | ser que seja tambem mais fermoza. [espaço] |O que vos haveis de fazer quando isto assim accon|tessa, he conformardesvos com elle, como | nos fazemos com vosco, que por vida minha | que quando eu estava em Londres, que tambẽ cui|dava que matava a braza ${ }^{6}$. Fostes vós alli ter, | vivos, dezenganeime, 55 verdade he que me | pezou, mas que quereis que fizesse? haviame | de enforcar? [espaço] Carmellia então socega|damente lhe respondeu: Assenta tão | bem, Prima, essa

\footnotetext{
${ }^{4}$ A lição de B é igual a de A; a de C parece ser de quão, mas o trecho está quase ilegível.

${ }^{5}$ Gridônia diz ironicamente que cobrirá o rosto das amigas, para que Fidélia não morra de susto diante da beleza daquelas princesas. A obrigação que Pavorante teria com Fidélia diz respeito ao fato de ter sido ela a interromper o combate entre ele e Primaleão, evitando a morte de ambos. Quanto a Almourol, não se percebe qual seria sua dívida para com a princesa. A palavra máscara, que em A é grafadamascàrras, nos outros códices aparece como mascaràs (B) e mascaras (C).

${ }^{6}$ A expressão matar a braza é registrada por Bluteau, que a dá como sinônimo de "apagar", embora neste contexto ela evidentemente significa "superar a todos, ser inigualável". Nesta passagem, Flérida refere-se ao primeiro encontro com Carmélia, narrado no cap. 03.
} 
confiança em vos, que | se a accompanhareis com hũa pouca ${ }^{7}$ de $\mid$ mais singileza, eu fora a que com inve|ja me enforcara, mas não vos posso ne|gar que sendo muita a que tenho a o vosso pa|recer, he mui pouca a que me fica do que | quereis parecerme. [espaço] $\mathrm{E}$

60 não sei em | verdade com que calidades mereço tirarẽ|me a qui sempre de rosto, porque sendo | parenta, e amiga de todas, e vendo em | todas o que dezejo para mim, alegrome tã|to de que cada hũa o tenha, que me não pos|so deixar de ter por mal paga da obri|gação em que esta vontade vos mette. | Mas sou Mofina, e provera a Deus que || [242v] cahira eu a o Mar quando estive preza antes que | tornar aqui a exprimentar

65 agravos de | quem os não mereço. [espaço] E com isto tra|balhando de encobrir algũas lagrimas | que appontavão, quis levantarce. Mas | Valeriza, que verdadeiramente era sua | Amiga, estranhandolhe aquella demõs|tração não lhe concentio. E indose pre|parando para lhe falar tão gravemente | como o cazo a seu parecer pedia, cha|marãonas de preça para hũa Estranha A|ventura, que á corte trouche hũ cava|lleiro Estranho, da qual, e do 70 successo do | Embaixador que foy a Bohemia daremos | conta no capitulo proximo.

\footnotetext{
${ }^{7}$ A concordância entre pouca e singileza é atestada também em B e C.
} 


\section{Capitulo 76}

De certa Aventura que trouche |Á corte hũ cavalleiro | Estranho, e do que nel|la se fes.

Ao tempo que as Princezas estavão | na converçação, e historias que contámos | estáva o Emperador, ElRey D Duar|dos, e os mais juntos tambem fallando | no que Dramuziando escrevera de El|Rey Vincisláo nas perfeições de sua filha || [243r] E em se viria elle em mandalla á | quella corte. ${ }^{1}$ E quem poderia ser aquel|le Cavalleiro do Sol, de quẽ tantas | Maravilhas se contavão. [espaço] E affirman|do cada hũ o que acerca de qualquer des|tas couzas lhe parecia, mas todos con|formes louvavão em Dramuziando a | gentileza que fizera em se offerecer à | guarda do valle. E estando assim pra|ticando nisto, entrou pella porta hum | cavalleiro grande, e bem feito, com | continente grave, e airozo, armado de $\mid$ huas armas pardas, lavradas de huns la|vores meùdos pardos tambem, mas de cor $\mid$ mais aberta, com que ainda que tristes não | deixavão de parecer

15 engenhozas, e ga|lantes. No escudo em campo de prata | hũas luas mingoadas, e outras cheas | com hua letra que dizia: He nature|za. [espaço] Mui olhado de todos com passo | como fica ditto, confiado, e vagarozo, sẽ | tirar o Elmo da cabeça, atravessou o ca|valleiro a salla a the chegar a o Estrado | a onde o Emperador tinha a sua ca|deira, e alli fazendolhe hũa grande re|verencia, se sentou em giolhos, e ti|rando a Manopla

20 direita quis tomar|lhe amão para beijarlha, porem o Empe|rador que nunca a dava a alguẽ que não | conhecesse, parecendolhe mui bem a || [243v] aquelle cavalleiro, puchoulhe pella mão e | fello levantar, dizendolhe que antes de o ouvir | e conhecer não faria mais que aquillo com | elle. [espaço] O Cavalleiro então disse.

De parte mui remotta venho se|nhor buscar esta corte como fonte Origi|naria de todas as perfeições, a que o prezen|te tempo, e o passado soube o nome, para | publicar nella hũa queixa com que vi|vo de certa Dama, a quem servi alguns | dias, e dequem recebi mui dezigual sa|tisfação do que meu amor lhe merecia. | E a publicar juntamente a que eu thomei des|te agravo de que rezultarà por ventura re|ceber outros das mãos de vossos cavalleiros | que damnem mais ao corpo, posto que se não | sintão tanto nalma.

\footnotetext{
${ }^{1} \mathrm{O}$ sentido da próxima frase exige que este ponto final seja desconsiderado.

${ }^{2}$ Palavra corrigida pelo copista: a letra $q$ foi escrita sobre um $d$.
} 
30 [espaço] Mas porque isto he | Materia emqueas ${ }^{3}$ Damas poderão ficar | intereçadas, folgara que me ouvira Vossa Magestade | diante da Senhora Emperatris, e das desta | caza.

Dias havia que à Corte não tinhão | vindo Aventuras de semelhante porte, e assim | alvoraçandoce muito todos os que ouvirão o Cava|leiro, e o Emperador tambem,

35 como elle herda|ra de seu Pay com os Estados abenignidade | sem nenhũa detença mandou recado à Emperatris que hia la com hua Aventura que de novo | era chegada. $\mathrm{E}$ a Emperatris mandou cha|mar logo as Princezas como fica ditto, sem || [244r] cujas prezenças nada podia ser ornado, e mã|dando avizar o Emperador que o $\operatorname{aguardava}^{4} \mid$ elle, com o cavalleiro estranho, e todos os Reys | que oaccompanhavão quando chegou se foi para ella ${ }^{5}$, e la depois de sentados em seus lugares | hũns, e outros, o Cavalleiro apos grandes ceri|monias, e cortezias, começou a fallar com a $\mid$ Emperatris desta Maneira.

Patente me he muito alta emuito po|deroza senhora quam pezada couza parece|rà às Damas, e ainda a os Cavalleiros de boa | oppinião que procure algũ thomar satisfação 45 | dos agravos, que recebeu de algũa ${ }^{6}$, a quem tenha $\mid$ servido, mas assim como são varios os rostos dos | homẽns, são tambẽ varios seus juizos, eos cazos. | E de ordinario acontecẽ muitos que senão compre|hendem em toda a pluralidade das leys, que para os | regularem estão feitas. Quais sejão os que eu te|nho recebido de hũa senhora a quem tenho ser|vido muito tempo, quais as razões que havia para que $\mid \operatorname{mos}^{7}$ não fizesse, direi só em hũa palavra, | e he, que sendo eu por ventura alheio, me furtei | para me entregar a ella, e sendo ella livre depois $\mid$ deme ter aceitado, seme furtou amim para fa|vorecer a quem tambẽ por ventura era cati|vo de outrem ${ }^{8}$. Se isto se ponderasse bem | não duvido de que não faltaria comizeração de | minha pena, mais que escandalo de minha | vingança, na qual despois de cuidar muitos dias $\mid$ tendo $^{9}$ sempre prezentes novos

\footnotetext{
${ }^{3}$ A junção destas palavras é resultado de um erro do copista, que inicialmente havia saltado o que ou o $a s$. 4 A lição "o aguardava" (comum a A, B e C) parece indicar que a Imperatriz, avisada do caso, chegou primeiro à sala onde o estrangeiro faria seu desafio, e ali permaneceu aguardando que o Imperador chegasse com os outros reis.

${ }_{6}^{5}$ Entenda-se: o cavaleiro estrangeiro se aproximou da Imperatriz Gridônia.

${ }^{6}$ Elipse do termo dama.

${ }^{7}$ A palavra mos provavelmente se refere a agravos.

${ }^{8}$ Isto é: o cavaleiro, que já estava comprometido com outra mulher, abandonou sua amiga em favor daquela de quem agora se queixava, pois sua nova senhora fizera o mesmo que ele, trocando-o por um novo servidor (que, por sua vez, também já era cativo de outrem). Trata-se, portanto, de uma sequiência de infidelidades amorosas.

${ }^{9}$ Palavra corrigida pelo copista.
} 
55 motivos de dores || [244v] me rezolvi em thomalla, porem não logo de | que maneira seria, mas não consentindo | outra o amor que lhe tive, nem consentindo o q que todos nos temos a nòs ficar sem ella, vim | a eleger por vingança, não so servilla, e ado|ralla como deantes, mas a determe dous me|zes nesta corte, e provar em justas, deque logo | direi as condições, dandome o Emperador | licença que so não dar hũ cavalleiro cauza 60 com | que hũa Dama justifique os agravos que lhe fas he | a maior satisfação que della se pode thomar ${ }^{10}$. $\mid$ E se Ouver alguem a quem isto pareça tão ar|rezoado que não se possa negar, bem sei que me | não faltarão muitos que me não concintão af|firmar que hũ retrato que estarà á porta de hũa | tenda minha he amais fermoza couza que se | possa ver, sendo juntamente a de que mais se deve fu|gir. [espaço] As condições se Vossa 65 Magestade e o Emperador | me derem licença para a assistencia que digo, São | que nenhũ cavalleiro poderá fazer batalha das | espadas comigo se ambos não viermos ao | chão, nem justar mais que tres encontros, e que se | me não derribar delles, que não possa tornar a | justar aquelle dia, nem obrigallo eu tambem | a nenhũa outra couza, e que o que me derribar | na justa, ou vencer na batalha, fique senhor da $\mid$ minha tenda, e 70 dos despojos que nella se acharẽ | juntamente com os escudos dos vencidos se | Ouver algũns, com hũas firmas que farão nelles | os que o forem de que não deixarão nunca de servir || [245r] suas Damas por mais ingratas que lhe sejão ${ }^{11}$.

Vedes aqui senhora o fim de mi|nha demanda, se agora vos parecer darme licença | irmehei a continuar nella athe que venha quẽ | me tire da obrigação, ou da vida, com quem | ella em mim parece que está unida.

Muito se alvoroçarão as Damas, e | muito os Cavalleiros com aquella Aventura. O Emperador deu licenca ${ }^{12}$ alegre mente. Ea Em|peratris pondo os olhos em Graciano respondeu | ao Cavalleiro: Eu vos prometto amigo que não | deveis ser Frances porque assim sabeis obrigar cõ | a vingança, como com o amor ${ }^{13}$. Essa Dama | de quem vos

\footnotetext{
${ }^{10}$ Leia-se: "vim a eleger por vingança não só [continuar] a servi-la e adorá-la como antes, mas deter-me dois meses nesta corte em justas (das quais logo direi as condições, dando-me licença o Imperador) para provar que não dar um cavaleiro causa para que uma dama justifique as injustiças que lhe faz é a única e maior satisfação que de uma dama se pode ter".

${ }^{11}$ Ou seja: o cavaleiro que conseguisse vencê-lo ficaria senhor de sua tenda e dos despojos que nela se achassem, juntamente com os escudos dos vencidos, em que seus antigos donos deveriam assinar um compromisso afirmando que nunca deixariam de servir suas damas, por mais ingratas que fossem.

${ }^{12}$ Falta o cedilha.

${ }^{13}$ A crítica aos franceses pelo descaso em questões amorosas é freqüente no Palmeirim de Inglaterra, onde porventura poderiam justificar-se pela experiência e desilusão amorosa de Francisco de Morais durante sua permanência em França. O motivo da censura se repetir nesta continuação é menos claro. Observe-se que prometto tem, nesta frase, o sentido de afirmo com certeza.
} 
80 queixais não sei que razão teria | para a troca, que fes, mas sei que quanta menor for, melhor | lhe estarà a ella, porque deixarvos sem cauza | he antojo de mulheres, a que senão pode por nome | e tela, não parece que pode ser sem vos ter obri|gado com algũa couza que aventurasse por vos |que por pequena que fosse peor lhe estaria que o de | que a vos a cuzais ${ }^{14}$. [espaço] Bem vos podeis ir ao | campo ja que o Emperador tem

85 dado licença | mas olhai não vades mais escandelizado do que | vindes, e essa Dama mais justificada do que vos | no la quereis mostrar. [espaço] O Retrato folgarei de | ver, se o fiardes de mim, tornavolohei a reste|tuir de pressa. [espaço] Eu mandarei o Retrato senhora | disse o cavalleiro, e quanto a o mais que Vossa Magestade me diz | quando esta minha enemiga justificasse meu cas|tigo com minha fraqueza, inda me ficaria \|

90 [245v] devendo o gosto de lhe dar melhor cauza para | elle, do que a agora tem ${ }^{15}$. [espaço] E com isto despedin|doce foice ao Terreiro do Paço, onde ja hũns | servidores seus lhe tinhão armado hũa tenda | muito commoda, e de fermozissima obra, e la|vores, tanto que senão tinha ali visto outra me|lhor, einda senão via o que era nella mais para | ver, que erão as historias, e figuras deque por den|tro era bordada das quais adiante se

95 tratarà. | Junto della estava outra Ordinaria, em | que se agazalhava a pouca botelheria de que | então se uzava no mundo ${ }^{16}$. Alli se appeou | o Cavalleiro deixando diversas oppiniões | de suas couzas nas Damas e Princepes, que | o ouvirão, das quais logo daremos conta.

\footnotetext{
${ }^{14} \mathrm{O}$ sentido do trecho parece ser o seguinte: a Imperatriz declara não saber a razão que a dama teria para trocar o cavaleiro por outro amante, mas acredita que, quanto menor a razão, mais demonstraria a honra daquela dama. Isso porque deixar seu amigo sem qualquer razão seria vaidade de mulheres indignas $[a$ que senão pode por nome] e tê-la [ou seja: ter razão para a troca que fez] só poderia ser pelo fato de o cavaleiro ter exigido dela alguma coisa que, por pequena que fosse, poderia desonrá-la ainda mais do que a acusação que ele lhe fazia.

${ }^{15} \mathrm{O}$ cavaleiro diz que, mesmo que fosse derrotado nas justas, ainda ficaria satisfeito, porque sua dama teria motivos melhores dos que até então para queixar-se dele.

16 A aventura deste cavaleiro permanecerá inconclusa nesta primeira continuação manuscrita do Palmeirim de Inglaterra.
} 


\section{Capitulo 77}

\section{Do que mais passou na corte a cer|ca da quella Aventura e do | que succedeu a Dramuzi|ando no valle.}

A algũas daquellas senhoras parecia que não se | podia achar maior fineza que a que aquelle Ca|valleiro mostrava, e nessa conformidade lhe | tinhão lastima em seus desastres, e mostravão | paixão contra a de quem elle se queixava. | Outras dizião que era aquella demonstração nas |[246r]cida mais de vaidade, que de amor, porque quando o el|le tivera de tantos quilates, que o obrigara a a|malla offendido em couza tão

10 sensitiva, primeiro o | ouvera de obrigar a não publicalla pello mun|do por dezarrezoada a ella, e a si por affeiçoado; | porque amor (dizião as que sustentavão esta oppi|nião) não he outra couza senão hũa negação | da vontade propria para que livremente se em|pregue na couza amada, procurando a | the com o dispendio da mesma vida as con|veniencias alheas. [espaço] E que não se podendo negar | que aquelle cavalleiro

15 ganhava oppinião e cre|dito no que de si dizia ficava claro que hũa, e ou|tra couza perdia ella, e que ja aquillo era atten|der elle mais ao que a si lhe convinha, que a o que à | outra lhe importava, o que se devia julgar ma|is depreça poramor proprio, que alheio. Isto pas|sava entre aquellas Princezas, e Carmellia res|pondeu a Valeriza, que era a Authora deste discur|so: [espaço] Bem poderá ser Valeriza que haja no amor | deste

20 Cavalleiro imperfeições, mas que deixe de | haver amor se he verdade o que conta não me pa|rece por certo, e não tenho por pequena ditta $\mid$ que as tenha porque a ser de outra maneira que vos | parece a vós que faltaria mais que apedrejarem | a mulher ${ }^{1}$. [espaço] Flerida que não deixava passar | occazião de se atravessar com Carmellia ou|vindolhe aquillo respondeulhe: Segundo isso | aquem amasse com essa perfeição que dizeis | não

25 se pode deixar de responder com agradeci||[246v]mento ${ }^{2}$. Por certo ouvi affirmarem a regra ( (lhe disse Carmellia) quanto á geralidade da natu|reza, mas quanto a mim deve ter mais, e menos | excepsões, quantos mais ou menos forem os sugei|tos, que apropria

\footnotetext{
${ }^{1}$ Ou seja: "Bem poderá ser, Valeriza, que haja no amor deste cavaleiro [algumas] imperfeições, mas que deixe de haver amor, se é verdade o que conta, não me parece certo; e é bom que as tenha [isto é, que o amor do cavaleiro tenha imperfeições], porque se não fosse assim, segundo vosso parecer, só faltaria apedrejarem a mulher”. A observação de Carmélia não se adequa bem aos argumentos de Valeriza, pois esta não estava acusando a dama, e sim o cavaleiro de não amá-la verdadeiramente.

${ }^{2}$ Flérida busca defender seu irmão, D. Duardos, procurando convencer Carmélia a tratá-lo com menos rigor.
} 
naturezá $a^{3}$ privilegiou por sin|gularidades, porque claro està que aquem tudo he | divido que não se pode obrigar de couza algũa ${ }^{4} \mid \mathrm{E}$ nesta materia me parece que seria perigoza $\mid$ 30 couza fallar muito [espaço] Etornando a continuar | com Valeriza acrecentou apertandolhe hũa | mão que lhe tinha thomado, E no que me rezolvo | he (prosupondo como tenho ditto que este homẽ | nos não engana) que não se passará elle a ou|tra Dama por qualquer agravo, quando por aquella $\mid$ thomou estoutro caminho ${ }^{5}$. [espaço] A Valeriza lhe | pareceu misteriozo aquelle acto, e de todo o jul|gara por tal se não tivera 35 entendido que Car|mellia peccava mais de obstinada, que de va|ria, e toda via lhe respondeu appertandolhe | tambem a mão: Não sei se nos està bem | sabermos muito, como vos dizeis, destas couzas, | porque ainda que seja por especulação, o muito espe|cular do que não convem á pessoa mostra pello | menos curiozidade escuzada ${ }^{6}$; porem amim | me parece que quem se muda que não amava, co|mo tambem quem não 40 sente, e assim me fi|caria amim sospeitozo oamor que que $\tilde{e}^{7}$ se mu|dasse, como o de quem não sentisse, porque se hũa | couza argue coração leve e facil, argue a outra | animo máo elivre ${ }^{8}$. [espaço] Ficava a questão agora $\|$ [247r] de que maneira hade ser o sentimento, de que | cauzas pode nascer, que demonstrações se ha|vião fazer delle, e a que havia de obrigar quẽ | o tivesse, mas hei medo que se me meter neste / discurso, que venha contra aminha primeira propos|ta a justificar a empreza deste cavalleiro. | Eassim sera Melhor que vamos ver o Terreiro | e se ha ja nelle quem o comesse a Entreter na | quillo que vem buscar. [espaço] Os cavalleiros tãbẽ | tinhão differentes oppiniões, porque $e^{9}$ lhes parecia | que das partes que aquelle deffendia so a que tocava | a o parecer das damas seria a sobre que lhe não | faltarião contendas, porque nas mais não vião | 50 quem por sua vontade quizesse confessar, que | se podião thomar maiores vinganças de mulhe|res, nem que não seria bem feito servillas sẽ|pre. [espaço] Floriano toda via disse para os outros: | Em tempo me podia amim thomar esta A|ventura, que mostrara eu bem

\footnotetext{
${ }^{3} \mathrm{O}$ acento não é reproduzido em $\mathrm{B}$ e $\mathrm{C}$.

4 Isto é: a pessoa amada por suas qualidades [a quem tudo he divido] não pode ser obrigada a corresponder aos sentimentos de quem a serve.

${ }^{5}$ Leia-se: "E estou convencida (pressupondo, como tenho dito, que este homem está dizendo a verdade) de que ele não passará a [servir] outra dama por qualquer injustiça [que sua amiga cometa], quando por aquela [a dama que o abandonou] veio até aqui propor estas justas [thomou estoutro caminho].

${ }^{6}$ A afirmação não parece fazer sentido, embora esteja reproduzida da mesma forma em B e C.

${ }^{7} \mathrm{C}:$ de quem.

${ }^{8}$ Entenda-se: "porque se uma coisa [quem se muda, isto é: quem abandona sua dama em favor de outra] permite inferir um coração inconstante, a outra [quem não sente, ou não ama verdadeiramente] permite inferir um ânimo mau e pouco inclinado ao amor".

${ }^{9}$ Palavra corrigida pelo copista.
} 
depressa a este | cavalleiro, que senão pode guardar fe a quem a | não tem comigo, mas ja agora, antes me po|rei da sua parte como devem ter feito quantas | Mulheres ha nesta caza, no favor das quais | se elle deve confiar, porque ellas nos quizerão | tão parvos a todos, como este vem ${ }^{10}$. [espaço] $\mathrm{E} \mid$ com isto se forão hũns, e outros à genella ver $\mid \mathrm{a}$ gritta que no povo andava com o alvorosso | da vinda da quelle Cavalleiro, o qual tanto | que chegou ás tendas mandou hũ Escudeiro | à Emperatris com hũ panno, em que estava || [247v] tirada pello natural hũa mulher mais que dos | peitos acima. [espaço] Tinha o 60 rosto entre redon|do, e comprido de huas cores branca, e encar|nada misturadas entre si, e vivissima cada | qual dellas. A bocca vermelha, pequena, e hũ | pouco voltada. O naris direito proporciona|damente comprido. [espaço] Os olhos à flor da cara | resgados, e graves, de cor entre verde, e parda. | Muitas pestanas, e sobrancelhas, mas tão lou|ras, que as fazião parecer não muitas [espaço] A testa | liza, e não grande nem direita. $\mathrm{O}$ cabel|lo fino, e delgado, tirante abranco, e pellas fon|tes hũa penugem mais branca, e mais del|gada ainda ${ }^{11}$. E de hũa ${ }^{12}$ a outra pella rais do $\mid$ cabello se lhe fazião tantos remodoinhos $^{13}$ que | lhe occupavão quazi toda a testa. [espaço] O que | pareceu este retrato a todas aquellas Senhoras | que o virão, e aos Reys, aquem depois o Manda|rão, não dis Henrrique Frusto neste lugar | nem conta palavra algũa que sobre isso dices|sem, 70 e sem mais nem mais passa de voo | a Bohemia continuando com as justas | de Dramuziando, e cura dos feridos, pella | Maneira seguinte.

Quatro dias faltavão a o Caval|leiro do Sol, dis elle, para acabar aobrigação dos oi|to que se offerecera a guardar a quelle valle | quando chegarão a elle Pavorante, e seus compa|nheiros. Do quinto se passou a maior parte | no que temos contado, e no fim

75 delle se foy || [248r] Dramuziando continuar aquella assisten|cia. [espaço] Ao sexto á tarde não faltarão justas | porque algũns cavalleiros da corte se quizerão | exprimentar com elle tendo por grande | gloria serem seus vencidos, e com essa se fica|rão. Assim passou tambem o setimo, e a o | Outavo estando ElRey, a Raynha, e sua filha | nas

\footnotetext{
${ }^{10} \mathrm{O}$ caráter donjuanesco de Floriano quando jovem justifica este comentário, que contraria frontalmente a idealização amorosa comum às novelas de cavalaria e aqui representada sobretudo pelos príncipes D. Duardos e Primaleão.

${ }^{11}$ Trata-se da mais completa descrição física de uma personagem na obra. Nariz direito significa "nariz reto"; a expressão à flor de, de acordo com Bluteau, significa "ao nível, na superfície" (relativa a olhos, como é o caso aqui, deve indicar olhos vivos e grandes, não fundos); a expressão olhos rasgados indica olhos "grandes, bem abertos da natureza". Desta descrição, o único aspecto incompreensível é o que quer dizer bocca hũ pouco voltada.

${ }^{12}$ Palavra quase ilegível devido à letra do copista; a lição apresentada é a de B e C.

${ }^{13} \mathrm{~B}$ : remoinhos; C: redemoinhos.
} 
tendas por honrrarem a Dramuziando, | e mui alegres todos, porque tinhão sabido que os

80 fe|ridos estavão ja restetuhidos a seu Acordo, e | as Donzellas se mostravão mais contentes, | Antes hũ bom espasso que se o dia acabasse trou|xa ${ }^{14}$ a ventura por alli tres cavalleiros juntos | que na riqueza das armas, e na maneira das | pessoas, mostravão ser estranhos, e de grão pre|ço, apos os quais chegou logo outro por dif|ferente parte com as mesmas apparencias | se não que parecia mais corpulento, e robusto. | Este pois 85 juntandoce com os tres salvarão|ce todos cortesmente, e tras isso hũ dos $\mid$ tres companheiros, que ja vinhão informados | do que alli passava, quis informar tambem | aquelle cavalleiro, e perguntoulhe se detremi|nava arriscar na quelle cazo sua pessoa? | Dias ha que caminho a isso, respondeu o outro, | mas pois vos chegastes primeiro razão será que | sejais tambem os primeiros no perigo delle, e se | for na honrra não me 90 contentarei pouco | por este breve espaço que ha que estamos juntos. | Dramusiando os tinha ja visto, e posto a $\|$ [248v] cavallo estava esperando por elles dezejozo de | mostrar a Fidellia que não fazia alli muita fal|ta o cavalleiro do Sol. [espaço] Os companheiros | depois de agradecerem a o Outro o comme|dimento com que lhes respondera, concerta|rãoce todos nas cellas, e hũ delles com a lan|ça baixa remeteu a Dramuziando,

95 que ja | partia para elle, e encontrandoce ambos em | cheio o cavalleiro Estranho quebrandoa em $\mid$ muitos pedassos no Escudo de seu contrario | não lhe fes padescer outro algũ danno; porẽ | Dramusiando encontrou a elle demaneira | que o fes fazer hũ dezairozo reves, perdendo | ambos os estribos, mas comtudo passou a ca|vallo por diante, e tornanto ${ }^{15}$ a thomar outras | lanças, tornarão a partir hũ para o outro, e | desta 100 segunda ves perdeu Dramusiando hum | estribo, e torceuce qualquer couza na cella. | Mas o Estranho veio a o chão com bem gran|de desacordo. [espaço] Não tardou outro de seus cõ|panheiros a querello vingar, e do mesmo mo|do depois de passarẽ duas carreiras tambem | lhe teve companhia, deixando Dramuzian|do com pouco gosto daquellas victorias porque | não forão havidas tão levemente, que lhe não | custassem revezes, e 105 perda de estribos. [espaço] $\mathrm{O} \mid$ terceiro se pos no posto, e foy tal a pressa que | teve para vingar a seus companheiros, e tal a | que a raiva deu tambẽ [espaço] Dramuziando, que | ambos errarão os encontros, e topandose ẽ $\|$ [249r] cheio com os corpos, e cavallos ${ }^{16}$, foi tal a pan|cada, que o de Dramuziando ajoelhou, e elle | esteve para saltar fora

\footnotetext{
${ }^{14} \mathrm{~B}, \mathrm{C}$ : trouxe.

${ }^{15} \mathrm{~B}, \mathrm{C}$ : tornando.

${ }^{16}$ Palavra corrigida pelo copista.
} 
cuidando que lhe cahia, | mas dandolhe rijo com as esporas, fello to|da via ir por diante 110 deixando seu contrario | estirado no campo com o cavallo morto, e | elle pouco menos. [espaço] O cavalleiro, que viera | so inda que via os outros no chão, não deixava | de os ter em muito, porque a elles não os conhecia | e de Dramusiando na estalagẽ lhe tinhão | ditto quem era. Elles sós erão os que se desesti|mavão, porque ainda que tambem conhecião | Dramusiando, fiavão tanto de si, que inda| lhes parecia que perdião mais no

115 dezengano |que nas quedas, e com este descontentamento | os deixaremos, por dizer o com que ficou o outro | que faltava. 


\section{Capitulo 78}

\section{Da terrivel batalha, que Dramusiando | teve com aquelle cavalleiro, e de | como no cabo se conhecerão. | E de como o Embaixador | chegou a Bohemia.}

Daquelle Cavalleiro dis agora a Historia | que tanto que vio acabada a justa dos tres compa|nheiros com o successo, que no capitulo passado \| [249v] temos visto, concertandoce na cella, e com|pondo primeiro a pessoa, vendo que o aguardava | Dramusiando, foice para elle ao maior correr | que o cavallo opodia levar, e encontrandoce $\mid$ ambos em cheio, despois de quebradas as lan|ças, topandoce os cavallos

10 com as cabeças | ambos vierão mortos ao chão ficando Dra|muziando tão embaraçado com o seu, que bẽ | pudera o cavalleiro que logo se pos em pe, fe|rillo muito a seu salvo, mas não so o não quis | fazer, antes tirandolhe o cavallo decima o | ajudou alevantar, e elle depois que esteve em pe | arrancando da espada disse para o cavalleiro: | Pezame muito senhor de me parecerdes tal que | vos não poderei pagar a cortezia que me

15 fi|zestes senão a tempo que o não possais agra|decer, porque sospeito que anão querereis antes. | Mas ainda que ter a honrra empenhada na | guarda deste valle me obrigue a que o não fassa | logo, entendei, que em vendo occazião procura|rei mostrarvos quão obrigado me tendes. [espaço] | E como isto disse, sem esperar reposta comesou | a carregallo de tantos, e tão pezados golpes, que | era necessario ao cavalleiro grande fe

20 para crer | contra o que exprimentava, que não nascião a | quellas obras que recebia das mãos de Dramusi|ando, mas da vontade do mesmo Dramuziando. | O cavalleiro tambẽ não tinha as mãos Ocio|zas antes as meneava de maneira que por | hum grande espaço não se conhecia quem || [250r] ficaria peor livrado daquella differença. | Assim andarão ferindoce com grande | espanto de quem os via, e com grande | paixão, que ambos de si

25 tinhão principal|mente Dramuziando, que com qualquer expe|riencia daquellas se hia desconfiando de | seu antigo valor. [espaço] Passadas finalmente | duas horas que a batalha durava semdescança|rem nunca, correndolhe o sangue por | tantas partes, que começavão ja os prezentes | a por em concideração se igualava o ri|gor da quella porfia ao da de Pavorante | com o cavalleiro do Sol. Dramuziando | que era grande Mestre de conhecer os alentos | alheios entendeu nos golpes que recebia quão | floxamente se meneavão ja os braços, que | lhes davão. Então metendo (como dizem) | as esporas em 
si, comesou a renovar a furia, | ea tempestade dos $\operatorname{seus}^{1}$ demaneira, que não | so aquem os exprimentava punhão espan|to, mas ainda aos que defora os vião. [espaço] E | vendo que o Cavalleiro queria antes morrer | que deixar de levar aquillo ao cabo, remeten|do 35 rijo a elle, poude levallo nos braços, | não o duvidando o outro muito que tambẽ cui|dava que não perderia por alli $^{2}$, mas são en|ganos de coração briozo, contra quẽ não | val senão a experiencia. E assim o vio | este cavalleiro, que não se podendo deffender | do perigo que buscara, oprimido da força $\|$ [250v] de Dramuziando, que tendoo entre os bra| $\cos ^{3}$ levantado da terra o fes abrir os | seus quazi ja desfallecido, e então lhe dis|se 40 elle: [espaço] Esta era a hora senhor cavallei|ro, que eu dezejava para vos servir em não | levar adiante esta batalha, o Sangue que | no principio della me poupastes. E | pondo o no chão, soltou o com muito comme|dimento, e cortezia. Ooutro respondeu: | Pois ainda senhor Dramusiando tendes ma|is razões das que cuidais para me concervar a | vida, e eu tambem muitas para a estimar | mais da qui por diante, porque a calidade de | 45 provarce hũ homẽ com vosco, he de ma|ior gosto, do que he de pena ficar vencido vos|so, pois que emfim não nacestes para o ser de | nimguem. [espaço] Então tirando o Elmo foi | delle conhecido, e dos outros cavalleiros, que ja $\mid$ se tinhão chegado, pello valente Ardimão | de França, com o qual tornando Dramu|ziando a abraçarce, se começou a quei|xar de querer conhecendoo que chegasse aquil|lo tanto ao cabo ${ }^{4}$. E antes

50 que parasse neste | queixume, a que Ardimão lhe respondesse, en|controu em outros novos abraços, e queixu|mes, porque logo os tres companheiros se lhe de|rão tambẽ a conhecer, osquais erão Trineo, | Arnedos, e Recindos, que seguindo as Aventu|ras divedidos despois que se partirão de Hespa|nha do castello de Braciliano, havia poucos \| [251r] dias que se tinhã tornado a ajuntar na | quelle Reyno, onde então os mais punhão |

55 a proa $^{5}$, pello acharem mais cheio de acon|tecimentos, do que os outros de Europa esta|vão naquelle tempo, e sabendo alli do que | logo se publicava a todos, que erão as ca|vallarias de Primaleão, indo a demandar | o valle das justas, entenderão ja perto | delle o que lhe tinha acontecido, e como Dra|muziando era seu sustituto aquelles di|as nellas, e rezolvendoce em justar com elle | aconteceulhes o que temos visto. [espaço]

\footnotetext{
${ }^{1}$ Elipse da palavra golpes.

${ }^{2}$ Ou seja: Dramusiando levantou o outro cavaleiro nos braços para o apertar, mas de início seu oponente não temeu este gesto.

${ }^{3}$ Falta o cedilha.

${ }^{4}$ Dramusiando começou a queixar-se de Ardimão que, mesmo sabendo que lutava com um amigo, deixou o combate chegar a tal extremo [tanto ao cabo].

${ }^{5}$ Pôr a proa significa “dirigir-se, encaminhar-se para algum lugar".
} 
60 Dramu|ziando tanto que os conheceu dobrando, como | diziamos, abraços, e queixumes, levou os to|da via à Princeza, e a ElRey, que sabendo | quem erão os recebeu com a cortezia que a | tão grandes Princepes era devida. [espaço] En|tão lhe disse elle que se ser seu cavalleiro zõ|bando obrava tão grandes extremos, que vis|se que seria onde aquillo fosse fallar de siso $?^{6} \mid$ por isso que tivesse escrupulo de fazer algũa | hora aquella

65 merce a alguem, porque seria $\mid$ sem duvida destruhido o mundo todo. [espaço] | Pello menos Dramusiando (lhe respondeu | a Princeza) não quero eu crer que zombais | vos agora, senão que amim me deveis a | gloria deste dia, por isso pondeme bẽ com | estes cavalleiros, que não estimo pouco conhe|cellos. [espaço] Então se forão todos accompanhan|doa e a ElRey a the o castello, e depois se re $\|[251 \mathrm{v}]$ colherão no Mosteiro, onde se curarão os $\mid$ feridos juntamente com Almourol, a | quem todos vizitavão com geral contenta|mento de se verem juntos, e a elle ja tão | melhorado. [espaço] E porque com aquelle dia se | acabara a guarda do valle, detreminou | ElRey que ao Outro se fossem para a cidade | tão contente com aquelles hospedes, como |o fazia ser a nobreza de seu animo, e a | estimação grande em que os tinha, porem | como Dramuziando, e

75 Ardimão não po|dião caminhar, não quis toda via bollirce $\mid$ sem elles com mais alguas esperanças de | poder ver a Pavorante, e a o do Sol. [espaço] | Ao outro dia chegando avizo a Dramuzian|do, que o Embaixador do Imperio era entrado | ja em Bohemia, foi forçozo que ElRey se | fosse para a cidade para la receber com mais | authoridade aquella personage, e assim o | fes indo todos aquelles cavalleiros que tinhão | saude 80 acompanhandoo a elle eà Prince|za, que tambem levou concigo, tão espan|tados de sua fermozura como no seguin|te capitulo nos pinta Henrrique Frusto.

\footnotetext{
${ }^{6}$ Entenda-se: é Dramusiando que se dirige a Fidélia dizendo: se quem se declarava cavaleiro da princesa por gracejo tornava-se capaz de realizar grandes maravilhas (como vencer Ardimão de França), ele não sabia o que seria capaz de realizar o cavaleiro que se dedicasse a ela seriamente.
} 


\section{Capitulo 79}

\section{Do que passou Pleonido com a | Princeza, e de como o Em||[252r]baixador chegou a o cas|tello onde os Princepes estavão.}

Acompanhando hião (dis Henr|rique Frusto) aquelles cavalleiros a Prince|za, tão admirados de couza tão fermoza | que senão foy Trineo, não houve algũ entre | elles, que anão julgasse pella maior couza que | vira. E tal era agravidade, e a compostura | de Fidellia, que sendo por outra parte muito | aprazivel, e branda, e indo fallando com | todos aquelles Princepes com amelhor sõ|bra do mundo, não ouve algũ entre elles |

10 sendo tais, e tamanhas pessoas, e sobretudo | livres, em que entrasse nem hũ muito leve pẽ|samento de a servirem como seus Caval|leiros, respeitandoa todas ${ }^{1}$ como a senhora de | tudo, e assim se encolhião para falarlhe, que el|la era a que tirava delles com aquella huma|nidade de que Deus a tinha dotado. Mas tal era $\mid$ o modo que lhes infundia no animo, o res|peito que dissemos ${ }^{2}$. [espaço] Assim chegarão à ci|dade onde forão

15 recebidos com grande | alvoroço do povo, alegre tambẽ de ver tais | Princepes entre si, crendo que algũ delles lhe | ficaria em caza, e que em qualquer que fos|se não podião deixar de de ganhar muito | Pleonido so era quem naquelle comum | contentamento se mostrava então sẽ elle, || [252v] pella falta da saude do cavalleiro so Sol | aquem estava ja affeiçoado demaneira, que | igualmente que a sua roim despozição, sen|tia ver tantos

20 Princepes na quella caza ${ }^{3} \mid$ porque como era discretto vendo Fidellia | em idade de cazar, e vendo à seu Pay na | em que vivia, sabendo juntamente que não | perdia elle nunca aquelle cuidado, bem | lhe parecia que não deixaria de lançar mão | de algũ da quelles Princepes, a o que o ajuda|va certo rumor que sobre isso ja andava no | povo, e como elle tinha assentado concigo | e cria firmemente que Primaleão adorava | a Princeza, 25 tambem por estes pensamẽ|tos tinha crido que haveria nelle callidade | em que elles não assentassem mal. Assim ven|doo naquelle tempo tão impedido para po|der tornar por si, conciderando o iminen|te perigo que corria, e quão perto a seu pare|cer ElRey estava de thomar hũa resolução | que não custasse menos que avida à quelle cava|lleiro, porquem

\footnotetext{
${ }^{1} \mathrm{~B}, \mathrm{C}:$ todos.

${ }^{2}$ Palavra corrigida pelo copista.

3 Entenda-se: Pleonido não estava contente porque, além da falta de saúde do Cavaleiro do Sol [igoalmente que a sua roim despozição], via todos aqueles outros príncipes naquela casa (e suspeitava que algum deles poderia propor casamento a Fidélia antes que o Cavaleiro do Sol estivesse em condições de fazê-lo).
} 
elle dezejava offerecer a sua | a todos os tormentos que na indignação de | Fidellia tinha certos, antes quis aventurar|ce á experiencia, que deixar de lhe fallar de | algua maneira nelle. E assim depois que | ella descançou algũas horas, vendo a à tar|de so, pondoce de giolhos e derramando | algũas lagrimas comessoulhe a falar des|ta maneira.

|| [253r] Como pode senhora alegarvos | serviços para vos obrigar com elles, quem o $\mid$ dia que não puzerdes nelle os olhos, se rezol|verá em menos ainda que cinza? ${ }^{4}$

35 E assim | para amerce que vos quero pedir não vos ponho | diante, senão as muitas que sempre me fizestes | que he aminha maior abonação, e esperação ${ }^{5}$. | Bem sabeis senhora como com zombarias, | e travessuras me inclinastes ao Cavalleiro | do Sol, que me amim de antes aborrecia tanto. | Parece que foi isto força da minha Estrella | que não poude sofrer verme tão adiante | como me tinha o servirvos ${ }^{6}$. [espaço] Mudeime de | Maneira, 40 que fóra de vos servir á vós, nenhũa | couza ha no mundo porque deixe de o servir | a elle. Para que vos eu sirva sem a particu|laridade, e entrada, com que costumava fazel|lo, o dia que me isto faltar, quando eu for tão torpe | que defenda o viver do sentimento, pello me|nos não o serei tanto, que deixe de me matar|com minhas proprias mãos, e para que eu não | perca sem culpa o lugar, que me vos destes sẽ | merecimento,

45 não vejo melhor caminho | com as couzas que por esta cidade andão pu|blicas, que dardesme agora licença para que me | torne a Valde Flores servir a o Cavalleiro |do Sol, e que me vá com elle se viver, e quando | não ficarmehei na quelle Mosteiro fazẽ|do penitencia dos erros que em vosso ser|viço tenho cometido ${ }^{7}$. [espaço] || [253v] E com isto derramando muitas mais lagri|mas não poude ir pordiante. [espaço] A Prin|ceza a o

50 principio bem cuidou que aquillo | serião algũns mimos de valido, ou des|contentamentos de Ennaclia, porem | vendo das razões que foy ouvindo, que tinhão | o ponto mais alto, não se affirmando a que | fim se encaminhavão, esteve hũ pouco | confuza com os olhos nelle. Emfim, como | o estimava tanto, e como de si não tinha

\footnotetext{
${ }^{4} \mathrm{O}$ verbo rezolver, neste contexto, significa "dissolver" ou "converter", significados atestados pelo Vocabulario de Bluteau.

5 Há mancha sobre abonação no manuscrito; a lição foi confirmada em B e C. Quanto ao termo esperação, trata-se de evidente erro do copista; B e C apresentam esperança.

${ }^{6}$ Leia-se: "Parece que isto foi inclemência do meu destino, que não suportou ver-me tão favorecido da fortuna como estava com o servir-vos".

${ }^{7}$ Entenda-se: Pleonido diz que o dia em que lhe faltar oportunidade de continuar a servir a princesa com a intimidade e liberdade costumeiras, ele irá matar-se com as próprias mãos. E acrescenta: já que, de acordo com rumores que ouvira, isto certamente acontecerá, ele pede licença à princesa para ir ao Vale de Flores e lá permanecer a serviço do Cavaleiro do Sol, ou então ir ao mosteiro, onde fará penitência por seus erros. Em todo este trecho, não conseguimos entender precisamente a passagem que defenda o viver do sentimento (linhas 42-43).
} 
te|mor algũ, quis entender melhor aquellas | couzas, e disselhes ${ }^{8}$ : [espaço] Ora Pleonido,

55 se a|pos fallar agora de sizo comvosco, e ouvir|vos fallar a vos tambẽ de sizo, vos ficão du|vidas de minha vontade, tão enganada | ficarei com o que de vos cuidava, como o vos | deveis de estar comigo. [espaço] Não sei que incon|venientes haja para vos não fazer amerce | que costumo, por que nem vejo em que a tenhais | desmerecido, nem о que acerca disso se possa | dizer pella cidade. Folgara que mo dices|seis, e folgarei tambẽ 60 que tenhais vos antes | razão de viver desconfiado, que não que me fi|que ella de o estar de vós, porque demelhor | vontade sofrerei repreheções do que as darei ${ }^{9}$. | Estava o Enano detreminado e rezoluto, | e inda que aquellas pallavras a todo o bom ju|izo podião ser temerozas, elle lançando | tudo detras das costas ${ }^{10}$ lhe respondeu [espaço] | O que ouso $^{11}$, senhora, he que vosso Pay vos manda \| [254r] a Constantinopla, e que isto

65 esperão a | qui os Hospedes, que de novo tem vindo, e que / O mesmo vem negociar o Embaixa|dor, que se espera. [espaço] Ora vede vos se naquel|la corte entre o embarasso de tantas Prin|cezas, e Damas, como dizem que ha nella | podereis vos ter hũa hora de enfadamento | em que vos lembreis de me ouvir, e vede | não o fazendo como poderei eu viver, ou | como será razão que viva? [espaço] A Prince|za ficou admirada do que o

70 Enano the dizia / porque fallando seu Pay com ella sempre / em todas as materias, naquella lhe não | tinha ainda fallado. E cuidando nisso | não achou em si a vontade mui alhea | da quelle caminho, porem parecendolhe que | serião juizos do povo, e desassombrada | hũ pouco das lagrimas de Pleonido disse|lhe rindo: [espaço] Bem vos entendo, lestes | ja a Choronica de Amadis de Gaula | quereis ser escudeiro do 75 Cavalleiro do | Sol, correr o mundo, ver as Damas delle, e | as Aventuras; e acharavos razão seme não | dissereis que havia eu de fazer jornada, por|que tambem nella se pode satisfazer o ap|petite de caminhar ${ }^{12}$. Eemfim senhor quando | as couzas se não ande prevenir, não he ra|zão que se adevinhem. O Cavalleiro do | Sol está ainda em estado

\footnotetext{
${ }^{8} \mathrm{O}$ correto aqui seria lhe. $\mathrm{B}$ : lhes; $\mathrm{C}$ : ilegível.

${ }^{9}$ Fidélia prefere que o anão viva desconfiado dela ao contrário, pois prefere ser repreendida por Pleonido q queixar-se dele.

${ }^{10}$ A expressão lançar às costas não é registrada por Bluteau. De acordo com o contexto, seu sentido deve ser "assumir uma responsabilidade ou um risco".

${ }^{11} \mathrm{~B}$ : ouso; C: ouço.

12 A observação, que atesta a fama do Amadis de Gaula como modelo ou principal representante das novelas de cavalaria, significa o seguinte: Fidélia insinua que Pleonido, estimulado pelo gosto das aventuras cavaleirescas, dizia aquilo apenas porque gostaria de se tornar o escudeiro do Cavaleiro do Sol; a princesa só não concorda com o fato de ele ter dito que ela também deveria viajar (fazer jornada: pois Pleonido dissera que o rei avaliava a possibilidade de mandá-la para Constantinopla), porque com a simples leitura do Amadis de Gaula já podia satisfazer o desejo de conhecer o mundo.
} 
que nem vos ha | Mister a vós, nem vós a elle, e eu estou || [254v] em Bohemia tão

80 vossa amiga como | sempre, porem mais sospeitoza hum | pouco. [espaço] Não me parece mal que va|des à menhã A o Mosteiro, que vejais | Dramuziando, e que saibais da saude | dos feridos, e em verdade vos digo | que vos de mui boas alvisaras se as no|vas forem boas. [espaço] E nesta materia | não temos mais que fallar, porque me | colhereis algũa ves tão aborrida, que vos | pareça mais pezada ainda que Enna|clia, e 85 então teremos tudo perdido. | E despedindo o com isto, ficou o Ena|no com toda sua agudeza sem saber | detreminar o modo de que ella ficava | com elle, porque assim sabia Fidellia | Moderar, e temperar suas acções | que não se lhe conhecia a vontade | em nenhũa dellas. [espaço] E indosse a o | outro dia ao Mosteiro absorto na espe|culação de suas duvidas, achou ja Dra|muziando levantado, e Ardimão | tambem inda que fraco, e

90 Almourol | da mesma maneira. E todos alvo|raçados esperando que aquella noite | chegasse alli o Embaixador, que veio | com grande ostentação, e caza, e foy | recebido da quelles cavalleiros, que depois | de deixarem ElRey na sua voltarão | logo ao Mosteiro com grãde gosto e || [255r] cortezia. Equerendo elle fazer a o | outro dia sua jornada e entrada | ElRey lho impedio, mandando o vi|zitar pella menhã, e rogarlhe que

95 des|cançasse. E ficando assim concerta|do a o outro dia entrou o Embaixa|dor da maneira que veremos. 


\section{Capitulo 80}

Da Entrada do Embaixador | na cidade, e de como EIRey de|pois de o ouvir deu conta á | Princeza do aque vinha, do | que lhe ella respondeu, e | de como se declarou | sua jornada para | Constanti|nopla.

Chegada pois a hora que se tinha | assinado para a Entrada do Embaixa|dor, elle accompanhado de Dramusi|ando, Recindos, Arnedos, Palmeirim | Frenellio, Belcar, Almourol, e Ardi|mão ${ }^{1}$, se foi á cidade aonde ElRey o | recebeu com toda a Magnificencia | e apparato, querendo Mostrarlhe | tambẽ sua grandeza, e depois o ||

10 [255v] levou á Raynha, e á Princeza, que a | quelle dia guardou para assombrar a os | Gregos com todas suas Helenas ${ }^{2}$. E | não o ficando pouco o Embaixador | depois das ordinarias couzas que lhes dis|se a todos da parte do Emperador da | Emperatris, e das Princezas, prezentou|lhes as pessas que lhes trazia. Despe|diose, e foice agasalhar em hũ quarto | dos Paços, que para elle, e para todos aquelles | Princepes ElRey tinha mandado

15 con|certar, onde porque o Embaixador não | queria perder tempo deu logo conta a | Dramusiando da commissã $\tilde{a}^{3}$ que trazia | ordenandolho assim o Emperador, e que | em tudo se regulasse por seu parecer, e | Conselho. [espaço] Dramusiando que tam|bem tivera carta sua particular em que | lha dava ${ }^{4}$ daquelle seu intento, inda que o |approvou muito, não deixava de lhe | parecer difficultozo pello amor que ElRey | tinha a sua filha,

20 e pella idade em que | estava, cuidando que o mesmo seria a|partalla de si para Constantinopla, que | apartarce della para o outro mundo; po|rem pedindo audiencia a o Outro | dia, o Embaixador, e Dramuziando | entrarão a ElRey, e propuserãolhe a | Matteria a pos lhe darem hũa car|ta de crença na conformidade que o $\|$ [256r] Emperador ordenava. E ElRey que | tinha entendido que aquillo era o que | mais convinha á honrra de sua filha, | e á utillidade de seus vassallos, vendo | que guiava

\footnotetext{
${ }^{1}$ Aqui há uma incoerência em relação ao final do cap. 71, onde o narrador declara que, depois de se oferecer para continuar a guardar o vale (o que decepcionara os cavaleiros mancebos, que tinham o mesmo desejo), eles cada hũ por sua parte se forão buscar suas Aventuras, tirando Almourol, aquem a ferida dos peitos não deu tão depressa lugar (linhas 111-112). Assim, Palmeirim de Lacedemônia, Frenélio e Belcar já deveriam ter partido de Boêmia.

${ }^{2}$ Não conseguimos perceber o que significa assombrar os gregos com suas Helenas. Ou o autor quis dizer que Fidélia quis superar a beleza das Helenas (e neste caso o termo Helenas significaria "princesas gregas") ou nesta passagem houve um erro de cópia (em nível muito alto da tradição manuscrita, pois todos os manuscritos são unânimes quanto à utilização de Helenas) e a palavra correta seria melenas, termo já conhecido naquele tempo, como atesta o Vocabulario de Bluteau.

${ }^{3} \mathrm{~B}, \mathrm{C}$ : comissão.

${ }^{4}$ Ou seja: lhe dava conta.
} 
Deus o negocio pellos meios | que mais pudera dezejar, dandolhe muitas | graças dentro de seu coração, respon|deulhes toda via gravemente, que a | materia pedia deliberação madura | e assentada por ser comũ a seus Reynos | de que sua filha era natural e forçada herdeira | por sua morte delle, que estava tão per|to como sua idade lhe pronosticava, |

30 que elle a trataria com o seu conselho, e | que brevemente responderia a o Empera|dor, aquem não deixava de se sentir | muito obrigado por aquella honrra, que | queria fazerlhe. E com isto fallarão | em outras couzas geraes, que ElRey folgava | de ouvir, e perguntava. Acabado o que | recolheuce a o apozento da Princeza | e depois de largas praticas lhe deu conta | da rezolução da quella embaixada, e do | gosto que elle della

35 tinha, ainda que em a|partalla de si via bem que se apartava | da vida, mas que como ella ja não po|dia ser muita, não queria elle antepor | seu gosto particular, a o que entendia que | convinha a sua vida della, e a o au|mento, e conservação de seus estados. || [256v] Que lhe rogava que como em tudo o ac|concelhava sempre, na quillo o acon|celhasse agora. [espaço] Não ignorou a | Princeza a importancia da quelle ne|gocio, e assim se

40 deteve muito, antes de res|ponder a seu Pay, porque por hũa parte / ponderava o seu gosto delle, aquẽ se | ella sentia por tantas cabeças obrigada ${ }^{5}$. Ponderava tambẽ o seu com aquelle | natural apetite, que está em todos de se | Mostrarem quando cuidão que prestão | para algũa couza. Via juntamente | os bẽns que rezultarião daquella jorna|da à quelle Reyno, a quem ella tinha | tanta obrigação de procurar muitos ${ }^{6}$ [espaço] E | não se 45 lhe escondião por outra parte os in|convenientes que se oppunhão aquillo. | Deixar sua caza. Deixar sua terra. Dei|xar seus Pays velhos. irse meter aonde | ainda que lhe farião muita honrra, não | conhecia nimguẽ, e sogeitar a vontade | livre e absoluta a horas, e ordens alheas. |E assim revolvendo tudo isto na fante|zia, emfim respondeu a o Pay, que bem | podia dispor della como lhe parecesse. |Eque nenhũa outra palavra lhe dissera se | 50 entre as que lhe elle tinha dito lhe não falla|ra tambẽ em cazar em Constantino|pla. ${ }^{7} \mathrm{E}$ que aquillo so respondia. Que pon|derasse Sua Alteza bem se convinha a hua || [257r] filha sua, e da idade que ella era ir atra|vessar tantos Mares, e tanta terra co|mo dali a Constaninopla havia, | a buscar marido, porque nem Bohemia | era tão fora domundo

\footnotetext{
${ }^{5}$ Não encontramos referência à expressão por tantas cabeças; mas o Vocabulario de Bluteau aponta "propósito, razão" como alguns dos significados possíveis para o termo cabeça. Neste caso, deve-se entender que a princesa se sentia obrigada por tantos motivos a procurar muitos bens para o reino de Boêmia.

${ }^{6}$ Elipse do termo bens. Não fica claro se o autor está se referindo ao reino de Boêmia ou ao de Constantinopla.

${ }^{7} \mathrm{O}$ sentido da próxima frase exige que este ponto seja desconsiderado.
} 
que a não pudes|sem vir buscar alli, nem quando o não fi|zesse pessoa, de quẽ elle tivesse muita sa|tisfação, hia muito em cazar, ou deixar | de cazar ${ }^{8}$, porque maior era sempre a | perda da reputação que a dos herdeiros | dos quais nunca havia tamanha falta | que em algũa maneira se não remede|asse. E perdido hũa ves o ponto ${ }^{9}$, e o brio | não se tornava a seu lugar tão facil | mente. Que isto era o que tinha que lhe lẽ|brar pella obrigação do conselho que lhe pe|dia, e que pella de filha, estava prompta| para lhe 60 obedecer sempre em tudo. El|Rey então thomandoa nos braços banhã|doa em lagrimas de contentamento | lhe disse: [espaço] Seme não custara tãto o que $e^{10} \mid$ vos a vós convẽ, cuidara filha que vos fica|va devendo muito pella obediencia que me tendes, | mas quẽ vos estima tanto como eu | e vos larga a vós por amor de vós com | vosco mesma vos paga, e em verdade | minha filha que não sei couza que valha tã|to. Concideravel era o

65 muito que me lẽbrais ${ }^{11} \mid$ se não foreis vos tal pessoa por vós, por $\mid$ mim, e pellos estados de que haveis ser senhora_|| [257v] que não se pode cuidar que mendigareis | Marido. Não hides a Constantino|pla por amor de vós, hides por amor de | vossos vassallos, pella protecção que farà | neste Reyno o parentesco, e conhecimen|to da melhor gente do mundo, que são os | Princepes que na quella corte se crião. $\mid$ E ainda que isto se

70 conceguisse estando | vos em Bohemia, não se pode conce|guir tão inteira mente outra couza | que eu sobre tudo dezejo, e he que se saiba | no mundo, que entenda o Emperador de | Constantinopla a estimação que se hade | fazer de hũa terra, que produs hũa planta | como vos sois. Isto he o porque vos la mando. | Isto he o porque vos aparto demim, e espero | em Deus nos tornaremos a ver muito cedo no es|tado que vos eu 75 dezejo.

Deixando a Princeza, se | foi ter com a Raynha com aqual teve | menos que fazer para a persuadir, porque | era senhora retirada, e não se lhe dava | muito de couzas do mundo.

Depois chamando os gran|des de sua Corte deu lhes conta do em | que estava detreminado, que todos aprova|rão como a couza que lhe estava melhor.

\footnotetext{
${ }^{8}$ A expressão hir muito em algo significa que se trata de assunto relevante.

9 O sentido de ponto, neste contexto, não é de fácil definição. Cremos que o termo possa significar "estado" ou "condição"

${ }^{10}$ Palavra corrigida pelo copista.

${ }^{11}$ C: "consideravel era muito que me lembrais"; a lição correta parece ser a dos mss. D, E, F, G: "consideravel era $e$ muito o que me lembrais".
} 
Ao outro dia dando reposta | ao Embaixador, e a Dramusiando | na conformidade do que o Emperador $\|$ [258r] queria com as palavras de confiança que | pedia a materia. $^{12}$

Publicouce a jornada para breves | dias com grande alvoroço do Reyno, e dos | 85 Princepes, que logo se offerecerão ao acõ|panhamento, do qual a seu tempo | daremos conta $^{13}$

${ }^{12}$ Apesar de o copista ter inserido um ponto final e mudado o parágrafo, a próxima frase só tem sentido se for lida como continuação desta.

${ }^{13} \mathrm{O}$ copista não pôs ponto final. 
|| [258v] (em branco) 
$\|$ [259r] Index 961

Capitulo $1^{\circ}$ em que se da conta da vida | que fazia o Emperador Primaleão, e os ou|tros Princepes, e como Daliarte detremi|nou de trazer os Donzeis, que criava á Cor|te. fol. 1 .

Capitulo $2^{\circ}$ do recado que teve o Empera|dor do Sabio Daliarte, e do alvoroço, que ou|ve na corte com elle. fol. 3

Capitulo $3^{\circ}$ como todos aquelles Prin|cepes que tiverão recado de Daliarte se apare|lharão, e partirão para Constantinopla, e do que | lhes succedeu. fol. 4V.

Capitulo $4^{\circ}$ do que succedeu a Dramusi|ando depois que partio de sua Ilha. fol. 6. V.

Capitulo $5^{\circ}$ do que aquelle Donzel passou | com Dramusiando, e de quem elle era, e de $\mid$ como Dramuziando se foi curar a sua caza $\mid$ fol. 9 . V.

Capitulo $6^{\circ}$ Em que se da razão de quem | erão os cavalleiros que Dramuziando achou | na batalha, e a cauza della, e de como D Flo|ris for ${ }^{962}$ armado cavalleiro. fol. 13.

Capitulo $7^{\circ}$ Em que se da conta como to|dos a quelles Reys, e Princepes chegarão a | Constantinopla, e do mais que nisto succe|deu. fol. 16. V.

Capitulo $8^{\circ}$ do mais que succedeu estando | aquelles Reys na Orta. fol. 19. V.

Capitulo $9^{\circ}$ da batalha que estes Caval||[259v]leiros ouverão, e do que della succedeu f. 22

Capitulo 10 Em que se da conta como a quelles dous cavalleiros chegarão juntos a Cons|taninopla, e do que fazia o sabio Daliarte para | ir a ella fol. 26.

Capitulo 11 de como aquelles Princepes | chegarão a Constantinopla, e do que mais ẽ | sua entrada succedeu. fol. 29

Capitulo 12 do que Daliarte disse ao Em|perador, e do que elle e os mais passarão com o Sa|bio, e os Princepes. fol. 31. V.

Capitulo 13 Como aquelles Princepes | forão armados cavalleiros, e das estranhas cou|zas que naquelle acto succederão. fol. 34 .

Capitulo 14 da grande perturbação que | na quelle cazo ouve, e de como D Duardos | acabou a Aventura. fol. 37.

Capitulo 15. do Torneio que aquelles Prin|cepes fizerão, e do que nelle succedeu fol. 40 .

\footnotetext{
${ }^{961}$ No manuscrito, o index recebe nova numeração. Optamos por dar sequiência à numeração do texto, por motivo de clareza.

${ }^{962}$ For por foi.
} 
Capitulo 16 do sucesso que teve aquella | batalha fol. 44 .

Capitulo 17 De quem erão os Cavallei|ros da Morte, e do que aconteceu às quatro | Princezas na Orta fol. 48. v.

Capitulo 18 das palavras que aquelle ca|valleiro disse, e do que as Princezas depois entre | si passarão. fol. 51.

Capitulo 19 Do que mais sucedeu a|quelle dia na Orta fol. 54

Capitulo 20 em que se torna a dar || [260r] conta de D. Floris, e Floramão e do que Gra|vanào disse a Valeriza. fol. 57

Capitulo 21 do que passou entre aquel|les cavalleiros fol. 60 .

Capitulo 22. de hua lastimoza A|ventura que á corte veio fol. 63

Capitulo 23. do mais que referio a Du|queza, e do assento que se thomou em suas | couzas. fol. $68 . \mathrm{V}$.

Capitulo 24 Do serão que ouve no pas|so, e do que em elle sucedeu fol. 72.

Capitulo 25. do que D Duardos passou | com Carmellia, e como ${ }^{963}$ se foi da Corte | fol. 74. V.

Capitulo 26 das novas que vierão a Dra|musiando, e como aquelles Cavalleiros | Mancebos se forão com elle todos à sua I|lha. fol. 77. V.

Capitulo 27 Do que passou na corte de|pois de partidos os Princepes. fol. 81

Capitulo 28 da prizão da quelles | Reys. fol. 82. V.

Capitulo $29 \mathrm{Do}^{964}$ modo porque estes Prin|cepes forão livres daquella prizão em que | hião fol. 85. V.

Capitulo 30 Em que se procegue a li|berdade dos Reys, e se declara quem era o que | os livrou. f. 88.

Capitulo 31 Em que se da conta quẽ | erão os Gigantes que prenderão o Emperador || [260v] e de como D Duardos se achou alli áquelle tẽ|po. fol. 90.

Capitulo 32 Em que se daá conta de qual | Trogonio achou seu amo. ${ }^{965}$ do que elle dizia, e do | como ouve vista dos Gigantes, e como os Reys | chegarão à cidade fol. 93. V.

Capitulo 33 Do que aconteceu a D Floris | no Reyno de Napoles com Cadramonio $^{966}$ fol. 96 . V.

\footnotetext{
${ }^{963}$ Palavra corrigida pelo copista.

${ }^{964}$ Palavra corrigida pelo copista.

${ }_{965}$ Este ponto deve ser desconsiderado.

${ }^{966}$ Palavra corrigida pelo copista.
} 
Capitulo 34 Da batalha que D. Floris e | Cadramonio tiverão, e do suceço della fol. 100 .

Capitulo 35 Da partida da quelles Re|ys e o que lhes aconteceu fol. 103.

Capitulo 36 De como os Reys derão ẽ | terra e forão encantados, e do que fes o Empera|dor com a fama de sua perdição. fol. 107.

Capitulo 37 Em que se da conta quẽ | encantou estes Reys, e de como Albaizar, Flo|rendos, e Floramão se partirão da corte fol. 110. V.

Capitulo 38 em que se da conta de algũas | delligencias de Daliarte, e do que succedeu a Dra|musiando, e a seus companheiros. fol. 113. V.

Capitulo 39 Do que aconteceu a D | Floris antes de sahir de Napoles fol. 116. V.

Capitulo 40 do que ElRey disse a D. | Floris, e do em que elle se rezolveu fol. 119. V.

Capitulo 41 Do estranho perigo em | que D Floris esteve, e como livrou fol. 122. V.

Capitulo 42 Do que sucedeu a Albaizar | e Beliazem depois que partirão de Constã|tinopla fol. 126.

|| [261r] Capitulo 43. De como Albaizar, e Bel|liazem forão ter á Ilha onde os Reys estavão |Encantados, e do que lhe sucedeu. fol. 130.

Capitulo 44. Do que disse Druzia a Al|baizar, e do em que se elle rezolveu. fol. 133

Capitulo 45. Do que aconteceu a Albaizar | com a gente que na quelle primeiro navio vinha fol. 135 . V.

Capitulo 46. Da cruel batalha que aquelles | cavalleiros fizerão, e de como chegou a elles o| outro navio fol. 139. V.

Capitulo 47. De quem era o cavalleiro que | no Navio vinha, e do que em sua chegada acon|teceu. fol. 143

Capitulo 48 Do fim daquellas batalhas, e | de como os Reys forão dezencantados, e D. | Duardos se foy sem ser conhecido. fol. 146.

Capitulo 49. De como aquelles Reys soube|rão quem os tirou do Encantamento, e como par|tirão para Constantinopla, e de como la che|garão. fol. 150.

Capitulo 50. De como D. Floris, e Vaspe|raldo se juntarão na quella paragem, e do mo|do porque D. Duardos veio ter a ella. fol. 152. V. 
Capitulo 51. De como D. Duardos dezem|barcou, e do que lhe sucedeu a the entrar no cas|tello. fol. 157.

Capitulo 52. Do mais que D. Duardos pas|sou na quelle castello, e da gente que nelle estava $\mid$ preza. fol. 160 . V.

Capitulo 53. como D. Duardos soltou || [261v] os prezos, e foy conhecido delles, e de como | cada hum depois seguio sua fortuna, e Flo|rendos, e Floramão chegarão a Constantino|pla. fol. 166.

Capitulo 54. Do que aconteceu a o Prin|cepe Primaleão no Reyno de Bohemia depo|is que partio da Ilha de Dramuziando fol. 169.

Capitulo 55. Do que sucedeu a Primaleão | em aquelle lugar em que estava. fol. 173

Capitulo 56. De como Primaleão foy de|mandar as tendas da Princeza, e das justas que | teve com seus cavalleiros. fol. 176. V.

Capitulo 57. Do que Primaleão disse à Prin|ceza, e como se ficou no valle continuando as $\mid$ justas outo dias. fol 180 . V.

Capitulo 58. Do que aconteceu a o Empe|rador Trineo depois que partio da Ilha de Dramu|ziando. fol. 183.

Capitulo 59. Do que aquelles homẽns passarão | entre si, e do que Trineo passou despois com hũ | delles. fol. 186.

Capitulo 60. Da conta que aquelle homẽ deu | de si a Trineo, e de como chegarão a o seu castel|lo fol. 190. V.

Capitulo 61. De como Trineo se despedio | do seu Hospede, e do que lhe succedeu indo ambos | com dous cavalleiros. fol. 195. V.

Capitulo 62. Da batalha que aquelles caval|leiros fizerão, do que rezultou della, e do que fazia | Primaleão na guarda do valle. fol. 198. V.

|| [262r] Capitulo 63. Do que fazia a Princeza | depois que se recolheu no seu castello fol. 202

Capitulo 64. Do que passou o Cavalleiro | do Sol com o Enano, e depois com alguns ca|valleiros com que justou fol. 205.

Capitulo 65. Do que passou o Cavalleiro | do Sol a o outro dia na guarda do valle fol 208 .

Capitulo 66. Do mais que passou entre a|quelles cavalleiros. 211. 
Capitulo 67. De como aquelle cavallei|ro estranho continuava em sua porfia, e | da Aventura com que se aquietou, e o do vallle continuou com os companheiros. fol. 214. V.

Capitulo 68. Do fim que teve aquella cruel | batalha, e de quem era o cavalleiro das armas | negras. fol. 218.

Capitulo 69. Em que se da conta como |Dramuziando, e aquelles cavalleiros alli vierão | ter, e do mais que sucedeu na cura dos feridos. | fol. 221. V.

Capitulo 70. Em que se continua a nar|ração dos outros meios por onde se veio a o que | atras fica escrito, e como Dramuziando sou|be do dezencantamento dos Reys, e do que sobre | isso fes, e de outras couzas. fol. 225.

Capitulo 71. Do que a Princeza respon|deu a seu Pay, e de como Dramuziando se | offereceu a continuar na Guarda do valle pel|lo cavalleiro do Sol. 228.

Capitulo 72. Do que passava em Cons $\|[262 \mathrm{v}]$ tantinopla, e de certo colloquio que tiverão | Carmellia, e Valeriza fol. 231. V.

Capitulo 73. Da trovação que entrou em | o animo de Carmellia com a chegada do | Escudeiro de Dramuziando á corte, e do | que passou com D. Floris, e de outras couzas | fol. 235.

Capitulo 74. Do que as Princezas passa|rão com D. Floris, e de como elle, e Vasperal|do partirão da Corte. 238.

Capitulo 75. Do que os Reys sentirão da | partida da quelles Cavalleiros, e do que mais ac|conteceu entre as Princezas. fol. 240. V.

Capitulo 76. De certa Aventura que trou|che á corte hũ cavalleiro Estranho, e do que nella | se fes. fol 242. V.

Capitulo 77. Do que mais passou na cor|te acerca da quella Aventura, e do que succe|deu a Dramuziando no valle. fol. 245. V.

Capitulo 78. Da terrivel batalha, que Dra|muziando teve com a quelle cavalleiro, e de | como no cabo se conhecerão. E de como o Em|baixador chegou a Bohemia. fol. 249.

Capitulo 79. Do que passou Pleonido cõ | a Princeza, e de como o Embaixador chegou | a o castello onde os Princepes estavão fol. 252. 
Capitulo 80. Da entrada do Embaixador na | cidade, e de como ElRey depois de o ouvir deu conta | á Princeza, e do que ella respondeu, e de como se decla|rou sua jornada para Constantinopla fol. 255. 


\section{APÊNDICES}




\section{APÊNDICE 1}

\section{GLOSSÁRIO}

Para a elaboração deste glossário, valemo-nos principalmente do Vocabulario Portuguez e Latino de R. Bluteau (1712), cujas definições em alguns casos transcrevemos literalmente, pois elucidam certas nuanças que definições mais modernas não transmitem. O Elucidário, de Viterbo (1798), também foi consultado, embora tenha nos ajudado bem menos. Recorremos ainda ao Dicionário Aurélio e, em algumas ocasiões, os Dicionários Huaiss e Caldas Aulete foram igualmente úteis. Por vezes, acrescentamos contribuições nossas a algumas das definições. Indicamos com aspas todas as definições tomadas literalmente de algum dos dicionários mencionados, embora só indiquemos a fonte no caso do Vocabulario, e Bluteau, ou do Elucidário, de Viterbo. Nos casos em que a consulta aos dicionários e o exercício de inferir algo a partir do contexto não foram suficientes para esclarecer o sentido de um vocábulo, anotamos nossas hipóteses marcando-as com um ponto de interrogação.

Este glossário visa a auxiliar a compreensão das passagens mais difíceis do texto. Para muitos termos, registramos apenas as acepções menos evidentes ou as que já caíram em desuso. É o caso de acabar, por exemplo: em certos contextos, a palavra pode significar "persuadir, convencer" ou "morrer". Desconsideramos as numerosas ocorrências em que o termo significa "terminar, concluir", evidentes para o leitor moderno.

É indicada entre parênteses a localização de uma ou mais ocorrências do termo em questão, de acordo com a seguinte convenção: número do capítulo, seguido do número da linha. Por exemplo: 6,119 refere-se ao capítulo 6, linha 119.

à flor: "ao nível, na superfície" (Bluteau); a expressão "olhos à flor da cara" parece indicar que seriam olhos vivos, chamativos (ao contrário de olhos fundos) $(77,63)$. abalançar-se: arrojar-se $(21,41)$.

aballar: partir $(32,79)$.

abarbar: dar de frente com algo $(43,6)$.

abborrecido: desestimado, objeto de aversão ou horror $(33,51)$. 
aberto: em 35,99, refere-se a navio danificado, que apresenta muitas aberturas, permitindo a entrada de água; "cor aberta" é cor de tonalidade mais clara? $(76,14)$. Ver apertado.

abominação: desaprovação, expressão de horror a algo $(23,109)$.

aborrido: aborrecido, enfadado $(79,85)$.

abra: enseada $(50,98)$.

acabar: persuadir, convencer $(6,46)$; morrer $(17,6)$.

açafate: "é um cestinho estendido em que as criadas costumam trazer a suas senhoras os toucados, lenços ou camisas" $(42,81)$.

accidente: caso, acontecimento $(7,9)$; desmaio $(16,101)$; achaque, doença $(41,83)$.

accometedor: impetuoso; que justa com ardor $(43,29)$.

achar: a expressão "achar menos" significa "sentir falta de algo" $(1,18)$.

acordar: tomar resolução em comum, em comum acordo $(31,25)$.

acordo: "sem acordo" significa "desacordado, desmaiado" $(4,68)$; "em seu acordo" significa "desperto, consciente" $(5,124)$.

acostumado: comum, ordinário, habitual $(14,96)$.

acreditado: que tem crédito, reconhecido, digno de confiança $(22,9)$.

acreditar: dar crédito, confirmar (10,55).

adiante: favorecido da fortuna $(79,39)$.

affirmar-se: firmar-se $(47,69)$.

afrontar: sentir calor? abafar-se? (56,49).

agazalhar (agasalhar): acolher, hospedar, receber $(2,28)$. Ver gazalhado.

agravo: injustiça, maldade $(76,60)$.

agulha: bússola $(35,90)$.

alabarda: certo tipo de arma $(15,26)$.

alamares: tiras que abotoam a frente de um vestuário, passando de um lado a outro da abotoadura $(27,26)$.

alancear: laçar $(29,18)$.

alar: "puxar para cima com cordas" (Bluteau) $(52,73)$.

alargar: adiar $(41,94)$.

alcançar: compreender, prever $(14,48)$.

aldabra: ferrolho ou tranca de porta $(51,106)$. 
aljofres: pérolas pequenas $(27,27)$.

allembrar: lembrar $(36,78)$.

altura: "tomar a altura" significa medir através de referências a estrelas a posição da embarcação $(35,89)$.

alverca: tanque de água ou vala para escoar água $(58,34)$.

alviçaras (alvisaras): recompensa concedida a quem traz boas notícias $(10,83 ; 79,84)$.

amartelado: firmemente afeiçoado $(56,34)$.

ambar: substância aromática que se retira do mar $(22,18)$.

ancias: "inquietações e penas do espírito" (Bluteau) $(32,100)$.

andas: espécie de liteira $(3,24)$.

ande: hão de $(1,19 ; 9,115 ; 12,59$ e outros $)$.

antojo: "depravada vontade, que algumas mulheres têm, depois de pejadas (grávidas), de comer coisas extraordinárias" (Bluteau); no contexto em que é usado, o termo parece significar "vaidade" $(76,81)$.

aparelhar: preparar $(2,43)$.

apartado: distante $(37,8)$.

apartar: separar (4,53).

apaxonado: irado $(8,93)$. Ver paixão.

apertado: "verde apertado" $(45,71)$ significa "verde escuro"? Ver aberto.

apertar: atormentar ou premer com golpes $(29,61 ; 29,67)$; "apertar as feridas" era o procedimento de atar as feridas com algum pano, de modo a estancar a perda de sangue $(30,24)$.

apetite (appetite): desejo $(37,22)$; appetites: paixões $(39,45)$.

aplicar: pôr em obra, executar (26,18).

apocripho: obra sem autenticidade comprovada $(45,25)$.

aprazado: marcado com antecedência $(43,39)$.

apreceber (aperceber): aprestar, aparelhar, preparar $(8,36)$.

apressado: a expressão "golpes apressados" significa "golpes pressurosos" (20,59). Ver pressa.

apurar: forçar, pressionar, constranger $(59,55)$.

ar: "modo e gesto do corpo; graça com que se faz alguma coisa" (Bluteau) $(7,34)$.

arção: parte arqueada e saliente da sela $(58,51)$. 
arguhir: repreender, acusar (65,10); inferir (os dois sentidos se aplicam a 15,90).

armar: a expressão "armar a alguém", de acordo com Bluteau, significa "usar de sutileza, para o induzir a fazer alguma coisa" $(24,33)$.

armilha: o mesmo que almilha; vestimenta semelhante a colete, com mangas curtas $(22,18)$.

arranco: puxão, solavanco $(13,87)$.

arremeter: acometer com força e ímpeto, cometer, remeter $(15,40)$.

arrezoado: razoável, aquilo "que segue os ditames da razão" (Bluteau) $(31,78)$.

arribar: desviar da rota original; retornar $(18,64 ; 36,89)$.

arrombada: "borda ou outra coisa envolvida e embrulhada, como se usa em navios"

(Bluteau); borda de navio $(35,70)$.

arte: modos, maneiras $(6,71)$.

aspereza: "rigor, dureza, austeridade" (Bluteau); em 13,17 refere-se à indiferença da mulher amada.

assegurar: tornar seguro, garantir $(22,73)$; a expressão "assegurar o ânimo" significa “acalmar, sossegar" $(17,74)$.

assendido: aceso $(11,28)$.

assentado: estabelecido, que tem posição estável $(70,19)$.

assentar: resolver, determinar (10,9).

assento: decisão, resolução $(23,2)$.

assinado: assinalado $(15,31)$.

assistencia: auxílio, ajuda, orientação $(41,8)$.

assistir: observar, acompanhar; permanecer $(35,6)$.

assombrado: a expressão "bem assombrado" significa "aprazível, deleitoso" (8,32;

14,99). "Bem assombrado se diz de muitas outras coisas, que mostram boas aparências" (Bluteau). O texto traz também o oposto: "mal assombrado" $(22,62)$.

assoutar: açoitar $(69,35)$.

astea (hastea): haste $(15,86 ; 53,18)$.

ataballe: espécie de tambor $(13,50)$.

atalhado: confuso, perplexo $(64,34)$.

atalhar: o termo é muito comum no texto e pode adquirir diversos significados de acordo com o contexto: interromper $(49,38)$; impedir, estorvar $(17,28)$; remediar, 
evitando ameaça ou perigo (21,63); ficar embaraçado, indeciso, perplexo (7,99 e $13,6)$; abreviar o caminho através de atalho $(20,61)$.

atasalhado: dilacerado, retalhado, muito ferido $(16,96)$.

atrazadas: passadas $(19,90)$.

atroar: fazer um grande estrondo $(11,18)$.

aviar: despachar $(66,54)$; preparado $(66,68)$.

avir-se: "estar conforme com alguém" (Bluteau) (57,10); arranjar-se, compor-se $(66,70)$.

avó: na grafia do copista, o termo tanto pode indicar "avó" (feminino, como em 1,46), como "avô" (masculino, como em 3,44).

ayo: aio, criado, escudeiro $(17,27)$.

bancos: bancos ou assentos dos remadores de uma embarcação $(36,10)$.

baqueada: queda $(69,26)$.

baralha: "andar metido na baralha" significa "desistir de suas pretenções" (Bluteau) $(24,72)$.

barra: entrada de um porto $(11,15)$; varão de ferro $(6,37)$.

bataria: bateria de artilharia; em sentido figurado, significa "acometimento, tentação" $(53,99)$.

bayo (baio): diz-se do cavalo castanho ou avermelhado $(4,103)$.

besta: tipo de arma antiga, que atirava setas ou balas de ferro $(55,33)$.

bolina: certo tipo de cabo ou corda utilizado para esticar as velas de embarcações $(53,13)$.

bolso: "dar um bolo de vela" $(35,92)$ parece significar "abrir parcialmente a vela".

borcado: brocado; tecido de seda ricamente trabalhado $(11,43)$.

botelheria: frasqueira? objetos de uso pessoal? $(76,95)$.

botica: farmácia; em 22,31 parece designar não tanto o posto de venda de medicamentos, mas sim o local em que seriam guardados.

braços: cabos utilizados para manobrar as vergas dos mastros de navios $(53,13)$.

brutualidade: brutalidade $(14,24)$.

bufete: mesa pequena ou aparador $(22,38)$.

bulir: mover, menear $(34,62)$.

cabeça: "propósito, razão" (Bluteau) $(80,41)$. 
cabeção: parte superior da vestimenta, gola em que se abotoa a capa $(27,31)$.

cabeço: a parte mais alta de um monte $(4,38)$.

cabedal: bens, riquezas; valor pessoal $(21,32)$.

cabelhado: amarelo escuro $(61,62)$.

cabo: cauda de cavalo $(33,43)$.

cabrestante: espécie de guincho usado para içar a âncora de um navio $(51,8)$.

cabrestilho: cabresto pequeno; corda com que se prendem as bestas $(58,51)$.

cahir: "entender, perceber" (normalmente na expressão “cahir em algo") $(28,62 ; 30,32)$.

calheta: pequena angra ou enseada $(50,98)$.

callar: "callar a vizeira" significa abaixá-la ou fechá-la $(34,15)$.

calvo: escalvado, árido $(43,23)$.

camilha: "cama pequena, em que na convalescença uma pessoa se encosta e descansa sem se despir" (Bluteau) (73,74).

caminho: "metaforicamente: instrumentos ou meios que se tomam para chegar a alguma coisa que se deseja" (Bluteau) $(34,73)$.

campo: em expressões como "escudo em campo branco hũ Leão morto" $(4,50)$, o termo indica o espaço do escudo sobre o qual se pintam outros símbolos.

cana: caule estreito de certo tipo de plantas; varinha $(55,40)$.

cançar: aborrecer $(35,16)$.

canipreto: de canelas pretas $(33,43)$.

canonizar: confirmar, arrematar; louvar, aprovar (os dois sentidos podem se aplicar à ocorrência em 56,59).

capella: "capella de flores" $(10,21)$ significa "grinalda ou coroa de flores"; pequena igreja (como em 12,91).

capello: espécie de touca comumente usada por viúvas $(23,112)$.

carregado: os exemplos dados por Bluteau são "rosto carregado, como o de quem está triste ou enfadado"; "carregado de anos"; "falando da cabeça, ou em outras partes do corpo, que não têm a sua esperteza natural" $(7,35)$.

carreiro: caminho estreito $(58,54)$.

cartapacio: "livro de mão [isto é, manuscrito], em que se escrevem várias matérias" (Bluteau) (20,27).

cartel: desafio $(65,49)$. 
casar: casar (ou caçar) a escota $(51,16)$ significa puxar a escota, ou vela de embarcação, até colocá-la em seu lugar.

cassoula: vaso onde se queimam resinas ou plantas aromáticas $(22,26)$.

castello: "castelo da proa" é a estrutura armada sobre o convés da proa de um navio $(35,68)$.

catadura: semblante, aspecto $(34,65)$.

cativo: mesquinho, mau $(29,39)$; preso $(59,23)$.

cauterio: correção, castigo $(60,64)$.

cava: fosso $(51,95)$.

caza: corte $(20,13)$; família real ou conjunto dos cortesãos $(17,18)$; quarto, aposento $(22,106)$; aparato e criados levados numa embaixada $(79,93)$.

cazo: acontecimento $(1,34)$; acaso $(14,84)$.

cebe: sebe, cerca de arbustos $(58,30)$.

cengido: cingido, preso, amarrado $(35,68)$.

cerpe: serpe, serpente $(11,53)$.

certo: seguro, garantido $(35,8)$.

chão: liso, sem ornamentos $(26,32)$.

charamella: certo instrumento de sopro $(13,50)$.

charneca: terreno seco onde cresce vegetação baixa $(58,28)$.

chea: cheia $(15,18)$.

chimeras: quimeras $(20,69)$.

choupo (chopo): certo tipo de árvore, alta e de tronco grosso $(8,26 ; 54,82)$.

chusma: "turba dos forçados de uma galé" (Bluteau) $(36,76)$.

cifra: "escritura enigmática com caracteres peregrinos, ou inventados, ou como os nossos trocados por outros em valor, ou em lugar (...); também chamamos cifra qualquer figura que encerra algum segredo (...); letras enlaçadas. De ordinário são letras do nome da pessoa" (Bluteau) $(21,85)$.

cilhas: tiras de pano ou couro com que se apertava a sela $(8,55)$.

circunspecção: exame detalhado de um tema; explanação $(14,86)$.

clauzular: decidir? ajustar? $(40,89)$; listar, enumerar $(49,5)$.

cobrar: tomar, conquistar $(41,46)$.

columbina: da forma ou da cor de pomba $(45,52)$. 
comer: tragar $(36,88)$.

cometer (cometter): ver arremeter; delegar $(40,49)$; "cometer o caminho ou a jornada" significa "percorrer o caminho" $(58,73)$.

comettimento: culpa, delito (Bluteau) $(23,63)$.

comissão: encargo, incumbência $(75,25)$.

como: assume, por vezes, valor temporal ("logo que", em 4,86 e 13,58) ou valor condicional ("caso, se", em 20,31).

compasso: medida, ordem, vagar $(61,15)$; "assentado em compasso" $(36,22)$ significa "postos em disposição regular, exata".

competencia: "pretensão de dois ou de muitos com emulação" (Bluteau); disputa $(36,72)$.

compor: "concertar; pôr em ordem" (Bluteau), agir com compostura e decoro $(9,15$; $15,19 ; 21,65)$.

compostura: modéstia, decoro $(12,41)$.

comprido: em expressões como "compridos de boas partes" significa "perfeito"; diz-se daquilo que foi bem realizado ou com perfeição $(10,82)$.

comprimentos: cumprimentos; "palavras cortezãs" (Bluteau) $(11,75)$.

concecção: concessão $(61,43)$.

concertado: posto em ordem, arrumado $(34,94)$.

concertar: pôr em ordem ou acordo; harmonizar $(40,40)$.

concerto: acordo, pacto $(25,15)$; "meios com que se compõe alguma desavença, discórdia etc" (Bluteau); consideração $(25,25)$.

concerva (conserva): "companhia de naus" (Bluteau) $(35,69)$.

concorrer: compartilhar uma atividade ou um destino $(6,40)$; "correr juntamente com outros para o mesmo lugar" (11,6); "ajudar alguém a fazer alguma coisa" (Bluteau) (11,22); reunir-se, ajuntar-se $(40,5)$.

condição: "inclinação e disposição natural” (Bluteau), temperamento (17,19); "má condição" significa "má vontade" $(57,37)$.

confiado: confiante $(22,72)$, arrogante $(16,68)$.

confiar: incutir confiança em alguém; tranqüilizar $(75,44)$.

conformidade: harmonia $(5,100)$.

conhecido: reconhecido, agradecido $(49,17)$. 
conjunção: circunstância, oportunidade $(68,55)$.

conjuro: invocação de magia $(48,84)$.

constantemente: com constância e resignação $(25,43)$.

contado: "ser contado" significa "tido em boa conta" $(39,38)$.

continencia: disposição, forma, aspecto $(7,61)$.

continente: ver continencia $(76,12)$.

conto: conta, cômputo, número $(20,13)$.

contra: na expressão "ir contra", significa "ir para ou na direção de" $(10,6)$.

contratar: a expressão "contratar inimizade" significa "pactuar uma animosidade recíproca" $(16,111)$.

contumacia: “obstinação inflexível” (Bluteau) $(68,29)$.

conveniencia: "utilidade, interesse" (Bluteau) $(64,16)$.

converçação: convívio, amizade $(6,25)$.

converçar: "tratar ordinária e familiarmente com alguém” (Bluteau) $(5,60)$.

converter: "mudar uma coisa em outra" (Bluteau) $(11,17)$.

corar: "disfarçar" (Bluteau) $(35,21)$.

correr-se: envergonhar-se $(4,91)$.

corrido: envergonhado $(13,30)$.

corrimento: vergonha $(44,52)$.

cortado: afligido (Bluteau) (49,60).

coxia: corredor central de uma galé $(36,10)$.

cramezim: carmesim; de cor encarnada ou vermelho vivo $(11,42)$.

criação: educação, boas maneiras $(71,15)$.

crueza: crueldade $(16,82)$.

cruzetas: cruzes pequenas $(2,10)$

cuberto: local oculto; esconderijo $(41,53)$.

cuidado: diligência, zelo $(2,51)$; inquietação, preocupação $(7,5)$; pensamentos amorosos $(5,75)$; atenção, ocupação $(10,74)$.

cuidar: julgar, supor $(10,95)$; imaginar $(16,15)$.

cumprir: ser necessário ou conveniente $(10,48)$; expressões como "cumprir com o que se deve" ou "cumprir com a estimação" significam "agir de acordo com a 
consciência ou com o dever; não agir de modo recriminável ou de modo a comprometer a honra" $(18,51)$.

curiozidade (coriozidade): engenho; "aplicação dos que investigam coisas ocultas" $(40,75)$.

curiozo: excepcional, raro, notável $(42,81)$; engenhoso, interessante $(60,60)$.

cursar: soprar (o vento) $(50,45)$.

curucheo: ornamento de forma piramidal que se ergue sobre o telhado do edifício $(50,103)$.

danar: prejudicar, estorvar a realização de algo $(37,64)$.

danno: defeito, erro $(18,40)$.

dar: golpear, atacar (28,52-53).

de antes: primeiramente, anteriormente $(15,12)$.

de contino: continuamente $(23,11)$.

de mistura: juntamente $(70,65)$.

de pancada: "inconsideramente e sem modo" (Bluteau); de repente $(73,24)$.

de prezente: presente $(70,32)$.

declarar: ler em voz alta, proferir $(14,39)$; revelar (uma intenção ou segredo) $(37,67)$.

deffender: impedir, estorvar $(15,83)$.

deffensão: defesa $(31,16)$.

demandar: encaminhar-se para algum lugar $(10,9)$.

demaziado: do verbo demaziar (demasiar), que significa "fazer alguma coisa com excesso" (Bluteau) $(45,84)$.

deputado: ordenado, assinalado, designado $(35,51)$.

derribar: derrubar do cavalo $(15,110)$.

derrota: caminho, rota $(4,25$ e 10,38$)$.

desacreditar (dessacreditar): tirar o crédito de algo $(56,109)$. Ver acreditar.

desafogado: "livre de alguma grande ocupação, opressão, cuidado etc" (Bluteau) $(34,26)$.

desagravar: reparar agravos ou injustiças $(54,70)$. Ver agravo.

desapressar (desapresar): liberar de um aperto ou perigo $(22,166 ; 74,60)$ (ver pressa).

desasombrado: descuidado, sem preocupação ou temor $(40,10)$.

desbaratar: derrotar, vencer $(26,10)$. 
descarga: desculpa, alívio $(61,13)$.

descercar: levantar o cerco $(38,22)$.

descobrir: revelar $(17,51)$.

descompostura: desconcerto, desalinho, falta de ordem $(19,64)$.

desconcerto: desarranjo, desordem, confusão $(22,27)$.

desconhecer: não reconhecer $(36,46)$.

descontentadisso: "dificultoso de contentar" (Bluteau) $(20,9)$.

descuido: desatenção $(13,15)$.

desestimação: desconsideração $(33,34)$.

desestimar: ter em pouca conta, menosprezar $(31,41)$.

desestrado: desastrado, "infeliz, desafortunado" (Bluteau) (22,53). Ver dezasatre.

desigual: "batalha desigual" é uma batalha injusta $(29,70)$ (ver igual); inconstante $(39,46)$.

desigualdade: diferença, incompatibilidade $(37,62)$.

despachar: expedir, enviar $(1,75)$; atender, deferir uma solicitação $(24,76)$.

despedir: atirar, lançar $(11,28)$; enviar embaixador $(3,15)$.

despejado: livre, desocupado $(58,47)$.

despejar: livrar, desembaraçar, desocupar $(15,115)$.

despeza: normalmente utilizado na expressão "despeza de sangue", que significa “derramamento de sangue, sacrifício" (16,7).

despicado: satisfeito, vingado, desforrado $(59,27)$.

despois: depois (as duas formas convivem no texto) (4,75).

despregar: "despregar as velas" significa "soltar as velas" $(43,82)$.

desviado: distante, afastado $(25,87)$.

detreminar: determinar, decidir-se, tomar uma resolução $(1,3)$.

devação: devoção $(64,37)$.

dezacostumado (desacostumado): incomum, estranho $(11,27)$.

dezarrezoado: "aquele que não tem nem entende razão; injusto, contrário à boa razão"

(Bluteau) (18,28).

dezastre (desastre): “infortúnio, calamidade" (Bluteau) (5,27); por desastre: por acidente, acidentalmente $(51,52)$.

dezemparar: desamparar $(9,74)$. 
dezenfado: distração, diversão $(27,10)$.

dezenfrear: soltar os freios dos cavalos $(58,49)$.

dezentoadamente: "fora do tom, sem tom" (Bluteau) $(33,62)$.

differença: disputa, combate $(78,23)$.

difficultar: encarecer a dificuldade de algo $(23,85)$.

difficultozo: difícil $(80,19)$.

diffirir: deferir, adiar $(56,112)$; respeitar, obedecer $(73,46)$.

dilatado: "comprido, largo" (Bluteau) $(58,29)$.

dilatar: adiar $(10,84)$; prolongar $(65,77)$.

dilligencia (deligencia): zelo, cuidado $(17,10)$; providências ou medidas tomadas $(24,16 ; 29,6)$; buscas $(36,94)$.

direito: reto, aprumado $(8,52)$; na expressão "ir (ou vir) direito" significa "diretamente" $(22,50)$.

direitura: em posição direita ou aprumada $(34,53)$. Ver direito.

discorrer: percorrer, atravessar (15,93).

discreto: "que tem muito engenho, muita agudeza" (Bluteau); inteligente e perspicaz $(18,41)$.

discrição: "prudência, juízo, entendimento; agudeza de engenho, que se mostra no falar, no escrever etc" (Bluteau) $(35,42)$.

discurçar: "ir examinando e examinando as razões que há pró e contra" (Bluteau) $(40,42)$.

discurso (descurso): decurso; "espaço do tempo que corre" (Bluteau) (6,42); "uso da razão" (Bluteau), argumento $(31,12)$; análise $(72,45)$.

dispozição: "estado da saúde de alguém”, "disposição interior, ânimo", "aptidão, talento, capacidade" (Bluteau) $(4,64)$

dissimular: "mostrar que não vê", relevar $(41,79)$.

dita (ditta): fortuna, sorte $(8,36)$. Ver ditozo.

ditozo: feliz, venturoso $(8,35)$.

divertir: "tirar ou diminuir a aplicação a algum estudo, negócio; desviar de alguma ocupação, empresa etc" (Bluteau) (47,61).

divizar: avistar (4,37).

dobar: fazer novelos $(53,53)$. 
documento: instrução (Bluteau) (6,115).

doer-se: condoer-se $(31,19)$.

domesticar: amansar, tornar sociável $(20,16)$.

donzel: jovem ainda não armado cavaleiro; "antigamente em Portugal era o nome que se dava aos primogênitos das casas ilustres, que se criavam no paço" (Bluteau). $(1,3)$.

drago: dragão $(13,75)$.

effeito: objetivo, intento, resultado $(32,36)$; causa? $(39,85)$.

eirado: terraço descoberto de uma casa ou construção qualquer $(51,23)$.

eleyção (elleyção): escolha $(18,83 ; 41,48)$.

elmo: espécie de capacete que compunha a armadura dos cavaleiros $(4,68)$.

embraçar: estorvar, atrapalhar (10,15); envolver, misturar (4,59).

embrechados: "pedrinhas, conchas, bocados de cristal e de outras matérias com que se fazem rochas e grutas nos jardins" (Bluteau) $(40,74)$.

embuçado: com o rosto coberto por capa ou véu $(31,86)$.

emparar: amparar $(22,138)$.

empecer: prejudicar, estorvar, impedir $(18,72)$.

emvasadura: bojo de uma carreta? $(51,14)$.

encalmado: calmo $(55,81)$.

encarnado: vermelho $(33,44)$.

encetar: cortar parte de algo; gastar; iniciar; experimentar pela primeira vez $(4,88$; $16,17)$.

encobrir: ocultar, esconder (7,29). Ver descobrir.

encontrar-se: arremeter contra outro cavaleiro, procurando derrubá-lo com a lança $(15,43)$.

encontro: choque entre cavaleiros numa justa ou batalha $(8,36)$.

enfiado: pálido, sem cor $(24,77)$.

enfiar: dar sequiência à narração $(8,96)$ (ver fio).

enfrear: pôr freios aos cavalos $(59,115)$.

engano: embuste; armadilha $(51,103)$.

engeitar: rejeitar $(39,83)$.

engolfar: dirigir a embarcação para alto mar $(30,49)$.

engraçado: que tem graça; interessante, belo $(54,59)$. 
enlear: iludir $(25,46)$; embaraçar $(48,74)$.

enormidade: "crime enorme" (Bluteau) $(40,89)$.

enrredo: "oculto artifício para conseguir o seu intento" (Bluteau) $(44,43)$.

entena: o mesmo que antena: "é o pau que atravessa o mastro do navio e onde se ata a vela" (Bluteau) $(34,9)$.

entendido: douto, discreto, inteligente $(6,56)$.

entendimento: inteligência, conhecimento $(14,74)$.

entrada: "dar entrada" significa "acolher, receber, favorecer" $(24,15)$; neste sentido também deve-se compreender a ocorrência em 39,47; "noite entrada" signfica "noite adiantada" $(34,95)$.

entranhavel: íntimo $(36,83)$.

entrar: nenhuma das acepções encontradas para o verbo são adequadas à ocorrência em 10,39, onde o termo parece significar "seguir".

entre si: a expressão "dizer entre si” significa "dizer para si” $(9,39)$.

enxarxia: enxárcia, conjunto das cordas que prendem os mastros e as velas de um navio $(35,86)$.

escandelizar: "se diz de cousas que se estranham e desagradam" $(51,19)$.

escolhido: seleto $(64,75)$.

escota: corda presa à vela de embarcações e utilizada para regular sua abertura $(51,16)$.

escurecer: esconder, ocultar $(22,126)$.

escuro: obscuro $(14,73)$.

escuzar-se: poupar-se, dispensar-se $(33,64)$.

escuzo: retirado, afastado $(41,14)$.

esforçado: alentado, valoroso; dotado de ânimo e forças $(6,56)$.

esmerilhão: falcão de caça $(4,102)$.

espaço (espasso): intervalo de tempo $(3,36 ; 4,66 ; 9,8)$.

espedaçado: despedaçado $(35,91)$.

espigar: crescer $(20,55)$.

espos (expos): “ir espos” significa ir atrás de alguém, buscando-o $(30,19)$; após $(60,98)$.

esquipação: "os marinheiros e a mais gente, que serve para a navegação" (Bluteau) $(38,15)$. 
estado: termo utilizado para indicar diversos significados, de acordo com o contexto: reino, império (1,25); "gênero de vida, profissão, modo de viver" (Bluteau), podendo indicar também o estado civil de alguém $(1,65 ; 17,66)$; situação de algo $(10,49)$; estado de saúde (5,52); classificação de um indivíduo segundo sua condição social $(11,12)$.

estartagema (extratagema): estratagema $(41,65 ; 60,94)$.

estilar: destilar $(22,23)$.

estimação: "o caso que se faz de uma pessoa, das suas prendas ou virtudes" (Bluteau); o valor de algo ou alguém $(5,89)$; honra pessoal $(18,51)$.

estimar: "julgar o preço" ou valor de algo ou alguém (Bluteau) $(2,53)$; considerar $(37,54)$.

estranhamente: "notavelmente, admiravelmente" (Bluteau) $(11,27)$.

estranho: incomum, que causa estranheza $(21,46)$.

estreitar: diminuir, dificultar $(42,54)$.

estrella: fortuna, destino $(22,10)$.

exercício: ofício, atividade $(1,12)$.

experimentar: provar, praticar $(5,60)$.

extacis: êxtase $(20,50)$.

extremado: perfeito, abalizado, excelente $(14,60)$.

extremo: "cabo, fim; que está mais afastado do meio; sentido moral: excessos ou vícios;

excesso, força, violência" (Bluteau). Termo comum em expressões como "extremos da natureza", referindo-se à extraordinária beleza de uma donzela $(2,47)$; "fazer extremos" significa cometer grandes feitos ou experimentar grandes sentimentos (15,93); "em extremo": sumamente (5,79-80).

fabrica: "estrutura, construção, composição" (Bluteau) $(64,8)$.

faca (facca): cavalo pequeno $(3,33 ; 65,58)$.

facção: "ação ou empresa militar" (Bluteau) $(55,5)$.

fadario: "alguma lida, pena, ou trabalho continuado" (Bluteau) $(70,30)$.

falda: fralda, beirada $(42,19)$.

falsar: "torcer, amolgar ou passar (falando em armas ou coisas semelhantes)" (Bluteau) $(34,18)$. 
faltar: deixar de cumprir uma obrigação $(10,104)$; sentir privação de algo necessário $(23,78)$; cometer falta $(20,38)$; estar ausente $(30,45)$.

fama: notícia $(36,3)$.

faxa: friso, beirada $(47,25)$.

fazenda: "riquezas, dinheiro, cabedais"; "bens de raiz, terra, quintas, etc" (Bluteau). $(10,60)$.

fee (fe): fé, fidelidade, lealdade $(22,92)$.

ferrada: gradeada, fechada com ferros $(41,14)$.

ferrado: aferrado, agarrado $(60,96)$.

fiar: confiar $(10,100)$; confiar algo aos cuidados de alguém $(12,50)$.

figura: forma $(36,20)$.

fineza: "ação feita com primor, com galantaria, com cortesania" (Bluteau) $(15,90)$.

fino: coisa perfeita, excelente; pessoa discreta e entedida (ver) $(21,22)$.

fio: sequiência, continuação $(13,90)$.

flematica: impassível, imperturbável $(3,54)$.

folgar: "ter gosto de alguma coisa, algum sucesso etc" (Bluteau) $(2,17)$.

fontes: frontes $(77,66)$.

fora: alheio $(18,14)$.

força: violência $(42,93)$.

forçado: "condenado às galés" $(36,13)$.

forçozo: forte, vigoroso $(9,61)$; “coisa que não se pode escusar” (Bluteau) $(34,49)$.

foro: tributo, dívida $(65,19)$.

forrar: libertar $(8,36)$.

forte: as expressões "forte couza" $(9,42)$ e "forte hora" $(17,42)$ indicam experiência ou momento "muito duro e áspero" (Elucidário).

fortuna: termo muito utilizado no texto e por diversos escritores da época, pode significar acaso $(7,9 ; 14,84 ; 23,16)$; sorte, destino ou sina $(4,26 ; 11,73 ; 12,59$; $14,71)$; boa sorte ou ventura $(17,19)$; e ainda caso ou situação arriscada $(9,78)$.

fresco: são, descansado $(29,53)$.

fretar: alugar (usa-se sobretudo com relação a frete de navios) $(31,86)$.

frexo: freixo, certo tipo de árvore grande e frondosa $(54,81)$.

furto: "a furto" significa "furtivamente". 
gabão: capote rústico com mangas e capuz $(58,85)$.

gáie: gage; penhor de desafio? $(55,96)$.

galante: "cortesão, polido, gracioso, que sabe falar ou obrar com graça" (Bluteau) $(5,127)$.

galé (gallé): tipo de embarcação utilizada predominantemente para guerra, que contava com velas mas movida principalmente por remos $(1,30)$.

galeáça (galleaça): embarcação semelhante à galé, mas maior que esta, usualmente com três mastros $(35,58)$.

galla: vestido rico, utilizado em festas $(21,101)$.

gallardão: prêmio, recompensa $(41,108)$.

galleota: pequena galé $(51,15)$.

gavea: mastro suplementar de uma embarcação $(10,39)$.

gazalhado: acolhimento (2,57).

genella (jenella): janela $(11,69)$.

gentar: jantar $(33,23)$.

gentilhomem: moço belo e galante; membro da nobreza $(4,104)$.

geral: "universal" (Bluteau); comum a todos $(35,71)$.

geralidade: generalidade $(77,26)$.

gesto: "aparência exterior" (Bluteau) $(7,34)$.

giesta: certo tipo de arbusto $(31,93)$.

giolho: joelho (7,64); sentar-se em giolhos: ajoelhar-se $(2,39)$.

goivo: certo tipo de flor que pode apresentar diferentes cores: branco, amarelo ou roxo $(55,49)$.

gosto: prazer $(1,9)$.

graduar: pesar, avaliar $(61,52)$.

grào: grau $(36,93)$.

grave: "sério, autorizado", que inspira confiança (Bluteau). Aparece freqüentemente em expressões como "grave na aparência" $(22,61)$.

grita (gritta): "gritaria” (Bluteau) $(15,109)$.

grosso (groço): gordo $(7,60)$; grande $(17,11)$ : “mar grosso" significa "mar agitado ou proceloso" $(35,94)$.

gualdrapa: pano usado sobre a sela de cavalos e palafréns $(27,35)$. 
guerra: a expressão "fazer guerra a alguém" significa "ter inimizade, fazer oposição, contrariar" $(35,18-19)$.

historia: narração $(1,84)$; caso $(19,66)$.

honestidade: "pudor, castidade, decência" (Bluteau) $(23,39)$.

honesto: casto, pudico $(6,22)$.

hora: ora (conjunção) $(15,62)$.

hospede: pode significar tanto "hóspede" como "anfitrião" (como em 61,2); a palavra pode ser flexionada no feminino: hospedas (como em 2,44).

igual: uma "batalha igual" é "batalha justa, em igualdade de condições" $(23,53)$ (ver desigual).

imaginação: pensamento $(4,32)$; suposição $(11,35)$; pensamentos ou contemplações amorosas $(13,23)$.

impinar: empinar $(34,24)$.

incessavelmente: incessantemente $(43,26)$.

inclinar: tornar favorável a algo $(22,91)$.

inconcideração: desconsideração $(25,16)$.

inconcideradamente: desconsideradamente $(45,92)$.

inconvenientes: empecilhos, dificuldades $(41,9)$.

indifferentemente: indistintamente (no sentido de "por completo") $(31,20)$.

indireitar-se: andar em direção a algo $(59,62)$.

industria: "destreza em alguma arte, engenho" (Bluteau) (4,90); “de industria" significa "propositadamente" $(28,65)$.

industriado: avisado, advertido $(48,48)$.

industriozamente: engenhosamente $(20,20)$.

inteiro: na expressão "estar inteiro" significa "estar são" $(16,101)$; completo $(35,55)$.

intelligencia: "secreta correspondência de uns com outros para algum intento" (Bluteau)

interpor: reconciliar $(41,73)$.

intervir: "achar-se presente; interpor a sua agência ou a sua autoridade para compor um negócio" (Bluteau) (41,89).

intrinceca: intrínseca $(36,12)$.

invenção: "arte, traça" (Bluteau) $(23,86 ; 41,44)$. 
izento: livre; "o que não tem amizades com empenho e não sabe viver sujeito às leis do amor" (Bluteau) (7,99).

jornada: "todo o caminho que se anda em um ou mais dias até chegar ao termo da viagem" (Bluteau); viagem $(6,76 ; 10,78)$.

jorrão: "certo tipo de carreta sem rodas com que se aplaina a terra alta" (Bluteau) $(51,14)$.

jugar: recrear-se $(6,40)$; oscilar, balançar $(52,50)$.

lagea: laje, pedra retangular $(52,49)$.

lançada: golpe de lança $(35,44)$.

lanceta: tipo de agulha utilizada para picar veias e fazer sangrias $(35,45)$.

lanço: “extensão, espaço, comprimento de um muro, edifício, etc” (Bluteau) (13,71).

lasso: laço; armadilha, engodo $(52,107)$.

lavrar: fazer, construir $(51,26)$.

leadouro (liadouro): pedras compridas que servem de emendas para muros ou paredes $(19,58)$.

lembrar: notar, perceber, dar-se conta $(38,8)$.

leonado: fulvo, ruivo escuro $(8,42)$.

lesa: ofendido, acusado; "consciência lesa": má consciência, consciência pesada (41,83).

letra: inscrição $(8,44)$.

levantar: pegar, apanhar do chão $(21,82)$; "levantar juramento" é dá-lo por quite $(44,68)$.

leve: ligeiro, inconstante, pouco firme $(39,83)$.

levemente: ligeiramente, facilmente $(9,103)$.

ley: fé, religião $(17,9)$.

libré: vestimenta, uniforme $(22,63)$.

lição: leitura, recitação $(14,93)$.

licença: "muita liberdade; mau uso da liberdade" (Bluteau); desregramento $(1,69)$.

lio: feixe de roupa $(58,81)$.

livre: em 17,63, tem o mesmo sentido de izento (ver).

lograr: obter $(1,9)$; usufruir, desfrutar $(10,74)$.

loriga: vestimenta composta por escamas de metal utilizada por cavaleiros $(36,57)$. 
louro: loureiro, certo tipo de árvore $(8,25)$.

ludibrio: "objeto exposto às variedades e inconstâncias da fortuna, do vento etc" (Bluteau) $(45,17)$.

lugar: "dar lugar" significa "permitir, dar oportunidade" $(6,119)$; "haver lugar" significa "ocasião, possibilidade, tempo disponível" $(15,30)$; "ter ou haver lugar" pode significar também "ter força, poder ou efeito" $(40,76)$.

maçã: "maçã da espada" é a parte arredondada do cabo da espada, que protege o punho $(15,80)$.

maça: massa $(11,40)$

machina: "massa grande; muitas coisas juntas" (Bluteau) (34,60); cogitação, ardil, trama $(41,18)$.

mal parado: periclitante, arriscado $(4,108)$.

malha: tecido com fios metálicos usado por cavaleiros $(36,57)$

manço: "falar manço" significa "falar baixo" $(56,6)$.

mangas: a expressão "em mangas de camisa" significa "sem casaco ou jaqueta sobre a camisa" $(55,47)$.

manifestação: revelação de um segredo $(25,68)$.

manoplas: luva de ferro para defesa das mãos $(56,110)$.

mão: pata $(11,55)$.

maranchão (marachão): caramanchão? $(58,76)$.

materia: assunto, tema $(1,27)$.

material: "grosseiro, sem sutileza, sem agudeza, sem discrição" $(16,60)$.

mea: meia $(3,39)$.

menos: em expressões como "achar menos" ou "ser menos" significa "faltar" ou "sentir falta de algo" $(1,18 ; 27,50)$.

mentir: enganar, desiludir $(60,114)$.

merce: favor, graça, benefício $(5,6 ; 12,34)$; benevolência, indulgência $(7,78 ; 30,10)$; bom acolhimento $(16,135)$.

merecimento: "o que alguém tem merecido por suas virtudes ou por suas culpas" (Bluteau) $(18,79)$.

mesurar: "mesurar as velas" parece significar "recolher as velas" $(50,45)$.

milagre: "obra extraordinária; coisa maravilhosa" (Bluteau) $(24,68)$. 
mingoada: "lua mingoada" significa "lua minguante" $(76,15)$.

mininice: meninice, infantilidade $(73,51)$.

ministro: "instrumento, meio ou medianeiro (falando em quem ajuda a outro na satisfação das suas paixões)" (Bluteau) $(36,61)$.

mitigar: abrandar, moderar $(17,18)$.

mocho: ave noturna, parecida com a coruja $(67,41)$.

mofino: infeliz, desditoso $(18,35)$.

moles (molles): molas? $(52,50)$.

molestes: moléstias $(23,13)$.

molestia: aborrecimento, enfado $(63,52)$.

momento: "peso, importância" de algo; suas conseqüências (Bluteau) $(21,77)$.

moneta: vela pequena usada para manobra de embarcações $(35,68)$.

monte: exercício de caça praticado por nobres; "hábito de monte" é a vestimenta apropriada para esta atividade $(27,39)$ (ver montear).

montear: caçar porcos ou cervos no monte ou na floresta; era exercício reservado à nobreza $(1,73)$. Ver monte.

monteiros: acompanhantes do rei ou príncipe no exercício de montear $(4,106)$.

mostrar: na expressão "mostrar o para que é" $(9,12)$ significa "mostrar do que é capaz".

mostras: provas $(6,113)$; amostras $(13,20)$; indícios, sinais $(22,95)$.

motinar-se: amotinar-se, agitar-se, alvoroçar-se $(34,83)$.

moucarrice: surdez? teimosia? $(54,49)$ O termo provavelmente está relacionado a "mouco", que significa "surdo".

movibel: "coisa capaz de movimento; coisa que se move" (Bluteau) $(37,36)$.

murzello: diz-se do cavalo de cor avermelhada e escura $(8,39)$.

namorado: apaixonado $(6,29)$; encantado, satisfeito $(9,89)$.

natural: habitante de certo lugar $(15,27)$; "senhor natural" significa "herdeiro ou senhor legítimo da terra" $(31,19)$.

necedade: "tolice, fatuidade" (Bluteau) $(35,43)$.

negaça: aquilo que se mostra "para atrair com engano" (Bluteau); isca, chamariz $(52,44)$.

niños: ninhos $(36,42)$. 
nota: "defeito, falta, ação de que alguém é notado e censurado" (Bluteau): "dar nota" provavelmente significa "cometer um erro" $(72,61)$.

novamente: recentemente $(69,84)$.

novel: diz-se do jovem recém ingressado na ordem da cavalaria $(6,81)$.

novo: inexperiente, ignorante $(14,45 ; 41,63)$; a expressão "de novo" pode significar

"outra vez, novamente" $(4,8 ; 13,64)$ ou "recentemente, ultimamente, há pouco tempo" $(1,18-19 ; 8,25 ; 10,70)$.

obrigação: dever de consciência $(5,45 ; 10,25)$; dívida de gratidão $(12,43)$; empenho $(13,58)$.

obrigado: que tem obrigação com alguém; agradecido (80,31). Ver obrigação.

obrigar: "estar obrigado a fazer alguma coisa; obrigar alguém, deixar alguém obrigado com mercês, beneficios, bons ofícios etc" (Bluteau) $(5,128 ; 13,63)$.

obzequio: "obras ou palavras cortesãs, reverentes; ganhar com obséquios a vontade de alguém" (Bluteau) (35,38).

occazião: motivo, causa, situação propícia, ensejo (21,52); em 41,59 parece indicar "oportunidade" ou "objetivo".

offender: atacar $(28,50)$

offendido: ferido $(14,96)$.

olmo: certo tipo de árvore $(54,81)$.

omisiar: indispor, intrigar $(22,92)$.

oppinião: nome, reputação (Bluteau) $(18,37)$.

opressa: oprimida $(22,158)$.

orar: proferir discurso $(41,95)$.

ordem: fila, fileira (em "três ordens de dentes":13,76); "dar ordem" significa "ordenar, aprestar" $(14,88)$.

ordinaria: comum $(76,94)$.

outeiro (oiteiro): monte, colina $(4,41 ; 71,81)$.

padastro (padrasto): monte ou colina $(55,11)$.

pago: "em pago" significa "em troca” $(4,83)$.

pairar: "Termo Náutico. Ir a nau flutuando de uma parte para outra, sem fazer viagem

(...). Andar pairando. Diz-se como metáfora náutica de quem anda buscando 
subterfúgios para evitar alguma coisa. Tergiversar. (...) Parar o navio por falta de vento" (Bluteau). $(1,49 ; 35,94)$.

paixão: sentimento ou afeto vivo e intenso. No texto, o mais comum é a cólera (cf. 4,71

e 21,63), mas o termo também pode indicar o sofrimento amoroso $(12,54)$.

palafrem: cavalo manso, próprio para senhoras $(4,103)$.

palrrar: falar $(62,27)$.

pão: trigo, plantação de trigo $(58,54)$.

parado: levado $(41,41)$. Ver mal parado.

parar: dar em um fim $(22,46)$.

parecer: aparência, beleza (17,54); em 42,67 "não era mal parecida" significa "não era feia".

parte: o termo é muito comum e assume várias significações: partes (nas expressões "boas partes", "sem partes" etc), de acordo com Bluteau, significa "talento natural, qualidades pessoais, prendas da natureza, qualquer habilidade, destreza em qualquer arte" $(1,45 ; 10,77 ; 20,15 ; 22,86)$; parte pode significar ainda "lugar, região" $(6,35 ; 6,87)$; “de parte” significa “à parte” $(19,81)$.

particula: "pequena palavra, que consta de uma ou duas sílabas" (Bluteau) $(14,72)$.

particular: "homem que não tem ofício público; que vive particularmente consigo, sem cargos nem dignidades na república” (Bluteau) $(44,7)$.

particularidade: intimidade $(72,18)$.

particularizar-se: relacionar-se com familiaridade ou intimidade com alguém $(74,24)$.

particularmente: em particular, em detalhe $(3,60)$.

partido: opção $(28,38)$.

paso: passo, passagem $(64,78)$.

passadiço: corredor que une duas casas ou construções diferentes $(49,70)$.

passados: antepassados $(14,33)$.

passar: acontecer, suceder $(16,104)$.

passo: devagar, lentamente $(17,78)$.

pee: pé $(28,46)$; “de pe” significa “a pé”, ou seja, não montado em cavalo $(73,75)$.

pega: certo tipo de ave pequena $(16,56)$.

pegado: próximo, junto $(55,103)$.

pelourinho: coluna posta em local público para expor e castigar os criminosos $(60,111)$. 
pelouro: bala de ferro ou pedra empregada na artilharia $(55,42)$.

penhores: "prenda, ou outra coisa que segura amizade, fidelidade, ou outra coisa que se promete" (Bluteau) (1,76).

perceito: ordem, conselho $(41,12)$.

perdição: perda, desaparecimento $(36,3)$.

perdimento: perda $(22,130)$.

perfil: fio, linha, contorno $(4,19 ; 15,97)$.

persevativo: antídoto $(60,65)$.

pesponto: técnica de costura que consiste em dar pontos muito próximos uns dos outros, com fios de prata ou ouro, formando como que uma linha contínua de muitos pontos $(54,58)$.

pessonha (peçonha): peçonha, veneno $(23,113 ; 66,39)$.

pezado: custoso, difícil (6,72); "molesto, enfadonho" (Bluteau) $(64,33)$; "vox pezada" pode significar "voz forte ou grave" $(15,126)$; severo, rigoroso $(29,27)$.

pezar (pesar): causar desgosto ou pesar; entristecer-se $(1,38 ; 5,34)$.

pezo: "em pezo" significa "na totalidade" $(15,95)$.

pião: soldado a pé $(32,29)$.

picão: espécie de picareta $(52,65)$.

pique: certo tipo de lança com ponta de ferro $(15,26)$.

pita: "é palavra do Brasil, e nome de uns fios amarelinhos, com que antigamente se faziam os pespontados dos punhos das camisas" (Bluteau); em 55,48 as fitas são negras e ornam a gola da camisa.

poderozo: capaz $(17,28)$.

polvilho: pó fino $(22,18)$.

pomo: "pomo da espada" significa "empunhadura da espada" $(46,75)$.

ponto: em expressões de negação, o termo é usado como reforço de sentido: p. ex. "não desviar um ponto" $(1,26)$; "sem mostrar um ponto de fraqueza" $(9,19)$; "estar a ponto" significa “estar pronto" $(30,38)$; grau $(79,53)$; estado? condição? $(80,57)$.

pontoso: pundonoroso, brioso $(20,10)$.

por amor: por causa de $(5,6-7)$.

por onde: por meio de $(15,16)$.

por todos: ao todo $(15,28)$. 
porque: às vezes significa "para que" (como em 61,10).

postigo: porta pequena; pequena abertura em porta ou janela grande $(19,43)$.

pouzar: pernoitar $(39,20)$.

praceta: praça pequena $(41,14)$.

prancha: a parte lateral da espada, em que ela é mais larga e não corta $(9,66 ; 34,50)$.

prassa: praça, fortaleza $(31,38)$.

pratica: conversa, diálogo $(5,22)$.

praticar: falar, conversar $(19,63)$.

pratico: pessoa experimentada ou conhecedora de algo (59,72); mal pratico: inexperiente, pouco versado em hábitos cortesãos $(75,42)$.

pregoar: apregoar $(8,7)$.

prepozito: propósito, motivo $(18,91)$.

pressa: na expressão, muito comum em novelas de cavalaria, "ali foi a pressa da batalha", significa “aperto, perigo" (Bluteau) (15,69). Ver apressado e apressadamente.

pressago: que faz presságios $(27,14)$.

prestes: preparado, prevenido $(15,46)$; “fazer prestes" significa "preparar ou prepararse" (1,81); "estar prestes" significa "estar pronto, preparado ou prevenido" $(10,43)$.

prevenção: cuidado, resguardo $(17,47)$.

prezentar: apresentar $(10,48)$; presentear $(10,61)$.

primeiro: próximo $(19,89)$.

primissão: permissão $(44,20)$.

prizões: cadeias (em 30,5 indica a corda utilizada para manter um refém).

proa: direção $(50,42)$; "pôr a proa" significa "dirigir-se para" $(78,55)$.

progressos: avanços $(15,114)$; resultados $(35,54)$.

prometter: firmar com certeza $(76,78)$.

promissão: promessa $(22,125)$.

prompto: atento $(18,80)$.

proprio: "ser próprio" pode significar "ser caro a alguém, ser pertinente a alguém" $(22,116 ; 26,33)$.

provocação: estímulo $(41,96)$. 
prumo: pedaço de chumbo amarrado a uma corda, formando instrumento utilizado por marinheiros para verificar a profundidade do mar ao se aproximarem da costa $(36,9)$.

publicar: "fazer alguma coisa pública com pregação ou trombeta; fazer uma coisa ser notória" (Bluteau); divulgar notícia (6,76); publicar-se: alardear-se $(22,98)$.

publico: de uso coletivo $(19,84)$.

puridade: segredo íntimo $(24,6)$.

quadra: "casa [quarto] que está mais adentro da sala e, pela forma que tem de ordinário quadrada, se chama quadra"; "quadra, chamam outros um pátio quadrado rodeado de edifícios" (Bluteau) $(53,20)$.

quadrilha: grupo de quatro cavaleiros ou combatentes a pé $(73,75)$.

quando: assume, por vezes, um valor condicional, como "se, em caso de" $(5,51 ; 7,49)$.

quarteirões: cada uma das quatro partes de um escudo $(4,49)$.

quarto: lado ou parte do corpo $(21,39)$.

quebra: infração, transgressão; neste sentido, é normalmente utilizado em expressões como "quebra de opinião" (18,38), "quebra da honra" $(28,11)$; perda, derrota, desonra $(56,93)$.

quebrada: "terra desigual e meio arruinada, como se vê em valas, outeiros, montes etc. em que chuvas impetuosas, cheias ou torrentes abriram e em certo modo quebraram em várias partes" (Bluteau) $(58,76)$.

quebrado: alquebrado, envelhecido $(7,64)$; "quebrar a palavra" significa "descumprir o que havia sido acordado" (16,130). Ver quebra.

quebrantado: alquebrado, extenuado $(34,95)$.

quietação: "tranqüilidade de espírito" (Bluteau) $(12,42)$.

quietar (aquietar): acalmar, amenizar, tranqüilizar $(13,72)$.

quieto: calmo, tranqüilo $(12,9)$.

quittar: desobrigar, redimir dívida $(29,26)$.

rasgados: "olhos rasgados" são olhos "grandes, bem abertos da natureza" (Bluteau) $(77,63)$.

rasto: "levar à rasto" significa "arrastar" $(36,47)$.

rateficar: ratificar $(44,74)$. 
razão (rezão): motivo, causa $(4,80 ; 6,60)$; "potência intelectiva" (Bluteau) $(17,26)$; ação justa ou razoável, que está de acordo com a razão: nesta acepção normalmente aparece na expressão “ser razão" $(8,23 ; 22,85)$; discurso, argumentação, fala: nesta acepção normalmente o termo é usado no plural $(10,55 ; 25,31)$; “dar razão de algo" significa "dar notícia ou dar parte de algo" $(2,62-3 ; 8,96)$; “ter razão com alguém" significa "ser próximo, estimar". Ver sem razão.

rebate: alarme; "dar rebate" significa "soar o sinal alarme" $(51,21)$.

rebuço: capuz ou parte da manta com que se cobre o rosto $(64,81)$.

recado: notícia, mensagem, informação $(2,2 ; 2,41)$; "pôr as coisas a recado, ou a bom recado", de acordo com Bluteau, significa pô-las “em lugar seguro” $(6,121)$.

recamera: "recâmara também se chama o aparato que leva um senhor de caminho [em viagem] de coisas para serviço de sua pessoa" $(36,26)$.

recontro: encontro, choque, batalha $(69,73)$.

redada: "lanço de rede" (Bluteau) $(49,49)$.

reduzir: reconduzir à forma original $(1,6)$; conduzir algo a certa forma ou estado $(1,66$; 9,95); diminuir de tamanho $(11,46)$.

referir: contar $(21,75)$.

refocilar: recrear-se, descansar; recobrar forças, revigorar; refestelar-se, deleitar-se $(56,50)$.

regallar: tratar com mimo e delicadeza $(6,22)$.

regallo: contentamento, prazer $(1,48)$.

regra: linha? $(60,110)$.

regular: igualar, comparar, conformar $(65,9)$; dirigir $(80,17)$.

reliquia: prenda preciosa $(23,102)$.

rellação (relação): narração, relato (12,72); a expressão "fazer relação" significa "relatar" (10,14).

remendado: "cavalo remendado: aquele que tem malhas a modo de remendos de várias cores" (Bluteau) $(27,33)$.

remeter ou remetter: ver arremeter.

remissão: perda de vigor ou força $(48,92)$.

remoella: "pirraça, acinte" (Bluteau) $(61,22)$.

reparar: proteger $(58,77)$. 
reposta: resposta (as duas formas convivem no texto) $(25,73)$.

repugnancia: em 18,7 o termo parece significar relutância, escrúpulo.

respeito: o termo é muito comum e, de acordo com o contexto, pode significar motivo, causa $(6,83 ; 9,55)$; “a respeito de" significa "por causa de" $(10,23 ; 15,12)$; “desses respeitos" significa "a respeito disso" (16,75); consideração, reverência, "caso, estimação" (Bluteau) $(18,50 ; 21,30 ; 22,12)$; "amizades nuas de respeitos" parece significar "sem formalidades" $(3,12)$; "soster o respeito" parece significar "conterse" $(25,20)$; respeito pode indicar ainda a idéia de conveniência social $(59,17)$.

restetuição: restituição; "estar em restetuição" significa "fazer justiça" $(64,32)$.

retirada: saída, alternativa $(60,81)$.

retirado: "apartado da comunicação da gente" (Bluteau) $(60,97)$.

retrete: cômodo pequeno e oculto $(22,102)$.

reves: golpe; infortúnio ou insucesso, especialmente no encontro com outro cavaleiro $(15,49)$.

revolver: de acordo com Bluteau, a expressão "revolver alguma coisa na memória" significa "andar cuidando nela" $(22,11)$; "revolver o mundo" significa "percorrer o mundo" em busca de alguma coisa $(42,17)$.

rezolver: "dissolver; converter" (Bluteau) (79,35); rezolver-se: convencer-se, estar convicto de algo $(77,31)$.

ribeira: riacho, regato $(50,93)$.

ribeiro: o mesmo que ribeira.

rigor: aspereza, severidade no trato $(4,39 ; 12,82 ; 13,14)$.

rizos (risos): riscos? traços? $(2,13 ; 27,33)$.

rocio: rossio, praça ou terreiro largo $(5,106)$.

rodella: pequeno escudo de forma circular $(41,22)$.

rodeo: espaço interior delimitado por cerca em forma de círculo? $(58,40)$.

roletes: "tranças de cabelo, que as mulheres acumulavam no alto da cabeça" (Elucidário) $(2,11)$.

romaria: viagem $(63,40)$.

rompente: na heráldica, o leão rompente é o leão em atitude de arremeter $(10,20)$.

rompimento: desentendimento, contenda $(38,41)$.

roqueiro: "castelo roqueiro" é um castelo assentado sobre uma rocha $(5,104)$. 
rostro: rosto (as duas formas convivem no texto) $(5,71)$.

rotura: abertura $(58,41)$.

ruço: pardo $(42,20)$.

salamear: fazer a salema, isto é: o "vozerio de marinheiros" (Bluteau) $(51,7)$.

salvo: "a vosso salvo" significa "em segurança, sem risco de dano" $(28,40)$.

sangue: família, geração, raça $(22,13 ; 22,82)$.

sanguinho: avermelhado, da cor do sangue $(10,20)$.

sarração: cerração $(35,65)$.

satisfação: "dar satisfação de si" significa o mesmo que "cumprir com o que se deve a si mesmo" $(39,76)$.

sciente: sábio, douto $(9,11)$.

segurar: vigiar, guardar $(32,37)$.

sem razão: ação injusta ou contra a razão $(18,33 ; 21,53)$. Ver razão.

sensitivo: sensível, delicado $(77,10)$.

sentimento: dor $(6,100 ; 14,30)$; pesar, ressentimento $(18,43)$.

sentir: perceber, notar; ouvir $(17,35 ; 18,27)$.

sequidão: secura, "aspereza de condição" (Bluteau) $(22,48)$.

setia (cetia ou settia): tipo de embarcação pequena, semelhante à caravela $(30,31)$.

sevandija: "qualquer pessoa de baixa estofa e de baixa estimação" (Bluteau) $(63,49)$.

sezudo (sizudo): sisudo, ajuizado $(6,22 ; 19,35)$.

si: $\operatorname{sim}(8,64)$.

siar-se: preocupar-se? $(46,17)$.

simitarra: sabre oriental de lâmina curva $(51,61)$.

singeleza (singileza): "sinceridade, lhaneza" (Bluteau) $(40,44 ; 75,57)$.

singellamente: sinceramente, honestamente $(52,127)$.

sitim: cetim $(27,30)$.

sizo (cizo): "falar de sizo" significa "falar a sério" (24,52-53): "de cizo" pode significar também "duramente" $(46,23)$.

sobraçado: sobreposto, em posição de destaque $(2,10)$.

sobreescrito: indicação do nome e endereço do destinatário em uma carta $(60,110)$. soer: costumar, ter por hábito. Alguns exemplos sohião $(1,15 ; 23,15)$; sohia $(12,81)$. sofrer: admitir, permitir $(5,119)$; suportar, agüentar $(7,18)$. 
sofrimento: "paciência ou tolerância" (Bluteau) $(33,72)$.

solto: são? $(46,85)$.

sombra: "figura, representação" (Bluteau) (13,11); "aparência, arremedo"; "sinal ou indício" (Bluteau) (44,7); "boa sombra" significa "de boa vontade, com bom aspecto" $(27,43)$.

sombreiro: chapéu de abas largas, que fazem sombra $(2,12)$.

sotil: sutil, delgado, leve $(46,104)$.

sucesso (successo): acontecimento $(4,106 ; 15,132)$; resultado $(16,02 ; 17,48)$.

supito: súbito $(21,41)$.

suppiditar (supetidar): conduzir? estimular? $(41,41)$; derrotar? submeter? $(60,45)$.

suprestição: crença infundada $(18,18)$.

surto: "aportado; chegado ao porto" (Bluteau) $(30,42)$.

suspenção: pausa $(43,44)$.

tabuleiro: degrau $(52,50)$.

tafetà: tipo de tecido de seda $(22,18)$.

talhos: talhes, feições $(12,39)$.

tardança: detença, atraso, demora.

tea: teia $(40,53)$.

telilha: tela fina $(2,10)$.

temidos: temerosos $(29,5)$.

tenca: certo tipo de peixe $(55,41)$.

tenção: intenção, objetivo $(5,15)$.

tento: atenção $(29,43)$.

ter: segurar, agarrar algo ou alguém $(21,30 ; 21,56)$; "ter conta" significa "estar atento" $(11,11)$; “ter mão" significa "parar" $(24,52)$ ou "teimar, obstinar-se" $(70,88)$.

terecena: depósito onde se guardam embarcações e apetrechos navais $(50,102)$.

termo: palavra de difícil definição, pode assumir diferentes significados: modo $(5,128$; $22,7)$; modos ou maneiras de alguém $(6,69 ; 16,74)$; estado $(23,57)$; prazo $(22,130)$; as expressões "fazer termos de desmaios" ou "termos mortais" $(9,131)$ indicam a agonia ou o risco de quem está à beira da morte.

terribilidade: "qualidade ou circunstância que faz uma coisa terrível" (Bluteau) $(25,6)$. tezo: "animoso, valente" (Bluteau) $(47,48)$. 
theatro: palco $(22,16)$.

tirado: afora, exceto $(20,56)$.

tirante: "tirante a branco" significa que uma cor é próxima do branco $(77,66)$.

tirar: puxar $(20,77 ; 79,12)$; atirar, arremessar $(6,37)$.

toleravel: suportável $(23,11)$.

torçaes: plural de torçal: cordão de seda $(22,19)$.

torcer: desviar, distorcer $(44,55)$.

torvação (turbação): turvação, perturbação $(13,25)$.

trabalhar: esforçar-se para conseguir algo $(4,75)$; aplicar-se com diligência $(6,17)$.

trabalho: sacrifício $(5,95)$; exercício $(6,34)$; perigo ou dificuldade $(7,42 ; 7,51)$.

trabalhozo: "homem trabalhoso: enfadonho, impertinente, ou que pode causar trabalhos" (Bluteau) $(5,123)$.

traça: plano, intento $(41,20)$.

traçar: maquinar, delinear um plano ou projeto $(39,85)$.

trance: transe, momento de aflição e perigo $(9,74)$.

trancelim: "espécie de cintilho de prata, ouro ou pedras enfiadas com que se apertava a copa do chapéu" (Bluteau); pode significar também trança fina de seda, ouro ou prata; cordão de ouro fino $(2,14 ; 27,32)$.

transido: "muito apertado de alguma penalidade" (Bluteau) $(31,94)$.

tras: depois $(3,49 ; 6,15)$.

tratar: combinar, acordar, pactuar $(15,111)$; conviver $(19,69)$.

travessia: vento que sopra em direção à costa $(35,100)$.

treição: traição; à treição: traiçoeiramente $(33,75)$.

trocado: mudado $(17,52)$.

ufania: "jactância, ostentação, soberba, arrogância” (Bluteau) $(18,85)$.

ultimamente: em último lugar, por fim $(6,116)$.

ultimo: máximo $(37,26)$.

uzar: praticar, exercer $(24,14)$.

vagar: calma, sossego $(23,97)$.

valedores: protetores $(26,9)$.

valer: socorrer, proteger $(4,69)$.

valhacouto: refúgio $(64,33)$. 
valia: amparo (12,7); préstimo $(19,73)$.

valido: criado que goza do favor e amparo de seu senhor $(79,52)$.

vallado: "terra levantada e assentada com balde, serve de cercar um campo, uma vinha ou outra propriedade" (Bluteau) $(59,77)$.

varge: vargem, várzea $(4,43)$.

varia: inconstante $(77,35)$.

variamente: diversamente $(1,22)$.

variar: alterar, modificar $(12,50)$.

vascilar: estar em dúvida, inseguro ou perplexo $(43,85)$.

vasquinha: "nome antigo de saias com muitas pregas" (Bluteau) $(55,47)$.

vaza: limo ou lodo do mar; areia $(36,8)$.

vela: "fazer á vela" significa "içar velas" $(23,108)$.

ventura: acaso, fortuna (ver) $(22,72)$.

venturozamente: ditosamente, afortunadamente $(15,78)$.

ver: "não era pouco para ver" significa admirável $(13,83)$.

verdugada: "antiga vestimenta de mulher" (Bluteau) $(55,46)$.

verisimel: verossímil $(45,30)$.

vidrento: frágil, suscetível $(73,54)$.

violla: violeta; "cor de violla": roxo escuro $(45,55)$.

vir: "vir a braços" é como se descreve a situação em que, num combate entre dois cavaleiros, eles medem suas forças procurando derrubar um ao outro sem usar arma alguma, apenas com a força dos braços $(9,60 ; 16,50)$; "vir em alguma coisa" significa "concordar, aceitar" (20,14; 22,81).

virtude: qualidade, valor $(14,54)$.

visto: "versado, perito" (Bluteau) $(59,80)$.

vivo: vivaz, vigoroso, ligeiro $(43,29)$.

vizeira: "é a abertura do capacete e a grade pequena, por onde se respira, quando se abaixa" (Bluteau) (16,24).

volta: "o caminho que se toma para alguma parte" (Bluteau); a expressão "na volta de" $(3,21)$ significa "em direção a" ou "a caminho de"; "tira de pano que cinge o pescoço, pregada no cabeção do jubão"; gola $(55,48)$ : “a voltas" significa “juntamente" $(57,29)$. 
vos (vox): voz $(29,38)$; "dar uma grão vox" singifica "exclamar, gritar, dizer a alta voz" $(50,25)$.

xarcea: $(47,10)$ ver enxarxia. 


\section{APÊNDICE 2}

\section{ÍNDICES}

Apresentamos a seguir os índices de personagens, de localidades e de obras citadas.

O primeiro índice tem por objetivo auxiliar o leitor a identificar os personagens e seus parentescos. Após a identificação de cada personagem, são anotados os números dos capítulos em que eles são mencionados. Foram consideradas também as referências indiretas, quando o nome do personagem em questão não é expressamente citado. Por exemplo: todos os capítulos em que o Imperador é lembrado são anotados junto ao nome de Primaleão (I).

A fim de evitar possíveis embaralhamentos causados por personagens com nomes repetidos (via de regra filhos e netos que tomam os nomes de pais e avós), distinguimo-los por números romanos. Assim, D. Duardos (I) é o rei de Inglaterra, pai de Palmeirim de Inglaterra; D. Duardos (II) é o príncipe, filho de Palmeirim, que recebeu o mesmo nome do avô.

Dada a posição desta obra no ciclo dos Palmeirins, alguns personagens de obras anteriores são lembrados no texto. Nestes casos, registramos a qual das partes do ciclo o personagem pertence, esclarecendo sumariamente seu papel e destino. É o caso, por exemplo, de Albaizar (I), personagem do Palmeirim de Inglaterra morto ao final daquela obra, mas freqüentemente lembrado nesta.

O índice geográfico permite identificar as regiões citadas na obra, aquilatandolhes também a importância, proporcional à quantidade de referências.

Por fim, o índice de obras citadas oferece a oportunidade de identificar e localizar as referências no texto a outras obras. Embora poucas, cremos que listá-las pode ser útil. 


\section{1. Índice de Personagens}

Albaizar (Abbaisar, Albaisar) (I): antigo Sultão de Babilônia, que morre na batalha final do Palmeirim de Inglaterra. É casado com Targiana e pai de Albaizar (II). 01, 06, $07,17,18,44$.

Albaizar (Albaisar) (II): filho de Albaizar (I) e Targiana. 15, 16, 17, 18, 19, 20, 21, 23, 24, 25, 26, 27, 28, 30, 32, 35, 37, 42, 43, 44, 45, 46, 47, 48, 49, 50, 51, 52, 70, 72.

Albarroco: personagem do Palmeirim de Inglaterra. Gigante aliado do Sultão de Pérsia, morto por Palmeirim. Seu filho, não nomeado, acompanha os Cavaleiros da Morte no torneio dos novéis em Constantinopla. 17.

Albuzario: personagem do Palmeirim de Inglaterra, onde se chamava Albuzarco. Gigante aliado do Sultão de Pérsia, morto por Floriano. Seu filho, não nomeado, acompanha os Cavaleiros da Morte no torneio dos novéis em Constantinopla. 17.

Almourol (I): gigante e guardião do castelo também chamado de Almourol, onde permanecia Miraguarda. Casou-se com Cardiga; pai de Almourol (II). Morto na batalha contra Albaizar (I). 05 .

Almourol (II): filho de Almourol (I) e Cardiga. 12, 13, 15, 16, 17, 26, 52, 65, 66, 67, 68, $69,70,71,75,78,79$.

Altea (Althea): amada de Floramão, morta por seu pai. 10, 20.

Appolidon (Appollidon, Appolydon): personagem do Amadis de Gaula. Antigo príncipe grego, senhor da Ínsula Firme e conhecedor das artes mágicas. 13, 14, 15, 35, 38, 48 .

Ardenio (Ardellio ou Ardelio): escudeiro de Primaleão (II). É filho do antigo escudeiro de Florendos, chamado Armelo. 54, 56, 62, 63, 70, 71.

Ardimão de França: filho de Germão de Orléans e Floriana (irmã de Graciano), é um dos cavaleiros criados na Ilha Perigosa. 12, 15, 16, 20, 24, 25, 26, 77, 78, 79.

Arlança: giganta, é esposa de Dramusiando e mãe de Pavorante. 04, 26, $31,38$.

Arláo, Conde: pai de D. Floris e de Miraguarda. 05, 06.

Armelo: escudeiro de Florendos no Palmeirim de Inglaterra. É pai de Ardênio, escudeiro de Primaleão (II). 54.

Arnedos (I): antigo rei de França, pai de Graciano. Personagem do Palmeirim de Inglaterra, morto na batalha contra Albaizar (I). 06. 
Arnedos (II). filho de Graciano e neto de Arnedos (I). É príncipe da França e um dos cavaleiros criados na Ilha Perigosa. 12, 15, 16, 26, 61, 62, 77, 78, 79, 80.

Barrocante: personagem do Palmeirim de Inglaterra. Gigante aliado do Sultão de Pérsia, morto por Dramusiando. Seu filho, não nomeado, acompanha os Cavaleiros da Morte no torneio dos novéis em Constantinopla. 17.

Belcar: neto do rei Frisol da Hungria e filho de pai também chamado Belcar. É irmão mais novo de D. Rosuel. 12, 15, 16, 25, 26, 52, 65, 66, 67, 68, 69, 70, 71, 80.

Beliazem (Belliazem): filho de Armênia, sucessor do Sultão de Pérsia. Companheiro de Albaizar (II). 15, 16, 17, 24, 36, 42, 43, 45, 46, 51.

Beroldo: rei de Espanha, filho de Recindos (I). É pai de Valeriza e Recindos (II). Sua esposa, nunca nomeada na Crônica de D. Duardos, chamava-se Melisa no Primaleón. 01, 03, 06, 07, 09, 23, 26, 28, 30, 35, 36, 72.

Blandindon (Blandidon): sultão de Niquea, filho de Belagris e Paudrícia. 01, 03, 07, 26, $28,35,36$.

Braceliano (Barceliano, Braciliano): cavaleiro natural da Espanha, corteja Daraja e torna-se amigo de Trineo. 58, 59, 60, 61, 62, 78.

Brusdolfo: gigante que aprisionava cavaleiros em sua ilha. É filho de Bracandor, personagem do Palmeirim de Inglaterra. 51, 52, 70.

Cadramonio (Cadrimonio): gigante, senhor da Ilha de Deiscla, aliado de Pamphilio. 23, $33,34,40$.

Calfarneo (Calfurneo): gigante morto por Floriano no Palmeirim de Inglaterra, onde aparece com nome de Calfúrnio. É irmão de Arlança e de Comboldão. 04, $26,31$.

Camilote: personagem do Primaleón, era um cavaleiro de aspecto selvagem. Num desafio feito na corte de Constantinopla, é derrotado por D. Duardos (I). 18.

Cardiga: giganta casada com Almourol (I); seu filho também se chama Almourol (II). 04.

Carmellia (Carmelia): filha de Floriano do Deserto e Leonarda, irmã de Vasperaldo. 01, $03,07,09,10,13,16,17,18,19,21,22,24,25,26,27,28,30,31,32,35,36,37$, $42,43,44,45,46,47,48,49,50,53,72,73,74,75,77$.

Cavaleiro do Leão: pseudônimo utilizado por Lisânio. 04, 05,

Cavaleiro do Salvage: pseudônimo utilizado por Floriano do Deserto no Palmeirim de Inglaterra. 03, 49. 
Cavaleiro do Sol: pseudônimo utilizado por Primaleão (II) durante sua permanência em Boêmia. 54, 55, 63, 64, 65, 66, 67, 68, 69, 70, 71, 73, 76, 77, 78, 79.

Cavaleiro dos Ciprestes: pseudônimo usado por D. Duardos II. 29, 30, 51, 53, 61.

Cavaleiros da Morte: pseudônimo utilizado por Albaizar (II) e Beliazem. 15, 16, 17, 18.

Celinda: camareira de Carmélia. 21, 22, 24, 25, 35, 36, 43, 70.

Colambar: giganta, mãe de Arlança, Calfarneo e Comboldão, morta no Palmeirim de Inglaterra. 28.

Comboldao (Camboldão): gigante irmão de Arlança e Calfarneo, no Palmeirim de Inglaterra aparece com o nome de Camboldão e foi morto pelo protagonista daquele livro. 04, 26, 31.

Daliarte: sábio conhecedor de artes mágicas, filho do Rei D. Duardos (I) e Argonida; irmão de Pompides e meio irmão de Palmeirim de Inglaterra e Floriano: 01, 02, 03, 04, 06, 07, 09, 10, 11, 12, 13, 14, 15, 16, 26, 28, 36, 37, 38, 48, 49, 53, 61, 68, 74.

Daraja: jovem pela qual Braceliano se apaixona. 59, 60.

Ditreo: filho de mais velho do rei Frisol, é tio de D. Rosuel e Belcar; sua morte é narrada no Palmeirim de Inglaterra. 51.

Dragonalte: filho do Conde Drapos da Normandia; é rei de Navarra e casado com Arnalta (sobre Dragonalte, ver cap. 03, nota 11). 03, 07, 26, 28, 35, 36.

Dramaciana: esposa de D. Rosuel, mãe de Belcar. 12.

Dramusiando (Dramuziando): gigante, filho de Farnaque. É casado com Arlança e pai de Pavorante. 01, 03, 04, 05, 06, 07, 08, 09, 10, 11, 13, 15, 16, 23, 26, 31, 38, 50, $54,67,68,69,70,71,72,73,75,76,77,78,79,80$.

Drusia Velona (Druzia ou Drucia Vellona): sábia conhecedora das artes mágicas, oriunda da Pérsia, que serve a Targiana. 37, 43, 44, 45, 46, 47, 48, 50, 74.

Duardos, D. (I): rei de Inglaterra, casado com Flérida (I). Pai de Palmeirim de Inglaterra, Floriano, Pompides e Daliarte. 01, 03, 04, 07, 09, 11, 12, 13, 14, 15, 17, 26, 27, 28, 29, 35, 36, 38, 41, 48, 49, 71, 76 .

Duardos, D. (II): filho de Palmeirim de Inglaterra e Polinarda; irmão de Flérida (II). 10, $12,13,14,15,16,18,19,20,21,22,24,25,26,29,30,31,32,34,44,45,47,48$, $49,50,51,52,53,62,67,68,69,70,72,73$. 
Duquesa de Monte Alto: leva D. Floris a Nápoles para vingar-se de Pamphilio. 10, 22, $23,32,33,34,39,40$.

Enaclia (Ennaclia): dama de companhia da princesa Fidélia. 55, 56, 63, 65, 66, 68, 79.

Evaristo: rei de Nápoles. 10, 22, 23, 33, 34, 39, 40, 41.

Fidelia (Fidellia): princesa de Boêmia; é filha do rei Venceslau e da rainha Rodegínia. $10,54,55,56,57,62,63,64,65,66,67,68,70,71,73,75,76,77,78,79,80$.

Filismarte: príncipe da Sicília. 23, 33, 34, 39, 40, 41.

Flerida (I): filha de Palmeirim de Oliva e irmã de Primaleão (I). Casada com D. Duardos (I), é mãe de Palmeirim de Inglaterra e Floriano do Deserto.07, 09, 12, 35.

Flerida (II): filha de Palmeirim de Inglaterra e Polinarda; irmã de D. Duardos (II): 01, 03, 07, 10, 13, 17, 18, 19, 20, 22, 24, 25, 26, 27, 32, 72, 73, 74, 75, 77.

Floramão: rei da Sardenha, companheiro de aventuras de Palmeirim de Inglaterra. 10, $11,12,19,20,21,23,24,25,26,27,28,37,52,53,54,68,69,70$.

Florendos (Florendós ou Florendes): filho de Primaleão (I) e Gridônia (I). Casado com Miraguarda, é pai de Primaleão (II) e Gridonia (II). 01, 02, 05, 06, 07, 09, 12, 13, $17,20,26,27,28,37,49,52,53,54,68,69,70$.

Floriano do Deserto: filho de D. Duardos (I) e Flérida (I), irmão gêmeo de Palmeirim de Inglaterra. Rei de Trácia, casado com Leonarda; é pai de Carmélia e Vasperaldo. 01, 03, 07, 08, 09, 11, 13, 15, 23, 25, 26, 27, 28, 30, 31, 35, 36, 37, $43,49,72,77$.

Floris de Lusitania, D.: filho do Conde Arláo, meio irmão de Miraguarda. 04, 05, 06, 07, 08, 09, 10, 11, 12, 15, 16, 19, 20, 21, 22, 23, 32, 33, 34, 38, 39, 40, 41, 45, 46, $47,48,49,50,70,72,73,74$.

Framustante: personagem do Palmeirim de Inglaterra. Gigante aliado de Albaizar (I) morto por Dramusiando. Seu filho acompanha os Cavaleiros da Morte no torneio dos novéis em Constantinopla. 17.

Francião: rei de Tessália, neto de Palmeirim de Oliva. No cap. 03, seu nome aparece grafado incorretamente (Francido): cf. cap. 03, nota 14 e cap. 07, nota 06. 03, 07, $26,28,35,36$.

Francido: ver Francião. 
Frenellio (Franellio): filho de Pompides. 03, 13, 15, 16, 26, 52, 65, 66, 67, 68, 69, 70, $71,80$.

Frisol: antigo companheiro de aventuras de Palmeirim de Oliva, foi rei da Hungria. Casado com Armida, teve dois filhos: Belcar e Ditreo. Sua morte é narrada no Palmeirim de Inglaterra. 51.

Graciano (Garciano): rei da França, filho de Arnedos (I). É pai de Arnedos (II). Sua esposa, aqui nunca nomeada, é Clarísia, irmã de Francião, conforme se lê no Palmeirim de Inglaterra. 01, 03, 04, 07, 26, 28, 35, 36, 76.

Grão Turco: pai de Targiana. 25.

Gravanào: escudeiro de D. Floris. 10, 19, 20, 21, 34,

Gridonia (I): filha da duquesa de Ormedes e princesa de Apolônia. Casada com Primaleão (I), é mãe de Florendos, Platir e Polinarda. 02, 07, 11, 12, 13, 15, 21, $22,23,25,27,49,72,73,76,80$.

Gridonia (II): filha de Florendos e Miraguarda. 01, 02, 07, 09, 1013, 17, 18, 19, 22, 23 , $24,27,32,49,61,62,72,73,74,75$.

Henrique Frusto (Henrrique Frusto ou Frustão): autor imaginário do livro. 15, 35, 37, $45,46,47,58,62,65,77,78,79$.

Julião: identidade falsa de D. Duardos (I) que, disfarçado de jardineiro, tenta conquistar o amor de Flérida no Primaleón. 18.

Leonarda: rainha de Trácia, neta de Sardamante. É casada com Floriano e mãe de Carmélia e Vasperaldo. 03, 07, 08, 09, 12, 13, 27, 35, 48, 49, 73.

Lisandra (Lysandra): filha do rei Evaristo de Nápoles. 23, 33, 34, 39, 40, 41.

Lisanio: tio materno de D. Floris, também chamado de Cavaleiro do Leão. 04, 05, 06, 10.

Ludimio: cavaleiro do reino de Boêmia. É parente de Enáclia, a quem serve como namorado. 56, 63, 68, 70, 71 .

Miraguarda: filha do Conde Arláo de Espanha, meia irmã de D. Floris. Casada com Florendos, é mãe de Primaleão (II) e Gridônia (II). 01, 02, 04, 05, 06, 07, 08, 09, $12,15,19,20,21,25,39,49,71$.

Palmeirim de Inglaterra: filho do Rei D. Duardos (I) e Flérida (I); irmão gêmeo de Floriano do Deserto. Casado com Polinarda, é pai de D. Duardos (II) e Flérida (II). 01, 03, 06, 07, 08, 09, 13, 15, 16, 17, 25, 26, 27, 28, 30, 35, 36, 43, 49. 
Palmeirim de Lacedemonia: filho de Platir. 12, 15, 16, 26, 52, 65, 66, 67, 68, 69, 70, 71, 80.

Palmeirim de Oliva: antigo Imperador de Constantinopla, pai de Primaleão (I) e Flérida (I). 01, 06, 76.

Pamphilio: cunhado da Duquesa de Montalto. 22, 23, 33, 34.

Pavorante: filho de Dramusiando e Arlança. 12, 13, 15, 16, 26, 38, 52, 65, 66, 67, 68, $69,70,71,73,75,77,78$.

Platir: filho de Primaleão (I) e Gridônia (I). É rei de Lacedemônia e pai de Palmeirim de Lacedemônia. Sua esposa, aqui nunca nomeada, chama-se Sidela, conforme informação do Primaleón e do Palmeirim de Inglaterra. 01, 07, 26, 27, 28, 35, 36, 69.

Pleonido: anão da companhia da princesa Fidélia. 55, 56, 57, 63, 64, 66, 70, 71, 79.

Polendos: filho de Francião, príncipe de Tessália (cf. nota 07, cap. 15). 15, 16, 26, 52 , 65, 66, 67, 68, 69, 70, 71.

Polinarda (Polynarda): filha de Primaleão (I) e Gridônia (I). Casada com Palmeirim de Inglaterra, é mãe de D. Duardos (II) e Flérida (II). 07, 12, 13, 15, 17, 35, 37, 49.

Polinardo (Polynardo): filho de Trineu e Agríola, personagens do Palmerín de Olivia, é irmão de Vernau. depois da morte de Vernau, governa o Império da Alemanha no lugar de seu sobrinho Trineu. Além disso, Polinardo é Conde de Flandres e duque de Borgonha (sobre este personagem, cf. o cap. 03, nota 12). 03, 07, 12, 26, 28, 35,36 .

Pompides: filho do rei D. Duardos (I) e de Argonida, irmão de Daliarte e meio irmão de Palmeirim de Inglaterra e Floriano. Rei de Escócia, casado com Armísia e pai de Frenélio. 01, 03, 07, 13, 26, 28, 36.

Primaleão (I): filho de Palmeirim de Oliva, torna-se Imperador de Constantinopla depois de sua morte. Casado com Gridônia (I), é pai de Florendos, Platir e Polinarda. 01, 02, 06, 07, 08, 09, 10, 11, 12, 13, 15, 16, 17, 20, 22, 23, 25, 26, 27, 28, 29, 30, 31, 32, 35, 36, 37, 39, 49, 70, 71, 73, 74, 75, 76, 80.

Primaleão (II) (Primalião). filho de Florendos e Miraguarda, neto de Primaleão (I). Irmão de Gridônia (II). 06, 10, 12, 13, 15, 16, 26, 54, 55, 56, 57, 62, 63, 64, 65, $66,67,68,69,70,71,73,76,77,78,79$. 
Rainha de Espanha: aqui não nomeada, no Palmeirim de Inglaterra chamava-se Onistalda. É casada com Beroldo e mãe de Recindos (II) e Valeriza. 12.

Rainha de França. aqui não nomeada, no Palmeirim de Inglaterra chamava-se Clarísia e era irmã de Francião. Casada com Graciano, é mãe de Arnedos (II). 12.

Recindos (I): antigo rei de Espanha, pai de Beroldo. No Palmeirim de Inglaterra era casado com Melisa. 06.

Recindos (II): filho de Beroldo, irmão de Valeriza. É príncipe da Espanha e neto de Recindos (I). 12, 15, 16, 20, 26, 61, 62, 77, 78, 79, 80 .

Rei da Hungria: no Palmeirim de Inglaterra era Estrelante, filho de Ditreu; nesta continuação nunca é nomeado. 03.

Rei da Sicília: pai de Filismarte. 33.

Rodegínia (Rodiginia): rainha de Boêmia, é casada com o rei Venceslau e é mãe da princesa Fidélia. 54, 64, 65, 67, 77, 80.

Rosuel, D.: filho de Belcar e Alderina. Casado com Dramaciana, é Duque de Ponta e Duraço. Seu irmão mais novo também se chama Belcar. 03, 07, 26, 35, 36.

Sardamante: antigo rei de Trácia, era conhecedor das artes mágicas e avô de Leonarda. $03,49$.

Selvião: irmão colaço de Palmeirim de Inglaterra; pai de Trigonio. 25.

Sidela: esposa de Platir e mãe de Palmeirim de Lacedemônia. É filha do rei Tarnais e rainha de Lacedemônia. 07, 12.

Soldão de Persia: personagem do Palmeirim de Inglaterra, que morre na batalha final do livro. É irmão de uma amiga de Targiana, chamada Armênia, que é a mãe de Beliazem. 17.

Targiana: filha do Grão Turco, foi casada com Albaizar (I). É mãe de Albaizar (II). 07, $17,18,37,43,44,48,49$.

Timandro: parente de Arlança, cavaleiro da Ilha de Dramusiando. 26, 31, 38.

Trigonio (Trogonio): filho de Selvião, escudeiro de D. Duardos II. 25, 31, 32, 50, 51, 53.

Trineo: filho de Vernau e Vasília, é herdeiro do Império alemão. 03, 12, 13, 15, 22, 23, $24,26,57,58,59,60,61,62,69,72,77,78,79$.

Urganda: Personagem do Amadis de Gaula. É sábia encantadora, antiga dona da Ilha Perigosa. 10. 
Valeriza (Valerisa): filha de Beroldo e Onistalda, é irmã de Recindos (II). 01, 07, 09, $10,17,18,19,20,21,22,24,25,26,27,29,30,32,69,72,73,74,75,77$.

Vasperado (Vesperaldo): filho de Floriano e Leonarda, irmão de Carmélia. 12, 13, 15 , $16,20,21,22,24,25,26,32,45,46,47,48,49,50,70,72,73,74$.

Vazilia: filha de Palmeirim de Oliva. Imperatriz da Alemanha. Foi casada com Vernau e é mãe de Trineu. 02.

Vernáu: filho de Trineo, antigo Imperador da Alemanha, e Agríola. Casou-se com Vasília, filha de Palmeirim de Oliva; seu filho tem o mesmo nome do avô, Trineo. Sua morte é narrada no Palmeirim de Inglaterra. 12.

Vinceslao (Vincesláo): rei de Boêmia, é casado com a rainha Rodegínia e é pai da princesa Fidélia. 54, 55, 57, 62, 63, 64, 65, 66, 67, 68, 70, 71, 75, 76, 77, 78, 80. 


\section{2. Índice geográfico}

Alemanha: Império herdado por Trineo, mas governado por seu tio Polinardo. 03, 69, 71.

Almourol: castelo pertencente à família de Miraguarda e D. Floris, situado às margens do Tejo. 04, 05, 07, 27, 71.

Alta Rocha: antigo nome da cidade de Lisboa. 10.

Artues: província do Condado de Flandres (provavelmente o Artois). 69.

Babilônia: reino governado por Targiana e seu filho Albaizar. 17, 25.

Bohemia: reino governado por Venceslau. 10, 54, 55, 62, 66, 67, 69, 73, 75, 77, 78, 79, 80.

Borgonha: ducado de Polinardo. 03.

Calés: cidade francesa de Calais. 04.

Constantinopla: capital do Império Grego. 01, 03, 06, 07, 10, 11, 14, 17, 25, 26, 28, 30 , $31,32,33,34,36,37,39,42,45,48,49,50,51,52,53,58,62,69,70,71,72,79$, 80.

Escócia: reino governado por Pompides. 03.

Espanha (Hespanha): reino governado por Beroldo. 01, 03, 04, 06, 26, 35, 58, 62, 69 , 78.

Estreito (de Gibraltar): 10.

Flandres (Flandes): condado de Polinardo. 03, 69.

Floresta das Três Fontes: floresta próxima a Constantinopla. 22, 27, 28, 29, 30, 31, 45 , 47.

França: reino governado por Graciano. 03, 04, 26, 35, 58.

Grécia: Império governado por Primaleão. 04, 06, 10, 17, 42, 54.

Hungria (Ungria): no Palmeirim de Inglaterra, o reino era governado por Estrelante. $03,10,36,51,53,62,68,69$.

Ilha de Deiscla: propriedade de Cadramonio. 23.

Ilha de Dramuziando: no Palmeirim de Inglaterra era chamada "Ilha Profunda". 03, 04, 26, 31, 38, 45, 54, 58, 62, 69. 
Ilha Perigoza: era ilha de Urganda, foi doada a Daliarte por Palmeirim; é ali que são criados os filhos dos sobreviventes da guerra contra Albaizar: 01, 02, 03, 04, 06, $07,10,12,13,17,31,38,48,56$.

Inglaterra: reino governado por D. Duardos. 03, 04, 10.

Ínsula Firme: propriedade de Appolidon. 14.

Lacedemônia: reino governado por Platir. 03, 35.

Linguadoc: província do reino de França. 58.

Lisboa: ver Alta Rocha.

Londres: capital do reino de Inglaterra. 03, 75.

Lusitania: província do reino de Espanha. 05.

Mar Adriático: 10.

Marca: região da Itália ou da Espanha?

Marselha (Marcelha): cidade do reino de França. 58.

Monte Etna: 34.

Nápoles: reino governado por Evaristo. 10, 22, 23, 33, 38, 39, 45.

Navarra: reino governado por Dragonalte. 03, 35, 36.

Niquea: reino governado pelo Sultão Blandidon. 03, 35.

Pleтии: porto de Inglaterra, provavelmente a cidade de Plymouth. 03.

Ponte e Duraço: ducado de D. Rosuel. 03.

Sicília (Cicilia): reino cujo príncipe é Filismarte. 23, 33, 41.

Tejo: rio na província de Lusitânia. 04, 05, 10.

Tessália (Thessalia): reino governado por Francião. 03, 35.

Trácia: reino governado por Floriano. 01, 03, 35, 49.

Transilvânia (Transcilvania): 69.

Turquia: reino governado por Targiana. 37.

Vale de Flores (Valdeflores): localizado no reino de Boêmia, é o vale onde Primaleão promove as justas em serviço à princesa Fidélia. 55, 57, 62, 65, 69, 78, 79. 


\section{3. Índice de obras citadas}

Chronica de Palmeirim: é o Palmeirim de Inglaterra, de Francisco de Morais. 01, 04, $06,17,37$.

Chronicas dos Reys de Inglaterra: obras fictícias; tratam-se de supostas crônicas históricas que completariam a narração da Crônica de D. Duardos. 10.

Chronica de Amadiz de Gaula: é o célebre livro de Montalvo a que, além das referências diretas aqui indicadas, o autor desta Crônica de D. Duardos faz muitas referências indiretas (citando personagens e situações da obra). 14, 79. 


\section{BIBLIOGRAFIA}

\section{Fontes primárias.}

\subsection{Obras manuscritas.}

CHRONICA DE PRIMALEÃO Emperador de Grecia Primeira Parte Em que se da conta das façanhas, que obrou o Princepe D. Duardos, e os mais Princepes que com elle se criarão, na Ilha Perigoza do Sabio Daliarte Composta Por Guilherme Frusto, Author Hibernio, e copiada, por Simisbero Pachorro, em quanto esteve occupado, ou encantado no Cume da Penha Riguroza, da Serra da Lua, pello odio do Sabio Bragamante. Cód. 12904 - Biblioteca Nacional de Lisboa.

CHRONICA DE PRIMALEÃO Emperador de Grecia Primeira parte Em que se da conta das façanhas, que obrou o Principe D. Duardos, e os mais Principes que com elle se criarão na Ilha Perigoza do Sabio Daliarte. Composta | Por Guilherme Frusto Author Hibernio, e copiada, por Simisberto Pachorro, emquanto esteve ocupado, ou encantado no cume da Penha Riguroza, da Serra da Lua, pello odio do Sabio Bragamante. Cód. 620 - Biblioteca Nacional de Lisboa.

CHRONICA DE PRIMALEÃO Emperador de Grecia. Segunda Parte. Em que se da conta das façanhas monstruozas, que obrou o Princepe D. Duardos e os mais cavalleiros de seu tempo. Composta Por Guilherme Frusto e tresladada por Simisberto Pachorro estando encantado no Cume da Penha Riguroza da Serra da Lua pello odio do Sabio Bragamante. Cód. 1201 - Arquivo Nacional da Torre do Tombo (Manuscritos da Livraria). 
CHRONICA DE PRIMALEÃO Emperador de Grecia. Terceira Parte. Cód. 1202 Arquivo Nacional da Torre do Tombo (Manuscritos da Livraria).

CHRONICA DO EMPERADOR Primalião, e outros Principes. Cód. 658 - Biblioteca Nacional de Lisboa.

CHRONICA DO INVICTO D. Duardos de Bretanha Princepe de Ingalaterra filho de Palmeiry, e da Princeza Polinarda, daqual se conta seus estremados feitos em Armas, e purísimos amores, com outros de outros Cavalleiros que en seu tempo Concorrerão. ComPosta por Henrique Frusto Chronista ingres, e tresladada em Portugues por Gomes Ennes de Zurara, que fes a Chronica del Rey Dom Afonso Henrriques de Portugal achada denovo entre seus Papeis. Cód. 6828 - Biblioteca Nacional de Lisboa.

CHRONICA DO INVICTO Invicto dom Duardos de Bretanha Principe de Inglaterra filho de |almeirim; e da Princeza Pollinarda naqual secontão seus estremados feittos em armas, e purissimos amores, com os de outros cavaleiros que emseu tempo concorrerão, composta por Henrique Frustu Chronista Ingres e tresladada emPortuguez por Guomes annes deZurarra, e | achada de novo entre seus papeis. Cód. 619 - Biblioteca Nacional de Lisboa.

PRIMEIRA PARTE DA VIDA de Premelião Emperador de Constantinopla, e de outros Principes da quelle tempo. Cód. 483 - Biblioteca Nacional de Lisboa.

PRIMEIRA PARTE DA VIDA de Primalião Emperador de Constantinopla e de outros Princepes daquele tempo. Cód. 1773 - Arquivo Nacional da Torre do Tombo (Manuscritos da Livraria).

\subsection{Obras impressas.}

BARROS, João de. Crónica do Imperador Clarimundo. Ed. de Marques Braga. Lisboa: Sá da Costa, 1953, 3 vols.

CERVANTES, Miguel de. Don Quijote de la Mancha. Ed. de Martín de Riquer. Barcelona: Planeta, 2004. 
FERNANDES, Diogo. Terceira parte da Chronica de Palmeirim de Inglaterra na qual se tratam as grandes cauallarias de seu filho o Principe Dom Duardos segundo, \& dos mais Principes, \& caualleiros que na Ilha deleytosa se criarão. Lisboa: Jorge Rodriguez, 1604 (reprodução xerográfica de exemplar da Biblioteca Nacional de Lisboa).

LOBATO, Baltasar Gonçalves. Quinta e sexta parte de Palmeirim de Inglaterra. Chronica do famoso Principe Dom Clarisol de Bretanha, filho do Principe dom Duardos de Bretanha, na qual se cõtão suas grandes cauallarias, \& dos principes Lindamor, Clarifebo, \& Beliandro de Grecia, filhos de Vasperaldo, Laudimãte, \& Primalião, \& de outros muitos principes, \& caualleiros famosos de seu tempo. Lisboa: Jorge Rodriguez, 1602 (reprodução xerográfica de exemplar da Biblioteca Nacional de Lisboa).

LOBO, Francisco Rodrigues. Corte na aldeia. Prefácio e notas de Afonso Lopes Vieira. Lisboa: Sá da Costa, 1945.

MARTORELL, Joanot. Tirante el Blanco. Traducción castellana del siglo XVI. Ed., introd. y notas de Martín de Riquer. Barcelona: Planeta, 1990.

MORAIS, Francisco de. Crônica de Palmeirim de Inglaterra, a que se ajuntam as mais obras do mesmo autor. Ed. Geraldo de Ulhoa Cintra. São Paulo: Anchietana, 1946, 3 vols.

Palmerín de Olivia. Ed. M. Carmen Marín Pina. Alcalá de Henares: Centro de Estudios Cervantinos, 2004 (Libros de Rocinante, 18).

Platir. Ed. de M. Carmen Marín Pina. Alcalá de Henares: Centro de Estudios Cervantinos, 1997 (Libros de Rocinante, 1).

Primaleón. Ed. de M. Carmen Marín Pina. Alcalá de Henares: Centro de Estudios Cervantinos, 1998 (Libros de Rocinante, 3).

RODRÍGUEZ DE MONTALVO, Garci. Amadís de Gaula. Ed. de Juan Manuel Cacho Blecua. 2. ed. Madrid: Cátedra, 1991, 2 vols.

VASCONCELOS, Jorge Ferreira de. Memorial das proezas da segunda Távola Redonda. Ed. de João Palma-Ferreira. Lisboa: Lello, 1998 (Col. Obras Clássicas da Literatura Portuguesa, Século XVI, nº 2). 


\section{Bibliografia geral.}

ASENSIO, Eugenio. El Palmeirim de Inglaterra. Conjecturas y certezas, in: Garcia de Orta: Revista da Junta de Investigações de Ultramar. Núm. esp., 1972, p. 127-136.

AVALlE-ARCE, Juan Bautista. Amadís de Gaula: el primitivo y el de Montalvo. México: Fondo de Cultura Económica, 1990.

AZEVEDO FILHO, Leodegário A. de. Iniciação em Crítica Textual. Rio de Janeiro: Presença / São Paulo: Edusp, 1987.

BOHIGAS BALAGUER, Pedro. La novela caballeresca, sentimental y de aventuras, in: DÍAZ-PLAJA, Guillermo (org.). Historia general de las Literaturas Hispánicas. Vol. II: Pre-Renacimiento y Renacimiento. Barcelona: Barna, 1951, p. 187-236.

BOHIGAS BALAGUER, Pedro. Orígenes de la novela caballeresca e Novelas caballerescas indígenas, in: DİAZ-PLAJA, Guillermo (org.). Historia general de las Literaturas Hispánicas. Vol. I: Desde las orígenes hasta 1400. Barcelona: Barna, 1949, p. 521-541.

BRANCO, Camilo Castelo. Introdução, in: LOBO, Fernão Rodrigues. Poesias e prosas inéditas. Porto: Tipografia Lusitana, 1868, p. IX-XXXI.

BURCKHARDT, Jacob. A cultura do Renascimento da Itália. Trad. Sérgio Tellaroli. São Paulo: Companhia das Letras, 1991.

CACHO BLECUA, Juan Manuel. Introducción al estudio de los motivos en los libros de caballerías: la memoria de Román Ramírez, in: Libros de caballerías (de “Amadis” al "Quijote”). Salamanca: SEMYR, 2002, p. 27-53.

CACHO BLECUA, Juan Manuel. Introducción, in: RODRÍGUEZ DE MOTALVO, Garci. Amadís de Gaula. 2. ed., Madrid: Cátedra, 1991, vol. 1, p. 19-216.

CAMBRAIA, César Nardelli. Livro de Isaac: Edição e Glossário (Cód. Alc 461). Tese de doutorado apresentada à Faculdade de Filosofia, Letras de Ciências Humanas da Universidade de São Paulo, São Paulo, 2000. 
CARDINI, Franco. O guerreiro e o cavaleiro, in: LE GOFF, Jacques (org.). O homem medieval. Trad. Maria Jorge Vilar de Figueiredo. Lisboa: Presença, 1989, p. 5778.

CARVALHO, Joaquim de. Livros de D. Manuel II, in: Obra completa. Vol. 4: História e Cultura (1948-1955). Lisboa: Calouste Gulbenkian, 1983, p. 435-532.

CARVALHO, Joaquim Barradas de. O Renascimento português: em busca de sua especificidade. Lisboa: Imprensa Nacional / Casa da Moeda, 1980.

CUESTA TORRE, María Luzdivina. La realidad histórica en la ficción de los libros de caballerías, in: Libros de caballerías (de “Amadís” al "Quijote”). Salamaca: SEMYR, 2002, p. 87-109.

DEUS, Maria Luísa do Couto Linhares de. Cartas éditas e inéditas de Fernão Rodrigues Lobo Soropita. Dissertação de mestrado apresentada à Faculdade de Letras da Universidade de Lisboa, 1987.

DEYERMOND, Alan. The lost genre in medieval Spanish literature, in: BUSTOS TOVAR, E. (org.). Actas del cuarto congreso internacional de hispanistas. Salamanca: Universidad, 1982, v. 1, p. 791-813.

DÍAZ DE BENJUMEA, Nicolas. Discurso sobre el "Palmerín de Inglaterra" y su verdadero autor, presentado a la Academia de Ciencias de Lisbona. Lisboa: Imprenta de la Real Academia de Ciencias, 1876.

DURÁN, Armando. Estructura y técnicas de la novela sentimental y caballeresca. Madrid: Gredos, 1973.

ELIADE, Mircea. Imagens e símbolos. Ensaio sobre o simbolismo mágico-religioso. Trad. Sônia Cristina Tamer. São Paulo: Martins Fontes, 1991.

FERRARO DE ORDUÑA, Lilia. "Palmerín de Olivia" y "Primaleón": algunas observaciones sobre su autoría, in: Actas del VIII Congreso Internacional de la Asociación Hispánica de Literatura Medieval. Santander: AHLM, 2000, p. 717728.

FERREIRA, Jerusa Pires. O tapete preceptivo do Palmeirim de Inglaterra. Tese apresentada ao Instituto de Letras da Universidade Federal da Bahia para Concurso de Professor Assistente do Departamento de Letras Clássicas e Vernáculas; Salvador, 1973. 
FERREIRA, Jerusa Pires. Os sermonários do diabo ou as novelas de cavalaria, in: MACHLINE, Vera C. et al (orgs.). Forma e ciência. São Paulo: Educ, 1995, p. 77-99.

FIGUEIREDO, Fidelino de. A épica portuguesa no século XVI. Lisboa: Imprensa Nacional / Casa da Moeda, 1993.

FIGUEIREDO, Fidelino de. História da Literatura Clássica. 2. ed., Lisboa: Clássica: 1930, 3 vols.

FINAZZI-AGRÒ, Ettore. A novelística portuguesa do século XVI. Trad. Carlos Moura. Lisboa: Instituto de Cultura Portuguesa, 1978.

FLORI, Jean. La caballería. Trad. Ángel Sánchez-Gijón. Madrid: Alianza, 2001.

GARIN, Eugenio. Idade Média e Renascimento. Trad. Isabel Teresa Santos e Hossein S. Shooja. Lisboa: Estampa, 1994.

GAYANGOS, D. Pascual de. Libros de caballerías, con un discurso preliminar y un catálogo razonado. Madrid: Atlas, 1963 (Biblioteca de Autores Españoles, XL).

GONZÁLEZ, Javier Roberto. La ideología profética del Palmerín de Olivia, in: Letras: Revista de la Facultad de Filosofía y Letras de la Universidad Católica Argentina, no 37,1998, p. 53-81.

GONZÁLEZ, Javier Roberto. Profecía mesiánica y profecía apocalíptica: la cuestión constantinopolitana en Las sergas de Espladián y Primaleón, in: Studia Hipánica Medievalia V. Actas de las VI Jornadas Internacionales de Literatura Española Medieval. Letras: Revista de la Facultad de Filosofía y Letras de la Universidad Católica Argentina, ns 40-41 (julio 1999-julio 2000), p. 125-135.

HEERS, Jacques. A Idade Média: uma impostura. Trad. António Gonçalves. Lisboa: Asa, 1994.

HUIZINGA, Johan. O declínio da Idade Média. Trad. Augusto Abelaira. 2. ed., Lisboa: Ulisseia, s/d.

INFANTES, Victor. Nominar las caballerías o de la titulación de un género, in: Letteratura cavalleresca tra Italia e Spagna (da “Orlando" al "Quijote”). Salamanca: SEMYR, 2004, p. 35-51.

KEEN, Maurice. Chivalry. New Haven / London: Yale University Press, s/d.

KÖHLER, Erich. L'aventure chevaleresque: idéal et réalité dans le roman courtois. 2. ed., Paris: Gallimard, 1984. 
LANCIANI, Giulia. Textos portugueses dos séculos XVI a XVIII. Problemas ecdóticos. Separata de Critique textuelle portugaise: Actes du colloque. Paris: Fondation Calouste Gulbenkian, 1986, p. 279-285.

LARA, Manuel Rodrigues. Introdução, in: MORAIS, Francisco de. Palmeirim de Inglaterra. Sel., prefácio e notas de M. R. Lapa. 2. ed., Lisboa: s/e, 1960, p. V-XV.

LIMA E ALMEIDA, Isabel Adelaide Penha Dinis de. Livros portugueses de cavalarias, do Renascimento ao Maneirismo. Dissertação de doutoramento em Literatura Portuguesa, apresentada à Faculdade de Letras da Universidade de Lisboa. Lisboa, 1988.

LIMA, Francisco Ferreira de. Palmeirim de Inglaterra: para educar e divertir o príncipe (e o leitor), in: Sitientibus: Revista da Universidade Estadual de Feira de Santana, $\mathrm{n}^{\mathrm{o}} 13,1995$, p. 91-113.

LÓPEZ ESTRADA, Francisco. "Siglos de oro: Renacimiento. Primer suplemento, in: Rico, F. (org). Historia y crítica de la Literatura Española. Barcelona: Crítica, 1991.

LUCÍA MEGÍAS, José Manuel. Imprenta y libros de caballerías. Madrid: Ollero \& Ramos, 2000.

LUCÍA MEGÍAS, José Manuel. Libros de caballerías castellanos: un género recuperado, in: Libros de caballerías. El Quijote. Investigaciones y relaciones. Letras: Revista de la Facultad de Filosofía y Letras de la Universidad Católica Argentina, $n^{\circ}$ 50-51, 2004-2005, p. 203-234.

MAGAlHÃES, Joaquim Romero de (coord.), História de Portugal (dir. J. Mattoso). Vol. III: No alvorecer da Modernidade (1480-1620). Lisboa: Estampa, 1997.

MARÍN PINA, M. Carmen. Introducción, in: Palmerín de Olivia. Ed. de M. Carmen Marín Pina. Alcalá de Henares: Centro de Estudios Cervantinos, 2004, p. IXXXXVII.

MARÍN PINA, M. Carmen. Introducción, in: Platir. Ed. de M. Carmen Marín Pina. Alcalá de Henares: Centro de Estudios Cervantinos, 1997, p. IX-XVIII.

MARÍN PINA, M. Carmen. Introducción, in: Primaleón. Ed. de M. Carmen Marín Pina. Alcalá de Henares: Centro de Estudios Cervantinos, 1998, p. IX-XXIII. 
MARÍN PINA, M. Carmen. La historia y los primeros libros de caballerías españoles, in: PAREDES, Juan (org.). Medioevo y literatura. Actas del V Congreso de la Asociación Hispánica de Literatura Medieval. Granada: Universidad, 1995, vol. III, p. 183-192.

MARÍN PINA, M. Carmen. Palmerín de Olivia (Guía de Lectura). Alcalá de Henares: Centro de Estudios Cervantinos, 2004 (Guías de Lectura Caballeresca, 6).

MEGALE, Heitor. "A Demanda do Santo Graal: Do Manuscrito ao Texto Modernizado", in: II Encontro de Edição Crítica e Crítica Genética: Eclosão do Manuscrito. São Paulo: FFLCH - USP, 1989, p. 23-29.

MEGALE, Heitor. A Demanda do santo Graal: do manuscrito ao texto modernizado, in: II Encontro de edição crítica e crítica genética: eclosão do manuscrito. São Paulo: Faculdade de Filosofia, Letras e Ciências Humanas da Universidade de São Paulo, 1989, p. 23-29.

MENDES, Odorico. Opúsculo acerca do Palmeirim de Inglaterra e do seu autor, no qual se prova haver sido a referida obra composta originalmente em português. Lisboa: Panorama, 1860.

MENÉNDEZ Y PELAYO, Marcelino. Orígenes de la novela. Buenos Aires: EspasaCalpe, 1946, 3 vols.

MOISÉS, Massaud. A criação literária. Prosa (I). 15. ed., São Paulo: Cultrix, 1994.

MOISÉS, Massaud. A Literatura Portuguesa. 22. ed., São Paulo: Cultrix, 1986.

MOISÉS, Massaud. A novela de cavalaria no Quinhentismo português: O memorial das proezas da segunda Távola Redonda, de Jorge Ferreira de Vasconcelos. São Paulo: Boletim da Faculdade de Filosofia. Ciências e Letras (USP), 218, 1957.

MOISÉS, Massaud. A novela de cavalaria portuguesa: achega bibliográfica, in: Revista de História, 29, ano VIII, 1957, p. 47-52.

MONGELLI, Lênia Márcia. Clarimundo e a épica de João de Barros. Tese de doutoramento em Literatura Portuguesa apresentada à Faculdade de Filosofia, Letras e Ciências Humanas da Universidade de São Paulo. São Paulo, 1982. 
NORMAS PARA A TRANSCRIÇÃO DE DOCUMENTOS MANUSCRITOS PARA A HISTÓRIA DO PORTUGUÊS DO BRASIL, In: A Carta de Pero Vaz de Caminha. Reprodução Fac-Similar do Manuscrito com Leitura Justalinear de A. G. Cunha, C. N. Cambraia e H. Megale. São Paulo: Humanitas, 1999, p. 23-26.

OLIVEIRA MARQUES, A. H. História de Portugal. 12. ed., Lisboa: Palas, 1985, v. 1.

PAIVA, Dulce de Faria. História da Língua Portuguesa. II. Século XV e meados do século XVI. São Paulo: Ática, 1988.

PALMA-FERREIRA, João. Prefácio, in: Crónica do Imperador Maximiliano, Cód. 490, Col. Pombalina da Biblioteca Nacional. Lisboa: Imprensa Nacional / Casa da Moeda, 1983, p. 9-72.

PATCHELL, Mary. The Palmerin romances in Elizabethan prose fiction. New York: Columbia University Press, 1947.

PETRUCCELLI, María Rosa. Personajes femeninos y voluntad de protagonismo en el Palmerín de Olivia, in: Studia Hispanica Medievalia IV. Actas de las V Jornadas Internacionales de Literatura Española Medieval. Letras: Revista de la Facultad de Filosofía y Letras de la Universidad Católica Argentina, 1996, p. 302-313.

PICCHIO, Luciana Stegagno. Proto-história dos Palmeirins: a corte de Contantinopla do Cligès ao Palmerín de Olivia", in: A lição do texto: filologia e literatura. Lisboa: Edições 70, 1979, p. 167-206.

PIRES, Maria Lucília Gonçalves. Introdução, in: LOBO, Francisco Rodrigues. A primavera. Ed. de M. Lúcia Gonçalves Pires. Lisboa: Vega, 2003 (Col. Obras Clássicas da Literatura Portuguesa, Século XVII, n 111), p. 7-37.

PURSER, William Edward. Palmerin of England. Some romarks on this romance and on the controversy concerning its authorship. Dublin: Brown and Nolan, 1904.

QUERIDO, José Baptista Fernandes. Fernão Rodrigues Lobo Soropita. Éditos e inéditos. Prosa e verso. Fixação do texto, notas e comentários. Dissertação de mestrado apresentada à Faculdade de Letras da Universidade de Coimbra, s/d.

RAMOS COELHO. O primeiro Marquês de Niza, in: Archivo Histórico Português, v. 1,1903 , separata. 
RÍO NOGUERAS, Alberto del. Del caballero medieval al cortesano renacentista. Un itinerario por los libros de caballerías, in: NASCIMENTO, Airas A. e RIBEIRO, Cristina Almeida (orgs.). Literatura Medieval. Actas da Associação Hispânica de Literatura Medieval (Lisboa, 1-5 Outubro 1991). Lisboa: Cosmos, 1993, vol. II, p. 73-80.

RIQUER, Martín de. Introducción, in: MARTORELL, Joanot. Tirante el Blanco. Traducción castellana del siglo XVI. Ed, introd. y notas de M. de Riquer. Barcelona: Planeta, 1990, p. VII-XC.

SARAIVA, António José, LOPES, Óscar. História da Literatura Portuguesa. 16. ed., Porto: Porto Editora, 1989.

SPAGGIARI, Barbara, PERUGI, Maurizio. Fundamentos da Crítica Textual. Rio de Janeiro: Lucerna, 2004.

SPINA, Segismundo. Introdução à Edótica. São Paulo: Cultrix / Edusp, 1977.

THOMAS, Henry. Las novelas de caballerías españolas y portuguesas. Trad. Esteban Pujals. Madrid: Consejo Superior de Investigaciones Científicas, 1952.

VARGAS DÍAZ-TOLEDO, Aurelio. Leomundo de Grecia: hallazgo de un nuevo livro de caballerías portugués, in: Voz y letra: revista de literatura, vol. 15 (2), 2004, p. 3-32.

VARGAS DÍAZ-TOLEDO, Aurelio. Noticia de un nuevo libro de caballerías: el Leomundo de Grecia de Tristão Gomes de Castro, in: Butlletí informatiu $i$ bibliogràfic, $\mathrm{n}^{\mathrm{o}} \quad 6,2003$ (disponível no endereço eletrônico: http://parnaseo.uv.es/Tirant/Butlleti.6/noticialeomundo.htm).

VARGAS DÍAZ-TOLEDO, Aurelio. Os livros de cavalarias em Castela e Portugal. Um caso particular: a Selva de cavalarias famosas, de António de Brito da Fonseca. Texto inédito.

VARGAS DÍAZ-TOLEDO, Aurelio. Os livros de cavalarias renascentistas na história da Literatura Portuguesa, in: Península: revista de estudos ibéricos, $\mathrm{n}^{\circ} 3,2006, \mathrm{p}$. 233-248.

WEST, Martin L. Crítica textual e técnica editorial. Trad. António Manuel Ribeiro Rebelo. Lisboa: Fundação Calouste Gulbenkian, 2002.

\section{Obras de Referência}


ANSELMO, António Joaquim. Bibliografia das obras impressas em Portugal no século XVI. Lisboa: Biblioteca Nacional, 1926.

ATTWATER, Donald. Dicionário de santos. Trad. Maristela R. A. Marcondes. 2. ed. São Paulo: Art Editora, 1991.

BARRETO, João Franco. Bibliotheca Luzitana, cópia xerográfica do ms. da Casa de Cadaval presente na sala de reservados da Biblioteca Nacional de Lisboa, 6 vols.

BLUTEAU, Raphael. Vocabulario portuguez e latino, aulico, anatomico, architetonico... Autorizado com exemplos dos melhores escritores portuguezes, $e$ latinos. Coimbra: Collegio das Artes da Companhia de Jesu, 1712, 10 vols. (foi consultada a versão digitalizada em CD-ROM realizada pela Universidade do Estado do Rio de Janeiro, sob a coordenação de Nireu O. Cavalcanti em 2000).

EISENBERG, Daniel, MARÍN PINA, M. Carmen. Bibliografía de los libros de caballerías castellanos. Zaragoza: Prensas Universitarias, 2000.

LE GOFF, Jacques, SCHMITT, Jean-Claude. Dicionário temático do Ocidente Medieval. Coord. trad. Hilário Franco. Bauru: Edusc / São Paulo: Imprensa Oficial do Estado, 2002, 2 vols.

LIVRO DE OIRO DA NOBREZA: apostilas à resenha das famílias titulares do Reino de Portugal. Lisboa: J. A. Telles da Silva, 1988, 3 vols.

MACHADO, Diogo Barbosa. Biblioteca Lusitana histórica, crítica e cronológica. 2. ed., Lisboa: Bertrand, 1930-1935, 4 vols.

RODRIGUES, José Manuel. Catálogo de uma curiosa biblioteca constituída por obras de História, Arte, Etnografia, Ultramar e muitos outros temas de interesse para bibliófilos e estudiosos. A venda em leilão desta biblioteca tem início às 21 horas, nos dias 20, 21, 22 e 23 de outubro de 1987 na casa da Imprensa de Lisboa. Sob a direção de José Manuel Rodrigues, largo do Calhariz, 14, tel. 328477 - 1200 Lisboa. Antiga Libraria Arnaldo H. Oliveira. Catálogo elaborado por José Manuel Rodrigues - livreiro - alfarrabista. Lisboa: s/e, 1987.

SILVA, Inocêncio Francisco da. Diccionario bibliographico portuguez: estudos de Innocencio Francisco da Silva applicaveis a Portugal e ao Brasil. Lisboa: Imprensa Nacional / Casa da Moeda, 1973, 24 vols. 
SOUSA, D. António Caetano de. História Genealógica da Casa Real Portuguesa. Nova ed. revista por M. Lopes de Almeida e César Pegado. Coimbra: Atlântida, 19461955,26 vols.

VITERBO, Joaquim de Santa Rosa. Elucidario das palavras, termos e frases que em Portugal antigamente se usaram e que hoje regularmente se ignoram. Porto: Civilização, s/d, 2 vols. 